\title{
Fronteiras do Brasil
}

\section{referências para a formulação de políticas públicas}

\section{Volume 6}

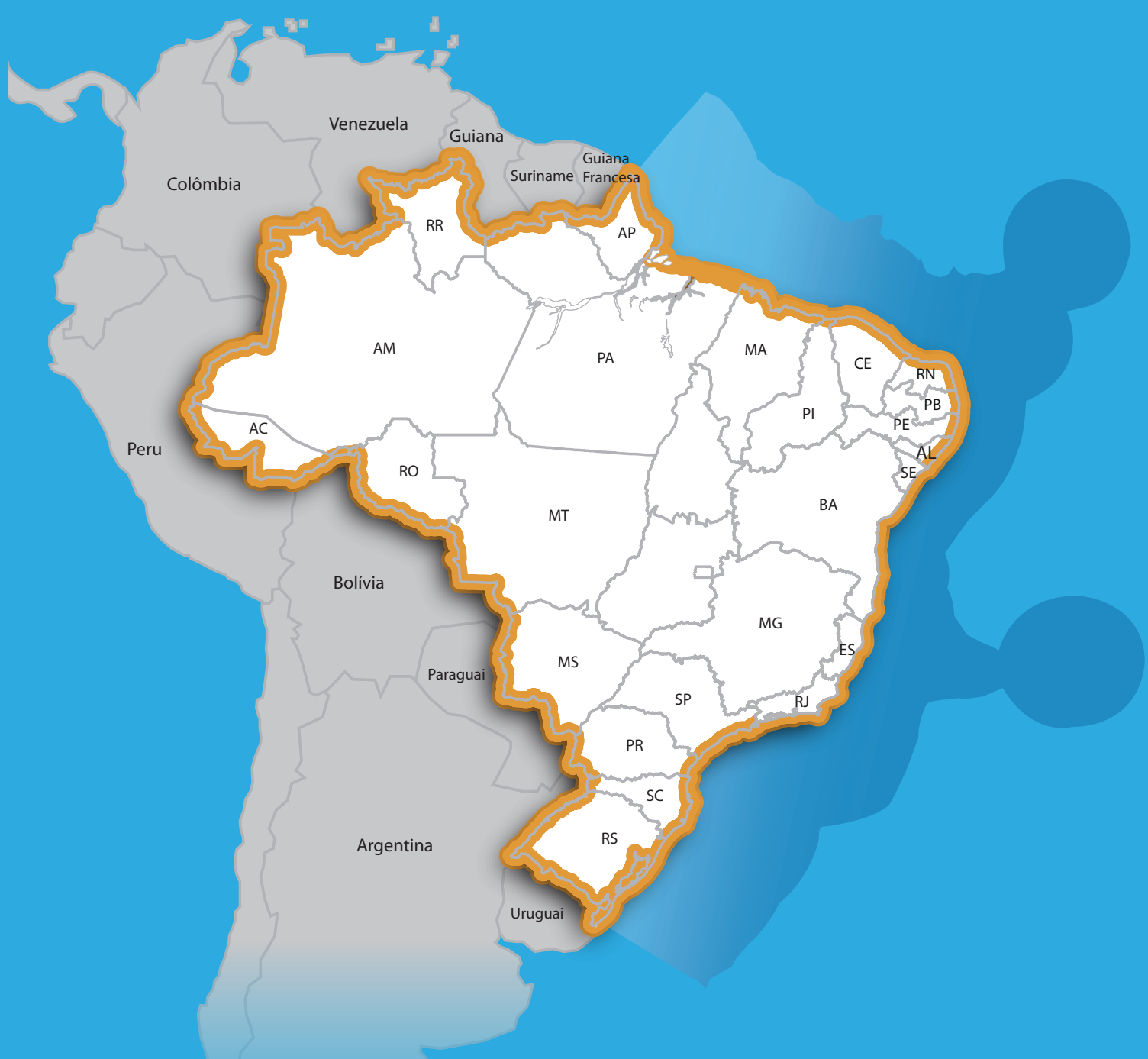

Autores

Bolívar Pêgo (Coordenador) 
Como produto final da parceria técnica do Ipea com o Ministério do Desenvolvimento Regional (MDR) no projeto A Política Nacional de Desenvolvimento Regional (PNDR) e a Faixa de Fronteira, por meio da pesquisa Fronteiras do Brasil: uma avaliação de política pública, trazemos a público o livro Referências para a Formulação de Políticas Públicas para as Fronteiras Brasileiras (volume 6). Tem como objetivo subsidiar a formulação de políticas públicas (planos, programas e ações) visando ao desenvolvimento eà integração do espaço fronteiriço. Este livro faz parte de uma série de seis publicações sobre fronteiras, quais sejam:

- volume 1, livro conceitual e autoral, publicado em novembro de 2018;

- volume 2, nacional, resultado da oficina de Brasília, publicado em junho de 2017;

- volume 3, elaborado a partir da oficina do arco Norte (Boa Vista, Roraima), publicado em junho de 2018;

- volume 4, produto da oficina do arco Central (Corumbá, Mato Grosso do Sul), publicado em dezembro de 2019;

- volume 5, resultado da oficina do arco Sul (Uruguaiana, Rio Grande do Sul), publicado em agosto de 2020; e

- volume 6, este, elaborado para subsidiar a concepção de um possível plano nacional de fronteiras.

Esta publicação é resultado das apresentações, debates, trabalhos em grupo, entrevistas e observaçōes de campo ocorridos em quatro oficinas temáticas, visitas técnicas a zonas de fronteiras de cinco países sul-americanos e um estudo técnico sobre cidade gêmea. As oficinas foram realizadas em Brasília (DF), Boa Vista (RR), Corumbá (MS) e Uruguaiana (RS). As visitas técnicas do arco Norte ocorreram em Bonfim (RR) - Lethem (Guiana) e Pacaraima (RR) - Santa Elena e Uairén (Venezuela). Quanto as do arco Central, as oficinas foram realizadas em Corumbá - Ladário (MS) - Puerto Quijarro - Puerto Suárez (Bolívia). Já no arco Sul aconteceram em Uruguaiana (RS) - Paso de los Libres (Argentina) e na tríplice fronteira Barra do Quaraí (Brasil) - Bella Unión (Uruguai) - Monte Caseros (Argentina). O estudo de cidade gêmea aconteceu em Cáceres (MT) - San Matías (Bolívia), com destaque para uma entrevista com o governador de Mato Grosso, em Cuiabá. Possui, também, uma visão sobre a fronteira litorânea, sua importância terrestre e marinha e seus desafios socioambientais. 


\section{Fronteiras do Brasil}

referências para a formulação de políticas públicas

\section{Volume 6}

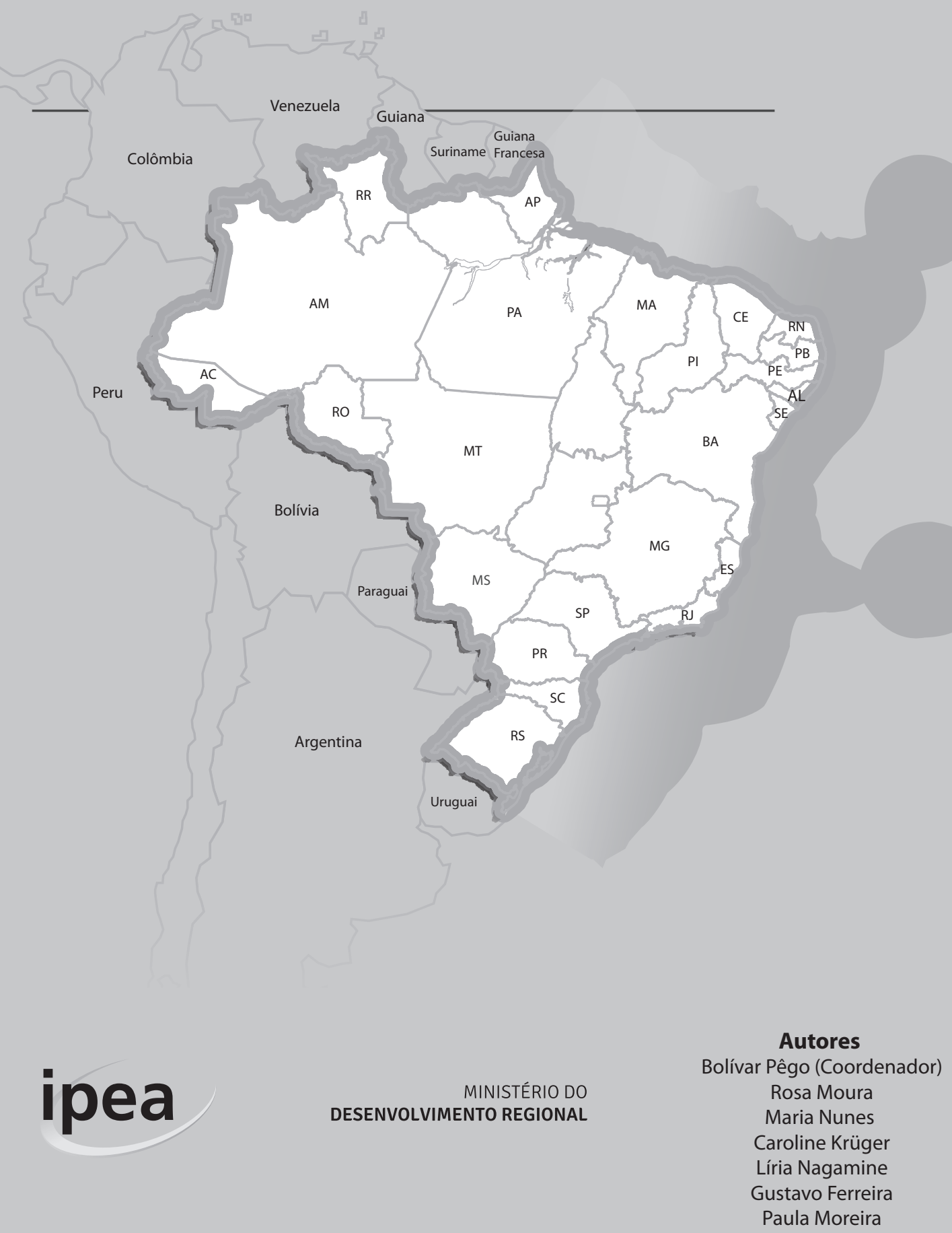




\section{Governo Federal}

\section{Ministério da Economia}

Ministro Paulo Guedes

\section{ipea 2 institudode pessuisa \\ ipea $a_{\text {teonomica anicata }}$}

Fundação pública vinculada ao Ministério da Economia, o Ipea fornece suporte técnico e institucional às ações governamentais - possibilitando a formulação de inúmeras políticas públicas e programas de desenvolvimento brasileiros - e disponibiliza, para a sociedade, pesquisas e estudos realizados por seus técnicos.

\section{Presidente}

Carlos von Doellinger

Diretor de Desenvolvimento Institucional Manoel Rodrigues Junior

Diretora de Estudos e Políticas do Estado, das Instituições e da Democracia

Flávia de Holanda Schmidt

\section{Diretor de Estudos e Políticas}

Macroeconômicas

José Ronaldo de Castro Souza Júnior

Diretor de Estudos e Políticas Regionais, Urbanas e Ambientais

Nilo Luiz Saccaro Júnior

Diretor de Estudos e Políticas Setoriais de Inovação e Infraestrutura

André Tortato Rauen

Diretora de Estudos e Políticas Sociais Lenita Maria Turchi

Diretor de Estudos e Relações Econômicas e Políticas Internacionais Ivan Tiago Machado Oliveira

Assessor-chefe de Imprensa e Comunicação André Reis Diniz

Ouvidoria: http://www.ipea.gov.br/ouvidoria

URL: http://www.ipea.gov.br 


\section{Fronteiras do Brasil}

referências para a formulação de políticas públicas

\section{Volume 6}

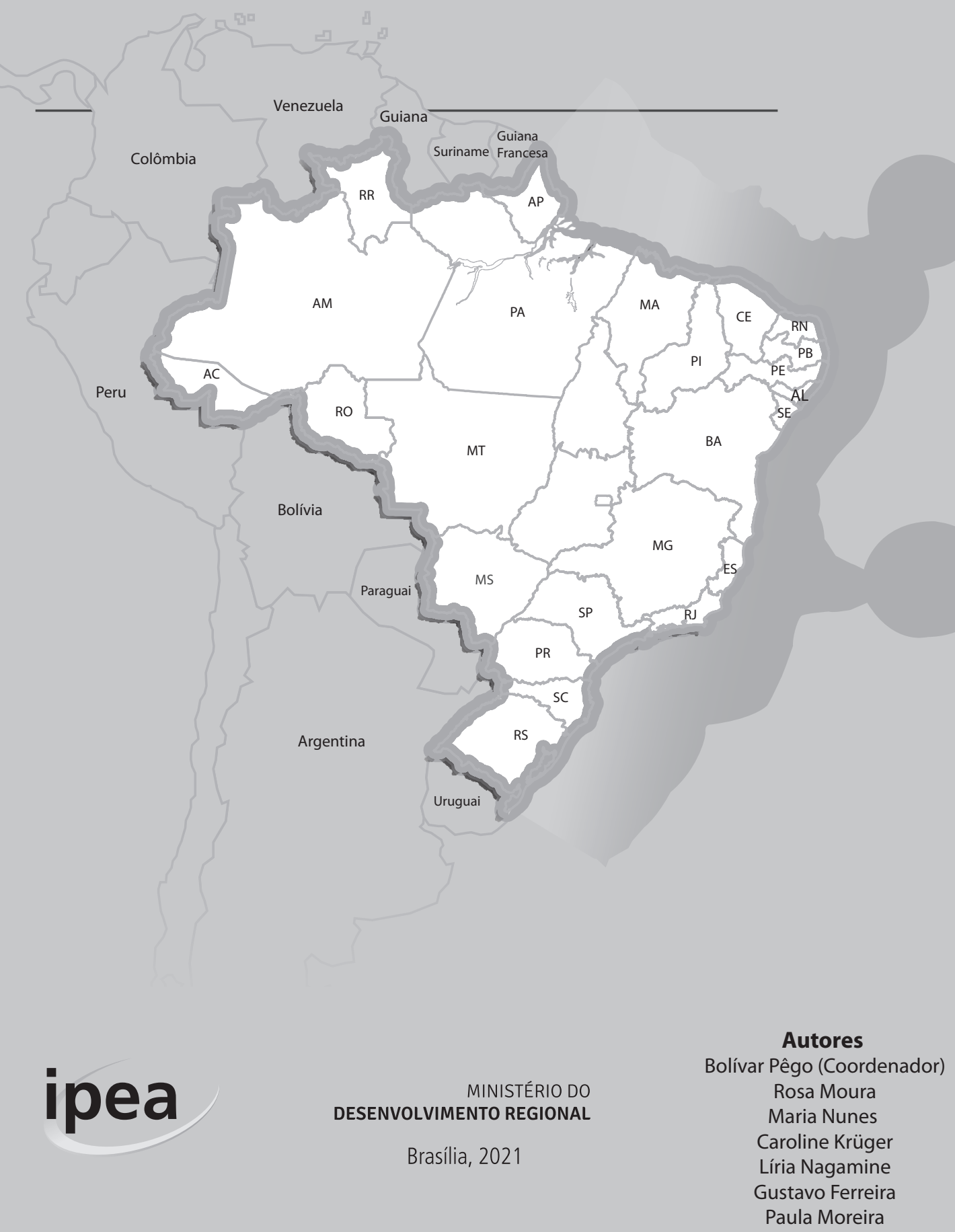


(C) Instituto de Pesquisa Econômica Aplicada - ipea 2021

Fronteiras do Brasil: referências para a formulação de políticas públicas

\section{COORDENAÇÃO GERAL}

\section{Bolívar Pêgo}

Coordenador geral de pesquisa em questões regionais, urbanas e ambientais na Diretoria de Estudos e Políticas Regionais, Urbanas e Ambientais (Dirur) do Ipea. Coordenador da pesquisa Fronteiras do Brasil: uma avaliação de política pública.

\section{COORDENAÇÃO TÉCNICA}

\section{Rosa Moura}

Pesquisadora sênior do Subprograma de Pesquisa para o Desenvolvimento Nacional (PNPD) na Dirur/lpea.

\section{EQUIPE TÉCNICA}

\section{Maria Nunes}

Pesquisadora do PNPD/Dirur/lpea.

\section{Caroline Krüger}

Pesquisadora do PNPD/Dirur/lpea.

\author{
Líria Yuri Nagamine \\ Pesquisadora do PNPD/Dirur/Ipea.
}

\section{Gustavo Ferreira}

Pesquisador do PNPD/Dirur/lpea.

\section{Paula Moreira \\ Pesquisadora do PNPD/Dirur/pea.}

\section{PARECERISTAS}

\section{Tito Carlos Machado de Oliveira}

Pesquisador do Centro de Análise e Difusão do Espaço Fronteiriço (Cadef) da Universidade Federal de Mato Grosso do Sul (UFMS).

\section{Tereza Cristina Cardoso de Souza Higa}

Professora titular da Universidade Federal de Mato Grosso (UFMT). Coordenadora do Grupo de Estudos Regionais Sul-Americanos (Gersa).

Fronteiras do Brasil : referências para a formulação de políticas públicas, volume 6 / Coordenador Bolívar Pêgo - Brasilia : Ipea, Ml, 2021.

367 p. : il., gráfs., mapas, color.

Inclui Bibliografia.

ISBN: 978-65-5635-019-6

1. Fronteiras. 2. Políticas Públicas. 3. Desenvolvimento Regional. 4. Integração Fronteiriça.

5. Integração Regional. I. Pêgo, Bolívar. II. Instituto de Pesquisa Econômica Aplicada. III. Brasil. Ministério da Integração Nacional.

Ficha catalográfica elaborada por Andréa de Mello Sampaio CRB-1/1650

DOI: http://dx.doi.org/10.38116/978-65-5635-019-6

As publicações do Ipea estão disponíveis para download gratuito nos formatos PDF (todas) e EPUB (livros e periódicos). Acesse: http://www.ipea.gov.br/portal/publicacoes

As opiniões emitidas nesta publicação são de exclusiva e inteira responsabilidade dos autores, não exprimindo, necessariamente, o ponto de vista do Instituto de Pesquisa Econômica Aplicada ou do Ministério da Economia.

É permitida a reprodução deste texto e dos dados nele contidos, desde que citada a fonte. Reproduções para fins comerciais são proibidas.

1. Este livro é produto do projeto A Política Nacional de Desenvolvimento Regional (PNDR) e a Faixa de Fronteira, pesquisa Fronteiras do Brasil: uma avaliação de política pública, e foi desenvolvido pela Diretoria de Estudos e Políticas Regionais, Urbanas e Ambientais (Dirur) do Ipea em parceria com o Ministério do Desenvolvimento Regional (MDR). 


\section{SUMÁRIO}

\section{APRESENTAÇÃO}

\section{CAPÍTULO 1}

INTRODUÇÃO

\section{CAPÍTULO 2}

CONTEMPORANEIDADE E MARCO LEGAL DA FAIXA DE FRONTEIRA BRASILEIRA

\section{CAPÍTULO 3}

DINÂMICAS RECENTES NA FRONTEIRA TERRESTRE DO BRASIL

\section{CAPÍTULO 4}

AVALIAÇÃO DAS POLÍTICAS PÚBLICAS VOLTADAS À FAIXA

DE FRONTEIRA TERRESTRE

\section{CAPÍTULO 5}

INTEGRAÇÃO E DESENVOLVIMENTO: A FRONTEIRA NA ARTICULAÇÃO

TERRITORIAL NACIONAL E SUL-AMERICANA

\section{CAPÍTULO 6}

MODELOS DE GOVERNANÇA NA FRONTEIRA

BRASILEIRA: ENTRE INTERMITÊNCIAS E CONTINUIDADES

\section{CAPÍTULO 7}

ELEMENTOS PARA UMA NOVA PROPOSTA DE DESENVOLVIMENTO E INTEGRAÇÃO FRONTEIRIÇA

\section{CAPÍTULO 8}

CONTRIBUIÇÕES INICIAIS PARA O ESTUDO DA FRONTEIRA LITORÂNEA ...285

\section{CAPÍTULO 9}

CONSIDERAÇÕES FINAIS 



\section{APRESENTAÇÃO}

Este livro, intitulado Fronteiras do Brasil: referências para a formulação de políticas públicas (volume 6), tem como objetivo subsidiar a formulação de políticas públicas (planos, programas e ações) visando ao desenvolvimento e à integração do espaço fronteiriço. Embora existam estudos de qualidade demandados pelo governo federal voltados a esse espaço e a essa finalidade, julgou-se necessário agregar aos resultados e às proposiçóes desses trabalhos demandas e recomendaçóes dos povos fronteiriços, gestores e agentes atuantes nas fronteiras, colhidas nas atividades realizadas pelo projeto A Política Nacional de Desenvolvimento Regional (PNDR) e a Faixa de Fronteira, pesquisa Fronteiras do Brasil: uma avaliação de política pública, desenvolvido em parceria do Ipea com o Ministério do Desenvolvimento Regional (MDR). Essas atividades colocam em foco as dinâmicas e os dilemas da fronteira brasileira neste início de década e são complementares aos resultados dos estudos citados, que servem como subsídios fundamentais à composição destas referências.

A esses subsídios, a inserção dos resultados dos debates promovidos pelo projeto da parceria Ipea e MDR reforçam a atualidade das referências trazidas neste trabalho. Esses debates tiveram como principal referência a realização de quatro oficinas de trabalho com ampla participação de agentes públicos e da sociedade, em Brasília e nos três arcos da fronteira terrestre (Norte, Central e Sul, respectivamente Boa Vista/Roraima, Corumbá/Mato Grosso do Sul e Uruguaiana/Rio Grande do Sul). Nessas oficinas, além de convidados especialistas que apresentaram temas candentes na região, houve um espaço dedicado a trabalhos em grupos temáticos para discussão dos principais eventos e fatos que limitam ou favorecem o desenvolvimento da região naquele arco fronteiriço, bem como apontamento de sugestôes e recomendaçôes para políticas públicas e açôes voltadas a enfrentar os problemas da fronteira. Em um espaço dedicado ao debate em sessão plenária, foram aprovadas propostas, sugestôes e encaminhamentos representativos de quem vive o cotidiano da regiâo, seja no papel de gestor, de colaborador ou de cidadão.

Além das oficinas de trabalho, o projeto realizou, complementarmente, visitas técnicas a arranjos transfronteiriços, envolvendo cinco países (Argentina, Bolívia, Guiana, Uruguai e Venezuela), que incluíram entrevistas com profissionais de profundo conhecimento das questóes fronteiriças. A sistematização desse material colhido em campo ofereceu um rico conjunto de informaçóes que permitiram focar a análise nas questóes fundamentais de cada arco da fronteira, assim como relacionar reclamos, sugestôes e recomendaçóes para a adequação das políticas em andamento ou formulação de políticas ajustadas às demandas dessa região. 
A própria concepção de fronteira foi discutida, ou seja, não se trata de uma fronteira, mas de várias, em função da extensão, diversidade e complexidade do território brasileiro. Ademais, postulou-se a necessidade de se considerar, além da fronteira terrestre, a litorânea, nas políticas do governo federal sobre o tema. A partir do exposto, considerou-se necessária, portanto, a elaboração deste livro, de cunho analítico e propositivo, que incorpora as mudanças das informaçóes sobre as fronteiras brasileiras, as concepçóes atuais, os resultados de trabalhos participativos e as proposiçôes resultantes de fóruns locais, bem como dados, mapas e resultados de análises mais recentes.

Entende-se, por fim, que, na perspectiva de formulação de uma política nacional de fronteiras, por parte do governo federal, é imprescindível a existência de referências que, com base nas informações disponíveis e nos anseios dos cidadãos envolvidos, deem suporte ao seu conteúdo, da maneira mais adequada possível à realidade nacional.

\section{Carlos von Doellinger}

Presidente do Ipea

Adriana Melo Alves

Secretária Nacional de Desenvolvimento Regional e Urbano do MDR 


\section{INTRODUÇÃO}

\section{BREVE HISTÓRICO DA PESQUISA}

Em 2016, o Ipea, em parceria com o Ministério da Integraçâo Nacional (MI), atualmente Ministério do Desenvolvimento Regional (MDR), deu início ao projeto A Política Nacional de Desenvolvimento Regional (PNDR) e a Faixa de Fronteira, pesquisa Fronteiras do Brasil: uma avaliação de política pública, cujo objetivo é fazer uma avaliação das políticas públicas ligadas à fronteira brasileira, em geral, e à PNDR em particular. Estudos anteriores realizados no âmbito do governo federal, voltados a subsidiar políticas direcionadas ao desenvolvimento e à integração da faixa de fronteira $(\mathrm{FF})$, foram tomados como pontos de partida a este trabalho. Entre eles, destacam-se, particularmente, os documentos conforme a seguir descritos.

- Programa de Desenvolvimento da Faixa de Fronteira (PDFF): elaborado em 2005 (Brasil, 2005).

- Bases para uma Proposta de Desenvolvimento e Integraçáo da Faixa de Fronteira (BPDIFF): elaboradas pelo Grupo de Trabalho Interfederativo de Integração Fronteiriça (GTIIF), que toma como ponto de partida o PDFF (Brasil, 2010).

- Diagnóstico socioeconômico e demográfico da faixa de fronteira: áreas críticas de segurança pública, elaborado no âmbito da pesquisa Segurança Pública nas Fronteiras, da Secretaria Nacional de Segurança Pública - Senasp (Brasil, 2015).

- Relatório de Pesquisa Municipios de fronteira: mobilidade transfronteiriça, migração, vulnerabilidades e inserção laboral, do projeto MT Brasil - migraçóes transfronteiriças: fortalece a capacidade do governo federal para gerenciar novos fluxos migratórios (ICMPD, 2016).

- Documento elaborado pelos núcleos de fronteira, Fronteira: consolidação dos planos de desenvolvimento e integração das faixas de fronteira (Brasil, 2017), particularmente na seção referente às proposiçóes e nova agenda de pesquisa. 
Como opçáo metodológica para o desenvolvimento do projeto, definiu-se como pressuposto fundamental às atividades o estabelecimento de contato direto com a região e a população fronteiriça, por meio de oficinas de trabalho, visitas técnicas, leituras do espaço, entrevistas, diálogos e debates com agentes públicos, privados e representantes dos vários segmentos da sociedade.

\section{MAPA 1}

Pesquisa fronteiras Ipea - MDR: oficinas realizadas e arranjos transfronteiriços visitados

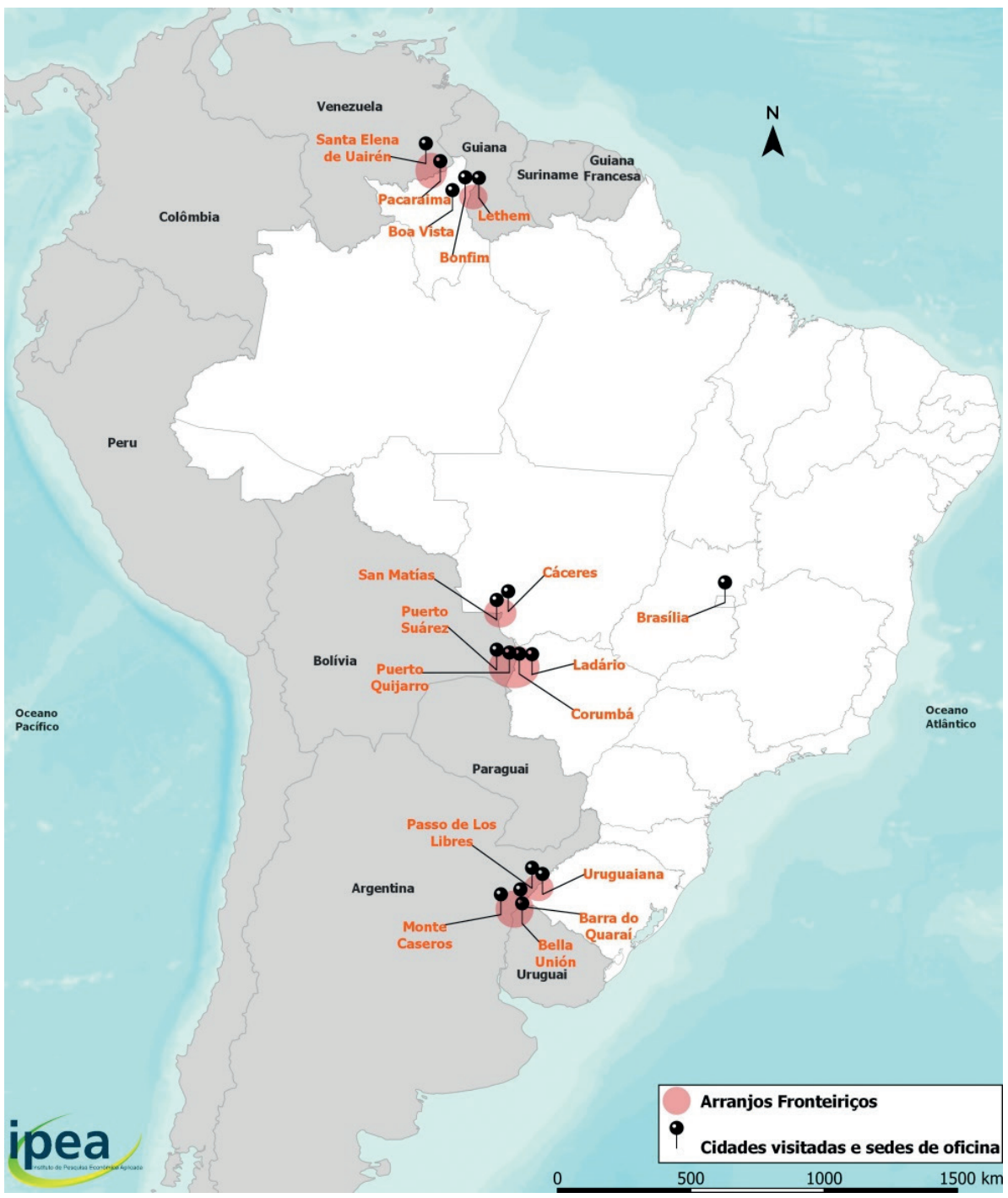

Elaboração: Equipe Fronteiras Ipea.

Obs.: 0 trabalho de Cáceres (Mato Grosso) - San Matías (Bolívia) refere-se ao estudo técnico de cidade gêmea solicitado pelo MDR. 
Foram realizadas quatro oficinas de trabalho, com atores que vivenciam, planejam, formulam programas e desenvolvem ações para o recorte de fronteira. Uma destas aconteceu em âmbito nacional, em Brasília, em junho de 2016, na qual se definiram os alinhamentos norteadores da pesquisa, a partir de um debate amplo sobre a problemática e as dinâmicas socioespaciais da regiáo da fronteira brasileira. As outras três oficinas aconteceram nos arcos: Norte, em Boa Vista (Roraima), em novembro de 2016; Central, em Corumbá (Mato Grosso do Sul), em junho de 2017; e Sul, em Uruguaiana (Rio Grande do Sul), em novembro de 2017 (mapa 1). Nessas oficinas, foram debatidas questóes atuais, necessidades e hipóteses para melhor conhecer a realidade local de cada arco da fronteira, como também analisar e avaliar as políticas públicas em curso e as relaçóes transfronteiriças, como forma de obter subsídios para a melhoria das açôes públicas sobre as fronteiras.

Cabe destacar que a oficina realizada no arco Sul foi precedida de encontros locais preparatórios, como a Reuniâo Trinacional Brasil - Argentina-Uruguai (em Barra do Quaraí, em 24 de agosto de 2017), que se desdobrou em encontros específicos de grupos temáticos em Monte Caseros (Argentina) e Bella Unión (Uruguai). As propostas resultantes foram discutidas e aprovadas no Encontro Trinacional (em Bella Unión, em 28 de setembro de 2017).

Complementarmente às oficinas, foram realizadas visitas técnicas e leituras do espaço em arranjos transfronteiriços, de forma a vivenciar o modo como se dá o controle no passo fronteiriço, bem como entrevistados agentes diretamente envolvidos no trato das questóes fronteiriças, totalizando mais de sessenta entrevistas. Os arranjos transfronteiriços visitados pela equipe foram: Bonfim (Roraima) Lethem (Guiana); Pacaraima (Roraima) - Santa Elena de Uairén (Venezuela); Corumbá - Ladário (Mato Grosso do Sul) - Puerto Quijarro-Puerto Suárez (Bolívia); Uruguaiana (Rio Grande do Sul) - Paso de los Libres (Argentina); e Barra do Quaraí (Rio Grande do Sul) - Bella Unión (Uruguai) - Monte Caseros (Argentina).

Além desses, o arranjo transfronteiriço Cáceres (Mato Grosso) - San Matías (Bolívia) foi objeto de trabalho de campo mais detalhado, em atenção à demanda do então MI, para analisar, diante dos critérios estabelecidos pela Portaria no 213/2016 (Brasil, 2016), se as relaçóes entre esses municípios lhes assegurariam as condiçóes para que Cáceres passasse a compor o elenco das cidades gêmeas, às quais se refere a portaria. O laudo afirmativo foi aprovado pelo MI em novembro de 2018, e a Portaria MDR no 1.080, de 24 de abril de 2019 (Brasil, 2019), como anexo da Portaria no 213/2016, inclui o município no rol das cidades gêmeas brasileiras.

Além das oficinas de trabalho, leituras do espaço de arranjos transfronteiriços e entrevistas a agentes locais e regionais, foram realizados estudos sobre temas específicos, que compreenderam aspectos teórico-conceituais, econômicos, sociais, 
ambientais, financeiros e de governança em relação aos municípios localizados na FF brasileira e seus vizinhos sul-americanos. Esses estudos vieram a compor uma publicação autoral, que integra a série Fronteiras do Brasil (Pêgo e Moura, 2018).

Como evento para discutir os resultados preliminares dessas etapas de trabalho, em 28 e 29 de novembro de 2018, foi realizado, em Brasília, o Seminário Fronteiras Brasileiras em Debate, que culminou com o lançamento dos três primeiros volumes da série: o de cunho autoral (volume 1) e os que dispóem os resultados das oficinas de Brasília e do arco Norte (volumes 2 e 3), respectivamente Pêgo e Moura (2018) e Pêgo et al. (2017; 2018). Também se encontram publicados os resultados das oficinas do arco Central (volume 4 - Pêgo et al., 2019) e do arco Sul (volume 5 - Pêgo et al., 2020). ${ }^{1}$

Salienta-se a eficácia da opção metodológica, por abrir espaço a observaçóes e proposiçóes originais e representativas das demandas das comunidades fronteiriças. Da mesma forma, a escolha dos agentes entrevistados, sempre com respeito a sugestôes obtidas por contatos nas regióes visitadas, assegurou ainda maior sustentaçáo e legitimidade ao elenco de proposiçóes aprovadas pelos participantes. A disponibilidade em publicaçóes da íntegra das palestras, dos debates e das entrevistas, gravadas e transcritas pela equipe Ipea, assim como dos relatórios de leituras do espaço realizadas, garante legitimidade às observaçóes e às proposiçóes colhidas e retrata personagens e momentos históricos da trajetória da pesquisa sobre as fronteiras no Brasil.

\section{MUDANÇAS NA COMPOSIÇÃO DA FAIXA DE FRONTEIRA TERRESTRE}

Outro fato que justificou a realização dessas referências a políticas públicas para a fronteira é o de que as próprias divisas político-administrativas dos municípios brasileiros sofreram ajustes, dado o uso de novas tecnologias de mensuração, o que levou à alteração do rol de municípios integrantes da faixa de fronteira terrestre (FFT), com a supressão de alguns integrantes e a inserção de outros municípios.

Em 2018, o Instituto Brasileiro de Geografia e Estatística (IBGE) divulgou os resultados do redimensionamento da malha municipal brasileira, com mudanças nas áreas de alguns municípios compreendidos na FF. Tais mudanças resultam do conjunto de operaçôes geoespaciais, a partir de mediçôes sobre insumos mais precisos, dada a melhoria das ferramentas de geoprocessamento, que envolveram os contornos dos municípios e das respectivas sedes. As alterações não envolvem quaisquer mudanças na demarcação das fronteiras do Brasil com os países vizinhos.

1. Além dos livros publicados, foram produzidos relatórios institucionais com sínteses das oficinas, disponibilizados artigos entre os Textos para Discussão (TDs), e ensaios que integram o Boletim Regional, Urbano e Ambiental (Brua), todos do Ipea. 


\section{Segundo o IBGE (2018a): ${ }^{2}$}

O referido estudo contempla a Lei no 6.634 , de 2/5/1979, regulamentada pelo Decreto nº 85.064, de 26/8/1980, cujo teor foi ratificado pela Constituição Federal de 1988, no parágrafo segundo do artigo $2^{\circ}$ - Cadastro dos municípios brasileiros com área total ou parcialmente localizada na Faixa de Fronteira, que é a faixa interna de 150 $\mathrm{km}$ de largura, paralela à linha divisória terrestre do território nacional, agregando as informações existentes (código geográfico e nome do município) com as produzidas na identificação e/ou classificação do município dentro da faixa, tais como: fronteiriço, parcial ou totalmente na faixa, referências da sede a linha de fronteira e ao limite da faixa interna.

A relação dos municípios da FF é, portanto, um produto derivado da Malha Municipal Digital do Brasil. Como principais resultados, permanece a identificação de onze Unidades da Federação (UFs) na composição dessa faixa, com 586 municípios, além das áreas de Lagoa dos Patos e Lagoa Mirim - consideradas áreas estaduais operacionais. Desse conjunto, total ou parcialmente afetado, 501 sedes municipais encontram-se dentro da FF e as demais 85 sedes, fora da referida faixa. A área total dessa faixa de $150 \mathrm{~km}$ de largura a partir da linha de fronteira é de $1.415 .611,46 \mathrm{~km}^{2},{ }^{3}$ equivalente a $16,6 \%$ da área total do país. ${ }^{4}$

As unidades político-administrativas do Brasil localizadas na FF

estâo sob as regras de segurança nacional, em especial, no tocante a obras públicas de engenharia civil, participação de estrangeiros em propriedades rurais ou empresas nestas áreas, concessóes de terras e serviços e auxílio financeiro do governo federal; secundariamente, no tocante à gratificaçáo especial de localidade e sujeita a regras especiais de uso do solo, de propriedade e de exploração econômica (IBGE, 2018a).

No âmbito dos municípios inseridos na FF, as mudanças de alguns integrantes merecem destaque. Considerando a relação oficial até então vigente, ${ }^{5}$ a atual lista do IBGE exclui seis municípios do conjunto: Envira e Pauini, do Amazonas; ${ }^{6}$ e Ibirubá, Jari, São Lourenço do Sul e Turuçu, do Rio Grande do Sul - todos por estarem situados fora dos $150 \mathrm{~km}$ estabelecidos para limite de inserção. A nova relação inclui quatro municípios ausentes da relação anterior: Governador Jorge Teixeira, de Rondônia; Ponte Serrada, de Santa Catarina; Nova Alvorada do Sul, de Mato Grosso do Sul; e Sertão, do Rio Grande do Sul (mapa 2).

2. Disponivel em: <https://bit.ly/3jEtiBV>. Acesso em: 18 fev. 2020.

3. É importante salientar que esse cálculo não incorpora a área total dos municípios cortados pela faixa dos $150 \mathrm{~km}$ de largura, mas apenas a área que se insere no interior dessa faixa. Em relação a estudos anteriores, muitos cálculos consideraram a área total dos municípios.

4. Para a superfície do Brasil, foi calculada a área de $8.510 .820,623 \mathrm{~km}^{2}$, publicado no Diário Oficial da União (DOU) № 53, de 19 março de 2019, conforme Resolução oㅜ 1, de 18 de março de 2019.

5. Disponível em: <https://bit.ly/33xMbki>. Acesso em: 18 fev. 2020.

6. Cabe observar que integrantes do Núcleo de Fronteira do Amazonas manifestam a necessidade de se rever essa exclusão, pelo fato de a faixa de fronteira passar pelos cursos d'agua que banham seus limites administrativos. 
MAPA 2

Mudanças na composição da faixa de fronteira terrestre - Brasil (2018)

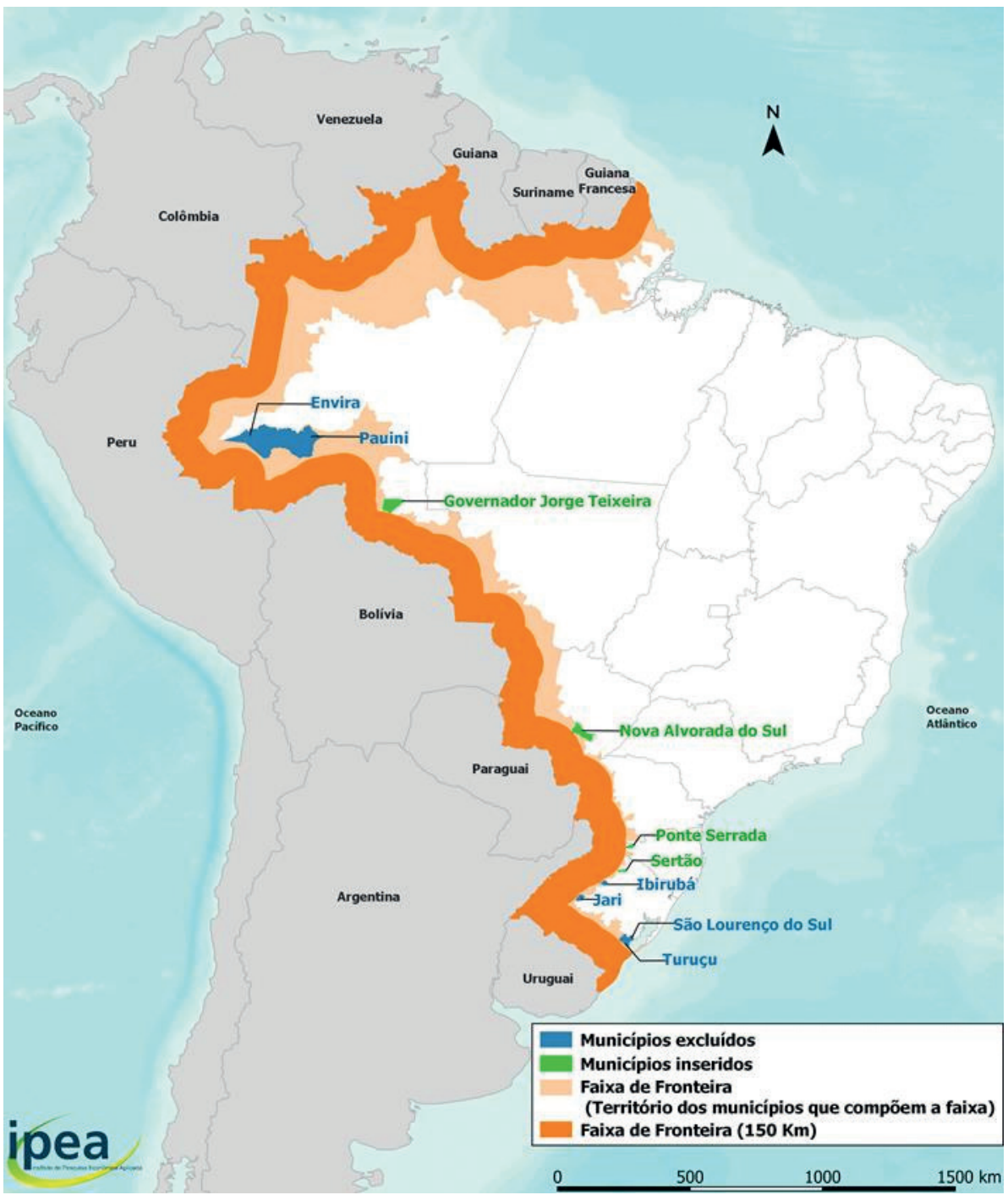

Fonte: IBGE (2018b).

Elaboração: Equipe Fronteiras Ipea.

Enfatiza-se, assim, que, entre os motivos de alteraçóes promovidos na mensuração das superfícies estaduais e municipais, no caso da FF, o principal recai sobre os ajustes e refinamentos cartográficos dos contornos dos polígonos 
estaduais e municipais em virtude de novos insumos cartográficos. ${ }^{7}$ Para efeitos deste trabalho, o estudo assume essa nova composição da FF nas bases de dados e nos cartogramas produzidos.

Ao se redimensionar os municípios inseridos na FFT, abre-se o momento de se aferir como a largura dos $150 \mathrm{~km}$ está favorecendo ou limitando o deslanchar da economia e a segurança na referida faixa, segundo quem nela vive. Nas atividades realizadas nos arcos da fronteira, houve debates bastante polêmicos quanto à manutenção dessa largura, à sua redução ou à adequação da largura às especificidades de cada arco. Apesar das polêmicas, há concordância quanto ao fato de que a faixa de fronteira deve ser redimensionada.

A atual largura funciona como um limitante aos financiamentos e à implantação de determinadas atividades econômicas, sobretudo aos municípios que têm pouca relação com a dinâmica fronteiriça e àqueles que têm percentuais mínimos da superfície territorial dentro dessa faixa, conforme se argumentou no arco Central (Pêgo et al., 2019). A mesma crítica foi retomada no arco Sul, onde se destacaram como limitaçôes impostas por ela: a militarização da região, cabível excepcionalmente em grande parte da região Amazônica; a obrigaçáo de autorizaçóes do Conselho de Defesa Nacional (CDN) para a instalação de empresas estrangeiras ou associadas a empresários locais; a restrição a investimentos estrangeiros e investimentos que possam comprometer a segurança da região; a proibição de aquisição de terras por parte de estrangeiros e relativização do domínio por parte dos proprietários nacionais - limitaçôes que estariam provocando, como consequência, dificuldades no alcance do desenvolvimento econômico e tecnológico (Pêgo et al., 2020).

Apontou-se, como prioritário à FF, um elenco de questôes muito mais urgentes que seu redimensionamento, como o reduzido número de profissionais que atuam na segurança pública ao longo dessa faixa, nos municípios onde a complexidade de contato entre os povos é elevada. Foi solicitada, também, a reciprocidade nos países vizinhos quanto à largura e outras definiçôes, como a faixa de livre comércio e circulação, os acordos bilaterais para controle e fiscalização, assegurando o acesso às principais centralidades fronteiriças, entendidas como cidades conectoras, entre outros (Pêgo e Moura, 2018; Pêgo et al., 2019; 2020).

Como síntese, permaneceram as perguntas: a FF deveria ser mantida apenas para efeito de segurança nacional, liberando-a de restriçóes para que possa fluir o desenvolvimento? Ou deveria se admitir uma nova concepção, com redução na largura, para que seja transformada de uma área de segurança e defesa para uma área de políticas sociais específicas e garantia de mobilidade entre os povos da fronteira?

7. Sobre alterações na malha municipal, ver: <https://bit.ly/3jDecwn>. Acesso em: 20 mar. 2020. 


\section{ESTRUTURA DO TRABALHO}

Este livro, intitulado Fronteiras do Brasil: referências para a formulação de politicas públicas (volume 6), é mais um passo consolidado de uma linha de pesquisa sobre as fronteiras do Brasil e representa uma contribuição ao debate e à formulação de políticas que se ajustem à realidade fronteiriça e transfronteiriça. O documento é composto por nove capítulos. O capítulo 1, esta introdução, faz um breve histórico da pesquisa Fronteiras do Brasil e aborda as mudanças na composiçáo da FFT; o capítulo 2, por sua vez, intitulado Contemporaneidade e marco legal da faixa de fronteira brasileira, apresenta a fundamentação normativa da FF, construção do arcabouço normativo recente para a FF brasileira e a lei de fronteira e suas territoriedades e controvérsias. $\mathrm{O}$ capítulo 3 analisa a FF, destacando a ocupação do território e seus conflitos socioambientais, interaçôes transfronteiriças e relações interfronteiriças. $\mathrm{O}$ capítulo 4 faz uma avaliação das políticas públicas e açóes para a integração e o desenvolvimento e programas voltados à FFT; por sua vez, o capítulo 5 destaca os acordos bilaterais e de cooperação fronteiriça, voltados à integraçáo e ao desenvolvimento dessa FF. O capítulo 6 analisa o modelo de gestão vigente para essa FF, abordando a criação e operacionalização da Comissão Permanente para o Desenvolvimento e Integração da Faixa de Fronteira (CDIF) e a FF, os desafios da CDIF na operacionalizaçáo da governança pública na FF e o diagnóstico e sugestóes. O capítulo 7 apresenta os elementos para uma nova proposta de desenvolvimento e integração fronteiriça, em termos de proposiçóes e da organização de uma agenda de pesquisa sobre o tema, com alguns encaminhamentos no âmbito da formulação de políticas públicas de desenvolvimento e integração e da gestão fronteiriça e transfronteiriça. Adicionalmente, como contribuição ao avanço nos estudos de um tema destacado em todos os arcos, o capítulo 8 agrega uma visão introdutória sobre a fronteira litorânea, sua importância terrestre e marinha, os desafios socioambientais, como também os principais programas voltados a essa fronteira. Finalmente, o capítulo 9 apresenta as consideraçóes finais, destacando-se as principais sugestóes e desafios das fronteiras terrestre e litorânea. Exceto o capítulo 2, que faz um resgate do marco legal sobre a FF, todos os demais privilegiam as observaçôes e proposiçôes dos participantes das atividades desenvolvidas pela pesquisa Fronteiras do Ipea.

Como a essência das referências deste trabalho provém de atividades de campo, mais uma vez se reconhece a contribuição dos participantes em cada etapa da pesquisa, incluindo palestrantes, integrantes de grupos temáticos de trabalho e das plenárias das oficinas, entrevistados, pareceristas e colaboradores, sem os quais esta pesquisa não teria sido concretizada. A eles se renovam os agradecimentos institucionais do Ipea e do MDR e, em particular, de cada membro da equipe da pesquisa. 


\section{REFERÊNCIAS}

BRASIL. Ministério da Integração Nacional. Secretaria de Programas Regionais. Programa de Desenvolvimento da Faixa de Fronteira. Proposta de reestruturaçáo do Programa de Desenvolvimento da Faixa de Fronteira: bases para uma política integrada de desenvolvimento regional para a faixa de fronteira. Brasília: MIR, 2005.

. Ministério da Integração Nacional. Bases para uma proposta de desenvolvimento e integraçáo da faixa de fronteira. Brasília: Grupo de Trabalho Interfederativo de Integração Fronteiriça, 2010.

. Ministério da Justiça; Secretaria Nacional de Segurança Pública, Pesquisa Segurança Pública nas Fronteiras. Diagnóstico socioeconômico e demográfico da faixa de fronteira: áreas críticas de segurança pública. Brasília: MJ; Senasp; Grupo Retis UFRJ, 2015.

. Ministério da Integração Nacional. Portaria no 213, de 19 de julho de 2016. Estabelece o conceito de "cidades gêmeas" nacionais, os critérios adotados para essa definição e lista todas as cidades brasileiras por estado que se enquadram nesta condição. Diário Oficial da União, Brasília, p. 1, 20 jul. 2016. Seção 1. Disponível em: <https://bit.ly/2HU3u6K>. Acesso em: 20 jan. 2020.

. Ministério da Integração Nacional. Fronteira: consolidação dos planos de desenvolvimento e integração das faixas de fronteira. Brasília: MI, 2017.

. Ministério da Integração Nacional. Portaria no 1.080 , de 24 de abril de 2019. Inclui o Município no Anexo da Portaria no 213, de 19 de julho de 2016, que estabelece o conceito de "cidades-gêmeas" nacionais, os critérios adotados para essa definição e lista todas as cidades brasileiras por Estado que se enquadram nesta condição. Diário Oficial da União, Brasília, p. 10, 29 abr. 2019. Disponível em: <https://bit.ly/36AX1YH>. Acesso em: 20 jan. 2020.

IBGE - INSTITUTO BRASILEIRO DE GEOGRAFIA E ESTATÍSTICA. Áreas dos municípios brasileiros. Rio de Janeiro: IBGE, 2018a. Disponível em: <encurtador.com.br/jqG29>. Acesso em: 20 jan. 2020.

. Municípios da faixa de fronteira. IBGE, 2018b. Disponível em: <https:// bit.ly/30FZs8N>. Acesso em: 20 jan. 2020.

ICMPD - INTERNATIONAL CENTRE FOR MIGRATION POLICY DEVELOPMENT. Municípios de fronteira: mobilidade transfronteiriça, migração, vulnerabilidades e inserção laboral - Relatório de Pesquisa do projeto MT Brasil. Migraçóes transfronteiriças. Fortalecendo a capacidade do governo federal para gerenciar novos fluxos migratórios. Viena: ICMPD; União Europeia, 2016. 
PÊGO, B.; MOURA, R. (Orgs.). Fronteiras do Brasil: uma avaliação de política pública. Rio de Janeiro: Ipea; MI, 2018. v. 1.

PÊGO, B. et al. (Orgs.). Fronteiras do Brasil: diagnóstico e agenda de pesquisa para política pública. Brasília: Ipea; MI, 2017. v. 2. 2018. v. 3.

Fronteiras do Brasil: uma avaliação do arco Norte. Brasília: Ipea; MI, Fronteiras do Brasil: uma avaliação do arco Central. Rio de Janeiro: Ipea; MDR, 2019. v. 4.

Fronteiras do Brasil: uma avaliação do arco Sul. Rio de Janeiro: Ipea; MDR, 2020. v. 5. 


\section{CONTEMPORANEIDADE E MARCO LEGAL DA FAIXA DE FRONTEIRA BRASILEIRA}

\section{INTRODUÇÃO}

Por ser considerada uma das áreas estratégicas para o Brasil, a faixa de fronteira (FF) aparece em textos normativos já no Segundo Reinado e nas constituiçóes promulgadas ao longo do período republicano brasileiro, até chegar à atual configuração.

Foi na Lei Imperial no $601 / 1850^{1}$ que o termo "faixa de fronteira" surgiu e passou a ser definido como área geográfica, com regime jurídico particular. $\mathrm{Na}$ lei em questáo, a propriedade da terra na faixa da fronteira estava sujeita a condiçóes diferenciadas das demais partes do território (art. 1o). De acordo com a mesma lei, a faixa de terras (de 10 léguas) que se estendia ao longo do limite internacional poderia ser concedida gratuitamente (Brasil, 2005, p. 174). No fim do século XIX, a Constituiçáo de 1891 estabeleceu no art. 64 que "pertenciam aos estados as terras devolutas situadas nos respectivos territórios, cabendo à União somente a porçáo do território que for indispensável para defesa das fronteiras, fortificaçóes, construções militares e estradas de ferro federais" (Brasil, 1891, art. 64).

Em relação à largura da FF brasileira, nas constituintes seguintes, foi sendo ampliada até a configuraçáo atual. $\mathrm{Na}$ Constituinte de 1930, a largura da faixa passou para a extensão de $100 \mathrm{~km}$, porém nenhuma concessão poderia ser feita acerca das terras fronteiriças para atividades produtivas sem a anuência prévia do Conselho Superior de Segurança Nacional (CSSN). A segurança da fronteira internacional e a incumbência de organizar políticas para tal fim também passaram para a competência da União. Competência que, na Constituição anterior (1891), era delegada ao Congresso Nacional.

O conteúdo da terceira Constituição brasileira (1934) retratou a função da FF no art. 166 e parágrafos, como para servir à "defesa do território nacional" (Brasil, 1934, grifo nosso). Por um lado, a nova redação não mudou os pressupostos levantados nas constituiçóes anteriores, nas quais a área da FF serviria à Força Nacional de Segurança Pública e à manutenção do território nacional, portanto à

1. Lei no 601 , de 18 de setembro de 1850 (Lei de Terras). Dispõe sobre as terras devolutas do Império. Coleção das Leis do Império do Brasil (1808-1889). Disponível na biblioteca da Câmara dos Deputados em: <https://bit.ly/3pHORq4>. Acesso em: 1ำ nov. 2019. 
"segurança nacional” ou à "defesa do território nacional". Por outro lado, deferiu que toda ocupação e utilização de terras na FF teria regulamentação em lei. ${ }^{2}$

$\mathrm{Na}$ Constituição de 1937, as regras para a concessão e utilização da terra na versão anterior foram mantidas. A mudança mais significativa nessa versão foi a ampliação da extensão da largura da FF, que passou para $150 \mathrm{~km}$. Em 1939, foi criada uma comissão para revisar a concessão de terras na FF brasileira e instalação de empresas das atividades desenvolvidas, implantação de vias de transportes e redes de comunicação. ${ }^{3}$

$\mathrm{Na}$ Constituição de $1946,{ }^{4}$ foram mantidos critérios estabelecidos, como a manutençâo das zonas indispensáveis à defesa nacional, e foi definido o Conselho de Segurança Nacional a declarar bases ou portos militares de excepcional importância para a defesa externa do país (Brasil, 1946). Outras legislações, como a Lei $\mathrm{n}^{\circ} 2.597 / 1955^{5}$ (revogada pela Lei $\mathrm{n}^{\circ}$ 6.634/1979), asseveraram o recorte da fronteira como zonas indispensáveis à segurança nacional, sendo mantida a extensão da largura em $150 \mathrm{~km}$ e criada a ferramenta de auxílio aos municípios circunscritos na faixa. A mesma lei (no 2.597/1955) contribuiu para a criaçáo e implementação das colônias militares (Brasil, 2010), tendo como linhas de ação ampliar o adensamento humano na fronteira e minimizar a atitude negligente dos governos estaduais em relação aos municípios fronteiriços.

$\mathrm{Na}$ Constituição Federal de 1967, o tema continuava a ser regido pela Lei no $2.597 / 1955$, revogada pela Lei no 6.634 , de 2 de maio de $1979,{ }^{6}$ principal referência jurídica sobre a FF, ainda no período atual. Entre as mudanças mais imediatas que a lei imprimiu, foi passar a gestão das questóes fronteiriças à Secretaria Geral do Conselho de Segurança Nacional (SG/CSN).

A atual Carta Magna, de 1988, não trouxe alteraçóes significativas para a matéria. A questão fronteiriça aparece em cinco artigos e sem alteraçôes de normas já estabelecidas por lei, como no que envolve as terras devolutas, e os 150 $\mathrm{km}$ de largura, que foram reforçados no art. 20. O art. 91 propóe critérios para a utilização e o uso da área de fronteira, delegando ao Conselho de Defesa Nacional (CDN), órgáo de consulta da Presidência da República (PR), a função de autorizar e estabelecer critérios relativos à preservação e à exploração dos recursos naturais.

2. No que se refere ao uso e à ocupação da $\mathrm{FF}$, tanto a propriedade pública, quanto a propriedade privada estão sujeitas a restrições.

3. Ver Decreto-lei no 1.968/1940, que regula as concessões de terras e vias de comunicação, bem como o estabelecimento de indústrias na FF.

4. Art. 34 Incluem-se entre os bens da União: II - a porção de terras devolutas indispensável à defesa das fronteiras, às fortificações, construções militares e estradas de ferro.

5. Art. 20 É considerada zona indispensável à defesa do país a faixa interna de 150 (cento e cinquenta) km de largura, paralela à linha divisória do território nacional, cabendo à União sua demarcação.

6. Dispõe sobre a FF e altera o Decreto-lei № 1.135, de 3 de dezembro de 1970, e dá outras providências. 
Essa parte do levantamento apoiou-se em várias publicaçóes e pesquisas realizadas. Entre elas, destacam-se a Proposta de reestruturação do Programa de Desenvolvimento da Faixa de Fronteira: bases para uma política integrada de desenvolvimento regional para a faixa de fronteira (Brasil, 2005); Bases para uma Proposta de Desenvolvimento e Integração da Faixa de Fronteira (Brasil, 2010); estudos legislativos sobre o tema, realizados por consultorias especializadas da Câmara Federal, ${ }^{7}$ pareceres de legisladores sobre algumas propostas que tinham como objetivo alterar o texto da lei da fronteira, e publicação dos resultados do seminário Faixa de fronteira: novos paradigmas (Brasil, 2004), trabalho do Gabinete de Segurança Institucional (GSI), vinculado à PR.

\section{FUNDAMENTAÇÃO NORMATIVA DA FAIXA DE FRONTEIRA}

Atualmente, a base normativa constitucional da FF se assenta na redação da Carta Magna de 1988, que pacifica a largura da FF, condiciona o uso e a ocupação da terra e a exploração econômica ao crivo dos órgãos e das entidades responsáveis pela fiscalização na área de fronteira (Brasil, 1979).

Na Constituição Federal de 1988 (CF/1988), a matéria encontra-se no Título III, que trata da Organização do Estado, capítulo II - da União: ${ }^{8}$

Art. 20 São bens da União:

$\$ 2$ $\mathrm{A}$ faixa de até cento e cinquenta quilômetros de largura, ao longo das fronteiras terrestres, designada como faixa de fronteira, é considerada fundamental para defesa do território nacional, e sua ocupação e utilização serão reguladas em lei.

Art. 21 Compete à União:

XII - explorar, diretamente ou mediante autorização, concessão ou permissão: (...) d) os serviços de transporte ferroviário e aquaviário entre portos brasileiros e fronteiras nacionais, ou que transponham os limites de Estado ou território; (...)

XXII - executar os serviços de polícia marítima, aeroportuária e de fronteiras; (Redação dada pela Emenda Constitucional no 19, de 1998).

(...)

7. Estudos e notas técnicas. Disponíveis em: <https://bit.ly/3jprbqy>. Acesso em: 18 nov. 2019.

8. A fronteira aparece como bens da União em outros itens da redação do art. 20 da CF/1988:

" $\|$ - as terras devolutas indispensáveis à defesa das fronteiras, das fortificações e construções militares, das vias federais de comunicação e à preservação ambiental, definidas em lei;

III - os lagos, rios e quaisquer correntes de água em terrenos de seu domínio, ou que banhem mais de um Estado, sirvam de limites com outros países, ou se estendam a território estrangeiro ou dele provenham, bem como os terrenos marginais e as praias fluviais; e

IV - as ilhas fluviais e lacustres nas zonas limítrofes com outros países; as praias marítimas; as ilhas oceânicas e as costeiras, excluídas, destas, as que contenham a sede de Municípios, exceto aquelas áreas afetadas ao serviço público e a unidade ambiental federal, e as referidas no art. 26, II; (Inciso com redação dada pela Emenda Constitucional no 46, de 2005)" (Brasil, 1988). 
Título IV - da organização dos poderes, capítulo II - do Poder Executivo, seção V do Conselho da República e do Conselho de Defesa Nacional, subseção II - do Conselho de Defesa Nacional:

Art. 91 O Conselho de Defesa Nacional é órgão de consulta do Presidente da República nos assuntos relacionados com a soberania nacional e a defesa do Estado democrático, e dele participam como membros natos: (...) $\$ 1$ 을 Compete ao Conselho de Defesa Nacional: (...) III - propor os critérios e condiçóes de utilização de áreas indispensáveis à segurança do território nacional e opinar sobre seu efetivo uso, especialmente na faixa de fronteira e nas relacionadas com a preservação e a exploração dos recursos naturais de qualquer tipo;

\section{(...)}

Título V - da defesa do Estado e das instituiçóes democráticas, Capítulo III - da segurança pública:

Art. 144 A segurança pública, dever do Estado, direito e responsabilidade de todos, é exercida para a preservação da ordem pública e da incolumidade das pessoas e do patrimônio, por meio dos seguintes órgãos: (...) $\$$ 1 A Polícia Federal, instituída por lei como órgão permanente, organizado e mantido pela União e estruturado em carreira, destina-se a: (Redação dada pela Emenda Constitucional no 19, de 1998) (...) III - exercer as funçōes de polícia marítima, aeroportuária e de fronteiras; (Redação dada pela Emenda Constitucional no 19, de 1998).

\section{(...)}

Título VII - da ordem econômica e financeira, capítulo I - dos princípios gerais da atividade econômica:

Art. 176 As jazidas, em lavra ou não, e demais recursos minerais e os potenciais de energia hidráulica constituem propriedade distinta da do solo, para efeito de exploração ou aproveitamento, e pertencem à União, garantida ao concessionário a propriedade do produto da lavra.

$\$ 1$ o A pesquisa e a lavra de recursos minerais e o aproveitamento dos potenciais a que se refere o "caput" deste artigo somente poderão ser efetuados mediante autorização ou concessão da União, no interesse nacional, por brasileiros ou empresa constituída sob as leis brasileiras e que tenha sua sede e administração no país, na forma da lei, que estabelecerá as condiçôes específicas quando essas atividades se desenvolverem em faixa de fronteira ou terras indígenas (Redação dada pela Emenda Constitucional $\mathrm{n}$ o 6, de 1995) (Brasil, 1988).

A principal lei infraconstitucional para a fronteira brasileira fixa a largura da FF em 150 km (Lei no 6.634/1979 - Lei de Fronteira). Apesar de ter sido elaborada em período de governos militares, os termos trazidos na CF/1988 dialogaram com a norma que já se encontrava implementada, inclusive tornando constitucionais pontos caros aos setores da segurança e 
defesa, como a manutençáo da largura da FF e regulaçáo de algumas atividades estratégicas do recorte, conforme descrito a seguir.

1) Lei no 6.634, de 2 de maio de 1979: dispóe sobre a faixa de fronteira, altera o Decreto-lei no 1.135, de 3 de dezembro de 1970, e dá outras providências:

Art. 1 É considerada área indispensável à Segurança Nacional a faixa interna de 150 (cento e cinquenta) $\mathrm{km}$ de largura, paralela à linha divisória terrestre do território nacional, que será designada como Faixa de Fronteira.

Art. $2^{\circ}$ Relaciona atividades que devem passar ao crivo do assentimento prévio para se desenvolverem na área da faixa.

2) Decreto no 85.064, de 26 de agosto de 1980: regulamenta a Lei no 6.634/1979, que dispóe sobre a faixa de fronteira: este regulamento estabelece procedimentos a serem seguidos para a prática de atos que necessitem de assentimento prévio.

3) Lei no 13.844 , de 18 de junho de 2019:9 dispóe sobre a organização da Presidência da República e dos ministérios, e dá outras providências:

Art. 19 Relaciona os ministérios: Ministério do Desenvolvimento Regional (MDR).

Art. 29 Constitui área de competência do Ministério do Desenvolvimento Regional: (...) IX - a Câmara de Políticas de Integração Nacional e Desenvolvimento Regional.

4) Atribuições das Forças Armadas (FA) - Lei Complementar (LC) no 97/1999, ${ }^{10}$ arts. 16 a 18, com alterações na $\mathrm{LC}$ no 117/2004 e inclusōes na $\mathrm{LC} \mathrm{n}^{\mathrm{0}}$ 136/2010 - açóes subsidiárias das FA:

a) atuar, por meio de açóes preventivas e repressivas, na faixa de fronteira terrestre (FFT), isoladamente ou em coordenação com outros órgãos do Poder Executivo, executando, dentre outras, as ações de:

- patrulhamento;

- revista de pessoas, veículos terrestres, embarcaçóes e aeronaves; e

- $\quad$ prisóes em flagrante delito.

9. A Lei no 13.844, de 18 de junho de 2019, revoga a Lei no 10.683, de 28 de maio de 2003, que definia o Ministério da Integração Nacional (MI), atualmente Ministério do Desenvolvimento Regional (MDR), como tutelar das questões fronteiriças. Entretanto, ao contrário da antiga estrutura ministerial que especificava a atuação e as responsabilidades no recorte fronteiriço (obras públicas em faixas de fronteiras), na redação do decreto em vigor, não há especificação da responsabilização do ministério sob a faixa de fronteira. Disponível em: <https://bit.ly/3joc4l7>. Acesso em: 3 nov. 2019. 10. Dispõe sobre normas gerais para a organização, o preparo e o emprego das Forças Armadas, trata das ações subsidiárias das Forças Armadas, no que abarca a ações de segurança pública na FF. Disponível em: <https://bit. ly/3dPcQwF>. Acesso em: 3 nov. 2019. 


\section{CONSTRUÇÃO DO ARCABOUÇO NORMATIVO RECENTE PARA A FAIXA DE FRONTEIRA BRASILEIRA}

O levantamento da regulamentação vigente na FF compreende o período 20092018 e se baseia em publicaçôes anteriores sobre planejamento e avaliação de políticas públicas para a regiāo, como a Proposta de Reestruturação do Programa de Desenvolvimento da Faixa de Fronteira - PDFF (Brasil, 2005) e Bases para uma proposta de desenvolvimento e integração da faixa de fronteira (Brasil, 2010).

O PDFF relacionou todos os diplomas que regulavam a matéria, a partir da institucionalização da Lei no 6.634/1979 (Lei de Fronteira), até 2003. A segunda publicação, Bases para uma proposta de desenvolvimento e integração da faixa de fronteira, levantou as proposições normativas por temáticas, reunindo informaçóes até 2008.

Em termos de temas tratados nas duas Casas Legislativas, conjuntamente às medidas do Executivo, há que se destacar a retomada da temática de segurança pública e controle das fronteiras em detrimento de matérias que envolviam o desenvolvimento regional e bem-estar social (integração e cidadania), buscado ao longo da década de 2000. Na relação atual, tais temas (integração e cidadania) aparecem mais em atos internacionais ${ }^{11}$ (binacional e/ou multilateral) que já se encontravam acordados ou mesmo em negociação em anos anteriores (tabela 1).

TABELA 1

Síntese das normas vigentes (2009-2018)

\begin{tabular}{lc}
\hline Temas & Quantidade \\
\hline Cidadania & 10 \\
Segurança e defesa & 10 \\
Desenvolvimento regional & 9 \\
Infraestrutura & 6 \\
Fundiário & 6 \\
Institucional & 6 \\
Vigilância sanitária & 2 \\
Meio ambiente & 1 \\
Total & $\mathbf{5 0}$ \\
\hline
\end{tabular}

Fontes: Portal da Legislação, disponível em: <https://bit.ly/37H3mT9>; Rede de Informação Legislativa e Jurídica (LEXML), disponível em: <https://bit.ly/36BRJLN>; Atividade Legislativa - Câmara dos Deputados, disponível em: <https://bit. ly/3ea5vbj>. Acessos em: 10 nov. 2019.

Elaboração: Equipe Fronteiras Ipea.

O alinhamento do Estado às políticas públicas, com acentuado conteúdo de segurança e controle, tem ganhado relevo nas matérias vinculadas à FF, produzidas

11. Denominação dada pelo site do Senado Federal, em atenção à natureza da matéria. 
no período 2009-2018. Como observado na tabela 1, as principais modificaçóes se materializaram por meio de decretos alinhados a programas de governo e alguns decretos legislativos emitidos para atender a fins específicos, dada sua peculiaridade no conjunto do regramento jurídico brasileiro.

Para análise dos temas da legislação, o PDFF (Brasil, 2005) dividiu os temas em: institucional (militar e civil); desenvolvimento econômico (infraestrutura, vigilância sanitária de fronteira, fundiário); e ambiente e cidadania. A publicação do Grupo de Trabalho Interfederativo de Integração Fronteiriça, Bases para uma proposta de desenvolvimento e integração da faixa de fronteira (Brasil, 2010), utilizou-se dos mesmos temas. O levantamento realizado neste trabalho das matérias normativas vigentes foi organizado sob os mesmos temas, por ordem cronológica, relacionando as seguintes informações: descrição da ementa, instrumento/número e data (quadro 1).

\section{QUADRO 1}

\section{Relação da legislação em vigência (2009-2018)}

\begin{tabular}{|c|c|c|}
\hline Descrição da ementa & $\begin{array}{l}\text { Instrumento e } \\
\text { número }\end{array}$ & Data \\
\hline $\begin{array}{l}\text { Declara a revogação de feitos, para os fins do art. } 16 \text { da LC no 95, de } 26 \text { de fevereiro de 1998, de } \\
\text { decretos relativos ao emprego das FA. }\end{array}$ & Decreto no 9.623 & $20 / 12 / 2018$ \\
\hline $\begin{array}{l}\text { Regulamenta a Lei no } 11.952 \text {, de } 25 \text { de junho de 2009, para dispor sobre a regularização fundiária das } \\
\text { áreas rurais, e dá outras providências. }\end{array}$ & Decreto n 9.309 & $15 / 3 / 2018$ \\
\hline $\begin{array}{l}\text { Reconhece a situação de vulnerabilidade decorrente de fluxo migratório provocado por crise hu- } \\
\text { manitária na República Bolivariana da Venezuela. Norma complementar do Decreto no 9.970/2019 } \\
\text { que revogou o Decreto no } 9.286 \text {, de } 15 \text { de fevereiro de } 2018 \text {. }\end{array}$ & Decreto no 9.285 & $15 / 2 / 2018$ \\
\hline $\begin{array}{l}\text { Promulga o Acordo-Quadro sobre Cooperação em Matéria de Defesa entre o Governo da República } \\
\text { Federativa do Brasil e o Governo da República do Paraguai, firmado em Assunção, em } 21 \text { de maio } \\
\text { de } 2007 .\end{array}$ & Decreto no 9.318 & $20 / 3 / 2018$ \\
\hline $\begin{array}{l}\text { Promulga o acordo entre o governo da República Federativa do Brasil e o governo da República } \\
\text { do Paraguai para a construção de uma ponte rodoviária internacional sobre o rio Paraguai entre } \\
\text { as cidades de Porto Murtinho e Carmelo Peralta, firmado em Brasília, em } 8 \text { de junho de } 2016 \text {. } \\
\text { Correlação Decreto Legislativo (DLG) no 110/2018. }\end{array}$ & Decreto no 9.471 & $14 / 8 / 2018$ \\
\hline $\begin{array}{l}\text { Altera o Decreto no } 6.956 \text {, de } 9 \text { de setembro de 2009, que regulamenta o disposto na Lei no } 11.898 \text {, } \\
\text { de } 8 \text { de janeiro de 2009, que dispõe sobre o Regime de Tributação Unificada na importação, por } \\
\text { via terrestre, de mercadorias procedentes do Paraguai. }\end{array}$ & Decreto no 9.525 & $15 / 10 / 2018$ \\
\hline $\begin{array}{l}\text { Altera a Instrução Normativa (IN) RFB no } 1.799 \text {, de } 16 \text { de março de 2018, que estabelece normas } \\
\text { complementares à Portaria MF n- 307, de } 17 \text { de julho de 2014, a qual dispõe sobre a aplicação do } \\
\text { regime aduaneiro especial de loja franca em fronteira terrestre. }\end{array}$ & IN/RFB no $1.866^{1}$ & $27 / 12 / 2018$ \\
\hline $\begin{array}{l}\text { Altera a IN da Secretaria da Receita Federal (SRF) no 121, de } 11 \text { de janeiro de 2002, a IN SRF no } \\
369 \text {, de } 28 \text { de novembro de 2003, a IN RFB no } 1.799 \text {, de } 16 \text { de março de 2018, e a IN no } 863 \text {, de } \\
17 \text { de julho de } 2008 \text {. }\end{array}$ & IN/RFB no $1.849^{2}$ & $28 / 11 / 2018$ \\
\hline Institui a Lei de Migração, regulamentada pelo Decreto no 9.199/2017. & Lei no 13.445 & $24 / 5 / 2017$ \\
\hline $\begin{array}{l}\text { Promulga o acordo entre o governo da República Federativa do Brasil e o governo da República } \\
\text { francesa referente ao transporte rodoviário internacional de passageiros e de cargas, firmado em } \\
\text { Paris, em } 19 \text { de março de } 2014 \text {. }\end{array}$ & Decreto no 8.964 & $18 / 1 / 2017$ \\
\hline $\begin{array}{l}\text { Aprova o texto do acordo para integração fronteiriça entre a República Federativa do Brasil e a } \\
\text { República do Peru na área de telecomunicações, assinado em Lima, em } 11 \text { de novembro de } 2013 \text {. } \\
\text { Promulgado pelo Decreto no 9.996, de } 29 \text { de agosto de } 2019 \text {. }\end{array}$ & $\mathrm{DLG} n \cong 87$ & $14 / 6 / 2017$ \\
\hline
\end{tabular}


(Continuação)

\begin{tabular}{|c|c|c|}
\hline Descrição da ementa & $\begin{array}{l}\text { Instrumento e } \\
\text { número }\end{array}$ & Data \\
\hline $\begin{array}{l}\text { Promulga o acordo entre o governo da República Federativa do Brasil e o governo da República } \\
\text { francesa para o estabelecimento de regime especial transfronteiriço de bens de subsistência entre } \\
\text { as localidades de Oiapoque (Brasil) e St. Georges de I'Oyapock (França), firmado em Brasília, em } \\
30 \text { de julho de } 2014 \text {. }\end{array}$ & Decreto no 8.960 & $16 / 1 / 2017$ \\
\hline $\begin{array}{l}\text { Promulga o acordo entre o governo da República Federativa do Brasil e o governo da República } \\
\text { francesa relativo à cooperação transfronteiriça em matéria de socorro de emergência, celebrado } \\
\text { em Paris, em } 11 \text { de dezembro de } 2012 \text {. Aprovado DLG № 166/2015. }\end{array}$ & Decreto $n^{\circ} 8.959$ & $16 / 1 / 2017$ \\
\hline $\begin{array}{l}\text { Regulamenta a Lei no } 12.855 \text {, de } 2 \text { de setembro de 2013, que institui a indenização devida à } \\
\text { ocupante de cargo efetivo das carreiras e planos vinculados à prevenção, ao controle, à fiscaliza- } \\
\text { ção e repressão dos delitos transfronteiriços. Carreiras e cargos: departamento de Polícia Federal; } \\
\text { auditoria-fiscal do trabalho; auditor fiscal federal agropecuário; Polícia Rodoviária Federal (PRF); } \\
\text { e Ministério da Fazenda. }\end{array}$ & $\begin{array}{r}\text { Decreto nos } \\
9.224 ; 9.225 ; \\
9.226 ; 9.227 \\
9.228\end{array}$ & $6 / 12 / 2017$ \\
\hline $\begin{array}{l}\text { Revoga o Decreto no } 9.147 \text {, de } 28 \text { de agosto de 2017, e revigora decretos nos } 84.404 / 1984 \text { e } \\
\text { 92.107/1985, que dispõem sobre a Reserva Nacional de Cobre e seus Associados (Renca), e dá } \\
\text { outras providências. }\end{array}$ & Decreto no 9.159 & 25/9/2017 \\
\hline $\begin{array}{l}\text { Promulga o acordo entre a República Federativa do Brasil e a República Oriental do Uruguai sobre } \\
\text { residência permanente com o objetivo de alcançar a livre circulação de pessoas, firmado em Brasilia, } \\
\text { em } 9 \text { de julho de 2013. Aprovado DLG no 152/2016. }\end{array}$ & Decreto no 9.089 & $6 / 7 / 2017$ \\
\hline $\begin{array}{l}\text { Promulga o acordo-quadro entre o governo da República Federativa do Brasil e o governo da Re- } \\
\text { pública Oriental do Uruguai para intercâmbio de informações e cooperação em segurança pública, } \\
\text { firmado em Montevidéu, em } 30 \text { de maio de } 2011 \text {. }\end{array}$ & Decreto no 9.096 & $18 / 7 / 2017$ \\
\hline $\begin{array}{l}\text { Promulga o memorando de entendimento entre o governo da República Federativa do Brasil, o } \\
\text { governo da República da Colômbia e o governo da República do Peru para combater as atividades } \\
\text { ilícitas nos rios fronteiriços ou comuns, firmado em Letícia, em } 20 \text { de julho de } 2008 \text {. Aprovado } \\
\text { pelo DLG no 388/2013. }\end{array}$ & Decreto no 8.698 & $28 / 3 / 2016$ \\
\hline $\begin{array}{l}\text { Promulga o acordo entre a República Federativa do Brasil e a República Argentina sobre localidades } \\
\text { fronteiriças vinculadas, firmado em Puerto Iguazú, em } 30 \text { de novembro de 2005. Aprovado DLG } \\
\text { no } 145 / 2011 \text {. }\end{array}$ & Decreto no 8.636 & $13 / 1 / 2016$ \\
\hline $\begin{array}{l}\text { Institui o Programa de Proteção Integrada de Fronteiras (PPIF) e organiza a atuação de unidades } \\
\text { da administração pública federal para sua execução. Revogou o Decreto no } 7.496 \text {, de } 8 \text { de junho } \\
\text { de } 2011 \text {, que "Institui o Plano Estratégico de Fronteiras". O Decreto nº 7.638, de } 8 \text { de dezembro } \\
\text { de } 2011 \text {, o alterava. }\end{array}$ & Decreto no 8.903 & $16 / 11 / 2016$ \\
\hline $\begin{array}{l}\text { Promulga o memorando de entendimento entre a República Federativa do Brasil e a República da } \\
\text { Colômbia para a Cooperação no Combate da Fabricação e Tráfico llícitos de Armas de Fogo, Munições, } \\
\text { Acessórios, Explosivos e Outros Materiais Relacionados, firmado em Bogotá, em } 19 \text { de julho de } 2008 .\end{array}$ & Decreto no 8.603 & $18 / 12 / 2015$ \\
\hline $\begin{array}{l}\text { Promulga o acordo entre o governo da República Federativa do Brasil e o governo da República da } \\
\text { Colômbia, para o estabelecimento da zona de regime especial fronteiriço para as localidades de } \\
\text { Tabatinga, Brasil, e Letícia, Colômbia, firmado em Bogotá, em } 19 \text { de setembro de 2008. Aprovado } \\
\text { DLG no } 280 / 2010 \text {. }\end{array}$ & Decreto $n^{\circ} 8.596$ & $18 / 12 / 2015$ \\
\hline $\begin{array}{l}\text { Promulga o acordo entre o governo da República Federativa do Brasil e o governo da República } \\
\text { Oriental do Uruguai para a criação de escolas e/ou institutos binacionais fronteiriços profissionais } \\
\text { e/ou técnicos e para o credenciamento de cursos técnicos binacionais fronteiriços, firmado em } \\
\text { Brasília, em 10 de abril de 2005. Aprovado DLG no } 804 / 2010 \text {. }\end{array}$ & Decreto no 8.455 & $20 / 5 / 2015$ \\
\hline $\begin{array}{l}\text { Promulga o acordo entre a República Federativa do Brasil e a República Oriental do Uruguai sobre } \\
\text { transporte fluvial e lacustre na hidrovia Uruguai-Brasil, firmado em Santana do Livramento, em } 30 \\
\text { de julho de } 2010 \text {. Aprovado DLG n 305/2013. }\end{array}$ & Decreto $n^{\circ} 8.548$ & $23 / 10 / 2015$ \\
\hline $\begin{array}{l}\text { Dispõe sobre a ratificação dos registros imobiliários decorrentes de alienações e concessões de } \\
\text { terras públicas situadas nas faixas de fronteira; e revoga o Decreto-lei no } 1.414 \text {, de } 18 \text { de agosto } \\
\text { de } 1975 \text {, e a Lei no } 9.871 \text {, de } 23 \text { de novembro de } 1999 \text {. }\end{array}$ & Lei no 13.178 & $22 / 10 / 2015$ \\
\hline
\end{tabular}


(Continuação)

\begin{tabular}{|c|c|c|}
\hline Descrição da ementa & $\begin{array}{l}\text { Instrumento e } \\
\text { número }\end{array}$ & Data \\
\hline $\begin{array}{l}\text { Promulga o protocolo adicional ao acordo de parceria e cooperação entre o governo da República } \\
\text { Federativa do Brasil e o governo da República Francesa com vistas à criação de um centro de } \\
\text { cooperação policial, firmado em Braślia, em } 7 \text { de setembro de 2009. Aprovado em } 2011 .\end{array}$ & Decreto $n^{\circ} 8.344$ & $13 / 11 / 2014$ \\
\hline $\begin{array}{l}\text { Promulga o Acordo para a Construção de uma Segunda Ponte Internacional sobre o rio Jaguarão, } \\
\text { nas proximidades das cidades de Jaguarão e Rio Branco, entre o governo da República Federativa } \\
\text { do Brasil e o governo da República Oriental do Uruguai, firmado em San Juan de Achorena, Colônia, } \\
\text { em } 26 \text { de fevereiro de } 2007 \text {. }\end{array}$ & Decreto $n \cong 7.900$ & $4 / 2 / 2013$ \\
\hline $\begin{array}{l}\text { Promulga o Acordo sobre Tráfico llícito de Migrantes entre os Estados-Parte do Mercosul, firmado } \\
\text { em Belo Horizonte, em } 16 \text { de dezembro de 2004, com as correções contidas do texto da Fé de } \\
\text { Erratas ao Acordo, firmado em } 28 \text { de junho de } 2007 \text {. }\end{array}$ & Decreto $n-7.953$ & $12 / 3 / 2013$ \\
\hline $\begin{array}{l}\text { Altera o Decreto no } 6.759 \text {, de } 5 \text { de fevereiro de } 2009 \text {, que regulamenta a administração das } \\
\text { atividades aduaneiras, a fiscalização, o controle e a tributação das operações de comércio exterior. }\end{array}$ & Decreto $n=8.010$ & $16 / 5 / 2013$ \\
\hline $\begin{array}{l}\text { Institui indenização devida à ocupante de cargo efetivo das carreiras e planos especiais de cargos que } \\
\text { especifica, em exercício nas unidades situadas em localidades estratégicas vinculadas à prevenção, } \\
\text { ao controle, à fiscalização e à repressão dos delitos transfronteiriços. }\end{array}$ & Lei $n^{0} 12.855$ & $2 / 9 / 2013$ \\
\hline $\begin{array}{l}\text { Dispõe sobre a fiscalização e o controle aduaneiros relativos ao comércio de subsistência em } \\
\text { localidades fronteiriças onde não existem pontos de fronteira alfandegados. }\end{array}$ & IN/RFB no 1.413 & $28 / 11 / 2013$ \\
\hline $\begin{array}{l}\text { Promulga o acordo entre o governo da República Federativa do Brasil e o governo da República da } \\
\text { Bolívia para a construção de uma ponte internacional sobre o Igarapé Rapirrã entre as cidades de } \\
\text { Plácido de Castro e Montevidéu, firmado em La Paz, em } 17 \text { de dezembro de } 2007 .\end{array}$ & Decreto $n^{0} 7.761$ & $19 / 6 / 2012$ \\
\hline $\begin{array}{l}\text { Altera o Decreto-lei no } 1.455 \text {, de } 7 \text { de abril de 1976, e passa a autorizar a instalação de lojas } \\
\text { francas em municípios da faixa de fronteira cujas sedes se caracterizam como cidades gêmeas de } \\
\text { cidades estrangeiras. }\end{array}$ & Lei no 12.723 & $9 / 10 / 2012$ \\
\hline $\begin{array}{l}\text { Promulga o acordo entre a República Federativa do Brasil e o Reino da Espanha, relativo ao } \\
\text { estabelecimento e funcionamento de centros culturais, firmado em Madri, em } 17 \text { de setembro de } \\
\text { 2007. Aprovado DLG em } 2009 \text {. }\end{array}$ & Decreto $n=7.842$ & $12 / 11 / 2012$ \\
\hline $\begin{array}{l}\text { Promulga o acordo, por troca de notas, para o estabelecimento de uma faixa non aedificandi em } \\
\text { zonas urbanas entre o governo da República Federativa do Brasil e o governo da República do } \\
\text { Paraguai, firmado em Assunção, em } 9 \text { de abril de 2008. Aprovado DLG no 594/2009. }\end{array}$ & Decreto $n \cong 7.763$ & $19 / 6 / 2012$ \\
\hline $\begin{array}{l}\text { Aprova o texto do acordo entre o governo da República Federativa do Brasil e o governo da República } \\
\text { da Guiana para o estabelecimento de regime especial fronteiriço e de transporte para as localidades } \\
\text { de Bonfim (Brasil) e de Lethem (Guiana), assinado em Bonfim-RR, em } 14 \text { de setembro de } 2009 .\end{array}$ & DLG no 358 & $13 / 12 / 2011$ \\
\hline $\begin{array}{l}\text { Promulga a Decisão do Conselho do Mercado Comum (CMC) no 33/2004, que cria o Fundo de } \\
\text { Financiamento do Setor Educacional do Mercosul (FEM), aprovada em Belo Horizonte, em } 16 \text { de } \\
\text { dezembro de } 2004 \text {. }\end{array}$ & Decreto no 7.484 & $18 / 5 / 2011$ \\
\hline $\begin{array}{l}\text { Altera e acresce dispositivos ao Decreto no } 6.759 \text {, de } 5 \text { de fevereiro de } 2009 \text {, que regulamenta a } \\
\text { administração das atividades aduaneiras, a fiscalização, o controle e a tributação das operações } \\
\text { de comércio exterior. }\end{array}$ & Decreto $n-7.213$ & $15 / 6 / 2010$ \\
\hline $\begin{array}{l}\text { Promulga o Acordo de Livre Comércio entre o Mercosul e o Estado de Israel, assinado em Monte- } \\
\text { vidéu, em } 18 \text { de dezembro de } 2007 .\end{array}$ & Decreto no 7.159 & $27 / 4 / 2010$ \\
\hline $\begin{array}{l}\text { Dispõe sobre a criação da Universidade Federal da Integração Latino-Americana (Unila) e dá } \\
\text { outras providências. }\end{array}$ & Lei no 12.189 & $12 / 1 / 2010$ \\
\hline $\begin{array}{l}\text { Regulamenta a Lei no } 11.952 \text {, de } 25 \text { de junho de 2009, para dispor sobre a regularização fundiária } \\
\text { das áreas urbanas situadas em terras da União no âmbito da Amazônia Legal, definida pela LC no } \\
\text { 124, de } 3 \text { de janeiro de 2007, e dá outras providências. }\end{array}$ & Decreto $\mathrm{n} \cong 7.341$ & $22 / 10 / 2010$ \\
\hline $\begin{array}{l}\text { Altera a LC no 97, de } 9 \text { de junho de 1999, que "dispõe sobre as normas gerais para a organização, } \\
\text { o preparo e o emprego das forças armadas", para criar o Estado-maior conjunto das FA e disciplinar } \\
\text { as atribuiç̧ões do ministro de Estado da Defesa. }\end{array}$ & LC no 136 & $25 / 8 / 2010$ \\
\hline
\end{tabular}


(Continuação)

\begin{tabular}{|c|c|c|}
\hline Descrição da ementa & $\begin{array}{l}\text { Instrumento e } \\
\text { número }\end{array}$ & Data \\
\hline $\begin{array}{l}\text { Promulga o Ajuste Complementar ao Acordo para Permissão de Residência, Estudo e Trabalho } \\
\text { a Nacionais Fronteiriços Brasileiros e Uruguaios, para prestação de serviços de saúde, firmado } \\
\text { no Rio de Janeiro, em } 28 \text { de novembro de 2008. Aprovado Decreto Legislativo no } 933 \text {, de } 11 \text { de } \\
\text { dezembro de 2009. }\end{array}$ & Decreto $n-7.239$ & $26 / 7 / 2010$ \\
\hline $\begin{array}{l}\text { Promulga o acordo entre a República Federativa do Brasil e a República Oriental do Uruguai sobre } \\
\text { Cooperação Policial em Matéria de Investigação, Prevenção e Controle de Fatos Delituosos, celebrado } \\
\text { em Rio Branco, Uruguai, em } 14 \text { de abril de } 2004 \text {. }\end{array}$ & Decreto $n^{0} 6.731$ & $12 / 1 / 2009$ \\
\hline $\begin{array}{l}\text { Promulga o acordo entre o governo da República Federativa do Brasil e o governo da República } \\
\text { da Bolívia para construção de uma ponte sobre o rio Mamoré entre as cidades de Guajará-Mirim } \\
\text { e Guayaramerín, firmado em Brasilia, em } 14 \text { de fevereiro de } 2007 .\end{array}$ & Decreto $n^{\circ} 6.858$ & $25 / 5 / 2009$ \\
\hline $\begin{array}{l}\text { Regulamenta a administração das atividades aduaneiras, a fiscalização, o controle e a tributação } \\
\text { das operações de comércio exterior. Alterado pelo Decreto no 8.010/2013. }\end{array}$ & Decreto $n=6.759$ & $5 / 2 / 2009$ \\
\hline $\begin{array}{l}\text { Promulga o acordo entre o governo da República Federativa do Brasil e o governo da República } \\
\text { da Bolívia para permissão de residência, estudo e trabalho a nacionais fronteiriços brasileiros e } \\
\text { bolivianos, celebrado em Santa Cruz da Serra, em } 8 \text { de julho de } 2004 \text {. }\end{array}$ & Decreto $n^{0} 6.737$ & $12 / 1 / 2009$ \\
\hline Dispõe sobre a criação da Universidade Federal da Fronteira Sul (UFFS) e dá outras providências. & Lei n- 12.029 & 15/9/2009 \\
\hline $\begin{array}{l}\text { Exclui do anexo VI da Lei no 11.897, de } 30 \text { de dezembro de 2008, obras relativas aos contratos nos } \\
\text { 066-PG/DER/RO e 067-PR/DER/RO, relativas à construção de trecho rodoviário - entroncamento } \\
\text { BR-364 - entroncamento RO-478 (fronteira Brasil/Bolívia - Costa Marques) - na BR-429 - RO. }\end{array}$ & DLG no 504 & 13/8/2009 \\
\hline $\begin{array}{l}\text { Dispõe sobre a regularização fundiária das ocupações incidentes em terras situadas em áreas da } \\
\text { União, no âmbito da Amazônia Legal; altera as leis nos } 8.666 \text {, de } 21 \text { de junho de 1993, e } 6.015 \text {, } \\
\text { de } 31 \text { de dezembro de 1973; e dá outras providências (Conversão da Medida Provisória - MP nº } \\
\text { 458, de 2009). }\end{array}$ & Lei no 11.952 & $25 / 6 / 2009$ \\
\hline $\begin{array}{l}\text { Regulamenta a MP no 458, de } 10 \text { de fevereiro 2009, para dispor sobre a regularização fundiária } \\
\text { das áreas rurais situadas em terras da União arrecadadas pelo Instituto Nacional de Colonização } \\
\text { e Reforma Agrária (Incra), no âmbito da Amazônia Legal, definida pela LC, no 124, de } 3 \text { de janeiro } \\
\text { de 2007, e dá outras providências. }\end{array}$ & Decreto $n^{0} 6.830$ & $27 / 4 / 2009$ \\
\hline
\end{tabular}

Fontes: Portal da Legislação, disponível em: <https://bit.ly/37H3mT9>; Rede de Informação Legislativa e Jurídica (LEXML), disponível em: <https://bit.ly/36BRJLN>; Atividade Legislativa - Câmara dos Deputados, disponível em: <https://bit. ly/3ea5vbj>. Acessos em: 10 nov. 2019.

Elaboração: Equipe Fronteiras Ipea.

Notas: ${ }^{1} \mathrm{~A}$ IN RFB no 1.866 é uma IN/SRF.

${ }^{2}$ A IN RFB no 1.849 altera a IN SRF no 121, de 11 de janeiro de 2002, que dispõe sobre a transferência de mercadoria importada e admitida em regime aduaneiro especial ou atípico para outro regime, a IN SRF no 369, de 28 de novembro de 2003, que dispõe sobre o despacho aduaneiro de exportação sem exigência de saída do produto do território nacional, a IN RFB no 1.799, de 16 de março de 2018, e a IN no 863, de 17 de julho de 2008, que dispõem sobre 0 regime aduaneiro especial de loja franca em fronteira terrestre e em zona primária de porto ou aeroporto alfandegado.

Apesar de este estudo se voltar a matérias normativas que tratam da temática fronteiriça, há algumas peças que foram relacionadas por trazerem impactos importantes aos fluxos transfronteiriços, a exemplo da Lei de Migração (Lei $\left.\mathrm{n}^{\mathrm{o}} 13.445 / 2017\right)$, cujo art. $1^{\circ}, \$ 1^{\circ}$, item IV, define como residente fronteiriço "pessoa nacional de país limítrofe ou apátrida que conserve a sua residência habitual em município fronteiriço de país vizinho" (Brasil, 2017a).

Outros destaques se devem às instruçōes normativas da Receita Federal do Brasil (RFB), que regulamentam o regime aduaneiro para a instalação das lojas francas em cidades gêmeas brasileiras (Lei no ${ }^{\circ}$ 12.723/2012), caracterizadas conforme critérios da Portaria nº 213/2016 e anexos, emitida pelo então Ministério da Integração Nacional (MI), atualmente Ministério do Desenvolvimento Regional (MDR) - Lei no 13.844/2019. 
No período 2009-2018, foram aprovadas 52 normas (leis e decretos) referentes às questóes fronteiriças, sendo 28 peças correspondentes a acordos internacionais formalizados com os vizinhos, dos quais dois decretos legislativos ${ }^{12}\left(\mathrm{n}^{\mathrm{os}} \mathrm{0}\right.$ 0087/2017 e 0358/2011) encontravam-se ainda em fase de promulgaçáo do ato bilateral. $\mathrm{O}$ ato do Decreto Legislativo no 0087/2017, Acordo para Integraçâoo Fronteiriça entre a República Federativa do Brasil e a República do Peru na Ârea de Telecomunicaçôes, firmado em Lima, em 11 de novembro de 2013, foi promulgado somente pelo Decreto no 9.996, de 29 de agosto de 2019.

Quanto à concentração das normas por temas (gráfico 1), cidadania e desenvolvimento regional somaram $38 \%$ das normas concretizadas no período. Do conjunto dos temas, há que se destacar as leis nºs 12.029/2009 e 12.189/2010, que cunharam as providências de criação de duas universidades federais: a UFFS, que atualmente conta com três campi, e a Unila, construída em Foz do Iguaçu (Paraná), importante região de fronteira tríplice no Sul do país, com fortes relaçôes com os vizinhos Paraguai e Argentina.

\section{GRÁFICO 1}

Distribuição da legislação vigente por temas (2009-2018)

(Em \%)

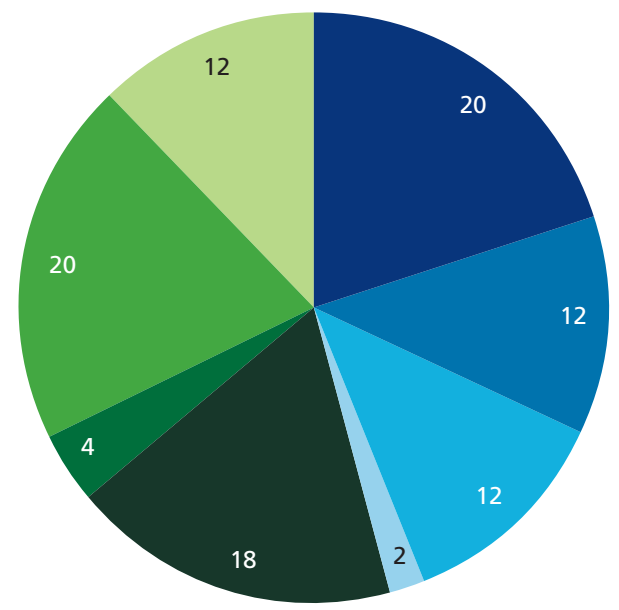

$\begin{array}{lllll}\text { Cidadania } & \text { Infraestrutura } & \text { Fundiário } & \text { Meio ambiente } & \begin{array}{l}\text { Desenvolvimento } \\ \text { regional }\end{array} \\ \begin{array}{l}\text { Vigilância } \\ \text { sanitária }\end{array} & \begin{array}{l}\text { Segurança e } \\ \text { defesa }\end{array} & \text { Institucional } & \end{array}$

Fontes: Portal da Legislação, disponível em: <https://bit.ly/37H3mT9>; Rede de Informação Legislativa e Jurídica (LEXML), disponivel em: <https://bit.ly/36BRJLN>; Atividade Legislativa - Câmara dos Deputados, disponível em: <https://bit. ly/3ea5vbj>. Acessos em: 10 nov. 2019.

Elaboração: Equipe Fronteiras Ipea.

12. Decretos legislativos são promulgados pelo presidente do Senado (Agência Senado, 2019). Disponíveis em: <https:// bit.ly/2NTsiPf $>$. Acesso em: 5 out. 2019. 
Ainda como rebatimento do tema na década, destaca-se a criação da Universidade Federal do Pampa (Unipampa), concebida pela Lei no 11.640/2008. Atualmente, essa universidade conta com dez campi distribuídos ao longo da FF do Rio Grande do Sul. No que tange à integração fronteiriça, a instituição tem um papel muito relevante na fronteira, com especial atenção para a formalização dos protocolos de intençóes que visam ao acesso da população que vive nas áreas de fronteira dos vizinhos Uruguai e Argentina.

Ainda na fronteira sul, destaca-se também a ampliação da rede federal na fronteira do Rio Grande do Sul. Só do Instituto Federal Sul-rio-grandense (IFSul), foram criados os campi Bagé (2010), Santana do Livramento (2010) e o campus avançado Jaguarão (2014). Essa ampliação possibilitou a implementação de programas de integração regional, a exemplo da implantação do campus de Santana do Livramento (2010), que ocorreu a partir de um protocolo de intençóes entre o IFSul e o Consejo de Educación Tecnico Profesional - Universidad del Trabajo del Uruguay (CETP-UTU), com oferta de cursos técnicos binacionais.

Há outras iniciativas de integração regional realizadas pelas instituiçóes de ensino ao longo da fronteira terrestre, a exemplo da oferta de cursos binacionais pelo Instituto Federal de Roraima (IFRR), que teve sua estrutura ampliada em três campi, em 2011. Apesar das iniciativas de ampliação de instituiçôes de ensino na fronteira pontuarem no tema cidadania, não pode ser negado seu papel no tema desenvolvimento regional.

O tema segurança pública e defesa do território ocupa $20 \%$ das normas formalizadas no período. Em relação às normas que tratam da defesa, aparecem no Decreto no 8.903/2016, o qual define, conjuntamente a outros órgãos, a participação das FA no PPIF; no Decreto no 9.318/2018, que se definiu no acordo de cooperação em matéria de defesa entre Brasil e o Paraguai; e por fim, no Decreto no 9.623/2018, que revogou os feitos relativos ao emprego das FA no território nacional. Particularmente, este último decreto autorizava a atuação das FA no estado de Roraima, nas FF norte e leste, e nas rodovias federais de Roraima, em virtude daquele ponto da fronteira se configurar na entrada da maioria dos fluxos migratórios de venezuelanos.

As demais normas (total de sete) são relativas à segurança pública. Essa matéria na fronteira é muito sensível, haja vista que, continuamente, tem-se ampliado o quadro de violência (homicídios, furtos, roubos, violência doméstica, entre outros) nos municípios e na regiáo de fronteira, bem como se espraiam por outros centros urbanos. Um breve levantamento nas estatísticas dos boletins de ocorrências (BOs) ${ }^{13}$ de 2018, disponibilizado pela Secretaria de Segurança Pública do Estado do Mato 
Grosso do Sul (Sejusp/MS), aponta que a prática de crimes que envolvem drogas ilícitas só foi superada pelos crimes de furto.

Ao se tratar das ações públicas no recorte fronteiriço brasileiro, pode-se apontar que, a partir de 2011, com a publicação do Decreto n⿳o 7.496/2011, que institui o Plano Estratégico de Fronteiras (PEF), houve um claro redimensionamento das açóes fronteiriças que tangenciou a segurança e o controle como metas principais, em detrimento de outros temas como cidadania, integração e desenvolvimento regional que vinham sendo buscados na agenda pública. Além dos termos do Decreto $\mathrm{n}^{\mathrm{0}} 7.496 / 2011$, que teve como objetivo articular várias instituiçóes em nível federal e desenvolver metodologias e instrumentos para promover o diálogo com instituiçóes em níveis estaduais e municipais, destacaram-se também a implementação e operacionalização de uma série de instrumentos de segurança e controle sobre os fluxos e as dinâmicas fronteiriças com seus vizinhos do subcontinente.

Entre os instrumentos, destacou-se a Estratégia Nacional de Segurança Pública nas Fronteiras (Enafron), a qual conduziu o projeto Policiamento Especializado de Fronteiras (Pefron), estabelecendo unidades em alguns pontos da fronteira terrestre, e também o eixo 7 do programa, que trazia como objeto a implementação do Gabinete de Gestão Integrada de Fronteira (GGI-Fron). A coordenação do PEF ficou a cargo de órgãos da segurança pública e de instituiçóes das FA. Este plano foi revogado pelo Decreto no $8.903 / 2016,{ }^{14}$ que trouxe poucas alteraçóes em torno de estratégias para a segurança pública na FF (Brasil, 2016).

Outro tema caro à fronteira terrestre brasileira concerne às questóes fundiárias, refletidas na quantidade de normas e no acirramento dos conflitos fronteiriços que tal insegurança jurídica delega. Tais conflitos se desenvolvem sob vários matizes e processos, e entre os mais visíveis destacam-se aqueles em que a ocupação de áreas de terras se estende ao território do país vizinho. Há, também, aqueles conflitos que envolvem a sobreposição de territórios e ampliação das disputas agrárias em desfavor dos povos originários (indígenas) e outras populaçóes que ocupam secularmente áreas ainda em litígio. Um exemplo desses conflitos ocorre na fronteira paraguaia, entre produtores de soja brasileiros (agronegócio da soja) e o movimento campesino paraguaio, que elevam a violência na fronteira ao alcançarem também os brasiguaios.

No tema do meio ambiente, a única norma em vigor (Decreto $n^{-9} 9.159 / 2017$ ) trata da exploração mineral na área de fronteira, entre outras. Tal feito revogou o Decreto no ${ }^{\circ}$ 9.147, de 28 de agosto de 2017, e revigorou os decretos $n^{\text {os }} 84.404 / 1984$ e 92.107/1985, que dispóem sobre a Reserva Nacional de Cobre e seus Associados (Renca), e dá outras providências. A particularidade do decreto que foi revogado é seu objeto: "extingue a Reserva Nacional do Cobre e seus Associados (Renca) 
para regulamentar a exploração mineral apenas na área onde não haja sobreposição com unidades de conservação, terras indígenas e faixa de fronteira”. Ao se extinguir a Renca, a sociedade entendeu que a exploração mineral exerceria forte pressão sobre outras reservas naturais e aos povos indígenas. Assim, a revogação do Decreto no $^{\mathrm{9}}$ 9.147/2017 se deu sob forte pressão popular junto ao Parlamento brasileiro, sobretudo representada por importantes segmentos da sociedade civil, o que ocorreu em menos de um mês.

Das normas que tratam do tema institucional, a maioria diz respeito às matérias militares (segurança e defesa) e as demais oficializaram atos internacionais (tabela 1). Há também a institucionalização do Decreto $\mathrm{s} / \mathrm{n} 2010,{ }^{15}$ que criou a Comissão Permanente para o Desenvolvimento e a Integração da Faixa de Fronteira (CDIF).$^{16} \mathrm{Tal}$ fórum constitui-se em um instrumento de gestão de políticas públicas de integração regional, com finalidade de propor diretrizes e coordenar açóes voltadas à atuação do governo federal na FF (Brasil, 2010). Tal feito (Decreto s/n 2010) foi revogado pelo Decreto no 9.961/2019, o qual reeditou a CDIF, com mudança na composição dos membros permanentes da comissão e redução do número de representantes de órgãos da administração federal. ${ }^{17}$

As iniciativas de infraestruturas consistiram na formalização de acordos binacionais para a construção das pontes: Ponte Rodoviária Internacional sobre o rio Paraguai, entre as cidades de Porto Murtinho, no Brasil, e Carmelo Peralta, no Paraguai; segunda Ponte Internacional sobre o rio Jaguarão, nas proximidades das cidades de Jaguarão, no Brasil, e Rio Branco, no Uruguai; e Ponte Internacional sobre o Igarapé Rapirrã, entre as cidades de Plácido de Castro, no Brasil, e Vila Evo Morales (antiga Montevidéu), na Bolívia (quadro 1).

Apesar de comporem carteiras de projetos de programas de investimentos, como o Programa de Aceleração do Crescimento (PAC), a Iniciativa para a Integração da Infraestrutura Regional Sul-Americana (IIRSA) e, posteriormente, o Conselho Sul-Americano de Infraestrutura e Planejamento (Cosiplan), as propostas de construção das pontes não se concretizaram. Em se tratando de iniciativas de infraestruturas no país, cabe ressaltar que, a partir de 2007, o PAC selecionou diversas açóes de investimento (rodovias, ferrovias, portos, energia elétrica) por todo o território nacional, com destaque para a concretização de substanciais investimentos do eixo energético na FF.

A relação das normas em vigor (quadro 1) demonstra que houve mudanças na direção de matérias relacionadas ao desenvolvimento da região de fronteira,

15. Decreto de 8 de setembro de 2010: institui a Comissão Permanente para o Desenvolvimento e a Integração da Faixa de Fronteira (CDIF). Disponivel em: <https://bit.ly/31CEBnj>. Acesso em: 12 nov. 2019.

16. Ver Pêgo et al. (2017, p. 48 e seguintes).

17. Ver capítulo 6 desta publicação. 
sobretudo, a partir de 2011. No período, verifica-se que, basicamente, a composição foi de atos internacionais e sobre o tema específico, registrou-se a institucionalização da Lei nº 12.723/2012 e suas instruçóes normativas, com vista à regulação da implantação das lojas francas em pontos da fronteira seca, nas cidades gêmeas.

$\mathrm{Na}$ análise das normas instituídas no período (2009-2018), ficou evidenciado que, na década atual, as peças criadas, e mesmo aquelas que reeditaram matérias que vinham sendo implementadas, demonstraram modificaçôes pouco significativas ou inovaçóes que pudessem mitigar efeitos substanciais na dinâmica do desenvolvimento regional ou local fronteiriço e o bem-estar, que é uma reivindicação legítima da população fronteiriça.

No levantamento das proposiçóes normativas para o recorte da FF em andamento nas Casas Legislativas (2009-2019), totalizaram-se 23 peças. O quadro 2 mostra a situação em que se encontravam as propostas em andamento nas Casas Legislativas.

QUADRO 2

Proposições normativas em andamento no Congresso Nacional (2009-2019)

\begin{tabular}{|c|c|c|}
\hline Proposições & Tipo & Situação/andamento \\
\hline $\begin{array}{l}1 \text { - Altera } 0 \text { art. } 144 \text { da CF/1988, para criar a Polícia Nacional } \\
\text { de Fronteiras. }\end{array}$ & $\begin{array}{l}\text { Proposta de Emenda à } \\
\text { Constituição (PEC) nำ3/2018 }\end{array}$ & $\begin{array}{l}\text { Em 21/12/2018. Designação de } \\
\text { relatoria. Senado Federal. }\end{array}$ \\
\hline $\begin{array}{l}2 \text { - Aumenta os valores a serem pagos pelo Programa Bolsa } \\
\text { Família (PBF) nos municípios da FF e dá outras providências. }\end{array}$ & $\begin{array}{l}\text { Projeto de Lei(PL) n 9.634/2018 } \\
\text { Apensado } \\
\text { PL no 8.140/2017 }\end{array}$ & $\begin{array}{l}\text { Em 21/2/2019. Mesa Diretora da } \\
\text { Câmara dos Deputados. }\end{array}$ \\
\hline $\begin{array}{l}3 \text { - Estabelece a obrigatoriedade do uso de cães farejadores } \\
\text { no combate ao ingresso ilícito de entorpecentes, drogas afins e } \\
\text { armas em território nacional via aeroportos, portos e fronteiras } \\
\text { terrestres, e dá outras providências. }\end{array}$ & PL no $10.742 / 2018$ & $\begin{array}{l}\text { Em 4/9/2019. Comissão de Segu- } \\
\text { rança Pública e Combate ao Crime } \\
\text { Organizado (CSPCCO). }\end{array}$ \\
\hline 4 - Cria o campus universitário de São Miguel do Oeste da UFFS. & PL no 7.308/2017 & $\begin{array}{l}\text { Em 10/7/2019. Parecer favorável. } \\
\text { Comissão de Trabalho, de Adminis- } \\
\text { tração e Serviço Público (CTASP). }\end{array}$ \\
\hline $\begin{array}{l}\text { 5 - Altera a Lei no } 8.256 \text {, de } 25 \text { de novembro de 1991, que "cria } \\
\text { áreas de livre comércio nos municípios de Boa Vista e Bonfim, } \\
\text { no estado de Roraima e dá outras providências". }\end{array}$ & PL no 7.812/2017 & $\begin{array}{l}\text { Em 29/8/2019. Comissão de Finanças } \\
\text { e Tributação (CFT). }\end{array}$ \\
\hline 6 - Cria o campus universitário de Concórdia da UFFS. & PL no 7.307/2017 & $\begin{array}{l}\text { Em 10/7/2019. Parecer favorável. } \\
\text { Localização CTASP. }\end{array}$ \\
\hline $\begin{array}{l}7 \text {-Altera o art. 16-A da LC no 97, de } 9 \text { de junho de 1999, para } \\
\text { dispor sobre as atribuições subsidiárias das FA e o patrulhamento } \\
\text { das fronteiras entre estados, territórios e o Distrito Federal. }\end{array}$ & $\begin{array}{l}\text { Projeto de Lei Complementar } \\
\text { (PLP) no 394/2017 }\end{array}$ & Em 26/8/2019. Devolução à CCP. \\
\hline $\begin{array}{l}8 \text { - Altera a Lei de Responsabilidade Fiscal - LRF (LCo 101, de } \\
\text { 2000), para tratar das transferências voluntárias relacionadas à } \\
\text { execução de ações em faixas de fronteira. }\end{array}$ & PLP no 388/2017 & $\begin{array}{l}\text { Em 22/8/2019. Comissão de Finanças } \\
\text { e Tributação (CFT). Designado relator. }\end{array}$ \\
\hline
\end{tabular}




\begin{tabular}{|c|c|c|}
\hline Proposições & Tipo & Situação/andamento \\
\hline $\begin{array}{l}\text { 9-Altera a Lei no } 6.009 \text {, de } 26 \text { de dezembro de 1973, que "dispõe } \\
\text { sobre a utilização e a exploração dos aeroportos, das facilidades } \\
\text { à navegação aérea, e dá outras providências". }\end{array}$ & PL no 5.070/2016 & $\begin{array}{l}\text { Em 5/9/2019. Comissão de Consti- } \\
\text { tuição e Justiça e Cidadania (CCJC). }\end{array}$ \\
\hline $\begin{array}{l}10 \text { - Regulamenta o disposto no inciso II do art. } 20 \text { da CF/1988, } \\
\text { que trata das terras devolutas da União, e dá outras providências. }\end{array}$ & PL no 5.843/2016 & $\begin{array}{l}\text { Em 24/9/2019. Comissão de Agri- } \\
\text { cultura, Pecuária, Abastecimento e } \\
\text { Desenvolvimento Rural (CAPADR). }\end{array}$ \\
\hline $\begin{array}{l}11 \text { - Altera o § 30 e acrescenta o § 50 ao art. } 176 \text { da CF/1988, e dá } \\
\text { outras providências (autoriza o poder público a explorar as jazidas } \\
\text { de recursos minerais que possam ser usadas em obras públicas). }\end{array}$ & PEC no 224/2016 & Em 19/8/2019. Na CCJC. \\
\hline $\begin{array}{l}12 \text { - Cria áreas de livre comércio nos municípios de Corumbá } \\
\text { e Ponta Porã, no estado de Mato Grosso do Sul, e dá outras } \\
\text { providências. }\end{array}$ & PL no 533/2015 & No Senado Federal. \\
\hline $\begin{array}{l}13 \text { - Acresce } 0 \text { art. } 6 \text { A à Lei no } 9.654 \text {, de } 2 \text { de junho de } 1998 \text {, } \\
\text { estabelece o adicional de insalubridade para a carreira de policial } \\
\text { federal rodoviário. }\end{array}$ & PL no 1.007/2015 & $\begin{array}{l}\text { Em 19/3/2019. Mesa Diretora da } \\
\text { Câmara dos Deputados. }\end{array}$ \\
\hline $\begin{array}{l}14 \text { - Cria área de livre comércio no município de Guaíra, no } \\
\text { estado do Paraná. }\end{array}$ & PL no 648/2015 & $\begin{array}{l}\text { Em 26/9/2019, na Comissão de } \\
\text { Desenvolvimento Econômico, Indústria, } \\
\text { Comércio e Serviço (CDEICS). Devol- } \\
\text { vida pelo relator sem manifestação. }\end{array}$ \\
\hline $\begin{array}{l}15 \text { - Altera o art. } 80 \text { da Lei no 9.503, de } 23 \text { de setembro de } 1997 \\
\text { (Código de Trânsito Brasileiro), para dispor sobre sinalização trilíngue. }\end{array}$ & PL no 7.033/2014 & $\begin{array}{l}\text { Em 28/8/2019. Comissão de Turismo } \\
\text { (CTUR). Designado relator. }\end{array}$ \\
\hline $\begin{array}{l}16 \text { - Altera a redação do art. } 2 \div \text {, inciso V da Lei no } 6.634 \text {, de } 2 \\
\text { de maio de } 1979, \text { para inserir os } \S \S 10,2 \circ \text { e } 30 \text {, que permitem } \\
\text { contratos de financiamento bancário em que se concede a } \\
\text { propriedade de terra como garantia, quando feitos em bancos } \\
\text { privados com capital estrangeiro e para propriedades que se } \\
\text { situem na faixa de fronteira. }\end{array}$ & PL no 7.391/2014 & Em 24/9/2019. No Senado Federal. \\
\hline $\begin{array}{l}17 \text { - Altera a Lei no } 6.634 \text {, de } 2 \text { de maio de 1979, "que dispõe } \\
\text { sobre a faixa de fronteira, altera o Decreto-lei no } 1.135 \text {, de } 3 \text { de } \\
\text { dezembro de 1970, e dá outras providências". }\end{array}$ & $\begin{array}{l}\text { PL no 7.860/2014 } \\
\text { Apensado ao PL n־2.275/2007 }\end{array}$ & Mesa Diretora da Câmara. \\
\hline $\begin{array}{l}18 \text { - Institui a Política Nacional de Defesa e de Desenvolvimento } \\
\text { da Amazônia Legal e da Faixa de Fronteira. }\end{array}$ & PL no 6.460/2013 & $\begin{array}{l}\text { Em 31/1/2019. Aguardando Designação } \\
\text { de Relator na CCJC. }\end{array}$ \\
\hline 19-Institui o Programa Fronteira Agrícola Norte, e dá outras providências. & $P L n=6.575 / 2013$ & $\begin{array}{l}\text { Em 19/12/2018. } \\
\text { Coordenação de Comissões Perma- } \\
\text { nentes (CCP). Parecer publicado. }\end{array}$ \\
\hline 20 - Altera o art. 144 da CF/1988 para criar a guarda de fronteira. & $\begin{array}{l}\text { PEC no 81/2011 } \\
\text { Apenso } \\
\text { PEC n 340/2017 }\end{array}$ & Em 8/8/2019, na CCJC. \\
\hline $\begin{array}{l}21 \text { - Altera o art. } 144 \text { da CF/1988 transferindo para a União a } \\
\text { segurança pública na área da Amazônia Legal. }\end{array}$ & PEC no 91/2011 & $\begin{array}{l}\text { Em 26/3/2019. Mesa Diretora da } \\
\text { Câmara dos Deputados. Aguardando } \\
\text { designação de relator. }\end{array}$ \\
\hline $\begin{array}{l}22 \text { - Requer a criação de subcomissão especial no âmbito da } \\
\text { Comissão de Relaç̃̃es Exteriores e Defesa Nacional para acom- } \\
\text { panhar as ações de proteção de nossas fronteiras. }\end{array}$ & Requerimento no 16/2011 & $\begin{array}{l}\text { Em 6/4/2011. Aprovado Requerimento. } \\
\text { Comissão de Relaçõ̃es Exteriores e de } \\
\text { Defesa Nacional (CREDN). }\end{array}$ \\
\hline $\begin{array}{l}23 \text { - Altera o } \S 1 \text { 10 do art. 1ํ da Lei no } 9.826 \text {, de } 23 \text { de agosto de } \\
\text { 1999, que dispõe sobre incentivos fiscais para desenvolvimento } \\
\text { regional, altera a legislação do Imposto sobre Produtos Indus- } \\
\text { trializados (IPI), e dá outras providências (Faixa de Fronteira Sul). }\end{array}$ & $\begin{array}{l}\text { PL no 6.904/2010 } \\
\text { Apensado a PL no6.903/2010 }\end{array}$ & $\begin{array}{l}\text { Em 26/3/2019. Mesa Diretora da } \\
\text { Câmara dos Deputados. Desarquivado. }\end{array}$ \\
\hline
\end{tabular}

Fonte: Centro de Documentação e Informação da Câmara dos Deputados. Disponível em: <https://bit.ly/37JfpiE >. Acesso em: 13 nov. 2019.

Elaboração: Equipe Fronteiras Ipea. 
O levantamento das proposiçóes em andamento no Congresso Nacional, assim como as normas instituídas no período evidenciam a preocupação do Legislativo com a segurança e o controle fronteiriço (tabela 2), em virtude de parte dos fluxos fronteiriços (de bens e pessoas) se assentarem em ilegalidades e crimes, como o tráfico de drogas ilegais, armas e pessoas, o contrabando de produtos (cigarro, têxteis, agrotóxicos, eletrônicos, brinquedos etc.), e evasão de divisas elevarem a violência na região.

\section{TABELA 2}

Síntese das proposições normativas em andamento nas Casas Legislativas (2009-2019)

\begin{tabular}{lc}
\hline Temas & Quantidade \\
\hline Segurança e defesa & 7 \\
Desenvolvimento regional & 7 \\
Cidadania & 3 \\
Fundiário & 2 \\
Institucional & 2 \\
Infraestrutura & 1 \\
Meio ambiente & 1 \\
Total & $\mathbf{2 3}$ \\
\hline \multicolumn{2}{c}{ Fonte: Centro de Documentação e Informação da Câmara dos Deputados. Disponivel em: <https://bit.ly/37JfpiE $>$. Acesso em: } \\
$\quad$ Elan nov. 2019.
\end{tabular}

As proposições do tema desenvolvimento regional se apresentam em maior número, diferenciado da quantidade de normas que foram concretizadas no período. $\mathrm{Na}$ relação, destaca-se o Projeto de Lei (PL) no 9.634/2018, que propóe ampliar os valores a serem pagos pelo PBF nos municípios da FF, em virtude da elevada taxa de pobreza de grande parte dos municípios fronteiriços. Apesar do caráter de assistência social, o programa de repasse de renda possui capacidade de rebatimentos mais rápidos na economia. Destacam-se, também, as propostas de criação de áreas de livre comércio com os vizinhos e a retomada das propostas de ampliaçáo da rede federal de ensino superior, sendo que a última iniciativa nesse sentido ocorreu com a formalização da norma que criou a Unila, em 2010.

A iniciativa que propóe a criação de instrumentos de governança para açóes na fronteira brasileira, o PL no 6.460/2013 (Política Nacional de Defesa e de Desenvolvimento da Amazônia Legal e da Faixa de Fronteira) coaduna ao conjunto de sugestôes e proposiçóes de instrumentos de governança que a avaliação do Tribunal de Contas da União (TCU) levantou (Brasil, 2015). Para a auditoria, a criação de uma política de Estado configuraria um grande avanço em termos de mudanças de caminhos para a construçáo e o aporte de uma agenda de longo prazo, pois a ausência de um instrumento de Estado que subsidie os programas e 
planos para a FF gera descontinuidades das ações, que ficam à mercê de programas de governos (Brasil, 2015).

A síntese do levantamento evidencia que as proposiçóes legislativas estão concentradas nos temas desenvolvimento regional, com 34\% do total de proposiçóes; segurança e defesa, 29\%; e cidadania, 13\% (gráfico 2).

\section{GRÁFICO 2}

Participação de matérias em discussão no Congresso Nacional (2009-2019) (Em \%)

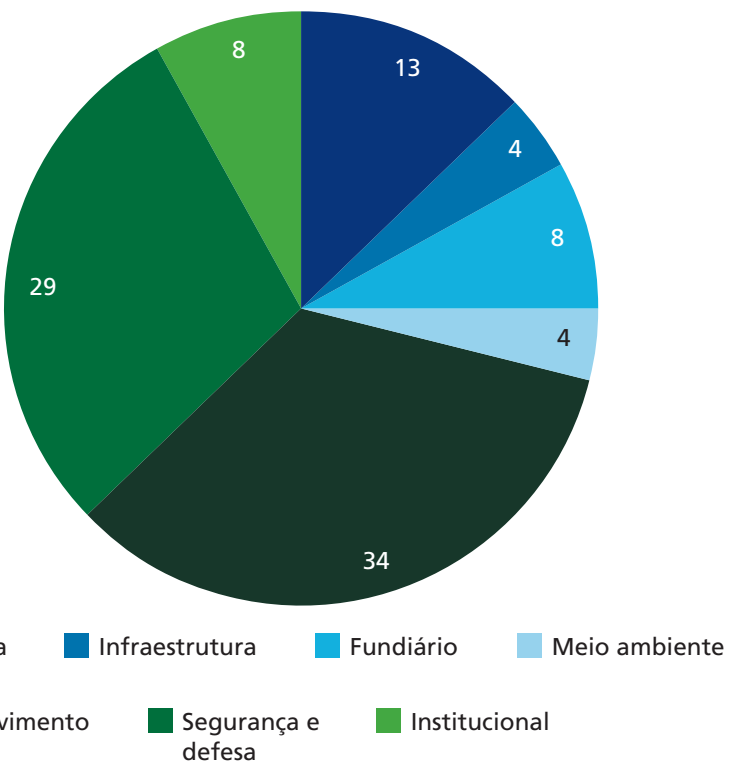

Fonte: Centro de Documentação e Informação da Câmara dos Deputados. Disponivel em: <https://bit.ly/37JfpiE > Acesso em: 13 nov. 2019.

Elaboração: Equipe Fronteiras Ipea.

Nas proposiçóes voltadas ao desenvolvimento regional, concentram-se as propostas de criação de área de livre comércio. Tais propostas abrangem áreas da fronteira dos estados de Roraima, Mato Grosso do Sul, Paraná e Rio Grande do Sul. No tema de segurança e defesa, chamam atenção as propostas de criação de corpo de segurança especializado em fronteira. No tema cidadania, aparecem propostas de ampliação da UFFS (proposta de criação de dois campi).

\section{A LEI DE FRONTEIRA E SUA TERRITORIALIDADE}

A base normativa da FF considera esse o recorte fundamental à segurança nacional, como expresso tanto na redação do $\$ 2^{\circ}$, do art. 20 da CF/1988, como pela Lei Infraconstitucional no 6.634, de 2 de maio de 1979, regulamentada pelo Decreto 
no 85.064/1980, o qual regula também as áreas de interesse estratégico do Estado no recorte fronteiriço (Brasil, 1980).

Apesar da Carta Magna de 1988 ratificar o conteúdo referente à largura da FF da Lei de Fronteira, as diferenças se assentam sob o contexto político ${ }^{18}$ em que a norma foi criada, sob a concepção de área de segurança nacional. ${ }^{19}$ A lei definiu a aplicação de normas e regramentos para a realização de determinadas atividades estratégicas na FF, com necessidade de manifestação expressa do Conselho de Segurança Nacional (CSN), ao qual cabia a concessão do ato de assentimento prévio (Brasil, 1979).

A modificação na concepção de "segurança nacional" sob a FF só surge com a redemocratização do Brasil, na $\mathrm{CF} / 1988$, permanecendo, porém, a visão estratégica de Estado $^{20}$ sobre a fronteira brasileira, agora como uma área de defesa nacional, sob diretriz do $\mathrm{CDN}^{21}$ (Lei no 8.183/1991, art. 1ํ, parágrafo único, alínea d). Apesar dessa lei, que definiu o CDN como regulamentador das áreas de defesa nacional, a definição das atividades estratégicas na FF permaneceu sob o auspício da Lei n 6.634/1979, mas submetidas agora ao conselho para fins de assentimento prévio.

Mesmo diante do contexto político em que foi criada a Lei de Fronteira, as atividades por ela reguladas para fins de monitoramento estratégico do Estado não perderam sua importância para a garantia dos interesses nacionais. Porém, notadamente, a importância do contexto em que foi criada, período em que o Estado detinha uma gestão centralizada, ajuda a ilustrar as inúmeras justificativas que buscam alterar o texto da lei, particularmente o art. 1 (largura da faixa), que permitiria que o rol de atividades estratégicas saísse do crivo do CDN. Outra justificativa comum a esse pleito, parte da restauração do período democrático no subcontinente que, sem as ameaças à integridade do território nacional, permite que a necessidade de manutenção de uma área tão larga não seja predominante sob a ótica da segurança nacional (área correspondente à FF).

Em se tratando das especificidades da redação da Lei de Fronteira, a largura da FF, relacionada no art. $1^{\circ}$, e parte das matérias que devem ser submetidas ao crivo de conselhos e fóruns específicos, relacionadas no art. 2º e demais artigos

18. Período de governos militares no Brasil (1964-1985).

19. Art. 1ํ, parágrafo único da Lei no 6.634/1979. Disponível em: <https://bit.ly/34kVFQs>. Acesso em: 13 out. 2019. 20. Entre as preocupações com a segurança nacional das fronteiras no período, incluía a possibilidade de conflito com a Argentina no segmento sul da fronteira brasileira. Possibilidade que foi afastada com a redemocratização e a integração dos países do Cone Sul do subcontinente na construção do Mercado Comum do Sul (Mercosul).

21. Lei no 8.183/1991. Dispõe sobre a organização e o funcionamento do Conselho de Defesa Nacional e dá outras providências (Brasil, 1991). Disponível em: <https://bit.ly/3jnzvRT>. Acesso em: 18 out. 2019.

De acordo com o § 1ㅇdo art. 91 da CF/1988, cabe ao CDN, entre outras competências: i) propor os critérios e as condições de utilização das áreas indispensáveis à segurança do território nacional e opinar sobre seu efetivo uso, especialmente na faixa de fronteira e nas relacionadas com a preservação e a exploração dos recursos naturais de qualquer tipo; e ii) estudar, propor e acompanhar o desenvolvimento de iniciativas necessárias a garantir a independência nacional e a defesa do Estado democrático (Brasil, 1988). 
que se relacionam às condições de uso e ocupação da FF sob a ótica da segurança nacional são comumente contestadas por vários setores da população fronteiriça.

Art. 1 É considerada área indispensável à Segurança Nacional a faixa interna de 150 (cento e cinquenta) km de largura, paralela à linha divisória terrestre do território nacional, que será designada como Faixa de Fronteira (Brasil, 1979).

A redação desse artigo foi reforçada na $\mathrm{CF} / 1988$ :

A faixa de até cento e cinquenta quilômetros de largura, ao longo das fronteiras terrestres, designada como faixa de fronteira, é considerada fundamental para defesa do território nacional, e sua ocupação e utilização serão reguladas em lei (Brasil, 1988 , art. $20, \$ 2^{\circ}$ ).

A redação do art. 20 da CF/1988 define a largura da faixa de fronteira em "até o limite de 150 quilômetros”, o que pressupóe que tal largura está apta às alteraçóes conforme a necessidade e conveniência de cada regiáo. A Lei no ${ }^{\circ}$ 6.634/1979 aplica a FF em $150 \mathrm{~km}$, a partir da linha do limite internacional.

No art. 2o da Lei no 6.634/1979, em virtude do caráter estratégico, as atividades sujeitas ao procedimento de "assentimento prévio" são as seguintes:

I - Alienação e concessão de terras públicas, abertura de vias de transporte e instalaçáo de meios de comunicaçóes destinados à exploração de serviços de radiodifusão de sons ou radiodifusão de sons e imagens.

II - Construção de pontes, estradas internacionais e campos de pouso.

III - Estabelecimento ou exploração de indústrias que interessem à Segurança Nacional, assim relacionadas em decreto do Poder Executivo.

IV - A exploração e o aproveitamento de recursos minerais e a colonização e loteamento rurais.

V - Instalação de empresas que se dediquem às seguintes atividades:

a) pesquisa, lavra, exploraçáo e aproveitamento de recursos minerais, salvo aqueles de imediata aplicação na construção civil, assim classificados no Código de Mineração; e

b) colonização e loteamento rurais.

VI - Transaçôes com imóvel rural que impliquem a obtenção, por estrangeiro, do domínio, da posse ou de qualquer direito real sobre o imóvel.

VII - Participação, a qualquer título, de estrangeiro, pessoa natural ou jurídica, em pessoa jurídica que seja titular de direito real sobre imóvel rural (Brasil, 1979).

Devido à parte das matérias relacionadas no art. 20 estarem submetidas ao assentimento prévio, residem as controvérsias mais consistentes dos "malefícios", em virtude da necessidade de submissão delas ao crivo do colegiado do CDN. 
Conforme o Decreto ํㅜ 85.064/1980, observa-se que as matérias enquadradas na Lei de Fronteira e regradas também em leis gerais são: mineração (Departamento Nacional de Produção Mineral - DNPM, código de mineração); ${ }^{22}$ radiodifusão de sons e imagens (Ministério das Comunicaçôes - leis nos 9.612/1998 e 13.424/2017, Decreto no 52.795/1963, e outros); concessão de terras públicas (Secretaria do Patrimônio da Uniáo - SPU, Lei no 9.636/1998 $8^{23}$ alterada pelas leis nos $11.481 / 2007$ e 13.465/2017; e Incra, leis nos 4.947/1966, 5.954/1973, 6.431/1977, 6.925/1981 e decretos $n^{\text {os }} 3.743 / 2001$ e 3.673/2000, leis n ${ }^{\text {os }} 5.954 / 1973,6.925 / 1981,9.871 / 1999$, $10.164 / 2000$ e outras); transação com imóvel rural envolvendo estrangeiro (Incra - Lei no 5.709/1971, ${ }^{24}$ IN no 94, de 17 de dezembro de 2018); e participação estrangeira em pessoa jurídica (PJ) brasileira (Banco Central do Brasil - Bacen e

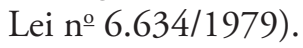

Desse modo, tais matérias, após análise dos órgãos federais competentes, devido à atividade pretendida se situar na FF (área indispensável à segurança do território nacional), são submetidas ao assentimento prévio do CDN, enquadradas à lei especial da FF (Lei no 6.634/1979).

As demais matérias tratadas no art. 2o (Lei no 6.634/1979) não se encontram regulamentadas, não sendo, portanto, impositivas de ritos especiais a serem seguidos pelo particular perante órgãos da administração pública.

$\mathrm{O}$ art. 3ำ da Lei de Fronteira (n⿳0 6.634/1979) remete às excepcionalidades que tratam nos itens III e IV do art. $2^{\circ}$ (transcrição do original):

Art. 2o Salvo com o assentimento prévio do Conselho de Segurança Nacional, será vedada, na Faixa de Fronteira, a prática dos atos referentes a:

III - Estabelecimento ou exploração de indústrias que interessem à Segurança Nacional, assim relacionadas em decreto do Poder Executivo.

IV - Instalação de empresas que se dedicarem às seguintes atividades:

22. 0 art. 91 delega ao CDN, órgão de consulta do Presidente da República, a tarefa de "propor critérios e condições de utilização de áreas indispensáveis à segurança do território nacional e opinar sobre seu efetivo uso, especialmente na faixa de fronteira e nas relacionadas como a preservação e a exploração dos recursos naturais de qualquer tipo". Posteriormente, a Lei no 8.183, de 11 de abril de 1991, regulamenta o $\S 10$ do art. 91 da CF/1988. 0 art. 176 estabelece condições específicas para a pesquisa e exploração dos recursos minerais do subsolo quando essas atividades se desenvolverem em FF e condiciona sua realização à autorização ou concessão da União.

23. Dispõe sobre a regularização, administração, aforamento e alienação de bens imóveis de domínio da União, altera dispositivos dos decretos-leis nos 9.760 , de 5 de setembro de 1946, e 2.398, de 21 de dezembro de 1987, regulamenta $0 \S 2^{\circ}$ do art. 49 do ato das disposições constitucionais transitórias, e dá outras providências. Disponível em: <https:// bit.ly/3jsuXtf>. Acesso em: 25 out. 2019.

24. Dispõe sobre a aquisição e 0 arrendamento de imóvel rural por pessoa natural estrangeira residente no país, pessoa jurídica estrangeira autorizada a funcionar no Brasil e pessoa jurídica brasileira equiparada à estrangeira e dá outras providências: § $6^{\circ}-$ Se o imóvel estiver localizado em faixa de fronteira ou em área considerada indispensável à segurança nacional, é obrigatório o assentimento prévio do Conselho de Defesa Nacional, independentemente da extensão de sua área. Disponível em: <https://bit.ly/3dRhhH5>. Acesso em: 25 out. 2019. 
a) pesquisa, lavra, exploraçáo e aproveitamento de recursos minerais, salvo aqueles de imediata aplicação na construção civil, assim classificados no Código de Mineração; e b) colonização e loteamento rurais.

V - Transaçóes com imóvel rural, que impliquem a obtenção, por estrangeiro, do domínio, da posse ou de qualquer direito real sobre o imóvel.

VI - Participaçáo, a qualquer título, de estrangeiro, pessoa natural ou jurídica, em pessoa jurídica que seja titular de direito real sobre imóvel rural.

(...)

Art. 3o $\mathrm{Na}$ faixa de Fronteira, as empresas que se dedicarem às indústrias ou atividades previstas nos itens III e IV do artigo 2o deverão, obrigatoriamente, satisfazer às seguintes condiçóes:

I - pelo menos 51\% (cinquenta e um por cento) do capital pertencer a brasileiros;

II - pelo menos 2/3 (dois terços) de trabalhadores serem brasileiros; e

III - caber a administração ou gerência à maioria de brasileiros, assegurados a estes os poderes predominantes.

Parágrafo único - No caso de pessoa física ou empresa individual, só a brasileiros será permitido o estabelecimento ou exploração das indústrias ou das atividades referidas neste artigo (Brasil, 1979).

No item III do art. 2o (Lei no 6.634/1979), a prática de ato referente ao "estabelecimento ou exploração de indústrias que interessem à Segurança Nacional" (Brasil, 1979) submete-se ao assentimento prévio do CDN, isto é, as indústrias que interessam à segurança nacional seriam as indústrias de defesa, atreladas às regras de mobilização nacional (Lei n⿳ำ 11.631/2007, regulamentada pelo Decreto no 6.592/2008) e às diretrizes da Política de Defesa Nacional e Estratégia Nacional de Defesa. As atividades empresariais que não sejam da área específica da indústria de defesa não estão sujeitas aos termos do inciso III do art. 2o da Lei no 6.634/1979.

\section{A LEI DE FRONTEIRA E SEUS CONTRASTES}

Como citado anteriormente, entre as principais questóes acerca da Lei de Fronteira, residem os "malefícios" de se delegar às atividades relacionadas no art. $2^{\circ} \mathrm{da}$

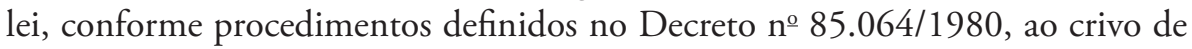
conselhos, colegiados, sobretudo da necessidade de assentimento prévio do CDN. Nesse sentido, entram as discussóes a respeito da largura da FF, haja vista que sua alteração retiraria parte das atividades do crivo do CDN.

Assim, buscando atender aos anseios da população fronteiriça (municípios), parlamentares seguem buscando alternativas normativas (propostas de lei e emenda constitucional), com fim de promover mudanças no regramento da FF em vigor, sobretudo com objetivo de reduzir sua largura ou mesmo uma possível extinção (quadro 3). 
QUADRO 3

Proposições de alteração da Lei de Fronteira no 6.634/1979 (2006-2019)

\begin{tabular}{|c|c|c|}
\hline Ementa & Tipo & Localização/situação \\
\hline $\begin{array}{l}1 \text { - Altera os arts. 1, 2ㅇ e 3ㅇ da Lei o } 6.634 \text {, de } 2 \text { de maio de } 1979 \text {, que dispõe } \\
\text { sobre a FF. }\end{array}$ & $\begin{array}{l}\text { PL no 1.144/ } \\
2019\end{array}$ & $\begin{array}{l}\text { Em 25/9/2015. } \\
\text { Comissão de Relações Exteriores } \\
\text { de Defesa Nacional (CREDN). }\end{array}$ \\
\hline $\begin{array}{l}\text { 2-Altera a Lei no } 6.634 \text {, de } 2 \text { de maio de 1979, "que dispõe sobre a faixa de fronteira, } \\
\text { altera o Decreto-lei no } 1.135 \text {, de } 3 \text { de dezembro de 1970, e dá outras providências". }\end{array}$ & $\begin{array}{l}\text { PL no 7.860/ } \\
2014\end{array}$ & Arquivado (rejeitado mérito). \\
\hline 3 - 0 § 2 do art. 20 da CF/1988, para reduzir a FF para $150 \mathrm{~km}$ de largura. & $\begin{array}{l}\text { PEC n-221 } \\
2009\end{array}$ & Prejudicada/arquivada. \\
\hline $\begin{array}{l}4 \text { - Altera o } \S 2 \text { do art. } 20 \text { da CF/1988, reduzindo de } 150 \mathrm{~km} \text { para } 50 \mathrm{~km} \text { a } \\
\text { largura da FF. }\end{array}$ & $\begin{array}{l}\text { PEC no 235/ } \\
2008\end{array}$ & Arquivada. \\
\hline 5-Altera 0 art. 1ํ da Lei no 6.634 , de 2 de maio de 1979, modificando a largura da FF. & $\begin{array}{l}\text { PL no 3.068/ } \\
2008\end{array}$ & Arquivado (rejeitado mérito). \\
\hline $\begin{array}{l}6 \text { - Revoga a Lei Federal no 6.634, de } 2 \text { de maio de 1979, que dispõe sobre a FF, } \\
\text { e altera o Decreto-lei no 1.135, de } 3 \text { de dezembro de } 1970 \text {. }\end{array}$ & $\begin{array}{l}\text { PL no 2.759/ } \\
2008\end{array}$ & $\begin{array}{l}\text { Arquivado (rejeitado mérito). } \\
\text { Apensados (2.275/2007). }\end{array}$ \\
\hline $\begin{array}{l}7 \text { - Altera a Lei no } 6.634 \text {, de } 2 \text { de maio de } 1979 \text {, criando condições de incentivo } \\
\text { para o desenvolvimento da FF da região Sul. }\end{array}$ & $\begin{array}{l}\text { PL n-3.321/ } \\
2008\end{array}$ & Desarquivado em 20/2/2019. \\
\hline 8 - Altera a Lei no 6.634, de 2 de maio de 1979, que dispõe sobre a FF. & $\begin{array}{l}\text { PL no 2.817/ } \\
2008\end{array}$ & $\begin{array}{l}\text { Arquivado (rejeitado mérito). } \\
\text { Apensado ao PL 2.275/2007. }\end{array}$ \\
\hline $\begin{array}{l}9 \text { - Altera a Lei no } 6.634 \text {, de } 2 \text { de maio de 1979, que dispõe sobre a FF, altera } \\
\text { o Decreto-lei no } 1.135 \text {, de } 3 \text { de dezembro de 1970, e dá outras providências. }\end{array}$ & $\begin{array}{l}\text { PL no } 2.275 / \\
2007\end{array}$ & Arquivado (rejeitado mérito). \\
\hline $\begin{array}{l}\text { 10 -Altera a Lei no 6.634, de } 2 \text { de maio de 1979, que "dispõe sobre a faixa de fronteira, } \\
\text { altera o Decreto-lei no } 1.135 \text {, de } 3 \text { de dezembro de 1970, e dá outras providências". }\end{array}$ & $\begin{array}{l}P L n=6.856 / \\
2006\end{array}$ & Arquivado em 19/2/2008. \\
\hline 11 - Dá nova redação ao § 2이o art. 20 da CF/1988, para dispor sobre a alteração da FF. & $\begin{array}{l}\text { PEC no 49/ } \\
2006\end{array}$ & Arquivada. \\
\hline
\end{tabular}

Fonte: Atividade Legislativa - Câmara dos Deputados, disponivel em: <https://bit.ly/3ea5vbj>. Acesso em: 13 nov. 2019. Elaboração: Equipe Fronteiras Ipea.

Das onze proposiçóes para a alteração da Lei no $6.634 / 1979$, levadas às Casas Legislativas no período 2006-2019 (quadro 3), somente duas permanecem tramitando no Congresso Nacional: os PLs nos $1.144 / 2019$ e 3.321/2008. A primeira proposta objetiva alterar os arts. 1으. 2o e $3^{\circ}$ da Lei no 6.634/1979. Para o legislador requerente, a alteraçáo corrige o descompasso do texto do diploma legal em relaçáo à Carta Magna de 1988, que consigna a proposta:

Pela comparaçáo entre o dispositivo constitucional e o dispositivo legal que tratam da Faixa de Fronteira, percebe-se que os constituintes foram além da rigidez da lei. Esta fixa a Faixa de Fronteira em 150 km (cento e cinquenta quilômetros) de largura, enquanto a Constituiçáo Federal estabelece em até $150 \mathrm{~km}$ (cento e cinquenta quilômetros) (...) (Brasil, 2019, mantida redação do original). 
A segunda proposta em andamento sobre o tema trata-se do PL no 3.321, instaurado em 2008, arquivado por conta da finalização do período legislativo e desarquivado nos primeiros meses da atual legislatura da Câmara dos Deputados (quadro 3), conforme teor do Requerimento $\mathrm{n}^{\mathrm{o}}$ 50/2019, publicado no sítio da Casa Legislativa.

Entre as inúmeras propostas normativas de alteração da Lei da Fronteira (quadro 3), exemplifica-se a PEC no 235/2008, ${ }^{25}$ que consigna:

A legislação infraconstitucional que cuida do tema, não obstante anterior a Constituição em vigor, é a Lei no 6.643/1979, que se encontra nitidamente em descompasso com a realidade internacional. De resto, a própria Constituiçáo de 1988 foi concebida ainda sob os influxos da "Guerra Fria", em contexto totalmente alheio à realidade presente. Vivemos o tempo da integraçáo regional e da construçáo de blocos econômicos. O tecido mais sensível para que se apliquem tais dinâmicas é, em verdade, a faixa de fronteira, que hoje se vê engessada e relegada economicamente à hipossuficiência, diante da legislação que ora pretendemos atualizar. Hoje, os mecanismos de segurança, controle e informaçáo instantânea dos quais dispóe o Estado transformam a legislaçáo brasileira de faixa de fronteira em obsoleta e comprometedora do desenvolvimento regional. As regiōes fronteiriças são sacrificadas pela Geografia e pela História. Não há mais razão para que o sejam também pelo Direito e pela Política (Brasil, 2008a).

Como pode ser observado na descriçáo de parte da justificativa da proposta, o entendimento da Lei de Fronteira como um instrumento restritivo ao desenvolvimento é o ponto em comum a outras iniciativas parlamentares para sua alteração. Tanto que, assim como na proposta relacionada, a maior parte das demais proposiçôes tem o entendimento de que a carência de políticas públicas e a estagnação econômica da região de fronteira se dão em virtude da localização dos municípios. Nesse raciocínio, a alteração da largura da FF retiraria parte significativa dos municípios da estagnação econômica e é nesse contexto que se destaca o PL no 2.275/2007 e apensos (quadro 3).

$\mathrm{Na}$ proposição e nos apensos desse PL, o autor relacionou as principais argumentaçôes para justificar a alteraçẫo da norma vigente e necessidade de mudança de ótica do Estado sobre a fronteira: "As fronteiras, entre naçóes desenvolvidas, democráticas e pacíficas, deixaram de ser barreiras. São entrepostos. Não afastam. Aproximam" (Brasil, 2007). Outro destaque da proposição assenta-se na criação de faixas distintas para cada recorte da fronteira: a primeira faixa de $50 \mathrm{~km}$ de largura, que se estenderia do extremo do limite sul, no Chuí (Rio Grande do Sul) a Ponta

25. A proposição da PEC ganhou notoriedade ao ser julgada como um instrumento para atender ao interesse da empresa estrangeira do segmento de papel e celulose, a sueco-finlandesa Stora Enso, que adquiriu grandes porções de terras na faixa de fronteira do Rio Grande do Sul e encontrou resistência à época, do Incra e de critérios cartorários para regularização das terras, em virtude da restrição legal. Conforme normativa da Casa, a proposta foi arquivada em virtude do fim da legislatura (2015) e não teve o interesse de outro parlamentar em dar continuidade ao pleito. 
Porã (Mato Grosso do Sul); outra faixa seria de $100 \mathrm{~km}$ e se estenderia a partir de Ponta Porã (Mato Grosso do Sul) a Guajará Mirim (Rondônia); e uma última faixa, de 150 km, se iniciaria no sul de Rondônia, de Guajará Mirim (Rondônia) até Monte Caburaí (Roraima).

Outro ponto do texto de tal proposiçáo eleva o destaque para a fronteira sul do país, o que evidencia na proposta o interesse regional do político.

No caso dos 3 estados sulinos as fraçóes de suas superfícies abrangidas pela faixa de fronteira, conforme a Lei atual, são enormes; esse fato inibe fortemente a alocaçáo de investimentos pretendidos pelas pessoas físicas e jurídicas de origem estrangeira, forçando o seu nível de competitividade econômica para baixo, ocasionando sérias consequências de ordem social para seus habitantes (Brasil, 2007, p. 3, redação mantida do original).

No voto que rejeita o pleito, a legisladora destaca fatores relevantes abarcados na proposição, como o crescimento da população nas fronteiras, o desenvolvimento econômico e social dessas regióes e o fim dos conflitos com as naçóes da América do Sul. Porém, a parecerista concluiu que mesmo na atualidade, com a extinção de cenários de conflitos (guerras) com os vizinhos do subcontinente, as FF constituem zonas sensíveis para a defesa nacional, necessitando assim mais debate da sociedade em torno da pretensão de sua alteração, como demonstra a reprodução de parte do voto:

A questáo que se coloca é bem mais complexa e abrangente e implica amplo debate sobre todos os aspectos constitucionais, legais e normativos da faixa de fronteira. A redução da faixa de fronteira fora do contexto desse imprescindível debate maior nos parece uma temeridade que pode não ter o condáo de alcançar os resultados positivos esperados. Pelo contrário: pode produzir resultados negativos para a Defesa Nacional, sem desenvolver, concomitantemente, a economia dessas sensíveis áreas geográficas (Brasil, 2009, p. 4).

Além da argumentação do voto reproduzida anteriormente, tal entendimento aponta para o risco que tais modificaçóes realizadas por meio ordinário ${ }^{26}$ podem inferir em outras demandas da população fronteiriça.

De todo modo, apesar das inúmeras iniciativas parlamentares advogarem a favor de alterar a Lei de Fronteira, a rejeição é igualmente elevada (quadro 3), o que evidencia o jogo de forças sobre a temática e mostra que parte do conjunto da sociedade coaduna com a necessidade de maior crivo do Estado sobre as atividades estratégicas realizadas no recorte fronteiriço.

Avaliando o debate sobre os argumentos de rejeição às proposiçôes de alteração da Lei no 6.634/1979, no que diz respeito à visão estratégica do Estado sobre o 
recorte fronteiriço, fica evidenciado em um dos relatórios de voto, ${ }^{27}$ elaborado para a votação da PEC no 235/2008 (quadro 3). No relatório do voto, o parlamentar reproduziu parte das argumentaçóes de uma nota técnica sobre a matéria, emitida pela assessoria parlamentar do Exército Brasileiro, a qual oferece argumentos desfavoráveis ao pleito (PEC no 235/2008).

Entre as argumentaçóes, esse relatório do voto destaca que a força terrestre buscou desconstruir as alegaçóes feitas pelos autores da PEC no 235 , no que concerne a: i) interesses da defesa externa; ii) cooperação com o desenvolvimento nacional; iii) Garantia da Lei e da Ordem (GLO); iv) vedação da prática de determinados atos na faixa de fronteira sem o assentimento prévio do CDN; e v) Política de Defesa Nacional. Assim, com o propósito de rejeitar o pleito, o autor do voto destacou no relatório as seguintes argumentações do Exército acerca da PEC em discussão:

1) Modificar a legislação que dá suporte à Faixa de Fronteira Nacional, considerando-se só o aspecto econômico como vetor de integração regional, como apresentado pelo autor, se mostra pouco conveniente, pois os aspectos estratégicos, de segurança e políticos têm relevância destacada no arco fronteiriço do país, conforme preconizado na Política de Defesa Nacional vigente.

2) O Brasil estabelece fronteira com quase todos os países da América do Sul, desde a época do Império, quando consolidou sua base territorial, situaçáo esta que reforça as necessidades de exercer acentuada vigilância naquelas importantes áreas.

3) Cabe salientar que o atual disciplinamento legal da matéria náo inviabiliza a ocupação e a exploração racionais das terras e bens nela situados, nem exclui o direito de propriedade de quem as possui (Brasil, 2008b, mantida redação do original).

Importante levantar que os três pontos destacados vêm ao encontro de consideraçôes e conclusóes elaboradas em alguns estudos, relatórios e notas técnicas, com o objetivo de subsidiar as decisóes dos parlamentares, como os estudos de consultorias do Legislativo brasileiro e levantamentos sobre o tema, como da Comissão Especial-Regulamentaçẫo da Faixa de Fronteira (extinta).

O primeiro estudo ora destacado acerca da necessidade de alteração da norma de fronteira, O Poder Legislativo em face da faixa de fronteira (Rocha, 2010), elaborado por um consultor legislativo da área XVII Segurança e Defesa Nacional, inicia suas consideraçôes alertando que a legislação sobre a FF, sozinha, não se configura em impedimento para o desenvolvimento das atividades econômicas na regiáo.

Um mergulho mais profundo na lei permitirá concluir, contrariamente ao pensamento de muitos, que qualquer tipo de atividade poderá ser desenvolvido nesse trecho do território brasileiro, ainda que algumas dependam do assentimento prévio do Conselho de Segurança Nacional (art. $2^{\circ}$ Lei no ${ }^{\circ}$ 6.634/1979). (...) Portanto, não 
há impedimento concreto para que essas atividades sejam desenvolvidas na Faixa de Fronteira, mas cada caso particular deverá ser submetido à apreciação discricionária do Conselho de Segurança Nacional (Rocha, 2010, p. 4).

Para o mesmo consultor legislativo, o gargalo está na gestão administrativa do fórum que viabiliza o assentimento prévio e não na exigência do feito. Porém, “isso é o bastante para fragilizar a lei e dar margem a pressóes no Congresso Nacional para que a mesma sofra modificaçóes, adequando-a à realidade enfrentada" (Rocha, 2010, p. 4).

A Comissão Especial-Regulamentação da Faixa de Fronteira, instituída com objetivo de propor iniciativas às questóes fronteiriças, apresentou, entre seus resultados, as seguintes ponderações sobre as proposiçôes legislativas de alteração da FF:

1) Maior parte tem por base o entendimento que a região da faixa de fronteira tem carência de políticas públicas e estagnação econômica.

2) No geral, consideram a faixa de fronteira como uma área restritiva ao desenvolvimento (Brasil, 2004).

Apesar disso, os resultados do levantamento da comissão evidenciam que a condição especial da FF é legitimada constitucionalmente para receber, de forma ampliada, incentivos diferenciados do restante do país. Sobre incentivos, há que

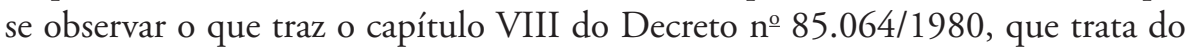
auxílio financeiro aos municípios da FF:

Art. 37 Para habilitar-se ao auxílio financeiro destinado à execução de obras públicas, previsto no art. 9o da Lei no 6.634, de 2 de maio de 1979, os municípios total ou parcialmente localizados na Faixa de Fronteira deverão, até 31 de julho do ano anterior ao da concessão, encaminhar à SG/CSN dados sucintos sobre a obra que pretendem realizar e seu orçamento estimado.

Parágrafo único - Em casos especiais, devidamente justificados, poderá ser concedido auxílio para aquisição de máquinas e equipamentos.

Art. 38 A SG/CSN estudará os pedidos de auxílio e, a partir de 1ํo de setembro, informará às Prefeituras da concessão ou não do auxílio solicitado.

Art. 39 Os recursos serão repassados diretamente às Prefeituras por intermédio da agência do Banco do Brasil S.A.

Art. 40 A aplicação dos recursos está sujeita a comprovação perante o Tribunal de Contas da União, por Intermédio da SG/CSN.

$\$ 1$ o - O emprego dos recursos limitar-se-á no exercício financeiro em que foram concedidos, podendo ser aproveitados no exercício imediato, como Restos a Pagar, desde que devidamente empenhados no exercício do recebimento.

$\$ 2^{\circ}$ - Enquanto as prestaçóes de contas não forem apresentadas, as Prefeituras não estarão habilitadas ao recebimento de auxílios posteriores. 
Art. 41 A SG/CSN baixará instruçóes detalhadas, visando a orientar as Prefeituras quanto à habilitação e repasse dos auxílios, aplicação dos recursos e prestação de contas (Brasil, 1980).

Nesse sentido, para a comissão, é fundamental que o "governo federal viabilize iniciativas ao fortalecimento econômico local, com perspectiva de solução de problemas dos municípios localizados na faixa de fronteira, [o que] certamente atenderá aos anseios da sociedade” (Brasil, 2004, p. 226). E com isso possa inibir parte dos argumentos usados em prol da crescente iniciativa parlamentar com objetivo de redução ou extinção da FF.

O terceiro estudo, um documento da Câmara dos Deputados, Desenvolvimento dos municipios na faixa de fronteira: necessidade de alteraçóes na Lei $n^{\circ}$ 6.634/1979, de Rocha (2008), trata das formas possíveis de alteraçóes da Lei de Fronteira. Para o autor,

existem basicamente duas linhas de ação: a primeira seria a alteração da própria carta magna, porém, como é sabido, a alteração da Constituição é um processo longo, lento e pesado. A segunda opção e mais viável seria a modificação do próprio texto da Lei no 6.634/1979 (Rocha, 2008, p. 10).

Destaca-se, também, a redação do $\$ 2^{\circ}$, do art. 20 da CF/1988, que estabelece que a FF seja de até $150 \mathrm{~km}$, "ou seja, alterar a legislação infraconstitucional não acarretaria vício de inconstitucionalidade, por não se tratar de limitação estrita, exata”. Assim, a Carta Magna, ao instituir a largura da FF, foi flexível. "Caberia na alteração legislativa instituir novo limite até o estabelecido pela Carta Magna” (Rocha, 2008, p. 11). A Lei no 6.634/1979 é uma norma infraconstitucional, logo pode ser alterada respeitando os limites estabelecidos na CF/1988.

Entretanto, o autor afirma que: "Não mudaria a lei em sua essência, ao mesmo tempo que iria adequar o nosso sistema jurídico e econômico às imposiçóes trazidas pela globalização, pelos compromissos no Mercosul e outros de caráter internacional" (Rocha, 2008, p. 11).

As argumentações postas indicam que a Lei nº 6.634/1979 não impóe obstáculos indiscriminados a alguma atividade econômica, logo se esvazia a instrumentalização das proposiçóes que visam alterar a lei ou reduzir a FF. Ademais, que o gerenciamento de assuntos estratégicos por um colegiado de Estado (CDN) não impede a edição de lei específica para direcionamento de incentivos à região, bem como promoção do desenvolvimento da região fronteiriça.

\section{CONSIDERAÇÕES FINAIS}

Quando se trata da elaboração de normas para a fronteira e mesmo nas propostas de legislação, é relevante considerar a conjuntura de interesses políticos no território. Ao se tratar de complexidades socioeconômicas e do caráter estratégico dos 
assentamentos humanos ao longo dessa faixa territorial brasileira, a mensagem presidencial (proferida em 2003) caracterizou as áreas da fronteira como um dos desafios ao desenvolvimento regional. Afirma a mensagem:

Merecem, portanto, uma atenção diferenciada neste contexto, dadas as más condições de vida de sua população e sua vulnerabilidade do ponto de vista socioeconômico, criando, inclusive, condiçóes para uma crescente penetraçáo da ilegalidade, contrabando e narcotráfico (Brasil, 2003).

Mesmo dividida em várias sub-regiôes, segundo seus aspectos físicos, econômicos, sociais e culturais (Brasil, 2005), por definição, a faixa de fronteira na Lei no 6.634/1979 foi ratificada na CF/1988 como uma faixa de terras de até $150 \mathrm{~km}$ a partir da linha divisória internacional. Essa faixa, além do seu papel de defesa do território, propicia várias formas de comunicação e atividades entre as populações fronteiriças e seu alto nível de interesse nacional.

Apesar do reconhecimento do recorte como área de interesse nacional, há uma flagrante deficiência dos governos em relação à gestão dos municípios fronteiriços que, comumente, possuem baixos índices de desenvolvimento, cujas origens são creditadas nas prerrogativas legais vigentes, a saber, ao regramento dos artigos da Lei de Fronteira (no 6.634/1979), que normatiza a necessidade de assentimento prévio do CDN para a exploração de atividades estratégicas na FF.

Há pouco esforço em esclarecer que existem outros fatores que interferem no baixo desenvolvimento do recorte de fronteira, inclusive fatos históricos pouco lembrados nas justificativas das propostas. Entre eles, cabe fazer referência à vocação atlântica do Brasil e à prática regular dos formuladores de políticas públicas em destinar investimentos (públicos e privados) para centros mais dinâmicos, sobretudo, aportes de recursos públicos às regiôes que já possuem maior capacidade de investimento.

Existem outros fatores que podem ser relacionados como origens do baixo desenvolvimento da regiáo, entre eles: i) baixa presença do Estado em vários pontos fronteiriços; ii) deficiências da infraestrutura econômica de integração; iii) grandes distâncias em relação a centros mais dinâmicos e de decisão; iv) vazios demográficos; e v) más condiçóes de vida da população dessas áreas e a sua vulnerabilidade socioeconômica. São fatores que criam condiçôes para a crescente penetração da ilegalidade e ampliação do domínio de organizaçôes criminosas na região para a prática de ilícitos transnacionais, com especial atenção para os crimes de tráfico de drogas entorpecentes ${ }^{28}$ armas e ilícitos contra o fisco nacional, como a atividade de contrabando na fronteira - cigarros, têxtil, eletrônicos etc. ${ }^{29}$ (Nunes, 2018).

28. Segundo o Escritório das Nações Unidas sobre Drogas e Crime (UNODC, sigla em inglês), o Brasil é considerado o país com a maior quantidade de drogas entorpecentes (pasta base e cocaína) apreendidas no mundo. A configuração da rota do tráfico coloca nossas fronteiras terrestres no centro desse processo.

29. Ver auditoria do TCU (Acórdão no 2.252/2015); e Sindifisco Nacional (2012), Fronteira em Foco, que é uma iniciativa do Sindifisco Nacional em prol da segurança das fronteiras brasileiras. Disponível em: $<$ https://bit.ly/2MNPvSO $>$. Acesso em: 25 out. 2019. 
Em relação à Lei de Fronteira (n⿳丷ㅜ6.634/1979), observa-se que tal norma não levanta temas relacionados ao desenvolvimento, ao fortalecimento da cidadania, à dinamização econômica e integração com países vizinhos. Porém, a observação quanto ao disciplinamento das atividades estratégicas na FF não exclui a implementação delas no regramento de fronteira, sendo a maior parte disciplinada por outras leis. Como exemplo, a exploração de recursos minerais na FF que tem seu procedimento dado pela Lei no $\mathbf{6} 6.634 / 1979$, item III:

I - A pesquisa e a lavra de recursos minerais somente poderáo ser efetuadas mediante autorização ou concessão da União, na forma da lei, que estabelecerá as condiçôes específicas quando essas atividades se desenvolverem em faixa de fronteira ou terras indígenas (Brasil, 1988, art. 176, $\$ 1$ ).

II - Compete ao Conselho de Defesa Nacional propor os critérios e condiçóes de utilização de áreas indispensáveis à segurança do território nacional e opinar sobre seu efetivo uso, especialmente na faixa de fronteira (Brasil, 1988, art. $91, \S 1$ ํ, inciso III).

III - A pesquisa, lavra, exploração e aproveitamento de recursos minerais em faixa de fronteira, exceto as de aplicação na construçáo civil, só serão permitidas com o assentimento prévio do Conselho de Defesa Nacional (Brasil, 1979, art. 2º, inciso IV, alínea a).

Sobre a atividade de exploração mineral, usada no exemplo anterior, evidencia-se o elevado tempo para a publicação do assentimento prévio. ${ }^{30}$ Portanto, não é a Lei da Fronteira o impeditivo à atividade: o que tem de ser revisto, caso necessário, são os procedimentos de gestão do conselho que viabiliza o assentimento prévio para a atividade (órgão do Executivo federal). Também é fato que a atividade de exploração mineral ocorre em vários pontos do recorte da fronteira brasileira, um exemplo da atividade na regiáo se dá no município de Corumbá (localizado no alto Pantanal de Mato Grosso do Sul) desde a década de 1970, na produção de minério de ferro e manganês, com atuação de empresas de peso do setor, como a mineradora Vale. ${ }^{31}$

Apesar das propostas legislativas, sobretudo aquelas que vislumbram alteração nos artigos da Lei de Fronteira, considerarem o recorte territorial fronteiriço como uma área restritiva ao desenvolvimento, as análises mais apuradas demonstram que a condição especial da FF é favorável ao direcionamento de mecanismos garantidores de incentivos compatíveis com a realidade e complexidade locais, totalmente diferenciados do restante do país.

Em virtude dos dados e das interpretaçôes sobre o que consta na legislação da fronteira em vigor não se configurarem em empecilhos aos programas de desenvolvimento fronteiriço, o que falta, então, para que a FF possa vislumbrar um 
desenvolvimento sustentável? Quais são os anseios e as expectativas da sociedade fronteiriça em relação aos investimentos (públicos e privados) na fronteira? Que medidas podem ter perspectivas de solucionar ou equacionar os problemas que os municípios localizados na fronteira têm em relação aos demais?

Como subsídio para colaborar na formulação de propostas, destacam-se as publicaçóes dos resultados das quatro oficinas realizadas pelo Ipea/MDR, ${ }^{32}$ três delas em pontos do limite internacional brasileiro, nas quais se buscou relacionar os anseios, as dificuldades e as propostas da população fronteiriça. ${ }^{33}$ Outro diagnóstico que pode colaborar na formatação de propostas às questôes inerentes à FF corresponde à síntese da publicação dos planos de fronteira, elaborada pelos Núcleos de Fronteira (Brasil, 2017b), além de outros diagnósticos e levantamentos que se encontram relacionados neste capítulo, que trata de experiências de gestão de governança fronteiriça.

Ao se tratar de aprimoramento do marco regulatório em tela, há que se considerar que o processo de desenvolvimento econômico brasileiro é determinado por fatores sociais e políticos. Assim, como traz a publicação Bases para uma proposta de desenvolvimento e integração da faixa de fronteira, "o aperfeiçoamento do marco regulatório da faixa de fronteira deverá priorizar a construção de mecanismos promotores de iniciativas e programas que conduzam a uma maior integração social, econômica e comercial desse território" (Brasil, 2010, p. 73).

Por fim, o aporte teórico consultado permite concluir que a FF é uma área de relevância estratégica para o conjunto nacional, porém a excepcionalidade da Lei da Fronteira não demanda impeditivo legal para que normas diversas (desde que acomodem a CF/1988) sejam formalizadas com objetivo de beneficiar e facilitar o desenvolvimento dos municípios da região de fronteira.

Mesmo diante da possibilidade de alteração da largura da FF, dada pelo artigo constitucional, tal matéria segue fomentando controvérsias entre os sujeitos fronteiriços, sobretudo os que advogam que a largura da faixa acaba por condicionar o dispositivo que regula as atividades econômicas no recorte. Isso demonstra que há uma disfunção no entendimento e narrativas de que a Lei de Fronteira dificulta o desenvolvimento econômico da região, a integração regional e o relacionamento entre os povos do subcontinente.

32. Brasília (Distrito Federal), Boa Vista (Roraima), Corumbá (Mato Grosso do Sul) e Uruguaiana (Rio Grande do Sul). 33. Ver Pêgo et al. (2018; 2019; 2020). 


\section{REFERÊNCIAS}

BRASIL. Constituição da República dos Estados Unidos do Brasil de 1891. Rio de Janeiro, 24 fev. 1891. Disponível em: <https://bit.ly/2FZhmvY>. Acesso em: 27 dez. 2019.

\section{Constituiçáo da República dos Estados Unidos do Brasil de 1934.}

Rio de Janeiro, 16 jul. 1934. Disponível em: <https://bit.ly/2J0a3oU>. Acesso em: 18 out. 2019 .

. Constituiçáo dos Estados Unidos do Brasil de 1946. Rio de Janeiro, 18 set. 1946. Disponível em: <https://bit.ly/2FZmoZo>. Acesso em: 27 dez. 2019.

. Lei no 6.634, de 2 de maio de 1979. Dispóe sobre a Faixa de Fronteira, altera o Decreto-lei no 1.135 , de 3 de dezembro de 1970 , e dá outras providências. Diário Oficial da Uniáo, Brasília, p. 6.113, 3 maio 1979. Seção 1.

. Decreto no 85.064, de 26 de agosto de 1980. Regulamenta a Lei no 6.634, de 2 de maio de 1979, que dispóe sobre a Faixa de Fronteira. Diário Oficial da União, Brasília, p. 16.899, 27 ago. 1980. Seção 1. STF, 1988.

Constituiçáo da República Federativa do Brasil de 1988. Brasília:

. Ministério do Planejamento, Orçamento e Gestão. Secretaria de Planejamento e Investimentos Estratégicos. Plano Plurianual 2004-2007: mensagem presidencial. Brasília: MP, 2003.

. Gabinete de Segurança Institucional. Seminário Faixa de Fronteira: Novos Paradigmas. Brasília: Gabinete de Segurança Institucional; Secretaria de Acompanhamento e Estudos Institucionais, 2004. Disponível em: <encurtador. com.br/pBGM8>. Acesso em: 20 set. 2019.

. Ministério da Integração Nacional. Secretaria de Programas Regionais. Programa de Desenvolvimento da Faixa de Fronteira. Proposta de Reestruturaçáo do Programa de Desenvolvimento da Faixa de Fronteira: bases para uma política integrada de desenvolvimento regional para a faixa de fronteira. Brasília: MI, 2005.

. Câmara dos Deputados. Projeto de Lei no 2.275 de 2007. Altera a Lei no 6.634 , de 2 de maio de 1979 "que dispóe sobre a faixa de fronteira, altera o Decreto-lei no 1.135, de 3 de dezembro de 1970, e dá outras providências". Brasília, out. 2007. Disponível em: <https://bit.ly/2TpPHHH>. Acesso em: 14 nov. 2019.

. Proposta de Emenda à Constituição no 235, de 2008. Dá nova redação ao $\$ 2^{\circ}$ do art. 20 da Constituição, para dispor sobre a alteração da faixa de fronteira. Brasília, 2008a. Disponível em: <https://bit.ly/35CKHFo>. 
. Comissão de Constituição e Justiça e de Cidadania da Câmara dos Deputados. Relatório da Proposta de Emenda à Constituição no 235, de 2008. Brasília, jun. 2008b. Disponível em: <https://bit.ly/2HvNGrj>.

. Câmara Dos Deputados. Comissão de Relaçóes Exteriores e de Defesa Nacional. Relatório de voto em separado do Deputado Doutor Rosinha - Projeto de Lei no 2.275, de 2007 (Apensos os Projetos de Lei nos 2.759, de 2008, 2.817, de 2008, e 3.068, de 2008). Brasília, 19 maio 2009. Disponível em: <https://bit. ly/3kwo7oa>. Acesso em: 13 nov. 2019.

. Grupo de Trabalho Interfederativo de Integração Fronteiriça. Bases para uma Proposta de Desenvolvimento e Integraçáo da Faixa de Fronteira. Brasília: Grupo de Trabalho Interfederativo de Integração Fronteiriça, 2010. Disponível em: <encurtador.com.br/bpyAT>. Acesso em: 3 out. 2019.

. Tribunal de Contas da União. Relatório de auditoria operacional para avaliaçáo de governança de políticas públicas de fortalecimento da faixa de fronteiras - Acórdão no 2.252/2015. Brasília: TCU, 2015. Disponível em: <https:// bit.ly/3ovle9l>. Acesso em: 5 mar. 2020.

. Decreto no 8.903 , de 16 de novembro de 2016. Institui o programa de proteçáo integrada de fronteiras e organiza a atuação de unidades da administração pública federal para sua execução. Diário Oficial da União, Brasília, p. 1, 2016. Seção 1.

. Lei no 13.445 , de 24 de maio de 2017. Institui a Lei de Migração. Brasília, 2017a. Disponível em: <https://bit.ly/3oCNPKa>. Acesso em: 12 nov. 2019.

. Ministério da Integração Nacional. Consolidação dos planos de desenvolvimento e integraçáo das faixas de fronteira. Brasília: MI, 2017b. Disponível em: <https://bit.ly/3jvVrdm>. Acesso em: 25 out. 2019.

. Câmara dos Deputados. Projeto de Lei no 1.144, de 2019. Altera os arts. $1^{\circ}, 2^{\circ}$ e $3^{\circ}$ da Lei no 6.634 , de 2 de maio de 1979 , que dispóe sobre a faixa de fronteira. Brasília, fev. 2019. Disponível em: <https://bit.ly/34qDKYC>. Acesso em: 5 mar. 2020.

NUNES, M. Papel e açôes das instituiçóes brasileiras na faixa de fronteira. In: PÊGO, B.; MOURA, R. (Orgs.). Fronteiras do Brasil: uma avaliação de política pública. Rio de Janeiro: Ipea; MI, 2018. v. 1.

PÊGO, B. et al. (Orgs.). Fronteiras do Brasil: diagnóstico e agenda de pesquisa para política pública. Brasília: Ipea; MI, 2017. v. 2.

Fronteiras do Brasil: uma avaliação do arco Norte. Brasília: Ipea; MI, 2018. v. 3. 
Fronteiras do Brasil: uma avaliação do arco Central. Rio de Janeiro: Ipea; MDR, 2019. v. 4.

. Fronteiras do Brasil: uma avaliação do arco Sul. Rio de Janeiro: Ipea; MDR, 2020. v. 5.

ROCHA, F. C. W. Desenvolvimento dos municípios na faixa de fronteira: necessidade de alteraçóes na Lei no 6.634/1979. Brasília: Câmara dos Deputados, fev. 2008. Disponível em: <https://bit.ly/2Hy93rB>. Acesso em: 28 out. 2019.

O Poder Legislativo em face da faixa de fronteira. Brasília: Câmara dos Deputados, dez. 2010. Disponível em: <https://bit.ly/2TsTtA9>. Acesso em: 28 out. 2019. 
CAPÍTULO 3

\section{DINÂMICAS RECENTES NA FRONTEIRA TERRESTRE DO BRASIL}

\section{OCUPAÇÃO DO TERRITÓRIO E CONFLITOS SOCIOAMBIENTAIS}

Os estudos realizados para a faixa de fronteira terrestre (FFT) brasileira pelo governo federal a partir do Programa de Desenvolvimento da Faixa de Fronteira (PDFF) (Brasil, 2005) adotam, para efeitos de análise e planejamento, uma macrodivisão em três grandes arcos: Norte, Central e Sul. Cabe apontar a primazia do olhar dos participantes das atividades realizadas nos arcos da fronteira, para os quais a primeira grande característica salientada foi a de que "são várias fronteiras" e que mesmo a divisão entre arcos não guarda homogeneidade interior, pois todos apresentam grandes diversidades regionais, econômicas, sociais, culturais e ambientais (Pêgo et al., 2017). Consequentemente, as políticas públicas e estratégias de desenvolvimento devem ser redefinidas e adequadas a essa realidade regional diversificada. As peculiaridades de cada arco foram sintetizadas conforme descrito nos parágrafos a seguir. ${ }^{1}$

No arco Norte, a diversidade da fronteira se marca na grande presença de reservas naturais e florestas, o que torna a própria Amazônia uma prioridade, pelo seu potencial de riquezas minerais e biodiversidade. É também relevante o número de terras indígenas (TIs) - fato que deu sentido à opção pela realização da primeira oficina de trabalho em Roraima e de uma das atividades de campo em Pacaraima, município brasileiro situado inteiramente em uma terra indígena. Há uma Amazônia além da identificada pelas riquezas naturais e pela importância ambiental, ou daquela noticiada pela crescente degradação de suas florestas. Uma Amazônia povoada por indígenas, populaçóes remanescentes de quilombos, ribeirinhos, pescadores artesanais, carvoeiros, seringueiros, castanheiros, coletores de açaí, quebradeiras de coco babaçu, entre outros povos tradicionais que habitam tanto espaços urbanos quanto rurais. Um grande desafio da Amazônia é a sua dimensão e sua baixa densidade demográfica, quando comparada às outras regiôes, o que exige que o discurso de que essa é uma "terra sem homens" precisa ser superado. Dessa forma, qualquer ação no arco Norte deve se reportar aos diversos agentes, atores e arranjos produtivos peculiares, como uma forma de aprimorar os diferentes projetos territoriais na construção de alternativas de desenvolvimento para a população (Pêgo et al., 2017; 2018).

1. Parágrafos extraídos dos relatórios das oficinas de trabalho, publicados por Pêgo et al. (2017; 2018; 2019; 2020a; 2020b), e da publicação autoral que integra o projeto (Pêgo e Moura, 2018). 
Por sua vez, no arco Central, reconheceu-se que a zona de fronteira é um espaço de interaçóes, contatos e fluxos sociais, econômicos e culturais, movido por semelhanças e contrastes. Nela habitam as pessoas, com suas vidas reais, estabelecendo vínculos e relações familiares, profissionais, comerciais e institucionais que superam a linha divisória territorial, particularmente nos arranjos transfronteiriços. Daí a necessidade de se estabelecer uma aproximação institucional e, também, de se aprofundar o relacionamento entre o governo do município brasileiro e o governo da cidade do país vizinho. Esses arranjos devem ser considerados como portas abertas do Brasil aos povos dos países vizinhos e portas desses países para os cidadãos brasileiros. Devido às grandes porçóes de limite seco, sem obstáculos físicos significativos de separação, há facilidade dos contatos, de aproximação entre os países em vários pontos da fronteira do arco Central, que se consolidam há séculos, sobretudo nas relaçóes de parentescos, que fazem com que haja maior entrelaçamento cultural dos povos, que compartilham danças, lendas comuns e valores. O movimento da economia fortalece essas relaçóes, por meio do comércio em ambos os lados do limite fronteiriço. Porém, há também a ocorrência de ilícitos que exigem das autoridades a criação de instrumentos para pacificar fatos que fazem parte da dinâmica fronteiriça, mudando o atual panorama de criminalização de determinados comportamentos (Pêgo et al., 2017; 2019).

Para os participantes do arco Sul, o mais povoado, denso e economicamente mais bem posicionado entre os arcos, a fronteira é um espaço aberto, ou seja, "sem fronteira". Esse lema vem sendo adotado pelos movimentos transfronteiriços desse arco e consta nos atos declaratórios das cidades irmãs Barra do Quaraí (Brasil), Monte Caseros (Argentina) e Bella Unión (Uruguai), pois, por mais que contemplem três naçóes, três estados/províncias/departamentos, três cidades, o espaço que se idealiza é o de uma só região com um só povo - "três pátrias, três cidades, um só povo" -, unido por uma cultura que permeia os três países (Pêgo et al., 2017; 2020a).

\subsection{Território, recursos e natureza}

\subsubsection{0 meio natural - biomas e recursos}

Sendo constituído por uma extensa linha de fronteira, o Brasil não somente faz limite com dez dos outros doze países da América do Sul (exceçáo de Chile e Equador), como compartilha com essas naçóes grandes porções de biomas naturais. Isso confere aos municípios da faixa de fronteira $(\mathrm{FF})$ uma relação transfronteiriça não somente social, cultural e histórica, mas também baseada na diversidade de paisagens, cobertura vegetal e possibilidades comuns de uso do solo.

A Amazônia é certamente o maior e mais complexo bioma, com 4,2 milhóes de $\mathrm{km}^{2},{ }^{2}$ correspondendo a $48,2 \%$ do território nacional, e aquele no qual a linha de

2. Informações disponiveis em: <https://bit.ly/3jit7Nq>. Acesso em: 20 fev. 2020. 
fronteira brasileira tem maior extensão, compartilhando esse bioma com a Guiana Francesa, Suriname, Guiana, Venezuela, Colômbia, Peru e Bolívia (mapa 1).

\section{MAPA 1}

\section{Biomas da América do Sul e do Brasil}

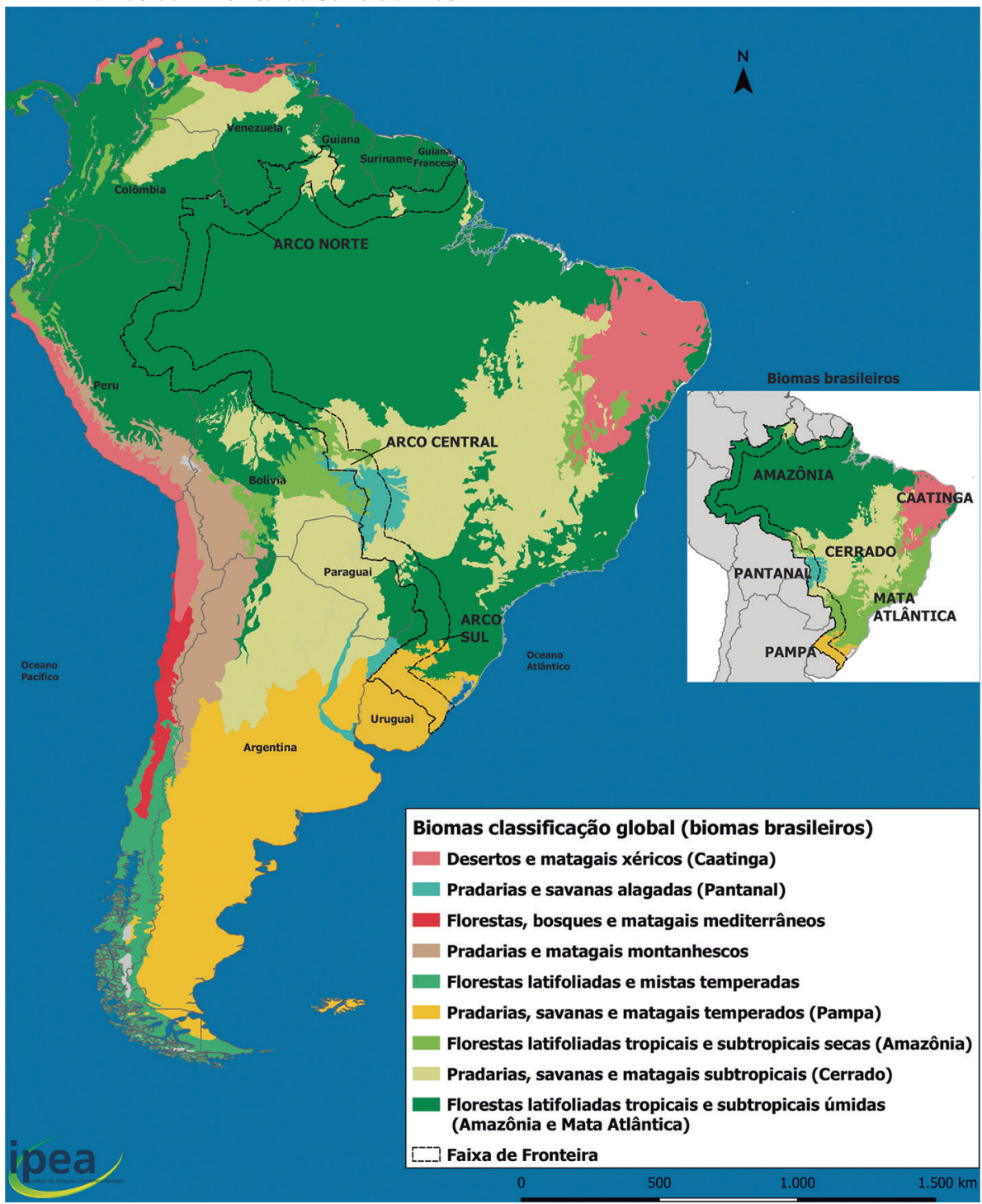

Fontes: IUCN/Unep The world database on protected areas (WDPA) - Annual Release 2010, disponível em: <https://bit. ly/3|70H7c>; IBGE (2004), disponível em: <https://bit.ly/2MSmwNC>. Acesso em: 20 jan. 2020.

Elaboração: Equipe Fronteiras Ipea.

Obs.: As cores da classificação dos biomas seguem o padrão definido em Unep (2016). 
Com a Bolívia e o Paraguai, na porção central-oeste de sua fronteira, o Brasil compartilha o bioma Pantanal (150,3 mil km², 1,8\% do território nacional), sendo que, com este último país, divide também o bioma Cerrado (2,03 milhóes de $\mathrm{km}^{2}$, $22 \%)$. Na porção sul da fronteira, o bioma da Mata Atlântica (1,3 milhão de $\mathrm{km}^{2}$, $15 \%)$ se estende desde a porção litorânea do Brasil até o Paraguai e a Argentina, e o bioma $\operatorname{Pampa}^{3}(176,5$ mil km², 2\%) é dividido com a Argentina e o Uruguai. Apenas o bioma Caatinga é exclusivamente brasileiro, com 844,4 mil km² (11\% do território nacional), e não comparte a fronteira com nenhum outro país. Diante disso, deve-se destacar que são as fronteiras que se sobrepóem aos biomas e não o contrário, e que, portanto, elas não dividem os biomas, o que exige que os cuidados com a preservação de sua biodiversidade sejam compartilhados entre os países abrigados por eles. Assim, a gestão ambiental é um desafio que se torna mais complexo nas regióes de fronteira.

As análises realizadas a partir da macrodivisão em três grandes arcos - Norte, Central e Sul - encontram uma base explicativa simples, ao se observar suas características gerais desde os limites dos biomas que atingem a FF.

O arco Norte encontra-se totalmente inserido no bioma Amazônia, constituindo-se no que pode ser chamado de "arco indígena", tanto pela presença substancial de populaçóes indígenas como pela necessidade inquestionável de preservação e conservação ambiental dessas áreas. É, consequentemente, a área com os maiores conflitos envolvendo TIs e atividades como mineração ou agropecuária. A FF no arco Norte atinge municípios do Amapá, do Pará, do Amazonas, de Roraima e do Acre. Grande parte desse arco é composta pela Floresta Amazônica, protegida seja por unidades de conservação (UCs) ou reservas indígenas, o que caracteriza a existência de uma extensa FF na qual ocorre grande mobilidade transfronteiriça de grupos indígenas. Roraima e Acre encontram-se totalmente inseridos na FF, assim como grande parte do Amapá, observando-se desta forma maior incidência de conflitos nesses estados. Para os participantes das atividades realizadas no arco Norte, a presença de áreas como UCs e TIs na FF exige tratamento especial. Apontam que esse arco vem sendo marcado por práticas de desmatamento da Floresta Amazônica, devido ao avanço da fronteira econômica com pouco respeito à importância do ecossistema e da biodiversidade da região. A possibilidade de esgotamento dos recursos naturais essenciais à sobrevivência dos povos tradicionais ${ }^{4}$ no arco Norte, em função de práticas de manejo de agentes dos vários capitais, nacionais e internacionais, instalados na regiâo, levou grupos a se organizarem

3. Equivale a $63 \%$ do território do Rio Grande do Sul.

4. De acordo com o Decreto no 6.040 , de 7 de fevereiro de 2007, que institui a Política Nacional de Desenvolvimento Sustentável dos Povos e Comunidades Tradicionais, estes podem ser definidos como "grupos culturalmente diferenciados e que se reconhecem como tais, que possuem formas próprias de organização social, que ocupam e usam territórios e recursos naturais como condição para sua reprodução cultural, social, religiosa, ancestral e econômica, utilizando conhecimentos, inovações e práticas gerados e transmitidos pela tradição" (art. 3ㄴ, § 1). 
em defesa das riquezas e do ambiente amazônico. Trabalham em uma perspectiva que se vale da gestáo local de recursos naturais de uso coletivo. Percebe-se que a atuação desses grupos ambientais tem tido significativa importância, não só porque se afirmam como trabalho em defesa de uma melhor distribuição fundiária como questão fundamental na melhoria da qualidade de vida no campo, mas sobretudo em virtude de motivarem e amadurecerem as discussóes sobre a realidade rural da Amazônia (Pêgo et al., 2018).

Uma prática que pode ser considerada uma experiência é a que vem sendo realizada na FF do arco Norte. Refere-se aos "arranjos transfronteiriços de conservação da natureza”, apresentados e debatidos na oficina realizada no arco Norte (Pêgo $e t$ al., 2018). São arranjos nos quais se desenvolvem práticas que procuram acomodar diferentes visóes de natureza: de uma natureza frágil, que possa ser planejada, que precisa ser protegida, ao mesmo tempo de uma natureza forte, que influencia o seu financiamento externo. O importante nesses arranjos é a convergência de um marco legal para articulação dos produtos florestais e uma forte conexão entre os atores locais, no mercado de trabalho, ainda pouco integrado, principalmente do trabalho volante, pouco regularizado. No caso do contexto internacional, há uma espécie de laboratório de experiências de governança global, com ideias sobre como lidar com esse tipo de solução de mecanismos espaciais.

Embora as FFs em Rondônia e em parte de Mato Grosso também façam parte do bioma amazônico, essas Unidades da Federação (UFs) foram englobadas juntamente com Mato Grosso do Sul no arco Central. Este arco, excetuando-se a porção atingida pelo bioma Pantanal (também uma área de grande comutação de povos indígenas), caracteriza-se por uma paisagem resultante da expansão da ocupação territorial brasileira, estabelecendo-se como uma transição entre a faixa preservada do arco Norte e a faixa de base produtiva agropecuária do arco Sul (Brasil, 2005). O arco Central define-se assim pela diversidade cultural e de base produtiva, que sinteticamente apresenta: i) mais ao norte, em Rondônia e em parte de Mato Grosso, frentes pioneiras de grandes produtores rurais de gado em pastagens que se instalaram em meio à cultura amazônica, permeadas por reservas indígenas e UCs; ii) na sequência, ainda entre reservas indígenas de Mato Grosso, verifica-se a expansão da agricultura de soja, demarcando um claro limite entre o Cerrado e o Pantanal, onde se estendem as fazendas de gado criado de forma extensiva; e iii) ao sul do Pantanal, o cenário em Mato Grosso do Sul é de mudança para o último arco, onde resquícios históricos materiais e imateriais do período do ciclo ervateiro encontram-se quase esquecidos pelo desenvolvimento agrícola em grandes e extensas áreas de produção de soja, desde o leste em São Paulo, não se distinguindo limites entre os biomas da Mata Atlântica e do Cerrado5 (Brasil, 2005; Observatório do Clima, 2019).

5. Mais informações disponiveis em: <https://bit.ly/3jit7Nq>. Acesso em: 20 jan. 2020. 
Esse processo de ocupação desencadeou conflitos fundiários e socioambientais, além de que se deu em um ambiente de compartilhamento internacional de biomas e grande biodiversidade, o Pantanal, a Floresta Amazônica e o Cerrado, e de encontro das duas grandes bacias hidrográficas sul-americanas, a Amazônica e a do Paraná-Paraguai. A incompatibilidade entre áreas protegidas nos dois lados da fronteira faz com que seja diferenciado o manejo dos produtos da silvicultura. Por exemplo, as práticas bolivianas permitem manejo adequado das florestas, alternando a exploração da vegetaçáo com a preservação do ambiente, e com isso se pode ter acesso a algumas espécies florestais com exploração proibida em território brasileiro. As fiscalizaçôes sanitárias animal e vegetal também requerem ajustes e lotação de pessoal em número e qualificação compatíveis com as necessidades dos postos fronteiriços, com fiscais federais presentes nas barreiras. Vale ressaltar o predomínio da ocupação da cadeia de carne e grãos, dado pela agricultura de precisão que ocupa o Cerrado brasileiro e tem avançado sobre a área de transição do Cerrado e da Floresta Amazônica (Pêgo et al., 2017; 2018).

Os participantes das discussóes do arco Central salientaram a baixa ambiental em relação ao complexo do Pantanal, com grande porção transfronteiriça a ser administrada compartilhadamente e seu alto grau de vulnerabilidade às dinâmicas em curso em outras unidades do relevo brasileiro, que vêm provocando efeitos devastadores. Entre eles, a ocupação dos planaltos pela agricultura moderna, que deslocam grandes volumes de detritos e vestígios de agrotóxicos para os cursos d'água que banham a planície pantaneira, além do assoreamento dos cursos d'agua e da degradaçáo do solo, principalmente pelo avanço da pecuária. Aliados ao manejo inadequado, alteram o equilíbrio hídrico e influenciam na dinâmica das plantas e da vida dos animais pantaneiros, que são também compartilhados com os países vizinhos. O garimpo também é uma atividade extremamente deletéria, destrutiva, principalmente do meio ambiente, e traz muitas atividades ilícitas. Portanto, os desafios ambientais no Pantanal são inúmeros: i) enfrentar a pressão das atividades agropecuárias, com especial atenção para o manejo da agricultura de grãos nos planaltos; ii) avaliar os impactos da implantaçáo de grandes obras, como a perspectiva de implantação da hidrovia Paraná-Paraguai; iii) mapear e monitorar as áreas de maior vulnerabilidade geoambiental; e iv) compatibilizar os períodos de defeso ou da piracema, para se disciplinar a pesca em águas compartilhadas, entre outros (Pêgo et al., 2019).

A FF encontra o arco Sul, formado por Paraná, Santa Catarina e Rio Grande do Sul. Nesse arco, integrado pelos biomas Mata Atlântica e Pampa, as UCs e reservas indígenas são pequenos pontos dispersos no território, comparativamente às grandes áreas nos outros arcos. Representa um espaço que sofreu grande processo de urbanização, no qual a FF tem relativamente alta proximidade às capitais e aos portos de escoamento da produção. Assim, não por acaso, é a FF cujos municípios são mais expressivos 
economicamente, seja pelo processo histórico de ocupação europeia (colonos sulinos), seja pela localização estratégica e de maior integração com os países vizinhos Paraguai, Argentina e Uruguai (Brasil, 2005; Observatório do Clima, 2019).

Apesar dessas condiçóes de bom desempenho socioeconômico, no trato da dimensão ambiental, participantes nas atividades do arco Sul alertam que as reservas ambientais sofrem com abandono e falta de investimentos; as legislaçóes entre os países são incompatíveis (como as relativas ao período de piracema - também apontado no arco Central -, à proibição de determinados componentes agrotóxicos, ao corte de madeira, entre outras), apesar de a lei brasileira ser mais protetiva ao meio ambiente. Essa falta de uniformidade legal entre os países favorece o desrespeito a práticas de manejo ambiental, de proteção de áreas e espécies vulneráveis, e incentiva o contrabando, como no caso de agrotóxicos, que nos países vizinhos são vendidos de forma abundante. Os desafios ambientais não são poucos no arco Sul, portanto. E no enfrentamento deles, há que se destacar a importância da uniâo das organizaçôes não governamentais (ONGs) da Tríplice Fronteira, que vem possibilitando a realizaçáo de projetos e a permuta de conhecimentos e experiências de gestâo socioambiental bastante válidas, em um conjunto de atividades que envolve universidades uruguaias e argentinas, bem como pesquisadores, historiadores e ambientalistas, partilhando saberes sobre a regiāo trinacional e produzindo conteúdos em diversas áreas (Pêgo et al., 2020a).

Entre os bens naturais fortalecidos pelas ONGs, citam-se a Reserva do Espinilho e o corredor biológico trinacional, composto pelo Parque Nacional do Espinilho, no Brasil, uma parte dos Campos General Ávalos, na Argentina, e o Parque Rincón de Franquía, no Uruguai. Esse corredor biológico trinacional guarda semelhanças ambientais e, por ser um ambiente mais aberto, é mais propício à observação de aves, algumas endêmicas. Ainda quanto às potencialidades naturais, destaca-se a presença dos rios Quaraí, Uruguai e Miriñay, ressaltando-se a importante compreensão de que "o rio não é para separar, não é uma fronteira, o rio é para unir". A Ilha Brasileira pode representar o centro dessa integraçáo (Pêgo et al., 2020a).

\subsubsection{Terras indígenas e unidades de conservação}

Confirmando as preocupaçóes e buscando elementos para refletir sobre os problemas apontados pelos participantes das atividades nos arcos da fronteira, agregam-se, a seguir, informaçóes qualificadas que apreendem em números e cartogramas a realidade descrita.

Dados da Fundação Nacional do Índio (Funai) indicam a existência, no Brasil, de 118,1 milhões de hectares de TIs, das quais 90\% (106,9 milhóes de hectares) se encontram regularizadas e os demais $10 \%$, em processo para a regularização (mapa 2). 
MAPA 2

Áreas de Tls - Brasil (2019)

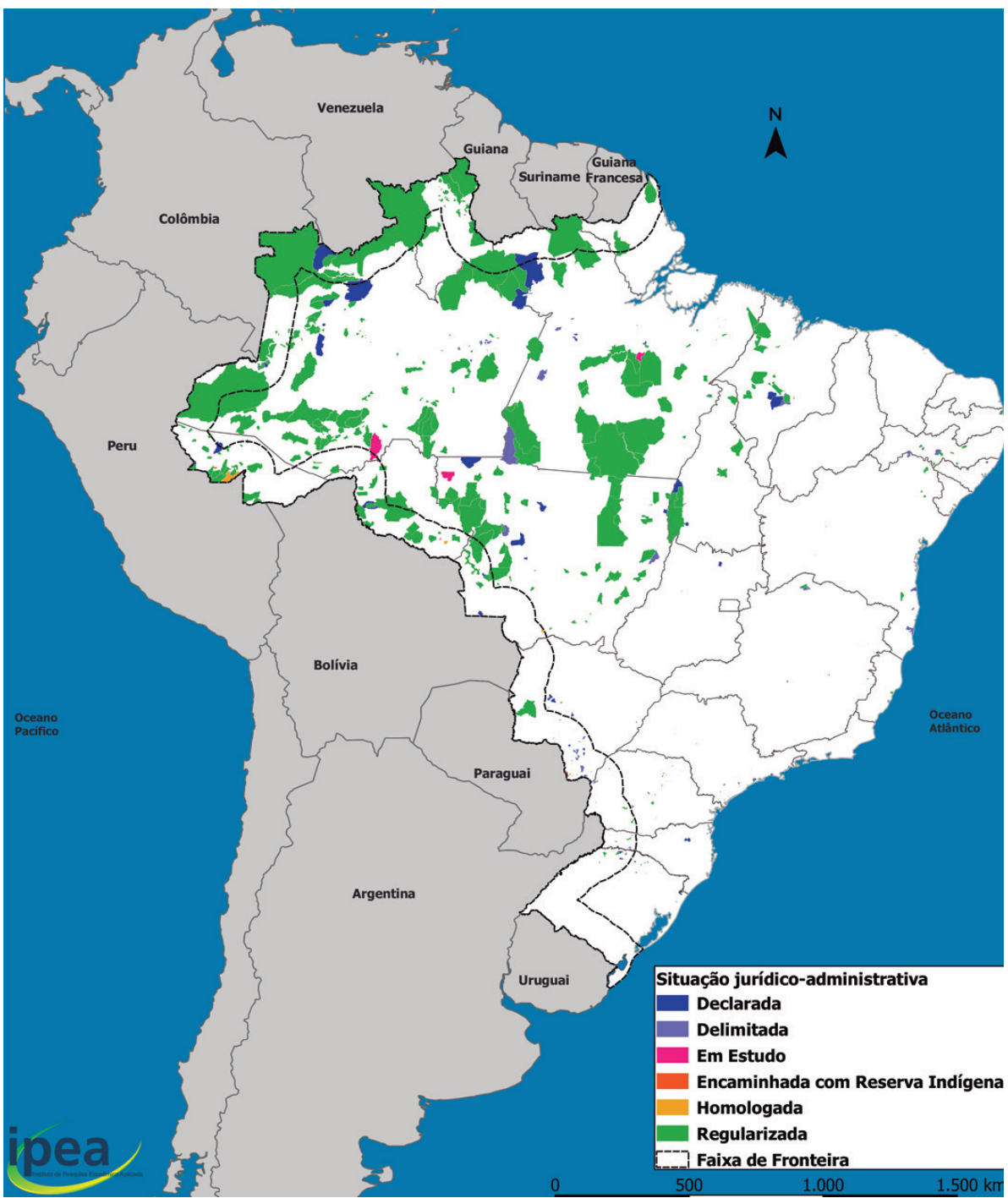

Fonte: Funai (2019).

Elaboração: Equipe Fronteiras Ipea. 
Desse total, 98,2\% (116,1 milhóes de hectares) se encontram em estados que compóem a Amazônia Legal. As preocupaçóes manifestadas pelos participantes das atividades do arco Norte náo eram, de forma alguma, infundadas. Mas as TIs também preenchem grandes extensôes de Rondônia e Mato Grosso, no arco Central e pequenas porçôes em Mato Grosso do Sul, com grande presença dos povos Guaranis.

Com base nas informaçóes desagregadas do Instituto Socioambiental (ISA), ${ }^{6}$ obtidas junto à Funai, 424 áreas indígenas localizam-se na Amazônia Legal, correspondendo a $23 \%$ de seu território. O Amazonas tem a maior proporção de seu território preenchido por TIs, ou seja, 28,54\%, seguido pelo Pará $(22,89 \%)$ e por Rondônia $(21,05 \%)$, conforme a tabela 1 . Em algumas UFs, as TIs tangenciam as sedes municipais, sendo que, no caso de Pacaraima (Roraima), todo o município está dentro de uma TI. O fato é que Pacaraima se elevou à condição de município quando o laudo antropológico de delimitação da reserva indígena estava sendo elaborado. A aprovaçáo do laudo, a aprovação da reserva e a inspeção do município aconteceram quase que paralelamente (Pêgo et al., 2018).

\section{TABELA 1}

Áreas de TIs por estado - Amazônia Legal' (22 out. 2014)

\begin{tabular}{lccc}
\hline UF & $\begin{array}{c}\text { Area da UF } \\
(\text { ha) }(\mathrm{A})\end{array}$ & $\begin{array}{c}\text { TI } \\
(\text { ha) }(\mathrm{B})\end{array}$ & $\begin{array}{c}\text { Sobre a UF (\%) } \\
(\mathrm{C})=(\mathrm{B}) /(\mathrm{A})\end{array}$ \\
\hline Acre & 16.491 .871 & 2.459 .834 & 14,92 \\
Amapá & 14.781 .700 & 1.191 .343 & 8,06 \\
Amazonas & 158.478 .203 & 45.232 .159 & 28,54 \\
Maranhão & 26.468 .894 & 2.285 .329 & 8,63 \\
Mato Grosso & 90.677 .065 & 15.022 .842 & 16,57 \\
Pará & 125.328 .651 & 28.687 .362 & 22,89 \\
Rondônia & 23.855 .693 & 5.022 .789 & 21,05 \\
Roraima & 22.445 .068 & 10.370 .676 & 46,20 \\
Tocantins & 27.842 .280 & 2.597 .580 & 9,33 \\
Total & $\mathbf{5 0 6 . 3 6 9 . 4 2 5}$ & $\mathbf{1 1 2 . 8 6 9 . 9 1 4}$ & $\mathbf{2 2 , 2 9}$ \\
\hline
\end{tabular}

Fonte: ISA (2015). Disponível em: <https://bit.ly/38hQWI4>. Acesso em: 20 nov. 2019.

Elaboração: Equipe Fronteiras Ipea.

Nota: ${ }^{1}$ Áreas calculadas pelo SIG/ISA, utilizando os limites das TIs lançados sobre a base 1:250.000 e os limites de estado do IBGE/Sivam na escala 1:250.000.

6. Optou-se por utilizar dados da ISA de 2015 (disponivel em: <https://bit.ly/38hQW|4>) para apresentar os desagregados para os estados em função do cuidado cartográfico deste órgão com os limites da Amazônia Legal, também porque os dados fornecidos pela Funai (2019) fornecem área total das TIs, sendo que muitas delas atingem dois ou mais estados. 
Esse município sofre restriçōes quanto a escrituração de imóveis, limitaçóes à cobrança do Imposto Predial e Territorial Urbano (IPTU) e outros tributos e taxas, o que pauperiza a receita municipal e inviabiliza a organização do território e a gestão urbana. $\mathrm{O}$ município fica privado também de segurança jurídica, pois o status jurídico está indefinido, já que se encontra dentro da área indígena São Marcos. Enfrenta ainda sérias dificuldades para obter ou criar linhas de crédito, particularmente a indígenas, além da inserção de transfronteiriços no Cadastro Único do Programa Bolsa Família, extensivo a estrangeiro residente no Brasil, com endereço comprovado, para que tenham acesso ao benefício.

Essa concentração de TIs na Amazônia Legal vem sofrendo efeitos de severos conflitos com o avanço da fronteira econômica. Há uma grande disputa de terra entre agricultores, pecuaristas, mineradores e indígenas, que tornam urgentes medidas que garantam direitos a esses povos originários de nosso território. Como é citado pelo ISA (2019), "há vozes dissonantes em relação ao tamanho das TIs na Amazônia, alegando que haveria 'muita terra para poucos índios'. Esses críticos se esquecem de que os índios têm que tirar todo seu sustento da terra." Há que se registrar a existência de um substrato rico em reservas minerais, fundamentalmente no subsolo amazônico, em se tratando da fronteira brasileira. Segundo informaçóes da Agência Nacional da Mineração (ANM), ${ }^{7}$ no arco Norte, o Amazonas produz ferro, estanho, nióbio e ouro; o Pará, alumínio, cobre, estanho, ferro, manganês, níquel e ouro; e o Amapá, ouro. No arco Central, ainda no bioma Amazônia, Rondônia produz estanho, manganês, nióbio, zinco e ouro; Mato Grosso, estanho, manganês e ouro; já no bioma Pantanal, Mato Grosso do Sul produz ferro e manganês (figura 1). 
FIGURA 1

Principais reservas minerais - Brasil (2017)

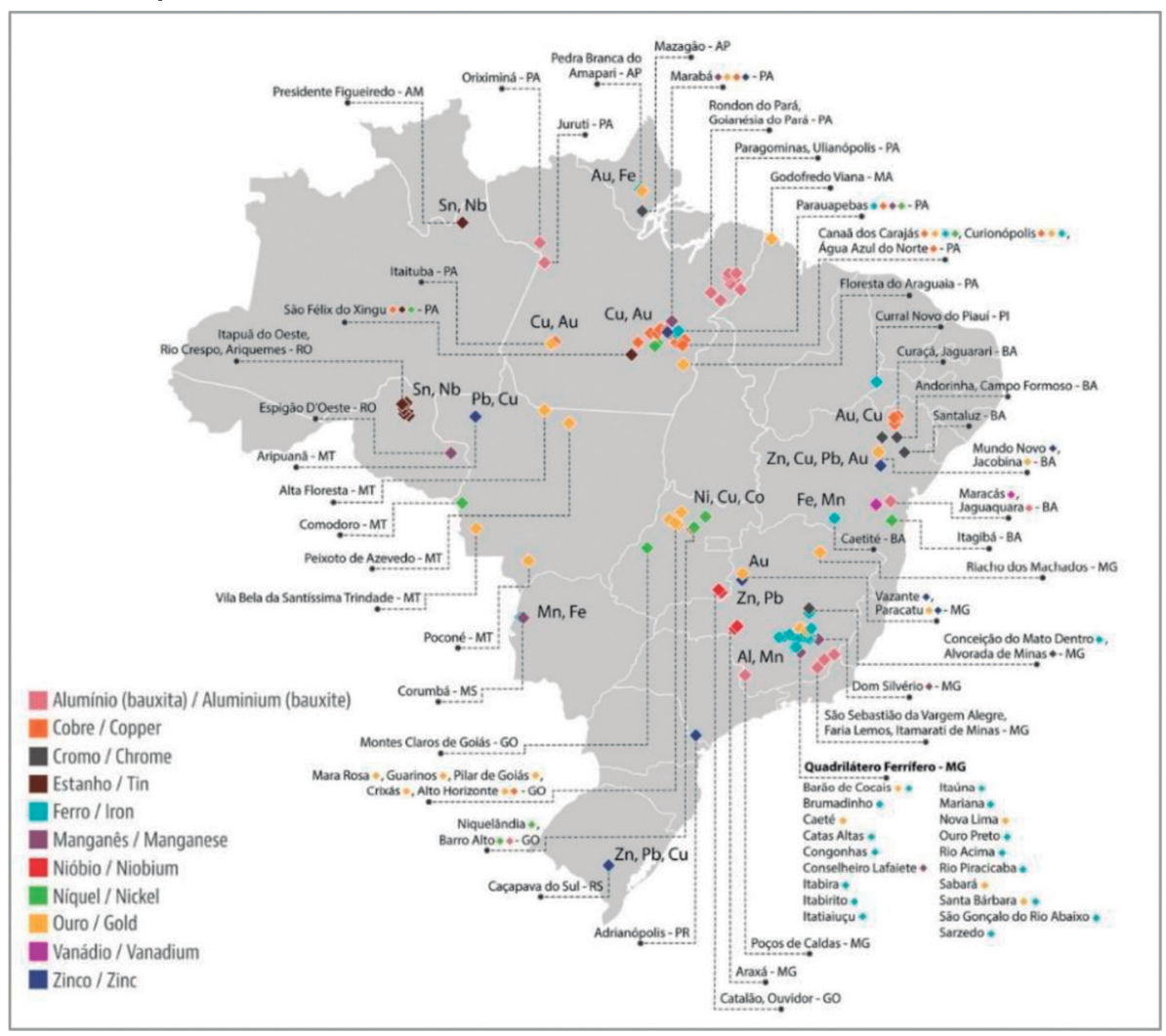

Fonte: ANM (Brasil, 2019a, p. 3).

Com essa disponibilidade, o avanço do extrativismo mineral vem acirrando disputas de espaço nas TIs, como mostram informaçóes do mapa 3, em que se visualizam extensas sobreposiçóes. Destacam-se as maiores proporçóes de áreas em sobreposição na FF do Amapá, do Pará, de Rondônia, de Mato Grosso e de Mato Grosso do Sul. Ressalta-se que, neste último estado, essa sobreposição é pouco perceptível no mapa, pois a área de suas TIs regularizadas (cerca de $600 \mathrm{mil}$ hectares $)^{8}$ é, comparativamente, menor que as áreas de TIs dos estados que compóem a Amazônia Legal (tabela 1), revelando o domínio da expansão da mineração e da fronteira agrícola sobre essa UF. Os conflitos sociais gerados pela desterritorialização indígena são evidenciados, contudo, ao se destacar como contraponto à menor área, que Mato Grosso do Sul é o segundo maior estado do Brasil em número de população indígena (somados os indígenas dentro e fora das TIs). Segundo dados

8. Área calculada com uso do software de geoprocessamento QGIS a partir de dados da Funai (2019). 
do Censo Demográfico 2010, do Instituto Brasileiro de Geografia e Estatística (IBGE), essa população seria de 77.025 habitantes.

\section{MAPA 3}

Reservas indígenas e áreas de extrativismo mineral - Brasil (2019)

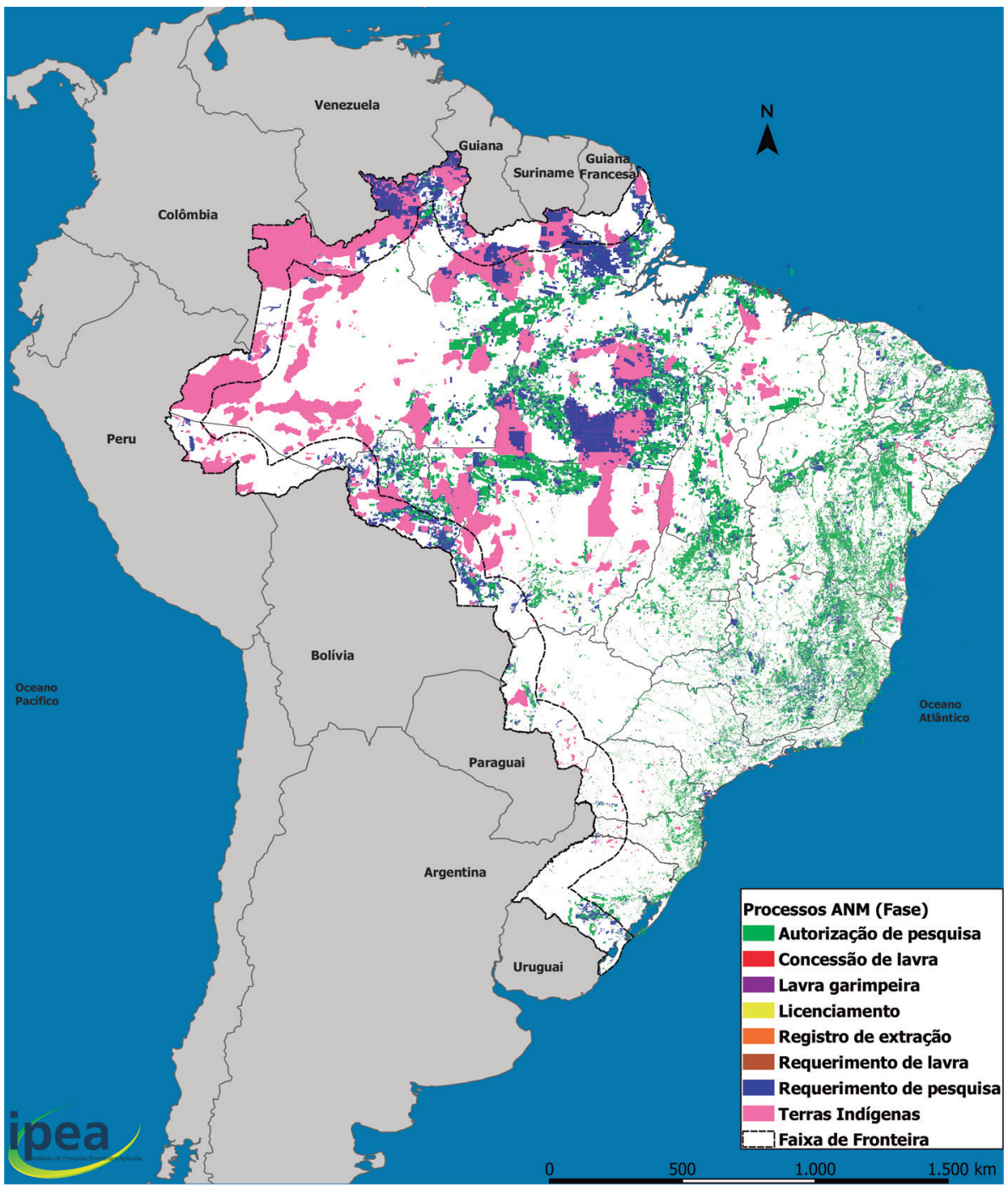

Fontes: Funai (2019); ANM (Brasil, 2019a).

Elaboração: Equipe Fronteiras Ipea.

Obs.: Foram legendadas apenas as categorias que aparecem na escala representada.

Igualmente às TIs, as UCs, sobretudo na Amazônia Legal, também vêm sofrendo com os conflitos inerentes ao processo de expansão da fronteira econômica, 
provocados por desmatamentos de grandes áreas para ocupação pela agropecuária e atividades de mineração, mas também mais próximos às áreas urbanizadas (capitais e cidades de médio porte).

Segundo dados do Painel Unidades de Conservação Brasileiras, do Ministério do Meio Ambiente (MMA), de 2019, ${ }^{9}$ entre as unidades protegidas, há no Brasil 2.412 UCs, considerando-se sobreposições entre áreas de proteção integral e áreas de uso sustentável. Particularizando os biomas pelos quais perpassa em maior proporção a FF, as UCs do bioma Amazônia agregam a maior área protegida do território nacional - $1.178 .370,2 \mathrm{~km}^{2}$, sendo o número de unidades correspondente a apenas $14,77 \%$ do total de UCs do país. No bioma Mata Atlântica, perfazem uma área bem menor e superam 50\% de UCs (tabela 2). O mesmo painel informa que a existência de planos de manejo e de conselho gestor para as UCs ainda está muito aquém do necessário. Das 351 UCs da Amazônia, apenas 94 possuem plano de manejo, e 188, conselho gestor, enquanto as demais não possuem esses meios fundamentais para gestão. Esses dados apontam para a fragilidade das unidades sem esses instrumentos em caso de acirramento de conflitos pelo uso da terra, e a exigência de práticas extrativistas adequadas.

\begin{tabular}{|c|c|c|c|c|c|}
\hline Bioma & Área da UC $\left(\mathrm{km}^{2}\right)$ & Quantidade de UC & Total de UC (\%) & Possui plano de manejo & Possui conselho gestor \\
\hline Amazônia & $1.178 .370,20$ & 351 & 14,77 & 94 & 188 \\
\hline Cerrado & $170.017,31$ & 438 & 18,43 & 70 & 89 \\
\hline Pantanal & $6.950,04$ & 25 & 1,05 & 5 & 2 \\
\hline Mata Atlântica & $106.670,22$ & 1364 & 57,41 & 239 & 344 \\
\hline Caatinga & $73.480,60$ & 201 & 8,46 & 15 & 50 \\
\hline Pampa & $5.528,68$ & 33 & 1,39 & 11 & 13 \\
\hline Total & $1.541 .017,10$ & 2.412 & 101,51 & 434 & 686 \\
\hline
\end{tabular}

Fonte: Painel Unidades de Conservação Brasileiras/MMA. Disponivel em: <https://bit.ly/38jBeWm>. Acesso em: 20 nov. 2019. Elaboração: Equipe Fronteiras Ipea.

A despeito dessa fragilidade, há que se considerar que essas unidades ainda são responsáveis por limitar o avanço dos desmatamentos e das queimadas nas regióes protegidas. Ao se comparar as áreas desmatadas mais recentemente, conforme dados da plataforma TerraBrasilis, do Instituto Nacional de Pesquisas Espaciais (Inpe), ${ }^{10}$ com a área coberta por UCs, constata-se que, de alguma maneira, a legalidade

9. Com dados atualizados em 15 de outubro de 2019. Disponível em: <https://bit.ly/34UygWo>. Acesso em: 20 nov. 2019. 10. TerraBrasilis é uma plataforma desenvolvida pelo Inpe para organização, acesso e uso por meio de um portal web dos dados geográficos produzidos pelos seus programas de monitoramento ambiental. Em um primeiro momento, visa atender principalmente ao Programa Amazônia, mas o conceito e os pacotes de software produzidos podem ser adaptados e customizados para atender a outros projetos que produzam dados geográficos e que tencionem oferecer acesso a estes no ambiente da internet. Disponível em: <https://bit.ly/39FvTZK>. Acesso em: 18 jan. 2020. 
dessas áreas ainda funciona como um limitante ao avanço da ação inconteste de todos os tipos de predação ambiental (mapa 4).

\section{MAPA 4}

Áreas desmatadas após 2000, excluindo os biomas Caatinga e Mata Atlântica - Brasil

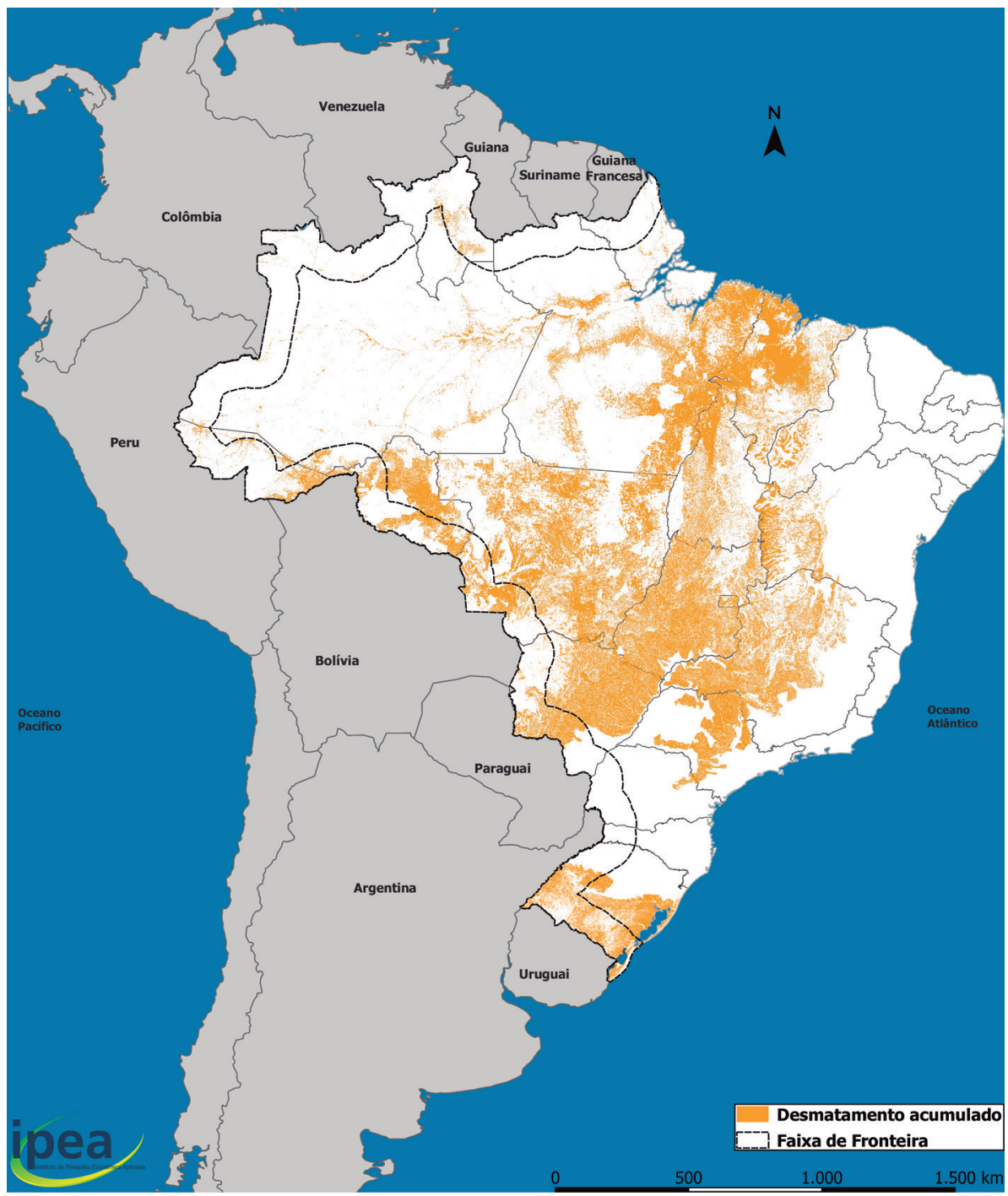

Fontes: Inpe (2018), disponível em: <https://bit.ly/2GCOIBe>. Acesso em: 20 jan. 2020; Assis et al. (2019).

Elaboração: Equipe Fronteiras Ipea.

Obs.: 1. Mapeamento baseado em metodologia encontrada em Câmara, Valeriano e Soares (2013).

2. A plataforma Terrabrasilis disponibiliza os dados de desmatamento categorizados por bioma, sendo que a série temporal de 2000 a 2018 só foi disponibilizada para as áreas da Amazônia Legal e do Cerrado. Para os biomas Pampa e Pantanal, a série cobre o intervalo 2000-2016. Os dados para os biomas Caatinga e Mata Atlântica não foram disponibilizados na plataforma até a confecção deste mapa. 
Além dos desmatamentos, dados do Programa Queimadas, também do Inpe (2019), apontam que os focos de queimadas na Amazônia aumentaram em 30\% em 2019, sendo registrados 89.176 focos. Porém, o maior crescimento do número de focos se deu no bioma Pantanal, com 10.025 focos, um crescimento de 493\% em relação ao ano anterior. No bioma Pampa, o aumento foi de 91\% (1.420 focos); no Cerrado, 62\% (63.874 focos); na Mata Atlântica, alta de 61\% (18.177 focos), e na Caatinga, 32\% (14.960 focos). Em 2020, dados do mesmo programa (Inpe, 2020) apontam que no período de $1^{\circ}$ de janeiro a 31 de outubro de 2020, em relação ao mesmo período de 2019, houve um considerável aumento por queimadas nos estados fronteiriços: Pará, com 59\% de aumento do número de focos, atingindo 33.449 focos em outubro; Mato Grosso, 54\% de aumento e 45.177 focos; Amazonas, $35 \%$ de aumento e 16.180 focos; Acre, $34 \%$ de aumento e 9.053 focos; e Mato Grosso do Sul, 12\% de aumento e 11.586 focos. Nesses estados, situam-se os dois biomas mais atingidos por queimadas no período: Amazônia (41,8\% do total de focos) e Cerrado (com 32,4\%). Tal crescimento exige medidas na agenda ambiental brasileira que rompam o ciclo de destruição ambiental provocado pelo avanço da fronteira econômica (Inpe, 2019).

Um mapeamento detalhado realizado pela Latentes, ${ }^{11}$ com base em informaçóes da ANM, do MMA, da Funai e do Instituto Nacional de Colonização e Reforma Agrária (Incra), identifica 4.536 áreas com risco de conflitos socioambientais no Brasil. Esses riscos são prenunciados pela proximidade das atividades de extrativismo mineral em relação às UCs, às terras indígenas, às comunidades remanescentes de quilombolas e aos assentamentos da reforma agrária. A sobreposiçáo dos layers (camadas) com essas informaçóes, além de permitir que se estimem possíveis áreas de tensão, mostra a extensão da cobertura do território do arco Norte por áreas legalmente reservadas a segmentos sociais e a unidades ambientais em condições de vulnerabilidade. Parte do arco Central também insere áreas contínuas de TIs e UCs nas mesmas condiçóes. ${ }^{12}$

A FF é, pois, um ambiente de riquezas naturais, biodiversidade e complexidades geradas pelo avanço da ocupação. Um espaço onde se realiza uma convivência plural não só pela presença do "lado de lá", como dos próprios povos que constituem a nação brasileira. Além da importante presença dos indígenas, são povos diversos com diferentes imaginários e identidades que compartem o espaço fronteiriço. É fundamental reconhecer tal pluralidade, identificar os conflitos e as tensôes e garantir o respeito aos direitos arduamente conquistados por segmentos sabidamente vulneráveis.

11. Grupo de trabalho coordenado pela Livre.jor, agência de jornalismo, com apoio do Fundo Brasil de Direitos Humanos $(\mathrm{FBDH})$, que desenvolve o projeto de mapeamento de dados públicos georreferenciados à disposição de defensores, pesquisadores e jornalistas.

12. Para mais informações, ver: <https://bit.ly/3cxUd1t>. Acesso em: 8 out. 2019. 


\subsubsection{A ocupação do território}

Quem vive na região pede que se atente para as distintas imagens que as fronteiras possuem para seus povos, que se discutam as imagens e ideias sobre fronteiras mobilizadas desde os centros de poder. É inegável a necessidade de reverter a visão negativa construída a respeito de habitantes de fronteiras, muitas vezes percebidos como pessoas "esquecidas". Essa é uma construção tão convincente que às vezes os próprios moradores das fronteiras se veem dessa forma, notam-se como pessoas que não estáo inseridas no território nacional, pessoas que não têm ajuda do governo brasileiro ou do outro país. Participantes das atividades nos arcos criticaram o modo de olhar, conceber e pensar a fronteira brasileira, sem ter em mente que a FF é muito mais que apenas um espaço que está "no meio" de um eixo de desenvolvimento ou de integração, ou apenas mais um ponto de passagem, um lugar por onde os fluxos se desenvolvem. Observaram que, para muitos, a fronteira é apenas naturalizada como uma área pobre, incompatível com o restante do país. Talvez pelo fato de relações inversamente proporcionais: mesmo que a FF corresponda a aproximadamente $27 \%$ do território nacional (considerando-se as áreas totais dos municípios integrantes), possui menos de $6 \%$ da população brasileira, constituindo um território de representação política muito baixa (Pêgo et al., 2017; 2018; 2019; 2020a).

Com base na atual composição da FF, seus 586 municípios correspondem a $10,5 \%$ do total dos municípios do Brasil, em 2019, e sua população, a 5,58\% do total da população brasileira. Estão assim distribuídos: 69 no arco Norte, 101 no Central e 416 no Sul (tabela 3). A considerar a área de todos os municípios inseridos ou cortados parcialmente por essa faixa, a área total abrangida é de 2.250.338 $\mathrm{km}^{2}$. Com essa distribuição, o arco Sul contribui com $71 \%$ dos municípios da FF e com apenas $10,7 \%$ de sua área total, enquanto o arco Norte responde pela maior extensão da área $(65,5 \%)$ e menor número de municípios. 
TABELA 3

Municípios, área e densidade demográfica, segundo recortes territoriais - Brasil

\begin{tabular}{|c|c|c|c|c|c|c|c|}
\hline Arco & $\begin{array}{c}\text { Quantidade de } \\
\text { municípios (2019) }\end{array}$ & $\begin{array}{c}\text { Municípios } \\
(\%)\end{array}$ & $\begin{array}{l}\text { Área } \\
2018^{1}\end{array}$ & $\begin{array}{l}\text { Área } \\
(\%)\end{array}$ & $\begin{array}{l}\text { Densidade } \\
(\text { hab./km²) }\end{array}$ & $\begin{array}{c}\text { População } \\
\text { estimada } 2019\end{array}$ & $\begin{array}{c}\text { População } \\
\text { estimada (\%) }\end{array}$ \\
\hline Norte & 69 & 11,77 & $1.472 .937,00$ & 65,45 & 1,6 & 2.358 .763 & 20,1 \\
\hline Central & 101 & 17,24 & $535.524,90$ & 23,8 & 5,34 & 2.860 .369 & 24,38 \\
\hline Sul & 416 & 70,99 & $241.876,10$ & 10,75 & 26,93 & 6.514 .316 & 55,52 \\
\hline Total da FF & 586 & 100,00 & $2.250 .338,00$ & 100,00 & 5,21 & 11.733 .448 & 100,00 \\
\hline FF & 586 & 10,52 & $2.250 .338,00$ & 26,48 & 5,21 & 11.733 .448 & 5,58 \\
\hline Demais & 4.984 & 89,48 & $6.247 .464,50$ & 73,52 & 31,76 & 198.413 .677 & 94,42 \\
\hline Brasil & 5.570 & 100,00 & $8.497 .802,50$ & 100,00 & 24,73 & 210.147 .125 & 100,00 \\
\hline
\end{tabular}

Fonte: IBGE (2018; 2019).

Elaboração: Equipe Fronteiras Ipea.

Nota: ${ }^{1}$ Inclui as áreas das lagoas dos Patos e Mirim.

$\mathrm{O}$ arco Norte registra, também, a menor densidade demográfica entre os três $\operatorname{arcos}\left(1,6 \mathrm{hab} . / \mathrm{km}^{2}\right)$ e $20 \%$ da populaçấo da $\mathrm{FF} \cdot{ }^{13}$ Outros $24,4 \%$ da população situam-se no arco Central, que já aponta uma pequena elevação na densidade, que é bastante similar à da FF (5,3 e 5,2, respectivamente). É o Sul que concentra mais de metade da população da FF, e uma densidade demográfica bem mais elevada, de aproximadamente $27 \mathrm{hab} . / \mathrm{km}^{2}$.

Os arcos não apresentam homogeneidade na distribuição da população, manifestando poucas áreas com maior densidade demográfica, exceto no arco Sul (mapa 5). Nos demais arcos, a população concentra-se nas capitais estaduais e centralidades principais, como também recobre esparsa e continuamente as áreas ao longo de vias fluviais e os pequenos povoados que pontuam as margens das rodovias.

13. Embora se reconheça que a densidade demográfica construída a partir de setores censitários expressa com mais precisão a distribuição da população no território municipal, considera-se neste estudo a densidade demográfica relativa à área do município, tanto por ser atualizada no âmbito das recentes medições quanto por se estimar a população para este final de década. As informações por setor censitário foram colhidas no Censo Demográfico 2010. 
MAPA 5

Densidade demográfica municipal - Brasil (2019)

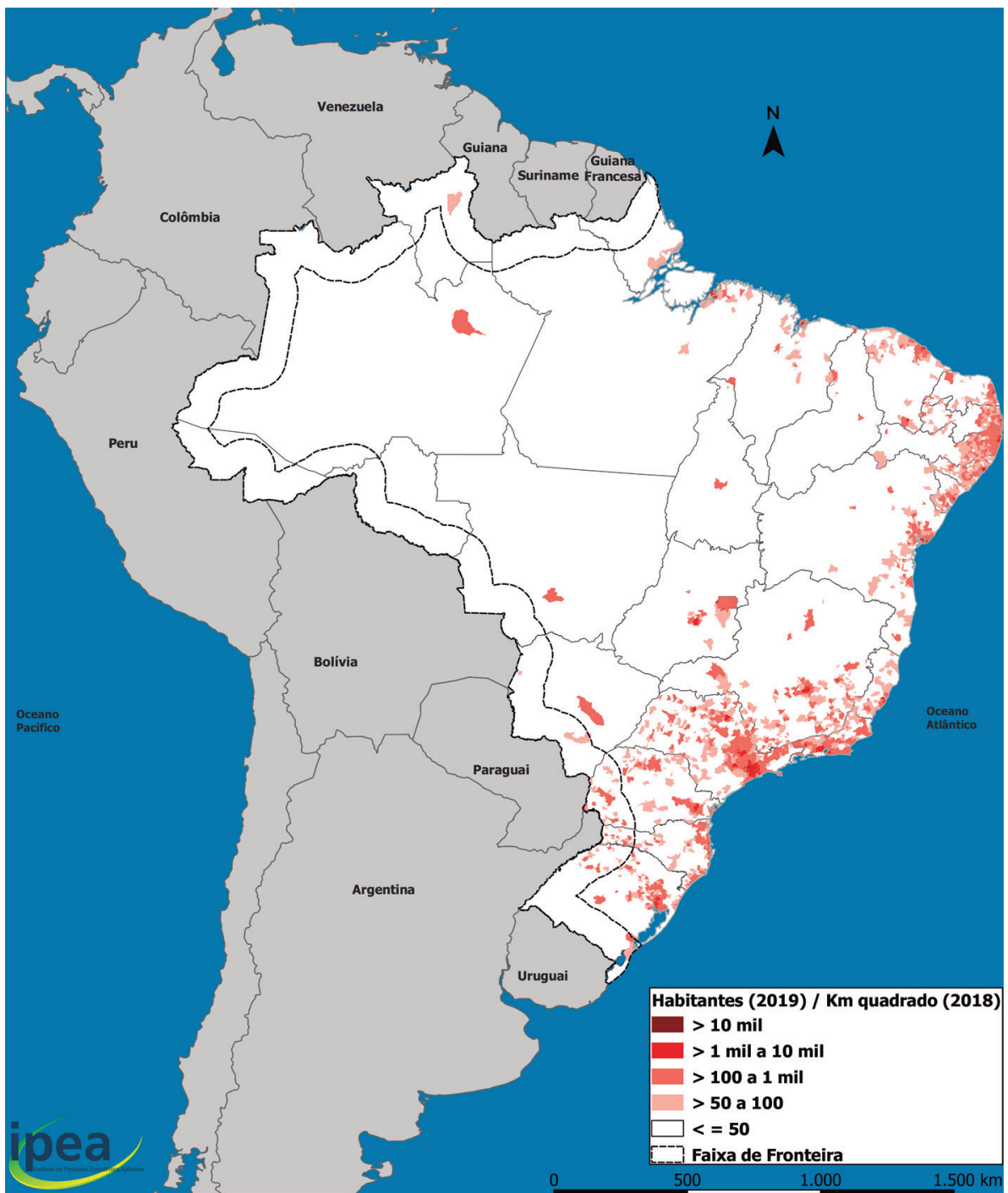

Fontes: IBGE (2018; 2019).

Elaboração: Equipe Fronteiras Ipea.

Ao se observar as densidades demográficas dos municípios da FF, comparativamente, constata-se que nenhum é classificado nos estratos com mais de 1 mil hab. $/ \mathrm{km}^{2}$ (tabela 4). Apenas o arco Sul tem uma pequena parcela de municípios no estrato entre 100 e 1 mil hab. $/ \mathrm{km}^{2}$, com destaque para Foz do Iguaçu, que apresenta a maior densidade demográfica desse arco $\left(418,1\right.$ hab. $\left./ \mathrm{km}^{2}\right)$. Nos três arcos, 
a maioria dos municípios classifica-se no estrato daqueles com menos de 50 hab./ $\mathrm{km}^{2}$, com grande número de ocorrências de municípios com menos de 10 hab./ $\mathrm{km}^{2}$. No arco Norte, apenas Boa Vista, capital de Roraima, possui densidade nesse estrato, alcançando $70,2 \mathrm{hab} . / \mathrm{km}^{2}$, sendo que Rio Branco tangencia o parâmetro, com 46,1 hab. $/ \mathrm{km}^{2}$. No Central, somente Dourados, Fátima do Sul e Ladário, todos de Mato Grosso do Sul, possuem mais que 50 hab. $/ \mathrm{km}^{2}$ (respectivamente 54,5; 60,9; e 68,5 hab. $\left./ \mathrm{km}^{2}\right)$.

\section{TABELA 4}

Densidade demográfica segundo estratos ${ }^{1}$ - Brasil (2019)

\begin{tabular}{lcccccc}
\hline Recorte territorial & $>10$ mil & $>1$ mil a 10 mil & $>100$ a 1 mil & $>50$ a 100 & $<=50$ & Total de municípios \\
\hline Norte & 0 & 0 & 0 & 1 & 68 & 69 \\
Central & 0 & 0 & 0 & 3 & 98 & 101 \\
Sul & 0 & 0 & 17 & 34 & 365 & 416 \\
Total da FF & 0 & 0 & $\mathbf{1 7}$ & $\mathbf{3 8}$ & $\mathbf{5 3 1}$ & $\mathbf{5 8 6}$ \\
\hline FF & 0 & 0 & 17 & 38 & 531 & 586 \\
Demais & 6 & 97 & 672 & 700 & 3.509 & 4.984 \\
Brasil & 6 & $\mathbf{9 7}$ & $\mathbf{6 8 9}$ & $\mathbf{7 3 8}$ & $\mathbf{4 3 0 4 0}$ & $\mathbf{5 . 5 7 0}$ \\
\hline
\end{tabular}

Fontes: IBGE (2018; 2019).

Elaboração: Equipe Fronteiras Ipea.

Nota: ${ }^{1}$ Habitantes (população estrato 2019)/ $/ \mathrm{km}^{2}$ (área 2018).

Os dados confirmam, por exemplo, que as ponderaçóes dos participantes das atividades das oficinas e de campo, de que um grande desafio da Amazônia é a sua dimensão, sua baixa densidade demográfica, o que exige que o discurso de que essa é uma "terra sem homens" precisa ser superado (Pêgo et al., 2018).

\subsection{População}

\subsubsection{Distribuiç̧ão e crescimento}

$\mathrm{Na} \mathrm{FF}$, poucos são os municípios que têm mais de $0,1 \%$ da população brasileira, sendo esses os mais concentradores dos respectivos arcos (tabela 5). Correspondem: às capitais de UFs Porto Velho (Rondônia), Rio Branco (Acre) e Boa Vista (Rorai$\mathrm{ma}$ ); e a algumas centralidades com importância regional e de centros conectores nas relaçóes transfronteiriças, como Cascavel (Paraná), Dourados (Mato Grosso do Sul), Chapecó (Santa Catarina), Pelotas e Rio Grande (Rio Grande do Sul), além de Foz do Iguaçu (Paraná), que polariza o maior arranjo transfronteiriço da linha de fronteira brasileira. 
TABELA 5

Municípios mais populosos dos $\operatorname{arcos}^{1}$ - Brasil (2019)

\begin{tabular}{lcccc}
\hline Município & Arco & População estimada (2019) & No Brasil (\%) & Na FF (\%) \\
\hline Porto Velho & Central & 529.544 & 0,25 & 4,51 \\
Rio Branco & Norte & 407.319 & 0,19 & 3,47 \\
Boa Vista & Norte & 399.213 & 0,19 & 3,40 \\
Pelotas & Sul & 342.405 & 0,16 & 2,92 \\
Cascavel & Sul & 328.454 & 0,15 & 2,80 \\
Foz do lguaçu & Sul & 258.532 & 0,12 & 2,20 \\
Dourados & Central & 222.949 & 0,11 & 1,90 \\
Chapecó & Sul & 220.367 & 0,11 & 1,88 \\
Rio Grande & Sul & 211.005 & 0,10 & 1,80 \\
\hline
\end{tabular}

Fonte: IBGE (2019).

Elaboração: Equipe Fronteiras Ipea.

Nota: ${ }^{1}$ Foram considerados apenas os municípios com participação superior a $0,1 \%$ no total da população brasileira.

O ritmo de crescimento da população também é heterogêneo entre os municípios. Considerando-se a taxa média geométrica de crescimento demográfico anual 2010-2019 dos municípios, verifica-se que o arco Norte é o que tem a maior proporção de municípios crescendo mais que o dobro da taxa média do Brasil (tabela 6). Mais da metade dos municípios desse arco cresce a taxas superiores a 2,16\% ao ano (a.a.). No arco Central, a maior proporção está entre os municípios com crescimento até a taxa média do país, 1,08\% a.a. Nesse arco, 21,8\% dos municípios perdem população no período. Esse desempenho de perda populacional é mais recorrente no arco Sul, constatado em mais de metade dos municípios (57\%), apesar de ser essa a região fronteiriça com maior dinamismo econômico. Nesse arco, são poucos os que crescem acima da taxa média do país, e apenas três municípios crescem mais que o dobro dessa média (2,16\% a.a.).

\section{TABELA 6}

Crescimento médio geométrico anual da população, segundo estratos - Brasil (2010-2019)

\begin{tabular}{|c|c|c|c|c|c|c|c|c|c|c|}
\hline \multirow{2}{*}{$\begin{array}{l}\text { Recorte } \\
\text { territorial }\end{array}$} & \multicolumn{2}{|c|}{$>=2,16$} & \multicolumn{2}{|c|}{$\begin{array}{c}>=1,08 \mathrm{a}< \\
2,16 \%\end{array}$} & \multicolumn{2}{|c|}{$>=0 \mathrm{a}<1,08 \%$} & \multicolumn{2}{|c|}{$<0$} & \multirow[t]{2}{*}{$\begin{array}{c}\text { Municípios criados } \\
\text { após } 2010\end{array}$} & \multirow[t]{2}{*}{ Total } \\
\hline & № & $\%$ & № & $\%$ & № & $\%$ & № & $\%$ & & \\
\hline Norte & 40 & 57,97 & 17 & 24,64 & 6 & 8,70 & 6 & 8,70 & 0 & 69 \\
\hline Central & 16 & 15,84 & 27 & 26,73 & 36 & 35,64 & 22 & 21,78 & 0 & 101 \\
\hline Sul & 3 & 0,72 & 43 & 10,34 & 133 & 31,97 & 237 & 56,97 & 0 & 416 \\
\hline Total da FF & 59 & 10,07 & 87 & 14,85 & 175 & 29,86 & 265 & 45,22 & 0 & 586 \\
\hline $\mathrm{FF}$ & 59 & 10,07 & 87 & 14,85 & 175 & 29,86 & 265 & 45,22 & 0 & 586 \\
\hline Demais & 326 & 6,54 & 1.188 & 23,84 & 2.604 & 52,25 & 861 & 17,28 & 5 & 4.984 \\
\hline Brasil & 385 & 6,91 & 1.275 & 22,89 & 2.779 & 49,89 & 1.126 & 20,22 & 5 & 5.570 \\
\hline
\end{tabular}

Fonte: IBGE (2019).

Elaboração: Equipe Fronteiras Ipea.

Obs.: 1,08\% a.a. é a taxa correspondente ao Brasil. 
A maioria dos municípios com as mais elevadas taxas de crescimento situa-se na linha de fronteira do arco Norte, muitos deles integrando arranjos transfronteiriços ou cidades na fronteira sem configurar arranjo com cidade correspondente do país vizinho. Em menor proporção, isso se repete nos demais arcos, nos quais o elevado crescimento também se relaciona com a presença do agronegócio. No arco Norte, encontram correspondência também com a proximidade a reservas extrativistas e atividades de mineração. Boa Vista (Roraima), Porto Velho (Rondônia) e Rio Branco (Acre) são as capitais de estados da FF com crescimento acima do dobro da média nacional, respectivamente 3,84\% a.a., 2,38\% a.a. e 2,16\% a.a.

Entre os municípios com as taxas negativas de crescimento mais marcantes encontram-se Japurá, com o mais elevado declínio (-10,30\% a.a.), situado na linha de fronteira do Amazonas. Merece destacar, também, Porto Vera Cruz, que compóe arranjo transfronteiriço na linha de fronteira do Rio Grande do Sul, com taxa de $-3,37 \%$ a.a.

Esse quadro de municípios com perda de população vem se dando desde a década de 2000 para uma porção de 44\% dos municípios da FF, enquanto, para os demais municípios brasileiros, a proporção é de 15,8\% (tabela 7). Em situação inversa, na FF, 45,4\% dos municípios apresentaram crescimento tanto entre 20002010 quanto 2010-2019.

TABELA 7

Evolução do crescimento médio geométrico anual da população - Brasil (2000-2010 e 2010-2019)

\begin{tabular}{|c|c|c|c|c|c|c|c|c|c|c|}
\hline \multirow[t]{2}{*}{ Recorte territorial } & \multicolumn{2}{|c|}{$\begin{array}{l}\text { Positivo/ } \\
\text { positivo }\end{array}$} & \multicolumn{2}{|c|}{$\begin{array}{l}\text { Negativo/ } \\
\text { positivo }\end{array}$} & \multicolumn{2}{|c|}{$\begin{array}{l}\text { Positivo/ } \\
\text { negativo }\end{array}$} & \multicolumn{2}{|c|}{$\begin{array}{c}\text { Negativo/ } \\
\text { negativo }\end{array}$} & \multirow{2}{*}{$\begin{array}{l}\text { Municípios } \\
\text { criados } \\
\text { após } 2000\end{array}$} & \multirow[t]{2}{*}{ Total } \\
\hline & № & $\%$ & № & $\%$ & № & $\%$ & № & $\%$ & & \\
\hline Norte & 62 & 89,86 & 1 & 1,45 & 0 & 0 & 6 & 8,70 & 0 & 69 \\
\hline Central & 66 & 65,35 & 10 & 9,90 & 0 & 0 & 22 & 21,78 & 3 & 101 \\
\hline Sul & 138 & 33,17 & 33 & 7,93 & 0 & 0 & 230 & 55,29 & 15 & 416 \\
\hline Total da FF & 266 & 45,39 & 44 & 7,51 & 0 & 0 & 258 & 44,03 & 18 & 586 \\
\hline FF & 266 & 45,39 & 44 & 7,51 & 0 & 0 & 258 & 44,03 & 18 & 586 \\
\hline Demais & 3.664 & 73,52 & 423 & 8,49 & 64 & 1,28 & 788 & 15,81 & 45 & 4.984 \\
\hline Brasil & 3.930 & 70,56 & 467 & 8,38 & 64 & 1,15 & 1.046 & 18,78 & 63 & 5.570 \\
\hline
\end{tabular}

Fontes: IBGE (2019); Censos Demográficos 2000-2010, disponível em: <https://bit.ly/2U13002>. Acesso em: 20 jan. 2020. Elaboração: Equipe Fronteiras Ipea.

Tal dinâmica foi motivo de preocupação e reflexão nas oficinas de trabalho realizadas nos três arcos da fronteira, particularmente no Sul, arco no qual mais de metade da população apresentou taxas negativas nos dois períodos analisados (mapa 6). 
MAPA 6

Evolução do crescimento da população - Brasil (2000-2010 e 2010-2019)

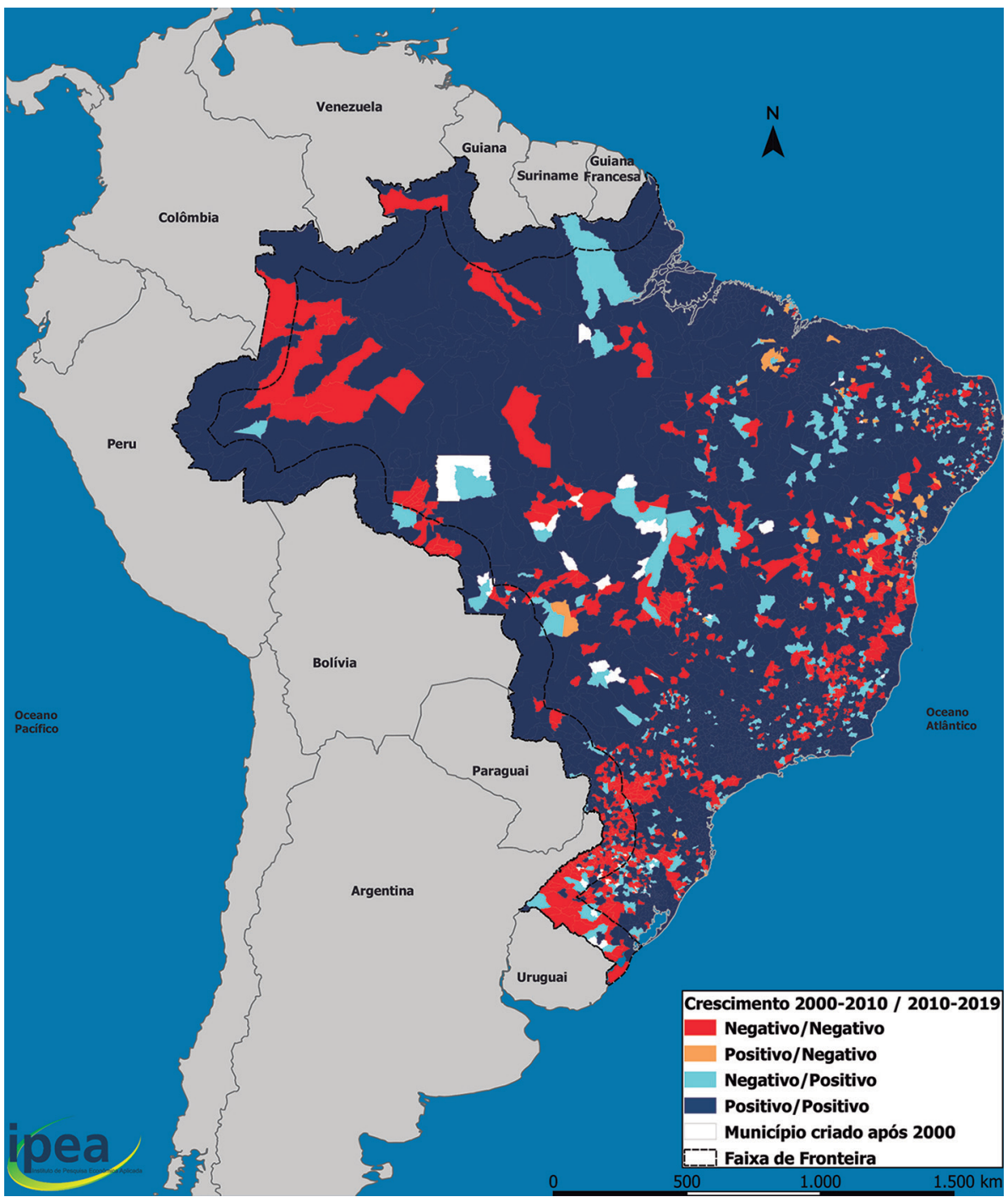

Fontes: IBGE (2019); Censos Demográficos 2000-2010, disponíveis em: <https://bit.ly/2U13002>. Acessos em: 20 jan. 2020. Elaboração: Equipe Fronteiras Ipea. 
Para os participantes das atividades do arco Sul, a região vem manifestando uma dinâmica econômica pouco relevante para os municípios, na medida que demonstra baixa capacidade de articulação interna, o que a torna relativamente dependente de açóes federais. Isso se confirmou em Sant'Ana do Livramento e São Borja, grandes municípios desse arco da fronteira, que apresentaram crescimento populacional negativo nos dois períodos analisados, e Uruguaiana, que, embora com taxa positiva no período 2010-2019, situa-se em 0,14\% a.a. O desafio, segundo os participantes, é o incremento da base produtiva, para garantir um patamar de renda para a população dos dois lados da fronteira, com a finalidade de suprir a falta de emprego existente (Pêgo et al., 2017; 2020a).

\subsubsection{Migrações e solicitações de refúgio}

O espaço fronteiriço tem a particularidade de conter vários portais para os fluxos de pessoas em movimentos de entrada e saída do país. Alguns desses portais são estruturados com equipamentos e equipes para controle dos movimentos; outros são espaços abertos, seja em vias alternativas que se criam cotidianamente nessas áreas ou mesmo nos postos fronteiriços oficiais, desprovidos de efetivos e equipamentos para o serviço de orientação e controle das entradas e saídas de pessoas e outros serviços aduaneiros.

No que se refere a migraçóes internacionais, fluxos que pressupóem mudança de domicílio e de país de moradia, observam-se distintos movimentos de população, considerando-se os portais de entrada da fronteira terrestre e os municípios da FF, conforme descrito a seguir.

1) Relativos às migraçóes de contato, ou seja, movimentos de curta distância entre os municípios brasileiros e dos países vizinhos, nos dois sentidos, entradas e saídas. Estudo no âmbito de "O Mercosul e as regiōes de fronteira", projeto do Ipea, com base nos dados do Censo Demográfico 2010, mostra que, no caso dos movimentos sul-americanos, ocorreu uma nítida mobilidade entre países limítrofes, com muitos dos fluxos recebidos ou enviados que se caracterizam por curta distância (Cardoso e Moura, 2017). Os migrantes tinham origem e destino não só relacionados a países limítrofes, como a municípios de estados/departamentos correspondentes em cada lado da fronteira, entre unidades espaciais pertencentes a regióes contíguas, apenas separadas pelo limite de Estado. ${ }^{14}$ Tanto os fluxos

14. 0 referido estudo demarca os destinos dos emigrantes de municípios com participação superior a 0,1\% do total dos emigrantes para a América do Sul (Cardoso e Moura, 2017). A maioria situa-se na linha de fronteira, e as correspondências são diretas: Amapá - Guiana Francesa; Pará - Suriname; Roraima - Venezuela; Acre - Bolívia; Rondônia - Bolívia; Mato Grosso - Bolívia; Mato Grosso do Sul - Bolívia e Paraguai; Paraná - Paraguai; Santa Catarina - Argentina; e Rio Grande do Sul - Argentina e Uruguai. Similar mapeamento em relação aos imigrantes tem a procedência agregada e mostra que, para a maioria desses mesmos municípios, a procedência é América do Sul - o que leva a pressupor que se assemelhe com os fluxos emigratórios, com as saídas originadas nos países vizinhos. 
imigratórios como os emigratórios nos municípios da linha de fronteira, e alguns da FF, sugerem essa mobilidade de contato, de transposição, que em muitos casos podem corresponder a estrangeiros ou brasileiros em retorno. São movimentos que têm uma natureza específica, que mostram a interação entre os povos fronteiriços que cruzam a fronteira sem se interiorizarem nos países, criando uma área transfronteiriça, na qual se mesclam atividades e características de um território e de outro.

2) Movimentos dos povos que desconhecem os limites fronteiriços em suas práticas de mobilidade, que ignoram as fronteiras. É o caso de muitos povos indígenas, a exemplo dos Waraos venezuelanos, que foram os primeiros sinalizadores da crise da Venezuela e da consequente diáspora desencadeada.

3) Movimentos que constituem corredores unidirecionais, sendo os mais expressivos os relativos a bolivianos que cruzam os vários postos fronteiriços de Mato Grosso e Mato Grosso do Sul, que servem à contínua entrada desses povos em fluxos majoritariamente para São Paulo. Resultados de mais de um Censo Demográfico alimentam estudos que analisam esses fluxos formados por pessoas que, em sua maioria, buscam uma ocupaçáo, muitas vezes precarizada e nos limites caracterizada como trabalho escravo, em oficinas de confecçóes na cidade de São Paulo. São fluxos que carecem de orientação no momento da chegada e proteção contra a ação predatória de coiotes e aliciadores.

4) Movimentos provocados por catástrofes, perseguiçóes e violência, ou crises agudas. São vários os estados e principalmente cidades fronteiriças que se viram ou se veem repentinamente com a incumbência de receber, acolher, orientar populaçóes em busca de sobrevivência. Brasileia e Assis Brasil, no Acre, foram cidades que se obrigaram a assumir a entrada dos haitianos que deixavam o país devastado pelo terremoto de 2010, vindos por uma rota bastante longa, que desembocava na fronteira do Brasil, Peru e Bolívia. Entravam no país por Iñapari, cidade peruana que compóe um arranjo transfronteiriço com Assis Brasil e Bolpebra (Bolívia), ou por Cobija, cidade boliviana que compóe arranjo com Brasileia e Epitaciolândia. Também, neste início de século, fluxos de populaçóes amedrontadas por conflitos armados na Colômbia se deslocaram ao Brasil, via Letícia, que compóe arranjo transfronteiriço com Tabatinga (Amazonas) e Santa Rosa, uma pequena ilha peruana. Mais recentes e também muito significativos são os fluxos de venezuelanos que chegam ao Brasil via Santa Elena de Uairén (Venezuela), que compóe arranjo transfronteiriço com Pacaraima (Roraima). Programas de interiorização rumo a outras cidades 
brasileiras foram formulados para conter a crise nas cidades de chegada, particularmente no caso dos haitianos e venezuelanos. ${ }^{15}$

5) Movimento de estudantes que deixam o Brasil para cursarem medicina, entre outros, nos municípios fronteiriços da Bolívia e do Paraguai, mas também em alguns próximos à fronteira. Ciudad del Este e Pedro Juan Caballero, no Paraguai, Santa Cruz de la Sierra, Cochabamba e até mesmo Cobija, na Bolívia, são alguns exemplos.

6) Movimentos desencadeados por programas governamentais, como o de saúde Mais Médicos, que, de 2013 a 2018, procurou atender a demandas básicas de municípios fronteiriços, pouco atrativos para os profissionais brasileiros.

Um esquema dos principais movimentos está expresso na figura 2. Cabe salientar a importância dos arranjos transfronteiriços como portais de entradas e saídas de todos os tipos de migrantes. No entanto, é também necessário lembrar a precariedade da maioria dos postos fronteiriços, alguns com dificuldade para exercer um controle mínimo, outros sem alguma operação de controle.

15. 0 destaque é a Operação Acolhida. Tratando-se de "uma grande força-tarefa humanitária executada e coordenada pelo governo federal com o apoio de agências da ONU e de mais de cem entidades da sociedade civil, a operação oferece assistência emergencial aos imigrantes venezuelanos que entram no Brasil pela fronteira com Roraima. Desde o início da crise migratória, estima-se que mais de 264 mil venezuelanos entraram e permaneceram no Brasil. Está organizada em três eixos: i) ordenamento da fronteira - documentação, vacinação e operação controle do Exército brasileiro; ii) acolhimento - oferta de abrigo, alimentação e atenção à saúde; e iii) interiorização - deslocamento voluntário de venezuelanos de Roraima para outras UFs, com objetivo de inclusão socioeconômica". Para mais detalhes, consultar: <gov.br/acolhida>. 


\section{FIGURA 2}

Principais fluxos migratórios via fronteira terrestre - Brasil (2018)

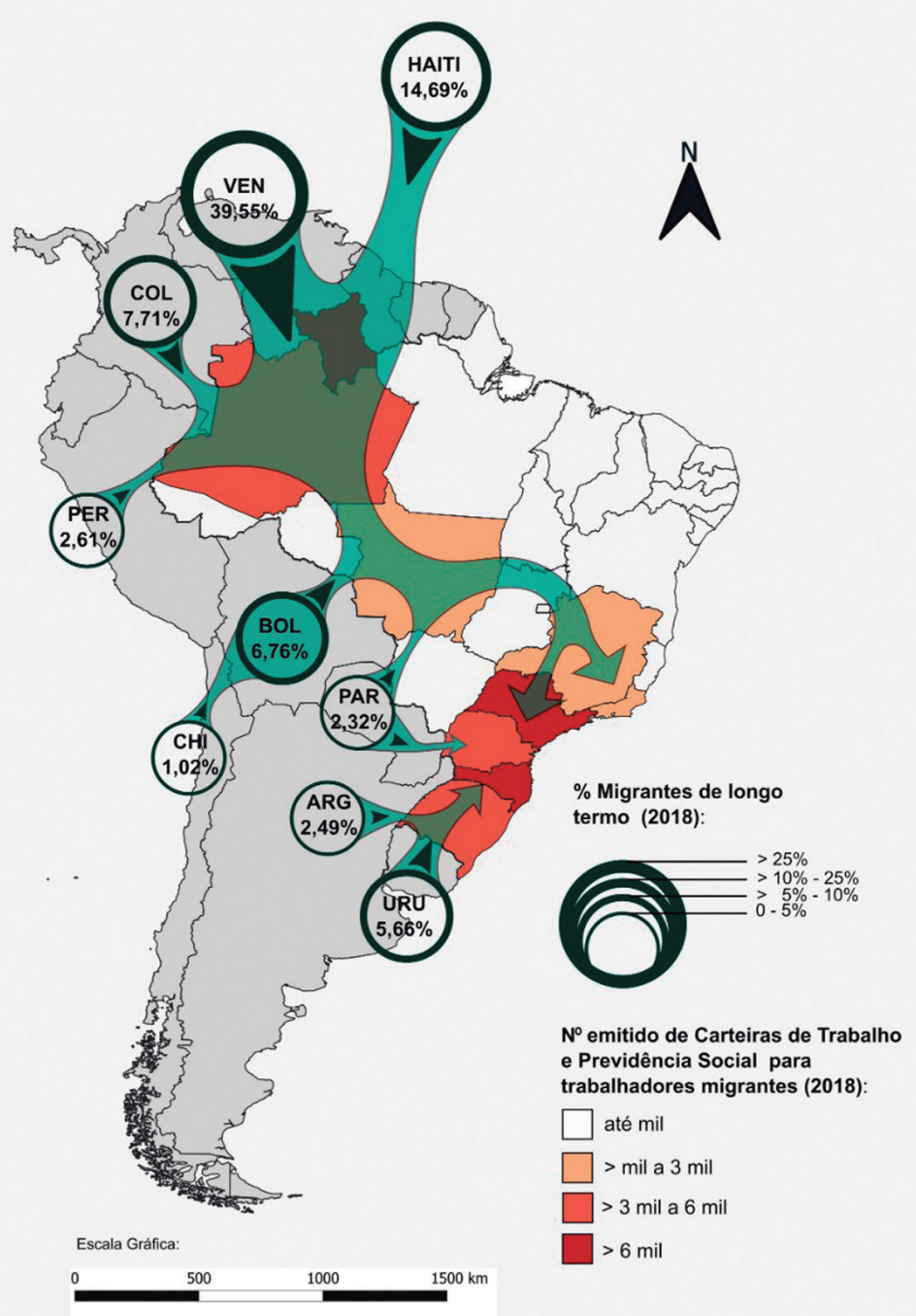

Fonte: Observatório das Migrações Internacionais - OBMigra (Cavalcanti et al., 2019).

Entre 2011 e 2018, segundo relatório anual do OBMigra, de 2019, foram registrados no país 492,7 mil imigrantes de longo termo (aqueles que, geralmente, permanecem no país em um período superior a um ano), sendo 106,1 mil haitianos, seguidos por bolivianos, venezuelanos, colombianos, argentinos, chineses, portugueses e peruanos, conforme grandeza dos fluxos (Cavalcanti et al., 2019). 
Essa ordem se altera em 2019, com o maior fluxo representado pelos venezuelanos (39\%), haitianos (14,7\%), colombianos $(7,7 \%)$, bolivianos $(6,8 \%)$ e uruguaios $(6,7 \%)$. Confirma-se a importância dos movimentos oriundos dos países limítrofes. O Sudeste absorveu 55,1\% dos fluxos entre 2011 e 2018; o Sul, 20,5\%; e o Norte, $8,6 \%$. O destaque coube a Roraima, que incorporou 4,3\%, devido à migração venezuelana. Entre os admitidos no mercado de trabalho formal em 2018, predominam os haitianos e os venezuelanos, e passam a compor o rol paraguaios e argentinos. Os bolivianos tiveram seu ápice no início do período, passando a posicionar-se como o quinto grupo a ocupar postos no mercado brasileiro em 2018.

O Acordo sobre Residência para Nacionais dos Estados Partes do Mercosul, de 2009, é uma das medidas que, nos anos recentes, facilitaram a permanência de imigrantes no país, particularmente bolivianos, entre outros oriundos de países do Mercosul. $\mathrm{O}$ acordo viabiliza a documentação dos que chegam e a regularização dos que já se encontram no país. Também ocorreram importantes açóes no âmbito de vistos humanitários, como os concedidos aos haitianos, e o acolhimento de solicitaçóes de refúgio, por migrantes de várias origens, que se ampliam no país. A simples concessão de documentos faz uma diferença sensível na preservação dos direitos dos migrantes.

No caso dos refugiados, o número de solicitações de refúgio no Brasil tem aumentado nos últimos anos. Em 2018, segundo relatório do Ministério da Justiça, há 80.057 solicitaçóes de reconhecimento da condição de refugiado no país (Brasil, 2018). Destas, 77,04\% (ou 61.681) são de venezuelanos. Os haitianos são o segundo grupo em solicitaçóes, mas alcançando nesse período apenas $8,7 \%$ do total. Nenhum outro país da América do Sul integra a lista entre os destacados. Esses dois grupos tiveram seus ápices de pedidos de refúgio em anos recentes: os haitianos, em 2013, 2014 e 2015; e os venezuelanos, em 2017 e 2018. As UFs que mais receberam solicitaçóes foram Roraima (63\% do total, ou 50.770 solicitaçôes) e Amazonas (13\%, ou 10.500). A considerar que, incluindo-se o ano de 2018, o país tem apenas 11.231 pessoas reconhecidas como refugiadas pelo Estado brasileiro, sendo $36 \%$ sírios, $15 \%$ congoleses e $9 \%$ angolanos, o afluxo de venezuelanos traz um novo elemento em termos de eficiência nos registros dos números de entradas e saídas a ser administrado pelos postos fronteiriços, particularmente os da fronteira terrestre.

A integração dos refugiados no mercado de trabalho formal vem se dando com lentidáo. Entre 2010 e 2018, dados do relatório do OBMigra registram que foram emitidas 76.878 carteiras de trabalho para solicitantes de refúgio e refugiados, sendo que em 2018 ocorreu o maior número de carteiras emitidas (36.384), majoritariamente para venezuelanos $(68,4 \%)$, haitianos $(19,1 \%)$ e cubanos $(4,8 \%)$, conforme Cavalcanti et al. (2019). 
O que os números apreenderam foi levantado nos debates e reflexóes em atividades realizadas nos arcos da fronteira. Participantes deram destaque à migração transfronteiriça, antecipando em 2016 os impactos sentidos por Roraima, particularmente na regiáo transfronteiriça de Pacaraima e Santa Elena de Uairén (Venezuela). Nas palavras dos participantes do arco Norte, ocorre uma crise que precisa ser tratada com absoluta seriedade, muita inteligência e muito discernimento. É preciso reconhecer que a população brasileira já foi atendida por eles, portanto agora é preciso acolhê-los e ter em conta a ligação estreita e até de dependência entre os dois países, como em relação à oferta de energia elétrica a Roraima pela Venezuela. A diáspora venezuelana não só impactou os serviços públicos de Pacaraima e Boa Vista, sobretudo de saúde e educação, mas também o comércio com o país vizinho, o que ficou evidente nos momentos de fechamento da fronteira internacional, afetando a geração de renda e divisas imediatas para os municípios, os estados e o Brasil (Pêgo et al., 2018).

A maioria dos migrantes venezuelanos chega ao Brasil por meio terrestre, sendo que os povos indígenas se deslocam a pé até a fronteira e de lá continuam a caminhar ou, como os demais, utilizam o transporte rodoviário até a capital Boa Vista. Entre os imigrantes não indígenas, há aqueles com maior nível de escolaridade que têm interesse em se deslocar para outras UFs brasileiras ou outros países da América do Sul. Porém, há um período, muitas vezes longo, de permanência do recém-chegado nas cidades da fronteira. Para acolher esses imigrantes indígenas e não indígenas, a criação de abrigos está entre as medidas mitigadoras dos efeitos da imigração. E essas vêm ocorrendo em Roraima e no Amazonas, executadas e coordenadas pelo governo brasileiro com o auxílio de organizaçóes internacionais especializadas, a exemplo da Organização das Naçóes Unidas (ONU) e da Organização Internacional de Migração (OIM), denominada Operação Acolhida. ${ }^{16}$ A situação merece atenção permanente e integrada dos governos locais e federal, para que refugiados não sejam cooptados para realização de atividades ilícitas (Moreira, 2018).

Outros movimentos migratórios contínuos também foram objeto de preocupação, como os deslocamentos de centro-americanos, fundamentalmente pelo Acre, e de bolivianos pelo arco Central, que oferece condiçóes operacionais para os bolivianos fazerem a travessia da fronteira com razoável facilidade e, também, para alçarem grandes centros urbanos brasileiros, particularmente São Paulo, com promessas de bons empregos na indústria têxtil. A problemática gerada é que esses empregos muitas vezes se transformam em trabalho escravo de uma população muito expressiva. Nesse movimento, existe uma ação predatória de "coiotes", que atravessam os imigrantes bolivianos por rotas alternativas, e que poderia ser coibida 
antes do passo fronteiriço. A ação dos coiotes é muito lesiva. Quando os migrantes chegam à fronteira, já tomaram tudo o que possuíam. Eles gastam muito no deslocamento, endividam a família e, por isso, não desistem e não retornam. Muitas vezes acabam pegando o caminho da clandestinidade para poder entrar. Falta uma instituição que oriente, um espaço unificado de assistência social para atender os migrantes, para que não precisem ficar passando de setor em setor, desorientados. E que impeça a ação dos aliciadores e dos que buscam "cobaias". Um espaço que acolha as ONGs que vão à fronteira orientar essas pessoas, pois, se chegarem antes, os aliciadores não agem. Faltam, também, casas de migrantes, um centro de apoio onde esses grupos se encontrem (Pêgo et al., 2019).

Sobre documentação, constata-se que são poucas as exigências para entrar no Brasil, e muitos acabam não passando pelo trâmite da migração, o que dificulta no momento de retornar ao país, pois náo se compra passagem sem o carimbo da migração, e nesse momento os migrantes são outra vez explorados, intimidados. Por isso, é necessário ter na fronteira uma estrutura de orientação.

Outros problemas foram apontados, como os nascimentos de bolivianos ocorridos em municípios brasileiros - caso de Cáceres (Mato Grosso) e Corumbá (Mato Grosso do Sul) -, sendo uma grande dificuldade a travessia dos bebês pela fronteira devido à documentação exigida. Parte significativa das crianças de San Matias, Puerto Quijarro e Puerto Suárez, por exemplo, é nascida no lado brasileiro. Há, também, no sentido inverso, muitos brasileiros com carteira de identidade boliviana. Essas situaçôes agravam o preconceito recíproco entre esses dois povos, sentido pela discriminação da presença do "outro", do "lado de lâ", na forma como são vistos os bolivianos que estáo em Cáceres: sentem-se bem tratados pelo povo, mas vistos como se estivessem à margem pela polícia; são associados ao narcotráfico, a todo o tipo de ilícitos, como se neles não houvesse a participação de brasileiros e, além disso, dados apontam que a participação estrangeira em crimes identificados no Brasil é ínfima. Deve-se anotar ainda a elevada presença de imigrantes bolivianos de regióes mais distantes, sobretudo da porção andina da Bolívia, e de brasileiros, também em assentamentos precários em Corumbá, sujeitos a alto grau de vulnerabilidade ao tráfico (Pêgo et al., 2019; 2020b).

Registra-se, também, no arco Central, a situação de brasileiros que migram para a Bolívia, em virtude de casamentos, trabalho (há muitos brasileiros que possuem comércios) e propriedade da terra, como também casos daqueles que buscam um emprego informal, nos quais se inserem famílias humildes que resolvem fazer sua vida com os bolivianos, muitas em estado de alta precariedade. Algumas vezes são foragidos da Justiça brasileira. Apesar da iniciativa do consulado para que se proceda à repatriação, a dificuldade está na falta de documentos de identificaçáo de muitos brasileiros (invisibilizados nas estatísticas) (Pêgo et al., 2019). 
Aspecto de alta vulnerabilidade é encontrado pelos migrantes no sistema prisional. Nas prisóes bolivianas, a situação de cárcere é realmente desumana e, além disso, brasileiros presidiários alegam que há morosidade na atuação da Justiça boliviana, devendo-se esta, muitas vezes, ao fato de que o preso tem que pagar por sua estada na prisão, o que garante, de certa forma, um "salário" à polícia. Em relação aos bolivianos presos no Brasil, a condição da mulher no sistema prisional em Corumbá é de significativo isolamento social (os estereótipos externos se repetem na prisão), e, no período semiaberto, não podem sair do sistema prisional, devido ao risco de evasão por travessia da fronteira (Krüger, Arruda e Mariani, 2018). Ainda, a presença do Primeiro Comando da Capital (PCC) subsidiando alimentos e produtos a apenados em presídios fronteiriços no Brasil, na Bolívia e no Paraguai possivelmente reordena, de forma territorial, o crime, uma vez que o ex-detento sai com uma dívida à organização, que requer o pagamento por meio da prestação de serviços (Oliveira e Krüger, 2018).

Com base em relatório da Comissão Econômica para a América Latina e o Caribe (Cepal), observa-se, no âmbito internacional dos direitos humanos, um endurecimento de políticas migratórias nas Américas, com externalização do controle migratório, securitização das fronteiras, criminalização dos migrantes (particularmente os irregulares), detenção e deportaçóes sumárias e limite ao acesso à proteção internacional e ao reconhecimento da condição de refugiados (Stefoni, 2017). Ao mesmo tempo, verifica-se lentidão no cumprimento de acordos referentes a migrantes e refugiados e restrição ao reconhecimento do direito a migrar, aos casos de sair de determinado território, mas não de entrar em outro país. Além disso, esses temas são tratados como assunto interno do Estado, salvaguardados pelo princípio de não ingerência em assuntos domésticos, com garantia da soberania estatal para definir quem entra e permanece no território, e a quem é vedada a entrada.

Considerando-se os fatos e as informaçóes analisadas, e diante de movimentos que se amplificam e trazem desafios urgentes à agenda social das fronteiras, mantiveram-se abertas algumas questóes relativas ao papel do país no sentido de garantir e proteger a dignidade humana dos imigrantes. Por exemplo, a Lei de Migração (Lei no 13.445/2017) surgiu como o principal instrumento de regulação e proteção de indivíduos em situação de refúgio, no entanto ainda não foi regulamentada, o que vem dificultando a ação do Comitê Nacional para os Refugiados (Conare) nos acordos para a aplicação ou não do conceito ampliado de refugiados aos venezuelanos. Há, também, esforços no reconhecimento e facilitação da inserção de refugiados, porém faltam iniciativas que agilizem o acesso de migrantes e refugiados a serviços públicos. Mesmo com a implementação da Operaçâo Acolhida aos migrantes venezuelanos, e ainda que, após 2018, tenham se multiplicado os instrumentos normativos de federalização do acolhimento a refugiados e solicitantes de refúgio venezuelanos no país, o processo de assistência humanitária emergencial 
continua lento, mais demorado que a média de permanência desse tipo de ação em outros países (Moreira, 2020).

\subsubsection{Mobilidade pendular para trabalho e/ou estudo}

Diferentemente de migraçóes, os fluxos pendulares de pessoas para trabalho e/ ou estudo em município que não o de residência, e que pode acontecer de se dar em outro país, também são bastante frequentes na FF, mais concentrados nos arranjos transfronteiriços. Segundo informaçóes do Censo Demográfico 2010 do IBGE, que não computa entradas dos países vizinhos, 34.975 pessoas deixavam municípios brasileiros para trabalhar no exterior, outras 34.335 para estudar e 741 para ambas as atividades (Cardoso e Moura, 2017). Há, ainda, pessoas que saíam para estudar em município brasileiro, mas que realizavam atividade de trabalho no estrangeiro. Os destaques encontram-se nos municípios fronteiriços, como Foz do Iguaçu (9,1\% do total do movimento pendular internacional), Santana do Livramento (3,8\%), Ponta Porã (2,9\%), Chuí (1,8\%) e Tabatinga (1,3\%). Esses deslocamentos representam a interação de pessoas no território para a realização de atividades de trabalho e/ou estudo. Quando ocorrem na fronteira, requerem a definição de políticas e medidas que garantam o livre trânsito das pessoas. Porém, conforme informado nas atividades nos arcos da fronteira, as pessoas que realizam comutaçôes diárias sofrem fundamentalmente com a inadequação do transporte público de passageiros, que com raras exceçóes cruza a linha de fronteira, assim como com a dificuldade de se obter o documento de transfronteiriço.

Em análise de Deschamps, Delgado e Moura (2018) com essa mesma base de dados, registra-se que, no caso de mobilidade pendular para estudo, o Uruguai é o destino de 46,1\% dos que se deslocam; a Bolívia e o Paraguai vêm na sequência, com respectivamente $16,63 \%$ e $15,96 \%$. No caso da mobilidade para o trabalho, é o Paraguai o principal destino, de $62,85 \%$ das pessoas, particularmente em fluxos entre Foz do Iguaçu e Ciudad del Este. O segundo destino preferencial é o Uruguai, para $18,92 \%$ das pessoas. As atividades que sustentam essa mobilidade são predominantemente do comércio e serviços. Em se tratando dos arranjos transfronteiriços, as atividades industriais se sobressaem nos do arco Norte $(31 \%$ dos motivos de deslocamento, sobretudo no arranjo Oiapoque - Amapá/St. Georges - Guiana Francesa), enquanto os do arco Central se destacam na atividade agrícola (20,1\% dos deslocamentos, em grande parte no arranjo Guajará-Mirim Rondônia/Guayaramerín - Bolívia).

A pendularidade também se dá por outras motivaçôes não abarcadas pelo Censo Demográfico 2010, como é o caso da pendularidade para o consumo, uso de determinados serviços, entre outros. O relatório do OBMigra de 2019 computa os movimentos regulares pelas fronteiras brasileiras e conclui que o motivo majoritário é o turismo, que responde por mais de $80 \%$ das entradas e saídas. Vem seguido 
dos temporários, pessoas em trânsito, residentes e fronteiriços, estes últimos com participação bem inferior aos demais.

Participantes do arco Sul apontam que esse movimento encontra problema nas aduanas, agudizado sazonalmente com as migraçôes de férias, época em que as instalaçóes não dão conta do enorme número de turistas que buscam as praias brasileiras. Em Uruguaiana, além do fluxo de pessoas, há filas de caminhóes em um mesmo espaço físico. Em Santa Catarina, a única entrada formalizada de conexão com a Argentina é a que passa por Dionísio Cerqueira, já que o percurso Paraíso (Santa Catarina) a San Pedro (Misiones, Argentina) tem a Ponte Internacional Peperi-Guaçu, que ainda não foi estruturada e sinalizada, e não há posto migratório em funcionamento. Também inexiste posto migratório em Barra do Quaraí, uma área importante de entrada e saída de turistas, tampouco um posto da Polícia Federal no controle migratório para regularizar a entrada no Brasil. Para tanto, o viajante tem que se deslocar até Uruguaiana (Pêgo et al., 2020a).

A diversidade de povos que habitam as fronteiras brasileiras se conjuga a um intenso movimento transfronteiriço, migratório, pendular, de passagem, que amplia a multidimensionalidade cultural e impóe açóes que garantam preservar identidades e fortalecer a interculturalidade. Tal diversidade por vezes acelera processos que exigem reflexão e açóes emergenciais.

\subsection{Economia, trabalho e infraestrutura econômica}

\subsubsection{Base produtiva}

Em relação à geração de renda, a FF participa com 5,24\% do total do produto interno bruto (PIB) ${ }^{17}$ de 2016 do Brasil, ${ }^{18}$ representando 5,52\% do valor adicionado bruto total (VAB) ${ }^{19}$ de 2016 (IBGE, 2019). Embora sendo baixa a sua representatividade nacional, o VAB dentro dos arcos da fronteira segue a mesma lógica proporcional de contribuição do PIB, sendo maior no arco Sul, com 66,01\%, seguida do arco Central, com 23,32\%, e do arco Norte, com 10,68\% (tabela 8).

17. Bens e serviços produzidos no país, descontadas as despesas com os insumos utilizados no processo de produção durante 0 ano. É a medida do total do valor adicionado bruto gerado por todas as atividades econômicas.

18. PIB dos municípios (plataforma geográfica interativa). Disponível em: <https://bit.ly/38kuVIA>. Acesso em: 20 jan. 2020.

19. Valor que a atividade agrega aos bens e serviços consumidos no seu processo produtivo. É a contribuição ao PIB pelas diversas atividades econômicas, obtida pela diferença entre o valor de produção e o consumo intermediário absorvido por essas atividades. 
TABELA 8

Faixa de fronteira: PIB, VAB total e por setor, segundo arcos (2016) (Em \%)

\begin{tabular}{|c|c|c|c|c|}
\hline Variável/setor & Total da FF & Arco Norte & Arco Central & Arco Sul \\
\hline \multicolumn{5}{|l|}{ Em relação ao total do Brasil } \\
\hline PIB total & 5,24 & 0,55 & 1,23 & 3,46 \\
\hline VAB total & 5,52 & 0,59 & 1,29 & 3,64 \\
\hline \multicolumn{5}{|l|}{ VAB em relação à FF } \\
\hline Agropecuária & 18,67 & 1,29 & 5,03 & 12,35 \\
\hline Indústria & 19,44 & 1,22 & 3,97 & 14,25 \\
\hline Serviços & 42,26 & 3,61 & 9,07 & 29,58 \\
\hline $\begin{array}{l}\text { Administração, defesa, educação e saúde } \\
\text { públicas e seguridade social }\end{array}$ & 19,63 & 4,55 & 5,26 & 9,82 \\
\hline Total & 100,00 & 10,68 & 23,32 & 66,01 \\
\hline \multicolumn{5}{|l|}{ VAB no arco } \\
\hline Agropecuária & 18,67 & 12,11 & 21,55 & 18,71 \\
\hline Indústria & 19,44 & 11,45 & 17,01 & 21,60 \\
\hline Serviços & 42,26 & 33,82 & 38,88 & 44,82 \\
\hline $\begin{array}{l}\text { Administração, defesa, educaçãa e saúde } \\
\text { públicas e seguridade social }\end{array}$ & 19,63 & 42,62 & 22,55 & 14,87 \\
\hline Total & 100,00 & 100,00 & 100,00 & 100,00 \\
\hline
\end{tabular}

Fontes: PIB dos municípios/IBGE, disponível em: <https://bit.ly/38kuVIA>; Atlas Nacional Digital do Brasil/IBGE, disponível em: $<$ https://bit.ly/2GEhcdU>. Acesso em: 20 jan. 2020

Elaboração: Equipe Fronteiras Ipea.

Somados, o VAB de serviços e administração, defesa, educação e saúde públicas e seguridade social é o mais representativo na FF, com $61,89 \%$, seguido de valores aproximados entre a indústria (19,44\%) e a agropecuária (18,67\%).

No arco Sul, o VAB de serviços possui a maior participação, com 29,58\% na $\mathrm{FF}$ e $44,82 \%$ no arco, podendo-se estabelecer que, para 165 municípios desse arco $(39,66 \%)$, as atividades de comércio e serviços se apresentam como maior valor adicionado entre os setores (tabela 9). Ainda relacionado ao setor de serviços, as atividades de administração, defesa, educação e saúde públicas e seguridade social representam o maior valor adicionado para sessenta municípios (14,42\%). E, embora o VAB da indústria se encontre em segunda posição, com 14,25\% de participação na FF, o VAB da agropecuária (12,35\%) é mais representativo para um número maior de municípios na FF: para 146 municípios, a agricultura se apresenta com o maior $\mathrm{VAB}$ municipal, enquanto para 37 municípios a pecuária é o maior, totalizando 183 municípios, ou seja, 43,99\% dos municípios do arco Sul. Por sua vez, a indústria apresenta-se como maior valor adicionado para somente oito municípios no arco Sul. 
TABELA 9

Faixa de fronteira: número de municípios por atividade com maior VAB, segundo arcos (2016)

\begin{tabular}{|c|c|c|c|}
\hline Atividade & Arco Norte & Arco Central & Arco Sul \\
\hline Agricultura, inclusive apoio à agricultura e à pós-colheita & 1 & 21 & 146 \\
\hline Produção florestal, pesca e aquicultura & 1 & - & - \\
\hline Pecuária, inclusive apoio à pecuária & - & 11 & 37 \\
\hline Indústrias extrativas & 1 & - & - \\
\hline Indústrias de transformação & - & 1 & 8 \\
\hline Comércio e reparação de veículos automotores e motocicletas & - & - & 4 \\
\hline $\begin{array}{l}\text { Administração, defesa, educação e saúde públicas e } \\
\text { seguridade social }\end{array}$ & 64 & 48 & 60 \\
\hline $\begin{array}{l}\text { Eletricidade e gás, água, esgoto, atividades de gestão de } \\
\text { resíduos e descontaminação }\end{array}$ & 1 & 2 & 12 \\
\hline Construção & - & - & 1 \\
\hline Demais serviços ${ }^{1}$ & 1 & 18 & 148 \\
\hline Total de municípios & 69 & 101 & 416 \\
\hline
\end{tabular}

Fonte: Atlas Nacional Digital do Brasil//BGE, disponivel em: <https://bit.ly/2GEhcdU>. Acesso em: 20 jan. 2020.

Elaboração: Equipe Fronteiras Ipea.

Nota: ${ }^{1}$ Transporte, armazenagem e correio; alojamento e alimentação; informação e comunicação; atividades financeiras, de seguros e serviços relacionados; atividades imobiliárias; atividades profissionais, científicas e técnicas, administrativas e serviços complementares; educação e saúde privadas; artes, cultura, esporte e recreação e outras atividades de serviços e serviços domésticos.

$\mathrm{O}$ arco Central, com 23,32\% de participação do VAB total da fronteira, diferencia-se em 42,69 pontos percentuais (p.p.) a menos em relação ao arco Sul. Assim como no arco Sul, despontam no Central as atividades de serviços em primeira posição, que, somadas às atividades de administração, defesa, educação e saúde públicas e seguridade social, representam $61,43 \%$ do seu valor adicionado, com 68 municípios com maior VAB nessa categoria. Também nesse arco, o VAB da agropecuária $(21,55 \%)$ é o mais representativo, sendo que para 21 municípios a agricultura representa o maior valor adicionado, e para 11 municípios a pecuária se destaca como maior. Somadas, agricultura e pecuária, a agropecuária é a maior em 31,68\% dos municípios. A indústria se destaca com 17,01\% do VAB do arco, contudo somente para um município é o maior valor adicionado. 
$\mathrm{O}$ arco Norte distingue-se dos demais arcos pela alta renda somada do VAB serviços e VAB administração, defesa, educação e saúde públicas e seguridade social, que juntos representam $76,44 \%$. O VAB da agropecuária e da indústria somados contribui com somente $2,51 \%$ de toda a FF; a agropecuária representa $12,11 \%$ do valor adicionado do arco; e a indústria, 11,45\%. Nessas atividades, somente um município possui como maior valor adicionado a agricultura, outro a produção florestal, pesca e aquicultura, e outro a indústria extrativa, contra 64 municípios que dependem do VAB da administração, defesa, educação e saúde públicas e seguridade social (92,75\%), evidenciando a importância da ação do Estado nesses municípios, como consequência da localizaçáo distante de grandes centros e da baixa acessibilidade em bioma amazônico, às quais se soma a restrição ao uso e ocupação do solo em virtude da proteçấo ambiental garantida em TIs e UCs.

Vale lembrar a importância dos recursos do Fundo Constitucional com impactos significantes sobre o crescimento do PIB per capita para os municípios na FF, trazendo evidências de que a continuidade do volume de empréstimos ao longo dos anos pode desempenhar um papel importante para que essas economias apresentem uma melhoria no que se refere a esse indicador (Resende e Silva, 2018).

O contexto da base produtiva brasileira em sua relação com a ocupação do território, os biomas e a proteção do meio ambiente foi visto a partir das informaçóes sobre as atividades da agropecuária com maior VAB nos municípios, produzido para o Atlas Nacional Digital do Brasil. ${ }^{20}$ No mapa 7, observa-se uma grande mancha formada por um conjunto de 2.123 municípios, cuja atividade de criaçáo de bovinos e outros animais se constitui no maior VAB municipal agropecuário. Constitui-se em atividade diretamente relacionada à exploração do espaço de pastagens naturais e da expansão das pastagens plantadas no Brasil, que se relaciona, por sua vez, ao crescente desmatamento dos biomas Cerrado e Amazônia nas últimas décadas. De acordo com dados do Censo Agropecuário, ${ }^{21}$ houve um crescimento de $9,15 \%$ das pastagens plantadas entre 2006 e 2017, que correspondem atualmente a um total de 111,8 milhóes de hectares. 
MAPA 7

PIB dos municípios: atividades da agropecuária - Brasil (2016)

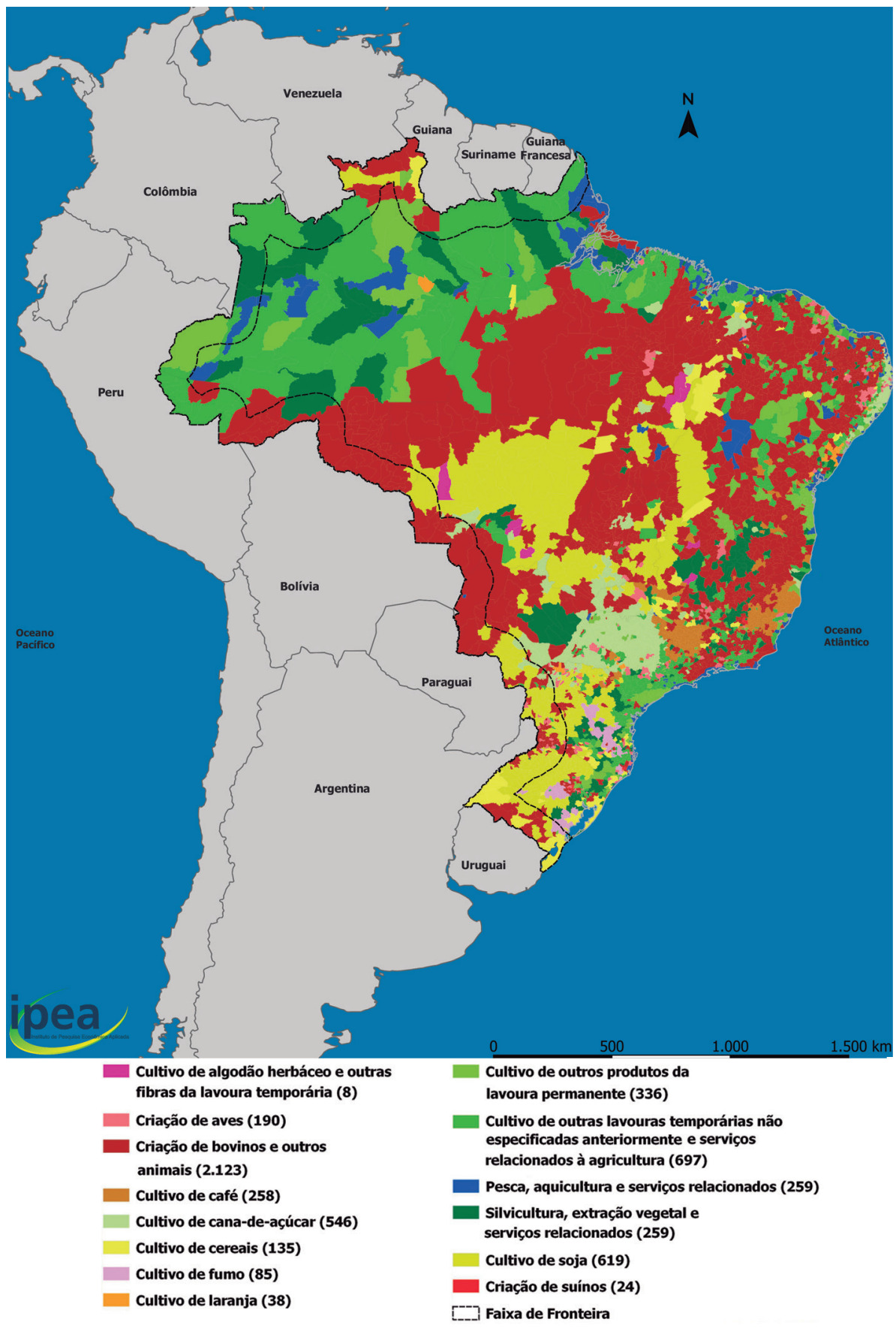

Fonte: PIB dos municípios//BGE (disponível em: <https://bit.ly/38kuVIA>).

Elaboração: Equipe Fronteiras Ipea. 
Outra cultura que atinge grandes conjuntos de municípios como atividade agropecuária mais importante é o cultivo da soja, sendo registrado em 619 municípios, abrangendo especialmente os biomas Cerrado e Mata Atlântica. Atinge em grande proporção os estados de Mato Grosso do Sul, Mato Grosso, Goiás, Tocantins, Maranhão, Piauí e Bahia, no Cerrado, e Paraná e Rio Grande do Sul no bioma Mata Atlântica, sendo que neste último atinge também parte do Pampa (mapa 7).

As informaçóes analisadas permitem visualizar o avanço da ocupação agropecuária no país e na FF, que gera conflitos de ocupação sobre relevantes biomas, conforme apontado na seção anterior. No arco Norte, a criação de bovinos e outros animais é a atividade mais importante para os municípios situados no Acre e em Rondônia, podendo-se apreender que se constitui parte integrante da grande extensão de municípios que desde a costa litorânea definem uma linha de pressão desta atividade sobre o bioma Amazônia. Além desses municípios, verificam-se outros no mesmo arco, na porção norte de Roraima, com condição favorável à atividade em função da formação campestre dessa região. Ademais, a localização da capital Boa Vista na FF é forte indutora do processo de ocupação. Salienta-se que, como visto nesta seção, esses municípios se situam em áreas abrangidas por considerável número de UCs e reservas indígenas, onde os conflitos indígenas, sociais e fundiários constituem-se em um dos maiores problemas.

Para além do umbral de domínio de pastagens plantadas, induzidas pelo valor do bovino no mercado de commodities, desdobra-se uma extensa área de um conjunto de municípios amazônicos mais protegidos, que possuem como atividades agropecuárias mais importantes a silvicultura, a extração vegetal e serviços relacionados, e o cultivo de lavouras temporárias não especificadas e serviços relacionados à agricultura, além de produtos da lavoura permanente, classificados como outros. Nesta vasta regiáo, pode-se inferir maior grau de proteçấo quanto maior a proximidade da FF, especialmente nas porçôes a noroeste, onde há fronteira com Colômbia e Peru. Deve-se ressaltar, contudo, que, pelas mesmas razóes de difícil alcance do governo e das frentes de desenvolvimento, a região enfrenta ainda conflitos associados à exploraçáo econômica mineral (legal e ilegal) com impactos ao meio ambiente e à população indígena, como reportado na seção anterior (Pêgo et al., 2018).

Os conflitos ambientais, minerários e indígenas representam uma dura realidade também para as áreas dos municípios do arco Central, de forma mais contundente tendo em vista a dominação preponderante do espaço principalmente pela criação de bovinos e pela cultura da soja, permeados por UCs e reservas indígenas. Não fossem as delimitaçóes dessas áreas protetivas, estariam certamente todas ocupadas por pastagem ou cultivo da soja (Pêgo et al., 2019). A tendência de diminuição de pastagens naturais em relação ao aumento de pastagens plantadas, observada no Censo Agropecuário 2017, sugere, segundo o IBGE (2017), "uma mudança da 
pecuária de caráter extensivo para intensivo, com maior utilização de tecnologia e insumos", ${ }^{22}$ qual seja, a expansão vertiginosa do agronegócio.

Se no arco Sul os conflitos indígenas náo se apresentam como o principal problema, a produção agrícola consolidada e mais antiga caminha lentamente para a redução do uso de agrotóxicos (Pêgo et al., 2020a). Nesse arco, o cultivo da soja é a atividade predominante na maior parte dos municípios, entremeada pela criação de bovinos, com exceção de Santa Catarina, onde predominam a criação de bovinos e a de aves. No Rio Grande do Sul, observa-se também a predominância no cultivo de cereais, entre municípios cuja criação de gado é preponderante. Rio Grande do Sul e Paraná destacam-se como os dois estados com maior número de estabelecimentos agropecuários usuários de defensivos químicos, que atingem $68,7 \%$ na região Sul (IBGE, 2017). Em relação a 2006, houve um aumento de $23,1 \%$ no número de estabelecimentos em todo o Brasil, verificando-se ainda que nas regiōes Norte e Centro-Oeste, nas áreas de expansão da fronteira agrícola, o percentual de estabelecimentos dobrou.

Outro conflito sulino, este imposto pela ampliação da oferta energética, é vivido por grande parte dos arranjos transfronteiriços localizados na fronteira do Rio Grande do Sul com a Argentina, que aguardam com preocupação a possibilidade de inundação de suas áreas agricultáveis, suas reservas e patrimônios naturais e históricos, bem como de suas áreas urbanas, dada a perspectiva de retomada da construção do complexo de barragens Panambi-Garabi, no rio Uruguai.

Partindo-se para o panorama revelado pela atividade industrial, as áreas industriais relevantes (AIR), ou microrregióes (do IBGE) caracterizadas por conterem mais de 10 mil empregos industriais no período considerado (1995-2015), demonstram a nova tendência de localização da indústria no interior de territórios de estados do Centro-Oeste, "revelando a dinâmica da produção industrial em áreas de expansão do agronegócio" (Neto, Silva e Severian, 2019, p. 14). De acordo com esse estudo, embora as regióes mais industrializadas continuem sendo o Sul e o Sudeste, o Centro-Oeste apresentou acréscimo de nove novas aglomeraçóes entre 1995 e 2015, quase duplicando sua participação no cenário nacional (partindo de quatro para treze no período), em meio a um quadro de declínio na participação relativa da indústria no PIB brasileiro. Enquanto a taxa média de crescimento do emprego das AIRs dessa regiáo foi de 3,5\% a.a. entre 1970-1991, no período recente 1995-2015, foi de 1,88\% a.a. De fato, as AIRs de Mato Grosso e Mato Grosso do Sul fazem parte de três grupos que apresentaram taxas de expansão em termos da dinâmica do emprego industrial superiores à média nacional. As AIRs próximas à $\mathrm{FF}$ do arco Central apresentaram entre duas e quatro vezes ou mais os valores da média nacional (figura 3).

22. Análise e informações do Atlas Nacional Digital, disponíveis em: <https://bit.ly/3rl8gfa>. Acesso em: 20 nov. 2019. 
FIGURA 3

Evolução do pessoal ocupado na indústria, segundo AIRs - Brasil (1995-2015)

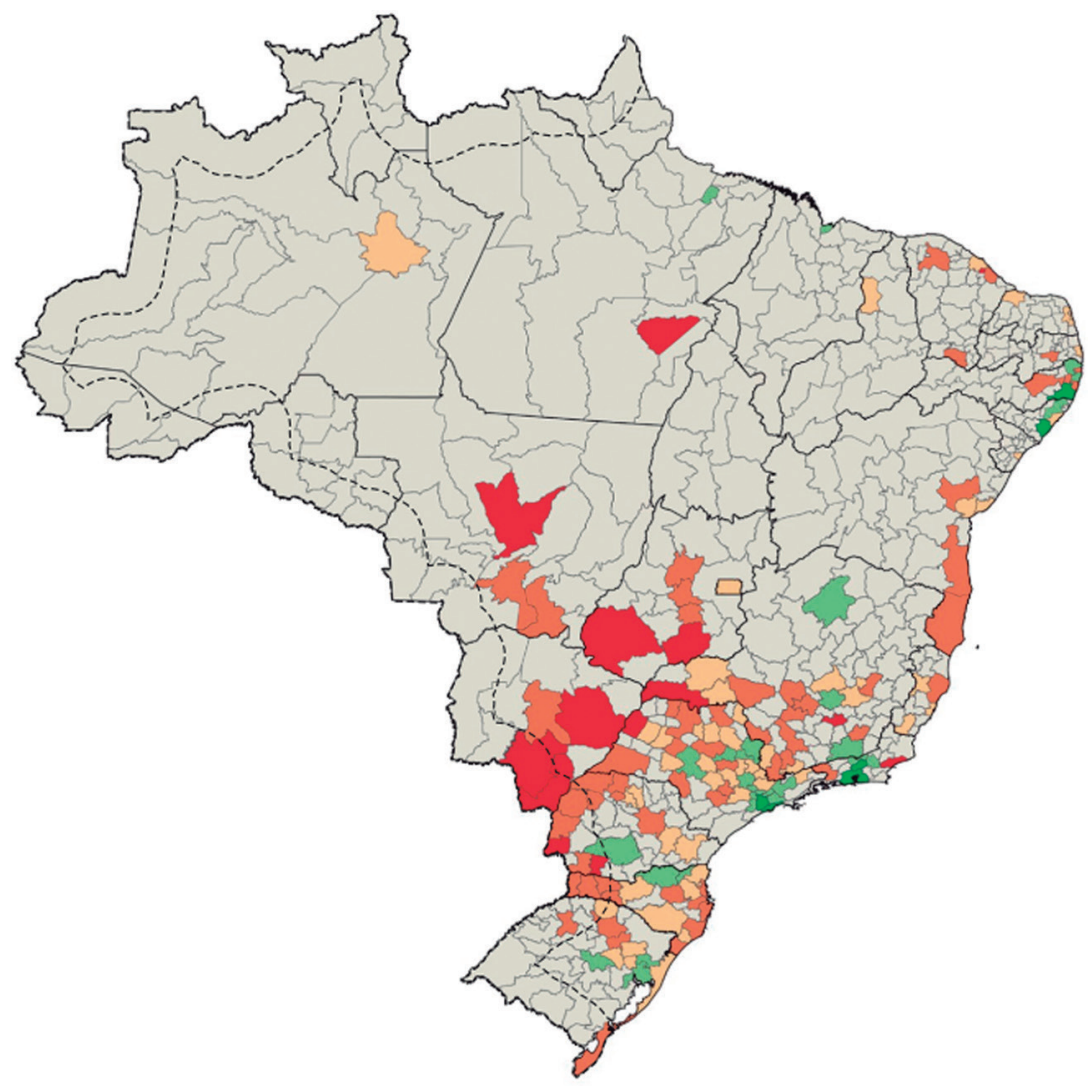

Legenda

Grupos de Aglomerações Industriais Relevantes [562]

GRUPO I - Quatro vezes (ou mais) superior à média nacional [14]

- GRUPO II - Entre 2 e 4 vezes a média nacional [61]

$\square$ GRUPO III - Acima e até 2 vezes a média nacional [51]

GRUPO IV - Abaixo da média nacional [28]

GRUPO V - Com taxas negativas de crescimento [6]

$\square$ Não é AIR [402]

....: Faixa de fronteira

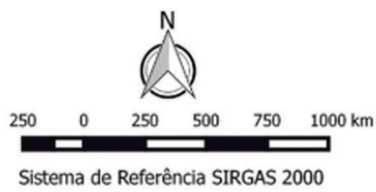

Fonte: Neto, Silva e Severian (2019, p. 22).

Elaboração: Equipe Fronteiras Ipea.

O conjunto de AIRs para o arco Sul revela também um aumento do número de unidades, mantendo pertinente o previsto em estudo anterior de Diniz e 
Crocco (1996), ao delimitar o polígono de área preferencial para a localização da indústria no país. ${ }^{23}$

\subsubsection{Trabalho}

Observando-se dados do Cadastro Geral de Empregados e Desempregados (Caged) do período de janeiro a setembro de 2019 , verifica-se uma expansão do emprego formal nos arcos, registrando-se um saldo de 45.439 postos de trabalho, o que representa 5,96\% dos postos gerados no Brasil. Os postos de trabalho gerados pela atividade extrativa mineral despontam pela sua maior representatividade nacional, com $10,50 \%$ do total do país, vindo em seguida a indústria de transformação, com $9,61 \%$, e os serviços, com 5,79\%. Apesar do perfil fortemente agropecuário dos arcos, juntos eles representam somente 3,53\% dos postos de trabalho de empregos formais gerados no Brasil, sendo que, nos arcos Norte e Sul, registraram-se saldos negativos neste setor, com a redução de $-1,91 \%$ e $-0,44 \%$ dos postos de trabalho de cada arco, respectivamente. Contudo, no arco Central, observa-se ser o segundo maior setor gerador de empregos, com 18,04\%, confirmando a tendência já observada nas análises anteriores (tabela 10).

TABELA 10

Faixa de fronteira: saldo do emprego formal por município e setor de atividade econômica, com ajustes (jan.-set./2019)

\begin{tabular}{|c|c|c|c|c|c|c|}
\hline \multirow{2}{*}{ Atividades } & \multicolumn{3}{|c|}{ FF } & \multirow{2}{*}{$\begin{array}{c}\text { Arco Norte } \\
\%\end{array}$} & \multirow{2}{*}{$\frac{\text { Arco Central }}{\%}$} & \multirow{2}{*}{$\begin{array}{c}\text { Arco Sul } \\
\%\end{array}$} \\
\hline & $\%(B R)$ & Unidade & $\%$ & & & \\
\hline Extrativa mineral & 10,50 & 659 & 1,45 & 2,67 & 2,26 & 0,67 \\
\hline Indústria de transformação & 9,61 & 13.195 & 29,04 & 16,72 & 14,62 & 41,44 \\
\hline $\begin{array}{l}\text { Serviccos industriais de } \\
\text { utilidade pública }\end{array}$ & $-1,97$ & (131) & $-0,29$ & $-3,44$ & 0,86 & $-0,63$ \\
\hline Construção civil & 3,53 & 4.112 & 9,05 & 22,23 & 4,93 & 9,98 \\
\hline Comércio & 1,38 & (421) & $-0,93$ & 6,85 & 3,85 & $-5,62$ \\
\hline Serviços & 5,79 & 24.554 & 54,04 & 56,76 & 55,27 & 52,72 \\
\hline Administração pública & 2,84 & 487 & 1,07 & 0,11 & 0,17 & 1,88 \\
\hline $\begin{array}{l}\text { Agropecuária, extração } \\
\text { vegetal, caça e pesca }\end{array}$ & 3,53 & 2.984 & 6,57 & $-1,91$ & 18,04 & $-0,44$ \\
\hline Total & 5,96 & 45.439 & 100,00 & 100,00 & 100,00 & 100,00 \\
\hline Total da FF & - & 100 & - & - & - & - \\
\hline
\end{tabular}

Fonte: Caged/Ministério do Trabalho (2019). Disponível em: <https://bit.ly/3tNbuKu>. Acesso em: 4 nov. 2019.

Elaboração: Equipe Fronteiras Ipea.

23. Polígono industrial compreendido pelas microrregiões industriais que, grosso modo, definiam uma área entre a Região Metropolitana (RM) de Belo Horizonte, descendo pela RM do Rio de Janeiro, indo à RM de São Paulo, se alongando pela RM de Curitiba, passando por microrregiões do interior de Santa Catarina e chegando à RM de Porto alegre. Esse polígono se fechava voltando em direção a Londrina (PR)-Maringá (PR) e Uberlândia (MG) e, por fim, à RM de Belo Horizonte. 
Embora os postos de trabalho do setor de extração mineral representem um peso maior do que os demais em relação ao Brasil nesta atividade, o nível de emprego gerado constitui-se em somente $1,45 \%$ do total da FF, com maior representatividade nos arcos Norte (2,67\%) e Central (2,26\%). Constata-se que, na FF, a atividade de serviços registrou o maior saldo positivo, com 54,04\%, sendo que os percentuais acima de $50 \%$ reproduzem-se igualmente em todos os três arcos, confirmando a predominância deste setor, conforme dados de VAB vistos anteriormente. Embora a indústria de transformação apresente saldos positivos representativos, com $41,44 \%$ no arco Sul, $16,72 \%$ no arco Norte e $14,62 \%$ no arco Central, observa-se diminuição com relação aos empregos gerados pelos serviços industriais de utilidade pública de 3,44\% no arco Norte e 0,63\% no arco Sul. Além disso, o setor de comércio apresentou queda de $0,93 \%$ no total dos arcos, número alavancado pelo arco Sul, onde a redução foi de 5,62\% em relação ao seu total. Destaca-se, por fim, um aumento no nível de emprego formal da construção civil nos três arcos, com 22,23\% no arco Norte, 9,98\% no arco Sul e 4,93\% no arco Central (tabela 10).

Uma leitura das observaçóes dos participantes das atividades nos arcos, por um lado, confirma as informaçóes apresentadas, e, por outro lado, agrega questóes de ordem econômica específicas, que não são capturados nas análises mais gerais.

Participantes do arco Norte destacaram duas vertentes fundamentais: integração da base produtiva não consolidada e necessidade de alternativas de geração de renda para as famílias. Nessas vertentes, pontuaram entre os problemas: arranjos produtivos locais (APLs) não identificados; falta de apoio à agricultura, à produção de alimentos e ao abastecimento; compra de produtos sem certificaçáo; precário intercâmbio comercial; trabalho informal; garimpo ilegal; pressão econômica e formas indevidas de apropriação do solo como responsáveis pela devastação da floresta; e falta de visão de desenvolvimento, por não se viabilizar a potencialidade de uso da biodiversidade. Foi salientada a importância dos acordos de cooperação sobre biodiversidade no Amapá e algumas açóes localizadas de apoio ao empreendedorismo, referentes aos APLs, no Alto Solimôes (Pêgo et al., 2018).

No arco Central, foi observada a falta de aportes de recursos e orientaçáo/ acompanhamento aos APLs, embora Mato Grosso do Sul tenha sido uma UF que funcionou como área teste para projetos de APLs. O destaque foi dado em relação ao arranjo mato-grossense de Vila Bela da Santíssima Trindade, e, do outro lado da fronteira, em San Matías (Bolívia), na região da Chiquitania, a "mancomunidade", um tipo de arranjo local em moldes bolivianos que representa uma forma muito importante de integração (Pêgo et al., 2019; 2020b).

Nos aspectos econômicos citados sobre o arco Central, participam também a mineração e o gás natural. Há uma grande reserva de ferro e manganês na região 
de Corumbá/Ladário, com características de qualidade físico-químicas muito raras; também o gás proveniente da Bolívia é uma das maiores fontes de receitas - Imposto sobre Circulação de Mercadorias e Serviços (ICMS) - em Corumbá. O oriente boliviano possui também um grande mercado consumidor para produtos mato-grossenses e brasileiros, e, em sentido contrário, a Bolívia possui grandes reservas de ureia que podem atender a toda a demanda de Mato Grosso, que importa esse produto de países como o Catar. No entanto, essa produção mineral começa a passar por problemas com a crise do consumo de minério de ferro no mercado internacional, assim como pelo esgotamento da infraestrutura de transporte do produto mineral por rodovias e inadequação da hidrovia. É necessário que se tomem medidas em relação à verticalização da cadeia produtiva do minério de ferro, e de agregação de valor à cadeia produtiva do gás. Nesse sentido, há ainda grande resistência nos órgáos ambientais, multas, morosidade na liberaçáo de licenças e problemas de legislaçáo (Pêgo et al., 2019). Outra especificidade da região, o abate de jacaré, está sofrendo limitaçóes por falta de recursos do Ministério da Agricultura, Pecuária e Abastecimento (Mapa) para custeio de fiscais que deveriam acompanhar o processo. Além da fiscalização, faltam veterinários credenciados, que também têm que acompanhar todas as etapas produtivas (Pêgo et al., 2020b).

Participantes do arco Sul fizeram referência à desindustrialização em importantes centros da FF, processo vivido por Uruguaiana, que, nas últimas décadas, passou por uma relativa perda de unidades produtivas. Foram fechados frigorífico, ${ }^{24}$ lanifício, curtume e tornada ociosa a usina termoelétrica. Apontaram que as dificuldades econômicas dos moradores da fronteira também estão relacionadas com os ciclos diferenciados da variação cambial. Nos momentos depressivos, é comum famílias inteiras migrarem para grandes centros ou outros estados, estabelecimentos comerciais encerrarem suas atividades e muitos imóveis residenciais serem fechados e postos à venda (Pêgo et al., 2020a).

24. Neste caso, houve uma política de incentivo com recursos subsidiados, por parte do governo federal, a grandes grupos e, assim, estes compraram os pequenos e médios empreendimentos. Como resultados diretos, advieram concentração do setor produtivo e desemprego na região. 
Similarmente, participantes do arco Central reportaram sobre a alternância no desempenho do comércio e serviços, dos municípios dos arranjos transfronteiriços e outros da linha de fronteira, provocada pela oscilação do câmbio: quando o câmbio está favorável desenvolve-se, pela ativação do comércio e dos serviços, de um lado; quando ele está desfavorável, desenvolve-se do outro lado, e sempre há uma regiâo deprimida (Pêgo et al., 2019).

Outros reclamos se deram generalizadamente nos três arcos, como a incipiente participação de empresas privadas e entidades civis na ativação da economia, muitas vezes provocada pela burocracia nas relaçóes com essas empresas, ou pela falta de uma política efetiva para a participação de empresas privadas e entidades civis na solução de desafios locais. Além desse, o reclamo de que não se constatam açóes eficazes para geração de emprego e renda, atração de empresas, nem a médio nem a longo prazos, e são insuficientes e descontínuos os esforços para investimentos em equipamentos educacionais e de capacitação ao trabalho. A mais forte crítica recaiu em que a presença do Estado está focada na ocupação e administração do território, em detrimento do desenvolvimento econômico e social. Mostrou-se a necessidade de definição de marco regulatório e de sistema de gestão transfronteiriça, com reforço do diálogo para o estabelecimento de parcerias, intercâmbios e disseminação de informações, dado o frágil processo de governança interfederativa e transfronteiriça (Pêgo et al., 2017; 2018; 2019; 2020a; 2020b).

De modo geral, foram apontados problemas no mercado de trabalho na FF, como as elevadas proporçóes de trabalhadores precarizados, ocupando postos nas atividades informais. É grande também a mendicância, particularmente por índios, não só dos países vizinhos. Particularmente no arco Central, há um alto índice de informalidade no comércio, subemprego em setores como a construção civil e conflitos relacionados aos feirantes (muitos deles bolivianos), além de muitos ambulantes nas cidades. Além do forte mercado informal, é elevado o contingente de trabalhadores ilegais, com grande número deles vindo de países vizinhos (Pêgo et al., 2019; 2020b).

Houve uma reflexão de que o trabalho funcional em determinadas fronteiras é tão elevado, que essa funcionalidade termina tornando-se uma ilegalidade; no oposto, o excesso de formalidade, assim como o excesso de funcionalidade, são prejudiciais para o processo de integração. Cidadãos são cooptados a trabalhar em atividades ilegais (ponderaram que, se tivessem um emprego, se estivessem inseridos no circuito produtivo, refutariam); ampliam-se as redes geográficas de informalidade, de funcionalidade, que na fronteira perpassam de um lado para o outro e se tornam muito mais flexíveis e complexas, comprometendo a segurança cidadã (Pêgo et al., 2019). 
A migração para o trabalho amplia o problema. No caso da região de fronteira com a Bolívia, as atividades que cabem aos bolivianos são a pecuária e a agricultura - quase sempre no mercado informal, que não exige documentação tampouco qualificação profissional -, e frequentemente são sazonais. Esses trabalhadores entram pelas estradas clandestinas, as "cabriteiras", comumente arregimentados pela figura do "gato", que faz a intermediaçâo entre o trabalhador e o fazendeiro. Além disso, a área de muitas fazendas também transpõe a fronteira (Pêgo et al., 2020b).

No urbano, é grande a mobilidade pendular para o trabalho. De modo geral nos arcos, os informais correspondem à mão de obra menos especializada, e os trabalhadores "tanto passam daqui para lá quanto de lá para cá". São domésticas, ambulantes, entre outros. Enfim, em toda a extensão da fronteira, há um alto nível de informalidades, sobretudo nas relações de trabalho no comércio e serviços, evidenciando a falta de instrumentos que formalizem as relaçóes fronteiriças cotidianas.

\subsubsection{Infraestrutura econômica}

Sob a ótica econômica, o desenvolvimento do agronegócio possui grande dependência de uma boa rede de infraestrutura, composta por geração de energia, infraestrutura de transporte (rodoviário, ferroviário, aquaviário e aéreo) e conectividade/logística. A rede de geração de energia do país traduz, em linhas gerais, os caminhos da produção e geração de renda, demonstrando inclusive o isolamento de grande extensão da FF amazônica e a interligação da região formada pelos estados do Acre e de Rondônia, no arco Norte e arco Central, respectivamente, à rede geradora (mapa 8$)$. 


\section{MAPA 8}

Usinas geradoras de energia e tensão das linhas elétricas - Brasil (2018)

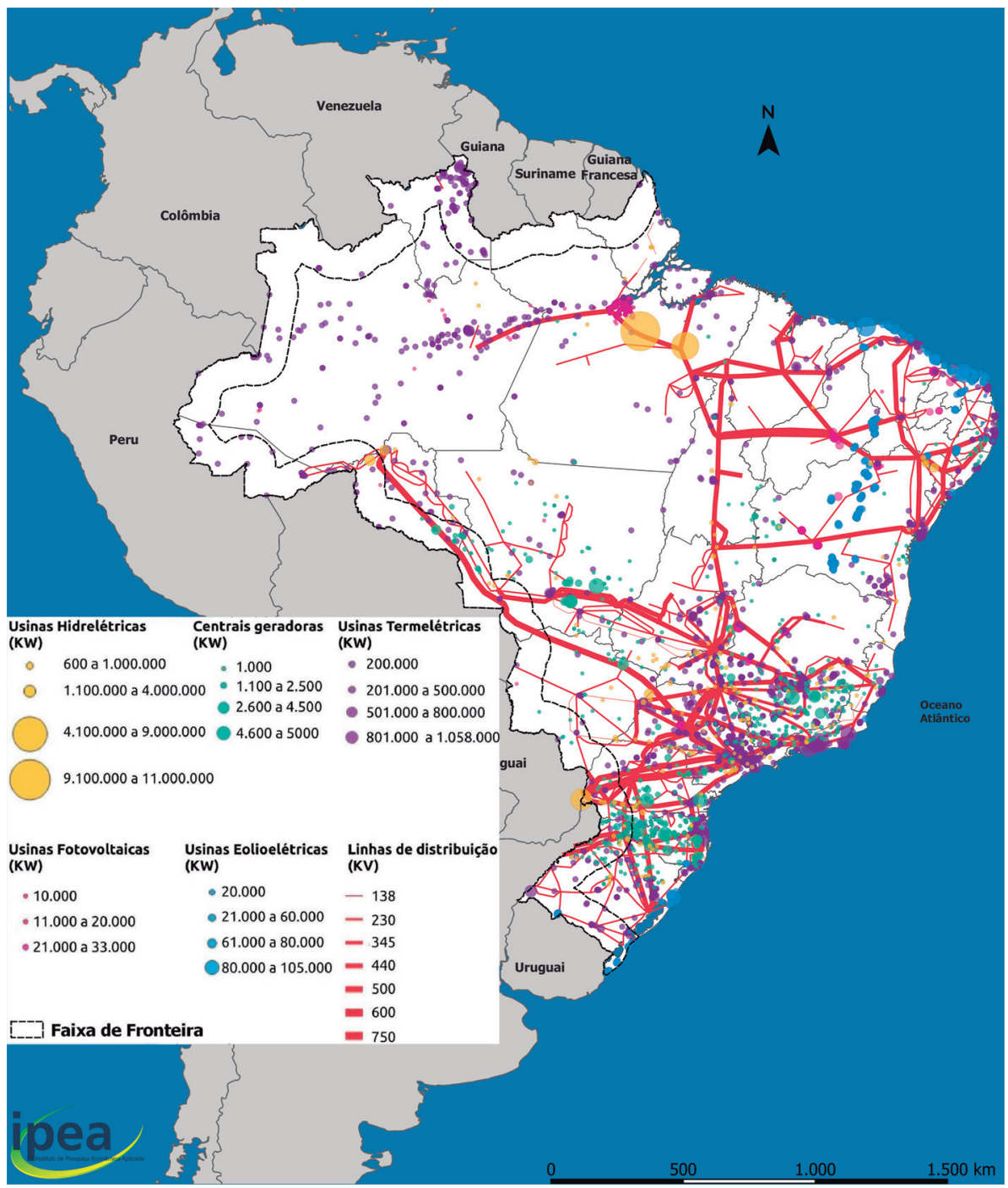

Fonte: Aneel (2018). Disponível em: <https://bit.ly/39WXeH6>. Acesso em: 20 nov. 2019.

Elaboração: Equipe Fronteiras Ipea.

Essa distribuição da atividade econômica tem apoio nas grandes infraestruturas de desenvolvimento, que vêm alcançando a fronteira terrestre brasileira nos arcos Central e Sul, com efetivos ganhos econômicos, a despeito de conflitos ambientais e sociais (Pêgo et al., 2019; 2020a). No arco Norte, a dinâmica econômica em curso encontra o desafio emergencial do desenvolvimento sustentável, a partir da 
preservação das áreas protegidas (naturais e indígenas), e, sob esse enfoque, o desafio de dirigir o investimento em seu potencial de riquezas minerais, biodiversidade e diversidade de possíveis arranjos produtivos peculiares às populaçóes tradicionais remanescentes indígenas, ribeirinhas, seringueiras, quilombolas, entre outras (Pêgo et al., 2018). Incorporando este mesmo objetivo, o agronegócio em curso nos arcos Central e Sul também enfrenta um grande desafio, qual seja o de encontrar um caminho harmônico entre a rentabilidade, a preservação e conservação do meio ambiente e a recuperaçáo e transformação de energias renováveis em insumos incorporados à cadeia produtiva, além da redução do uso de agrotóxicos, visando à produção de bens potencialmente competitivos que possam levar a uma mudança de paradigmas globais (Pêgo et al., 2019; 2020a).

Participantes das atividades nos arcos mostraram ciência de que toda forma de integração entre países passa pela integração física, exigindo atenção à infraestrutura, para que esta seja propiciada. No entanto, as obras de infraestrutura ao longo da FF se apresentam insuficientes, com estruturas deficitárias, falta de funcionários para viabilizar o aproveitamento das interligaçóes fronteiriças, entre outros limitantes (Pêgo et al., 2017; 2018; 2019; 2020a).

Entre as principais necessidades e óbices estão: pontes entre os países, a exemplo das acordadas que não foram construídas pela falta de definição de modelagem (se pública, público-privada etc.), ou as existentes que não operam por ausência de aduana; o estado precário de estradas de conexão internacional, muitas sem pavimentação; investimentos na construção de infraestrutura de transportes, porém sem os serviços e as manutençôes necessárias; e aeroportos que não operam internacionalmente. ${ }^{25}$

Especificamente aos arcos, no Norte, os participantes destacam que as vias de conexão são um grande problema. Mesmo que a maior bacia hidrográfica do país se situe na regiấo, as hidrovias não garantem a conexâo necessária aos deslocamentos internos ao arco, nem viabilizam integrar essa fronteira ao restante do território. A malha rodoviária é insuficiente e precária, e os serviços aéreos carecem de rotas e tarifas que permitam deslocamentos de muitos segmentos sociais. Caso específico muito discutido foi a ponte Oiapoque (Amapá)-St. Georges (Guiana Francesa), pronta há cinco anos, porém sem operar, dada a ausência de aduana; também o caso da rodovia Oiapoque-Macapá, que não está totalmente pavimentada. A região possui deficiência em equipamentos e formas de comunicação, sendo inexistente a integração dos serviços de telecomunicaçóes e também de controle com os países vizinhos; há deficiência de servidores para atendimento e são frágeis os canais de comunicação, particularmente pela instabilidade na conexão da internet (Pêgo et al., 2018).

25. Para mais detalhes sobre projetos de integração da infraestrutura física no continente sul-americano, ver: <https:// bit.ly/3aKC1zd>. Acesso em: 20 nov. 2019. 
$\mathrm{O}$ arco Central carece de investimentos para a melhoria da infraestrutura de todos os modais (ferroviário, rodoviário, aeroviário e hidroviário), o que torna a ideia do corredor bioceânico apenas um "sonho". Em Cáceres (Mato Grosso), algumas infraestruturas econômicas estáo sem uso, como o aeroporto, ou à espera de reativação, caso do porto; a zona de processamento e exportação (ZPE) e a hidrovia Paraná-Paraguai continuam como promessas; a possibilidade de se integrar ao sistema de transporte intermodal, com saída para o Pacífico, via Bolívia, depende do asfaltamento no trecho entre San Matías e San Ignacio de Velasco, cuja pavimentação tem sido articulada politicamente diante da possibilidade de aquisiçấo da ureia boliviana por Mato Grosso. Outro problema é que é vedado o acesso de composição de trem boliviano ao território brasileiro (Pêgo et al., 2019; 2020b).

A ampliação do sistema energético é uma necessidade premente, particularmente nos arcos Norte e Central, o primeiro dependente de transmissáo a partir da Venezuela (Pêgo et al., 2018; 2019). Além disso, a dotação de infraestruturas, aduanas integradas para facilitação do perpasse de cargas, duplicação de rodovias ou reposiçáo, no caso do transporte ferroviário, incrementariam as possibilidades de atração de novos investimentos à região da FF.

Dessa forma, propostas de cunho econômico e de infraestrutura para a FF são necessárias desde uma visão nas escalas global e nacional, visto ser evidente que os arcos apresentam relação direta com os biomas e a regionalização na escala nacional, com impactos na produção do espaço local. Assim, tais propostas somente serão eficazes se consideradas na aproximação com as necessidades específicas da FF. Para a FF, é imperativo pensar nas potencialidades econômicas que se evidenciam pelas frentes de expansão dos negócios a partir, também, de setores de menor expressão, como os posseiros, camponeses, mineradores e indígenas, e sugerir estratégias nacionais ou binacionais para fortalecer a diversificação das cadeias produtivas, voltadas à inclusão dos pequenos e médios produtores e empreendedores. De acordo com os participantes, é necessário pensar em formas pelas quais os municípios da fronteira possam utilizar a fronteira não somente para gerar, mas para agregar valor.

Finalmente, a perspectiva gerada pela noção da fronteira que só existe a partir do outro, ou do que está do outro lado da linha, seria constituída em consonância com o grande potencial econômico. Infraestruturas de mobilidade transfronteiriças que ligam pontos por meio de fluxos econômicos, cuja regra básica é a menor distância, são fatores que podem dinamizar a economia regional, especialmente nos arranjos transfronteiriços, alinhando políticas públicas e fortalecimento de negócios integrados. Tal perspectiva é salientada pelos participantes do arco Sul a partir da ideia da fronteira como um espaço aberto, constituindo-se em uma evolução do arco cuja integração já alcançou patamares mais elevados na fronteira 
brasileira, uma região baseada em pequenas propriedades e extremamente marcada pela dinâmica transfronteiriça do Mercosul (Pêgo et al., 2020a).

É possível incorporar tal ideia em torno de regiōes integradas pela cultura com grandes oportunidades de exploração - como no arco Central para o turismo, pela presença dos rios e alagados que formam o Pantanal, das Missóes Jesuíticas, que integram parte do território da Bolívia e que podem ser articuladas a pacotes internacionais com Cuzco, potencialidade esta apontada pelos participantes desse arco. Ou mesmo o cultivo da soja com produtores que plantam em ambos os lados da fronteira (Pêgo et al., 2019; 2020b). É preciso, também, de acordo com os participantes do arco Norte, dar positividade ao significado de se pensar a Amazônia do ponto de vista da Pan-Amazônia, a partir da integração dos povos, do compartilhamento da ciência e tecnologia, do comércio, da inclusão produtiva e da melhoria na qualidade de vida dos que nela vivem (Pêgo et al., 2018). E, ainda, de acordo com os participantes do arco Central, colocar em discussão as oportunidades para os municípios de fronteira mediante a possibilidade de finalização da implantação dos corredores bioceânicos (Pêgo et al., 2019).

\subsection{Desigualdade social}

\subsubsection{Concentração da pobreza, isolamento e conflitos}

Ao se tratar da área social na fronteira, de imediato há que se reconhecer a concentração de pobreza extrema nas áreas indígenas, a ausência de prestação de serviços essenciais, como saúde e educação, agravada pelo isolamento das comunidades. Se por um lado os indígenas enriquecem a diversidade dos povos dos arcos Norte e Central, com suas práticas específicas e sábias no relacionamento com a natureza, por outro, sofrem a ausência de um tratamento específico, que reconheça e sane a sua condição de pobreza, e tome atitudes que preservem os direitos desses povos quanto aos conflitos inerentes ao processo de expansão da fronteira econômica (Pêgo et al., 2018; 2019). Participantes nas atividades da regiâo reclamam da ausência de medidas que priorizem a integraçáo das TIs com outros setores da sociedade, facilitando a mobilidade, a prestação de serviços essenciais, como saúde e educação, ausentes devido a dificuldades de deslocamento e acesso das comunidades. Em um extremo, foi salientado que para muitos povos indígenas não existe fronteira. Em outro extremo, há muita dificuldade quanto à mobilidade nas regiôes de fronteira onde existem terras indígenas, o que as mantêm desintegradas em relaçấo a outros setores da sociedade. Foi salientado, também, que não é bom o diálogo entre a Funai e os governos estaduais e municipais, particularmente quanto à prestação de serviços essenciais e mobilidade nas áreas de fronteira que são terras indígenas.

Outro grande desafio nos arcos Norte e Central é o contato de seu território com algumas das áreas fronteiriças mais pobres do subcontinente. A condição de 
isolamento em relação a áreas mais dinâmicas de seus respectivos países faz com que os moradores de pequenos povoados e cidades fronteiriças se voltem à busca de serviços nas cidades brasileiras. Essas, devido ao porte de serviços que oferecem e à menor distância a percorrer, suprem suas necessidades de atendimento, inclusive por serviços públicos, além da disponibilidade de produtos em geral no comércio. Porém, as relaçóes fronteiriças do Brasil com seus vizinhos, além dos laços de parentesco e compadrio, do compartilhamento de culturas que os aproximam, formatam outras dinâmicas transfronteiriças, como altos níveis de mobilidade e práticas informais e também ilegais (Pêgo et al., 2018; 2019; 2020b).

$\mathrm{Na}$ região da fronteira do arco Central, um grande problema está ligado à titulação da propriedade da terra, particularmente no caso dos Chiquitanos, que estão em ambos os lados da fronteira. Essa dificuldade de regularizar a posse provoca impasses, enfrentamentos políticos, conflitos com fazendeiros e insegurança entre os ocupantes. Os títulos foram dados a terceiros sobre áreas originalmente povoadas, e não sobre espaços vazios como era anunciado, mas sim sobre espaços ocupados pelas populaçóes chiquitanas e pelos bugres. Há casos de dupla, até tripla documentação, sobreposição de territórios e títulos, além de conflitos de competência jurídica entre a União e os estados. Entre as comunidades chiquitanas, a maioria foi sendo empurrada para territórios ainda sem títulos, constituindo adensamentos que atualmente operam como reservas de máo de obra para as grandes fazendas. Muitos desalojados das terras não tiveram outra opção que não as cidades, onde formaram bairros com elevada população chiquitana. São expressivos os conflitos por terras na fronteira do Paraguai e os internos à FF, entre indígenas e fazendeiros (Pêgo et al., 2019; 2020b). ${ }^{26}$

As longas distâncias e o isolamento enfrentados pela população, bem como a precariedade das ações públicas e a descontinuidade de projetos e ações desenvolvidas, foram salientados como os principais problemas sociais desses arcos. No arco Norte, a luta entre as comunidades tradicionais e o que convencionalmente é tratado como "ocupação de desenvolvimento" torna-se um tema sensível. Historicamente, a grande extensão da Amazônia, com sua ocupação tradicional, sobretudo de povos originários, foi tida como "terra sem gente", o que fortalece e justifica os discursos nem sempre harmônicos sobre ocupação dos espaços amazônicos (Pêgo et al., 2018).

Uma questão observada pela equipe Ipea nas cidades fronteiriças de Roraima com a Venezuela e a Guiana é o domínio de produtos e de comerciantes chineses. Sobretudo, na cidade guianense de Lethem, há no comércio o domínio tanto dos produtos como dos comerciantes chineses, sobrepondo-se aos comerciantes tradicionais. Tal característica tem contribuído para aumentar a exclusão social,

26. Conforme relatado na subseção 1.1.2, Terras indígenas e unidades de conservação, Mato Grosso do Sul é o segundo estado em número de população indígena (IBGE, 2010), distribuída em pequena área de terras indígenas. 
eliminar traços arquitetônicos e culturais originais do lugar, conferindo certa uniformidade à paisagem urbana. Por seu turno, na cidade fronteiriça venezuelana de Santa Elena de Uairén, verificam-se produtos chineses nos estabelecimentos de comércio da área central, destacando-se que, tanto nesta cidade como em Lethem, há dificuldade de encontrar produtos regionais (Pêgo et al., 2018).

\subsubsection{Vulnerabilidade social}

Além dos conflitos urbanos, como antecipado na seção anterior, os povos da fronteira passam por graves ameaças de conflitos socioambientais. Caso dos povos indígenas, quilombolas, ribeirinhos e assentados, particularmente nas regióes de florestas, onde a conciliação ser humano/natureza exige conhecimentos específicos, transmitidos na vivência cotidiana com o meio. Os arcos Norte e Central possuem muitas regióes que carecem de respeito a esse cuidado necessário. Mesmo diante da riqueza natural, do substrato diversificado em minérios, da biodiversidade existente, esses arcos apresentam os mais elevados índices de vulnerabilidade social (IVS) na fronteira. Esse índice, desenvolvido pelo Ipea, busca mensurar a desigualdade social brasileira. ${ }^{27}$

De modo geral, os índices referentes a 2010 mostram avanços significativos em relação aos de 2000, na redução da vulnerabilidade social neste recorte territorial, como em todo o país. Mesmo assim, nenhum dos três arcos, de forma agregada, encontra-se na faixa de muito baixa vulnerabilidade social (tabela 11). O Norte espelha a condição de muito alta vulnerabilidade $(0,505)$, o Central, de média $(0,320)$, e o Sul, de baixa. O Brasil apresenta o índice em 0,326, média vulnerabilidade, como o arco Central.

TABELA 11

Comparativo dos IVS por dimensões, segundo arcos - Brasil (2000 e 2010)

\begin{tabular}{|c|c|c|c|c|c|c|c|c|}
\hline \multirow{2}{*}{ Arco } & \multicolumn{2}{|c|}{ IVS geral } & \multicolumn{2}{|c|}{ IVS infraestrutura urbana } & \multicolumn{2}{|c|}{ IVS capital humano } & \multicolumn{2}{|c|}{ IVS renda e trabalho } \\
\hline & 2000 & 2010 & 2000 & 2010 & 2000 & 2010 & 2000 & 2010 \\
\hline Norte & 0,654 & 0,505 & 0,664 & 0,474 & 0,735 & 0,586 & 0,562 & 0,457 \\
\hline Central & 0,477 & 0,320 & 0,358 & 0,224 & 0,577 & 0,421 & 0,494 & 0,315 \\
\hline Sul & 0,353 & 0,237 & 0,166 & 0,118 & 0,429 & 0,209 & 0,465 & 0,285 \\
\hline Brasil & 0,446 & 0,326 & 0,351 & 0,295 & 0,499 & 0,392 & 0,445 & 0,326 \\
\hline
\end{tabular}

Fonte: Costa e Marguti (2015).

Elaboração: Equipe Fronteiras Ipea, com base em Pinto, Oliveira e Marguti (2018).

No entanto, ao se analisar o comportamento dos municípios, a homogeneidade colhida no índice agregado se fragmenta em comportamentos bastante distintos, tanto no que se refere à formação de manchas contínuas de municípios na mesma condição de vulnerabilidade social, mais visíveis no arco Norte, quanto 
à composição de mosaicos de municípios em condições de grande assimetria, mais perceptíveis no arco Sul (mapa 9).

MAPA 9

Índice de vulnerabilidade social - Brasil (2010)

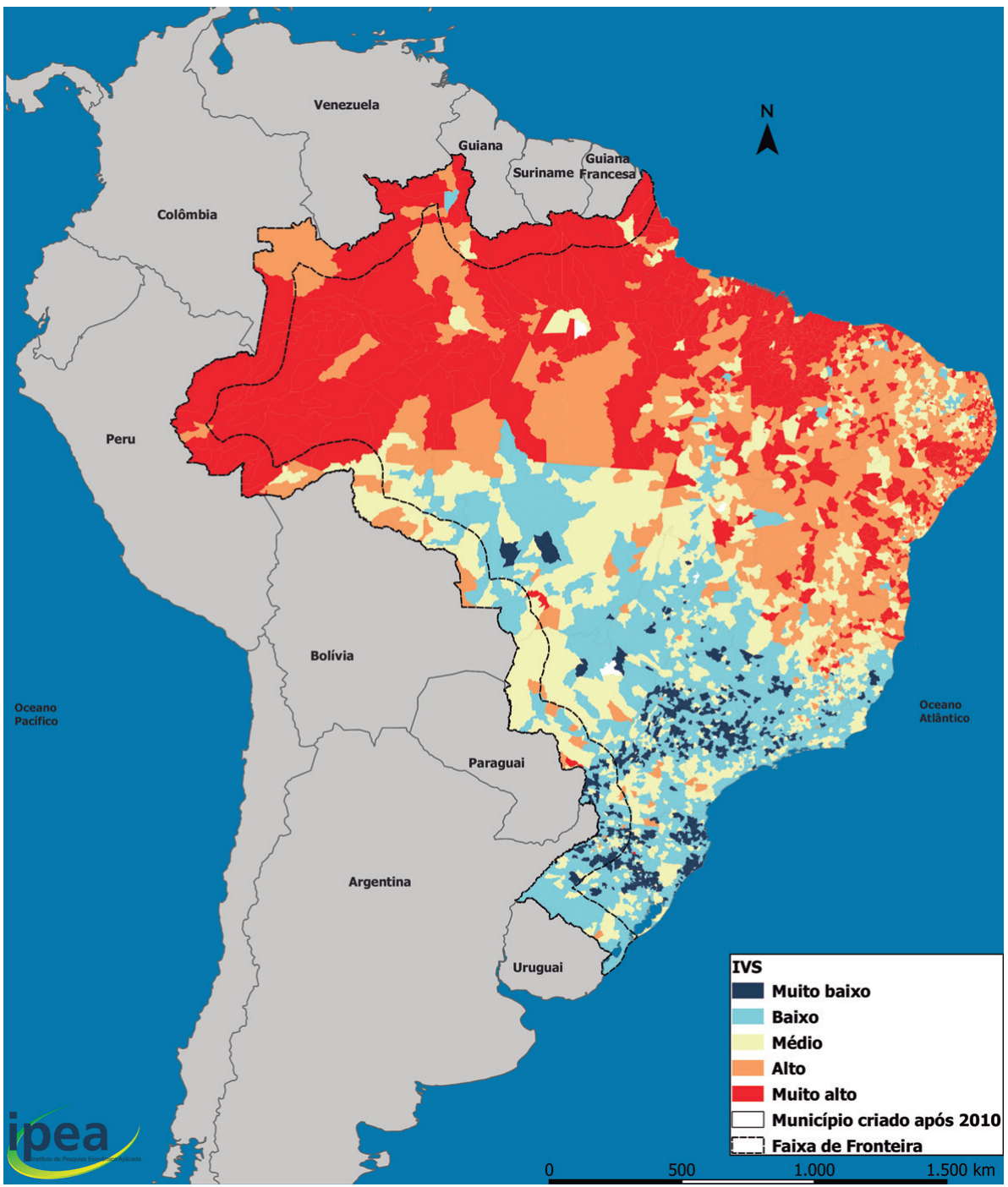

Fonte: Costa e Marguti (2015).

Elaboração: Equipe Fronteiras Ipea.

A distribuição dos municípios conforme o IVS aponta que, em 2010, 70\% dos municípios do arco Norte se classificavam na pior situaçáo de vulnerabilidades social, com o índice indicando nível de muito alta vulnerabilidade, e outros $23 \%$, 
no nível de alta vulnerabilidade; no arco Central, mais da metade dos municípios apresentava nível de média vulnerabilidade, assim como 21,4\% dos municípios do arco Sul (tabela 12). O índice de baixa vulnerabilidade social é registrado em $31,7 \%$ dos municípios do arco Central e em 55\% dos do arco Sul. Por sua vez, o de muito baixa vulnerabilidade social contemplava apenas municípios do arco Sul, em uma proporção de $21,1 \%$.

TABELA 12

Distribuição dos municípios, segundo índice de vulnerabilidade social e recortes territoriais - Brasil (2010)

\begin{tabular}{|c|c|c|c|c|c|}
\hline \multirow{2}{*}{ Recorte } & \multicolumn{5}{|c|}{ Vulnerabilidade } \\
\hline & Muito alta & Alta & Média & Baixa & Muito baixa \\
\hline \multicolumn{6}{|c|}{ Arco Norte } \\
\hline № & 48 & 16 & 4 & 1 & 0 \\
\hline$\%$ & 69,57 & 23,19 & 5,80 & 1,45 & 0,00 \\
\hline \multicolumn{6}{|c|}{ Arco Central } \\
\hline № & 3 & 15 & 51 & 32 & 0 \\
\hline$\%$ & 2,97 & 14,85 & 50,50 & 31,68 & 0,00 \\
\hline \multicolumn{6}{|c|}{ Arco Sul } \\
\hline № & 0 & 10 & 89 & 229 & 88 \\
\hline$\%$ & 0 & 2,40 & 21,39 & 55,05 & 21,15 \\
\hline \multicolumn{6}{|c|}{ Demais municípios } \\
\hline № & 761 & 1.141 & 1.119 & 1.430 & 528 \\
\hline$\%$ & 15,28 & 22,92 & 22,47 & 28,72 & 10,60 \\
\hline \multicolumn{6}{|c|}{ Brasil } \\
\hline № & 812 & 1.182 & 1.263 & 1.692 & 616 \\
\hline$\%$ & 14,59 & 21,24 & 22,70 & 30,40 & 11,07 \\
\hline
\end{tabular}

Fonte: Costa e Marguti (2015).

Elaboração: Equipe Fronteiras Ipea.

Análise realizada por Pinto, Oliveira e Marguti (2018) evidencia quais os componentes que são mais expressivos na composição dos índices em cada arco. Em 2010, o índice geral dos três arcos teve como principal influência a dimensão capital humano. Esta dimensão se compóe dos seguintes indicadores: i) mortalidade até 1 ano de idade; ii) percentual de crianças de 0 a 5 anos que não frequenta a escola; iii) percentual de crianças de 6 a 14 anos que náo frequenta a escola; iv) percentual de mulheres de 10 a 17 anos de idade que tiveram filhos; v) percentual de mães chefes de família, sem ensino fundamental completo e com pelo menos um filho menor de 15 anos de idade; vi) taxa de analfabetismo da população de 15 anos ou mais de idade; vii) percentual de crianças que vivem em domicílios em que nenhum dos moradores tem o ensino fundamental completo; e viii) percentual 
de pessoas de 15 a 24 anos que não estudam, não trabalham e são vulneráveis à pobreza. Ou seja, estas condiçóes sociais da população apresentavam diferentes níveis de precariedade, mas ocorriam generalizadamente entre os municípios da FF nos três arcos. No arco Norte, junta-se a essa a dimensáo infraestrutura urbana, que se compóe dos indicadores: i) percentual de pessoas em domicílios com abastecimento de água e esgotamento sanitário inadequados; ii) percentual da população que vive em domicílios urbanos sem o serviço de coleta de lixo; e iii) percentual de pessoas em domicílios vulneráveis à pobreza e que gastam mais de uma hora até o trabalho. São as condiçóes de moradia e do meio que se encontram com elevada precariedade entre os municípios desse arco. Nos arcos Sul e Central, é a dimensáo renda e trabalho que se soma ao capital humano. Essa dimensão se compóe dos indicadores: i) proporção de vulneráveis à pobreza; ii) taxa de desocupação da populaçáo de 18 anos ou mais de idade; iii) percentual de pessoas de 18 anos ou mais sem ensino fundamental completo e em ocupação informal; iv) percentual de pessoas em domicílios vulneráveis à pobreza e dependentes de idosos; e v) taxa de atividade das pessoas de 10 a 14 anos de idade. Tal dimensão que as condiçóes ao trabalho se encontram deficitárias.

Esses resultados se encaixam nas observaçóes debatidas pelos participantes nas atividades nos arcos da fronteira. Eles reconhecem que, apesar dos avanços sociais ocorridos nos últimos anos, os habitantes dos municípios fronteiriços do Brasil ainda vivem uma realidade de carências, na qual faltam abastecimento de água e esgotamento sanitário adequado, educação de qualidade, e renda domiciliar compatível com as necessidades básicas das famílias, sem que seus membros tenham que recorrer ao trabalho informal ou ao trabalho infantil. As políticas públicas voltadas aos aspectos sociais da fronteira ainda são incipientes, e sem contemplar as exigências que a condição fronteiriça requer, fundamentalmente nas áreas de saúde, educação, cultura, mobilidade e acessibilidade (Pêgo et al., 2017; 2018; 2019; 2020a; 2020b).

\subsubsection{Saúde}

$\mathrm{Na}$ área de saúde, no Programa de Aceleração do Crescimento (PAC) 2, no eixo PAC Comunidade Cidadã, foram definidos investimentos em equipamentos sociais para construção de novos estabelecimentos e reforma e ampliação das unidades de atendimento primário de saúde, sendo responsável por parte significativa da ampliação de Unidades Básicas de Saúde (UBS) e Unidades de Pronto Atendimento (UPA) nos municípios fronteiriços (Nunes, 2018). Entretanto, o aumento numérico dos estabelecimentos de UBS nos municípios fronteiriços não foi acompanhado na mesma proporção pela cobertura das Equipes de Saúde da Família (ESF), o que se reflete na precariedade da qualidade dos serviços de saúde oferecidos aos cidadáos. 
Foram destacados pelos participantes como graves problemas a não integração dos serviços públicos, oferta incipiente e baixa qualidade nos serviços de saúde, carência e sobrecarga dos equipamentos (falta de hospitais e de especialistas), saúde primária precária, e saneamento deficitário e por vezes inexistente, com despejos de rejeitos nos rios, lixôes a céu aberto, entre outros (Pêgo et al., 2017; 2018; 2019; 2020a; 2020b).

A precariedade de serviços e equipamentos públicos em alguns dos países vizinhos, além da distância dos centros urbanos mais próximos (muitas vezes por estradas sem pavimentação), leva seus habitantes a buscarem atendimento em cidades brasileiras. $\mathrm{O}$ atendimento emergencial a estrangeiros na área de saúde, que é uma garantia constitucional, provoca sobrecarga nos orçamentos públicos das pequenas cidades brasileiras. Porém, esses estrangeiros fronteiriços consomem produtos brasileiros (gêneros alimentícios, móveis etc.) e pagam para o Brasil os devidos impostos aos produtos consumidos, tanto que o comércio dos municípios brasileiros que possuem esse tipo de relação (caso das cidades gêmeas) se ressente em situação de fechamento das passagens de fronteira.

Os municípios dos arranjos transfronteiriços do arco Central têm feito grande esforço para garantir atendimento emergencial a todos os cidadãos dos dois lados da linha de fronteira, mas carecem de apoio e de acordos internacionais que tornem essa relação o mais bilateral possível. Também têm trabalhado para enfrentar o risco de endemias e epidemias - como as gripes, as doenças tropicais como a dengue, e as zoonoses, como a raiva canina e a febre aftosa -, mas sofrem limitaçóes na área de vigilância sanitária. $\mathrm{O}$ orçamento das cidades de fronteira é muito baixo diante das demandas, tanto de saúde e educação como de segurança pública, e o que se combina nos acordos tratados não tem continuidade (Pêgo et al., 2019; 2020b).

Ainda no âmbito da saúde, quanto à nova política uruguaia de regulação do mercado de cannabis, o plano de monitoramento em curso, as autoridades de segurança e os atores do sistema de justiça criminal brasileiros conhecem pouco a nova legislação uruguaia. Não receberam instrução de seus superiores, esclarecimentos específicos do governo uruguaio, ou treinamento para o enfrentamento da nova realidade, e demonstram desconfiança quanto ao seu alcance e potenciais impactos, em especial no contexto de uma zona de fronteira. As abordagens da população domiciliada na FF, em relação ao problema das drogas, são conservadoras, preferindo-se a repressão à legalização, denotando uma associação entre o uso de substâncias entorpecentes, marginalidade e violência. Para a maioria dos estudiosos, a medicalização do problema parece preferível à sua criminalização. As autoridades de segurança e atores do sistema de justiça criminal uruguaios procuram prevenir a produção de efeitos negativos sobre o país vizinho, ampliando a cooperação interinstitucional, por meio de dura repressão aos delitos de drogas e preservação 
estrita da ordem pública. A disponibilidade e o consumo, quer de cannabis quer de outras drogas, não está aumentando, e não houve qualquer prejuízo à ordem pública (Pêgo et al., 2020a).

\subsubsection{Educação e cultura}

Ao longo do debate sobre a eficácia das políticas para a fronteira, concluiu-se que houve significativo aporte na área de segurança, com destaque ao Programa Calha Norte (PCN). ${ }^{28}$ Todavia, constatou-se uma oferta restrita e de baixa capilaridade na área da educação e cultura, com falta de escolas binacionais e cursos de língua estrangeira (sendo o idioma um grave problema de comunicação e interação), ausência de ensino técnico-profissionalizante e de nível superior, e falta de oportunidades em pesquisa, desenvolvimento e inovação (Pêgo et al., 2017; 2018; 2019; 2020a; 2020b).

Mesmo assim, destacaram-se bons resultados na educação em relação aos Institutos Federais de Educação, Ciência e Tecnologia (IFs), que têm oportunizado a entrada de estrangeiros, a educação profissional e os cursos de idiomas, e o Programa Escolas Interculturais de Fronteira (Peif), no qual são estimuladas a educação bilíngue e as trocas culturais. É usual que a língua estrangeira praticada na educação formal brasileira seja o inglês, mas na fronteira deve-se discutir a inserção do espanhol. É preciso melhorar a comunicação, não só porque o espanhol está sendo falado nos limites de muitos municípios e há alunos de língua espanhola nas escolas brasileiras, mas até como condição de reciprocidade (Pêgo et al., 2018; 2019; 2020a).

$\mathrm{Na}$ Bolívia, por exemplo, os alunos estudam português. Por meio do acesso mútuo à educação, do aprendizado da língua espanhola nas escolas brasileiras e do português nas dos países vizinhos que falam esse idioma, e também por causa da existência de documentos comuns aos dois ou três países, é possível fazer valer direitos comuns de cidadania aos povos transfronteiriços (Pêgo et al., 2019; 2020b). A despeito dessa importância, algumas escolas bilíngues, que existem em cidades gêmeas do arco Sul, conforme citado nos debates, não estão em funcionamento (Pêgo et al., 2020a).

No enfrentamento de tais problemas, os principais desafios são o fortalecimento de uma educação transfronteiriça e o estímulo à cooperação e ao entendimento entre os povos fronteiriços, em prol de uma cultura, história e costumes comuns,

28. "Foi criado em 1985 pelo governo federal diante de uma preocupação dos militares sobre a causa amazônica. Naquela época, se propagava a cobiça internacional sobre as reservas naturais estratégicas do país. Desde 1999 sob a coordenação do Ministério da Defesa, o Calha Norte tem o propósito de promover a ocupação e o desenvolvimento ordenado e sustentável da região amazônica. 0 programa abrange 379 municípios, distribuídos em oito estados: Acre, Amapá, Amazonas, Mato Grosso, Mato Grosso do Sul (FF), Pará, Rondônia e Roraima". Para mais detalhes, consultar: $<$ https://bit.ly/2YVtcNB>. 
em convivência. Contudo, nos últimos anos tem aumentado a dificuldade de trânsito de escolares entre os países, ou mesmo de pessoas que buscam realizar atividades transfronteiriças, como as "cavalgadas ecológicas", com participantes dos três países fronteiriços no arranjo de Barra do Quaraí/RS (Pêgo et al., 2020a).

A questão cultural é vista como um problema da região de fronteira. Participantes do arco Sul lamentam que as populaçóes sáo pouco interessadas no estudo e no desenvolvimento dos valores regionais, com discernimento limitado da própria identidade, apesar de viverem em um território com potencialidades imensas, tanto históricas, quanto culturais, turísticas, sociais e ambientais. A grande riqueza de uma fronteira está na integração e o seu grande problema é o isolamento (Pêgo et al., 2020a).

No arco Norte, destacou-se a ação do Instituto do Patrimônio Histórico e Artístico Nacional (Iphan) no cumprimento de seu papel de proteção e preservação do patrimônio histórico natural, material e imaterial. Sugeriu-se que o mais importante é que as políticas públicas saiam do papel para que consigam mudar a realidade da FF (Pêgo et al., 2018).

\section{INTERAÇÕES TRANSFRONTEIRIÇAS}

\subsection{Articulação à rede de cidades}

\subsubsection{Hierarquia e rede de relações}

Os municípios da FF e suas centralidades mais expressivas são pouco articulados à rede urbana brasileira, sendo que isso também ocorre em relação aos municípios fronteiriços e às redes de cidades dos respectivos países. Distância das centralidades principais, meios de comunicação e acessibilidade precários são os motivos das limitadas articulaçóes entre os centros, tanto no arco Norte quanto no Central (Pêgo et al., 2018; 2019). Essas condições reforçam os arranjos transfronteiriços como centralidades de importância regional nas respectivas áreas de fronteira, assim como estreitam vínculos entre municípios dos países vizinhos e centralidades brasileiras, pois muitas vezes as dificuldades de conexão e as distâncias são maiores nesses países. 
Informações colhidas pelo IBGE na pesquisa Regiōes de Influência das Cidades - Regic 2018 evidenciam que a "hinterlândia das cidades brasileiras avança sobre o território dos demais países, sendo referência tanto de cidadáos estrangeiros quanto de brasileiros residentes no exterior para a aquisição de produtos e o usufruto de serviços" (IBGE, 2020, p. 147). ${ }^{29}$ São muitos os motivos das relaçóes externas que ligam algumas cidades brasileiras a cidades dos países vizinhos, compondo regióes de influência que transcendem as fronteiras nacionais, alimentadas por um fluxo constante de pessoas que se deslocam, nos dois sentidos, para acesso a bens e serviços. A pesquisa realizada observa que a influência de uma cidade ao fornecer bens e serviços é proporcional à distância a partir das fronteiras, ou seja, quanto mais se afasta da fronteira torna-se menor o número de localidades relacionadas à cidade.

No arco Sul, a FF guarda maior proximidade às principais centralidades da rede urbana brasileira, que é mais adensada na porção leste do país, e possui vias de ligação com centralidades dos países vizinhos em melhores condiçôes que nos demais arcos (mapa 10). Mesmo assim, há cidades na fronteira do Rio Grande do Sul com mais facilidade de acesso a centralidades dos países vizinhos que às brasileiras (Pêgo et al., 2020a). Particularmente no arco Norte, há localidades sem acesso pelo sistema rodoviário, a exemplo do arranjo transfronteiriço Tabatinga (Amazonas)-Letícia (Colômbia)-Santa Rosa (Peru), no qual o acesso é por via aérea ou fluvial. Ainda assim, vale apontar que o aeroporto na região não opera voos internacionais (Pêgo et al., 2018).

29. Para essa informação, o IBGE valeu-se do conhecimento empírico das agências do IBGE, que responderam "de quais cidades dos países vizinhos são oriundas as pessoas que vêm adquirir bens e serviços no Brasil" (IBGE, 2020, p. 147). Os bens e serviços considerados foram os mesmos relativos à pesquisa sobre a relação entre cidades brasileiras. No caso das cidades da FF, pesquisou-se a atratividade internacional para: compras de calçados e vestuários, compras de móveis e eletroeletrônicos, serviços de saúde de baixa e média complexidade, serviços de saúde de alta complexidade, ensino superior, atividades culturais, atividades esportivas e uso de aeroportos. 
MAPA 10

Principais ligações rodoviárias federais e articulações com o sistema viário sul-americano - Brasil (2018)

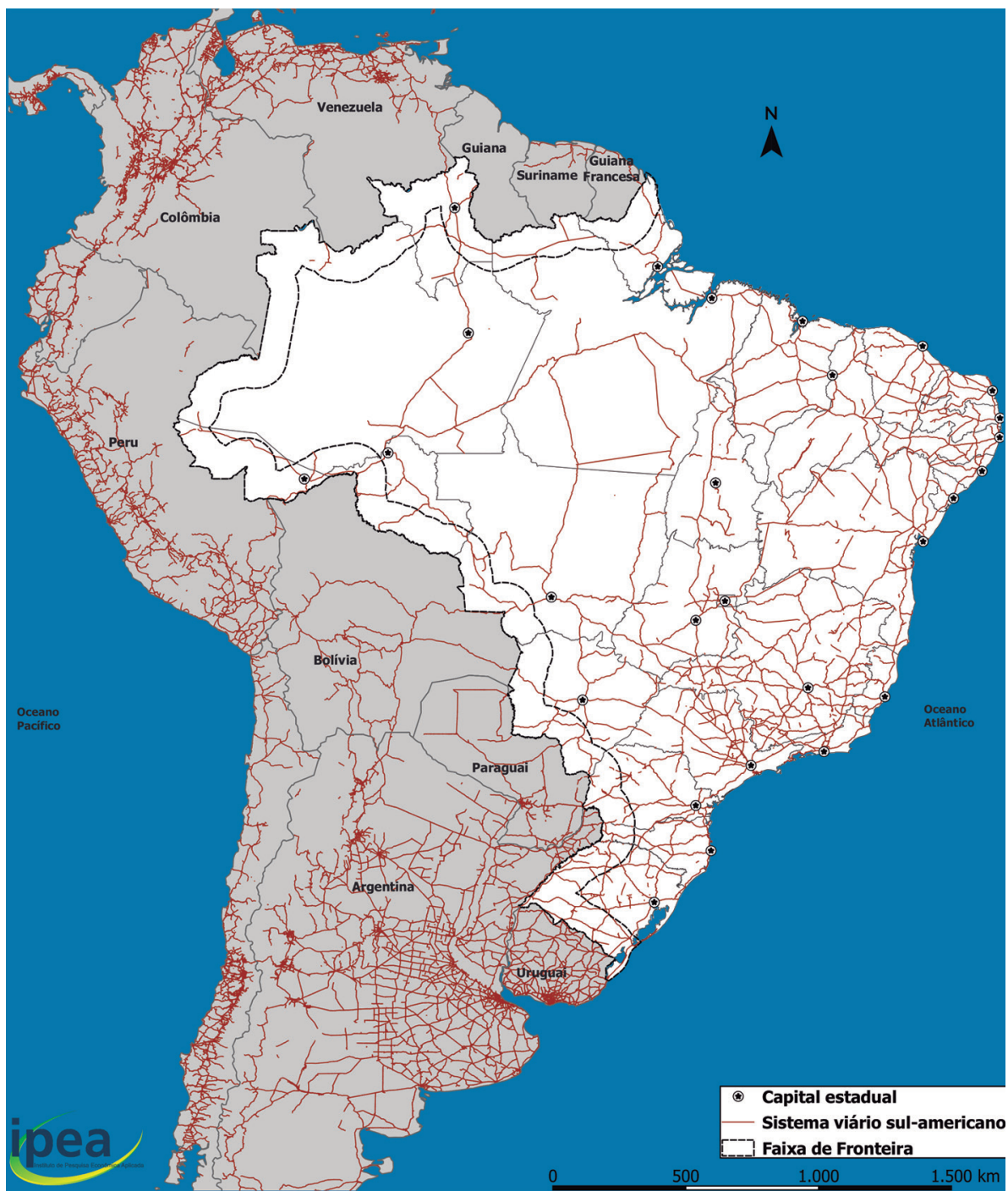

Fontes: IBGE (2018); DNIT (2018), disponível em: <https://bit.ly/3kcw2pP>. Acesso em: 20 jan. 2020; Meijer et al. (2018). Elaboração: Equipe Fronteiras Ipea. 
Os principais centros da FF dão suporte à organização desse território e garantem o acesso a bens e serviços à população residente dos dois lados da fronteira. Ademais, algumas dessas centralidades e outras, situadas fora da FF, casos de Manaus e Cuiabá, funcionam como "conectoras" (Egler, 2015) na integração e na interação transfronteiriça, articulando atividades econômicas e socioculturais, tornando-se destinos iniciais de trajetórias longas de migrações internacionais, entre outras funçóes.

Segundo a pesquisa Regic (IBGE, 2020), são poucos os municípios da FF classificados nos patamares superiores da hierarquia de centros. Não há algum na condição de metrópole ou capital regional A (mapa 11). Classificados como capitais regionais $\mathrm{B}$, portanto, na posição mais elevada entre as categorias de centros presentes na FF, encontram-se os arranjos populacionais de Porto Velho (capital de Rondônia), no arco Central; e Cascavel (Paraná) e Chapecó (Santa Catarina), no arco Sul. ${ }^{30}$ Como capital regional $\mathrm{C}$ foram classificadas as capitais estaduais Rio Branco (Acre) e Boa Vista (Roraima), no arco Norte, assim como Dourados (Mato Grosso do Sul), no arco Central, e os arranjos populacionais de Pelotas (Rio Grande do Sul) e o internacional de Foz do Iguaçu (Paraná) e Ciudad del Este (Paraguai), no arco Sul. Dois destaques são relevantes: o de que todos os centros classificados como capitais regionais no arco Norte são capitais de UFs, cuja posição reforça a FF nesse arco, como também de Porto Velho, no arco Central; e o de que, como nas regióes mais urbanizadas do país, a configuração espacial em arranjos populacionais que integram mais de um município, comum em regióes adensadas, passa a pontuar também os municípios mais urbanizados dos arcos Norte e Central.

30. Segundo o IBGE (2020, p. 11), a unidade urbana de análise e exposição dos resultados dessa pesquisa trata-se de município e arranjo populacional - este considerando o "fato de que a unidade funcional Cidade, objeto do atual estudo, pode vir a ser composta não apenas por um, mas por vários Municípios que são indissociáveis como unidade urbana. Trata-se de Municípios conturbados ou que possuem forte movimento pendular para estudo e trabalho, com tamanha integração que justifica considerá-los como um único nó da rede urbana". 


\section{MAPA 11}

Hierarquia e rede de relações dos centros urbanos da FF - Brasil (2018)

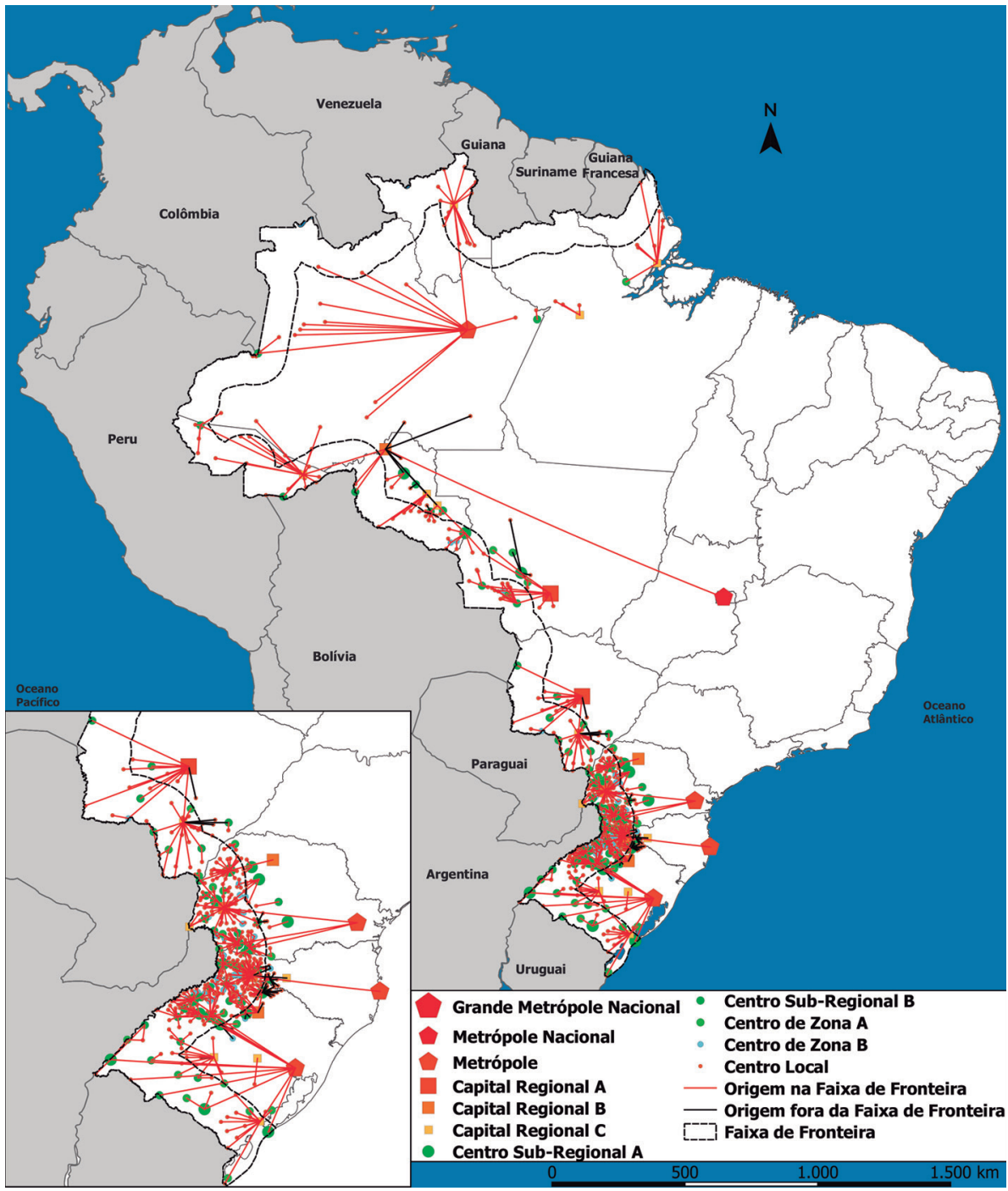

Fonte: IBGE (2020)

Elaboração: Equipe Fronteiras Ipea.

Conforme o IBGE (2020), essas centralidades integram as regióes de influência das metrópoles, condicionadas fundamentalmente pelo sistema viário principal ou por vias fluviais. No arco Norte, a metrópole Manaus tem uma região de influência marcada por poucos centros de níveis intermediários, formada apenas pela rede da capital regional Boa Vista (Roraima), como nível intermediário capaz de polarizar uma rede própria. Os municípios do Amapá integram a rede de Macapá, que é 
uma das três capitais regionais que estruturam a região de influência da metrópole Belém, caracterizada por ampla extensão territorial.

Brasília, metrópole nacional, inclui em sua região de influência, também de grande extensão, a rede da capital regional Rio Branco (Acre), diretamente polarizada por Porto Velho, que passa a articular-se com maior nitidez à rede urbana do arco Central. Tal articulação impóe que seja repensada a inclusão do Acre no arco Norte da FFT, posto que cada vez mais as relaçóes entre cidades dessa UF se estreitam com cidades de Rondônia e Mato Grosso, como também da Bolívia e do Peru, fundamentalmente após a abertura da interoceânica, Estrada do Pacífico tema a ser abordado na continuidade desta seção. ${ }^{31}$

No arco Central, Brasília também polariza cidades da FF que participam das regióes de influência das capitais regionais Porto Velho (Rondônia) e Cuiabá (Mato Gosso). Já as cidades de Mato Grosso do Sul recebem o alcance da influência direta da grande metrópole nacional, São Paulo, pelas redes das capitais regionais Campo Grande e Dourados.

No arco Sul, três metrópoles polarizam as cidades da FF de seus respectivos estados, apoiadas por capitais regionais, todas configuradas por arranjos populacionais: Curitiba (Paraná), pelo arranjo de Cascavel e pelo internacional de Foz do Iguaçu; Florianópolis (Santa Catarina), pelo de Chapecó; e Porto Alegre (Rio Grande do Sul), pelo de Pelotas.

Além dessas centralidades dos patamares superiores da hierarquia dos centros metrópoles e capitais regionais - a rede das cidades da FFT se complementam com um importante conjunto de centralidades em níveis intermediários. $\mathrm{O}$ arco Norte apoia a estruturação de sua rede em três centros sub-regionais: Cruzeiro do Sul (Acre), os arranjos populacionais internacionais Brasileia (que inclui Epitaciolândia e Cobija, esta na Bolívia) e Tabatinga (com Leticia, na Colômbia), além de um centro de zona, formado pelo arranjo populacional Laranjal do Jari (Amapá) - Almeirim (Pará).

No arco Central, doze centros sub-regionais e seis centros de zona complementam a rede. Os centros sub-regionais, em Mato Grosso do Sul, são compostos pelos arranjos populacionais de Aquidauana, Jardim, assim como pelos arranjos internacionais de Corumbá (com Ladário e Puerto Quijarro, este na Bolívia) e Ponta Porã (com Pedro Juan Caballero, no Paraguai), além de Naviraí; em Mato Grosso,

31. A reflexão sobre um reenquadramento do Acre nos arcos fronteiriços, deixando o Arco Norte e passando a se integrar ao Arco Central, encontra justificativa em estudo do IBGE, desenvolvido com base na Regic 2007 (IBGE, 2008), que pautaram uma divisão urbano-regional do Brasil (IBGE, 2013). Nessa divisão urbano-regional, em sua escala mais abrangente, as doze metrópoles de então e mais duas capitais regionais (Porto Velho e Cuiabá) polarizam catorze Regiões Ampliadas de Articulação Urbana, "que possuem o mérito de revelar no território nacional o protagonismo da geografia traçada pelos fluxos socioeconômicos no processo contínuo de estruturação do território nacional." (IBGE, 2013, p. 5). Entre elas, o Acre se insere integralmente na região articulada por Porto Velho. A pesquisa mais recente, Regic 2018 (IBGE, 2020), confirma essa polaridade. 
pelas cidades de Cáceres, Pontes e Lacerda, e Tangará da Serra; em Rondônia, pelo arranjo populacional internacional de Guajará-Mirim (com Guayaramerín, na Bolívia), Pimenta Bueno, Rolim de Moura e Vilhena. Os centros de zona de Mato Grosso do Sul correspondem a Amambai, Mundo Novo e Rio Brilhante; e, em Mato Grosso, a Barra do Bugres, Mirassol d'Oeste e Sapezal.

Tanto no arco Norte quanto no Central, essas centralidades, mesmo quando classificadas nos patamares intermediários da escala hierárquica, como centros sub-regionais e centros de zona, assumem relevante papel na rede de cidades, devido à rarefação da rede nessas regiōes do Brasil, à grande distância entre os municípios e à precariedade de vias de interligaçáo.

$\mathrm{Na} F F$ no arco Sul, a rede urbana é mais densa que nos demais arcos. Além das capitais regionais já citadas, completam essa rede 34 centros sub-regionais e 41 centros de zona $\mathrm{A},{ }^{32}$ muitos compondo arranjos populacionais internacionais.

Nas oficinas de trabalho, os participantes criticaram o desconhecimento sobre as relações entre centros nas regiōes fronteiriças e o papel dos arranjos transfronteiriços nas articulaçóes da rede de cidades (Pêgo et al., 2017; 2018; 2019; 2020a). Também se desconhece o significado e a importância das cidades conectoras nas relaçóes fronteiriças, sobre o tecido contínuo de relaçóes que se constrói a partir da localização de empresas, de atividades agropecuárias e de mineração, que transpassam os dois lados das fronteiras em área sob influência dessas cidades. Também foi registrado que não há uma articulação regional das cidades que integram a FF, e, na grande maioria, as articulaçôes são individuais, em função de atendimento às demandas locais. Evidenciaram, ainda, que as áreas de fronteira estão pouco integradas aos sistemas metropolitanos, além de que a articulação dos subsistemas urbanos e regionais se diferencia entre os países vizinhos, muitas vezes pela carência de infraestruturas de circulação e mobilidade. Poucos estudos alcançam a variedade dos detalhes que contextualizam a rede urbana sul-americana, e um limitante é a ausência de dados compatíveis metodológica e temporalmente entre os países vizinhos.

\subsubsection{Morfologias de concentração}

A baixa densidade de centralidades expressivas entre os municípios da FF é espelho das escalas de inserção no processo brasileiro de urbanização, nas quais se encontram seus municípios. Tomando em consideração essa classificação, 113 municípios se classificam na escala "em metropolização", correspondendo a 19\% do total de municípios da FF. Outros 92 estão classificados na escala dos "fortemente urbanizado" 
(16\% do total). Quase metade, ou 284 municípios, na classe dos urbanizados (48\% do total) e 97 estão classificados entre os "em transição para o urbano".

Os elementos que fazem a distinção entre cada uma dessas escalas residem fundamentalmente em informaçôes do IBGE sobre grau de urbanização, ocupação majoritária da população e ocorrência de fluxos pendulares da população para estudo e/ou trabalho, além de continuidade de mancha de ocupação. Os municípios classificados na primeira escala, ou seja, no estágio mais avançado da urbanização ou em metropolização, além de apresentarem esses indicadores em grau superior ao patamar máximo considerado, têm um traço peculiar: desenvolvem manchas de ocupação em contiguidade e continuidade com outros municípios. ${ }^{33}$ Entre esses se classificam os arranjos transfronteiriços, que sintetizam os mais elevados graus de urbanização, predominância de ocupação em atividades não agrícolas, desenvolvimento de fluxos pendulares, nesse caso entre municípios de diferentes países, e a configuração de manchas contínuas de ocupação, sobre as quais a linha de fronteira tem completa porosidade, viabilizando as interaçóes e a mobilidade transfronteiriça.

$\mathrm{Na} \mathrm{FF}$ também, estão ausentes áreas de grande concentração de população, encontrando-se apenas médias concentraçóes populacionais (unidades formadas por um ou mais municípios, com população entre 100 mil e 750 mil habitantes), e arranjos populacionais com menos de 100 mil habitantes conforme IBGE (2016; 2020). No arco Norte, segundo IBGE (2016), há apenas duas médias concentraçóes populacionais, representadas por Rio Branco (Acre) e Boa Vista (Roraima); no arco Central, os arranjos populacionais de Porto Velho (Rondônia), Ponta Porã (Mato Grosso) e Corumbá (Mato Grosso do Sul) configuram médias concentraçóes populacionais, com destaque aos dois últimos pela categoria de arranjos populacionais internacionais. No arco Sul, no Paraná, os arranjos populacionais de Cascavel, Toledo, Umuarama e Foz do Iguaçu - este internacional; em Santa Catarina, o arranjo populacional de Chapecó; e no Rio Grande do Sul, os arranjos populacionais de Bagé, Pelotas, Sant'Ana do Livramento e Uruguaiana - os dois últimos, internacionais.

Entre os arranjos populacionais, que representam continuidade de mancha de ocupação ou intensos fluxos de comutação pendular, o maior número é do tipo internacional (IBGE, 2020) ou se situam na linha de fronteira, integrando-se aos arranjos transfronteiriços, que serão objetos de item específico (2.2) desta seção. Entre os não fronteiriços, alguns se estendem transpassando limites estaduais, casos de Nhamundá (Amazonas)-Farol (Pará), Laranjal do Jari (Amapá)-Almeirim (Pará) e Itapiranga (Santa Catarina)-Barra do Guarita (Rio Grande do Sul).

33. Para mais informações sobre a metodologia, a classificação e o perfil dos municípios nas escalas, ver Moura, Oliveira e Pêgo (2018). 
Os demais correspondem a: Jardim-Guia Lopes da Laguna e Aquidauana-Anastácio, ambos em Mato Grosso do Sul; e no arco Sul, Pato Branco-Vitorino (Paraná), São Carlos-Águas de Chapecó (Santa Catarina), e no Rio Grande do Sul, Cerro Largo-Salvador das Missóes, São Gabriel-Santa Margarida do Sul, Santo Ângelo-Entre Ijuís, Taquaruçu do Sul-Vista Alegre e Pedro Osório-Cerrito.

Como observado, a configuração de arranjos populacionais é uma tendência do processo de metropolização. Nas regiôes de fronteiras, é recorrente haver cidades em interação, com expressivos movimentos pendulares da população, fluxos de comutação transfronteiriça e diversidade sociocultural. Formam-se mosaicos urbanos complexos, com papel de intermediação nas redes urbanas dos distintos países, que devem ser compreendidos em sua totalidade. Constata-se, porém, que essas centralidades não são fortalecidas por políticas públicas adequadas às suas demandas e ao seu papel na rede de cidades, como será abordado na sequência.

\subsection{Arranjos transfronteiriços}

\subsubsection{Conceito, identificação e importância}

Há muitas formas de interação entre os povos das fronteiras, desde relaçóes familiares, de compadrio, até relaçóes culturais, sociais e econômicas. Todas se estabelecem na esfera do informal, prescindindo de políticas que incorporem suas especificidades, e, por isso, sofrem limitações. Tais formas de interação transfronteiriça se dão no âmbito dos espaços rurais e urbanos, dos trechos de fronteiras secas ou molhadas, mas é nos arranjos transfronteiriços que adquirem maior visibilidade e enfrentam os maiores conflitos, com as limitaçôes impostas pelas relaçóes cotidianas em um espaço uno, porém cortado por uma linha divisória de fronteira entre países. Esses arranjos são formados por municípios do Brasil e de países vizinhos que, juntos, compóem unidades socioterritoriais, decorrentes de um processo de ocupação com continuidade da mancha edificada (desconsiderando separação por cursos de água) ou sem continuidade de mancha de ocupação, porém com forte articulação e comutação entre si.

É importante iniciar esta seção oferecendo alguns elementos para que se dê clareza ao termo "transfronteiriço", que se refere a uma zona onde convivem povos e culturas, por onde perpassam fluxos e se realizam atividades comuns aos países fronteiriços, criando uma zona híbrida, na qual há uma mesclagem de identidades, e a construção de uma nova identidade. Esta compreensão é trazida de abordagem de Moura e Oliveira (2018, p. 244), em produção autoral no projeto do Ipea, com base na 
concepção em nota de Reitel e Zander (2004), ${ }^{34}$ para quem o adjetivo transfronteiriço traduz travessia, passagem, transgressão, e se aplica aos movimentos e relaçóes no limite político entre dois Estados. Sua noção relaciona-se à condição de proximidade, às relaçóes estabelecidas entre unidades espaciais pertencentes a regióes contíguas, separadas por um limite de Estado. Indo além, um espaço transfronteiriço assume, conforme esse autor, a porosidade da fronteira, o triunfo da abertura sobre o bloqueio, da interação sobre a separação, e do estabelecimento de trocas organizadas ou devidas à existência de diferenciais entre os países, e permite a troca ou a mesclagem de características de um território para outro.

No caso específico dos arranjos espaciais transfronteiriços, ocorre uma configuração bidimensional, que apresenta tanto a dimensão da aglomeração, cidade ou povoado de cada lado da fronteira, quanto a dimensão pela qual perpassam as relaçóes transfronteiriças. São relaçóes que transcendem a dimensão dos municípios autônomos que compóem o arranjo, posto que se estabelecem em um espaço de interaçóes cotidianas que prescindem da linha de fronteira. Dizem respeito às atividades como trabalho e estudo, consumo, uso de serviços e, fundamentalmente, as relações familiares e socioculturais. São relaçóes que se dão entre unidades espaciais contíguas, separadas pelo limite fronteiriço, e que exigem o exercício de funções públicas que, mesmo não integradas, são complementares.

Foram considerados arranjos transfronteiriços tanto os arranjos populacionais fronteiriços (IBGE, 2016) quanto as cidades gêmeas, conforme a Portaria no 213/2016 do Ministério da Integração Nacional - MI (Brasil, 2016). ${ }^{35}$ Essas unidades foram identificadas com base em critérios com distinções, mas que apresentam complementariedade no que se compreende por transfronteiriço. Uma busca em imagens, por meio do Google Earth, de toda a linha de fronteira, e em estudos de caso desenvolvidos no âmbito acadêmico, levou à sugestão da existência de outros arranjos, que merecem ser confirmados a partir de estudos em campo (mapa 12). Esses arranjos têm papel central nas relaçóes entre os países e grande influência sobre os demais municípios da linha de fronteira. ${ }^{36}$

34. Reitel, B.; Zander, P. Espace transfrontalier. Hypergéo, Français Régions et Territoires, 2004. Disponível em: <https:// bit.ly/3m0e03E>. Acesso em: 20 jan. 2020.

35. Para mais informações sobre as metodologias empregadas nessas identificações, além de outras reflexões a respeito, ver Moura e Oliveira (2018).

36. No trabalho consultado se sublinham as dificuldades na obtenção de informações compatíveis ou comparáveis sobre os municípios dos países vizinhos, e a grande dificuldade na análise desses espaços em sua totalidade. 
MAPA 12

Arranjos transfronteiriços e principais conexões com o sistema viário sul-americano Brasil (2019)

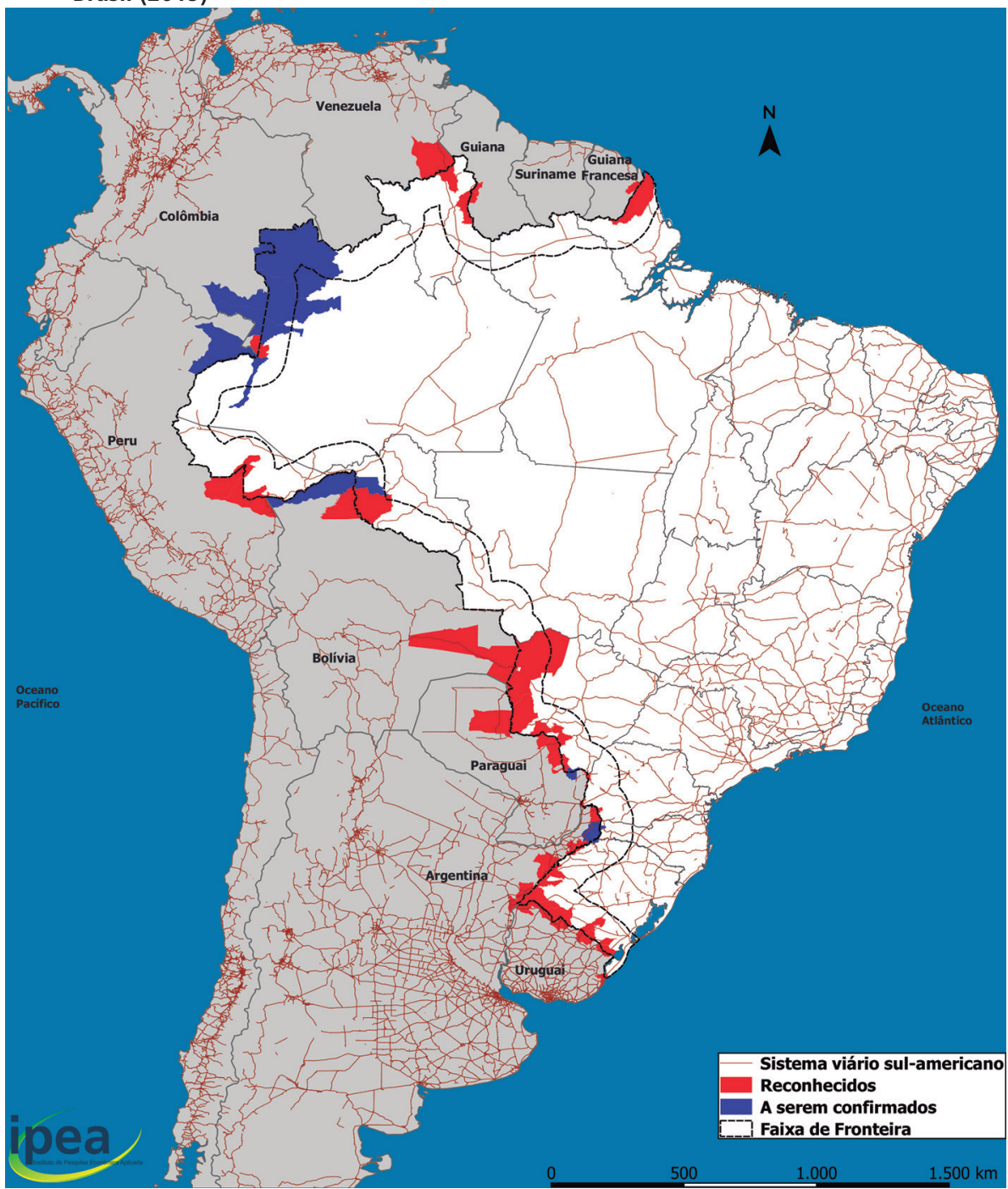

Fontes: IBGE (2016); Brasil (2016b; 2019b); DNIT (2018), disponível em: <https://bit.ly/3kcw2pP>. Acesso em: 20 jan. 2020; e Meijer et al. (2018).

Elaboração: Equipe Fronteiras Ipea.

Há ainda inúmeros arranjos identificados com características similares a esses, indicados a estudos mais detalhados para que se confirmem como transfronteiriços e passem a integrar o elenco das "cidades gêmeas" do MDR. Ressalta-se que em todos foram detectadas relações internacionais com municípios dos países vizinhos, como confirmam informaçóes da pesquisa que integra o estudo Regic 2018 (IBGE, 2020). 
Alguns municípios da linha de fronteira, sem continuidade/contiguidade de ocupação observada, também se relacionam com municípios e povoados de países vizinhos, e são destacados na sequência.

No arco Sul, encontra-se o maior número de arranjos transfronteiriços, identificados a partir de IBGE (2016) e Brasil (2016b), além de possíveis arranjos a serem confirmados com base em estudo com maior nível de detalhe. São dois arranjos compartidos entre os estados de Mato Grosso do Sul-Paraná, e Paraná-Santa Catarina; dois arranjos em fronteira tríplice (Brasil-Paraguai-Argentina, e Brasil-Argentina-Uruguai); e treze arranjos singulares confirmados (quadro 1), além de três possíveis arranjos a serem confirmados e algumas cidades da linha de fronteira com ocorrência de relaçóes internacionais, embora sem uma correspondência contígua no país vizinho (quadro 2).

QUADRO 1

Arco Sul: arranjos transfronteiriços

\begin{tabular}{|c|c|c|c|c|}
\hline UF & Arranjos transfronteiriços & $\begin{array}{l}\text { Número de municípios } \\
\text { (Brasil mais país vizinho) }\end{array}$ & $\begin{array}{l}\text { Arranjos fronteiriços } \\
\text { (IBGE, 2016) }\end{array}$ & $\begin{array}{l}\text { Cidades gêmeas } \\
\text { (portarias Ml, 2016; } \\
\text { e MDR, 2019) }\end{array}$ \\
\hline \multirow{3}{*}{ Paraná } & $\begin{array}{l}\text { Guaíra (PR), Mundo Novo (MS)/Salto del Guairá } \\
\text { (Paraguai) }\end{array}$ & 3 & $\mathrm{x}$ & $x$ \\
\hline & $\begin{array}{l}\text { Foz do Iguaçu, Santa Terezinha de Itaipu' (PR)/Ciudad } \\
\text { del Este, Hernandarias, Minga Guazú, Presidente } \\
\text { Franco (Paraguai)/Puerto Iguazú (Argentina) }\end{array}$ & 7 & $\mathrm{x}$ & $x$ \\
\hline & $\begin{array}{l}\text { Santo Antônio do Sudoeste, Pranchita'/San Antonio } \\
\text { (Argentina) }\end{array}$ & 3 & $x$ & $x$ \\
\hline $\begin{array}{l}\text { Santa } \\
\text { Catarina }\end{array}$ & $\begin{array}{l}\text { Dionísio Cerqueira (SC), Barracão (PR), Bom Jesus } \\
\text { do Sul (PR)/Bernardo de Irigoyen (Argentina) }\end{array}$ & 4 & $x$ & $x$ \\
\hline \multirow{14}{*}{$\begin{array}{l}\text { Rio Grande } \\
\text { do Sul }\end{array}$} & Sant'Ana do Livramento/Rivera (Uruguai) & 2 & $x$ & $x$ \\
\hline & Uruguaiana/Paso de los Libres (Argentina) & 2 & $x$ & $x$ \\
\hline & São Borja/Santo Tomé (Argentina) & 2 & $x$ & $x$ \\
\hline & Quaraí/Artigas (Uruguai) & 2 & $x$ & $x$ \\
\hline & Jaguarão/Rio Branco (Uruguai) & 2 & $\mathrm{x}$ & $x$ \\
\hline & Itaqui/Alvear (Argentina) & 2 & $x$ & $x$ \\
\hline & $\begin{array}{l}\text { Barra do Quaraí/Bella Unión (Uruguai)/Monte } \\
\text { Caseros (Argentina) }\end{array}$ & 3 & $\mathrm{x}$ & $x$ \\
\hline & Chuí/Chuy (Uruguai) & 2 & $x$ & $x$ \\
\hline & Porto Xavier/San Javier (Argentina) & 2 & $x$ & $x$ \\
\hline & Porto Mauá/Alba Posse (Argentina) & 2 & $x$ & $x$ \\
\hline & Garruchos/Azara (Argentina) & 2 & $x$ & - \\
\hline & Porto Vera Cruz/Panambí (Argentina) & 2 & $x$ & - \\
\hline & Aceguá/Aceguá (Uruguai) & 2 & - & $x$ \\
\hline & Total: 17 arranjos & 44 & 16 & 15 \\
\hline
\end{tabular}

Fontes: IBGE (2016); Brasil (2016b; 2019b).

Elaboração: Equipe Fronteiras Ipea.

Notas: ' Santa Terezinha do Itaipu e Pranchita são apontadas pelo IBGE como integrantes de arranjos fronteiriços, mas não se inserem na relação do MDR.

${ }^{2}$ Aceguá faz parte do arranjo populacional de Bagé e Candiota, não considerado pelo IBGE como arranjo populacional internacional, porém desenvolve mancha de ocupação contínua com Acegua (Uruguai) e relações transfronteiriças com Villa Isidoro Noblía (Uruguai) confirmadas pela base de dados do Regic 2018 (IBGE, 2020). 
QUADRO 2

Arco Sul: cidades e respectivos povoados fronteiriços, com ou sem correspondentes no país vizinho

\begin{tabular}{|l|l|c|c|c|}
\hline UF & \multicolumn{1}{|c|}{ Município } & Povoado no município & $\begin{array}{c}\text { Localidade correspon- } \\
\text { dente }\end{array}$ & País fronteiriço \\
\hline \multicolumn{2}{|c|}{ Arranjos transfronteiriços a serem confirmados em estudos } \\
\hline Paraná & Capanema & - & Andrezito & Argentina \\
\hline Santa Catarina & Paraíso & - & San Pedro & Argentina \\
\hline Rio Grande do Sul & Tiradentes do Sul & Porto Soberbo & El Soberbo & Argentina \\
\hline \multirow{2}{|c|}{ Cidade ou povoado sem correspondência identificada } & Argentina \\
\hline
\end{tabular}

Fontes: Machado (2005); Moura e Oliveira (2018); IBGE (2020).

Elaboração: Equipe Fronteiras Ipea.

Obs.: Algumas cidades do Paraná, lindeiras ao lago de Itaipu, mantêm relações com cidades do Paraguai (como São Miguel do Iguaçu, Pato Bragado, Santa Helena e Serranópolis do Iguaçu; alguns municípios do Rio Grande do Sul, na fronteira com a Argentina, como Alecrim, Doutor Mauricio Cardoso, Herval, Novo Machado, juntamente com os arranjos transfronteiriços já identificados compõem uma rede de cidades com fluxos de relações internacionais entre ambos os lados da fronteira (IBGE, 2020).

No arco Central, além do arranjo já incluído por compartilhamento com o Paraná, no arco Sul, há oito arranjos transfronteiriços singulares, nenhum trifronteiriço (quadro 3), e dois a serem estudados, além de importantes cidades da linha de fronteira com ocorrência de relações internacionais, embora sem uma correspondência contígua observada no país vizinho (quadro 4).

QUADRO 3

Arco Central: arranjos transfronteiriços

\begin{tabular}{|c|c|c|c|c|}
\hline UF & Arranjos transfronteiriços & $\begin{array}{l}\text { Número de } \\
\text { municípios } \\
\text { (Brasil mais } \\
\text { país vizinho) }\end{array}$ & $\begin{array}{c}\text { Arranjos } \\
\text { fronteiriços } \\
\text { (IBGE, 2016) }\end{array}$ & $\begin{array}{c}\text { Cidades gêmeas } \\
\text { (portarias Ml, } \\
\text { 2016; e MDR, } \\
\text { 2019) }\end{array}$ \\
\hline Rondônia & Guajará-Mirim/Guayaramerín (Bolívia) & 2 & $x$ & $x$ \\
\hline Mato Grosso & Cáceres/San Matías (Bolívia) & 2 & - & $x$ \\
\hline \multirow{7}{*}{$\begin{array}{l}\text { Mato Grosso } \\
\text { do Sul }\end{array}$} & Ponta Porã/Pedro Juan Caballero, Zanja Pytá (Paraguai)'1 & 3 & $x$ & $x$ \\
\hline & Corumbá, Ladário/Puerto Quijarro, Puerto Suarez (Bolívia) & 4 & $x$ & $x$ \\
\hline & Bela Vista/Bella Vista del Norte (Paraguai) & 2 & $x$ & $x$ \\
\hline & Coronel Sapucaia/Capitán Bado (Paraguai) & 2 & $x$ & $x$ \\
\hline & Paranhos/Ypejhú (Paraguai) & 2 & $x$ & $x$ \\
\hline & Porto Murtinho/Pto. Palma Chica (Carmelo Peralta) (Paraguai) & 2 & - & $x$ \\
\hline & Total: 8 arranjos & 19 & 6 & 8 \\
\hline
\end{tabular}

Fontes: IBGE (2016; 2020); Brasil (2016b; 2019b).

Elaboração: Equipe Fronteiras Ipea.

Nota: ' Zanja Pytá, desmembrado de Pedro Juan Caballero em 2012, compõe mancha de ocupação contínua com Sanga Puitã, distrito de Ponta Porã. 
QUADRO 4

Arco Central: cidades e respectivos povoados fronteiriços, com ou sem correspondentes no país vizinho

\begin{tabular}{|c|c|c|c|c|}
\hline \multirow[t]{2}{*}{ UF } & Município & $\begin{array}{l}\text { Povoado no } \\
\text { município }\end{array}$ & $\begin{array}{l}\text { Localidade } \\
\text { correspondente }\end{array}$ & País fronteiriço \\
\hline & \multicolumn{4}{|c|}{ Arranjos transfronteiriços a serem confirmados em estudos } \\
\hline Rondônia & Nova Mamoré & - & Villa Bella & Bolívia \\
\hline \multirow[t]{2}{*}{ Mato Grosso do Sul } & Sete Quedas & - & Pindoty Porã & Paraguai \\
\hline & \multicolumn{4}{|c|}{ Cidade ou povoado sem correspondência identificada } \\
\hline \multirow{2}{*}{ Rondônia } & Costa Marques & - & - & Bolívia \\
\hline & Pimenteiras do Oeste & - & - & Bolívia \\
\hline Mato Grosso do Sul & Aral Moreira & - & - & Paraguai \\
\hline
\end{tabular}

Fontes: Machado (2005); Moura e Oliveira (2018); IBGE (2020).

Elaboração: Equipe Fronteiras Ipea.

$\mathrm{O}$ arco Norte possui sete arranjos identificados, sendo dois trifronteiriços (Brasil-Colômbia-Peru, e Brasil-Peru-Bolívia) e cinco arranjos singulares (quadro 5). É o que possui o maior número de possíveis arranjos recomendados a estudos, com um total de sete (quadro 6). É também o arco onde cidades da linha de fronteira tornam-se importantes elos de relaçôes internacionais, nem sempre tendo uma cidade ou povoado com correspondência contígua observada no país vizinho.

QUADRO 5

Arco Norte: arranjos transfronteiriços

\begin{tabular}{|c|c|c|c|c|}
\hline UF & Arranjos transfronteiriços & $\begin{array}{l}\text { Número de municípios } \\
\text { (Brasil mais país vizinho) }\end{array}$ & $\begin{array}{l}\text { Arranjos fronteiriços } \\
\text { (IBGE, 2016) }\end{array}$ & $\begin{array}{l}\text { Cidades gêmeas } \\
\text { (portarias MI, 2016; } \\
\text { e MDR, 2019) }\end{array}$ \\
\hline \multirow{3}{*}{ Acre } & $\begin{array}{l}\text { Brasiléia, Epitaciolândia /Cobija } \\
\text { (Bolívia) }\end{array}$ & 3 & $x$ & $x$ \\
\hline & $\begin{array}{l}\text { Assis Brasil /Bolpebra (Bolívia)/ } \\
\text { Iñapari (Peru) }\end{array}$ & 3 & $x$ & $\mathrm{x}$ \\
\hline & $\begin{array}{l}\text { Santa Rosa do Purus/Puerto } \\
\text { Esperanza (Peru) }\end{array}$ & 2 & - & $x$ \\
\hline Amapá & $\begin{array}{l}\text { Oiapoque/St. Georges (Guiana } \\
\text { Francesa) }\end{array}$ & 2 & $x$ & $\mathrm{x}$ \\
\hline Amazonas & $\begin{array}{l}\text { Tabatinga/Letícia (Colômbia)/ } \\
\text { Santa Rosa (ilha) (Peru) }\end{array}$ & 3 & $\mathrm{x}$ & $x$ \\
\hline \multirow{3}{*}{ Roraima } & Bonfim/Lethem (Guiana) & 2 & $x$ & $x$ \\
\hline & $\begin{array}{l}\text { Pacaraima/Santa Elena de Uairén } \\
\text { (Venezuela) }\end{array}$ & 2 & - & $x$ \\
\hline & Total: 7 arranjos & 17 & 5 & 7 \\
\hline
\end{tabular}

Fontes: IBGE (2016); Brasil (2016b; 2019b).

Elaboração: Equipe Fronteiras Ipea. 
QUADRO 6

Arco Norte: cidades e respectivos povoados fronteiriços, com ou sem correspondentes no país vizinho

\begin{tabular}{|c|c|c|c|c|}
\hline \multirow{2}{*}{ UF } & Município & Povoado no município & Localidade correspondente & País fronteiriço \\
\hline & \multicolumn{4}{|c|}{ Arranjos transfronteiriços a serem confirmados em estudos (11) } \\
\hline \multirow{2}{*}{ Acre } & Capixaba & Vila Amapá & Villa Bela & Bolívia \\
\hline & Plácido de Castro & - & Villa Evo Morales & Bolívia \\
\hline \multirow{6}{*}{ Amazonas } & Benjamin Constant & - & Islandia & Peru \\
\hline & \multirow{2}{*}{ São Gabriel da Cachoeira } & lauretê & Yavarate & Colômbia \\
\hline & & Cucui & San Carlos de Río Negro & Venezuela \\
\hline & Japurá & Vila Bittencourt & La Pedrera & Colômbia \\
\hline & Santo Antônio do Içá & Ipiranga & Tarapaca & Colômbia \\
\hline & \multicolumn{4}{|c|}{ Cidade ou povoado sem correspondência identificada (9) } \\
\hline Acre & Acrelândia & - & - & Bolívia \\
\hline Amazonas & Atalaia do Norte & - & - & Peru \\
\hline Roraima & Normandia & - & - & Guiana \\
\hline
\end{tabular}

Fontes: Machado (2005); Moura e Oliveira (2018); IBGE (2020).

Elaboração: Equipe Fronteiras Ipea.

Pela unidade formada por municípios de mais de um país, esses arranjos exigem políticas e intervençôes específicas ao meio urbano aglomerado, no qual há um grande número de funçôes públicas de interesse comum, como é o caso fundamentalmente do transporte urbano de passageiros, que garante a mobilidade e a conectividade cotidiana entre as partes do arranjo; o uso do solo, que deve ser disciplinado considerando-se a existência de mancha contínua de ocupação; e o saneamento básico e gestão ambiental, cuja demarcação de fronteira não tem poder de influir em processos naturais. Não menos importantes, alinham-se a esses a gestão da educação, atenção à saúde, oferta de moradia, assistência social, relaçóes de trabalho, atividades esportivas e culturais, segurança. Nenhuma ganha eficácia se não compartilhada pelos municípios, estados e países sobre os quais incidem os arranjos transfronteiriços. Se a gestão dessas funçóes é bastante complexa entre municípios brasileiros, como se verifica nas regióes metropolitanas e aglomeraçóes urbanas, ao implicarem municípios de distintos países, o grau de complexidade se torna ainda maior.

Os arranjos transfronteiriços podem ser considerados os principais portais de entrada/saída da fronteira terrestre brasileira. Mas não apenas eles merecem atenção. Há um conjunto de pequenas cidades ou povoados da linha de fronteira que, embora não configurem arranjo espacial com cidade ou povoado do lado de lá, também funcionam como portais para esses fluxos. No arco Norte, Acrelândia 
(Acre), Atalaia do Norte (Amazonas), São Gabriel da Cachoeira-Cucui (Amazonas) e Normandia (Roraima) têm importância nas relaçôes fronteiriças, embora não encontrem correspondência contígua observada nos países vizinhos, respectivamente Bolívia, Peru, Venezuela e Guiana. No arco Central, são duas cidades de Rondônia, Costa Marques e Pimenteiras do Oeste, na fronteira com a Bolívia; e em Mato Grosso do Sul, Aral Moreira, na fronteira com o Paraguai. Na fronteira do Rio Grande do Sul com a Argentina, na mesma situaçáo de cidade fronteiriça sem correspondência imediata no país vizinho, apontam-se Porto Lucena e Esperança do Sul. No entanto, a análise das relaçóes internacionais realizada pela pesquisa Regic 2018 (IBGE, 2020) aponta um feixe de buscas de cidades da Argentina a municípios sul-rio-grandenses, como Alecrim, Doutor Mauricio Cardoso, Herval, Novo Machado que, juntamente com os arranjos transfronteiriços já identificados, compóem uma rede de relaçôes internacionais entre os dois lados da fronteira. No Paraná também se verificam relações entre cidades situadas às margens do lago de Itaipu, como Sáo Miguel do Iguaçu, Pato Bragado, Santa Helena e Serranópolis do Iguaçu, com cidades do Paraguai.

Postos em discussão, os participantes das atividades nos arcos ressaltaram a importância dos arranjos transfronteiriços como focos irradiadores na implementação de políticas públicas e na construção de alternativas que representem os vários segmentos da sociedade local. Porém, falta compreender a natureza das relaçóes transfronteiriças, para que as políticas para fronteiras incorporem essa dinâmica real de tais espaços (Pêgo et al., 2017; 2018; 2019; 2020a; 2020b). Também se salientou a importância de distinguir os níveis de complexidade dos arranjos transfronteiriços, seja pela morfologia das manchas de ocupação, densidade, tamanho populacional, distância entre as centralidades da aglomeração que configuram, ou pela combinação entre esses elementos. Conforme o nível de complexidade, deveriam ir sendo agregados elementos para políticas públicas, dado que a complexidade se manifesta nas áreas de educação, saúde, assistência social, mobilidade urbana, entre outras (Pêgo et al., 2019).

Muito se discutiu o desafio da gestáo de funçóes públicas de interesse comum e do atendimento a direitos sociais no que pode ser entendido como um vácuo do espaço transfronteiriço. Alguns casos exemplificam a necessidade de políticas mais efetivas e específicas à natureza dos arranjos transfronteiriços, tais como: i) o atendimento à saúde carece de portaria ministerial específica para os hospitais em área de fronteira; ii) os direitos de pais de filhos nascidos em outro país, por falta de atendimento no município brasileiro, ficam prejudicados pela dificuldade do registro do nascimento; iii) o benefício social de ação continuada só é garantido em território brasileiro, privando brasileiros que, por motivos familiares, residem do lado internacional dos arranjos; e iv) a dificuldade do traslado de corpos para 
sepultamento (Pêgo et al., 2017; 2018; 2019; 2020a; 2020b). Embora exista a possibilidade, é necessário viabilizar a carteira de identidade fronteiriça/tarjeta vicinal fronteriça, visando facilitar a circulação de pessoas, realização de negócios e desenvolvimento de atividades (Pêgo et al., 2020a).

Diferenças nas legislaçôes municipais, nas capacidades técnicas das equipes das prefeituras e nos padróes operacionais, falta de convergência entre planos diretores urbanos, além de assimetrias na capacidade econômica e especificidades dos elementos culturais, aumentam os problemas da gestão urbana nas cidades fronteiriças. Ademais, a legislação de cooperação para esses arranjos transfronteiriços tem conteúdos quase que somente internacionais, relegando o território local e suas peculiaridades, ocorrendo, por vezes, uma dualidade entre as políticas internacionais e as políticas locais, devido à sua incidência (Pêgo et al., 2017).

A gestão urbana se enquadra entre os problemas da fronteira no arco Norte, onde se apontou a inexistência do planejamento integrado das áreas urbanas nesses arranjos, de regulação urbanística e de sistema de governança compartida. Apontou-se, também, a falta de uma maior aproximaçáo nos órgáos de planejamento e administração entre as cidades vizinhas para adoção de medidas e agendas conjuntas. O município de Pacaraima (Roraima) se destacou como exemplo na concentraçáo de problemas que dificultam a gestão urbana, pelo fato de que a sede municipal se encontra dentro de uma terra indígena. Mesmo assim, o município vinha oferecendo minimamente transporte de estudantes, vagas em escolas locais, acolhimento em postos de saúde e assistência social, com base em acordo verbal entre as prefeituras. Com a crise provocada pelo afluxo de migrantes venezuelanos, esses problemas se agravaram (Pêgo et al., 2018).

Nos arranjos transfronteiriços do arco Central, como nos demais, são comuns as diferenças de valor das tarifas de serviços (telefonia, internet) entre o Brasil e os demais países, considerados serviços internacionais, além da prática de preços diferenciados a brasileiros para abastecimento de combustível, entre outras questôes. Ocorrem, também, os conflitos na prestação de serviços, particularmente de transporte público e individual, além de disputas pelos equipamentos urbanos. Há problemas fundiários, seja em assentamentos urbanos que ocupam os dois lados da fronteira (Brasil-Bolívia), gerando insegurança jurídica aos assentados, seja em disputas por estrangeiros de grandes porçôes de terras na região da fronteira Brasil-Paraguai, para exploração da agricultura moderna, com desmatamentos ilegais e desalojamentos de camponeses e povos de etnias diversas para a ampliação da área de grãos de produtores brasileiros. Para muitos, o isolamento geográfico, econômico e social desse espaço em relação à própria nação, e a ausência de políticas e mecanismos adequados de gestão, promovem uma espécie de "aliança pragmática" ou paradiplomacia entre os municípios fronteiriços (Pêgo et al., 2019; 2020b). 
Complementam os participantes do arco Sul que administrar espaços contínuos como unidades quase sempre se esbarra em bloqueios burocráticos, mas há esforços para que isso ocorra - como exemplo, citaram a preservação da flora e da fauna no lado brasileiro desse arco (Pêgo et al., 2020a).

Os arranjos transfronteiriços são também portais de passagem de fluxos migratórios internacionais dos países vizinhos ou procedentes de longa distância. No Amapá, há fluxo migratório de haitianos via Oiapoque à Guiana Francesa. Os arranjos de Roraima, particularmente Pacaraima, estão vivendo um período de intenso afluxo de imigrantes venezuelanos. Tabatinga é a porta de entrada para transfronteiriços peruanos e colombianos com destino a Manaus e outras cidades da Amazônia brasileira, e também para haitianos. Os arranjos do Acre são portais para a entrada sistemática de migrantes provenientes do Haiti, do Senegal e da República Dominicana, com destino ao abrigo institucional em Rio Branco, de onde seguem seus destinos, majoritariamente para o Sudeste e o Sul do país (Pêgo et al., 2018; Moreira, 2018). No arco Central, Corumbá se destaca como um dos principais acessos para povos de vários países sul e centro-americanos, constituindo-se particularmente em um corredor de passagem de bolivianos com destino a São Paulo (Pêgo et al., 2019). No arco Sul, Uruguaiana é portal para a entrada de imigrantes africanos (senegaleses, ganeses, nigerianos), haitianos e chineses, que se dirigem a Sáo Paulo e Rio de Janeiro. Por Foz do Iguaçu passam haitianos, libaneses e chineses, entre os quais, com exceção dos primeiros, muitos integram colônias locais nessa cidade e em Ciudad del Este (Pêgo et al., 2020a).

\subsubsection{Mobilidade transfronteiriça cotidiana}

Em seção anterior, item 1.2.2, foram abordados os movimentos pendulares da população para estudo e/ou trabalho em outro município que não o da residência, e dimensionados seus fluxos. Destaca-se que, em 2010, entre os municípios da FF, os arranjos transfronteiriços respondiam pelo maior número de fluxos de saída com destino internacional. No caso desses deslocamentos internacionais, os dados do IBGE registram apenas as saídas do Brasil para municípios de outros países, o que inviabiliza a mensuração das entradas.

Em catorze municípios, mais de $20 \%$ dos deslocamentos pendulares para estudo destinavam-se a outro país, chegando a superar $50 \%$ das pessoas que trabalhavam e/ou estudavam em outro município, como em Chuí e Sant'Ana do Livramento (Rio Grande do Sul) e Tabatinga (Amazonas). Nos arranjos transfronteiriços, parcela expressiva dos estudantes sai para cursar as etapas infantil e fundamental da educação básica, enquanto em outras porções do território nacional os deslocamentos internacionais para estudo estão mais associados ao nível superior de ensino (graduação e pós-graduação). 
No caso dos deslocamentos para trabalho, a quase totalidade dirigia-se para países da América do Sul: o Paraguai recebia quase dois terços destes fluxos, provenientes de oito arranjos transfronteiriços, com destaque para os polarizados por Foz do Iguaçu e Ponta Porá; o Uruguai recebia 18,9\%, articulando sete arranjos, entre os quais se sobressai o de Sant'Ana do Livramento, seguido pelo de Chuí.

Neste final de década, o relatório do Observatório das Migraçóes Internacionais confirma a importância desses movimentos, quando localiza os países beneficiados com registros para fronteiriços. ${ }^{37}$ Em relação à maior parte dos países vizinhos essa mobilidade se intensificou na década, porém, para os bolivianos e colombianos, na década anterior ocorreram registros superiores. O relatório aponta que os "uruguaios responderam por 75,9\% dos registros para fronteiriços, seguidos por paraguaios com 17,0\%. A participação dos demais vizinhos foi bastante residual" (Cavalcanti et al., 2019).

Além dos números, foi ampliado o leque das motivaçóes das saídas e das entradas nesses movimentos transfronteiriços e agudizada a problemática que as pessoas enfrentam nesses fluxos. Para essa reflexão, mais uma vez valeu-se aqui das participaçóes dos fronteiriços nas atividades desenvolvidas nos arcos Norte, Central e Sul do projeto em curso e das visitas aos arranjos transfronteiriços realizadas pela equipe Ipea. ${ }^{38}$ Valeu-se, também, de resultados da pesquisa de campo "Municípios de fronteira: mobilidade transfronteiriça, migração, vulnerabilidades e inserção laboral" (Brasil, 2016a), ${ }^{39}$ e das informaçōes sobre ligaçôes entre centros da pesquisa Regic 2018 (IBGE, 2020), assim como de alguns estudos de caso específicos, devidamente anotados.

Sublinham-se algumas importantes consideraçôes que mostram as especificidades das migrações internacionais e outros deslocamentos fronteiriços, pois:

37. Informaç̧ões sobre imigração podem ser vistas, também, no Portal da Imigração do Ministério da Justiça e Segurança Pública. Disponível em: <https://bit.ly/3d4PeG7>. Acesso em: 26 fev. 2020.

38. Os arranjos transfronteiriços visitados pela equipe foram: Bonfim (Roraima)-Lethem (Guiana); Pacaraima (Roraima)-Santa Elena de Uairén (Venezuela); Cáceres (Mato Grosso)-San Matías (Bolívia); Corumbá-Ladário (Mato Grosso do Sul)-Puerto Quijarro-Puerto Suárez (Bolívia); Uruguaiana (Rio Grande do Sul)- Paso de los Libres (Argentina); e Barra do Quaraí (Rio Grande do Sul)-Bella Unión (Uruguai)-Monte Caseros (Argentina). Além desses, membros da equipe visitaram os arranjos Ponta Porã (Mato Grosso do Sul)-Pedro Juan Caballero; e Foz do Iguaçu (Paraná)-Santa Terezinha de Itaipu (PR)-Ciudad del Este, Hernandarias, Minga Guazú, Presidente Franco (Paraguai)-Puerto Iguazú (Argentina). 39. Realizada no âmbito do projeto do Ministério da Justiça e Cidadania "MT Brasil: Migrações transfronteiriças (Brasil, 2016a). Fortalecendo a capacidade do governo federal para gerenciar novos fluxos migratórios". 
para além do ato de cruzar fronteiras internacionais, são processos que inevitavelmente colocam os seus sujeitos em contato com outras realidades sociais, permeando ou criando barreiras, produzindo ou repulsando trocas culturais. Entretanto, a migração fronteiriça ou transfronteiriça não é sempre um processo de migração tradicional, posto que duas características importantes inexistem, que seriam o animus de sair por determinado tempo, e de fixar residência em outro país. O "fronteiriço" se desloca e retorna, mantendo relaçóes e atividades em ambos os lados da fronteira, como os deslocamentos populacionais nas zonas de fronteiras entre países vizinhos. No limite, são processos migratórios temporários, cujos sujeitos são pessoas ou grupos que ultrapassam as fronteiras, diária, cíclica ou sazonalmente por razóes de trabalho. Neste caso, seria melhor inclusive falar em mobilidade humana, não necessariamente em migração dada ausência de alguns elementos, como o animus de ficar (Brasil, 2016a, p. 50).

Esse ir e vir cotidiano ou esporádico adquire especificidades em cada arco, e no próprio interior deles, pois tem relaçóes diretas com a natureza das interaçóes que se dão com cada país vizinho. Inicia-se a análise dessas especificidades a partir das informaçóes da pesquisa Regic 2018, as quais permitem observar que, das ligaçóes internacionais computadas, quinze podem ser consideradas de longa distância e 211 descrevem fluxos de curta distância. Somadas, apontam para 226 ligaçóes internacionais. Os fluxos direcionados a cidades da FF representam majoritariamente contatos de curta distância (mapa 13), poucas vezes incluindo municípios localizados mais distantes na linha de fronteira. Os fluxos de longa distância, nem sempre destinados a cidades da linha de fronteira, registram uma única finalidade no destino, entre três motivaçóes, i) seja a busca por ensino superior (ligaçóes entre com Bogotá, Caracas, Lima, Tacna e Quito e municípios do Rio Grande do Sul); ii) atividades esportivas (Lima, Quito e Santa Cruz de la Sierra, também a esses municípios brasileiros, além daqueles entre Medellín e Chapecó (SC); e iii) atividades culturais, na ligação entre Buenos Aires e Corumbá (MS). ${ }^{40}$

40. Segundo o IBGE (2020), no caso da primeira motivação, os deslocamentos ocorrem em virtude de convênios com bolsas de graduação e pós-graduação destinados a alunos de países sul-americanos, como também a refugiados venezuelanos, da Úniversidade Federal de Pelotas (Ufpel). A motivação de esportes se deve a um torneio internacional anual infantil de futebol, realizado por Alegrete (RS), e no caso de Chapecó, existência de partidas internacionais. 


\section{MAPA 13}

Ligações internacionais com destino a municípios da FFT - América do Sul (2018)

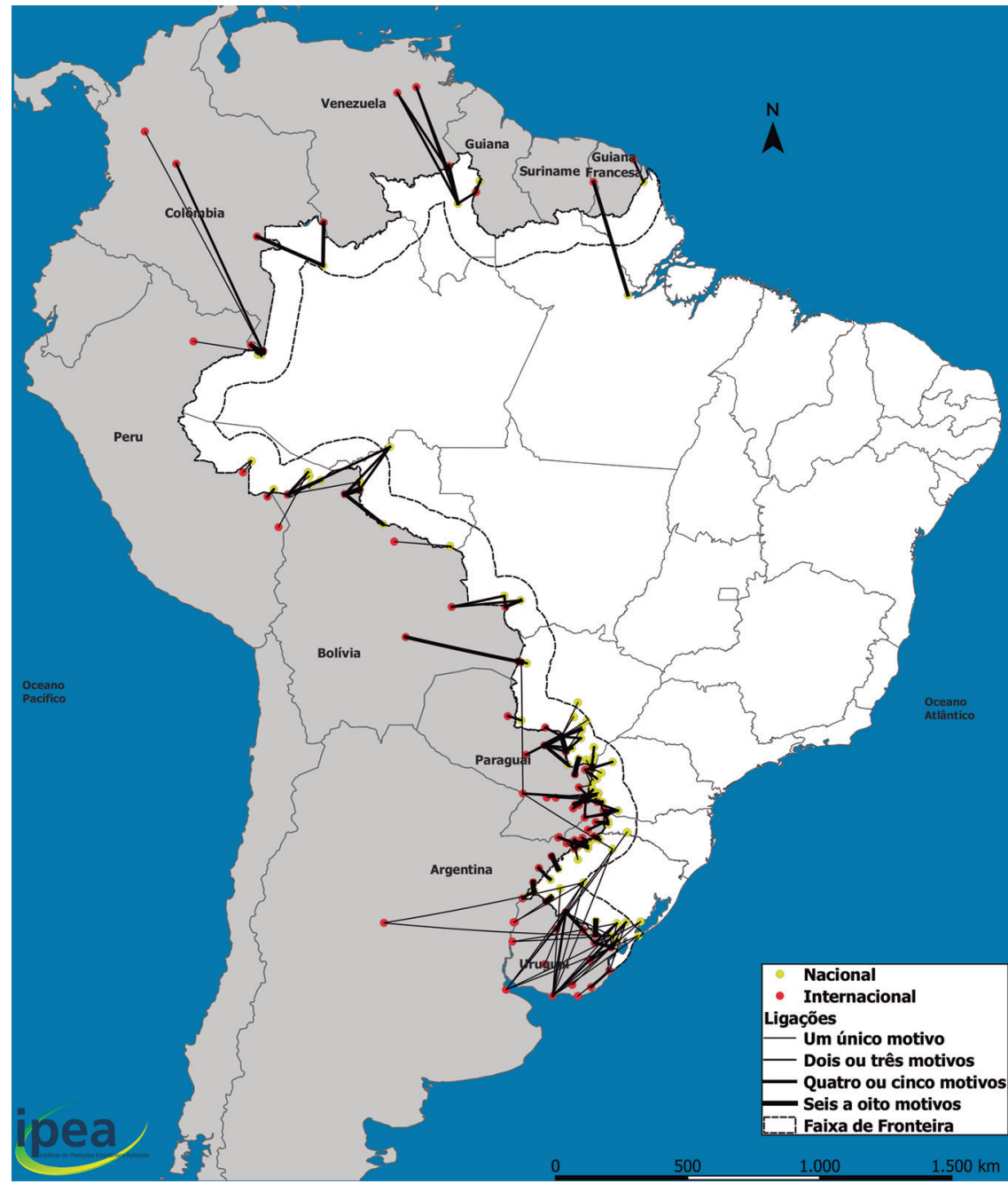

Fonte: IBGE (2020).

Elaboração: Equipe Fronteiras Ipea.

Obs.: Não foram mapeadas as ligações de longa distância entre: Bogotá-Capão do Leão, Pelotas; Buenos Aires-Corumbá; Caracas-Capão do Leão, Pelotas; Lima-Alegrete, Capão do Leão, Pelotas, Rio Grande; Medellín-Chapecó; Quito-Alegrete, Capão do Leão, Pelotas; Santa Cruz de la Sierra-Alegrete; Tacna-Santana do Livramento.

Tendo em consideração os 563 fluxos detectados nas 226 ligações entre cidades dos países vizinhos e cidades brasileiras, sejam de curta ou longa distância, as atividades culturais são as principais motivaçóes, estando presente em $125 \mathrm{flu}$ xos (22,2\% do total dos fluxos), sejam por atividades rotineiras de proximidade, comuns nos arranjos transfronteiriços, sejam pela realização de festivais e eventos em cidades mais distantes da linha de fronteira (tabela 13). 


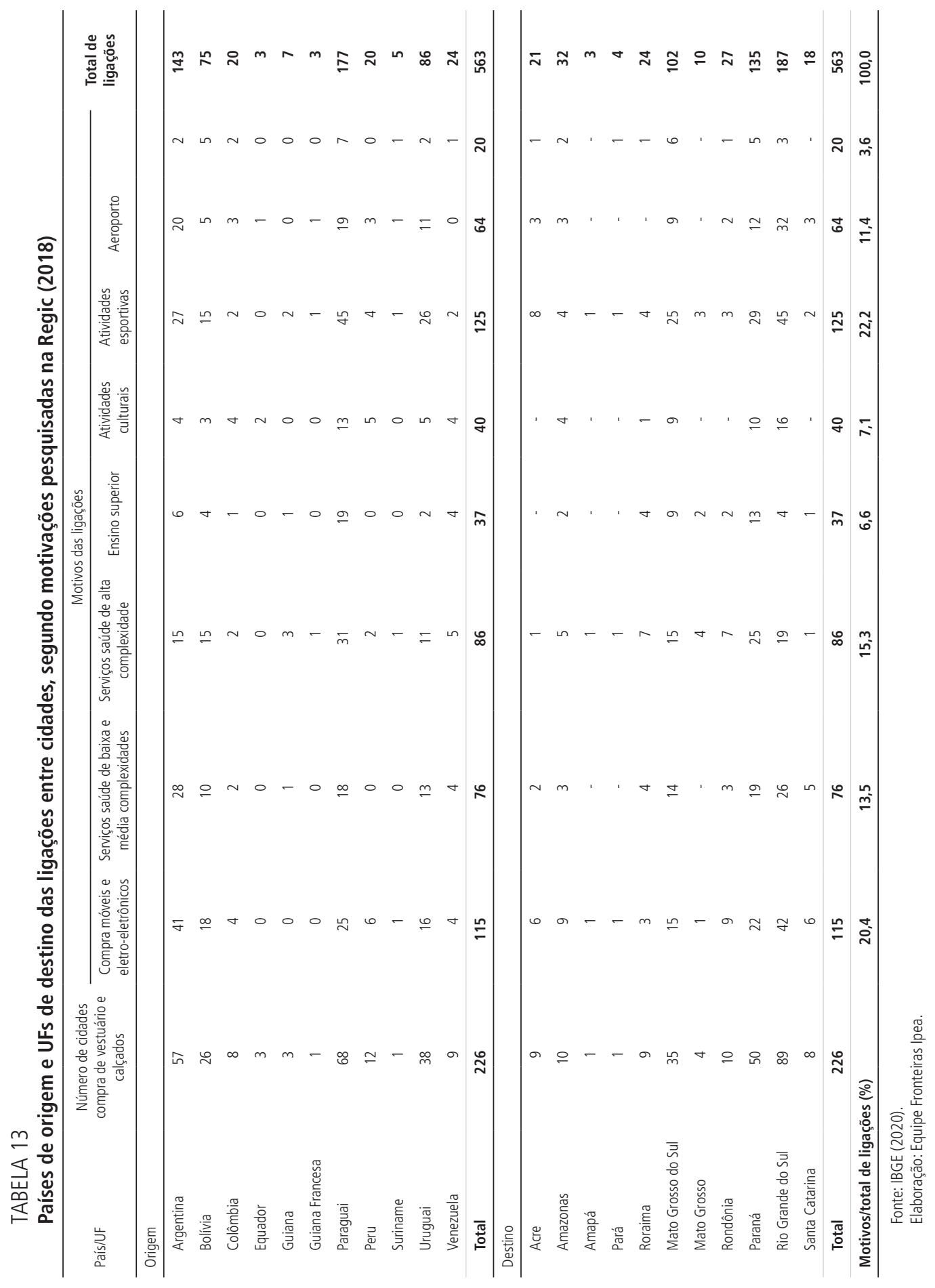


O segundo motivo mais referenciado é compra de vestuário ou calçados, motivo de 115 fluxos $(20,4 \%)$ e o terceiro, a busca por serviços de saúde de baixa e média complexidade, em 86 fluxos (15,3\%). No caso da saúde, o atrativo está na oferta pública universalizada no Brasil, enquanto nos países vizinhos a atenção primária se encontra privatizada.

As cidades de destino com o maior número de cidades de origem das ligaçóes internacionais e o maior elenco de motivos para deslocamentos vindos do estrangeiro correspondem a arranjos populacionais internacionais, com destaque a Foz do Iguaçu (Paraná) e Ponta Porã (Mato Grosso do Sul), com o maior número de municípios de origem e de motivos, seguidos por Corumbá (Mato Grosso do Sul) e Guajará-Mirim (Rondônia). Paraguai e Argentina são os países com os maiores números de cidades (68 e 57 respectivamente) que realizam ligaçóes com cidades brasileiras (quadro 7). Vềm seguidos por Uruguai e Bolívia. Rio Grande do Sul é o estado com o número mais elevado de cidades com atratividade internacional na FF (89 cidades). Paraná e Mato Grosso do Sul vêm na sequência, com respectivamente 50 e 35 cidades.

QUADRO 7

Países e número de cidades de origem e UFs e número de cidades de destino das ligações internacionais

\begin{tabular}{|l|c|c|c|}
\hline País de origem & Número de cidades & Estado de destino no Brasil & Número de cidades \\
\hline Paraguai & 68 & Rio Grande do Sul & 89 \\
\hline Argentina & 57 & Paraná & 50 \\
\hline Uruguai & 38 & Mato Grosso do Sul & 10 \\
\hline Bolívia & 26 & Amazonas & 10 \\
\hline Peru & 12 & Rondônia & 9 \\
\hline Venezuela & 9 & Acre & 9 \\
\hline Colômbia & 8 & Roraima & 8 \\
\hline Equador & 3 & Santa Catarina & 4 \\
\hline Guiana & 3 & Mato Grosso & 1 \\
\hline Guiana Francesa & 1 & Amapá & 1 \\
\hline Suriname & 1 & Pará & $\mathbf{2 2 6}$ \\
\hline Total & $\mathbf{2 2 6}$ & Total & 9 \\
\hline
\end{tabular}

Fonte: IBGE (2020).

Elaboração: Equipe Fronteiras Ipea.

As demais fontes tomadas como referência mostram mais essas especificidades. No arco Norte, a mobilidade da populaçáo, particularmente nos arranjos transfronteiriços, em grande parte se trata de um movimento informal, mas que alimenta um mercado de trabalho importante para as populaçóes dedicadas a 
atividades extrativas ou atividades tipicamente urbanas. Peculiar ao arco são os deslocamentos para atividades no garimpo, particularmente na Guiana Francesa, Suriname e Venezuela, em muitos casos garimpo ilegal, e atividades ligadas a ele, assim como para a busca de combustível na Venezuela (quadro 8). Tal mobilidade oferece oportunidade de trocas e interaçóes que ativam dinâmicas territoriais as quais devem ser pensadas no âmbito transfronteiriço (Pêgo et al., 2018; Brasil, 2016a).

QUADRO 8

Arco Norte: motivações específicas da mobilidade transfronteiriça

\begin{tabular}{|c|c|c|c|}
\hline \multicolumn{3}{|c|}{ Motivações por cidade do arranjo } & \multirow{2}{*}{$\begin{array}{c}\text { Controle transfronteiriço } \\
-\end{array}$} \\
\hline Oiapoque (AP) & St. Georges (Guiana Francesa) & - & \\
\hline $\begin{array}{l}\text { Serviços de hospedagem e alimen- } \\
\text { tação, comércio local }\end{array}$ & $\begin{array}{l}\text { Comércio de importados, trabalho nos } \\
\text { garimpos, construção civil, serviços } \\
\text { domésticos (mulheres), atividades } \\
\text { informais na agricultura }\end{array}$ & - & $\begin{array}{l}\text { A entrada na Guiana Francesa } \\
\text { é muito controlada; circulação } \\
\text { livre em poucos quarteirões } \\
\text { próximos à fronteira. }\end{array}$ \\
\hline Bonfim (RR) & Lethem (Guiana) & - & - \\
\hline $\begin{array}{l}\text { Serviços de saúde e de educação } \\
\text { fundamental, trabalho não qualificado } \\
\text { (informal) }\end{array}$ & $\begin{array}{l}\text { Trabalho em atividades do comércio e } \\
\text { garimpo (Guiana e Suriname), consumo } \\
\text { de importados }\end{array}$ & - & Circulação sem controle \\
\hline Pacaraima (RR) & Santa Elena de Uairén (Venezuela) & - & - \\
\hline $\begin{array}{l}\text { Serviços de saúde e de educação } \\
\text { fundamental, consumo no varejo, } \\
\text { trabalho informal }\end{array}$ & $\begin{array}{l}\text { Comércio de importados, combustível, } \\
\text { saúde privada (odontologia, oftalmologia } \\
\text { e estética), turismo (Monte Roraima e } \\
\text { litoral caribenho), trabalho informal } \\
\text { nos garimpos }\end{array}$ & - & $\begin{array}{l}\text { Circulação sem controle, } \\
\text { exceto em casos de total } \\
\text { fechamento da fronteira } \\
\text { venezuelana }\end{array}$ \\
\hline Tabatinga (AM) & Leticia (Colômbia) & Santa Rosa (Peru) & - \\
\hline $\begin{array}{l}\text { Refúgio (desplazados da Colômbia } \\
\text { e fugidos da violência da selva } \\
\text { peruana), produtos básicos do } \\
\text { comércio varejista (alimentos) }\end{array}$ & $\begin{array}{l}\text { Saúde privada, dada a diferença dos } \\
\text { custos de serviços especializados, edu- } \\
\text { cação privada, e compra de importados }\end{array}$ & $\begin{array}{l}\text { Acesso por transporte } \\
\text { fluvial ao território peruano } \\
\text { (Iquitos) }\end{array}$ & Circulação sem controle \\
\hline Assis Brasil (AC) & Iñapari (Peru) & Bolpebra (Bolívia) & - \\
\hline $\begin{array}{l}\text { Serviços de saúde básica, edu- } \\
\text { cação fundamental, assistência } \\
\text { social, trabalho no comércio local } \\
\text { informal (artesanatos e produtos } \\
\text { hortifrutigranjeiros) }\end{array}$ & $\begin{array}{l}\text { Trabalho informal em serrarias; serviços } \\
\text { odontológicos e medicina privada }\end{array}$ & $\begin{array}{l}\text { Compra de eletrônicos, } \\
\text { assentamentos (agricultura } \\
\text { familiar) }\end{array}$ & Circulação sem controle \\
\hline Brasiléia (AC) & Epitaciolândia (AC) & Cobija (Bolívia) & - \\
\hline $\begin{array}{l}\text { Serviços de saúde básica, educação } \\
\text { fundamental, assistência social, } \\
\text { produtos agropecuários (frutas, } \\
\text { carnes), trabalho no comércio local } \\
\text { informal (artesanatos e produtos } \\
\text { hortifrutigranjeiros) }\end{array}$ & $\begin{array}{l}\text { Serviços, comércio varejista, trabalho } \\
\text { informal e acesso ao posto da Polícia } \\
\text { Federal para regularização de docu- } \\
\text { mentação migratória }\end{array}$ & $\begin{array}{l}\text { Comércio de importados, } \\
\text { turismo, cursos de medicina } \\
\text { na cidade ou em outras } \\
\text { localidades da Bolívia, } \\
\text { investimentos }\end{array}$ & Circulação sem controle \\
\hline Demais arranjos (lado brasileiro) & Demais arranjos (lado peruano) & - & - \\
\hline Serviços públicos e comércio varejista & $\begin{array}{l}\text { Compras de produtos importados, } \\
\text { serviços de navegação para o interior } \\
\text { do Peru, educação, atividades em } \\
\text { serrarias, atividades noturnas }\end{array}$ & - & Circulação sem controle \\
\hline
\end{tabular}

Fontes: Pêgo et al. (2018); Brasil (2016a); Oliveira (2006); Euzébio (2014).

Elaboração: Equipe Fronteiras Ipea. 
No arco Central, além das especificidades de cada arranjo, os participantes identificaram dois movimentos transfronteiriços bem caracterizados: os fluxos de pessoas para trabalho em atividades urbanas e rurais, composto na maioria por trabalhadores informais, pouco especializados, que tanto cruzam a fronteira na direçâo da Bolívia ou Paraguai quanto na desses países em direção ao Brasil; e os fluxos para estudo, nos ensinos fundamental e médio, verificados tanto nas escolas urbanas quanto nas rurais, localizadas próximas à fronteira, e educação superior, fundamentalmente cursos de medicina, em cidades da Bolívia e do Paraguai (quadro 9). Outros fluxos comuns são a busca por serviços públicos nas cidades brasileiras, particularmente saúde, dada a não universalização da saúde pública nos países vizinhos, e a procura do comércio de importados nos países vizinhos. Ressalta-se que há proprietários brasileiros de lojas nos países vizinhos e vice-versa. Uma peculiaridade na movimentação transfronteiriça nos arranjos da fronteira com a Bolívia é a predominância de bolivianos na produção para comercialização de hortigranjeiros nas cidades fronteiriças brasileiras (Pêgo et al., 2019; 2020b; Brasil, 2016a).

QUADRO 9

Arco Central: motivações específicas da mobilidade transfronteiriça

\begin{tabular}{|c|c|c|c|}
\hline \multicolumn{3}{|c|}{ Motivações por cidade do arranjo } & \multirow{2}{*}{$\begin{array}{c}\text { Controle } \\
\text { transfronteiriço } \\
-\end{array}$} \\
\hline Guajará-Mirim (RO) & Guayaramerín (Bolívia) & - & \\
\hline $\begin{array}{l}\text { Serviços públicos e compras no varejo, } \\
\text { trabalho no comércio informal (vendem } \\
\text { hortifrutigranjeiros) }\end{array}$ & Compras de importados & - & Circulação sem controle \\
\hline Cáceres (MT) & San Matías (Bolívia) & - & - \\
\hline $\begin{array}{l}\text { Trabalho informal em fazendas ou em } \\
\text { atividades urbanas, acesso a serviços } \\
\text { públicos de saúde e educação fundamental, } \\
\text { comércio local, e atividades culturais }\end{array}$ & $\begin{array}{l}\text { Acesso a cursos de medicina em } \\
\text { cidades da Bolívia, medicina privada } \\
\text { especializada, venda de produtos da } \\
\text { agricultura e pecuária (de assentados } \\
\text { próximos à fronteira), atividades } \\
\text { culturais }\end{array}$ & - & $\begin{array}{l}\text { Maior controle apenas } \\
\text { de ordem fitossanitária, } \\
\text { na entrada para o } \\
\text { território brasileiro }\end{array}$ \\
\hline Corumbá-Ladário (MS) & Puerto Quijarro (Bolívia) & $\begin{array}{l}\text { Puerto Suárez } \\
\text { (Bolívia) }\end{array}$ & - \\
\hline $\begin{array}{l}\text { Serviços públicos da saúde e educação, } \\
\text { trabalho informal no comércio (funda- } \\
\text { mentalmente em feiras, comercializando } \\
\text { hortifrutigranjeiros, roupas e utensílios)' }\end{array}$ & $\begin{array}{l}\text { Comércio de importados (em muitos } \\
\text { casos como proprietários de lojas), } \\
\text { acesso a Santa Cruz de la Sierra e } \\
\text { outras cidades bolivianas para cursos } \\
\text { de medicina }\end{array}$ & $\begin{array}{l}\text { Turismo, } \\
\text { atividades } \\
\text { noturnas }\end{array}$ & $\begin{array}{l}\text { Circulação sem controle, } \\
\text { exceto em situações } \\
\text { de protestos recentes }\end{array}$ \\
\hline Ponta Porã (MS) & Pedro Juan Caballero (Paraguai) & - & - \\
\hline $\begin{array}{l}\text { Trabalho no comércio e serviços (formal } \\
\text { e informal), trabalho como domésticas, } \\
\text { serviços públicos de educação e saúde, } \\
\text { propriedade de terras }\end{array}$ & $\begin{array}{l}\text { Trabalho no comércio e serviços } \\
\text { (formal e informal), compra de } \\
\text { importados, cursos de medicina na } \\
\text { cidade, propriedade de terras }\end{array}$ & - & Circulação sem controle \\
\hline
\end{tabular}


(Continuação)

\begin{tabular}{|c|c|c|c|}
\hline \multicolumn{3}{|c|}{ Motivações por cidade do arranjo } & $\begin{array}{c}\text { Controle } \\
\text { transfronteirico }\end{array}$ \\
\hline Demais arranjos (lado brasileiro) & Demais arranjos (lado paraguaio) & - & - \\
\hline $\begin{array}{l}\text { Serviços públicos de saúde, educação e } \\
\text { assistência social, trabalho rural (fazendas } \\
\text { de gado e soja ou relacionado ao turismo) } \\
\text { e trabalho urbano informal, turismo } \\
\text { (parques, cavernas, rios e cachoeiras, } \\
\text { sítios arqueológicos, pesca) }\end{array}$ & $\begin{array}{l}\text { Comércio de importados, trabalho } \\
\text { rural (fazendas de gado e soja ou } \\
\text { relacionado ao turismo), turismo } \\
\text { (parques, cavernas, rios e cachoeiras, } \\
\text { sítios arqueológicos, pesca), trabalho } \\
\text { em carvoarias, serrarias e trabalho } \\
\text { urbano informal }\end{array}$ & - & Circulação sem controle \\
\hline
\end{tabular}

Fonte: Pêgo et al. (2019; 2020b); Brasil (2016a).

Elaboração: Equipe Fronteiras Ipea.

Nota: ${ }^{1}$ As roupas e utensílios novos são oriundos majoritariamente da China, e os usados são doações principalmente dos Estados Unidos e da Bolívia, que os recebem e revendem. Para maiores informações sobre a origem e caminho percorrido pelas roupas e utensílios vendidos nas feiras em Corumbá, ver Ferreira e Costa (2014).

No arco Sul, a circulação interna nos arranjos transfronteiriços obedece a um controle rígido de documentação apenas no cruzamento dos postos para entrada e saída da Argentina. Nesse arco, além de muitas motivaçóes que se repetem nos arcos já citados, como aquelas decorrentes do trabalho, do comércio e do uso de serviços públicos no Brasil, há um movimento muito intenso de uso e sustentação da atividade turística, particularmente no caso do Parque Nacional do Iguaçu, visitado dos lados brasileiro e argentino (quadro 10). Esse parque tem como principal componente as Cataratas do Iguaçu, que se faz complementar por inúmeros produtos naturais (circuitos, trilhas, atividades náuticas, parques naturais) ou construídos (praia artificial, bares no gelo, memoriais, parques temáticos), em maior oferta em Foz do Iguaçu, que sistematicamente oferece novos atrativos a um amplo segmento de visitantes nacionais, dos países vizinhos assim como internacionais de longa distância. Integram esse circuito turístico os grandes centros comerciais e o comércio de rua, para compras de produtos importados (bebidas, perfumes, vestuário e eletrônicos), majoritariamente em Ciudad del Este. Para sustentação dessa indústria do turismo e desse intenso comércio, são muitas as atividades dos setores secundário e terciário que empregam formal e informalmente moradores dos três lados da fronteira, que circulam cotidianamente no interior do arranjo. Sáo lojistas, atendentes, ambulantes presentes nas três centralidades do arranjo, assim como trabalhadores da construçáo civil, do segmento de serviços domésticos, entre outros (Pêgo et al., 2020a; Brasil, 2016a). 
QUADRO 10

Arco Sul: motivações específicas da mobilidade transfronteiriça

\begin{tabular}{|c|c|c|c|}
\hline \multicolumn{3}{|c|}{ Motivações por cidade do arranjo } & \multirow{2}{*}{$\begin{array}{c}\text { Controle } \\
\text { transfronteiriço }\end{array}$} \\
\hline $\begin{array}{l}\text { Foz do Iguaçu-Santa Terezinha } \\
\text { do Itaipu (PR) }\end{array}$ & $\begin{array}{l}\text { Ciudad del Este, Hernandarias, } \\
\text { Minga Guazú, Presidente Franco } \\
\text { (Paraguai) }\end{array}$ & Puerto Iguazú (Argentina) & \\
\hline $\begin{array}{l}\text { Trabalho formal e informal em } \\
\text { atividades do comércio e serviços, } \\
\text { trabalho na construção civil e } \\
\text { serviços domésticos, busca por } \\
\text { serviços de saúde, educação e } \\
\text { assistência social, turismo (visita } \\
\text { ao Parque Nacional do Iguaçu), } \\
\text { parques temáticos, praia artificial, } \\
\text { bares no gelo, memoriais, templos } \\
\text { e mesquitas, comércio varejista } \\
\text { e combustível }\end{array}$ & $\begin{array}{l}\text { Trabalho formal e informal em } \\
\text { atividades do comércio e serviços, } \\
\text { trabalho na construção civil e } \\
\text { serviços domésticos, comércio } \\
\text { de importados (bebidas, per- } \\
\text { fumes, vestuário e eletrônicos) } \\
\text { em grandes centros comerciais } \\
\text { e o comércio de rua, cursos de } \\
\text { medicina e medicina privada, } \\
\text { comércio varejista e combustível }\end{array}$ & $\begin{array}{l}\text { Trabalho formal e informal } \\
\text { em atividades do comércio } \\
\text { e serviços, turismo: visita ao } \\
\text { Parque Nacional do Iguaçu, } \\
\text { comércio de importados, } \\
\text { restaurantes, comércio } \\
\text { varejista e combustível }\end{array}$ & $\begin{array}{l}\text { Circulação sem } \\
\text { controle na fronteira } \\
\text { com o Paraguai e } \\
\text { com controle rígido, } \\
\text { na fronteira com } \\
\text { a Argentina }\end{array}$ \\
\hline Barracão (PR) & Dionísio Cerqueira (SC) & $\begin{array}{l}\text { Bernardo de Irigoyen (Ar- } \\
\text { gentina) }\end{array}$ & - \\
\hline $\begin{array}{l}\text { Serviços públicos, particularmente } \\
\text { saúde, trabalho em atividades do } \\
\text { comércio e serviços (predominância } \\
\text { do informal) }\end{array}$ & $\begin{array}{l}\text { Serviços públicos, particularmente } \\
\text { saúde, trabalho em atividades do } \\
\text { comércio e serviços (predominância } \\
\text { do informal) }\end{array}$ & $\begin{array}{l}\text { Comércio, trabalho em } \\
\text { atividades do comércio e } \\
\text { serviços (predominância } \\
\text { do informal) }\end{array}$ & $\begin{array}{l}\text { Controle rígido no } \\
\text { trânsito de veículos, } \\
\text { mas o deslocamento } \\
\text { de pessoas é livre }\end{array}$ \\
\hline Uruguaiana (RS) & Paso de los Libres (Argentina) & - & - \\
\hline $\begin{array}{l}\text { Trabalho, majoritariamente informal, } \\
\text { no comércio, e compras no varejo, } \\
\text { conforme variação cambial }\end{array}$ & $\begin{array}{l}\text { Trabalho em lavouras de arroz, } \\
\text { no plantio e colheita, compras } \\
\text { no varejo, compras de produtos } \\
\text { importados, compras no varejo } \\
\text { conforme variação cambial }\end{array}$ & - & $\begin{array}{l}\text { Controle rígido na } \\
\text { entrada e saída da } \\
\text { Argentina }\end{array}$ \\
\hline Barra do Quaraí (RS) & Monte Caseros (Argentina) & Bella Union (Uruguai) & - \\
\hline $\begin{array}{l}\text { Compras no comércio varejista, } \\
\text { dependendo da oportunidade } \\
\text { cambial }\end{array}$ & $\begin{array}{l}\text { Compras no comércio varejista, } \\
\text { dependendo da oportunidade } \\
\text { cambial }\end{array}$ & $\begin{array}{l}\text { Busca por brasileiros aos } \\
\text { serviços básicos de saúde, } \\
\text { incluindo pré-natal e partos, } \\
\text { trabalho no corte da cana, } \\
\text { compra de produtos impor- } \\
\text { tados, comércio varejista, } \\
\text { dependendo da oportunidade } \\
\text { cambial }\end{array}$ & $\begin{array}{l}\text { Circulação livre na } \\
\text { fronteira com o } \\
\text { Uruguai, e controle } \\
\text { na fronteira com } \\
\text { a Argentina }\end{array}$ \\
\hline Demais arranjos (lado brasileiro) & Demais arranjos (lado argentino) & Demais arranjos (lado uruguaio) & - \\
\hline $\begin{array}{l}\text { Compra de produtos do comércio } \\
\text { varejista alimentos e vestuário, } \\
\text { atividades formais e informais } \\
\text { no trabalho urbano e rural, } \\
\text { atividades culturais }\end{array}$ & $\begin{array}{l}\text { Compra de produtos importados, } \\
\text { atividades formais e informais no } \\
\text { trabalho urbano e rural, turismo } \\
\text { missioneiro, cursos de medicina } \\
\text { (Santo Tomé), atividades culturais }\end{array}$ & $\begin{array}{l}\text { Comércio e serviços públicos, } \\
\text { compras nos free shops, } \\
\text { atividades culturais }\end{array}$ & $\begin{array}{l}\text { Circulação livre na } \\
\text { fronteira com o } \\
\text { Uruguai, e controle } \\
\text { na fronteira com } \\
\text { Argentina (na maio- } \\
\text { ria, deslocamentos } \\
\text { por balsas) }\end{array}$ \\
\hline
\end{tabular}

Fontes: Pêgo et al. (2020a); Brasil (2016a).

Elaboração: Equipe Fronteiras Ipea. 
Uma peculiaridade nesse arco é que, no caso da fronteira com o Uruguai, a busca por serviços públicos também ocorre na direção inversa, de educação ou de serviços básicos de saúde em cidades uruguaias, incluindo pré-natal e partos, o que obriga o registro dos nascimentos no país vizinho. Barra do Quaraí exemplifica essa busca justificada pelo mais fácil acesso/menor distância a Bella Unión que a Uruguaiana. Destacam-se o impacto do cruzamento da fronteira e a efêmera permanência nos arranjos durante a temporada de praias, com opçáo fundamentalmente do litoral catarinense. Como o controle é rígido por parte da Argentina, formam-se imensas filas para os trâmites de entrada e saída em relação a esse país. Há que salientar que a maioria dos arranjos transfronteiriços na fronteira com a Argentina sofre com as dificuldades da travessia por balsas, além da preocupação de estas sucumbirem diante da retomada da construçáo do complexo de barragens Panambi-Garabi, no rio Uruguai (Pêgo et al., 2020a).

Foi consenso entre participantes das atividades da pesquisa nos três arcos que o comércio é o principal gerador de fluxo de pessoas entre localidades nas regióes de fronteira. Os produtos importados (vestuário, perfumes e bebidas), como também os equipamentos eletrônicos e combustíveis, apareceram como principais produtos que estimulam o movimento de brasileiros para as cidades fronteiriças de outros países. Por sua vez, produtos brasileiros referentes à alimentação, industrializados ou não, são muito consumidos pelos bolivianos, peruanos, paraguaios, colombianos e venezuelanos, e, dependendo das oscilações cambiais, pelos argentinos, uruguaios, guianenses e franco-guianenses. Se as oscilaçôes cambiais redirecionam os fluxos transfronteiriços, as cidades sentem intensamente seus efeitos, podendo-se afirmar que as questóes conjunturais têm mais peso que as questóes estruturais nesses arranjos. Ou seja, a mudança cambial faz os fluxos mudarem imediatamente de direção de país de busca, inverterem-se, e por paradoxal que pareça, quando a economia de um país entra em crise, a procura para consumo por moradores do país vizinho favorece a economia local da cidade do país em crise (Pêgo et al., 2017; 2018; 2019; 2020a).

Sobre a grande mobilidade na regiáo em consequência das relaçóes de trabalho, com a maior parte dessas ocupaçôes no mercado informal, o estímulo vem do mercado, que "chama" trabalhadores de ambos os lados das fronteiras. A informalidade pode ser atribuída às diferentes legislaçôes trabalhistas, que dificultam o processo de contratação de pessoas dos países vizinhos, à burocracia na regularização da documentação, no caso de migrantes, a uma grande quantidade de ocupaçóes informais em atividades por conta própria e sem registros, à baixa qualificação dos postulantes aos postos, que os submete às ocupaçóes menos qualificadas, e à exploração e sonegação dos encargos trabalhistas por parte dos empregadores (Pêgo et al., 2019). 
Da mesma forma que a força de trabalho, muitos dos produtos oferecidos pelo comércio de importados não se formalizam ao entrar no país, além de que circula nos balcóes um grande volume de mercadorias falsificadas. Nesse caso, os fatores que propiciam a informalidade, o contrabando e a "pirataria" são: i) a burocracia para tirar documentação; ii) a ausência de casas de câmbio oficial junto aos postos fronteiriços; e iii) o descontrole e, fundamentalmente, a ausência de fiscalização, conivência de fiscais e impunidade dos infratores. Também são recorrentes os casos de estabelecimentos comerciais registrados em nome de brasileiros, ou de estrangeiros casados com brasileiros, que assim fogem da burocracia da legalização. O mesmo ocorre com a propriedade da terra, e em ambos os casos, no Brasil ou nos países vizinhos (Pêgo et al., 2019; 2020a).

Além das motivaçóes especificadas, observam-se deslocamentos noturnos de brasileiros nos três arcos da fronteira para frequência a bares, casas noturnas e restaurantes, casas de jogos, entre outras diversóes nas cidades "do lado de lá" das fronteiras. Junto a esse movimento há o movimento de ilícitos, seja o tráfico de drogas, seja o tráfico de pessoas, particularmente mulheres, crianças e outros segmentos vulneráveis, como indígenas, para a prostituição. Além disso, é recorrente o aliciamento desses mesmos segmentos para servirem de "mulas" no tráfico de drogas, assim como o aumento da violência e da criminalidade (Pêgo et al., 2019; 2020a). ${ }^{41}$

Merecem destaque dois outros movimentos urbanos e rurais que efetivamente fazem o amálgama da interação nessas áreas transfronteiriças: os fluxos familiares e a mobilidade indígena. Os fluxos que se ativam nas relaçóes familiares, dado que os laços de parentesco, compadrios e amizades desconhecem fronteiras, induzem trocas culturais e a manifestação de uma interculturalidade que enriquece as relaçóes sociais, e motivam uma série de atividades que fazem com que os povos se desloquem internamente aos arranjos para a vivência do cotidiano em família, do exercício do apoio e da solidariedade, comemoraçôes e festividades, sem limitaçóes fronteiriças (Pêgo et al., 2018; 2019; 2020a; 2020b). O outro movimento intenso e generalizado, a mobilidade intensa de povos indígenas, no caso dos arranjos buscam as áreas urbanas fundamentalmente para acesso a serviços de assistência social, mas também para atividades informais e mendicância. Estão presentes em todos os arranjos transfronteiriços, em menor escala ou ausentes apenas nos das fronteiras com Argentina e Uruguai (Pêgo et al., 2018; 2019; 2020a).

41. Sobre esse tema, que terá uma seção na sequência deste trabalho com depoimentos dos participantes nas atividades dos arcos, recomendam-se ainda as publicações Brasil (2015) e Brasil (2016a). 


\subsection{Gestão transfronteiriça}

\subsubsection{Funções públicas de interesse comum}

Inúmeras funções públicas estimulam a mobilidade no espaço transfronteiriço e lhe dão suporte, e a rigor exigem práticas de gestão compartilhadas, pois atendem a interesses comuns aos moradores e frequentadores dos municípios dos dois ou três lados da fronteira. Entre as mais importantes encontram-se os transportes públicos e outros meios de deslocamento nesses espaços transfronteiriços.

O transporte público é comumente precário, e, na maioria dos arranjos transfronteiriços, os ônibus urbanos chegam apenas até a linha de fronteira, de onde retornam à cidade de origem (Pêgo et al., 2017; 2018; 2019; 2020a; 2020b). As pessoas buscam morar próximas ao posto de fronteira, para facilitar e baratear seu deslocamento pendular. Essa limitação de percurso, ao mesmo tempo em que abre uma oportunidade para taxistas, acaba gerando conflitos pela demanda de passageiros entre esses profissionais dos municípios dos diferentes lados da fronteira. A exemplo, segundo relatos de participantes da oficina no arco Central, taxistas brasileiros não entram na Bolívia e os bolivianos que entram no Brasil se tornam clandestinos; além disso, o taxista brasileiro é impedido de abastecer lá, onde a gasolina é mais barata (Pêgo et al., 2019; 2020b). Em alguns arranjos, os transportes públicos são autorizados a cruzar a fronteira, caso da fronteira com o Paraguai, e neles, como no caso da travessia da Ponte da Amizade de Ciudad del Este a Foz do Iguaçu, os serviços de táxis na travessia ajudam a burlar o limite da cota de compras de importados, pois não são vistoriados, enquanto ônibus urbanos que cruzam a fronteira são recorrentemente vistoriados, às vezes com intimidação a passageiros e penalidades apenas a pequenos consumidores. Na travessia Barra do Quaraí-Bella Unión-Monte Caseros, além da precariedade física da comunicação, restrita a pequenas lanchas para passageiros entre cidades que se encontram frente a frente, o passageiro ainda deve obedecer aos trâmites da migração, que exigem várias autorizaçóes obtidas em pontos distintos da cidade, que não o do embarque (Pêgo et al., 2020a).

Serviços públicos de saúde, educação, assistência social e de garantia dos direitos do trabalho também encontram limitações. A busca de estrangeiros por atenção de saúde traz dificuldades para o Sistema Único de Saúde (SUS), que não prevê ressarcimento pelo país vizinho ao serviço prestado, tampouco tem orçamento destinado a esse tipo de atenção. Também não prevê a compensação ao país fronteiriço que atende a brasileiros. A sobrecarga ocasiona problemas nas condiçóes e nas redes de atendimento. $\mathrm{Na}$ maioria dos arranjos, o cidadáo estrangeiro, tendo em mãos o visto provisório, providencia o Cadastro de Pessoa Física (CPF) e com ele o Cartão SUS, identificando como local de residência a casa de um familiar ou amigo. Com isso, têm acesso liberado aos serviços (Pêgo et al., 2018; 2019; 2020a; 2020b). Na oferta desses serviços, algumas cidades fronteiriças teriam a possibilidade 
de praticar o intercâmbio de especialidades médicas, o uso de equipamentos de alta complexidade, entre outros, mas são restringidos por limitaçôes referentes à autorização do Conselho Regional de Medicina brasileiro aos profissionais da saúde dos outros países (Pêgo et al., 2019; 2020b).

Isso dificulta, também, personagens do cotidiano das cidades fronteiriças da Bolívia e Paraguai, os estudantes de medicina, que encontram restriçóes para praticar a residência em universidades ou hospitais no Brasil, mesmo em algumas cidades que buscam esse tipo de colaboração. Reivindicações explícitas dos grupos de trabalho no arco Central foram de que essa residência pudesse ser realizada nos hospitais e centros de saúde das cidades fronteiriças e que se aproveitassem equipamentos e recursos humanos qualificados da Bolívia para ajudar nos levantamentos iniciais das patologias em brasileiros e bolivianos e nos encaminhamentos aos serviços de saúde, sobretudo em atenção à população rural e mais periférica das cidades (Pêgo et al., 2019; 2020b). Vale ressaltar que, no caso da existência de faculdades de medicina no próprio arranjo transfronteiriço (como em Ciudad del Este, Pedro Juan Caballero, Cobija ou Santo Tomé), muitos estudantes residem do lado brasileiro, se o câmbio for favorável; estudantes que cursam medicina em Santa Cruz de la Sierra ou Cochabamba são passageiros frequentes em Corumbá e Cáceres - ambas as cidades pleiteiam a abertura de curso de medicina no município. Universidades da Bolívia oferecem bolsas de estudo, cursos de espanhol e homologação de títulos, e promovem intercâmbio de estudantes.

No caso da educação fundamental, são acordos entre municípios, muitas vezes informais, que garantem vagas a crianças estrangeiras, muitas vezes filhos de brasileiros residentes no país vizinho, ou simplesmente de moradores das proximidades da linha de fronteira, com maior proximidade das escolas brasileiras. O transporte escolar e a alimentação de alunos, fundamentalmente nas áreas rurais desses municípios, também resulta de acordos municipais, podendo sofrer restriçōes em mudanças de prefeitos (Pêgo et al., 2018; 2019; 2020a; 2020b).

Se educação e saúde são serviços pouco questionados entre os prestados a estrangeiros, pela natureza e importância do que oferecem, há bastante polêmica entre moradores no caso do acesso a direitos sociais como o Bolsa Família, ${ }^{42}$ que garante benefício a famílias carentes de moradores estrangeiros no Brasil, inscritos no Cadastro Único para Programas Sociais, para o que o documento necessário também é o CPF. Outro serviço com acesso problemático a brasileiros residentes nos países vizinhos, embora tenham direito, é o Benefício de Prestação Continuada (BPC). ${ }^{43}$ Embora a busca por serviços públicos seja comprovada, são raros os

42. Programa de transferência direta de renda, direcionado às famílias em situação de pobreza extrema residentes no Brasil. Para se candidatar ao programa, é necessário que a família esteja inscrita no Cadastro Único para Programas Sociais do Governo Federal.

43. Esse benefício é um dispositivo da Lei Orgânica da Assistência Social que garante 1 salário mínimo mensal à pessoa com deficiência e ao idoso com 65 anos ou mais, desde que comprovem não possuir meios de prover a própria manutenção, nem de tê-la provida por sua família. 
acordos para gestão cooperada e não se pratica o princípio da reciprocidade nesses casos (Pêgo et al., 2018; 2019; 2020a; 2020b).

Entre as funçôes públicas de interesse comum, muitas se encontram à espera para serem pensadas e geridas conjuntamente: a gestão ambiental, a destinação do lixo, o tratamento e distribuição de água e coleta de esgoto, a oferta de moradia, o uso do solo, entre as fundamentais. $\mathrm{O}$ fato é que os espaços transfronteiriços se tornam cada vez mais densos, ocupados em continuidade, perpassados por fluxos multidirecionais, por relaçóes sociais inequivocamente estreitas entre seus moradores. Entretanto, a gestão compartilhada raramente é praticada, dada a dificuldade de articulação e diálogo entre as esferas de governo de um mesmo país, acrescidas a essas a instância internacional. A complexidade é inegável, mas o exercício não é impossível, como se observará na seção seguinte.

\subsubsection{Experiências de gestão compartilhada}

Algumas práticas podem ser apontadas como exemplares na gestão compartilhada, muitas vezes formalizada apenas nas esferas locais. É o caso do diálogo e cooperação entre municipalidades, expresso em inúmeros consórcios firmados na região de fronteira, apesar do fator limitativo da legislação brasileira, que não permite a participação nesses consórcios de municípios dos países limítrofes. Um caso que enfrentou o obstáculo é o Consórcio Intermunicipal da Fronteira (CIF), que une os municípios de Dionísio Cerqueira (Santa Catarina), Barracão e Bom Jesus do Sul (Paraná) e, como parceiro informal, Bernardo de Irigoyen (Misiones, Argentina). Conforme apresentado na oficina do arco Sul, o consórcio foi criado em 2009 como uma associação pública, de direito público, que objetiva elaborar e encaminhar propostas de desenvolvimento para os municípios, com vistas a revitalizar a região. Foram mostrados os êxitos e as perspectivas positivas abertas pelo CIF, no tocante ao desenvolvimento regional e a projetos urbanos para o arranjo transfronteiriço sobre o qual incide, e que vem motivando iniciativas similares (Pêgo et al., 2020a).

Decorrente desse consórcio, que ganhou força pela unidade e pela participação, é também exemplar o Parque Turístico Ambiental de Integração, que une os municípios desse arranjo. Cortado pelo rio Peperi-Guaçu e relevante paisagem natural, o parque realiza atividades recreativas, comerciais, gastronômicas e esportivas, além de possuir trilhas que perpassam os países e municípios, oferecendo uma experiência de vivência transfronteiriça, de respeito às diferentes culturas e de reforço a uma identidade resultante do intercâmbio social e cultural e do ideal de integração entre os povos (Pêgo et al., 2020a).

Da mesma forma são notáveis os projetos ambientais de preservação na tríplice fronteira Brasil, Argentina e Paraguai, incentivados pela Itaipu Binacional. São projetos voltados à gestão de bacias hidrográficas, ao monitoramento e 
avaliação ambiental, ao patrimônio natural e biodiversidade, educação ambiental, piscicultura e produção rural sustentável, propostos em um programa binacional e operacionalizados com participaçáo dos governos dos países, estados e municípios beneficiados, assim como da comunidade acadêmica e da sociedade da região (Brasil, 2016a).

$\mathrm{Na}$ tríplice fronteira Brasil, Uruguai e Argentina, é notável o movimento de união das ONGs (particularmente de Barra do Quaraí, Bella Unión, Monte Caseros), que vem possibilitando a realizaçáo de projetos compartilhados, permuta de conhecimentos e experiências, envolvendo pesquisadores e universidades brasileiras, uruguaias e argentinas, bem como ambientalistas, que partilham saberes e conteúdos sobre a região trinacional. Esse movimento organiza eventos trinacionais, como a cavalgada ecológica, ou assume funçôes relegadas pelos estados, como a limpeza e manutenção da Ilha Brasileira, um santuário ecológico que vem se constituindo um símbolo dessa área transfronteiriça. Tais iniciativas demonstram que a sociedade quer a integração e consegue avançar nesse caminho, mesmo que tenha que enfrentar as dificuldades impostas pelos órgáos públicos e a morosidade dos encaminhamentos oficiais (Pêgo et al., 2020a).

$\mathrm{Na}$ área da cultura, também nessa tríplice fronteira, vem sendo realizado um projeto de pesquisa com o lema "Três países, três fronteiras, um só povo", cujo principal objetivo é promover a integração da região, por meio da articulação de universidades e escolas dos três países, com a criação de um Diploma Universitário Trinacional em Gestão de Políticas Culturais, assim como outro em Jornalismo. O projeto, cuja ideia foi aprovada pelo Comitê Trinacional de Fronteira, em 2017, defende a proposta educativa de fortalecer a integração e a cooperação na tríplice fronteira, por meio de uma série de encontros que permitirão impulsionar políticas de gestáo cultural transfronteiriça enfocadas na construção de uma visão-identidade territorial/regional, e ao mesmo tempo transformadora da educação (Pêgo et al., 2020a).

Outro exemplo cultural é o Moinho Cultural Sul-Americano, em Corumbá, que resulta do aproveitamento das antigas instalaçôes do Moinho Mato-grossense, recicladas durante o processo de revitalização da área portuária de Corumbá. O prédio possui auditório, refeitório, biblioteca, videoteca, salas de dança e música e amplo espaço para atividades ao ar livre. A instituição atua fundamentalmente na ação pedagógica, ação social e na atividade "Moinho in Concert", que é uma das realizaçóes de maior visibilidade do Moinho Cultural, pois aproxima o grande público a uma arte de qualidade, em que os principais protagonistas são crianças e adolescentes, moradores de Corumbá-Ladário (Brasil) e Puerto Suárez-Puerto Quijarro (Bolívia) (Pêgo et al., 2019).

$\mathrm{Na}$ educação voltada para formaçôes especializadas, a escola agrícola de Cáceres oferece aos bolivianos cursos de inseminação, e o Instituto Técnico Superior de 
San Matías (Bolívia) tem parceria com o Instituto Federal de Mato Grosso (IFMT), que oferece curso de bovinocultura a alunos bolivianos (Pêgo et al., 2020b). Há, também, a atuação da Universidade Federal do Pampa (Unipampa), que disponibilizou vagas para uruguaios e argentinos. Em ambos os casos, todavia, não se conseguiu garantir a validação dos certificados para atuaçáo desses profissionais nos países de origem (Pêgo et al., 2020a).

Também, relativamente à pecuária, destacam-se as açóes compartilhadas entre o governo de Mato Grosso e o do Departamento de Santa Cruz (Bolívia), voltadas à prevenção de sanidade animal, com interaçáo na busca de serviços e formação de trabalhadores nessa área. Para uma eficiência maior na aplicação da metodologia brasileira de imunização, tem ocorrido capacitação dos bolivianos para vacinação de animais e uso de vacinas brasileiras, pois essas são encontradas em cidades mais próximas, e prontas para imunizar. Além das vacinas, conjuntamente com os brasileiros, os bolivianos controlaram o comércio de anabolizantes, que era permitido na Bolívia e dificultava a exportação, dado que a Europa não compra carnes de animais que fazem o uso desses produtos. Ainda na integração desses serviços está a busca dos produtores da Bolívia por reprodutores no Brasil, e a Empresa Brasileira de Pesquisa Agropecuária (Embrapa), por meio de parcerias com criadores, está fazendo melhorias na genética daquele país, trabalhando com inovação tecnológica, mudança de processos (idades do abate, alimentação). Segundo os produtores e técnicos do Instituto de Defesa e Sanidade Animal do Estado do Mato Grosso (Indea), entrevistados pelo Ipea em atividades de campo, os brasileiros vêm assimilando as regras e costumes dos bolivianos, e eles os do Brasil, e assim foi criada uma cultura local de manejo animal compartilhado na fronteira, que deu sustentação ao sucesso do programa América do Sul Livre da Aftosa, diante da necessidade de salvaguardar a pecuária da fronteira e a economia do Brasil. Também no âmbito de ações compartilhadas, o Indea participou da elaboração da Lei Nacional de Defesa Sanitária Animal da Bolívia, inexistente até entâo (Pêgo et al., 2020b).

$\mathrm{Na}$ área de saúde, Rondônia adquiriu um barco para ser utilizado como hospital e atender à populaçáo da fronteira Brasil-Bolívia, com a participaçáo de médicos bolivianos e brasileiros. Essa importante iniciativa de cooperação e de integração ainda tem questôes pendentes, referentes à operacionalização, regime de contratação e segurança jurídica relacionada aos aspectos laborais para atuação dos agentes de saúde de ambos os países, além da repartição dos custos de operaçáo, inclusive da aquisição de medicamentos (Pêgo et al., 2019).

No âmbito da articulação internacional, Barra do Quaraí é um município que se beneficia da oferta de equipamentos e serviços de Bella Unión (Uruguai), como ambulâncias, hospitais, médicos, bombeiros, limpeza de fossas etc. Porém, com dificuldades, pois é necessário haver uma contrapartida aos empréstimos e 
serviços por parte da municipalidade brasileira, que encontra obstáculos legais e aduaneiros para ressarcimentos. Em determinados casos ocorre até o risco de puniçôes legais, o que dificulta a cooperação entre as cidades (Pêgo et al., 2020a).

Há, ainda, acordos internacionais e regionais que favorecem e podem tornar exitosos projetos integrados entre instituiçóes como o Mercosul, o Parlamento do Mercosul (Parlasul), o Conselho de Desenvolvimento e Integração Sul (Codesul), a Zona de Integração do Centro-Oeste da América do Sul (Zicosul) e o Bloco Regional de Intendentes, Prefeitos e Alcaldes do Mercosul (Bripam), a serem analisados na sequência deste trabalho (Pêgo et al., 2020a).

$\mathrm{O}$ arranjo produtivo transfronteiriço da cadeia de produtos florestais (com ênfase em madeira e castanha, entre outros) é também um exemplo de gestão compartilhada exitosa entre Brasil (Acre) e Bolívia (Departamento de Pando). A partir da década de 1990, teve início a convergência de um marco legal para articulaçáo da extração e comercialização de produtos florestais. Apesar do diálogo muito escasso interinstitucional, setorial e transnacional, existente entre os dois países, havia uma forte conexáo entre os atores locais, particularmente no mercado de trabalho. Com apoio do Grupo Retis, da Universidade Federal do Rio de Janeiro (UFRJ), buscou-se e obteve-se uma maior integração e, também, a regularização desse tipo de trabalho, principalmente do trabalho volante, pouco regularizado; uma complementaridade entre a extração de madeira e os outros produtores florestais, como a castanha, com mercados globais importantes; e uma adequação da infraestrutura de circulação, que contou com investimentos do Banco Nacional de Desenvolvimento Econômico e Social (BNDES). Assim, logrou-se uma conexão não só para os mercados locais urbanos regionais, mas também globais, tanto da madeira quanto da castanha (Pêgo et al., 2018).

\section{RELAÇÕES INTERFRONTEIRIÇAS}

Constatada a importância das relaçóes e articulaçóes transfronteiriças, fortemente representadas em interaçôes e contatos entre povos e muitas vezes formalizadas em acordos entre países, outro feixe de relaçóes carece de prioridade na agenda de debates. Refere-se às relaçóes interfronteiriças de longa distância, caracterizadas pelos corredores terrestres internacionais, ferroviários ou rodoviários, pelas ligaçôes bioceânicas e, particularmente neste estudo, às relaçôes internas ao próprio território, estabelecidas entre as fronteiras terrestre e litorânea - esta, a ser objeto do capítulo 8.

No caso deste feixe, algumas indagaçóes inquietaram a equipe e perpassaram as atividades realizadas. Quais as relaçōes existentes entre a fronteira terrestre e a litorânea? Quais as rotas que as unem? Quais as trocas que realizam entre si? $\mathrm{Na}$ reflexão desencadeada em busca de respostas, uma volta ao passado mostrou que, 
desde os primórdios da colonização e ocupação do território, foram abertas vias de ligação para escoamento de produtos primários entre essas fronteiras. Um salto ao futuro revela que se projetam infraestruturas de conexôes que permitirão ao território alcançar um padrão mais elevado e mais equitativo de desenvolvimento, além de se consolidarem eixos de integração entre os países sul-americanos. Alguns passos vêm sendo dados neste tempo presente, ainda permeado mais de demandas que de realizações.

\subsection{Relações históricas entre fronteiras e metrópoles}

Durante o ciclo econômico primário exportador, as metrópoles, situadas na faixa litorânea, tiveram presença histórica nas relaçóes com as porçóes distantes das fronteiras terrestres, que se articularam em uma rede de fluxos econômicos. Tomando por base a análise de Moura (2019), ${ }^{44}$ muitos foram os programas de ocupação do território, grandes investimentos em infraestruturas além da fundação e equipamentação de cidades que se tornaram elos nas relaçôes entre os países sul-americanos, e que abriram um diálogo para a realização de projetos comuns, cooperados, com grande potencial de integração no subcontinente.

Produtos como borracha, erva-mate, charque, entre outros, motivaram a ocupação do território e exploração de riquezas naturais. São exemplos a Marcha para o Oeste, promovida pelo governo brasileiro nos anos 1940, e a Marcha para El Este, promovida pelo governo paraguaio nos finais dos anos 1950. Mais que ocupar o território no interior fronteiriço desses países, essas iniciativas visavam, no caso brasileiro, ao controle dos monopólios pecuário e ervateiro (centrado na Companhia Erva Matte Laranjeira), e, no caso paraguaio, abrir a propriedade de terras a estrangeiros, dada a revogação da lei que proibia essa prática na faixa de $150 \mathrm{~km}$ de suas fronteiras. Durante os governos militares desses países, nos anos 1970 e 1980, foram realizados investimentos em obras como aeroportos, pontes, rodovias e fundamentalmente na construção da hidrelétrica binacional de Itaipu. Somadas ao atrativo turístico das cataratas do rio Iguaçu, consolidaram o maior arranjo transfronteiriço do território sul-americano, articulando Foz do Iguaçu (Paraná), Ciudad del Este (Paraguai) e Puerto Iguazú (Argentina), com uma população estimada, em 2019, de aproximadamente 900 mil habitantes.

Outros exemplos históricos se deram nos três arcos fronteiriços, como a ferrovia Madeira- Mamoré, associada à exportação da borracha, pensada para ligar a Bolívia ao Atlântico, em trecho não navegável dos rios Madeira e Amazonas, que deu origem à cidade de Porto Velho (Rondônia). Também o ramal ferroviário Barra do Quaraí-São Borja (Rio Grande do Sul), da The Brazil Great Southern Railway Co.,

44. Análise que articula estudos da pesquisa Fronteiras do Brasil: uma avaliação de política pública, do Ipea, e do projeto Organização do espaço urbano-metropolitano e construção de parâmetros de análise das dinâmicas de metropolização, do Observatório das Metrópoles. 
a qual fazia entroncamento com a North Western of Uruguay Railways, em direção a Salto, no Uruguai, que visava ao transporte de charqueadas. E, ainda, a Estrada de Ferro Noroeste do Brasil, de Bauru (São Paulo) a Corumbá (Mato Grosso do Sul), de onde se integrava à Ferroviaria Oriental, com destino a Santa Cruz de la Sierra, na Bolívia (figura 4) ${ }^{45}$ Em outros países da América do Sul, as ligaçóes ferroviárias também aproximaram a fronteira das metrópoles, ou mais precisamente, das saídas marítimas para exportação, como a ferrovia General Manuel Belgrano, que ligava as fronteiras da Bolívia e do Chile ao Atlântico, via Buenos Aires; o Ferrocarril Transandino Mendoza-Los Andes, que conectava Atlântico e Pacífico, conexão até então feita pela passagem através do estreito de Magalhães.

\section{FIGURA 4}

Exemplos históricos de projetos de integração física do subcontinente - América do Sul

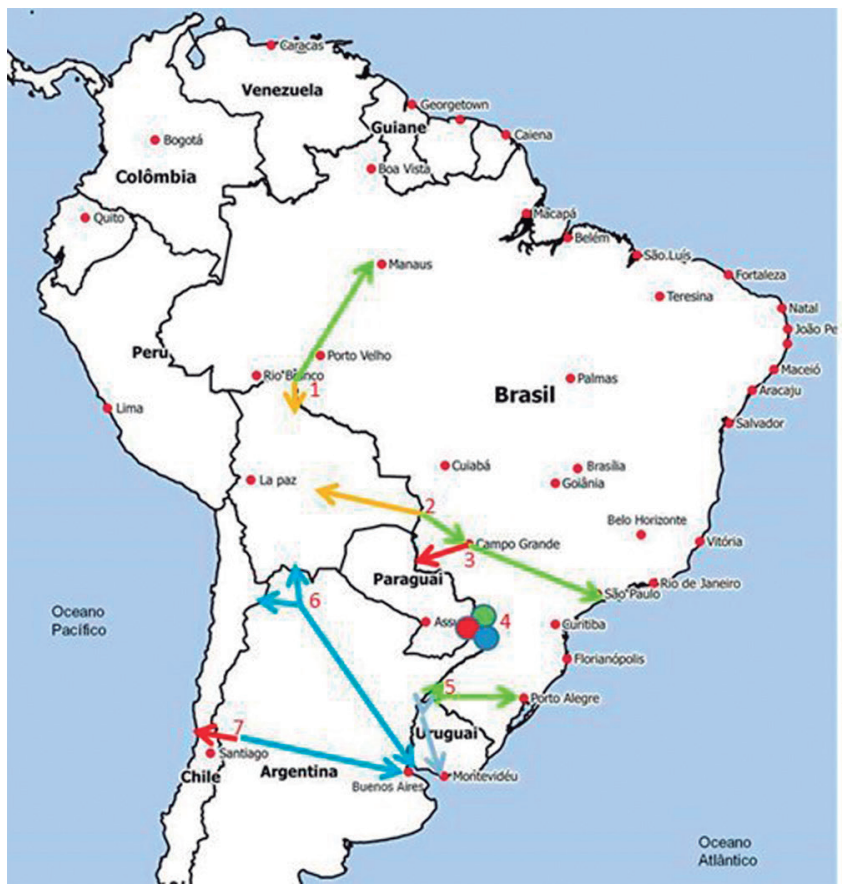

1. Madeira/Mamoré (GuajaráMirim/Guayaramerin)

2. Trem do Pantanal/Expreso Oriental (Corumbá/Santa Cruz de la Sierra)

3. Noroeste (Campo Grande/PontaPorã)

4. Marchas Oeste/Este: arranjo transfronteiriço Foz do Iguaçu / Ciudad del Este/ Puerto Iguazú

5. Barra do Quaraí/São Borja/Porto Alegre; Salto/Montevidéu

6. Tren las Nubes/Quebrada de Humahuaca

7. Ferrocarril Transandino (Mendoza/Los Andes)

Fonte: Moura (2019).

Adaptação: Equipe Fronteiras Ipea.

Além de ferrovias, a abertura do canal Tamengo, em meados do século XX, exemplifica uma parceria entre Brasil e Bolívia, para conexão da Laguna Cáceres, em Puerto Suárez (Bolívia), ao rio Paraguai, nos limites de Corumbá, para facilitar o fluxo de mercadorias entre a Bolívia e o oceano Atlântico. 
As obras ferroviárias apontadas, por motivações específicas, entraram em decadência, arrastando nesse processo centros prósperos, equipados, conectados às redes de cidades dos respectivos países, além de toda uma rede de pequenas cidades que emergiam nas estações, ao longo de seus trilhos. ${ }^{46}$ Deixaram marcos históricos no patrimônio arquitetônico das cidades, transtornos urbanos pelo abandono de suas infraestruturas, além da memória e da expectativa dos moradores de que um dia voltem a operar. Projetos de retomada vêm ocorrendo, mas apenas como ramais turísticos, ou na reativação de trechos para transporte de cargas, "sempre acompanhados de apelativo discurso que tenta criar a imagem de que os tempos de ouro estarão de volta" (Moura, 2019, p. 12).

\subsection{A inseparabilidade entre metrópole e cidade da fronteira terrestre}

Participantes das atividades nos arcos fronteiriços argumentam que está havendo um retrocesso nas estratégias de desenvolvimento na fronteira terrestre, que desconstrói conquistas do período de integração histórica entre o Brasil e os países vizinhos, e que aumenta cada vez mais os danos do isolamento, pela distância dos centros de decisão e desatenção do Estado (Pêgo et al., 2018; 2019; 2020a; 2020b).

Algumas dessas obras voltaram a ser consideradas em projetos entendidos como de integração sul-americana, a exemplo dos previstos pela Iniciativa para a Integração da Infraestrutura Regional Sul-Americana (IIRSA) - transformada em instância técnica do Conselho Sul-Americano de Infraestrutura e Planejamento (Cosiplan) -, que incluem infraestruturas de grande porte direcionadas a criar corredores bioceânicos, porém poucos foram iniciados. Em relação a esses projetos, os participantes apontam impactos socioambientais já vistos na regiáo fronteiriça, e salientam críticas ao fato de serem decididos sem participação das comunidades envolvidas, além de relegarem necessidades fundamentais ao cotidiano dos povos fronteiriços. São projetos que perpetuam essas localidades como pontos de passagem, corredores, portais de entrada e saída terrestre entre os países, perdendo seu sentido histórico de elos (Pêgo et al., 2017; 2019; 2020a).

Como portais terrestres de entrada e saída dos países, os arranjos transfronteiriços e outras localidades da FFT enfrentam carências e estigmas, enquanto sentem a presença remota da metrópole em seu cotidiano. Por um lado, são portais de chegada e partida de migrantes e refugiados, como já abordado na subseçáo 1.2.2. Por outro, alguns itens do consumo metropolitano e de outras cidades passam por esses portais, como bens lícitos e ilícitos. Entre os lícitos, uma variedade de produtos que ativam o comércio popular de importados, transportados por fluxos de sacoleiros, intermediários ou comerciantes precários, ou no turismo de compras nas cidades de fronteira, e induzem a presença de uma população flutuante, cuja condição de

46. Para mais informações sobre esses projetos históricos e as motivações de suas desativações, ver Moura (2019). 
passagem amplia as demandas básicas dos moradores, já desatendidas pelos frágeis poderes locais dos municípios fronteiriços (Pêgo et al., 2019; 2020a; 2020b).

No caso dos ilícitos, a proximidade da fronteira a áreas produtoras de drogas torna os arranjos transfronteiriços e outras localidades da FFT pontos vulneráveis. Mas é na metrópole que o comércio de drogas atribui maior valor ao produto traficado, onde grupos do crime organizado comandam a atuação nas regióes de fronteira, e onde o consumo tem elevado e diversificado a demanda. Outros ilícitos passam por esses portais, e o reclamo dos participantes é quanto à necessidade de um maior contingente estatal na região, para inibir e controlar os fluxos e os crimes transfronteiriços ligados a eles, com capacidade de enfrentamento e controle sistemático do volume de produtos ilegais que atravessam o limite internacional e que, comumente, vão circular nas metrópoles e grandes centros urbanos brasileiros. Ressaltam que o estigma que provocam na fronteira terrestre é em certa maneira descabido, pois informam que a maior proporção de armas, drogas e produtos contrabandeados entra pelos portos e aeroportos da fronteira litorânea (Pêgo $e t$ al., 2019; 2020a; 2020b).

\subsection{Principais conexões entre a fronteira terrestre e a litorânea}

No início do século XXI, um elenco de projetos de grandes infraestruturas foi desenvolvido no âmbito da IIRSA, fórum técnico do Cosiplan. Conforme relatado por Moura e Pêgo (2016), esses projetos são a principal referência no que tange a eixos de integração e desenvolvimento na América do Sul, tendo como objetivo articular áreas de produção e consumo, com o fim de reduzir custos, atrair novas inversóes e promover a integração dos doze países sul-americanos com outras regióes do mundo. No entendimento do Cosiplan (2017), não há integração para a unidade sul-americana se não houver integração física entre os países do subcontinente. Entre os projetos prioritários elencados, foram anunciados investimentos para dez eixos de integração (figura 5) e seus respectivos projetos prioritários. Contudo, passada mais de uma década, poucos foram iniciados ou inteiramente concluídos conforme a previsão. 
FIGURA 5

Eixos de integração e desenvolvimento do Cosiplan - América do Sul (2017)

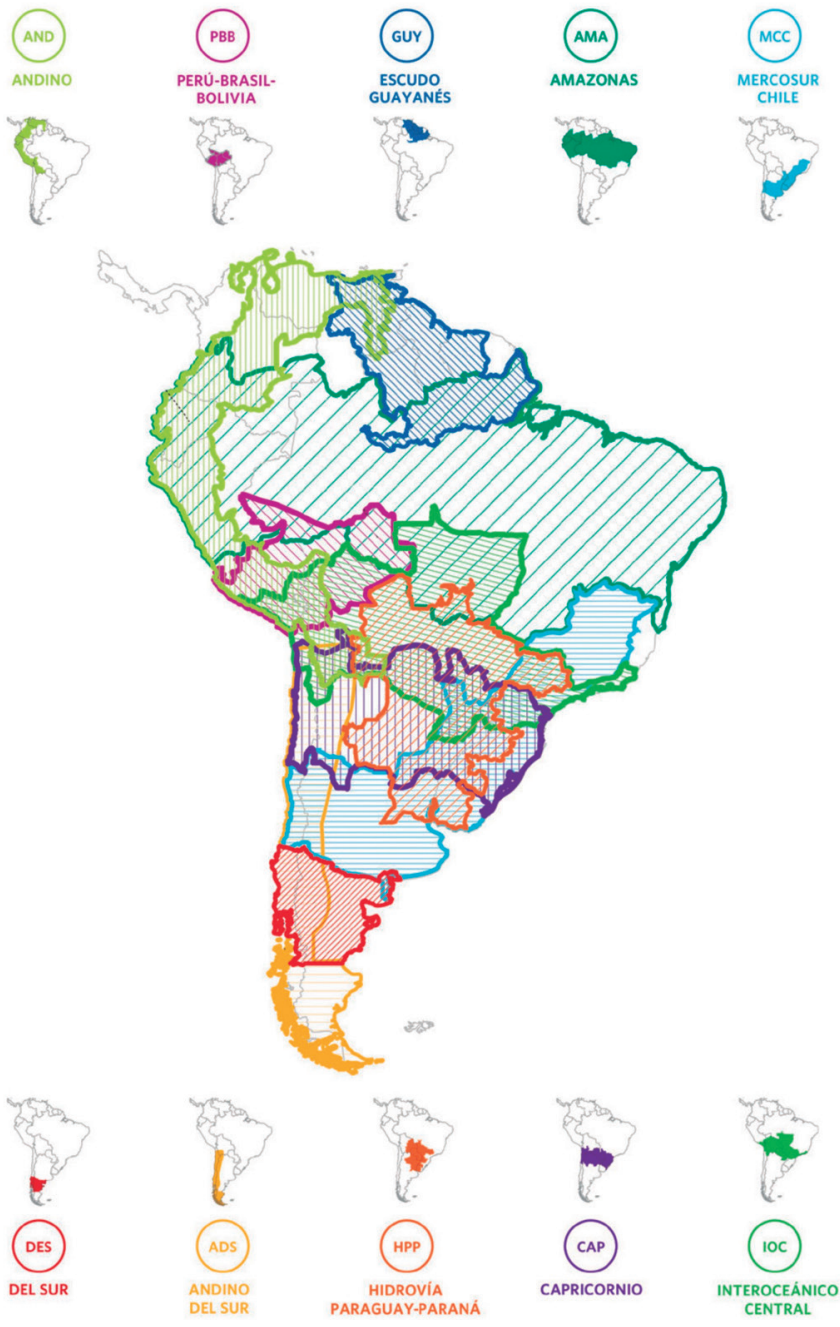

Fonte: Cosiplan (2017, p. 167).

Adaptação: Equipe Fronteiras Ipea.

A Agenda de Projetos Prioritários de Integração (API), 2017, incluiu um total de 29 projetos com objetivo estratégico e alto impacto para a integração física e o desenvolvimento socioeconômico da região (figura 6). São projetos voltados à conexão, com vários eixos e corredores viários (rodoviário, hidroviário e ferroviário), acessos a portos e aeroportos, pontes, túneis, equipamentos para interconexão, redes de transmissão de energia, gasodutos, assim como de desenvolvimento e planejamento territorial e sistema de informação (Cosiplan, 2017). Essa agenda resulta da revisão criteriosa e da atualização do portfólio original de 2011, com reordenação 
dos projetos. No documento que a apresenta, informa-se que a maioria das obras concluídas até 2016 pertencem ao Peru, mas que há projetos aprovados em todos os eixos, exceto o referente à hidrovia Paraguai-Paraná e o grande eixo Peru-Brasil-Bolívia. Informa-se, também, que o Corredor Bioceânico Paranaguá-Antofagasta, apesar do interesse dos países envolvidos, não está entre os projetos prioritários.

FIGURA 6

Agenda de projetos prioritários da API (Cosiplan) - América do Sul (2011)
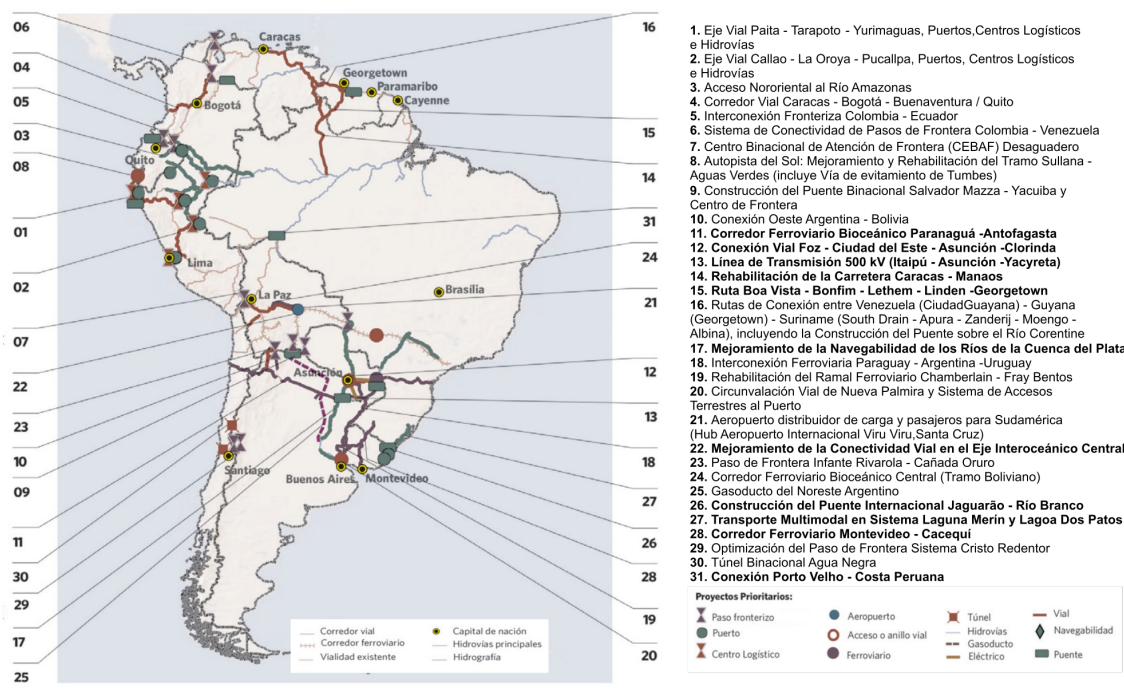

Fonte: Cosiplan (2017, p. 20-21).

Elaboração: Equipe Fronteiras Ipea.

Obs.: Em negrito, os projetos com participação no Brasil.

Como observado, desses 31 projetos, onze incidem sobre ou tangenciam o território brasileiro, a maioria programada para as APIs de 2022-2027. A API 2017-2022 integra catorze projetos estruturados, entre os quais o Brasil participa diretamente de três, descritos a seguir.

7) Construção da Ponte Internacional Jaguarão (Rio Grande do Sul)-Rio Branco (Argentina), (projeto 26), cuja ligação é feita atualmente pela Ponte Barão de Mauá, de 1929, tombada pelo Iphan desde 2011. O projeto prevê a recuperação dessa ponte e a construção de uma segunda ponte entre essas cidades. Em setembro de 2015, foi aberta uma licitação para a obra, mas não foi dada continuidade à implementaçáo do projeto. Em 2018, no âmbito da Lei Orçamentária Anual (LOA), houve uma previsão de recursos, porém suficiente apenas para a elaboração do projeto. ${ }^{47}$ 
8) Conexão Porto Velho-Costa Peruana (projeto 31), que está sendo feita precariamente pela rodovia interoceânica Brasil e Peru (ou rodovia do Pacífico), que conecta a BR-363 à BR-317 (entre Boca do Acre e Assis Brasil), prevista como corredor de escoamento dos gráos oriundos de Rondônia e Mato Grosso. A Rodovia Interoceânica ligará o Brasil aos portos peruanos de Ilo, Maratani e San Juan, no Oceano Pacífico. Em janeiro de 2006, foi inaugurada a ponte binacional, que liga os municípios de Assis Brasil, no Acre, a Ińapari, no Peru, com 240 metros de extensão, pista duplicada e passagem para pedestres nas laterais. A conexão que permite entre o Atlântico e o Pacífico já vem sendo explorada. Inclusive, já há uma linha de ônibus que faz, duas vezes por semana, levando cinco dias, o trajeto Rio de Janeiro-São Paulo-Campo Grande-Cuiabá-Porto Velho-Rio Branco-Assis Brasil, atravessando a fronteira para o Peru, em Ińapari, e seguindo a Puerto Maldonado-Cuzco-Abancay-Nazca-Ica. Percorre a Amazônia peruana e a Cordilheira dos Andes, atingindo a altitude de 4.726 metros, e faz conexão ao Equador e à Colômbia. ${ }^{48}$

9) Projeto estruturado Corredor ferroviário Argentina-Uruguai-Brasil, que é uma extensão do tramo programado entre Montevidéu-Cacequi (projeto 28). Constitui-se na reabilitação de ramais ferroviários do Uruguai, alcançando cidades fronteiriças com a Argentina e o Brasil. Neste caso, os trilhos partem de Rivera, que integra o arranjo transfronteiriço de Sant'Ana do Livramento (Rio Grande do Sul) (Cosiplan, 2017).

Para a API 2023-2027, foram selecionados mais doze projetos estruturados, sendo cinco com incidência em território brasileiro (Cosiplan, 2017).

1) Conexão viária Foz do Iguaçu-Ciudad del Este-Asunción-Clorinda (projeto 12): encontra-se em fase de pré-projeto. Prevê, em território brasileiro, a construção da ponte entre Porto Meira, em Foz do Iguaçu, e Presidente Franco, no Paraguai, com conclusão esperada para 2023.

2) Rota Boa Vista-Bonfim-Lethem-Linden-Georgetown (projeto 15), projeto de recuperação viária que se encontra em execução e permitirá conexôes entre o oeste da Venezuela, Roraima, Guiana e Suriname.

3) Melhoria da navegabilidade dos rios da Bacia do Prata (projeto 17), que fluem na Argentina, Brasil, Paraguai e Uruguai, resultando em significativas reduçóes de custo do transporte em fluxos de tráfego interno e inter-regional, bem como extrarregionais, contribuindo na integração econômica e no desenvolvimento sustentável da regiáo. O projeto referente 
à melhoria da navegabilidade entre a foz do rio Apa e Corumbá, na fronteira entre Brasil e Paraguai, encontra-se na dependência de estudos por parte do governo brasileiro, em atençáo a imposição do Poder Judiciário.

4) Melhoria da conectividade do eixo interoceânico central (projeto 22), que abrange, entre os subprojetos componentes, o anel viário de Campo Grande e a área de controle integrado Corumbá-Puerto Suárez (Bolívia).

5) Transporte multimodal no sistema Laguna Merin-Lagoa dos Patos (projeto 27), para melhoria na conectividade entre o sul do Brasil e o leste do Uruguai. A dragagem da Laguna Merin foi concluída em 2015, e o início das obras na Lagoa dos Patos, com dragagem do Canal da Feitoria, estava previsto para 2020.

Dos projetos da agenda 2011, dois avançaram, mas ainda com pendências:

1) Linha de transmissão $(500 \mathrm{kV})$ Itaipu-Assunção-Yacyreta (projeto 13): completo e em operação desde outubro de 2013 apenas o trecho Hernandárias a Assunção, no Paraguai $(348 \mathrm{~km}$ de linhas de transmissão e 759 torres). ${ }^{49}$

2) Rodovia Manaus-Caracas (projeto 14): BR-174/AM/RR, sendo 255,7 $\mathrm{km}$ no estado do Amazonas e 715,7 km em Roraima. O trecho final da rodovia é o marco Brasil Venezuela número 8 (BV8), que demarca o lugar de origem da vila Pacaraima, na cidade de Pacaraima/RR. A rodovia encontra-se concluída, com contratos de conservação e manutenção ativos. ${ }^{50}$

Sobre o projeto não priorizado (mapa 14), Corredor ferroviário bioceânico Paranaguá-Antofagasta (projeto 11), em agosto de 2019, na sede do governo do estado do Paraná, reuniram-se os governadores do Paraná e de Mato Grosso do Sul com dirigentes privados, representando empresários chineses e portugueses, para discutir a retomada do projeto (Martins, 2019). A Estrada de Ferro Paraná Oeste (Ferroeste) e a Secretaria do Planejamento e Projetos Estruturantes do Paraná formaram um grupo de trabalho para avaliar os modelos propostos no projeto. Essa obra tem grande importância, pois reduz em 8 mil quilômetros a viagem de produtos brasileiros até os mercados da Ásia. Mas esbarra em um conjunto de dificuldades. São quatro países envolvidos que devem conjuntamente superar alguns desafios: sistema de concessão comum, integração aduaneira, questóes tributárias, tarifa do transporte, e unificação das exigências ambientais. 


\section{MAPA 14}

Corredor Ferroviário Bioceânico Paranaguá (Brasil)-Antofagasta (Chile)

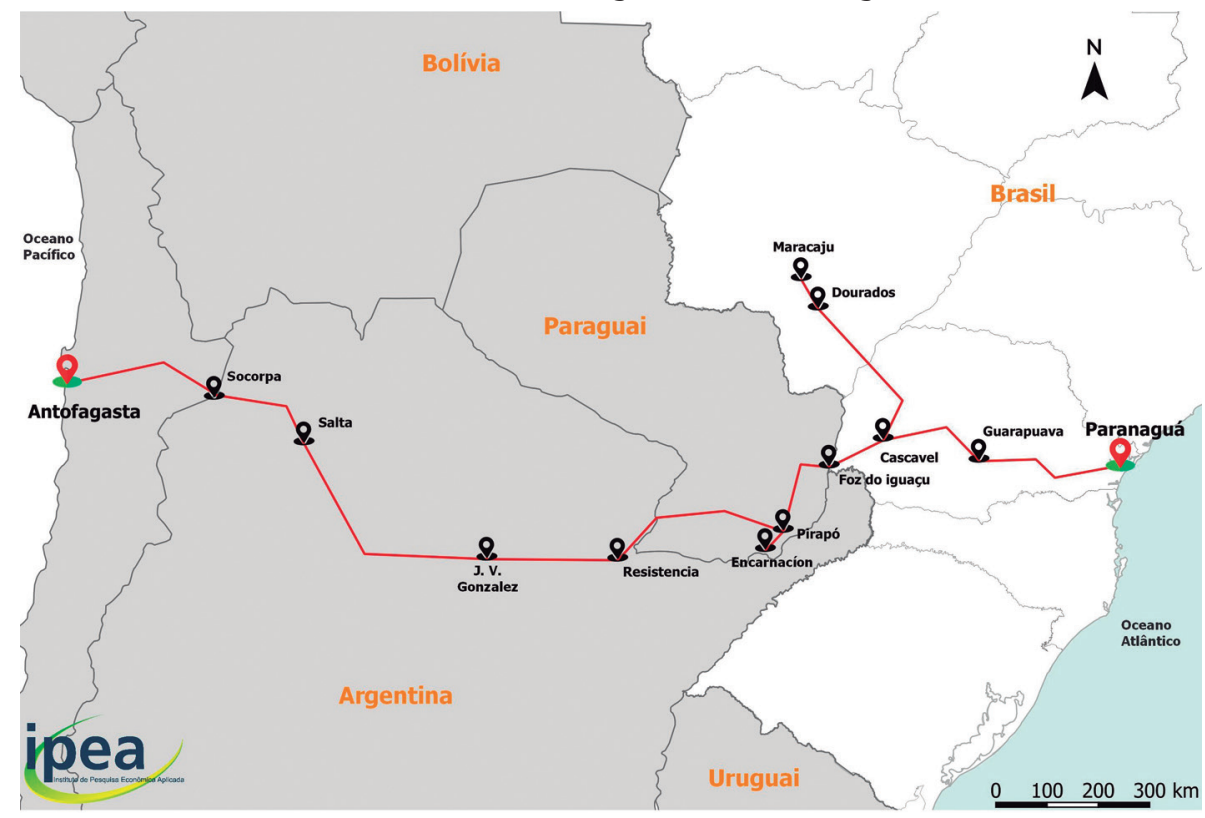

Fonte: BNDES (2010).

Elaboração: Equipe Fronteiras Ipea.

Alguns outros projetos se delinearam, como a construção da Ferrovia Transcontinental, ${ }^{51}$ com extensão prevista de 4,4 mil quilômetros em território brasileiro, ligando o porto do Açu, no estado do Rio de Janeiro, passando por mais cinco estados brasileiros, até o porto de Ilo, no Peru. Pretende-se tornar uma alternativa de transporte em regiōes já consolidadas, como Ipatinga (Minas Gerais) e Lucas do Rio Verde (Mato Grosso) e outras que poderão se consolidar tendo como alternativas de exportação/importação duas saídas, uma no Oceano Atlântico e outra no Pacífico.

Para os participantes do arco Central, está havendo um retrocesso nas estratégias de desenvolvimento na área fronteiriça. Em termos de infraestrutura, Corumbá é o portão de entrada e saída da principal rota bioceânica, e abriga parte da mais importante hidrovia transnacional do subcontinente sul-americano. Rememoraram período de integração histórica entre Brasil e Bolívia, que há oitenta anos construíram juntos a interligação, através do canal Tamengo, na região de Corumbá e Ladário, de uma hidrovia que conectou Brasil, Paraguai, Argentina e Uruguai. A região teve, anteriormente, uma das maiores redes ferroviárias do Brasil, que 
se estendia de Corumbá a Santos, no estado de São Paulo, que já não tem mais. Ademais, a operação aérea é restrita e tem que ser repensada. A região de Cáceres também tem importantes infraestruturas paralisadas (Pêgo et al., 2019; 2020b).

Apesar desse conjunto de projetos, e em função dos resultados daqueles já implementados, o reclamo dos participantes é quanto à ausência de participação dos povos fronteiriços na tomada de decisão sobre eles, além de que, muitas vezes, os elevados investimentos em infraestruturas "de passagem" ignoram as necessidades locais ou não incidem sobre elas. Levá-las em consideração poderia efetivamente trazer melhorias do desenvolvimento e do cotidiano das localidades da fronteira (Pêgo et al., 2018; 2019; 2020a).

\section{REFERÊNCIAS}

ASSIS, F. G. et al. TerraBrasilis: a spatial data analytics infrastructure for largescale thematic mapping. ISPRS International Journal of Geo-Information, v. 8, n. 11, p. 513, 2019.

BNDES - BANCO NACIONAL DE DESENVOLVIMENTO ECONÔMICO E SOCIAL. Avaliação dos Corredores Bioceânicos. BNDES, 2010.

BRASIL. Ministério da Integração Nacional. Secretaria de Programas Regionais. Programa de Desenvolvimento da Faixa de Fronteira. Proposta de Reestruturaçáo do Programa de Desenvolvimento da Faixa de Fronteira: bases para uma política integrada de desenvolvimento regional para a faixa de fronteira. Brasília: MIN, 2005.

- Ministério da Justiça e Cidadania. Municípios de Fronteira: mobilidade transfronteiriça, migração, vulnerabilidades e inserção laboral - Relatório de Pesquisa do projeto MT Brasil. ICMPD; União Europeia, 2016a.

Ministério da Integração Nacional. Portaria no 213, de 19 de julho de 2016. Estabelece o conceito de "cidades gêmeas" nacionais, os critérios adotados para essa definição e lista todas as cidades brasileiras por estado que se enquadram nesta condição. Diário Oficial da Uniáo, Brasília, v. 138, p. 12, 20 jul. 2016 b. Disponível em: <https://bit.ly/3l2R4Ir>. Acesso em: 20 jan. 2020.

. Ministério da Justiça e Segurança Pública. Refúgio em números. 4. ed. Conare, 2018. $46 \mathrm{p}$.

Agência Nacional de Mineração. Anuário mineral brasileiro: principais substâncias metálicas - ano base 2017. Brasília: ANM, 2019a.

. Ministério de Desenvolvimento Regional. Portaria no 1.080, de 24 de abril de 2019. Inclui o Município de Cáceres-MT no Anexo da Portaria n. 213, de 19 de julho de 2016, que estabelece o conceito de "cidades gêmeas" nacionais, os 
critérios adotados para essa definição e lista todas as cidades brasileiras por Estado que se enquadram nesta condição. Diário Oficial da Uniáo, Brasília, v. 81, p. 10, 29 abr. 2019b. Disponível em: <https://bit.ly/3ewumG5>. Acesso em: 20 jan. 2020. CÂMARA, G.; VALERIANO, D. M.; SOARES, J. V. Metodologia para o cálculo da taxa anual de desmatamento na Amazônia Legal. São José dos Campos: INPE, 2013. Disponível em: <https://bit.ly/3esF4NS>. Acesso em: 20 jan. 2020.

CARDOSO, N. A.; MOURA, R. Regiōes de fronteira e fluxos migratórios: o caso do Paraná. In: PENHA, B.; DESIDERÁ NETO, W. A.; MORAES, R. F. (Orgs.). O Mercosul e as regióes de fronteira. Rio de Janeiro: Ipea, 2017. p. 53-100.

CAVALCANTI, L. et al. Imigraçáo e Refúgio no Brasil: A inserção do imigrante, solicitante de refúgio e refugiado no mercado de trabalho formal. Brasília: OBMigra, 2019.

COSIPLAN - CONSEJO SURAMERICANO DE INFRAESTRUCTURA Y PLANEAMIENTO. Agenda de Proyectos Prioritarios de Integración (API) 2017. Buenos Aires: Unasur, 2017. 184 p.

COSTA, M. A.; MARGUTI, B. O. Atlas da vulnerabilidade social nos municípios brasileiros. Brasília: Ipea, 2015. 77 p.

DESCHAMPS, M.; DELGADO, P.; MOURA, R. Mobilidade pendular na faixa de fronteira brasileira: particularidades dos arranjos transfronteiriços. In: PÊGO, B.; MOURA, R. (Orgs.). Fronteiras do Brasil: uma avaliação de política pública. Rio de Janeiro: Ipea; MI, 2018. v. 1. p. 293-321.

DINIZ, C. C.; CROCCO, M. A. Reestruturação econômica e impacto regional: o novo mapa da indústria brasileira. Nova economia, Belo Horizonte, v. 6, n. 1, p. 77-103, jul. 1996.

EGLER, C. A. G. Referenciais básicos para uma metodologia de identificação do sistema urbano da América do Sul. In: FURTADO, B.; PÊGO, B. (Coords.). Rede urbana e integraçáo produtiva no Brasil e na América do Sul. Brasília: Ipea; Cepal; Ipardes, 2015.

EUZÉBIO, E. F. A fluidez territorial na fronteira ocidental da Amazônia: as cidades gêmeas Tabatinga (Brasil) e Leticia (Colômbia). Confins Revista franco-brasilera de geografia, n. 21, 2014. Disponível em: <http://confins.revues.org/9659>. Acesso em: 18 ago. 2016.

FERREIRA, F. L; COSTA, G. V. L. "Brechó fronteiriço": comércio global de roupas de segunda mão em Corumbá-MS. In: REUNIÃO BRASILEIRA DE ANTROPOlOGIA, 29., 2014, Natal, Rio Grande do Norte. Anais... Brasília: ABA, 2014. Disponível em: <https://bit.ly/2TY8BFO>. Acesso em: 20 jan. 2020. 
FUNAI - FUNDAÇÃO NACIONAL DO ÍNDIO. Terra Indígena - regularizada, homologada, declarada, delimitada e área em estudo. FUNAI, 2019. Disponível em: <https://bit.ly/2JGNo1p>. Acesso em: 20 jan. 2020.

IBGE - INSTITUTO BRASILEIRO DE GEOGRAFIA E ESTATÍSTICA. Diretoria de Geociências. Coordenação de Geografia. Regióes de influência das cidades 2007. Rio de Janeiro: IBGE, 2008.

. Diretoria de Geociências, Coordenação de Geografia. Divisão Urbano Regional 2010. Rio de Janeiro: IBGE, 2013.

Arranjos populacionais e concentraçóes urbanas no Brasil - Coordenação de Geografia. 2. ed. Rio de Janeiro: IBGE, 2016.

. Áreas dos municípios brasileiros. IBGE, 2018. Disponível em: <https:// bit.ly/3k5CJdd>. Acesso em: 20 jan. 2020.

. Estimativas da populaçáo residente no Brasil e unidades da federaçáo com data de referência em $1^{\circ}$ de julho de 2019. Rio de Janeiro: IBGE, 2019.

. Diretoria de Geociências. Coordenação de Geografia. Regióes de influência das cidades 2018. Rio de Janeiro: IBGE, 2020. Disponível em: <https:// biblioteca.ibge.gov.br/visualizacao/livros/liv101728.pdf>. Acesso em: 30 jul. 2020.

INPE - INSTITUTO NACIONAL DE PESQUISAS ESPACIAIS. Infoqueima. Boletim mensal de monitoramento de queimadas, v. 4, n. 11, nov. 2019.

. Infoqueima. Boletim mensal de monitoramento, v. 5, n. 10, out. 2020.

ISA - INSTITUTO SOCIOAMBIENTAL. Localizaçáo e extensão das TIs. 2019. Disponível em: <https://tinyurl.com/y3el2oaq>. Acesso em: 7 nov. 2020.

KRÜGER, C.; ARRUDA, D.; MARIANI, M. Por dentro do cárcere: Evidências de violência institucional em um presídio feminino na fronteira entre Brasil e Bolívia. Dilemas, Rio de Janeiro, v. 11, n. 3, p. 435-452, set.-dez. 2018.

MACHADO, L. O. Estado, territorialidade, redes - Cidades gêmeas na zona de fronteira sul-americana. In: SILVEIRA, M. L. (Org.). Continentes em Chamas Globalização e Território na América Latina. Rio de Janeiro: Civilização Brasileira, 2005. p. 246-284.

MARTINS, C. Após dez anos, projeto de corredor bioceânico ganha novo capítulo. Gazeta do Povo, 19 ago. 2019. Disponível em: <https://bit.ly/2JycQG8>. Acesso em: 20 jan. 2020.

MEIJER, J. R. et al. Global patterns of current and future road infrastructure. Environmental Research Letters, v. 13, n. 6, 2018. Disponível em: <https://bit. ly/3mYAwCe>. Acesso em: 23 mai. 2020. 
MOREIRA, P. G. Entorno e primeiras respostas $(\mathrm{G})$ locais à instabilidade na Venezuela. Boletim Regional, Urbano e Ambiental Ipea, n. 18, p. 87-95, jan.-jun. 2018.

Imigraçáo Venezuela - Roraima: evolução, impactos e perspectivas. Relatório Técnico. Ipea (Dirur), 2020. 59 p.

MOURA, R. Metrópoles e cidades de fronteira: o que as torna inseparáveis? Boletim Observatório das Metrópoles, 19 set. 2019. Disponível em: <https:// tinyurl.com/y2f2zdtl>. Acesso em: 20 jan. 2020.

MOURA, R.; OLIVEIRA, S. Referências sobre a faixa de fronteira e os arranjos transfronteiriços do Brasil. In: PÊGO, B.; MOURA, R. (Orgs.). Fronteiras do Brasil: uma avaliação de política pública. Rio de Janeiro: Ipea; MI, 2018. v. 1. p. 243-292.

MOURA, R.; OLIVEIRA, S.; PÊGO, B. Escalas da urbanização brasileira. Rio de Janeiro: Ipea, 2018. (Texto para Discussão, n. 2372).

MOURA, R.; PÊGO, B. Aglomeraçóes urbanas no Brasil e na América do Sul: trajetórias e novas configuraçóes. Rio de Janeiro: Ipea, 2016. (Texto para Discussão, n. 2203).

NETO, A. M.; SILVA, R. de O.; SEVERIAN, D. Perfil e dinâmica das desigualdades regionais do Brasil em territórios industriais relevantes. Brasília: Ipea, 2019. (Texto para discussão, n. 2511).

NUNES, M. O Programa de Aceleração do Crescimento e as fronteiras. In: PÊGO, B.; MOURA, R. (Orgs.). Fronteiras do Brasil: uma avaliação de política pública. Rio de Janeiro: Ipea; MI, 2018. v. 1. p. 381-411.

OBSERVATÓRIO DO CLIMA. Mapa de uso e cobert do solo do Brasil. 2019. Disponível em: <https://plataforma.mapbiomas.org/>. Acesso em: 7 dez. 2020.

OLIVEIRA, G.; KRÜGER, C. As relaçôes de reciprocidade e dívidas morais entre o presídio e a rua: A expansão e transnacionalização do Primeiro Comando da Capital (PCC) na fronteira Brasil-Bolívia. Dilemas, Rio de Janeiro, v. 11, n. 1, p. 28-52, jan.-abr. 2018.

OLIVEIRA, M. M. A mobilidade humana na tríplice fronteira: Peru, Brasil e Colômbia. Estudos Avançados, v. 20, n. 57, p. 183-196, 2006.

PEGO, B. et al. (Orgs.). Fronteiras do Brasil: diagnóstico e agenda de pesquisa para política pública. Brasília: Ipea; MI, 2017. v. 2.

PÊGO, B. et al. (Orgs.). Fronteiras do Brasil: uma avaliação do arco Norte. Brasília: Ipea; MI, 2018. v. 3. 
PÊGO, B. et al. (Orgs.). Fronteiras do Brasil: uma avaliação do arco Central. Rio de Janeiro: Ipea; MDR, 2019. v. 4.

PÊGO, B. et al. (Orgs.). Fronteiras do Brasil: uma avaliação do arco Sul. Rio de Janeiro: Ipea; MDR, 2020a. v. 5.

PÊG, B. et al. Estudo técnico sobre a viabilidade de criação da "cidade gêmea" Cáceres (Brasil) - San Matías (Bolívia). Brasília: Ipea; MDR, 2020 b.

PÊGO, B.; MOURA, R. (Orgs.). Fronteiras do Brasil: uma avaliação de política pública. Rio de Janeiro: Ipea; MI, 2018. v. 1.

PINTO, C. V. S.; OLIVEIRA, S.; MARGUTI, B. O. Um estudo sobre as situações de vulnerabilidade social nos arcos de fronteira do Brasil. In: PÊGO, B.; MOURA, R. (Orgs.). Fronteiras do Brasil: uma avaliação de política pública. Rio de Janeiro: Ipea; MI, 2018. v. 1. p. 197-242.

RESENDE, G. M.; SILVA, D. F. C. Avaliação dos fundos constitucionais de financiamento nos municípios da faixa de fronteira das regióes Norte e Centro-Oeste: uma abordagem em painel espacial para o período 1999-2011. In: PÊGO, B.; MOURA, R. (Orgs.). Fronteiras do Brasil: uma avaliação de política pública. Rio de Janeiro: Ipea; MI, 2018. v. 1. p. 352-380.

STEFONI, C. Panorama de la migración internacional en América del Sur. Documento elaborado no marco da Reunión Regional Latinoamericana y Caribeña de Expertas y Expertos en Migración Internacional, ao Pacto Mundial para una Migración Segura, Ordenada y Regular. Centro Latinoamericano y Caribeño de Demografía (CELADE)-División de Población de la Comisión Económica para América Latina y el Caribe (CEPAL). Santiago: Cepal, 2017. (Serie población y desarrollo).

UNEP - UNITED NATIONS ENVIRONMENT PROGRAMME. Panorama Ambiental Global - GEO-6: avaliação regional da América Latina e do Caribe. Unep, 2016. Disponível em: <https://bit.ly/38fYLYj>. Acesso em: 20 jan. 2020. 


\section{AVALIAÇÃO DAS POLÍTICAS PÚBLICAS VOLTADAS À FAIXA DE FRONTEIRA TERRESTRE}

\section{INTRODUÇÃO}

As etapas de uma política pública, também conhecidas como policy-making process, são divididas sequencialmente para melhor entendimento, podendo ser sintetizadas em: construção da agenda política, formulação, implementação e avaliação (Faria, 2005; Howlett, Ramesh e Pearl, 2013; Secchi, 2013; Souza, 2006; Wu et al., 2014). Apesar deste processo não se dar de forma exatamente sequencial, mas muitas vezes sobreposta, esta abordagem é utilizada para sistematizar resultados e discussōes para um planejamento racional (Resende, 2014).

Com esse panorama, a avaliação de políticas públicas, que se insere como objetivo deste capítulo, consiste em um procedimento sistemático de levantamento e análise de dados para a identificação dos seus resultados (Dagnino, 2002; Frey, 2000), visando subsidiar decisóes em relação a modificaçóes, melhorias ou ampliaçôes de programas e políticas específicas (Bartik e Binghan, 1995).

Importante inteirar que, entre as especificações em termos temporais para a avaliação das políticas públicas - entre elas, ex-ante, realizada antes da tomada de decisão; intermediária, realizada durante o processo; ou ex-post, ao seu fim (Oliveira e Passador, 2019; Resende, 2014) -, esta pesquisa se caracteriza como ex-post. E entre as diversas abordagens para avaliação destas políticas - como a centrada em objetivos, na administração, nos consumidores, em especialistas, em adversários ou em participantes (Worthen, Sanders e Fitzpatrick 2004) -, esta avaliação parte das análises das impressóes individuais dos participantes.

Nesse contexto, o avaliador não é um "criador de médias", mas aquele que "descreve valores e necessidades de indivíduos e subgrupos" (Worthen, Sanders e Fitzpatrick, 2004, p. 110), em que toda pessoa seria o melhor juiz dos eventos que lhe dizem respeito (House, 1983). Esta escolha se deu porque, como afirmam Guba e Lincon (1981), a investigação baseada no paradigma positivista, ou seja, hipotético-dedutiva, é limitada ao lidar com problemas complexos, interativos em ambientes dinâmicos do mundo real, como o cenário fronteiriço em questão. 
Tal fato, somado à limitação de dados quantitativos para avaliação mista (quanti-qualitativa) das políticas públicas implementadas na faixa de fronteira (FF) brasileira, fez com que, em um trabalho conjunto entre o Ipea e o Ministério do Desenvolvimento Regional (MDR), como citado nos capítulos anteriores, fossem realizadas oficinas em Brasília e nos arcos Norte, Central e Sul, reunindo significativos atores para análise e avaliação das açôes públicas. Complementarmente, foram realizados nestas ocasióes trabalhos de campo para levantamento de dados, aplicados questionários, promovidas entrevistas e grupos focais (Pêgo et al., 2017a; 2017b; 2018; 2019; 2020a).

Para esta análise, além dos dados primários levantados para a avaliação das políticas públicas em tela, mais precisamente nas respostas aos questionários aplicados, foram utilizados dados secundários de levantamento de documentos públicos e pesquisas realizadas em bases de dados consolidadas, como Scopus, Web of Science, Portal Capes de Periódicos, Biblioteca Digital Brasileira de Dissertaçôes e Teses.

Assim, com a execução de análises temporais das açóes públicas, e de conteúdo, com o auxílio do software NVivo, esses resultados são apresentados e discutidos nas seçôes a seguir. $\mathrm{Na}$ seção 2, descrevem-se temporalmente as principais açôes públicas voltadas à FF; na seção 3 , aborda-se a presença das fronteiras no Plano Plurianual (PPA); na seção 4, com técnica de análise de conteúdo, avalia-se, a partir das observaçóes dos participantes, as políticas públicas consideradas; e, por fim, realiza-se a descrição de alguns importantes apontamentos a serem considerados.

\section{AÇÕES PARA A INTEGRAÇÃO E O DESENVOLVIMENTO: POLÍTICAS PÚBLICAS VOLTADAS À FAIXA DE FRONTEIRA}

Os territórios de fronteira internacional na América Latina tendem a apresentar indicadores de menor renda e níveis inferiores de bem-estar da populaçáo, condiçóes de atraso e vulnerabilidade socioeconômica e ambiental, manifestando de maneira particular as desigualdades territoriais da região (Moura e Pêgo, 2016). Tendo em vista este cenário, no caso brasileiro, muitas foram as políticas públicas destinadas à FF, como demonstra a figura 1, a qual apresenta, em uma perspectiva temporal, as ações públicas federais na região. Importante destacar que a maioria destas políticas foi implementada a partir de 2000, com exceção de dois programas que remetem à década de 1980 (Krüger et al., 2017). Com relação aos investimentos, verifica-se que a responsabilidade está fortemente centrada no governo federal, com baixa articulaçáo dos programas em termos de descentralização para os âmbitos estaduais e municipais (Krüger, Dantas e Castro, 2018). 
FIGURA 1

Linha do tempo das políticas públicas implementadas na faixa de fronteira ${ }^{1}$
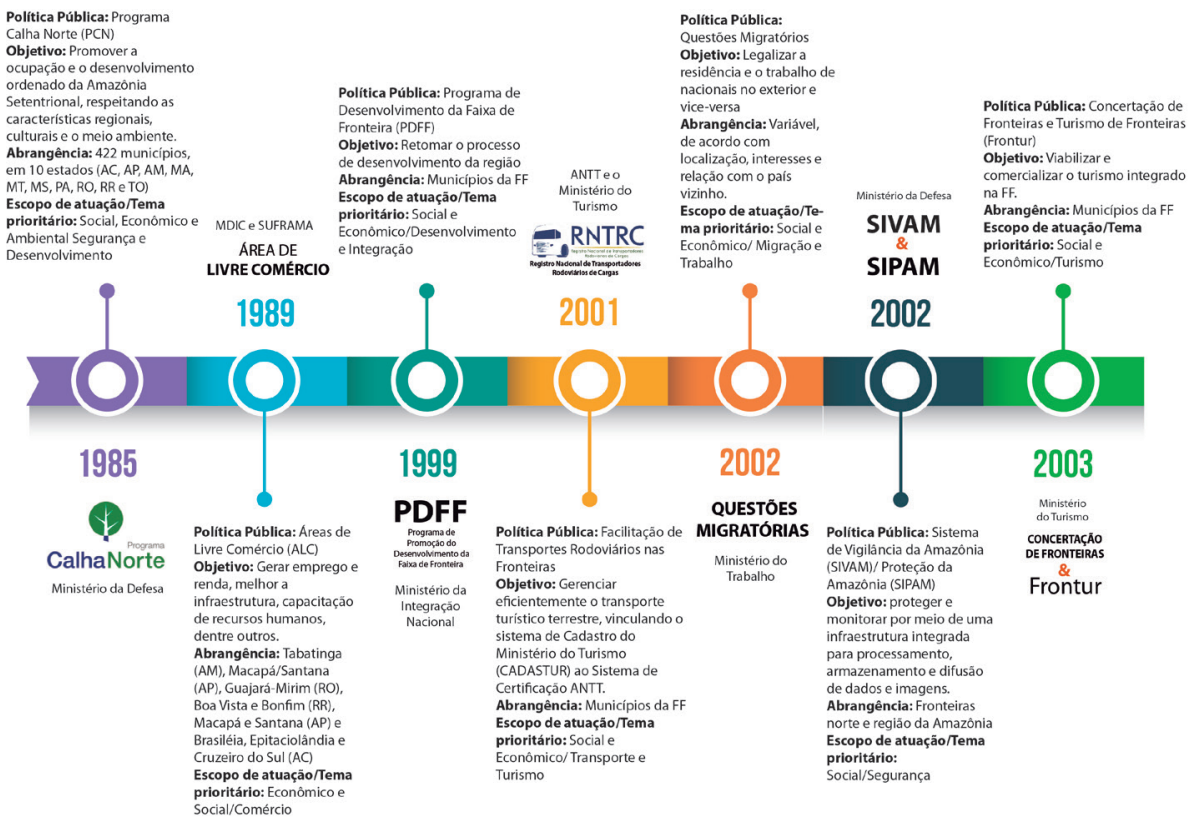

\begin{tabular}{|c|c|c|c|c|c|c|}
\hline $\begin{array}{l}\text { Política Pública: Projeto } \\
\text { Intercultural Bilíngue } \\
\text { Escolas de Fronteira } \\
\text { Objetivo: Construir um } \\
\text { modelo comum de } \\
\text { ensino em escolas da } \\
\text { zona de fronteira a partir } \\
\text { de um programa de } \\
\text { educaçāo intercultural } \\
\text { (português e espanhol). } \\
\text { Abrangência: } \\
\text { Cidades-gêmeas no Brasil } \\
\text { com paises limitrofes4 } \\
\text { Escopo de atuação/Te- } \\
\text { ma prioritário: } \\
\text { Social/ Educaçăo }\end{array}$ & $\begin{array}{l}\text { Ministério } \\
\text { da Saúde }\end{array}$ & $\begin{array}{l}\text { Política Pública: Fronteiras e } \\
\text { Questôes Migratórias/SINIVEM e } \\
\text { PRONASCI } \\
\text { Objetivo: Mapear criminosos } \\
\text { para reduzir os indices de } \\
\text { criminalidade regionais e } \\
\text { mitigar os impactos dos fluxos } \\
\text { migratórios em direçăo ao } \\
\text { território nacional } \\
\text { Abrangência: Municípios da FF } \\
\text { Escopo de atuaçâa/Tema } \\
\text { prioritário: } \\
\text { Social/Segurança }\end{array}$ & 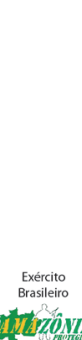 & $\begin{array}{l}\text { Política Pública: Regularização } \\
\text { Fundiária } \\
\text { Objetivo: Priorizar a } \\
\text { regularizaçăo fundiária e a } \\
\text { ratificaçăo de títulos na FF. } \\
\text { Abrangência: Municípios da FF } \\
\text { Escopo de atuação/Tema } \\
\text { prioritário: } \\
\text { Econômico e ambiental/ } \\
\text { Regularização Fundiária e } \\
\text { Licenciamento Ambiental }\end{array}$ & $\begin{array}{l}\text { Ministerio da } \\
\text { Pntegraço Nacional } \\
\text { PROMESOM }\end{array}$ & $\begin{array}{l}\text { Politica Pública: Plano } \\
\text { Estratégico de Fronteiras } \\
\text { (PEF//Operação Sentinela e } \\
\text { Operação Agata } \\
\text { Objetivo: Aperfeiçoar a gestāo } \\
\text { integrada das instituiçōes } \\
\text { envolvidas com segurança } \\
\text { pública nas regiōes de fronteira } \\
\text { e reprimir os crimes } \\
\text { transfronteiriços, como o tráfico } \\
\text { de pessoas, drogas, armas e } \\
\text { muniçōes, o contrabando de } \\
\text { mercadorias, além dos crimes } \\
\text { ambientais. } \\
\text { Abrangência: Municípios da FF } \\
\text { Escopo de atuaçāo/Tema } \\
\text { prioritário: Social e Ambiental } \\
\text { /Segurança-combate a crimes } \\
\text { transfronteiriços e ambientais }\end{array}$ \\
\hline
\end{tabular}

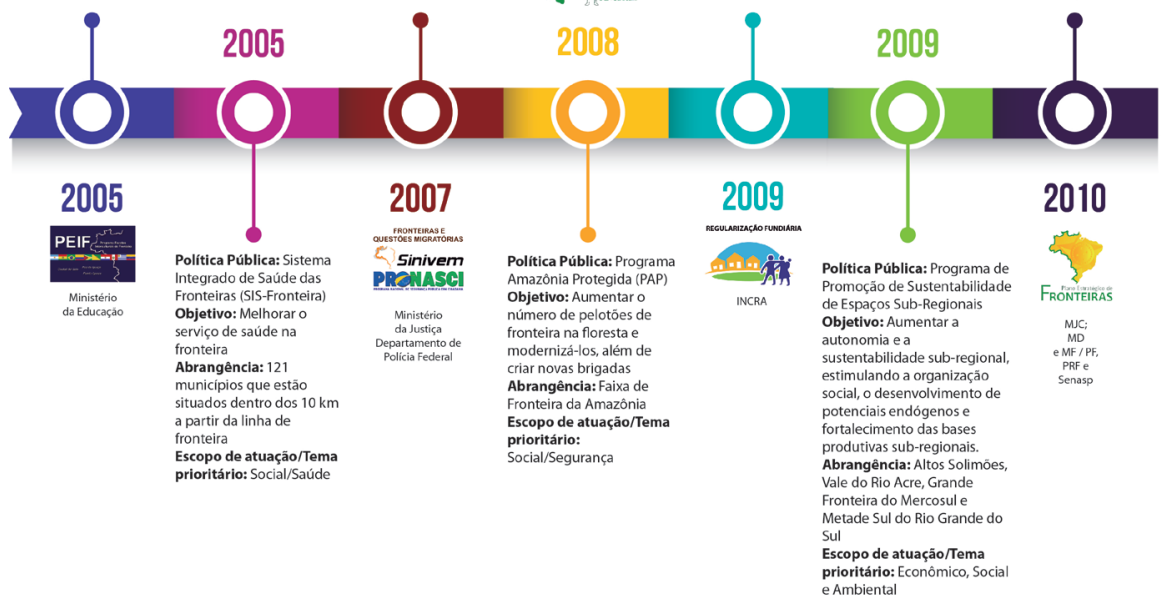




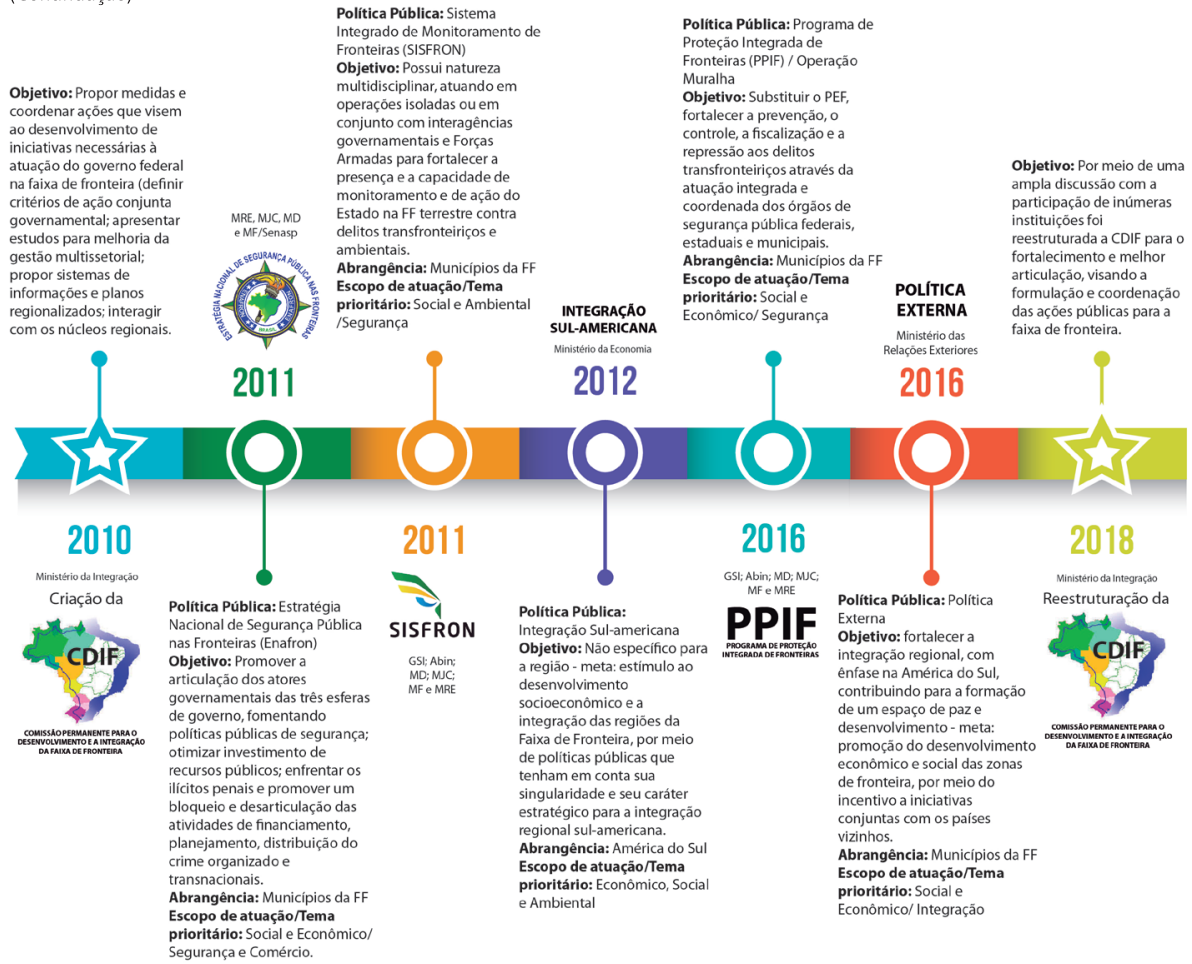

Fonte: Textos que foram referências para a figura.

Elaboração: Equipe Fronteiras Ipea.

Nota: ${ }^{1}$ A nomenclatura dos ministérios, das pastas e respectivas ações governamentais estão descritas na figura como constavam no respectivo período.

Um desses programas, o Programa Calha Norte (PCN), foi implementado como projeto inicialmente em 1985, tendo sua trajetória marcada por três importantes momentos. No primeiro deles, que se estendeu até 1989, o PCN tinha como escopo açóes em resposta a demandas de cunho militar - projeto de ocupaçáo geopolítica de áreas consideradas importantes para a defesa e de revisão da política indigenista (Miyamoto, 2009; Brasil, 2016a). No segundo momento, entre 1990 e 2002, o programa passou por um período de recursos orçamentários escassos, tendo uma redefiniçẫo na relaçâo civil-militar (Brasil, 2016a). A partir de 2003, em seu terceiro momento, o PCN teve um aumento em seus recursos e passou por uma ampliação em sua área de atuação, dando importância também a sua vertente civil, com convênios junto às prefeituras nas áreas de saúde, educação e bens públicos (Brasil, 2016a). Atualmente, o programa compreende 422 municípios dos seguintes estados: Amapá, Acre, Amazonas, Maranhão, Mato Grosso, Mato Grosso do Sul, Pará, Rondônia, Roraima e Tocantins (Brasil, 2020). 
Ainda na década de 1980, mais precisamente em 1989, tiveram início as áreas de livre comércio (ALCs), ou seja, áreas fronteiriças que passaram a ter benefícios fiscais ${ }^{1}$ de entrada e saída de mercadorias para o apoio a projetos de produção, infraestrutura econômica, entre outros, visando ao desenvolvimento destas regióes e incremento das relaçôes bilaterais (Krüger, Dantas e Castro, 2018). As ALCs tiveram início em Tabatinga (AM) e se expandiram a outras cidades fronteiriças, principalmente para a correção do viés concentrador do desenvolvimento intrarregional centrado na Zona Franca de Manaus (ZFM). Contudo, o incentivo fiscal tem se mostrado insuficiente para o desenvolvimento dos municípios de fronteira beneficiados pela ALC, sendo buscadas alternativas como garantia de estímulo ao investimento empresarial, como a autorização por meio da Lei no $12.723 / 2012$ das lojas francas (free shops), que tem gerado grandes expectativas às cidades gêmeas quanto à ampliação das oportunidades econômicas (Antunes, Senhoras e Trevisan, 2012, p. 59; Pêgo et al., 2020a).

Na década de 1990, o governo federal começou a trabalhar na concepção do projeto Sistema de Vigilância da Amazônia (Sivam)/Proteção da Amazônia (Sipam), que visava proteger e monitorar as fronteiras norte e a regiáo Amazônica, por meio de uma "infraestrutura integrada para a aquisição, visualização, processamento, armazenamento e difusão de dados e imagens" (Andrade e Lima, 2018, p. 131), com "finalidades múltiplas, como proteção aos voos, controle de tráfego aéreo, vigilância ambiental, combate ao contrabando e tráfico de drogas, mapeamento das queimadas e florestas, e fazer levantamentos ambientais" (Miyamoto, 2009, p. 88). O projeto foi "gestado como uma forma mais apropriada de aprofundar e cumprir o objetivo militar" do PCN, e, mesmo com dificuldades em termos conjunturais, conseguiu atingir seu intento, sendo inaugurada em 2002 sua primeira etapa (Andrade e Lima, 2018; Miyamoto, 2009).

Importante situar que o cenário de transição da década de 1980 para a de 1990 foi marcado pela abertura política e promulgação da Constituição Federal de 1988 (CF/1988), que abriu espaço para o fomento de políticas públicas "ao demandar da União a execução de planos nacionais e regionais de desenvolvimento e ordenamento do território, estabelecendo entre os objetivos fundamentais da República Federativa do Brasil a redução das desigualdades regionais" (Krüger et al., 2017, p. 49). Contudo, com a crise continuada da economia brasileira na década de 1990, apresentando elevado deficit fiscal, as ações voltaram-se para "o domínio da política monetária", centrada no "combate à inflação" (Cargnin, 2014, p. 20),

1. Semelhantemente a ZFM, as ALCs oferecem benefícios fiscais, como incentivos do Imposto sobre Produtos Industrializados (IPI) e do Imposto sobre Circulação de Mercadorias e Prestação de Serviços (ICMS). Para mais informações sobre a criação das ACLs, ver: Lei no 7.965/1989 - Tabatinga (AM); Lei no 8.210/1991 - Guajará-Mirim (RO); Lei no 8.256/1991 - Bonfim (RR) e Boa Vista (RR); Lei no 8.387/1991 - Macapá e Santana (AP); Lei no 8.857/1994 - Brasiléia, Epitaciolândia e Cruzeiro do Sul (AC) (Brasil, 1989; 1991a; 1991b; 1991c; 1994); entre outras. 
o que limitou o planejamento de forma geral e corroborou para a falta de recursos para as políticas públicas em andamento (Miyamoto, 2009, p. 96).

Mesmo com esse quadro adverso, em 1999, foi implementado o Programa para o Desenvolvimento Social da Faixa de Fronteira (PDSFF) - 1999-2002 -, que, sendo avaliado negativamente "devido à alocação de recursos sem diretrizes claras, desconsiderando as diferenças sub-regionais" (Krüger et al., 2017, p. 42), foi reestruturado e passou a se chamar Programa para o Desenvolvimento da Faixa de Fronteira (PDFF), tendo quatro eixos norteadores: i) fortalecimento institucional; ii) desenvolvimento econômico integrado; iii) cidadania; e iv) marco regulatório (Gadelha e Costa, 2005; Scherma, 2015). Com este direcionamento de esforços para o desenvolvimento, especialmente de regiōes vulneráveis do Brasil, em 2003, entrou em vigor a Política Nacional de Desenvolvimento Regional (PNDR), a qual, além de dar centralidade a esse processo se desdobrando em novos planos e programas (Cargnin, 2014), teve como seus principais instrumentos os fundos constitucionais de financiamento (FCFs), ${ }^{2}$ que em seu uso, de 1999 a 2011, os municípios dos arcos Central e Norte da FF tiveram "impactos significativos sobre o crescimento do produto interno bruto (PIB) per capita" (Resende e Silva, 2018, p. 375).

Fortalecendo esse cenário de retomada do desenvolvimento, além das políticas citadas, nos anos 2000, emergiram diversas políticas públicas, que foram implementadas na regiáo de fronteira, estando estas apresentadas na figura 1, quais sejam: i) facilitação de transportes rodoviários em fronteiras; ii) questóes migratórias; iii) concertação de fronteiras e turismo de fronteiras (Frontur); iv) Programa Escolas Interculturais de Fronteira (Peif); v) Sistema Integrado de Saúde nas Fronteiras (SIS-Fronteiras); vi) fronteiras e questóes migratórias - Sistema Integrado Nacional de Identificação de Veículos em Movimento (Sinivem) e Programa Nacional de Segurança Pública com Cidadania (Pronasci); vii) Programa Amazônia Protegida; viii) regularização fundiária; ix) Promoção da Sustentabilidade de Espaços SubRegionais (Promeso); entre outros (Brasil, 2005; 2008; 2009; 2010b; 2010c; 2016a; Krüger et al., 2017).

Entre as açóes públicas citadas, no aspecto desenvolvimento, destacam-se o Frontur, o Peif, o SIS-Fronteiras e o Promeso. O primeiro fomentou a aproximação cultural por meio do turismo, como uma ferramenta estratégica para a integração e o desenvolvimento econômico dos países da América do Sul (Brasil, 2010b). O Peif, iniciado em 2005 como Projeto Escola Intercultural Bilíngues de Fronteira (PEIBF), promoveu a construção de um "modelo de ensino comum nas escolas de fronteira, a partir do desenvolvimento de um programa para

2. Criados pela CF/1988 e regulamentados pela Lei no 7.827/1989, esses fundos visam ao "desenvolvimento econômico e social das regiões menos desenvolvidas" (Resende e Silva, 2018, p. 351). 
a educação intercultural, com ênfase no ensino do português e do espanhol" (Brasil, 2008, p. 2), englobando as cidades gêmeas do Brasil, do Uruguai, da Argentina, do Paraguai e da Venezuela. Na área de saúde, o SIS-Fronteiras, por meio de um aporte financeiro a 121 municípios fronteiriços, buscou "promover a integração de açôes e serviços de saúde na região e contribuir para a organização e o fortalecimento dos sistemas locais de saúde" (Brasil, 2010c, p. 5), perdurando até $2014 .^{3}$ O SIS-Fronteiras foi extinto pelo Ministério da Saúde (MS) sem avaliação geral dos seus resultados (Krüger et al., 2017). O Promeso, apesar de não ser específico para a região de fronteira, objetivou promover a articulação das políticas públicas, "identificando potencialidades e vulnerabilidades socioeconômicas, culturais, político-institucionais e ambientais" (Brasil, 2009, p. 6). Neste ínterim, é relevante citar que estudos demonstraram melhorias nos indicadores socioeconômicos na maioria dos municípios fronteiriços entre 2005 e 2013, e, mesmo não sendo possível atribuir os resultados às políticas públicas específicas citadas, houve melhorias nos indicadores educacionais, seguidas por avanços em saúde e emprego e renda (Brasil, 2015a; Krüger, Dantas e Castro, 2018).

Em 2010, ampliaram-se as discussóes relativas ao desenvolvimento regional fronteiriço com a criaçáo da Comissão Permanente para o Desenvolvimento e a Integração da Faixa de Fronteira (CDIF) e a instituição dos núcleos de fronteira, que entre as suas atribuiçóes constava a formulação de Planos Regionalizados de Desenvolvimento e Integração Fronteiriços (PDIFs) (Brasil, 2010). Ainda assim, nesse período, grande parte das políticas públicas para a região foram sendo esvaziadas e descontinuadas, como o PDFF, que tinha a maioria dos seus recursos oriundos de emendas parlamentares (Gimenez, 2015). Assim, a busca pelo desenvolvimento da fronteira ficou resumido ao Programa Integração Sul-Americana, que não era específico para a região e visava fortalecer a integração regional como um todo (Brasil, 2011). O programa teve dificuldades operacionais, "especialmente quanto ao contingenciamento de recursos, uma vez que, não era prioritário no governo federal" e não se mostrou efetivo (Scherma, 2015, p. 211).

Diante desse cenário, em 2012, foi proposto pelo MDR o Plano de Desenvolvimento Regional e Sustentável para a Faixa de Fronteira - Plano Brasil Fronteira (Brasil, 2012), que teria os mesmos princípios norteadores do PDFF, "todavia com mudanças em estratégias, objetivos, modelo de gestáo e indicadores resultados da experiência acumulada anteriormente". O plano teria incorporado de forma significativa as "disparidades regionais", criando um modelo de gestão regionalizado, no qual os municípios e outros atores locais "seriam os protagonistas das propostas de projetos e de sua gestão, levando em conta as suas especificidades"; seriam assim trabalhadas as prioridades por meio de "pactos de fronteiras".

3. 0 encerramento se deu por iniciativa do próprio MS, por meio da Portaria GM/MS no 622/2014 (Brasil, 2014). 
Contudo, a falta de centralidade do tema fronteiriço, a disponibilizaçáo de recursos e o apoio de outros ministérios, tiveram papel "fundamental para que o plano não se institucionalizasse" (Gimenez, 2015; Scherma, 2015, p. 213).

Desde então, as açóes públicas federais para a FF tiveram seus escopos sumariamente resumidos à área de segurança, como demonstram as políticas públicas implementadas desde 2010: i) Plano Estratégico de Fronteiras (PEF)/Operaçóes Sentinela e Ágata, 2010; ii) Estratégia Nacional de Segurança Pública nas Fronteiras (Enafron), 2012; iii) Sistema Integrado de Monitoramento de Fronteiras (Sisfron), 2012; e iv) Programa de Proteção Integrado de Fronteiras (PPIF)/Operação Muralha, 2016. Depois destas açóes, o Programa Desenvolvimento Regional e Territorial e o Programa Temático Justiça, Cidadania e Segurança Pública, ambos de 2016, apesar de não serem específicos para a região, contemplaram açóes para ela, como o avanço na implantação do Sisfron e do Sistema de Vigilância Agropecuária Internacional (Vigiagro), que reforçam a atuação e fiscalização na fronteira, além de proverem a constituição de infraestrutura complementar (Brasil, 2016a).

Percebe-se, assim, uma tendência dos decisores políticos em tornarem as açôes públicas para a fronteira territorial brasileira não mais específicas, mas um/ uns entre diversos outros objetivos inseridos em macropolíticas, por exemplo, a política externa implementada em 2016, que perdurou até 2019, que teve como objetivo geral "fortalecer a integração regional, com ênfase na América do Sul, contribuindo para a formaçáo de um espaço de paz e desenvolvimento", e, entre suas metas, estava a promoção do "desenvolvimento econômico e social das zonas de fronteira, por meio do incentivo a iniciativas conjuntas com os países vizinhos que permitam o enfrentamento dos desafios comuns", abarcando "áreas de saúde, educação, segurança pública, meio ambiente, entre outros, com vistas à melhoria da qualidade de vida de seus habitantes" (Brasil, 2016b, p. 205-206).

Ao analisar o escopo de atuação das açóes públicas em pauta, verifica-se que a maioria dos investimentos se deu em desenvolvimento de ordem socioeconômica, comparativamente à dimensão ambiental. Esta última dimensão encontra-se presente nos seguintes programas analisados: i) o PCN, que possui como prioridade a defesa da Amazônia (Miyamoto, 2009); ii) "o projeto de regularização fundiária, que, apesar de não traçar como objetivo expresso à preservação ambiental, contextualiza esta dimensão referindo-se ao processo de licenciamento ambiental" (Krüger $e t$ al., 2017); e iii) o PEF e o Sisfron, os quais, mesmo não tendo em "seus cernes a questão ambiental, buscam reprimir crimes transfronteiriços, como tráfico e contrabando, além de crimes ambientais" (Krüger, Dantas e Castro, 2018, p. 336).

Dessa forma, embora os princípios do desenvolvimento sustentável tenham sido incluídos "progressivamente no arcabouço normativo brasileiro, o progresso na implementação destas açóes segue um curso mais lento", sendo ainda premente 
a "necessidade de se colocar em prática essas diretrizes" (Fiorino, 2010; Krüger et al., 2017), permanecendo um desequilíbrio de instrumentos que pautem as dimensôes econômicas, sociais e ambientais nas ações públicas para a FF, e que não sejam descontinuados, mas inseridos em projetos de Estado, ou seja, de longo prazo. Complementarmente, constatou-se que, em termos da intersetorialidade das políticas públicas em análise, apesar de "haver fraca articulação nas ações propostas entre os entes da Federaçáo", desde 2010, com o PEF, "verifica-se uma maior articulação entre os diferentes ministérios" (Krüger, Dantas e Castro, 2018). Isto pode ter sido fruto da atuação da CDIF, pois as discussôes que a impulsionaram apontaram que o grande entrave das açôes públicas fronteiriças não se encontrava na falta de políticas, mas em sua desarticulação e fragmentação (Brasil, 2010).

Por fim, indo ao encontro das discussōes até aqui realizadas, quando se trata da CDIF, visando fortalecer a articulação para a formulação e coordenação das políticas para a FF, houve uma ampla discussão com a participação de inúmeras instituiçôes, resultando na reestruturação da comissão em 2018 (Brasil, 2018).

Ainda, em 2019, o Tribunal de Contas da União (TCU) realizou uma análise das políticas federais para a FF, apontando que estas objetivavam "promover o desenvolvimento sustentável da região, por meio do estímulo ao crescimento econômico com responsabilidade ambiental e justiça social", entre outros; todavia, a maioria das açóes relacionadas à região não tinha individualização orçamentária específica ${ }^{4}$ (TCU, 2019). A auditoria realizada pelo TCU, para avaliar os aspectos de governança do conjunto de políticas públicas para o fortalecimento da FF, averiguou que (TCU, 2019, p. 1-2):

- não consta na legislação brasileira uma política nacional para a FF;

- não foram formalmente estabelecidos instrumentos que possibilitem a identificação dos papéis e das responsabilidades dos envolvidos na política, de maneira a reduzir efeitos de sobreposiçóes e lacunas de atuação conjunta;

- falta sistematização específica para os países fronteiriços e mecanismos de cooperação internacional;

- existem fragilidades na lógica de intervenção integrada que abrangem as políticas federais relacionadas à FF;

- há insuficiência de planos capazes de orientar plenamente as ações dos diversos órgáos que atuam na região;

4. Os recursos consignados no PPA e na Lei Orçamentária Anual (LOA) podem se referir exclusivamente a essa região, apenas parcialmente ou, ainda, totalmente direcionados a outros locais (TCU, 2019). 
- a participação social e de partes interessadas em todas as fases dessas políticas federais ainda é limitada;

- Existe baixo grau de investimentos e carência de recursos humanos, materiais e financeiros dos órgãos responsáveis pela prevenção, pelo controle, pela fiscalização e repressão aos crimes transfronteiriços;

- fatores políticos, institucionais, operacionais e legais criam obstáculos à unidade de esforços;

- o modelo de monitoramento e avaliação utilizado pelos agentes executores das políticas públicas não fornece dados suficientes;

- não foi implantado um sistema de gestão de riscos capaz de identificar e gerenciar eventos que afetem os objetivos das açóes governamentais; e

- mecanismos utilizados para promover a comunicação e a prestação de contas da execução dessas políticas não asseguram a transparência.

\section{A PRESENÇA DAS FRONTEIRAS NO PLANO PLURIANUAL}

A CF/1988 trouxe forte amparo ao planejamento governamental, estabelecendo em seu art. no 165 o PPA, que se iniciou no período 1991-1996 e constitui-se como "um instrumento que determina, entre outros, diretrizes, objetivos e metas da administração pública durante um período de quatro anos" (Amorim, 2016, p. 11).

O PPA teve suas normas para elaboração e execução dos orçamentos da União regulamentadas no Decreto n 2.829/1998 (Brasil, 2000). Desde então, foram seis PPAs (2000-2003, 2004-2007, 2008-2011, 2012-2015, 2016-2019 e 2020-2023), nos quais o tema fronteiriço esteve inserido de modo evolutivo, e o governo federal fez ajustes ao desenho do modelo de planejamento à medida que encontrou desafios práticos de implementação (Amorim, 2016).

No PPA 2000-2003, a fronteira foi citada no tópico que insere a garantia da "defesa nacional como fator de consolidação da democracia e do desenvolvimento", sendo descrito que, devido ao Brasil se situar em uma "das regiōes mais desarmadas do mundo, em grande parte graças à relação de confiança com seus vizinhos", e possuir grandes dimensōes territoriais e "imenso patrimônio de recursos naturais ainda inexplorados", recomendar-se-ia que o país contasse "com forças suficientemente preparadas para gerar a dissuasão eficaz” (Brasil, 2000, p. 13).

O mesmo documento enfatiza as atividades de defesa na Amazônia, apontando a necessidade de ampliação e consolidação da presença do Estado na região e a intensificação da vigilância, com a implantação de unidades militares, ajudando as "fronteiras mais remotas a integrar a população civil à cidadania e, por extensão, à defesa nacional” (Brasil, 2000, p. 13). 
No PPA 2004-2007, a fronteira também é citada no contexto de defesa, sendo abordada no tópico "Preservar a integridade e a soberania nacionais" (Brasil, 2003). Contudo, em tal contexto, a ênfase não está exclusivamente pautada no aspecto militar, mas no esforço global, no qual a "defesa da soberania, nos seus múltiplos aspectos é responsabilidade de toda a sociedade", compreendendo, também, a conjuntura política, econômica, social e científico-tecnológica (Brasil, 2003, p. 95).

Além disso, no PPA 2004-2007, a fronteira é evidenciada conjuntamente à costa brasileira, abordando-se a extensão continental de ambas, a singularidade da terrestre com as suas relaçóes históricas bilaterais fraternas com todos os países sul-americanos e, especialmente, as "relações multilaterais com os países da Calha Amazônica e do Cone Sul, representados pelo Pacto Amazônico e pelo Mercado Comum do Sul (Mercosul)" (Brasil, 2003, p. 95). Abordou-se, ainda, o diferencial da região como área potencial para abertura de sistemas de integração com os países vizinhos, por meio da melhoria da mobilidade urbana e redução do custo no uso multimodal (Brasil, 2003).

No PPA 2008-2011, o contexto de integração fronteiriça adquiriu ainda mais destaque, ao ser ancorado no tópico "Fortalecer a inserção soberana internacional e a integração sul-americana” (Brasil, 2007, p. 100). Neste tópico, descreve-se que, apesar de o Brasil ser o país mais desenvolvido economicamente da América do Sul, o que gera assimetrias quando comparado aos seus vizinhos, essa situação deve ser enfrentada de modo que não haja obstáculos no processo de integração, pois a "América do Sul integrada é fundamental para a inserção de todos os seus países na arena global" (Brasil, 2007, p. 100).

Outro ponto novamente pautado foi a relevância das instituiçóes e dos foros internacionais para a integração, a coordenação política dos países sul-americanos e a expansão dos fluxos de comércio com outras regióes (Brasil, 2007). Ademais, no PPA 2008-2011 é descrita a importância da execução dos projetos entre o Brasil e os países vizinhos, como: infraestrutura econômica (exemplificado com diversas pontes e rodovias executadas); financiamentos; facilitação para importações e exportaçóes; integração energética; comunicação; e implementação de açóes e políticas públicas de cooperação. Neste último tópico são apontadas para este ínterim as açóes públicas a seguir descritas (Brasil, 2007, p. 104).

1) Programa Sul-Americano de Apoio às Atividades de Cooperação em Ciência e Tecnologia (Prosul), cujo intuito foi apoiar atividades de cooperação em ciência, tecnologia e inovação (CT\&I) entre grupos dos países sul-americanos, mediante a geração e a apropriação de conhecimento em temas estratégicos e a elevação da capacidade tecnológica dos países. 
2) Projeto Competitividade e Meio Ambiente (CyMA), cujo objetivo esteve em promover o desenvolvimento sustentável do setor produtivo do Mercosul, inserindo-o em uma política de integração regional que contenha estratégias e programas fomentadores da gestão ambiental e de uma produção mais limpa.

3) Diretrizes para promoção da gestão da qualidade do ar no âmbito do Mercosul.

4) Desenvolvimento de um sistema de informação ambiental compartilhado, que envolve os quatro países do bloco.

5) Elaboração do relatório nacional da Iniciativa Latino-Americana e Caribenha para o Desenvolvimento Sustentável (Ilac), que tratou de estatísticas e indicadores ambientais e de desenvolvimento sustentável.

6) No campo da educação, ferramenta descrita como fundamental para a integração sul-americana, foi citado o Setor Educacional do Mercosul (SEM), com a atividades nas áreas de educação superior, tecnológica-profissional e de educação básica.

7) Ainda no campo da educação, aponta-se, também, a atuação do Ministério da Educação (MEC) para a concretização do Instituto Mercosul de Estudos Avançados (Imea), criado em 2006, que objetivou qualificar recursos humanos para atuar na regiáo, atendendo a demandas nos setores ambientais, recursos hídricos, integração regional, arqueologia e desenvolvimento agrícola.

No PPA 2012-2015, a fronteira é citada preponderantemente na seção "Integridade e soberania nacional”, na qual quatro temas inter-relacionais são enfatizados: integração, desenvolvimento, institucionalização e segurança (Brasil, 2011). Em relação à integração sul-americana, foi evidenciado seu fortalecimento por meio da "integração econômica" e do "desenvolvimento socioeconômico compartilhado, os quais contribuíram para a preservação da paz na região", permanecendo, contudo, o desafio de "superação das assimetrias", devendo ser promovido o "desenvolvimento" dos países mais "atrasados", de forma a tornar o "espaço sul-americano uma grande área econômica, dinâmica e inovadora” (Brasil, 2011, p. 96).

A crescente institucionalização do Mercosul, da União das Nações Sul-Americanas (Unasul) e de seus conselhos, entre eles o Conselho de Defesa Sul-Americano (CDS), apresentou-se como "fundamental mecanismo consultivo para prevenção de conflitos", impulsão da "cooperação militar regional e a integração produtiva da indústria regional de defesa” (Brasil, 2011, p. 96). Porém, apesar do avanço do tema institucional, permanece a necessidade de ampliação da participação destes países nas "discussões sobre os principais temas relacionados à paz e à segurança 
internacionais, com prioridade ao desarmamento e a não proliferação de armamento nuclear", em fóruns de organismos multilaterais, como a "Organização das Naçóes Unidas (ONU), o Banco Mundial e o Fundo Monetário Internacional (FMI)”, sendo apontada, neste aspecto, a necessidade de uma "reforma da governança global" (Brasil, 2011, p. 96).

Temas reiterados também no PPA 2012-2015 foram os aspectos relativos à segurança, sendo pontuado o desafio da gestão pública, haja vista a dimensão territorial da fronteira brasileira, seu caráter continental e marítimo, e a quantidade de países limítrofes (Brasil, 2011). Foi apontada a necessidade de açóes para o combate à entrada de drogas e de armas, ao contrabando e a homicídios nas regióes de fronteira (Brasil, 2011).

Complementarmente, para operação exitosa nesse território, sugeriu-se a "mobilidade e interoperabilidade das Forças Armadas", a implantação de onze unidades especiais de fronteira da Polícia Rodoviária Federal (PRF), e o posicionamento estratégico e ativo do Brasil “, para a construção de um continente politicamente estável, próspero e unido, com base nos ideais democráticos e de justiça social” (Brasil, 2011, p. 97).

Chegando ao PPA 2016-2019, dois aspectos foram evidenciados mais fortemente a respeito do território fronteiriço, sendo eles a segurança e a integração de políticas públicas, como mostram os objetivos estratégicos do referido PPA, os quais apontam para o controle de fronteiras e a promoção de uma cultura de paz, por meio do "fortalecimento da segurança pública e redução de homicídios, com integração de políticas públicas entre os entes federados" (Brasil, 2015b, p. 38).

Entre as ações públicas destacadas no PPA 2016-2019 para a região estão, como citado antes, o Programa Desenvolvimento Regional e Territorial, o Programa Defesa Nacional e o Programa Temático Justiça, Cidadania e Segurança Pública (Brasil, 2015b). Contudo, nenhum destes programas é específico para a fronteira territorial brasileira, mas contemplam açóes para ela, como o avanço na implantação do Sisfron e do Vigiagro, os quais reforçam a atuação e a fiscalização na região, além de proverem a constituição de infraestrutura complementar (Brasil, 2015b).

O último PPA em análise, o de 2020-2023, semelhantemente ao anterior, não trata de políticas públicas específicas para a FF, sendo a região em estudo abordada no âmbito do programa Justiça, do Ministério da Justiça e Segurança Pública (MJSP), o qual traz, entre seus objetivos, o reforço da fiscalização das fronteiras, "de modo a aumentar a segurança da populaçáo brasileira" (Brasil, 2019, p. 31).

Ao analisar os PPAs, depreende-se que há uma evolução do entendimento sobre a fronteira territorial brasileira, nota-se que o tema avança entre os seus objetivos estratégicos, partindo de uma concepção de limite, com ações mais restritas à segurança e soberania, para a proposição de uma atuação mais dinâmica para a 
integração e o desenvolvimento. Contudo, a institucionalização do PPA, como instrumento de planejamento governamental nesta região, ainda carece de açóes que abranjam de forma equânime estas áreas e não se limitem aos esforços de contingenciamento e aumento de efetivo das áreas de segurança na região, como percebido nos últimos planos. Ademais, permanece a necessidade de aprimoramento entre orçamento, planejamento e execução das açôes públicas, verificando "o quanto do que foi planejado é executado a partir de dados mais concretos” (Amorim, 2016, p. 139). E, assim, quais destas açôes devem ter continuidade política, sendo ajustadas e redesenhadas, de forma a não serem "esvaziadas" e extintas, mas aprimoradas em novos PPAs, e, principalmente, nas mudanças governamentais.

\section{AVALIAÇÃO DAS POLÍTICAS PÚBLICAS IMPLEMENTADAS NA FAIXA DE FRONTEIRA}

\subsection{0 método}

Dada a limitação de dados quantitativos resultantes das políticas públicas em análise, como citado antes, o Ipea, em parceria com o MDR, encontrou caminhos para avaliar estas açóes públicas. Foi feito um levantamento de dados primários em oficinas de trabalho. A primeira oficina foi realizada em Brasília, onde foram discutidos e alinhados o escopo e a estrutura dos demais levantamentos da pesquisa. Posteriormente, as oficinas ocorreram nas sub-regióes da FF, também denominadas arcos, assim sendo: em Boa Vista (Roraima) - arco Norte; em Corumbá (Mato Grosso do Sul) - arco Central; e em Uruguaiana (Rio Grande do Sul) - arco Sul.

Com esse escopo, esta pesquisa tem natureza qualitativa, possuindo caráter exploratório, baseando-se em uma amostra de dados que objetivou levantar a percepção dos participantes a respeito das políticas públicas implementadas na FF do Brasil e, consequentemente, gerar análises e compreensão aprofundada dos resultados (Malhotra, 2012).

A técnica utilizada para a coleta dos dados foi a aplicação de questionários e grupos temáticos. ${ }^{5}$ Apesar da participação total de 231 pessoas nas quatro oficinas realizadas (Pêgo et al., 2017a; 2017b; 2018; 2019; 2020a), nem todos os participantes integraram os grupos de trabalho (GTs) e responderam aos questionários. Parte destes acompanharam discussóes temáticas, limitando-se a participarem das palestras, dos debates etc. Deste modo, o questionário foi respondido por 114 pessoas; sendo $30,7 \%$ dos questionários respondidos na oficina de Brasília; 22,8\%, na oficina do arco Norte; $21,9 \%$, na oficina do arco Central; e 24,6\%, na oficina do arco Sul. Seus perfis institucionais, a forma de organização dos GTs e as perguntas norteadoras, bem como o processo de identificação de categorias, são descritos a seguir.

5. Além desses, as atividades da pesquisa envolveram apresentações, debates, observações locais etc. 


\subsubsection{Perfil institucional dos participantes}

Para as quatro oficinas realizadas, foram convidados representantes de relevantes instituiçóes relacionadas à temática fronteiriça, sendo estes considerados especialistas nos temas e nas demandas que envolvem a regiáo. Uniram-se a eles, principalmente nas oficinas dos arcos, gestores e representantes da comunidade local. A tabela 1 apresenta a composição dos participantes das oficinas, observando que eles foram relatados mediante uma classificação institucional e não nominal.

TABELA 1

Oficinas de trabalho: perfil institucional e quantidade de participantes

\begin{tabular}{lccccc}
\hline \multirow{2}{*}{ Perfil institucional } & \multicolumn{5}{c}{ Quantidade de participantes } \\
\cline { 2 - 6 } & Brasília & Arco Norte & Arco Central & Arco Sul & Total \\
\hline Agentes públicos & 51 & 36 & 60 & 51 & 198 \\
Federais & 40 & 15 & 27 & 15 & $\mathbf{9 7}$ \\
Estaduais & 11 & 20 & 9 & 4 & 44 \\
Municipais & 0 & 1 & 24 & 32 & 57 \\
Organismos internacionais & 5 & 2 & 5 & 7 & $\mathbf{1 9}$ \\
Instituições privadas & 0 & 3 & 0 & 5 & $\mathbf{8}$ \\
Organizações não governamentais (ONGs) & 0 & 0 & 3 & 3 & 6 \\
Total & $\mathbf{5 6}$ & $\mathbf{4 1}$ & $\mathbf{6 8}$ & $\mathbf{6 6}$ & $\mathbf{2 3 1}$ \\
\hline
\end{tabular}

Fonte e elaboração: Equipe Fronteiras Ipea.

A partir dos dados de identificação, foi possível caracterizar o perfil institucional dos agentes participantes das oficinas, predominantemente de instituiçóes federais $(41 \%)$, seguidos dos pertencentes a instituiçóes municipais $(24 \%)$, estaduais (19\%) e, em menor número, internacionais (8\%). Evidencia-se, ainda, que os agentes públicos são preponderantes (85\%), e, entre as instituiçôes presentes, as universidades e instituiçōes de pesquisa foram representativas (48), sendo assim $20 \%$ dos participantes das oficinas, o que demonstra interesse e articulação dos agentes públicos e pesquisadores para o aprimoramento de políticas públicas. É, ainda, relevante destacar a participação de instituiçóes privadas (3\%) e de ONGs (2\%), demonstrando a pluralidade da representatividade, além da ampla experiência na temática em estudo de forma geral entre os participantes (tabela 1).

\subsubsection{Organização dos grupos de trabalho e perguntas norteadoras}

Os participantes das oficinas, um total de 114, que integraram os GTs (A, B e C) foram organizados de acordo com suas escolhas temáticas e conhecimentos, visando à discussão de aspectos distintos da gestão pública da FF. Na primeira 
oficina (realizada em Brasília), os grupos foram dispostos a partir das seguintes temáticas: i) Grupo A - integração e desenvolvimento; ii) Grupo B - mobilidade transfronteiriça; e iii) Grupo $\mathrm{C}$ - arranjos transfronteiriços e rede urbana, compostos respectivamente por $51,4 \% ; 25,7 \%$; e $22,8 \%$ dos participantes.

A partir da análise dos resultados da oficina em Brasília, as perguntas e os temas para discussão foram aprimorados para levantamento nas demais oficinas que ocorreriam nas sub-regióes da FF, sendo redefinidos como: i) o Grupo A economia e desenvolvimento, composto por 46,2\% (arco Norte), 32\% (arco Central) e 32,1\% (arco Sul) dos participantes de cada evento; ii) o Grupo B - gestão urbana, composto por 26,9\% (arco Norte), 44\% (arco Central) e 25\% (arco Sul) dos participantes de cada evento; e iii) o Grupo C - defesa do território e integração entre os povos, composto por 26,9\% (arco Norte), 24\% (arco Central) e 42,9\% (arco Sul) dos participantes de cada evento.

Verifica-se, a partir da formação dos GTs, que o tema desenvolvimento teve maior procura pelos participantes em Brasília e no arco Norte, quando comparado aos demais GTs. O tema gestáo urbana possuiu maior procura no arco Central, diferentemente do que foi apresentado no arco Sul, em que o tema defesa do território e integração entre os povos foi preponderante em percentual de participantes. Estes resultados refletem náo somente a diversidade entre os arcos da FF, mas também os temas prioritários na visão dos participantes; estando evidenciada, de uma forma geral, a deficiência de açóes públicas de desenvolvimento em toda a FF, mas especialmente no arco Norte (Pêgo et al., 2017a); a necessidade de congruência na gestão urbana dos municípios lindeiros do arco Central (Pêgo et al., 2019); e os esforços de integração acompanhados dos desafios legislativos apontados pelos participantes no arco Sul, à exemplo, a falta de amparo legal aos consórcios transfronteiriços (Pêgo et al., 2020a).

A respeito das perguntas norteadoras, ao todo foram três modelos de questionários aplicados, tendo cada GT questôes distintas voltadas as suas respectivas temáticas. Apesar dessa diversidade, todos os modelos foram compostos por três grupos de questóes abertas, sendo para esta análise selecionadas as respostas às questôes relativas à avaliação das ações públicas. Optou-se, assim, por selecionar, em cada um dos GTs, as perguntas que abordavam a análise e a avaliação de políticas públicas, visando aprofundar as investigaçóes relativas ao tema, eliminando as questôes que não eram específicas à temática em cada agrupamento. As respectivas perguntas norteadoras são apresentadas no quadro 1 . 
QUADRO 1

Perguntas norteadoras de avaliação de políticas públicas nos questionários

\begin{tabular}{|c|c|c|c|}
\hline \multirow[b]{2}{*}{ 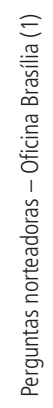 } & 1 GT-A - Integração e desenvolvimento & 1 GT-B - Mobilidade transfronteiriça & $\begin{array}{l}1 \mathrm{GT}-\mathrm{C} \text { - Arranjos transfronteiriços e } \\
\text { rede urbana }\end{array}$ \\
\hline & $\begin{array}{l}\text { Como os governos dos países têm } \\
\text { buscado, individualmente ou de } \\
\text { forma bi tri lateral, elaborar planos de } \\
\text { desenvolvimento das fronteiras? } \\
\text { Como esses planos se articulam? } \\
\text { Qual a avaliação e que medidas } \\
\text { podem ser sugeridas para melhorar } \\
\text { as políticas públicas voltadas direta } \\
\text { e indiretamente para as regiões de } \\
\text { fronteiras? }\end{array}$ & $\begin{array}{l}\text { Os governos dos países/estados têm } \\
\text { buscado, individualmente ou de forma } \\
\text { bi tri lateral, elaborar políticas públicas } \\
\text { nas regiões de fronteira? } \\
\text { Como essas políticas se articulam? } \\
\text { Qual a avaliação e que medidas } \\
\text { podem ser sugeridas para melhorar } \\
\text { as políticas públicas voltadas direta } \\
\text { e indiretamente à mobilidade e ao } \\
\text { trabalho nas regiões de fronteira? }\end{array}$ & $\begin{array}{l}\text { Como os governos têm buscado, indi- } \\
\text { vidualmente ou de forma bi tri lateral, } \\
\text { elaborar planos diretores e políticas } \\
\text { públicas para as cidades das regiões } \\
\text { de fronteira? } \\
\text { Como esses planos e políticas se } \\
\text { articulam? } \\
\text { Qual a avaliação e que medidas } \\
\text { podem ser sugeridas para melhorar os } \\
\text { planos diretores urbanos e as políticas } \\
\text { públicas nas regiões de fronteira? }\end{array}$ \\
\hline \multirow[b]{2}{*}{ 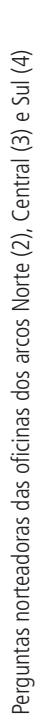 } & $\begin{array}{l}\text { 2, } 3 \text { e } 4 \text { GT-A - Economia } \\
\text { e desenvolvimento }\end{array}$ & 2, 3 e 4 GT-B - Gestão urbana & $\begin{array}{l}\text { 2, } 3 \text { e } 4 \text { GT-C - Defesa do território e } \\
\text { integração entre os povos }\end{array}$ \\
\hline & $\begin{array}{l}\text { Como avalia as políticas públicas e as } \\
\text { ações referentes a: } \\
\text { infraestrutura e logística (presença ou } \\
\text { previsão de corredores viários, circu- } \\
\text { lação, transportes, aduana, pontes, } \\
\text { navegação); } \\
\text { financiamento (infraestrutura e } \\
\text { equipamentos urbanos); e } \\
\text { tecnologia (pesquisa em universida- } \\
\text { des, institutos federais, e outros). }\end{array}$ & $\begin{array}{l}\text { Como avalia as políticas públicas e as } \\
\text { ações referentes a: } \\
\text { planejamento e gestão (integração } \\
\text { entre municípios do arranjo transfron- } \\
\text { teiriço, participação e debates entre } \\
\text { segmentos dos dois lados da fronteira, } \\
\text { ações compartilhadas); } \\
\text { oferta de equipamentos e serviços } \\
\text { (saúde, educação, cultura, mobilidade, } \\
\text { circulação urbana, saneamento, ges- } \\
\text { tão das águas/rios, entre outros); e } \\
\text { turismo (patrimônio arquitetônico, his- } \\
\text { tórico, natural e paisagístico, turismo } \\
\text { de compras, turismo de passagem no } \\
\text { cruzamento da fronteira). }\end{array}$ & $\begin{array}{l}\text { Como avalia as políticas públicas e as } \\
\text { ações referentes a: } \\
\text { gestão ambiental (unidades de } \\
\text { conservação, recursos minerais, } \\
\text { biodiversidade, vigilância sanitária, } \\
\text { cooperação internacional); } \\
\text { povos da região (nações indígenas, } \\
\text { ribeirinhos, assentados, quilombolas, } \\
\text { garimpeiros, posseiros, minera- } \\
\text { dores, agricultores, pecuaristas e } \\
\text { madeireiros); } \\
\text { migrações (impactos das migrações, } \\
\text { estratégias de acolhimento ao } \\
\text { imigrante, orientação ao emigrante, } \\
\text { inclusão produtiva, sistema de moni- } \\
\text { toramento); e } \\
\text { segurança (ilícitos ambientais, } \\
\text { mineração irregular, biopirataria, } \\
\text { hidropolítica, tráfico de drogas, armas } \\
\text { e pessoas, cooperação técnica na área } \\
\text { de inteligência, protocolo comum } \\
\text { entre órgãos de controle da fronteira). }\end{array}$ \\
\hline
\end{tabular}

Fonte e elaboração: Equipe Fronteiras Ipea.

\subsubsection{Procedimentos para a identificação de categorias}

Após a coleta e organização dos dados, utilizou-se o método da análise de conteúdo temático, que consiste em um conjunto de procedimentos objetivos e sistemáticos para categorização dos temas abordados com maior frequência em questionários, entrevistas, documentos, entre outros (Bardin, 2011; Malhotra, 2012). Para isso, a verificação foi realizada com o auxílio do software NVivo, que contribui ao agilizar a organização e o processo de investigação (Mozzato e Grzybovski, 2011). As análises se desenvolveram em três estágios, seguindo a metodologia proposta por Bardin (2011), Saldaña (2013) e Miles, Huberman e Saldaña (2013), conforme a seguir. 
1) No primeiro estágio, foram determinadas as categorias a priori, formadas pela seleção das respostas às questôes de avaliação das políticas públicas implementadas na FF (quadro 1).

2) No segundo estágio, foram determinadas as categorias a posteriori. Para isso, realizou-se a contagem de palavras, pois por meio dela são identificados indícios de temas materiais na pesquisa (Kaefer, Roper e Sinha, 2015). Na contagem de palavras, foram retiradas as que não apresentavam significado no contexto, como preposiçóes, advérbios, conjunçóes e verbos; optando-se por incluir as cem palavras mais citadas com no mínimo cinco letras, apresentadas nas nuvens de palavras (figura 2, na próxima subseção).

3) No terceiro estágio, os temas materiais foram codificados. A codificação das respostas foi realizada por meio da análise dos seus significados a partir da convergência e divergência das respostas. Foram consideradas opinióes convergentes às respostas citadas por mais de uma pessoa; e divergentes, as respostas isoladas. As respostas convergentes determinaram categorias que foram incluídas na matriz, e as divergentes, desconsideradas.

Esses resultados permitiram a criação de uma matriz de categorias identificadas, dada pela convergência das categorias a priori e a posteriori (tabela 2, na próxima subseção). A partir destas categorias, foram selecionadas as respostas representativas dos participantes em cada contexto. Na próxima seção, estes resultados são apresentados nas nuvens de palavras e na matriz de categorias identificadas, sendo analisados e discutidos.

\subsection{Avaliação das políticas públicas fronteiriças a partir da perspectiva dos participantes}

Com o tratamento dos dados qualitativos e a contagem de palavras, utilizando-se o software NVivo, foi possível verificar a frequência com que cada termo aparece nos documentos analisados, assim sendo, nos arquivos referentes às respostas às questōes avaliativas das políticas públicas fronteiriças. Esta análise teve por objetivo evidenciar os fatores-chave para a melhoria das açóes públicas nos referidos territórios. Assim, como mostra a figura 2, percebem-se temas materiais congruentes e diversificados, expressos em cada nuvem de palavras. Esses temas são resultantes das análises de questóes aplicadas nas oficinas realizadas em Brasília e nos arcos Norte, Central e Sul da FF. 


\section{FIGURA 2}

Nuvens de palavras resultantes das análises das respostas aos questionários aplicados nas oficinas de trabalho em Brasília (2A), no arco Norte (2B), no arco Central (2C) e no arco Sul (2D) da faixa de fronteira terrestre

2A - Brasília

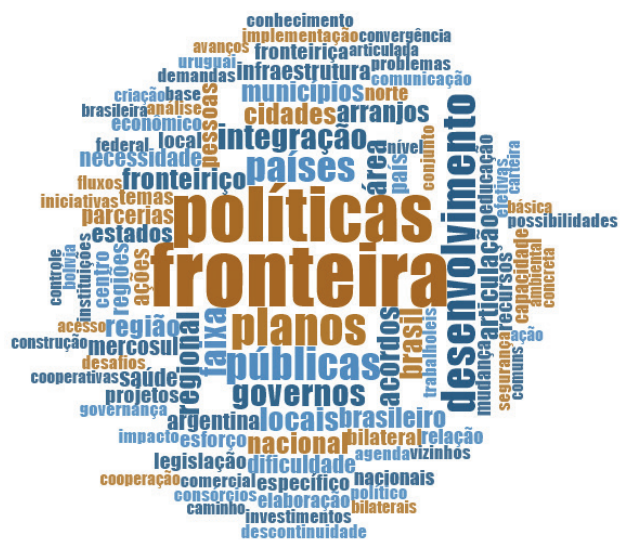

2C - Arco Central

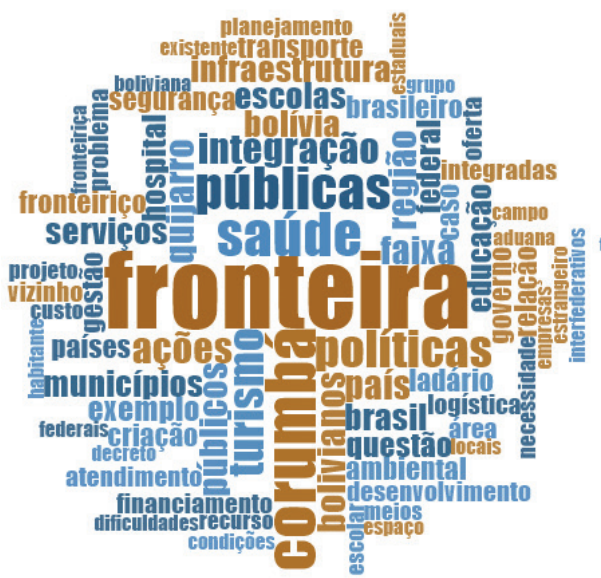

2B - Arco Norte

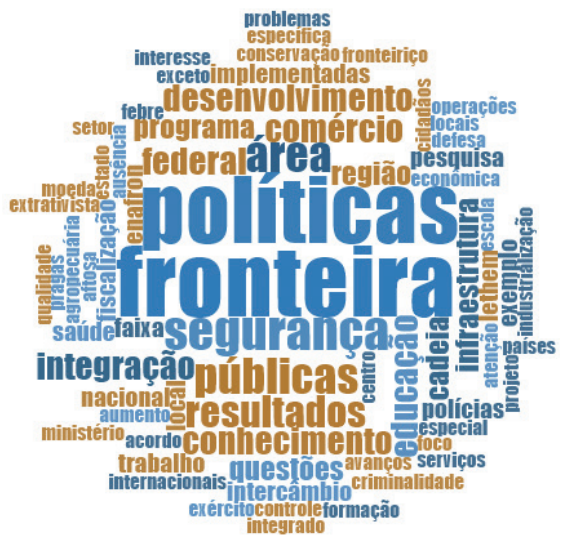

2D - Arco Sul

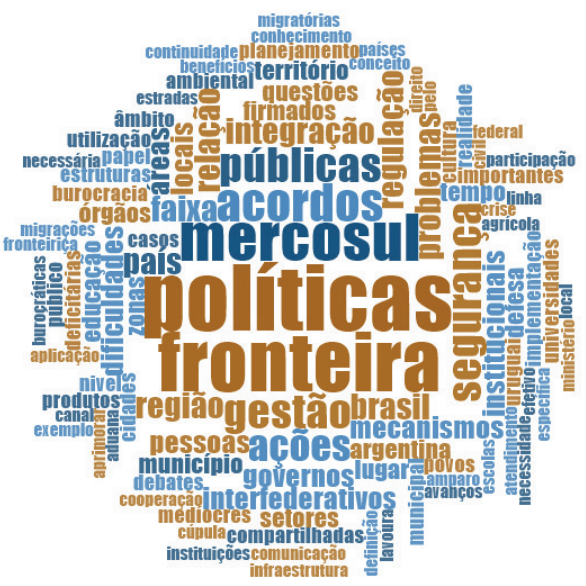

Fonte: Oficinas de trabalho.

Elaboração: Equipe Fronteiras Ipea.

De forma geral, nas falas dos participantes, são evidenciadas escalas de temas materiais-chave com grande distinção, mas relativamente semelhante ao se comparar os resultados das quatro oficinas. Ou seja, apesar dos termos salutares demonstrarem escala de prioridades diversas, os fatores-chave para a melhoria das políticas públicas são correspondentes para os participantes. Os resultados demonstraram nas quatro oficinas os seguintes elementos-chave comuns: fronteira (território, região, área, faixa, linha, local, espaço, lugar); política (pública, programa, plano/planejamento, ação, decreto, 
legislação, regulação, amparo, continuidade, direitos, participação etc.); governos (federal/federativo/interfederativo, ministério, estadual, municipal etc.); fronteiriço (habitantes, povos, pessoas, grupos, vizinho, estrangeiro, migrante/migração etc.); integração (acordo, cooperação, Mercosul, intercâmbio, relação, compartilhar, debater etc.); gestão; desenvolvimento; infraestrutura e serviços (saúde/hospital/atendimento, educação/escolas/universidades; conhecimento/cultura; trabalho; industrialização; lavoura/agrícola/agricultuta/agropecuária; meio ambiente/ambiental/conservação; transporte/logística/estradas; defesa/exército; segurança/fiscalização/controle/aduana; comércio, turismo, comunicação etc.); recursos/condiçôes; instituiçóes; empresas; entre outros (figura 2). Assim, diante da contagem de palavras, o indício destes temas materiais apontou os fatores-chave a serem analisados nas respostas dos participantes.

Da análise de conteúdo das respostas, emergiram quatro macrocategorias temáticas, que agruparam as falas dos participantes. A primeira (1) relaciona-se ao desempenho das politicas públicas, estando subdividida em outras cinco subcategorias: (1.1) baixa descentralização e articulação interfederativa; (1.2) desafios em planejamento, orçamento e gestão de políticas públicas; (1.3) falta de institucionalidade política; (1.4) descontinuidade das políticas públicas; e (1.5) carência de informaçôes para monitoramento e avaliação. A segunda categoria (2) é infraestrutura e acesso a serviços; vem seguida da categoria (3) acordo e integração política e econômica, nacionais, bi e trilaterais, e da (4) diversidades sociocultural e territorial. Importante salientar, que a ordem de classificação das categorias, apresentadas na tabela 2, evidencia a prevalência entre elas nos apontamentos, demonstrando, entre o total de participantes, a porcentagem que abordou o respectivo elemento em cada GT, ou seja, GT-A - Economia e desenvolvimento; GT-B - Gestão urbana; e GT-C - Defesa do território e integração entre os povos.

TABELA 2

Matriz de categorias identificadas

(Em \%)

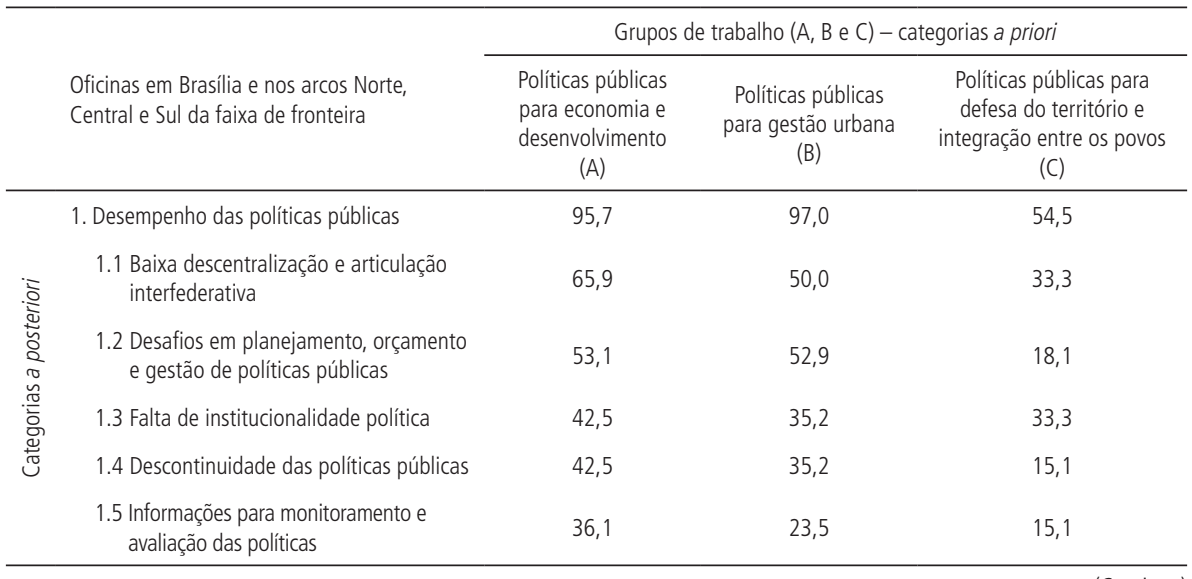




\begin{tabular}{|c|c|c|c|c|}
\hline & \multirow[b]{2}{*}{$\begin{array}{l}\text { Oficinas em Brasília e nos arcos Norte, } \\
\text { Central e Sul da faixa de fronteira }\end{array}$} & \multicolumn{3}{|c|}{ Grupos de trabalho (A, B e C) - categorias a priori } \\
\hline & & $\begin{array}{l}\text { Políticas públicas } \\
\text { para economia e } \\
\text { desenvolvimento } \\
\text { (A) }\end{array}$ & $\begin{array}{l}\text { Políticas públicas } \\
\text { para gestão urbana } \\
\text { (B) }\end{array}$ & $\begin{array}{l}\text { Políticas públicas para } \\
\text { defesa do território e } \\
\text { integração entre os povos } \\
\text { (C) }\end{array}$ \\
\hline \multirow{3}{*}{ 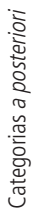 } & 2. Infraestrutura e acesso a serviços & 51,0 & 76,4 & 72,7 \\
\hline & $\begin{array}{l}\text { 3. Acordos e integração política e econômica, } \\
\text { nacionais, bi e trilaterais }\end{array}$ & 44,6 & 91,1 & 39,9 \\
\hline & 4. Diversidade sociocultural e territorial & 14,8 & 23,5 & 15,1 \\
\hline
\end{tabular}

Fonte: Oficinas de trabalho.

Elaboração: Equipe Fronteiras Ipea.

Primeiramente, ao analisar a tabela 2, verifica-se que a incidência de apontamentos sobre o baixo desempenho das políticas públicas fronteiriças foi maior no GT-B - gestão urbana $(97,0 \%)$ e no GT-A - economia e desenvolvimento (95,7\%), comparativamente ao GT-C - defesa do território e integração entre os povos $(54,5 \%)$, demonstrando que, apesar das categorias apontadas pelas falas dos participantes serem gerais em relação às políticas públicas fronteiriças, o aspecto de defesa e segurança permanece como área prioritária nas açôes governamentais, em detrimento às demais açóes para a melhoria da gestão ou desenvolvimento, por exemplo (Krüger et al., 2017; Krüger, Dantas e Castro, 2018). Em relação à infraestrutura e ao acesso a serviços, foi preponderante entre os GTs a constatação de que poucas políticas públicas tiveram açóes além do limite internacional para o aprimoramento dessas áreas (Pêgo et al., 2017a; 2017b; 2018; 2019; 2020a).

Outro ponto relevante a ser considerado a partir da tabela 2 diz respeito à escassez de políticas públicas que respaldem acordos e integraçâo para a melhoria da gestão urbana, principalmente entre as cidades gêmeas da FF e seus homólogos nos países vizinhos (Pêgo et al., 2017a; 2017b; 2018; 2019; 2020a), evidenciado por grande parte dos participantes do GT-B $(91,1 \%)$. Ainda, apesar das características socioculturais e territoriais serem claramente distintas entre as sub-regiōes da FF, e este fator ser descrito em inúmeros documentos governamentais (Brasil, 2005; 2011; 2016a), foram apontados por todos os grupos (GT-A 14,8\%; GT-B 23,5\%; GT-C 15,1\%) os desafios das políticas públicas implementadas em considerá-lo no desenho destas para a regiáo.

Tratando especificamente de cada categoria elencada, o desempenho das politicas públicas se apresentou preponderante entre as falas e evidenciou cinco elementos que repercutem diretamente nos resultados das açóes públicas. O primeiro deles é a baixa descentralização e articulação interfederativa. Para os correspondentes da pesquisa, as políticas públicas fronteiriças são concebidas à distância, sem participação efetiva 
dos povos das fronteiras, seus principais interessados. E o processo de construção das políticas federais ainda se apresenta centralizado, com pouca participação dos governos locais e dos municípios envolvidos. Estas evidências corroboram com as afirmaçôes de Abrucio (2007) e Arretche (2006) de que o processo de descentralização no Brasil ocorreu com baixos incentivos à articulação intergovernamental, além de contar com a sobrevivência do patrimonialismo, promovendo falhas no desempenho das açóes do poder público.

Esse cenário torna-se, ainda, mais complexo por se tratar da FF, pois se já há pouca representatividade da população desta localidade na articulação intragoverno, no processo de construção das políticas públicas para a regiâo, não há autonomia e respaldo jurídico para direcionamento de soluçôes às problemáticas locais transfronteiriças. Assim, tornam-se essenciais iniciativas que promovam maior articulação por meio de diálogo entre os entes federativos (no caso brasileiro, estados e municípios), como também o fortalecimento dos núcleos de fronteira e da CDIF para estabelecimento de um marco legal, de forma que os núcleos possam articular planos de desenvolvimento na região fronteiriça, conjuntamente com os países vizinhos; consolidando, assim, uma agenda transnacional (Krüger et al., 2016).

O segundo elemento, largamente apontado entre os participantes, diz respeito aos desafios em planejamento, orçamento e gestão de políticas públicas, como demonstra a seguinte fala de um participante:

no planejamento e na gestão, a integração transfronteiriça, com participação, debates e açôes compartilhadas, acontece somente em nível local dos municípios, mesmo assim de forma pontual e sem planejamento. Os governos centrais (...) estáo ausentes ou sáo pouco participativos. Dessa maneira, a maior parte das decisóes e encaminhamentos não se concretiza.

A esse respeito, Milani (2008, p. 576) aponta que as "soluçôes não encontradas no plano nacional podem ser pensadas criativamente, desenvolvidas e implementadas localmente", desempenhando os governos locais "a função nodal no processo de articulação das redes de política pública, desde que, para desempenhar tal papel, tenham os recursos orçamentários e os meios políticos e institucionais necessários". Contudo, sendo os municípios fronteiriços carentes de institucionalidade política e orçamentária, as açôes em âmbito local tornam-se restritas e sem efetividade.

Essa afirmação está associada ao terceiro elemento relacionado ao desempenho das políticas fronteiriças, a falta de institucionalidade política, conforme evidenciado na seguinte afirmação: "a fronteira carece de institucionalidade, tanto no aspecto da legislação, quanto das organizaçóes e suas respectivas capacidades (pessoas, orçamento etc.). O número de funcionários que 'pensam e trabalham' as fronteiras é bastante reduzido e as iniciativas são pouco 'enraizadas'”. De modo geral, os resultados demonstraram que as políticas públicas fronteiriças careceram 
de integração intersetorial e interinstitucional, se apresentando incipientes, pouco efetivas, destituídas de fórmulas institucionais que tenham características de estabilidade e durabilidade, e, especialmente, no caso da formulação de políticas públicas bilaterais, praticam-se apenas tentativas de diálogo, sem formar ação mais coordenada, inclusive institucionalmente, resultando em baixo nível de convergência e difícil execução (Pêgo et al., 2017a, p. 248).

As limitaçôes em institucionalidade política têm efeito na descontinuidade das políticas públicas na região (quarto elemento), pois geram dependência excessiva de disposiçôes individuais. Neste sentido, é perceptível, ao retomarmos o histórico político da FF, que, apesar de programas terem sido implementados, nas trocas de governo as políticas tiveram seus recursos diminuídos ou até interrompidos (Brasil, 2016a). Portanto, faz-se necessário a formação de um arcabouço legal que ampare, além das questóes de segurança e defesa, a continuidade de programas essenciais ao desenvolvimento, com o estabelecimento de uma agenda que agregue objetivos e metas de longo prazo. Esta dinâmica consistente e coesa das políticas públicas é fundamental para corroborar com as demandas contemporâneas do desenvolvimento sustentável, conforme argumentado por Leal Filho (2000) e Bursztyn e Bursztyn (2012).

O quinto elemento concatenado ao desempenho das políticas é a carência de informaçôes para monitoramento e avaliação das políticas na FF. Segundo os correspondentes, as políticas públicas para as regióes de fronteira devem ser sistematicamente avaliadas, por meio do levantamento contínuo de informações de fluxo (em complemento a informaçóes de estoque), adicionado a dados sobre os demais países da América do Sul, com base em elementos provenientes da própria zona fronteiriça. Estas falhas são condizentes com Jannuzzi (2012), que relata um conjunto de deficiências a serem corrigidas nos sistemas avaliativos nacionais, como a descontinuidade nos levantamentos e os problemas na cobertura territorial dos dados gerados.

Sobre a segunda categoria, infraestrutura e acesso a serviços, percebe-se que a falta dos aparatos institucionais e legais somada à escassez de recursos públicos formam um cenário de restriçôes orçamentárias e políticas para execução e término de obras de infraestrutura e melhoria dos serviços públicos prestados. Além disso, nas falas dos participantes, a construção de infraestruturas e disposição de serviços resultantes das açóes públicas implementadas na fronteira tiveram dificuldade de articulação com os países vizinhos, por exemplo: em compensação orçamentária; burocracias para efetivação de obras propulsoras de mobilidade urbana; limitados acordos para gestão integrada de serviços públicos, como vigilâncias sanitárias, ambientais e epidemiológicas; açôes para erradicação de pragas e doenças descoordenadas, entre outros. Ainda assim, a mobilidade e o acesso a serviços existentes podem ser facilitados, buscando a harmonização das políticas e acordos bilaterais. 
Dessa forma, ao chegar à terceira categoria, acordos de integração política e econômica nacionais bi e trilaterais, os correspondentes descreveram que é impreterível a aprovação de legislação que legitime a formação (ou o fortalecimento) de consórcios multifinalitários entre cidades fronteiriças, promovendo a melhoria da qualidade dos serviços públicos, pois, pela falta de amparo legal, são poucas as experiências de planos integrados. Mesmo que as localidades dividam problemáticas, como a incidência de doenças tropicais na fronteira norte, que reverberou em parceria entre Suriname e platô das Guianas para compartilhamento de conhecimento e tecnologia, ou a carteira de fronteiriço na fronteira sul, que facilitou o trabalho do cidadão brasileiro em cidade homóloga no país vizinho, e da mesma forma o contrário. E haja experiências exitosas, tais iniciativas são pontuais, complexas e não necessariamente imediatas, isso porque ainda se faz necessário avançar na adoção de medidas de equivalência (desburocratizadas), sobretudo em relação à circulação de pessoas, serviços, educação e trabalho; e a premência de facultar termos, acordos, revogando limitações legais que impedem a mútua cooperação entre governos locais e provinciais para o desenvolvimento integrado (Pêgo et al., 2017a; 2017b; 2018; 2019; 2020a).

Assim, dada a quarta categoria, a diversidade sociocultural e territorial das regióes que compóem a faixa de fronteira, não há como estabelecer uma política pública única como resposta a todas as demandas existentes, náo havendo, também, um modelo de avaliação homogênea para estas açôes. Estas características se apresentam mais complexas para algumas localidades, como as cidades da região Norte, que estão mais distantes do centro político e econômico do país, além de apresentar maiores dificuldades socioeconômicas, quando comparadas às demais localidades da fronteira nacional (Brasil, 2015a). Ou seja, além de haver uma clara diferenciação entre os arcos da FF, deve-se sustentar uma segura diferenciação entre aqueles municípios que apresentam maior grau de complexidade em relação ao processo de integração e implementação de políticas públicas dos demais municípios fronteiriços.

Ao finalizar, é importante ainda ressaltar que, apesar das açôes públicas terem sido avaliadas pelos participantes em seus contextos gerais, algumas delas foram citadas especificamente, demonstrando a maior divulgação ou repercussão de seus escopos de açóes, como as na área de segurança: Enafron, que, segundo os participantes, proporcionou a aquisiçáo de equipamentos, parceria e intercâmbio entre as polícias; Sisfron; e operaçôes especiais, tais como Ágata e Sentinela. Além destas, foram pautados o Peif, programa que oportunizou intercâmbio entre as escolas, mas que foi descontinuado em muitas localidades por falta de recursos; e o SIS-Fronteira, que aumentou a receita para a saúde, mas se limitou ao "lado brasileiro", sendo também extinto. 
Também foram citados programas não específicos para a região de fronteira, mas que tiveram açôes no local, como o Rotas de Integração Nacional e o Programa Fitossanitário, do Ministério da Agricultura, Pecuária e Abastecimento (Mapa), cujos resultados foram descritos como avanços lentos e de duração mínima, perdurando somente durante a vigência do projeto, devido aos governos atuarem de maneira errática e desordenada, desarticulada, sem efetivo diálogo entre os atores. Foi pontuado ainda, que, apesar destas açóes, as principais políticas públicas para a fronteira acabam revestindo-se de caráter militar ou paramilitar, nas quais o foco das operaçóes encontra-se concentrado em torno das questóes impostas a partir dos grandes centros urbanos do país, tais como o tráfico de armas ou de drogas, deixando de enfrentar os principais desafios socioeconômicos ou ambientais da fronteira.

Nesse sentido, as alternativas apontadas pelos participantes não se encontram em cauterização, fechamento ou muros, mas no encontro de alternativas para se construir uma fronteira com capacidade de controle seletivo, como ponderado na seguinte afirmação:

a gente quer poder passar. Não quer que isso seja impossível. E outras coisas, se abastecer também de serviços públicos que são muito relevantes, que estáo presentes, muitas vezes logo ao lado e são a solução mais fácil, mais barata. Seria bom que isso fosse reconhecido (Pêgo et al., 2017a).

Para isso, a legitimação por meio de amparo legal da fronteira como zona e náo como limite é crucial, assim como a retomada de um plano de governo que vise à governança transfronteiriça, ou seja, a "coordenação de políticas" e o "gerenciamento de interdependências territoriais para o alcance de melhores resultados" (Krüger, 2019, p. 23), com priorização do desenvolvimento sustentável da região a longo prazo, com diretrizes temporais, orçamentárias e metas claras, nas vertentes ambientais, sociais e econômicas (Fiorino, 2010; Leibenath, 2007), cujo escopo preze o locus e reconheça os diferenciais das sub-regionais, tendo o fronteiriço como beneficiário prioritário e agente direcionador das demandas latentes para a região (Pêgo et al., 2017a; 2017b; 2018; 2019; 2020a).

\section{CONSIDERAÇÕES FINAIS}

Os resultados da avaliação das políticas públicas federais voltadas à FF demonstram que, de modo geral, elas foram implementadas com maior incidência a partir de 2000, com exceção do Programa Calha Norte e das ALCs, que remetem a década de 1980, e do PDSFF, de 1999, reestruturado como PDFF. Além destes, houve pelo menos onze programas nos anos 2000 que abarcaram a região ou grande parte dela, nas áreas de transporte, turismo, migração, educação, saúde, fiscalizaçãa, regularização fundiária, segurança, desenvolvimento sustentável, entre outros. Em 2010, com o diagnóstico de que estas açôes encontravam-se desarticuladas e 
fragmentadas, foi criada a CDIF, visando coordenar e estimular a articulação com os governos regionais. Também foram criados os núcleos de fronteira, tendo como um dos objetivos principais gerar planos regionalizados para a regiāo.

Desde então, apesar da ampliação das discussōes relativas ao desenvolvimento regional fronteiriço, ocorreu um esvaziamento e encerramento da maioria destes planos. Houve, em seguida, tentativas de implementação de programas de desenvolvimento específicos para a regiâo, como o Plano Brasil Fronteira, mas a falta de centralidade do tema fronteiriço, de disponibilização de recursos e de apoio de outros ministérios foram cruciais para a sua não institucionalização. Avançaram neste período programas que tiveram como tema prioritário pautas em segurança e fiscalização, como o PEF, a Enafron, o Sisfron, o Programa de Proteção Integrada de Fronteiras etc. Em 2018, foi criado um GT, sob a coordenação do então Ministério da Integração Nacional (MI), visando aperfeiçoar a PNDR. Fez parte dessa revisão a discussão do papel da CDIF, com intuito de tornar a comissão ainda mais qualificada para cumprir seu papel de coordenação das políticas de fronteira no Brasil. A partir de 2019, várias atividades foram realizadas, entre elas a volta do cronograma de reunióes com instituiçôes federais ligadas ao tema fronteira e com os núcleos estaduais de fronteira.

Complementarmente, ao analisar a pauta dos PPAs, percebeu-se que, apesar do tema ter avançado no entendimento e planejamento governamental, partindo de uma concepção de limite, com açôes mais restritas à segurança e soberania, para a proposição de uma atuação mais dinâmica de integração e desenvolvimento, nos últimos PPAs, resumiu-se a metas em macroprogramas governamentais. Verifica-se ainda que muitos programas implementados na região tiveram escopo em grande medida socioeconômico, mas que pouco integraram o tema ambiental. Além disso, a responsabilidade dos seus investimentos esteve fortemente centrada no governo federal, com baixa articulação dos programas em termos de descentralizaçâo para os âmbitos estaduais e municipais.

Além de um conjunto de demandas em infraestrutura e acesso a serviços essenciais, averiguou-se, por meio da avaliação executada pelos participantes das oficinas, que, apesar dos avanços que as políticas públicas em pauta proporcionaram, diversos fatores influenciaram negativamente o desempenho das ações públicas na região, entre eles se destacam a baixa descentralização e articulação interfederativa, a descontinuidade das políticas públicas e a carência de informaçóes para monitoramento e avaliação.

Esses apontamentos também foram ratificados pelo TCU em sua auditoria, em 2019, que salientou a premência de conter na legislação brasileira uma política nacional para a FF, com instrumentos e responsabilizaçáo clara entre os órgãos que atuam na regiáo; planejamento e implementação articulados entre os entes federativos; com a essencial participação social; mecanismos de investimento e cooperação internacionais estabelecidos; e monitoramento e avaliaçáo para gerenciamento dos objetivos e das açôes governamentais. 


\section{REFERÊNCIAS}

ABRUCIO, F. Trajetória recente da gestão pública brasileira: um balanço crítico e a renovação da agenda de reformas. Revista de Administraçáo Pública. Rio de Janeiro, Edição Especial Comemorativa, p. 67-86, 1967-2007.

ALLEN, E. A. Calha Norte: military development in Brazilian Amazonia. Development and Change, v. 23, n. 1, p. 71-99, 1992.

AMORIM, I. T. A institucionalizaçáo do plano plurianual (PPA): um estudo no governo federal brasileiro nos períodos de 2000-2003 e 2004-2007. 2016. Dissertação (Mestrado) - Faculdade de Economia, Administraçáo e Contabilidade, Universidade de São Paulo, São Paulo, 2016.

ANDRADE, I. O.; LIMA, R. C. Segurança e defesa nacional nas fronteiras brasileiras. In: PÊGO, B.; MOURA, R. (Orgs.). Fronteiras do Brasil: uma avaliação de política pública. Rio de Janeiro: Ipea; MI, p. 111-150, 2018.

ANTUNES, E. M; SENHORAS, E. M.; TREVISAN, R. Dinâmica fronteiriça no arco norte brasileiro no contexto das Áreas de Livre Comércio. Cadernos de Finanças Públicas, Brasília, n. 12, p. 39-63, dez. 2012.

ARRETCHE, M. Federalismo e políticas sociais no Brasil: problemas de coordenação e autonomia. In: SARAVIA, E; FERRAREZI, E. (Org.). Políticas públicas: coletânea. Brasília: Enap, 2006.

BARDIN, L. Análise de conteúdo. 1. ed. São Paulo: Ediçóes 70, 2011.

BARTIK, T.; BINGHAM, R. Can economic development programs be evaluated? Kalamazoo, Michigan: Upjhon Institute for Employment Research, 1995. (Working Paper, p. 95-29).

BRASIL. Lei no 7.965, de 22 de dezembro de 1989. Cria área de livre comércio no município de Tabatinga, no estado do Amazonas, e dá outras providências. Diário Oficial da União, Brasília, 1989. Disponível em: <https://bit.ly/38CzzLV>. Acesso em: 4 abr. 2020.

. Lei no 8.210, de 19 de julho de 1991. Cria a área de livre comércio de Guajará-Mirim, no estado de Rondônia, e dá outras providências. Diário Oficial da Uniáo, Brasília, 1991a. Disponível em: <https://bit.ly/2IyXEIP>. Acesso em: 4 abr. 2020.

Lei no 8.256, de 25 de novembro de 1991. Cria áreas de livre comércio nos municípios de Boa Vista e Bonfim, no estado de Roraima e dá outras providências. Diário Oficial da Uniáo, Brasília, 1991b. Disponível em: <https://bit. ly/3nkaUzC>. Acesso em: 4 abr. 2020. 
. Lei no 8.387 , de 30 de dezembro de 1991. Dá nova redação ao $\$ 1$ 1o do Art. $3^{3}$ aos Arts. $7^{\circ}$ e $9^{\circ}$ do Decreto-Lei no 288, de 28 de fevereiro de 1967, ao caput do Art. 37 do Decreto-Lei no 1.455, de 7 de abril de 1976 e ao Art. 10 da Lei no 2.145, de 29 de dezembro de 1953, e dá outras providências. Diário Oficial da Uniáo, Brasília, 1991c. Disponível em: <https://bit.ly/3lpx6Ig>. Acesso em: 4 abr. 2020.

. Lei no 8.857 , de 8 de março de 1994. Autoriza a criação de áreas de livre comércio nos municípios de Brasiléia e Cruzeiro do Sul, no estado do Acre, e dá outras providências. Diário Oficial da Uniáo, Brasília, 1994. Disponível em: <https://bit.ly/2Iuo4uP>. Acesso em: 4 abr. 2020.

Parecer no 17/2000-CN - Plano Plurianual 2000-2003: diretrizes estratégicas e macro-objetivos. Anexo 1. Brasília: 2000. 536 p. Disponível em: $<$ https://bit.ly/35nsfBM>. Acesso em 2 abr. 2020.

. Ministério do Planejamento, Orçamento e Gestão. Plano Plurianual 2004-2007: projeto de lei. v. 1. Brasília: MPOG, 2003. 104 p. Disponível em: $<$ https://bit.ly/3prRDhQ>. Acesso em: 2 abr. 2020.

. Ministério da Integração Nacional. Proposta de reestruturaçáo do Programa de Desenvolvimento da Faixa de Fronteira. Brasília: MI, 2005.

Ministério do Planejamento, Orçamento e Gestão. Plano Plurianual 2008-2011: desenvolvimento com inclusão social e educação de qualidade Mensagem Presidencial. Brasília: MPOG, 2007. 124 p. Disponível em: <https:// bit.ly/32EiHRc>. Acesso em: 2 abr. 2020.

. Ministério da Educação; Ministerio de Educación, Ciencia y Tecnología. Escolas de Fronteira. Brasília; Buenos Aires: MEC; MECT, p. 37, março de 2008. Disponível em: <https://bit.ly/35nKwi8>. Acesso em: 4 abr. 2020.

. Ministério da Integração Nacional. Programa de Promoçáo da Sustentabilidade em Espaços Sub-Regionais (Promeso). Brasília: MI, 2009.

- Ministério da Integração Nacional; Grupo de Trabalho Interfederativo de Integração Fronteiriça (GTIIF). Bases para uma proposta de desenvolvimento e integraçáo da Faixa de Fronteira. Brasília: GTIIF, 2010a.

. Ministério da Saúde. Relatório de Desempenho do Projeto SIS-Fronteiras. Brasília: Secretaria Executiva; Sistema Integrado de Saúde das Fronteiras, 2010 b.

. Ministério do Turismo. Frontur: turismo de fronteira 2004-2010. Brasília: MT, 2010c. 147 p.

Ministério do Planejamento, Orçamento e Gestão. Plano Plurianual 2012-2015: desenvolvimento, produtividade e inclusão social - Mensagem Presidencial. Brasília: MPOG, 2011. 278 p. Disponível em: <https://bit.ly/3ppIgPq>. Acesso em: 2 abr. 2020. 
. Ministério da Integração Nacional. Plano de Desenvolvimento Regional e Sustentável para a Faixa de Fronteira - Plano Brasil Fronteira. Brasília: MI, 2012.

. Ministério da Saúde. Portaria no 622, de 23 de abril de 2014. Dispóe sobre os prazos para conclusão da implementação das açóes previstas no Sistema Integrado de Saúde das Fronteiras (SIS-Fronteiras) e sobre o repasse de incentivo financeiro. Brasília: MS, 2014. Disponível em: <https://bit.ly/3po4oK3>. Acesso em: 6 set. 2019.

- Ministério da Justiça. Secretaria Nacional de Segurança Pública. Diagnóstico socioeconômico e demográfico da faixa de fronteira: áreas críticas de segurança pública. Pesquisa Segurança Pública nas Fronteiras. Brasília: MJ, 2015a. 567 p.

. Ministério do Planejamento, Orçamento e Gestão. Plano Plurianual 2016-2019 - Mensagem Presidencial. Brasília: 2015b. 205 p. Disponível em: <https://bit.ly/3kqtnc3>. Acesso em: 2 abr. 2020.

. Ministério da Justiça. Mapeamento das políticas públicas federais na faixa de fronteira: interfaces com o Plano Estratégico de Fronteiras e a Estratégia Nacional de Segurança Pública nas Fronteiras. Brasília: MJ, 2016a. 187 p.

. Ministério das Relaçóes Exteriores. Programa: 2082 - Política Externa Diário Oficial da União, Brasília, 14 de jan. 2016b. Disponível em: <https://bit. ly/36tZliB>. Acesso em: 2 abr. 2020.

Resolução no 1, de 8 de novembro de 2018. Aprova o Regimento Interno da Comissão Permanente para o Desenvolvimento e a Integração da Faixa de Fronteira (CDIF). Diário Oficial da União, Brasília, 2018. Disponível em: $<$ https://bit.ly/35nCXYO>. Acesso em: 2 abr. 2020.

Ministério da Economia. Secretaria Especial de Fazenda. Secretaria de Avaliação, Planejamento, Energia e Loteria. Plano Plurianual 2020-2023 - Mensagem Presidencial. Brasília: Secap; ME, 2019. p. 49. Disponível em: <https://bit. ly/2IBl9jV>. Acesso em: 2 abr. 2020.

. Ministério da Defesa. Programa Calha Norte: Departamento do Programa Calha Norte - Relatório Situacional 2019. Brasília: MD, p. 36, 2020. Disponível em: <https://bit.ly/32EyYoY>. Acesso em: 2 abr. 2020.

BURSZTYN, M. A; BURSZTYN, M. Fundamentos de política e gestão ambiental: caminhos para a sustentabilidade. Rio de Janeiro: Garamond, 2012.

CARGNIN, A. P. Política nacional de desenvolvimento regional e repercussóes no Rio Grande do Sul. Mercator, Fortaleza, v. 13, n. 1, p. 19-35, jan./abr. 2014. 
DAGNINO, E. Sociedade civil, espaços públicos e construção democrática no Brasil: limites e possibilidades. In: DAGNINO, E. (Org.). Sociedade civil e espaços públicos no Brasil. São Paulo: Paz e Terra, 2002.

FARIA, C. A. P. A Política da avaliação de políticas públicas. Revista Brasileira de Ciências Sociais, v. 20, n. 59, 2005.

FIORINO, D. J. Sustainability as a conceptual focus for public administration. Public Administration Review, v. 70, p. 78-88, 2010.

FREY, K. Políticas públicas: um debate conceitual e reflexóes referentes à prática da análise de políticas públicas no Brasil. Planejamento e Políticas Públicas, Brasília, n. 21, p. 212-259, 2000.

GADELHA, C. A. G.; COSTA, L. Política nacional de integração e desenvolvimento das fronteiras: o Programa de Desenvolvimento da Faixa de Fronteira (PDFF). In: OLIVEIRA, T. C. M. (Org.). Territórios sem limites: estudos sobre fronteiras. Campo Grande: Editora UFMS, 2005. p. 25-46.

GIMENEZ, H. M. Defesa nacional, segurança pública e relaçóes internacionais: uma análise sobre a fronteira Bolívia-Brasil (2005-2014). 2015. 2 v. Tese (Doutorado) - Universidade de Brasília, Brasília, 2015.

GUBA, E.; LINCOLN, Y. Effetive evaluation. San Francisco: Jossey-Bass, 1981. HOUSE, E. Assunption underlyng evaluation models. In: MADAUS, G.; SCRIVEN, M.; STUFFLEBEAM, D. (Orgs.). Evaluation models: viewpoints on educational and human services evaluation. Boston: Kluwer-Nijhoff, 1983.

HOWLETT, M.; RAMESH, M.; PERL, A. Política pública: seus ciclos e subsistemas: uma abordagem integradora. 3. ed. Rio de Janeiro: Elsevier, 2013. 305 p. JANNUZZI, P. M. Indicadores sociais no Brasil: conceitos, fontes de dados e aplicaçôes. 5. ed. Campinas: Alínea, 2012.

KAEFER, F.; ROPER, J.; SINHA, P. A software-assisted qualitative content analysis of news articles: example and reflections. Forum Qualitative Sozialforschung, Berlin, v. 16, n. 2, p. 1-20, 2015.

KRÜGER, C. Da avaliação de impacto à governança transfronteiriça: contribuiçóes para o aperfeiçoamento da gestão de políticas públicas. 2019. 176 p. Tese (Doutorado) - Faculdade de Economia, Administração e Contabilidade, Universidade de São Paulo, Ribeirão Preto, 2019.

KRÜGER, C.; DANTAS, M.; CASTRO, M. Políticas públicas e desenvolvimento: uma análise aplicada ao contexto da faixa de fronteira no Brasil. In: PEGO, B.; MOURA, R. (Orgs.). Fronteiras do Brasil: uma avaliação de política pública. Rio de Janeiro; Brasília: Ipea; MI, p. 325-350, 2018. 
KRÜGER, C.; DANTAS, M. K.; PASSADOR, C. S. Gestão da regiâo fronteiriça nacional: uma análise de conteúdo para subsídio de políticas públicas. In: ENCONTRO BRASILEIRO DE ADMINISTRAÇÃO PÚBLICA, 5., 2018, Viçosa, Minas Gerais. Anais... Viçosa: EBAP, 2018.

KRÜGER, C. et al. Políticas públicas para o desenvolvimento da faixa de fronteira nacional: uma análise da percepção dos atores públicos envolvidos. In: ENCONTRO DE ADMINISTRAÇÃO PÚBLICA E GOVERNANÇA (ENAPG), 7., 2016, São Paulo, São Paulo. Anais... São Paulo: ENAPG, 2016.

KRÜGER, C. et al. Análise das políticas públicas para o desenvolvimento da faixa de fronteira brasileira. Ambiente e Sociedade, São Paulo, v. 20, n. 4, 2017.

LEAL FILHO, W. Dealing with misconceptions on the concept of sustainability. International Journal of Sustainability in Higher Education, v. 1, n. 1, p. 9-19, 2000 .

LEIBENATH, M. Europeanisation of cross-border governance? A case study on the cause, form and consequences of a co-operation project in the German-Polish-Czech border triangle. Space and Polity, London, v. 11, n. 2, p. 151-167, 2007.

MALHOTRA, N. K. Pesquisa de marketing: uma orientação aplicada. 6. ed. Porto Alegre: Bookman, 2012.

MILANI, C. O princípio da participação social na gestão de políticas públicas locais: uma análise de experiências latino-americanas e europeias. Revista de Administraçáo Pública, Rio de Janeiro, v. 42, n. 3, 2008. Disponível em: <http:// dx.doi.org/10.1590/S0034-76122008000300006 >. Acesso em: 3 dez. 2020.

MILES, M. B.; HUBERMAN, A. M.; SALDAÑA, J. Qualitative data analysis. London: Sage, 2013.

MIYAMOTO, S. O Brasil e a fronteira norte: política e estratégia. Estudios Avanzados, Santiago, v. 12, p. 75-103, 2009.

MOURA, R.; PÊGO, B. Aglomeraçóes urbanas no Brasil e na América do Sul: trajetórias e novas configurações. Brasília: Ipea, p. 1-76, 2016. (Texto para Discussão, n. 2203).

MOZZATO, A. R.; GRZYBOVSKI, D. Análise de conteúdo como técnica de análise de dados qualitativos no campo da administração: potencial e desafios. Revista de Administraçáo Contemporânea, Maringá, v. 15, n. 4, p. 731-747, 2011.

OLIVEIRA, L. R.; PASSADOR, C. S. Ensaio teórico sobre as avaliaçóes de políticas públicas. Cadernos EBAPE.BR, Rio de Janeiro, v. 17, n. 2, p. 324-337, 2019. Disponível em: <https://bit.ly/2UwBcCs>. Acesso em 28 ago. 2019. 
PÊGO, B.; MOURA, R. (Orgs.). Fronteiras do Brasil: uma avaliação de política pública. Rio de Janeiro; Brasília: Ipea; MI, v. 1, 2018, 453 p. Disponível em: $<$ https://bit.ly/2ILBgvm>.

PÊGO, B. et al. (Orgs.). Fronteiras do Brasil: diagnóstico e agenda de pesquisa para política pública. Rio de Janeiro; Brasília: Ipea; MI, v. 2, 2017a, 276 p. Disponível em: <https://bit.ly/2IKpTnN>. Acesso em: 2 abr. 2020.

PÊGO, B. et al. (Orgs.). Fronteiras do Brasil: uma avaliação do arco Norte. Rio de Janeiro; Brasília: Ipea; MI, v. 3, 2017b. 296 p. Disponível em: <https://bit.ly/38Ur0vV>.

PÊGO, B. et al. (Orgs.). Fronteiras do Brasil: uma avaliaçấo do arco Central. Rio de Janeiro; Brasília: Ipea; MDR, v. 4, 2019, 344 p. Disponível em <https:// bit.ly/2UxNMBg>. Acesso em: 2 abr. 2020.

PÊGO, B. et al. (Orgs.). Fronteiras do Brasil: uma avaliação do arco Sul. Rio de Janeiro: Ipea, v. 5, 2020a. Disponível em: <encurtador.com.br/nwEI7>.

RESENDE, G. M. (Ed.). Avaliaçáo de políticas públicas no Brasil: uma análise de seus impactos regionais. Rio de Janeiro: Ipea, 2014.

RESENDE, G. M.; SILVA, D. F. C. Avaliação dos fundos constitucionais de financiamento nos municípios da faixa de fronteira das regióes Norte e Centro-Oeste: uma abordagem em painel espacial para o período 1999-2011. In: PÊGO, B.; MOURA, R. (Orgs.). Fronteiras do Brasil: uma avaliação de política pública. Rio de Janeiro; Brasília: Ipea; MI, p. 351-380, 2018.

SALDANAA, J. The coding manual for qualitative researchers. London: Sage, 306 p. 2013.

SCHERMA, M. A. As políticas brasileiras para a faixa de fronteira: um olhar a partir das relações internacionais. 2015. 272 f. Tese (Doutorado) - Universidade Estadual de Campinas, Campinas, 2015.

SECCHI, L. Políticas públicas: conceitos, esquemas de análise, casos práticos. 2. ed. São Paulo: Cengage Learning, 2013.

SOUZA, C. Políticas públicas: uma revisão da literatura. Sociologias, Porto Alegre, v. 8, n. 16, p. 20-45, 2006.

TCU - TRIBUNAL DE CONTAS DA UNIÃO. Políticas Federais para a faixa de fronteira. Relatório de Políticas e Programas de Governo 2019. Brasília: TCU, 2019. Disponível em: <https://bit.ly/35B3Rwo>. Acesso em: 2 abr. 2020.

WORTHEN, B.; SANDERS, J.; FITZPATRICK, J. Avaliação de programas: concepçóes e práticas. São Paulo: Editora Gente, 2004.

WU, X. et al. Guia de políticas públicas: gerenciando processos. Brasília: Enap, 2014. 


\section{INTEGRAÇÃO E DESENVOLVIMENTO: A FRONTEIRA NA ARTICULAÇÃO TERRITORIAL NACIONAL E SUL-AMERICANA}

\section{INTRODUÇÃO}

Nas atividades realizadas no projeto Fronteiras do Brasil, uma parceria entre o Ipea e o Ministério do Desenvolvimento Regional (MDR), os temas integraçáo e desenvolvimento foram unanimemente considerados como da mais alta relevância. Esses temas não podem ser tomados separadamente, ou tratados como fragmentos, mas devem representar o princípio de soberania nacional, dos povos da nação brasileira, do território enquanto uma totalidade. Tal percepção colocou em destaque, em todas as atividades realizadas, a compreensáo de seus povos sobre o sentido da fronteira, a necessidade de sua concepção como integrante ativa da unidade territorial e do desenvolvimento brasileiro e sua importância nas açóes para integração sul-americana.

Para a compreensão das observaçóes dos participantes, destaca-se, desde já, sua concepçáo de fronteira como elemento de articulaçáo. Para o Brasil, para os estados fronteiriços e fundamentalmente para as pessoas que moram nessa regiáo, esse tema exige um enfoque plural: é inequívoco que são fronteiras e não somente uma fronteira, o que torna contraproducente tratá-la como uma só. Portanto, falar da fronteira brasileira é falar de diversas fronteiras. Não só porque esta percorre uma enorme diversidade regional, mas também porque o contexto dos estados nacionais do continente é bastante heterogêneo, e a diferenciação existente entre as áreas fronteiriças dos países que integram o subcontinente sul-americano deve ser percebida. Assim, estratégias distintas devem ser adotadas na busca do desenvolvimento e da integração da fronteira brasileira, para que atendam às particularidades regionais e às diferenciaçóes socioterritoriais da faixa e da linha de fronteira (Pêgo et al., 2017; 2018; 2019; 2020a; 2020b; Pêgo e Moura, 2018).

Nesse entendimento, a fronteira é o traspasse de uma forma de organização social e territorial à outra. Em alguns casos, passar de um país para o outro não significa uma ruptura de paisagem, de costumes ou de atividades econômicas; em outros casos, as mudanças e diferenças entre territórios nacionais aparecem de maneira progressiva, dificilmente perceptíveis; em outros mais, as rupturas são visíveis e marcantes. $\mathrm{Na}$ ausência de conflitos políticos e territoriais, como ocorre no caso brasileiro, o limite e a fronteira são percebidos como lugar de encontro, 
de união e interação construtiva, e não de separação. Daí, a fronteira deve ser concebida como um ambiente de oportunidades, e suas positividades devem ser enaltecidas, levando-se em conta e desmistificando a visão que se tem da fronteira como o lugar da prática de delitos. Deve-se, portanto, reforçar a ideia de que se trata de um lugar de aproximação e potencialidades.

Dada a recorrência do debate atual, tanto no arco Sul quanto no Central foram postos em discussão o controle permanente e o fechamento de fronteiras como a construção de muros separando países. Tal prática vem sendo justificada por algumas naçóes como um aporte à segurança, mas se constitui, de fato, em uma separação entre território desenvolvido e não desenvolvido. E há uma dificuldade de compreensão desse debate. A classe política (parlamentares) tem um conhecimento restrito ou mesmo um desconhecimento profundo do que vem a ser a fronteira.

Depois de um período muito rico, no final do século passado, de desfronteirização global (abertura das fronteiras, integração), no século atual isso se reverte e o mundo começa a passar por um processo de refronteirizaçáo (fechamento cada vez maior, com relação às suas fronteiras). Se não se depreender a condição positiva de fronteira e não se tornar favorável a um processo de integração, pode significar um reforço à refronteirização, ao novo processo de fechamento. Esse comportamento tem encontrado lastro nos debates ou nas narrativas políticas atuais. Mas se deve discordar do que está colocado no mundo hoje, o fechamento, pois isso é extremamente danoso tanto para o Brasil quanto para o conjunto geral da América Latina. De acordo com Pêgo et al. (2020a; 2020b), deve-se, sim, reconhecer, sempre, que existe "o lado de lá", reforçando a proposta de integração, que exigirá um processo de formalização daquilo que hoje é funcional (quase ilegal).

Orientados por essas compreensões sobre o sentido da fronteira, na seção 2 , será elaborada uma síntese dos principais acordos bilaterais e de cooperação fronteiriça em vigência na fronteira brasileira, ilustrada, na sequência, por destaques que representam a visão dos participantes das atividades do projeto. Em continuidade, na seção 3, também sob a compreensão dos participantes, serão abordadas as políticas voltadas à integração e ao desenvolvimento das regiốes das fronteiras.

\section{ACORDOS BILATERAIS E DE COOPERAÇÃO FRONTEIRIÇA}

As regióes de fronteira são espaços onde se projetam, gradativamente, oportunidades de desenvolvimento regional, mediante o fortalecimento da cooperação internacional, por meio de acordos bilaterais e/ou específicos de cooperação fronteiriça. Entre as oportunidades que se apresentam, estão: infraestrutura; turismo; projetos de geração de energia; parques científicos; esforços conjuntos na atração de investimentos estrangeiros; e criação de fundos de investimentos transnacionais.

A partir desse ponto de vista, esta seção trata dos acordos bilaterais e de cooperação fronteiriça com participação brasileira à luz das informaçóes recolhidas ao 
longo das oficinas realizadas nos arcos, e atualizados para 2019. A apresentação dos dados é feita a partir da apresentação dos documentos por arco, respectivamente: Norte, Central e Sul.

Nos últimos anos, o Brasil assinou uma série de documentos com vistas ao desenvolvimento dessas regióes, porém merece destaque a metodologia do levantamento aqui apresentado. Ele foi pensado em consideração ao ponto de vista dos participantes, como uma lente que identifica quais iniciativas tiveram mais relevância para eles.

\subsection{Acordos destacados nos arcos}

\subsubsection{Arco Norte}

Brasil e Guiana compartilham 1.606 quilômetros de fronteira. O governo da ex-colônia britânica mantém forte relacionamento bilateral com o Brasil como forma de inserir-se diplomaticamente na América do Sul, sem que haja prejuízo para seus laços com o Caribe. Esse relacionamento se aprofundou a partir da década de 1990, uma vez que muitos brasileiros, sobretudo manauaras e roraimenses, passaram a residir no país vizinho.

Como consequência, houve constante menção a esse país nas falas dos participantes da oficina do arco Norte, principalmente acerca do Acordo de Alcance Parcial de Complementação Econômica no 38, assinado entre Brasil, Guiana e São Cristóvão e Névis, em 2001. ${ }^{1} \mathrm{O}$ acordo foi subscrito ao amparo do art. 25 do Tratado de Montevidéu (1980), internalizado no Brasil pelo Decreto no 3.989/2001 e tendo entrado em vigor em 2004 (Pêgo et al., 2018).

$\mathrm{O}$ acordo tem como objetivo "promover o incremento dos fluxos de comércio bilaterais por meio do intercâmbio de preferências tarifárias entre as partes, cooperação em temas de comércio e participação crescente do setor privado" (Brasil, 2001). Entre as medidas acordadas estão: manutenção de preferências tarifárias acordadas para importação de produtos, como carnes, hortaliças, frutas, grãos, madeiras e carvão etc.; e reduçôes percentuais de tarifas aplicadas às importaçóes no momento de despacho aduaneiro.

Foram mencionados, ainda, acordos sobre importação e exportação de energia elétrica entre Brasil, Guiana e Venezuela (Pêgo et al., 2018). Para se ter uma ideia, o Brasil é o grande centro de geração e consumo de energia elétrica quando considerados os países do Mercosul, em função de sua extensão territorial e industrialização. No entanto, são escassas as interconexóes elétricas na regiáo sul-americana, de uma forma geral, visto que os acordos gerados nesse setor foram 
gestados em períodos diversos, sem a respectiva harmonização setorial, visando atender às demandas momentâneas e/ou emergenciais.

Por exemplo, a linha Boa Vista-Guri Dam, que conecta o extremo norte brasileiro com a Venezuela, ${ }^{2}$ é um tipo de conexão radial, na qual somente Roraima (RR) se beneficia do processo de recebimento de energia. $\mathrm{O}$ desequilíbrio nessa relação foi demonstrado pelos recorrentes apagóes no estado ao longo dos últimos dois anos, período no qual ocorreu piora no relacionamento bilateral entre os países.

Mais especificamente com a Guiana, os participantes da oficina citaram o Acordo de Transporte Rodoviário Internacional de Passageiros e Cargas, com o Brasil. O acordo assinado em 2003, e internalizado no Brasil pelo Decreto no 9.446/2018, prevê restituiçóes às partes que sofrerem algum dano durante viagem e indenizaçóes. Esse foi o primeiro passo para a possibilidade de criação de uma rota terrestre entre Boa Vista-Georgetown, com circulação de ônibus e veículos particulares (Brasil, 2018).

Recentemente, a Agência Nacional de Transportes Terrestres (ANTT) divulgou a Portaria no 53/2019, na qual autorizou empresas brasileiras de ônibus a prestarem serviços regulares de transporte rodoviário internacional de passageiros entre os países (Brasil, 2019).

Nesse sentido, também foi trazida à pauta o Acordo de Transporte Rodoviário Internacional de Passageiros e Cargas, entre Brasil e Venezuela, internalizado por meio do Decreto no 2.975/1999. No decreto, estão descritos os transportes: por rodovia; rodoviário internacional; comercial; de passageiros; carga; empresa transportadora; entre outros itens. Ademais, estabeleceu-se a autorização de entrada e saída de veículos das partes contratantes que "transportem passageiros ou carga através dos pontos habilitados na fronteira, com base na reciprocidade, de conformidade com as leis e regulamentos existentes em cada país” (Brasil, 1999).

Ainda no contexto da cooperação bilateral na região amazônica, cabe destacar o programa de cooperação transfronteiriça e transnacional, financiado pelo Fundo Europeu de Desenvolvimento Regional (Feder), voltado ao desenvolvimento do espaço entre Guiana Francesa, Suriname e os estados do Amapá e do Amazonas, no Brasil, o Interreg $\mathrm{V}$ - Amazônia. O programa de cooperação para o período 2014-2020 tem como prioridades: melhorar o transporte disponível na área de cooperação, a fim de aumentar a mobilidade nessa parte da Amazônia; proteger a biodiversidade excepcional e o patrimônio natural e cultural, por meio de açóes conjuntas de preservação ambiental; combater as questóes sociais e de saúde, por meio da cooperação científica e de saúde; e promover o desenvolvimento do

2. A Venezuela possui o terceiro maior potencial elétrico do continente, sendo sua matriz elétrica formada prioritariamente por usinas hidroelétricas, seguidas por centrais térmicas. 
comércio em setores-chave, como agroalimentar, energias renováveis, tecnologias da informação e comunicação, entre outras.

No Brasil, o programa já apoiou o Projeto Açaí Ação, no Amapá. Trata-se de uma ação de transferência de tecnologias que tem como objetivo a dinamização da cadeia produtiva do açaí, nas comunidades agroextrativistas do Platô das Guianas; além da valorização dos recursos e conhecimento das populaçóes locais, desenvolvimento de práticas agroecológicas e consolidação de mercados de qualidade, por meio da construção coletiva de conhecimentos.

Além das estratégias bilaterais, registrou-se a existência de iniciativas no âmbito multilateral como o Projeto de Cooperação sobre Compartilhamento de Conhecimentos e Experiências para o Zoneamento Ecológico-Econômico e Roraima (ZEE-RR), no âmbito da Organização do Tratado de Cooperação Amazônica (OTCA).

O ZEE do estado faz parte de um projeto maior de Macrozoneamento Ecológico-Econômico (MacroZEE) da Amazônia Legal, criado com o fím de ser um "instrumento de orientação para a formulação e espacialização das políticas públicas de desenvolvimento, ordenamento territorial e meio ambiente, assim como para as decisóes dos agentes privados" (Brasil, 2010b).

Sendo assim, cabe ao MacroZEE da Amazônia Legal definir estratégias abrangentes de estruturação do território amazônico que envolvam a logística de transporte e a rede de cidades, que em outras palavras significa a definição das territorialidades. Já aos zoneamentos estaduais, a exemplo do ZEE-RR, assim como outros, ficam reservadas as análises e definiçốes mais diretas quanto ao uso da terra e à questão fundiária.

Também teve destaque o Fórum de Integração Trinacional Região de Madre de Diós/Peru, Acre/Brasil e Pando/Bolívia (MAP). A região constitui o núcleo da Amazônia Sul-ocidental (Peru, Brasil e Bolívia) e é caracterizada pela existência de bosques úmidos tropicais com enorme diversidade biológica e cultural (Pêgo et al., 2018).

A primeira reunião ocorreu em 1999, após um grupo de pesquisadores se reunir para discutir os efeitos das mudanças climáticas em regióes de fronteira. Eles perceberam a necessidade de fortalecimento da integração como forma de garantir o funcionamento de um sistema de alerta, contribuindo para a busca de soluçóes integradas e auxiliando o poder público e a sociedade civil.

Fazem parte do MAP representantes de: instituiçóes acadêmicas, como aqueles da Universidade Federal do Acre (Ufac) e do Instituto Federal do Acre (Ifac); organizaçóes sociais, a exemplo da comitiva de Madre de Diós e de Pando; organizaçóes não governamentais; e organismos municipais e governamentais, nomeadamente 
Defesa Civil, Companhia Especial de Fronteira, Instituto de Mudanças Climáticas e Regulação de Serviços Ambientais (IMC), Corpo de Bombeiros e Secretaria de Estado de Meio Ambiente (Sema).

Os participantes deliberaram novas decisões a partir de fóruns, reuniōes e feiras, nos quais são discutidas estratégias para o fortalecimento da economia local, infraestrutura e planejamento regional. Espera-se, com isso, que a regiáo da tríplice fronteira possa ser integrada por meio do desenvolvimento sustentável mediante processos e acordos de integração comuns (Pêgo et al., 2018).

Além dessa iniciativa, existem ainda os planos de criação de um Comitê Trinacional da Bacia do Alto Rio Acre e do estabelecimento de consórcios intermunicipais. O primeiro já está em fase de negociação e pretende ser "um fórum de discussão para assuntos de interesse comum dos três países para apoiar, facilitar e fortalecer açóes conjuntas na região, com vistas ao desenvolvimento sustentável da Amazônia Sul-ocidental" (Reis e Los Rios, 2005, p. 9). Já os consórcios preveem conciliar aspiraçóes comuns de governos dos municípios fundadores da bacia para promoção da conservação, proteçấo e desenvolvimento regional do MAP.

Ainda no plano multilateral, houve lembrança do programa de emissão de identidade fronteiriça a cidadãos de países-membros do Mercosul. Porém, o bloco foi pouco mencionado ao longo do evento (Pêgo et al., 2018).

Além dos acordos firmados, cabe salientar a importância do Programa Calha Norte (PCN), um dos mais citados pelos participantes das oficinas. Criado em 1985, esse programa tinha como objetivo inicial aumentar a presença do governo federal no norte da Amazônia brasileira e nos rios da bacia do Solimóes, contribuindo para a defesa nacional e o desenvolvimento, prestando assistência aos assentamentos locais e protegendo a fronteira, mediante o estabelecimento da presença militar (Nery, 2019).

Para tal, o PCN envolveu quatro áreas de ação prioritária: aumento da presença militar e governamental; proteção de fronteiras internacionais; fortalecimento das relaçóes bilaterais (sobretudo comércio, cooperação técnica e de infraestrutura); e definição de política apropriada para grupos indígenas, em especial da etnia Yanomami. Mais tarde, a lógica foi ampliada e passou a abranger ainda o combate ao tráfico de drogas e a preservaçáo do meio ambiente. ${ }^{3}$

No entanto, o PCN se tornou um programa de desenvolvimento liderado por militares para construir bases, aeródromos, estradas e outros tipos de infraestruturas, sendo que o ponto principal do programa foi a implantação de pelotóes especiais de fronteira do Exército em locais estratégicos próximos a assentamentos

3. Mais informações em: <https://tinyurl.com/rest8g4>. 

sul-americana

indígenas ao longo da fronteira norte. A partir dos anos 2000, os recursos do programa passaram a ser destinados ao desenvolvimento econômico de municípios amazônicos, mediante pavimentação de estradas, construção de novas escolas, creches e campos de futebol (Nery, 2019).

\subsubsection{Arco Central}

No arco Central, o documento mais lembrado foram os Acordos de Roboré (1958), que trouxeram à pauta, pela primeira vez, o tema da compra de gás boliviano e da construção de um gasoduto (Pêgo et al., 2020a).

A preocupação colocada pelos participantes da oficina, sobre o acordo de implantação de um gasoduto entre Bolívia e Brasil, é que a utilização do gás deveria ser ampliada para outros municípios próximos à Bolívia, a exemplo de Corumbá, em Mato Grosso do Sul (MS).

Os participantes também valorizaram a medida que retirou a necessidade de visto para que brasileiros e bolivianos pudessem circular entre os países (Pêgo et al., 2019; 2020b). O acordo entre o Brasil e a Bolívia sobre Facilitação para o Ingresso e Trânsito de seus Nacionais em seus Territórios foi assinado em 2004 e diz que tanto brasileiros quanto bolivianos poderão ingressar, transitar e sair de ambos os territórios mediante a apresentaçáo, apenas, de seu documento de identidade nacional vigente. A iniciativa foi uma importante contribuição à redução do problema das migraçóes internacionais em área de fronteira, uma vez ampliou a perspectiva de livre circulação de trabalhadores nessas áreas.

A menção aos acordos internacionais da ANTT se deu, sobretudo, no âmbito da revisão do transporte de passageiros em ônibus urbanos na fronteira entre Brasil e Bolívia. No Brasil, o Decreto no 99.704/1990 trata do acordo sobre transporte internacional terrestre, entre esses países mais Argentina, Chile, Paraguai, Peru e Uruguai (Brasil, 1990). Os termos do acordo são aplicados tanto ao transporte direto de um país a outro como ao trânsito para um terceiro país.

Nesse sentido, também houve menção ao Acordo para Permissão de Residência, Estudo e Trabalho a Nacionais Fronteiriços Brasileiros e Uruguaios, para Prestação de Serviços de Saúde, bem como o ajuste complementar a esse instrumento, especificando a prestação de serviços de saúde na fronteira entre as localidades fronteiriças dos países citados. ${ }^{4}$ Ambos foram promulgados, respectivamente, por intermédio dos decretos $\mathrm{n}^{\mathrm{os}}$ 5.105/2004 (Brasil, 2004) e 7.239/2010 (Brasil, 2010a).

4. Localidades fronteiriças, respectivamente, do Brasil e do Uruguai: Chuí/Chuy; Santa Vitória do Palmar-Balneário do Hermenegildo/Barra de Chuy; Barra do Chuí/La Coronilla; Jaguarão/Rio Branco; Aceguá/Aceguá; Santana do Livramento/ Rivera; Quaraí/Artigas; Barra do Quaraí/Bella Unión. Para mais informações, ver capítulo 3, subseção 2.2, que trata dos arranjos transfronteiriços nesta publicação. 
Por intermédio do primeiro instrumento, é concedido aos nacionais de qualquer desses países exercer trabalho, ofício ou profissão no país vizinho, com as consequentes obrigaçóes e direitos previdenciários deles decorrentes.

\subsubsection{Arco Sul}

Em relação a esse instrumento, com o ajuste complementar, Brasil e Uruguai estabeleceram a prestaçáo recíproca de serviços de assistência de emergência e cooperação em defesa civil nas zonas de fronteira apresentadas. O documento ressalta o desejo em encontrar soluçôes comuns para o bem-estar e a saúde das populaçôes, além de buscar amparar o intercâmbio que já existe na prestação de serviços de saúde humana na região fronteiriça.

Houve a sugestão por parte dos participantes que, por meio do acordo, ficasse estabelecida a possibilidade de contratação de médicos uruguaios no Brasil e vice-versa, sem as formalidades afins às contrataçôes públicas tal como existem atualmente. Os contratados obedeceriam às normas contidas no referido documento, possibilitando a troca de experiências, mão de obra e colaboração nas regiôes de fronteira elencadas (Pêgo et al., 2020b).

Ainda na área de saúde, já se encontra em fase de execução o projeto trilateral Brasil, Alemanha e Uruguai de Apoio ao Fortalecimento do Sistema Nacional Integrado de Saúde do Uruguai com Ênfase em Localidades com Menos de Cinco Mil Habitantes. O projeto contou com o apoio do KfW Bankengruppe, que é o banco alemão de desenvolvimento, por meio de doaçóes para a construção e a reforma de unidades de saúde uruguaias na fronteira com o Brasil.

O acordo de 2004 entre Brasil e Uruguai e o seu ajuste complementar serviram de modelo para a negociação de instrumento semelhante no âmbito do Mercosul, mediante a criação do Grupo Ad Hoc sobre Integração Fronteiriça (Gahif), por meio do Decreto do Conselho do Mercosul no 5/2002. Entre suas funçóes estáo: elaboração de propostas de instrumentos normativos destinados a facilitar as relaçóes entre as comunidades fronteiriças; recomendar a adoção de medidas que possam beneficiar as populaçôes fronteiriças; e criar instrumentos que promovam a maior integração dessas áreas (Mercosul e CMC, 2002).

No entanto, desde sua criaçáo, o Gahif se reuniu poucas vezes e com pouco êxito. Segundo Sausi e Oddone (2010, p. 5),

as poucas reunióes desenvolvidas se deram sem a representação de populaçóes fronteiriças; somente os governos nacionais participaram, em total ausência de unidade sub-nacionais, tratando a cooperaçáo fronteiriça segundo uma lógica absolutamente top-down. 
O acordo não chegou a entrar em vigor, porém Brasil e Argentina, estados-membros do bloco, optaram por assinar uma versão bilateral do documento. Entretanto, os autores comentam que as iniciativas de cooperação transfronteiriça do Mercosul são mais amplas e encontram-se resumidas no quadro 1 .

QUADRO 1

Estrutura institucional do Mercosul e temática fronteiriça

\begin{tabular}{|c|c|}
\hline Órgão & Instrumento \\
\hline \multirow{2}{*}{$\begin{array}{l}\text { Conselho Mercado } \\
\text { Comum (CMC) }\end{array}$} & Grupo Ad Hoc de Alto Nível para a Reforma Institucional (Ganri): Decreto CMC no 21/2005. \\
\hline & $\begin{array}{l}\text { Grupo de alto nível para a elaboração de um Programa de Cooperação Sul-Sul (Ganasur): XXXV } \\
\text { CMC, Ata no 1/2008, Punto 17.11. }\end{array}$ \\
\hline \multirow{7}{*}{$\begin{array}{l}\text { Grupo Mercado } \\
\text { Comum (GMC) }\end{array}$} & $\begin{array}{l}\text { Subgrupo de Trabalho no } 6 \text { Meio Ambiente: Resolução GMC no 20/1995 e Decreto CMC nº 59/2000. } \\
\text { Grupo Ad Hoc Manejo Adequado de Caça de Espécies Migratórias e Comuns nas áreas Trans- } \\
\text { fronteiriças (GAGCAT): XXXVIII SGT no } 6 \text {. }\end{array}$ \\
\hline & $\begin{array}{l}\text { Grupo Ad Hoc de Especialistas Fundos para a Convergência Estrutural do Mercosul (Gahefocem): } \\
\text { Decreto CMC no 24/2005 Reg. Art. } 25 \text {. }\end{array}$ \\
\hline & $\begin{array}{l}\text { Coordenado pela Comissão de Representantes Permanentes do Mercosul (CRPM) criada pelo } \\
\text { Decreto CMC no } 11 / 2003 \text {. }\end{array}$ \\
\hline & $\begin{array}{l}\text { Fórum Consultivo de Municípios, Estados Federados, Províncias e Departamentos do Mercosul } \\
\text { (FCCR): Decreto CMC no } 41 / 2004 \text {. }\end{array}$ \\
\hline & Grupo de Trabalho de Integração Fronteiriça (GTIF): VII FCCR-CN, Ata no 1/2008. \\
\hline & $\begin{array}{l}\text { Reunião Especializada de Infraestrutura da Integração (REII): Resolução GMC no 89/2000 e } \\
\text { Decreto CMC no 59/2000. }\end{array}$ \\
\hline & Gahif: Decreto CMC no 5/2002. \\
\hline $\begin{array}{l}\text { Comissão de } \\
\text { Comércio do } \\
\text { Mercosul (CCM) }\end{array}$ & $\begin{array}{l}\text { Comitê Técnico no 2, assuntos aduaneiros: Dir. CCM no 1/1995 e Decreto CMC no 59/2000. } \\
\text { Subcomitê Técnico de Controles e Operatória em Fronteira (SCTCOF). }\end{array}$ \\
\hline $\begin{array}{l}\text { Secretaria do } \\
\text { Mercosul (SM) }\end{array}$ & Direção da SM. Unidade Técnica Focem: Decreto CMC no 24/2005 Regl. Art. 19. \\
\hline
\end{tabular}

Fonte: Sausi e Oddone (2010, p. 4).

Elaboração: Equipe Fronteiras Ipea.

Ainda dentro do Mercosul, participantes das atividades nos três arcos mencionaram a importância do Projeto Escola Intercultural Bilíngue de Fronteira (PEIBF), que tem o propósito de promover um "modelo de ensino comum em escolas de zona de fronteira, a partir do desenvolvimento de um programa para a educação intercultural, com ênfase no ensino do português e do espanhol" (Brasil e Argentina, 2008, p. 2).

O projeto foi criado em 2005 a partir de ação bilateral entre Brasil e Argentina e definiu as cidades gêmeas como lugares privilegiados para o desenvolvimento das açôes propostas. No quadro 2, relacionam-se as escolas participantes. 
QUADRO 2

Relação de escolas participantes do PEIBF por país e cidade gêmea

\begin{tabular}{|c|c|c|c|c|c|}
\hline $\begin{array}{l}\text { Relação } \\
\text { fronteiriça }\end{array}$ & Brasil & Argentina & Uruguai & Paraguai & Venezuela \\
\hline \multirow{10}{*}{$\begin{array}{l}\text { Cidade } \\
\text { gêmea }\end{array}$} & Dionísio Cerqueira (SC) & Bernardo de Irigoyen & - & - & - \\
\hline & Foz do Iguaçu (PR) & Puerto Iguazú & - & - & - \\
\hline & Uruguaiana (RS) & Paso de Los Libres & - & - & - \\
\hline & São Borja (RS) & Santo Tomé & - & - & - \\
\hline & Itaqui (RS) & Alvear & - & - & - \\
\hline & Itaqui (RS) & La Cruz & - & - & - \\
\hline & Chuí (RS) & - & Chuy & - & - \\
\hline & Jaguarão (RS) & - & Rio Branco & - & - \\
\hline & Ponta Porã (MS) & - & - & Pedro Juan Caballero & - \\
\hline & Pacaraima (RR) & - & - & - & Santa Elena de Uairén \\
\hline
\end{tabular}

Fonte: Ministério da Educação (MEC). Disponível em: <https://tinyurl.com/yyxqb4yq>. Acesso em: 26 nov. 2019.

Elaboração: Equipe Fronteiras Ipea.

Obs.: SC - Santa Catarina; PR - Paraná; e RS - Rio Grande do Sul.

Somente São Borja, Jaguarão e Pacaraima, no Brasil, possuem duas escolas do projeto, as demais cidades gêmeas do lado brasileiro possuem apenas uma cada. Ao mesmo tempo, Santo Tomé, Rio Branco e Santa Elena do Uairén, na Argentina, no Uruguai e na Venezuela, respectivamente, possuem duas escolas, quando consideradas as cidades gêmeas dos países vizinhos. Há no total treze escolas no lado brasileiro e treze escolas nos países parceiros da iniciativa.

Para além das escolas oficialmente listadas pelo governo federal, há ainda aquelas derivadas de iniciativas não governamentais, a exemplo do Instituto Moinho Cultural Sul-Americano. O instituto tem como missão diminuir a vulnerabilidade de crianças e adolescentes em área de fronteira, oferecendo acesso a aulas de dança, música, tecnologia, idiomas, entre outras. Localizada em Corumbá, a iniciativa atende, além da população local, crianças e adolescentes de Ladário, também no Mato Grosso do Sul, e das cidades bolivianas de Puerto Suárez e Puerto Quijarro.

\subsubsection{Avanços nos acordos sulinos}

Mais especificamente, o Rio Grande do Sul tem tido avanços quanto à aproximação com as fronteiras da Argentina e do Uruguai e, como resultado dessa maior relação com os vizinhos, foi assinado um protocolo de intençóes com o governo uruguaio. No entanto, uma vez que o tema das relaçóes internacionais, e sobretudo fronteiriças, está centralizado no governo federal, há restriçóes quanto à celebração de acordos não conflitantes com os interesses nacionais. Os participantes manifestaram o desejo de revitalização do Mercosul e, em especial, de seu propósito econômico. 
Desde 2016, o governo do Rio Grande do Sul passou a dialogar diretamente com o governo central argentino. Em 2017, houve a assinatura da Carta de Porto Alegre, que contou com a participação de representação dos dois governos nacionais. O conteúdo do documento: i) sintetizou os interesses comuns entre os estados brasileiros do Sul com aqueles das províncias da Argentina; ii) enfatizou a promoção e o aprofundamento da integração entre regióes, do desenvolvimento regional e da busca conjunta de novos mercados internacionais; e iii) registrou o interesse na criação de empresas cooperativas binacionais, que possam integrar cadeias de valor dos setores produtivos de ambos os países, com ênfase no setor da agroindústria, de forma a atender a demandas internas e de mercados extra hemisféricos.

Seguindo a mesma lógica, a Carta de Corrientes, assinada em 2017 entre governadores do Brasil e da Argentina, deu prosseguimento às tratativas iniciadas na reunião de Porto Alegre. Ela propôs a interligação estratégica viária, hidrográfica e aérea entre os países; além da unificação das regras dos serviços de migração e de vigilância sanitária nas fronteiras.

Como menor destaque entre os participantes, porém de grande importância, está a Zona de Integração do Centro-Oeste da América do Sul (Zicosul). Essa instância de integração tem como objetivo geral coordenar posiçóes conjuntas de governos nacionais e regionais. Dela fazem parte: Argentina, Bolívia, Brasil, Chile, Paraguai, Peru e Uruguai, além dos municípios sumarizados no quadro 3.

QUADRO 3

Províncias, departamentos e estados-membros do Zicosul, por país

\begin{tabular}{|c|c|}
\hline País & Província, departamento ou estado \\
\hline Argentina & $\begin{array}{l}\text { Províncias de Catamarca, Chaco, Córdoba, Corrientes, Formosa, Jujuy, La Rioja, Misiones, Salta, Santa } \\
\text { Fe, Santiago del Estero e Tucumán. }\end{array}$ \\
\hline Bolívia & Departamentos de Beni, Chuquisaca, Cochabamba, Oruro, Pando, Potosí, Santa Cruz e Tarija. \\
\hline Brasil & Estados de Mato Grosso (MT), MS, PR, SC e RS. \\
\hline Chile & Províncias de Antofagasta, Arica e Parinacota, Atacama, Coquimbo e Tarapacá. \\
\hline Paraguai & $\begin{array}{l}\text { Departamentos de Alto Paraguay, Alto Paraná, Amambay, Boquerón, Caaguazú, Caazapá, Caninduyú, Central, } \\
\text { Concepción, Coordillera, Guairá, Itapúa, Misiones, Neembucú, Paraguarí, Presidente Hayes e San Pedro. }\end{array}$ \\
\hline Peru & Províncias de Arequipa, Puno y Moquegua e Tacna. \\
\hline Uruguai & $\begin{array}{l}\text { Departamentos de Artigas, Canelones, Cerro Largo, Colonia, Durazno, Flores, Florida, Lavalleja, Maldonado, } \\
\text { Montevideo, Paysandú, Río Negro, Rivera, Rocha, Salto, San José, Soriano e Tacuarembó. }\end{array}$ \\
\hline
\end{tabular}

Fonte: Zicosur. Disponível em: <https://tinyurl.com/yyed8g5b>. Acesso em: 26 nov. 2019.

Elaboração: Equipe Fronteiras Ipea.

A Zicosul tem como objetivo específico promover a visão competitiva dessas regiôes no contexto internacional, por meio do desenvolvimento do comércio exterior com outros mercados, assim como a promoção da integração social e cultural, como mecanismo para o desenvolvimento econômico das partes que a 
integram. Entre suas áreas prioritárias estão: comércio e indústria; infraestrutura e serviços; e meio ambiente, turismo e cultura.

Os participantes mencionaram, também, a atuação do Conselho de Desenvolvimento e Integração Sul (Codesul), do qual fazem parte Mato Grosso do Sul, Paraná, Santa Catarina e Rio Grande do Sul. O conselho foi constituído em 1961 e tem como algumas de suas competências: formular diretrizes da política de desenvolvimento das regiôes; propor estratégias e planos de ação com vistas a inserção da economia regional no processo de integração latino-americano; e estimular o intercâmbio em áreas como turismo e agricultura entre os governos dos estados signatários.

Mais recentemente, os sete governadores do Sul e do Sudeste brasileiros formaram um consórcio para a realização de açóes conjuntas. O Consórcio de Integração Sul e Sudeste (Cosud) tem como temas principais de atuação: segurança pública; combate ao contrabando de bens e produtos; saúde; educação; desenvolvimento econômico; inovação e tecnologia; gás natural; infraestrutura; e outros.

Com relação aos instrumentos financeiros de promoção nas iniciativas de desenvolvimento de integração citados, são destaques o Fundo Financeiro para o Desenvolvimento da Bacia do Prata (Fonplata) e o Fundo para Convergência Estrutural do Mercosul (Focem). O primeiro concentra suas atividades em projetos de médio e pequeno portes, de forma a complementar o trabalho que já é realizado por grandes instituiçôes financeiras multilaterais, como o Banco Interamericano de Desenvolvimento (BID), a Corporação Andina de Fomento (CAF), autoidentificada como Banco de Desenvolvimento da América Latina, e o Novo Banco de Desenvolvimento (NDB) ou Banco de Desenvolvimento do BRICS.

O Fonplata apoiou o Programa de Desenvolvimento da Faixa de Fronteira (PDFF) em Ponta Porã (MS). O programa aprovado em 2019 teve como objetivo contribuir para a melhoria da qualidade de vida da população desse município mediante investimentos em mobilidade urbana, saneamento urbano e desenvolvimento social e cultural. O PDFF já havia sido financiado em Corumbá, em 2014.

Já o Focem destina-se ao financiamento de programas de promoção da convergência estrutural, desenvolvimento da competitividade e promoção da coesão social em economias menores e de regióes menos desenvolvidas do bloco econômico, além do apoio ao funcionamento da estrutura institucional e fortalecimento do processo de integração. O fundo entrou em operação em 2007 e tem contribuído para a melhoria de alguns setores, como: habitação; transporte; capacitação tecnológica; incentivos a microempresas; e melhoria de condiçóes sanitárias. $\mathrm{O}$ maior beneficiário de projetos financiados pelo fundo é o Paraguai, seguido pelo Uruguai, e não há algum projeto aprovado para a Argentina. 
Merece destaque, ainda, o Acordo sobre Localidades Fronteiriças Vinculadas, assinado na cidade argentina de Puerto Iguazú, em 2005. O acordo estabelece que residentes em cidades de fronteira terão direito a um documento de trânsito vicinal fronteiriço, podendo, assim, exercer seu ofício ou profissão do outro lado da fronteira, tendo os mesmos direitos trabalhistas e previdenciários. Ademais, permite o direito ao ensino público e aos serviços públicos de saúde com as mesmas condiçôes de gratuidade e reciprocidade de nacionais. Os benefícios se estendem ainda à livre circulação de veículos automotores de uso particular e ao intercâmbio de professores, alunos e materiais educativos.

Em resumo, os participantes apontaram as iniciativas que consideraram mais importantes do seu ponto de vista. Ao longo do texto, elas foram apresentadas conforme os arcos e por tipo de acordo - se bilateral ou multilateral -, além de sua caracterização básica: data de criação, objetivos e açóes já implementadas ou em processo de implementação. Os instrumentos mais citados pelos participantes, ao longo das atividades, foram sumarizados no quadro 4.

QUADRO 4

Instrumentos vigentes de maior relevância para os participantes das oficinas, por arco

\begin{tabular}{|c|c|}
\hline Arcos & entos \\
\hline Norte & $\begin{array}{l}\text { Acordo de Alcance Parcial de Complementação Econômica no } 38 . \\
\text { Acordos sobre importação e exportação de energia elétrica, entre Brasil, Venezuela e Guiana. } \\
\text { Acordo de Transporte Rodoviário Internacional de Passageiros e Cargas, entre Brasil e Guiana. } \\
\text { MAP. } \\
\text { Projeto de cooperação sob coordenação da OTCA e do Ministério de Relações Exteriores (MRE), por meio da Agência } \\
\text { Brasileira de Cooperação (ABC) sobre compartilhamento de conhecimentos e experiências em relação ao ZEE-RR, como } \\
\text { modo do desenvolvimento da pecuária. } \\
\text { Programa para emissão de identidade fronteiriça (Mercosul). } \\
\text { Acordo de Transporte Rodoviário Internacional de Passageiros e Cargas, entre Brasil e Venezuela. }\end{array}$ \\
\hline Central & $\begin{array}{l}\text { Acordo de compra de gás natural da Bolívia pelo governo brasileiro (1999). } \\
\text { Acordo entre o Brasil e a Bolívia sobre Facilitação para o Ingresso e Trânsito de seus Nacionais em seus Territórios (2004). } \\
\text { Acordos de Roboré (1958). } \\
\text { Acordos internacionais da ANTT de transporte de passageiros em ônibus urbanos na fronteira entre Brasil e Bolívia. } \\
\text { Protocolo de intenções do governo do Rio Grande do Sul com o governo uruguaio. }\end{array}$ \\
\hline Sul & $\begin{array}{l}\text { Carta de Porto Alegre (2017). } \\
\text { Carta de Corrientes (2017). } \\
\text { Acordo para Permissão de Residência, Estudo e Trabalho a Nacionais Fronteiriços Brasileiros e Uruguaios, para Prestação } \\
\text { de Serviços de Saúde (2008). } \\
\text { Zicosul. } \\
\text { Cosud. } \\
\text { Codesul. } \\
\text { Fonplata. } \\
\text { Focem. } \\
\text { Acordo de Localidades Fronteiriças Vinculadas, no âmbito do Tratado de Puerto Iguazú (2005). }\end{array}$ \\
\hline
\end{tabular}

Fontes: Resultados das oficinas realizadas nos arcos Norte (Boa Vista), Central (Corumbá) e Sul (Uruguaiana). Disponíveis em: Pêgo et al. (2017; 2019; 2020a).

Elaboração: Equipe Fronteiras Ipea. 


\section{POTENCIALIZAR O DESENVOLVIMENTO E PRATICAR A INTEGRAÇÃO}

A observação de que falta à região das fronteiras uma estratégia de desenvolvimento foi unânime, e se enfatizou a imprescindibilidade de que se priorizem medidas nessa direção. Foi feita a crítica de que medidas de defesa e segurança são importantes, mas revertem menos do que o esperado e necessitado para o desenvolvimento da região com relação a termos econômicos, sociais e no trato das questóes ambientais. Assim, uma estratégia de desenvolvimento, compatível à pluralidade e diversidade da fronteira, e voltada a esse espaço como um elemento de união e articulaçáo, foi a demanda que se repetiu em todas as atividades.

Foram levantadas também medidas específicas em curso que poderiam ser otimizadas e que, de alguma maneira, contribuiriam para o alcance de melhorias na qualidade de vida dessas regióes, além de um elenco de oportunidades que aproveitadas fariam deslanchar o desenvolvimento na faixa de fronteira (FF), muitas das quais exigem o enfrentamento de desafios. Algumas especificidades da fronteira podem significar, ao mesmo tempo, oportunidades e dificuldades, cabendo reconhecer o motivo das dificuldades que geram, enfrentá-las e, assim, otimizar a condição de oportunidade que se abre, recomendaram os participantes.

No arco Norte, foi dada grande ênfase a essa oportunidade reprimida. Um programa de desenvolvimento seria uma grande oportunidade para a regiáo. Representante da Secretaria de Planejamento e Desenvolvimento do Estado de Roraima (Seplan/RR) destacou a proposição da instituição de um programa de desenvolvimento sustentável e de geração de emprego e renda, ancorado em pilares como: i) questão sanitária; ii) ZEE; iii) licenciamento ambiental; iv) regularização fundiária; v) incentivos fiscais; vi) infraestrutura econômica; vii) acesso ao mercado; viii) tecnologias; ix) assistência rural; e x) assistência técnica. Esse conjunto de propostas possibilitará criar condições a soluçôes favoráveis à produção em Roraima. No mesmo programa, avalia-se a distância dessa Unidade da Federação (UF) em relação ao centro-sul do Brasil e se opta por incentivar a integração à Comunidade do Caribe (Caricom), sediada em Georgetown, Guiana. Visualiza-se uma região geoeconômica para atender às demandas e, também, para receber e distribuir produtos e serviços do Brasil, da Guiana e da Venezuela (Pêgo et al., 2018).

Para os participantes do arco Norte, a fronteira é o espaço de integração entre o país e seus vizinhos; a proximidade dos países e o contato com o exterior são vistos como possibilidade para formatar interesses e estratégias comuns, falar um segundo idioma, dar liberdade à circulação das pessoas com facilidade do ir e vir entre cidades, o que garante a interaçấo entre os moradores de ambos os países. Nesse espaço, a biodiversidade foi apontada como um meio potencial de geração de trabalho e renda, assim como o empreendedorismo e outras alternativas laborais, visto que ajudam a evitar a entrada em atividades ilícitas. Acrescentem-se o grande 
potencial de riquezas minerais e biodiversidade, a vivificação das fronteiras, a proteção ao meio ambiente e o uso sustentável dos recursos naturais, que são aspectos essenciais para o desenvolvimento e integração amazônica (Pêgo et al., 2017; 2018).

No arco Central, oportunidades e dificuldades se encontram na grande extensão terrestre e lacustre da fronteira. Ao mesmo tempo em que se vive grande necessidade e carência de segurança pública, a regiấo se destaca pelo enorme potencial para o turismo, pela presença dos rios e alagados que formam o Pantanal - representativo de uma grande oportunidade - e pelas missóes jesuíticas, que integram parte do território da Bolívia e que podem ser articuladas a pacotes internacionais com Cusco. Destaca-se a comunidade Santo Corazón, em San Matías, no arranjo transfronteiriço com Cáceres, última missão jesuítica localizada no sudeste da área protegida, a qual expressa as culturas dos Chiquitanos e dos Ayoreos. O oriente boliviano possui, também, um grande mercado consumidor para produtos mato-grossenses e brasileiros, e, em sentido contrário, a Bolívia possui grandes reservas de ureia, as quais podem atender a toda a demanda do Mato Grosso, que importa esse produto de países como o Catar (Pêgo et al., 2019; 2020b).

No arco Central, a situação fronteiriça e central de Corumbá, na América do Sul, coloca o município em condição de sediar o debate sobre a fronteira em caráter permanente, o que poderia ser facilitado com a presença de uma universidade temática, a exemplo da Universidade Federal da Integração Latino-Americana (Unila). Se, por um lado, o acolhimento a centenas de crianças bolivianas na rede de ensino representa um custo para os cofres públicos, por outro, oferece a oportunidade de um rico intercâmbio cultural e aprendizado mútuo (Pêgo et al., 2019).

Diante da extensão de fronteira seca, das açôes e das políticas públicas de defesa fitossanitária brasileira no arco Central, é necessário defender o comércio externo de proteína animal. Essa preocupação do Brasil é importante e os bolivianos fronteiriços colaboram, tanto é que construíram uma ação exitosa. Porém, os relatos de bolivianos (matieños) dáo conta que os trabalhadores bolivianos que imunizam os animais contra as pandemias (febre aftosa, raiva animal, entre outras), para garantir a sanidade animal do rebanho da região fronteiriça, não recebem algum tipo de prevenção contra doenças letais ao humano, a exemplo infecção pela raiva. Para as fiscalizaçóes sanitárias animal e vegetal, deveria haver um fiscal federal presente nas barreiras. A parceria do controle fitossanitário entre o Mato Grosso e a União tem avançado, haja vista a erradicação da aftosa no estado (1992-1996). ${ }^{5}$ Mas, de

5. É importante destacar a efetividade da política bilateral Brasil-Bolívia na erradicação da aftosa. Esta é uma política de integração exitosa. 0 último caso ocorreu em 1996, no município de Colíder (MT). Como parte do Plano Estratégico para Erradicação da Febre Aftosa (PNEFA), em novembro de 2019 ocorreu a última etapa de vacinação do rebanho da região. Em até dois anos sem vacinação, Rondônia, Acre, Mato Grosso e Amazonas poderão recorrer à Organização Mundial de Saúde Animal (OIE) para obter o certificado de área livre de aftosa sem vacinação. Informações do Mapa disponível em Última... (2019). 
acordo com Pêgo et al. (2019; 2020b), as autorizaçóes de importação de animais e remédios continuam centralizadas nas mãos do Ministério da Agricultura, Pecuária e Abastecimento (Mapa).

Quanto ao arco Sul, são muitas as potencialidades e oportunidades da região. Uma oportunidade é a densidade populacional e institucional presente na FF, além da disponibilidade de infraestrutura para circulação entre os países e a intensidade de fluxos comerciais, cruzando as fronteiras (Pêgo et al., 2020a). A educação também é apontada como grande elemento de positividade nos três arcos fronteiriços, e o Programa Escolas Interculturais de Fronteira (Peif), desenvolvido no âmbito do Mercosul, foi destacado como fundamental, pelas ricas transformaçóes que vem promovendo em relação à integração cultural. Atualmente, as unidades existentes localizam-se em maior proporção nas fronteiras Brasil-Paraguai e Brasil-Uruguai.

Entre os representantes do arco Sul, a educação, em todos os seus níveis e modalidades, é vista como uma grande oportunidade na fronteira, apesar da dificuldade de acessá-la. Foi constatado o efeito transformador, na dinâmica política e econômica de cidades como Santana do Livramento e Jaguarão, com a chegada de universidades federais. Essas universidades trazem pessoas, mobilizam discussóes, provocam mudança na cultura local e geram empregos diretos e indiretos (Pêgo et al., 2020a).

\subsection{Integração}

As políticas de integração afetam, em geral, de maneira mais direta e imediata, as regiōes de fronteira, por facilitarem a circulação de pessoas e proporcionarem acesso a serviços públicos e privados nos dois lados da linha divisória. Em contrapartida, a porosidade das fronteiras também pode amplificar problemas relacionados a ilícitos transnacionais, como tráfico de drogas e contrabando. Apesar dessa dualidade, os impactos positivos das políticas de integração são fundamentais para o desenvolvimento da FF, principalmente por proporcionarem legislação adequada às especificidades da região. Seriam ainda mais relevantes se identificados os atores envolvidos nessas políticas e se estreitado o entendimento entre as necessidades dos habitantes da região, criando, dessa forma, ações e resultados efetivos. Assim pensam os participantes das atividades dos arcos da fronteira (Pêgo et al., 2017; 2018; 2019; 2020a; 2020b).

No entanto, os participantes ponderaram que o país vive um atraso no processo de integraçáo, devido à estagnação de estudos e açóes com esse propósito. Processos de integração desencadeados trataram a fronteira como espaço acessório, periférico. Além disso, passaram ao largo de atender às comunidades em suas necessidades cotidianas mais básicas, sem se consubstanciarem em políticas públicas e legislaçôes que permitissem passos efetivos em direção à integração regional. 
São evidentes as dificuldades na articulação de acordos de integração, resultando em poucas experiências positivas.

Argumentou-se no arco Sul que, ao se falar da fronteira, obrigatoriamente, há que se tratar da integraçáo em seu sentido amplo. Diferentemente daquela compreensão de integração apenas interagências, a integração que se pleiteia deve ser buscada nas dinâmicas espaciais transfronteiriças, em seu potencial para o desenvolvimento, nas articulaçóes entre os estados, entre forças de segurança, na busca de construir uma irmandade e consolidar uma amizade. Constatou-se, em entrevistas locais, paradoxalmente, que grande parte da população da fronteira nunca cruzou o controle migratório, pela dificuldade de acesso e por um receio imposto em relação ao "outro".

A ideia de integração é histórica e desde a ocupação do território pessoas se uniram e transformaram econômica e culturalmente a região fronteiriça. Há que se reforçar e subsidiar o prosseguimento dessa prática, que nunca se esvaiu, promovendo a união, a integração e a força da unidade. Isso já ocorre naquelas cidades onde o controle migratório é externo e se cria na região de contato entre os países um ambiente de vigorosas relaçôes transfronteiriças. É o caso de cidades nos limites entre Brasil e Uruguai, nas quais a interação e a integração são mais favorecidas. Além disso, nas cidades fronteiriças desses países, as equipes de governo reúnem-se sistematicamente para discutir as questóes de interesse comum (Pêgo et al., 2020a).

No arco Norte, muito se indagou quanto à definição de políticas e estratégias para a região (Pêgo et al., 2018): para quem a Amazônia é estratégica? Será que o país todo está pensando na Amazônia e nas soluçóes que se devem encontrar para a sua integração? E nas soluçôes que sua integração proporcionará ao desenvolvimento nacional?

Já o arco Central conta uma história de superação dos limites impostos pela distância das áreas mais povoadas do país e de construção de alternativas para integração regional à economia internacional. A construção, no início do século passado, compartida entre Brasil e Bolívia, da interligação da hidrovia que abriu a possibilidade de exportação da produção regional é uma mostra de que é possível encontrar alternativas para o desenvolvimento. Esse foi um período áureo, em que se construíram também rodovias e a ferrovia, e as cidades adquiriram vigor e centralidade, como mostra o patrimônio histórico e arquitetônico, por exemplo, de Cáceres e Corumbá (Pêgo et al., 2019; 2020b).

Conforme relatado pelos participantes, os processos de integração nesse arco são históricos, com avanços e retrocessos, muito ao sabor do movimento político vigente. Nas últimas décadas, vários setores brasileiros e bolivianos têm realizado encontros temáticos para a identificação de potencialidades de intercâmbio de negócios entre os países. Apesar de o movimento de formalização dessa aproximação 
ser mais ligado ao setor de negócios, os eventos culturais também têm tido um papel importante na integração, particularmente entre Brasil e Bolívia.

Outros acordos foram firmados entre esses dois países com objetivo de estreitar relaçóes, como o acordo por trocas e notas para a criação de Comitê de Integração Fronteiriça entre Brasil e Bolívia, cujo objetivo é promover a integração política, econômica, social, física e cultural das populaçóes lindeiras. Firmaram-se, também, instrumentos de integração, como o Acordo para Permissão de Residência, Estudo e Trabalho a Nacionais Fronteiriços Brasileiros e Bolivianos. Com o Paraguai, encontra-se em negociação o Acordo Bilateral sobre Localidades Fronteiriças Vinculadas.

Como saídas para a integração, o já citado programa de desenvolvimento, proposto pela Seplan/RR, pode ser a grande oportunidade para o arco Norte, como afirmaram os participantes. Sua implementação possibilitaria soluçóes favoráveis à produção em Roraima e região, favorecendo a integração de Roraima à Caricom. A Amazônia estaria, assim, sendo pensada como uma região geoeconômica do ponto de vista Pan-Amazônico, a partir de relaçóes comerciais e econômicas, do compartilhamento da ciência e tecnologia, da inclusão produtiva e da integração e melhoria nas condiçóes sociais da população (Pêgo et al., 2018).

Ponderou-se, no arco Central, que a fronteira é muito carente, muito precária, e os governos vizinhos têm a sua política própria, seus costumes, além de que trabalham de forma distinta do Brasil, fato que exige que se volte para a integraçáo em reunióes bilaterais, garantindo maior objetividade e especificidade nos acordos. Devido à política incongruente do governo federal, os estados passaram a estabelecer diálogos diretos com os países vizinhos, como o Mato Grosso, que tem estreitado suas relações com alguns departamentos da Bolívia (Pêgo et al., 2019; 2020b).

Concordando com essa linha, participantes do arco Sul citaram ainda que, de modo geral, os acordos que são estabelecidos entre os países são decididos longe da fronteira e que, diante das decisóes tomadas, os municípios devem acatar os termos, adequarem-se e implementarem. Da mesma forma, devido a restriçóes, muitos acordos são pactuados localmente, não formalizados, e sem condiçóes garantidas de respeito aos compromissos, casos em que o desempenho das articulaçóes exige maior empenho das partes, particularmente dos executivos, nos casos das cidades vinculadas. Pleiteou-se que seja rediscutida a responsabilidade de cada ente na formulação e na implementação das políticas, em nível de fronteira (Pêgo et al., 2020a).

A experiência no arco Sul vem mostrando que as relaçóes entre os países exigem negociaçóes e formalidades que, em muitos casos, não avançam por entraves burocráticos ou por jogos de interesses. A principal restrição é que o tema das relações internacionais (fronteiriças) é centralizado pelo governo federal, diferentemente da 
Argentina, onde a Constituição Nacional prevê que as províncias possam celebrar acordos internacionais, desde que não sejam conflitantes com os interesses nacionais. As dificuldades para alinhar as ações com os países vizinhos esbarram em alguns aspectos, como as diferenças de língua, de território, de acessos, de documentação e de validação de títulos, que, apesar de reivindicadas, seguem sem soluçôes que facilitem a interação existente entre os países vizinhos. Há, também, diferenças de legislação, que têm limitado a preservação do meio ambiente e a prática da pesca e favorecido o contrabando de agrotóxicos etc. Além disso, a morosidade na compreensão e atuação sobre processos naturais, caso da presença do mexilhão dourado nas águas do rio Uruguai, cujo retardamento das medidas de combate permitiu a reproduçáo do molusco em larga escala, provocando sério problema ecológico (Pêgo et al., 2017; 2020a).

Sobre o Mercosul, muito debatido nas atividades do arco Sul, alegou-se que sua presença não é sentida pela população fronteiriça, pelo fato de o bloco ter assumido apenas o processo de integração das grandes empresas nacionais e transnacionais, relegando a fronteira a mero corredor viário de seus fluxos comerciais. A presença do porto seco em Uruguaiana, decorrente de política do Mercosul, é um exemplo dado, pois intensificou o trânsito de veículos na cidade e ao longo das rodovias, particularmente de caminhóes. Como consequência, aumentou a insegurança nas estradas, exigindo maior trabalho da Polícia Rodoviária Federal. Essa movimentação vem gerando mais arrecadação por parte da Receita Federal do Brasil, cujos recursos se destinam ao governo central, náo ficando alguma parcela para aplicar na segurança dos próprios caminhoneiros, do trânsito e de demandas decorrentes que se estabeleceram no município (Pêgo et al., 2017; 2020a).

O Fórum de Governadores Brasil Sul vem realizando reuniôes com os governadores dos estados do Paraná, de Santa Catarina, do Rio Grande do Sul e, mais recentemente, de Mato Grosso do Sul, e com governadores de províncias da Argentina. Outro fórum informal de diálogo regional se dá no âmbito da Zicosul, que abrange o norte da Argentina, partes do Sul e do Centro-Oeste do Brasil, o sul da Bolívia, o sul do Peru e o Chile. Trabalho parceiro também se dá no Bloco Regional de Intendentes, Prefeitos e Alcaldes do Mercosul (Bloque Regional de Intendentes, Prefeitos y Alcaldes del Mercosur - Bripam), e que agora incorporará empresários em sua constituição, possibilitando um conjunto de açóes de integração, principalmente com a Argentina (Pêgo et al., 2020a).

Esses fóruns, no entanto, devem incorporar as contribuiçóes apresentadas pelos governos regionais e locais, pautadas na integração e cooperação. É o caso da demanda por fortalecimento da integração intra e inter-regional, além da maior articulação da área fronteiriça com os países vizinhos; da legitimação e ampliação de iniciativas consorciadas e associativistas; e da criação de áreas fronteiriças baseadas na coesão social e territorial, que depende do desenvolvimento harmônico e 
funcional, de modo que a dimensão do conflito não supere o bom relacionamento ali existente (Pêgo et al., 2020a).

Nesse sentido, foi dado destaque, no arco Central, às intençóes de integração em políticas públicas e infraestruturas entre o Mato Grosso, o Mato Grosso do Sul e o Departamento de Santa Cruz, na Bolívia. Mas foi citada a falta de um plano regional de desenvolvimento, elaborado conjuntamente. O comitê de fronteira vem trabalhando com mais ênfase junto aos municípios situados na linha de fronteira, e, nesse contexto, foram levantadas algumas intençóes e discussóes para posterior desenvolvimento de políticas específicas para a região. Já dentro dessa visão estratégica, em 2015, houve um acordo com o entâo Ministério da Integração Nacional (MI) para realização de planos de desenvolvimento regional, e foi priorizado o plano de desenvolvimento da FF, com promessas de recursos. Mas, nada aconteceu (Pêgo et al., 2019; 2020b).

Um ponto importante foi destacado na integração de serviços na fronteira Brasil-Bolívia pelos participantes do arco Central: a busca dos produtores da Bolívia por reprodutores no Brasil, para o que a Empresa Brasileira de Pesquisa Agropecuária (Embrapa), por meio de parcerias com criadores, está fazendo melhorias na genética do rebanho daquele país, trabalhando com inovação tecnológica e mudança de processos (idades do abate, alimentação etc.). Segundo os produtores e técnicos do Instituto de Defesa e Sanidade Animal do Mato Grosso, os brasileiros vêm assimilando as regras e os costumes da Bolívia, e os bolivianos, as do Brasil, e assim foi criada uma cultura local transfronteiriça de manejo animal compartilhado, que deu sustentação ao sucesso do Programa Hemisférico de Erradicação da Febre Aftosa (Pêgo et al., 2020b).

Os participantes do arco Sul mostraram que a integração fronteiriça entre Brasil e Uruguai tem sido implementada, de um lado, entre as cidades vizinhas de Livramento-Rivera, Quaraí-Artigas, Chuí-Chuy, Jaguarão-Río Branco e Barra do Quaraí-Bella Unión, dos lados brasileiro e uruguaio, respectivamente; de outro, pela Bacia de Lagoa Mirim. Foram criadas comissóes com foco geográfico, a exemplo da Comissão Mista Brasileiro-Uruguaia para o Desenvolvimento da Bacia da Lagoa Mirim (CLM) e da Comissão Mista Brasileiro-Uruguaia para o Desenvolvimento da Bacia do Rio Quaraí (CRQ). Dentro da Nova Agenda de Cooperação e Desenvolvimento Fronteiriço do Brasil, assinada no Uruguai (2002), foram constituídos grupos de trabalho (GTs) para discussão dos temas de saúde, educação, formação profissional, cooperaçóes policial e judicial e meio ambiente e saneamento.

Em 2008, foi criado o Comitê Binacional de Integração em Saúde Santana do Livramento-Rivera, com o objetivo de elaborar políticas públicas de saúde que integrem ambas as comunidades limítrofes. Desse comitê, surgiu a proposta de um ajuste complementar sobre autorização de residência, estudo e trabalho para 
cidadãos fronteiriços uruguaios e brasileiros, para a prestação de serviços de saúde, que foi assinado pelos ministros de Saúde e referendado pelas comissóes de saúde dos parlamentos de cada país. Essa nova agenda tem se transformado, nos últimos anos, em um paradigma a ser adaptado e seguido nas demais fronteiras brasileiras, uma vez que busca fortalecer uma discussão integrada dos diversos aspectos relacionados à vida na fronteira, com vistas à melhoria da qualidade de vida das populaçóes que lá residem (Pêgo et al., 2020a).

Desafio levantado nos debates gerais é a transferência de recursos financeiros de um lado para o outro da fronteira. As limitaçóes de financiamento para açóes integradas associadas a impedimentos legais para empregar dotaçóes orçamentárias do outro lado da fronteira levam a uma grande dependência de recursos de organismos internacionais, que novamente esbarra na baixa capacidade técnica dos municípios para elaboração de projetos. Dessa forma, estabelece-se uma grande dependência das chancelarias e dos órgãos dos governos nacionais, fazendo com que problemas relativamente pequenos necessitem de auxílio da chancelaria, da execução de diálogos e trâmites lentos e burocráticos (Pêgo et al., 2017; 2018; 2019; 2020a; 2020b).

Em complemento, agregaram os participantes do arco Sul que, mais que recursos, está faltando integração interna entre municípios, estados e Nação. Entre os órgãos que trabalham a questão do desenvolvimento e da integração na FF, cada um tem uma forma de trabalhar e uma política diferente; com os mesmos interesses, as mesmas vontades, mas desintegrados para realizar com efetividade esse trabalho. Entre a expectativa e a existência de recursos, e dessa até a execução pleiteada, há uma grande dificuldade, pois está o que chamam de "vontade política”, e que apenas alguns têm papéis de decisão mais privilegiados. As decisóes não são tomadas na fronteira; os agentes atuantes na fronteira são convidados a reuniôes nas capitais dos estados ou em Brasília, e isso não tem sentido. Aí reside o desafio da ampliação da representatividade dos municípios da fronteira em todas as instâncias de decisão, a começar por eleger representantes regionais para o Parlamento (Pêgo et al., 2020a).

Observaram, também, que há desintegração acadêmica entre as universidades, as quais deveriam dialogar mais entre si. Muitas vezes, docentes e alunos passam pela região para estudos e pesquisas, sem a compreensão de que a fronteira é muito mais do que apenas um dos territórios, pois representa o conjunto. Por exemplo, vão ao Parque Estadual do Espinilho, no RS, para estudar o ecossistema, mas dissociado do outro lado da fronteira, voltando-se apenas ao lado brasileiro. Apontaram, também, a distância das universidades em participar da atenção às demandas da região, da formulação de políticas públicas. Essas demandas têm que ser acolhidas pela universidade, no sentido de contribuir nas soluçóes, na busca de experiências que já trouxeram resultados em outras regióes (Pêgo et al., 2020a). 
Sublinharam os participantes, em geral, que o tema fronteira deve ser entendido e marcado como parte de uma preocupação maior: a integração latino-americana. E de supor que a integração das fronteiras e o uso que vem sendo dado a elas nesse processo de integraçáo contribuem e/ou podem contribuir ainda mais para a integração latino-americana (Pêgo et al., 2017; 2018; 2019; 2020a; 2020b; Pêgo e Moura, 2018). As indagaçôes que permaneceram dizem respeito à integração entre conhecimentos científico e acadêmico e políticas públicas: Como articular essas dimensôes? Como incorporar a contribuição do conhecimento? Como fazer com que esses diálogos (a exemplo dessas oficinas) venham a interferir efetivamente na política pública?

\section{REFERÊNCIAS}

BRASIL. Decreto no 99.704 , de 20 de novembro de 1990. Dispóe sobre a execução no Brasil do Acordo sobre Transporte Internacional Terrestre, entre o Brasil, a Argentina, a Bolívia, o Chile, o Paraguai, o Peru e o Uruguai. Diário Oficial da União, Brasília, p. 22.124, 21 nov. 1990. Seção 1. Disponível em: <https:// tinyurl.com/yxkyfs2m>. Acesso em: 26 nov. 2019.

. Decreto no 2.975, de 1ํ de março de 1999. Promulga o Acordo de Transporte Rodoviário Internacional de Passageiros e Carga, celebrado entre o Governo da República Federativa do Brasil e o Governo da República da Venezuela, em Caracas, em 4 de julho de 1995. Brasília: Presidência da República, 1999. Disponível em: <https://tinyurl.com/tgv6a2o>. Acesso em: 26 nov. 2019.

. Decreto no 3.989, de 29 de outubro de 2001. Dispóe sobre a execuçáo do Acordo de Alcance Parcial entre a República Federativa do Brasil e a República Cooperativista da Guiana, de 27 de junho de 2001. Brasília: Presidência da República, 2001. Disponível em: <https://tinyurl.com/vgn96p8>. Acesso em: 25 nov. 2019.

. Decreto no 5.105, de 14 de junho de 2004. Promulga o Acordo entre o Governo da República Federativa do Brasil e o Governo da República Oriental do Uruguai para Permissão de Residência, Estudo e Trabalho a Nacionais Fronteiriços Brasileiros e Uruguaios, de 21 de agosto de 2002. Brasília: Presidência da República, 2004. Disponível em: <https://tinyurl.com/rxr3tp7>. Acesso em: 26 nov. 2019.

Decreto no 7.239, de 26 de julho de 2010. Ajuste Complementar ao Acordo para Permissáo de Residência, Estudo e Trabalho a Nacionais Fronteiriços Brasileiros e Uruguaios, para Prestação de Serviços de Saúde de 2008. Diário Oficial da Uniáo, Brasília, p. 1, 27 jul. 2010a. Seção 1.

Decreto no 7.378 , de 1ํㅡㄹ de dezembro de 2010. Aprova o Macrozoneamento Ecológico-Econômico da Amazônia Legal (MacroZEE) da Amazônia Legal, altera o Decreto no 4.297, de 10 de julho de 2002, e dá outras providências. Brasília: 

sul-americana

Presidência da República, 2010b. Disponível em: <https://tinyurl.com/w8pe9eg>. Acesso em: 27 nov. 2019.

. Decreto no 9.446, de 11 de julho de 2018. Promulga a Emenda ao Anexo II do Acordo de Transporte Rodoviário Internacional de Passageiros e Cargas entre a República Federativa do Brasil e a República Cooperativista da Guiana, firmada em Georgetown, em 29 de junho de 2009. Brasília: Presidência da República, 2018. Disponível em: <https://tinyurl.com/rn42mx8>. Acesso em: 26 nov. 2019.

. Portaria no 53, de 25 de junho de 2019. Ministério da Infraestrutura. Agência Nacional de Transportes Terrestres. Homologa a expedição de licença originária (documento de idoneidade) a Sociedade Empresarial Dantas Transportes e Instalaçôes S.A., para a prestação dos serviços regulares de transporte rodoviário internacional de passageiros entre a República Federativa do Brasil e a República Cooperativista da Guiana para o serviço da linha Internacional Boa Vista (BR) Lethem (GUY). Diário Oficial da União, Brasília, p. 27, 16 jul. 2019. Seção 1.

BRASIL. Ministério da Educação; ARGENTINA. Ministerio de Educación, Ciencia y Tecnología. Escolas de Fronteira. Brasília: MEC; Buenos Aires, mar. 2008. MERCOSUL - MERCADO COMUM DO SUL; CMC - CONSELHO DO MERCADO COMUM. Decreto no 5, de 5 de julho de 2002. Grupo Ad Hoc sobre Integração Fronteiriça. Buenos Aires, 2002.

NERY, C. E. S. A importância do Programa Calha Norte no desenvolvimento da infraestrutura militar na Amazônia Ocidental nos últimos 20 anos. 2019. Trabalho de Conclusão de Curso - Escola de Comando e Estado-Maior do Exército, Rio de Janeiro, 2019.

PEGG, B. et al. (Orgs.). Fronteiras do Brasil: diagnóstico e agenda de pesquisa para política pública. Brasília: Ipea; MI, 2017. v. 2.

Fronteiras do Brasil: uma avaliação do arco Norte. Brasília: Ipea; MI, 2018. v. 3.

. Fronteiras do Brasil: uma avaliação do arco Central. Rio de Janeiro: Ipea; MDR, 2019. v. 4.

. Fronteiras do Brasil: uma avaliação do arco Sul. Rio de Janeiro: Ipea; MDR, 2020a. v. 5.

Estudo técnico sobre a viabilidade de criação da "cidade gêmea" Cáceres (Brasil) - San Matías (Bolívia). Brasília: Ipea; MDR, 2020b.

PÊGO, B.; MOURA, R. (Orgs.). Fronteiras do Brasil: uma avaliação de política pública. Rio de Janeiro: Ipea; MI, 2018. v. 1. 
REIS, V.; LOS RIOS, M. Bacia Trinacional do Alto Rio Acre. 2005. Disponível em: <https://tinyurl.com/yy2p2drz>. Acesso em: 28 nov. 2019.

SAUSI, J. L. R.; ODDONE, N. A cooperaçáo transfronteiriça entre as Unidades Sub-nacionais do Mercosul. 2010. Disponível em: <https://tinyurl.com/ yycrg2qg>. Acesso em: 26 nov. 2019.

ÚLTIMA etapa de vacinação contra aftosa ocorrerá em novembro nos estados do AC, RO, MT e AM. Gov.br, 27 mar. 2019. Disponível em: <https://tinyurl.com/ y53zjs96>. Acesso em: 18 jan. 2021. 


\section{MODELOS DE GOVERNANÇA NA FRONTEIRA BRASILEIRA: ENTRE INTERMITÊNCIAS E CONTINUIDADES}

\section{INTRODUÇÃO}

Do reconhecimento da necessidade de um modelo de governança que abarcasse a diversidade e a complexidade do espaço fronteiriço brasileiro e das dinâmicas transfronteiriças, como contextualizado na publicação Bases para uma proposta de desenvolvimento e integração da faixa de fronteira, em novembro de 2008, foi "proposta a criação de um grupo multidisciplinar que pudesse, na medida do possível, representar legitimamente os interesses, competências e atribuiçóes das instituições públicas, privadas ou da sociedade civil organizada que ali atuam" (Brasil, 2010, p. 9).

Assim sendo, o Comitê de Articulação Federativa (CAF), ${ }^{1}$ da Secretaria de Relaçôes Institucionais da Presidência da República (SRI/PR), propôs a criação do Grupo de Trabalho Interfederativo (GTI), ${ }^{2}$ que ficou sob coordenação do então Ministério da Integração Nacional (MI), atual Ministério de Desenvolvimento Regional (MDR), com objetivo de elaborar propostas voltadas ao desenvolvimento e à articulação de ações de integração fronteiriça com os países vizinhos e o Mercosul, bem como na concertação de ações articuladas entre as unidades federadas fronteiriças.

Ancorado na experiência federativa e visando ao fortalecimento da capacidade financeira, técnica e gerencial dos governos locais, o CAF instituiu o GTI, com a finalidade de fortalecer mecanismos de articulação intergovernamental. Entre os diagnósticos realizados pelo GTI, identificou-se um nexo entre a localização e o porte dos municípios fronteiriços com indicadores socioeconômicos e baixa performance, no desenvolvimento regional, maior grau de dependência das transferências financeiras e carências administrativas de outros níveis de governo.

\footnotetext{
1. 0 CAF foi constituído em 2003, como uma forma de gerar um "encontro de agendas" entre os municípios e o governo federal, como instância consultiva e de assessoria junto à Casa Civil da PR, e com o comitê atuando como a expressão direta do chefe de governo. No âmbito da PR, o CAF esteve lotado na SRI. Apesar de sua capacidade de governança, o comitê não tinha suporte constitucional que Ihe conferisse capacidade decisória, como as experiências a despeito de outras experiências, como o alemão, 0 canadense e 0 australiano. Assim, em vez de atribuir-lhe capacidade, tal instância foi revogada pelo Decreto no 9.784/2019. Disponível em: <https://bit.ly/3koleUq>. Acesso em: 23 nov. 2019. 2. Instituído pela Resolução no 8, de 19 de novembro 2008, revogada pelo Decreto no 9.961/2019. Composto por órgãos federais e entidades civis e configurou-se na primeira iniciativa da Comissão Permanente para o Desenvolvimento e a Integração da Faixa de Fronteira (CDIF).
} 
Assim, diante dos grandes desafios enfrentados pelo grupo para atender a objetivos táo complexos na elaboração de políticas públicas para o recorte, ficou demonstrada a necessidade da criaçáo de um modelo de gestão de cunho mais permanente, com característica principal de voltar-se à criação de uma rede de instituiçôes que vinham concretizando-se pelo diálogo intersetorial e federativo permanente do CAF e em outras instâncias.

Apoiado nas experiências e na sinergia dos fóruns federativos de atuação na fronteira, o GTI propôs a criaçáo da CDIF, ${ }^{3}$ um foro colegiado integrado por representantes de órgãos federais e estaduais, associações municipais e entidades civis. Um instrumento de gestão das políticas públicas para a região e de integração fronteiriça, com finalidade de propor diretrizes e coordenar açóes voltadas à atuação do governo federal (Brasil, 2010).

A composição da primeira edição da CDIF, cuja instalação só ocorreu no primeiro trimestre de 2011, congregou vinte instituiçóes federais, sendo a maioria de representação oriunda dos ministérios e várias entidades de classe, com membros permanentes.

Entidades convidadas:

- Serviço Brasileiro de Apoio às Micro e Pequenas Empresas (Sebrae);

- Associação Brasileira de Municípios (AMB);

- Confederação Nacional dos Municípios (CNM);

- $\quad$ Frente Nacional de Prefeitos (FNP);

- Conselho de Desenvolvimento dos Municípios Lindeiros ao Lago de Itaipu (Lindeiros);

- Conselho de Desenvolvimento e Integração Sul (Codesul)/Rio Grande do Sul; e

- Fórum de Governadores da Amazônia Legal.

Como modelo institucional, a iniciativa parece ter sido inspirada no Grupo de Trabalho Permanente (GTP) para arranjos produtivos locais (APL) ${ }^{4}$ iniciativa do Ministério do Desenvolvimento, Indústria e Comércio Exterior, atual Ministério da Indústria, Comércio Exterior e Serviços (MDIC), que foi produzida em parceria com o sistema Federação das Indústrias do Estado de São Paulo (Fiesp), Manual de atuação em arranjos produtivos locais. $\mathrm{O}$ documento faz a apresentação do grupo:

O GTP APL, criado pela necessidade de articulação das açóes governamentais para apoio integrado aos APLs, é composto por 33 instituiçóes governamentais e náo governamentais, com a atribuiçáo de elaborar e propor diretrizes gerais para a atuaçáo coordenada do governo no apoio a APLs em todo o território nacional (Brasil e Fiesp, 2007, p. 15). 
$\mathrm{Na}$ formatação da CDIF, o GTI apoiou-se nas estratégias de atuação adotadas pelo $\mathrm{GTP}^{5}$ que consistiram em:

descentralizaçáo do planejamento e da ação, promoçáo do protagonismo dos empresários e instituiçóes presentes nos APLs e publicidade ao processo de acolhimento das demandas dos APLs tendo como base a elaboraçáo de um Plano de Desenvolvimento dos Arranjos Produtivos Locais e a colaboraçáo entre os entes federados (Brasil e Fiesp, 2007, p. 17).

A primeira edição da CDIF avança na disposição de ampliar o diálogo intersetorial e federativo por meio de uma rede de atores que atuam de forma integrada e colaborativa, aberta à participação das instituiçóes interessadas, sem restriçóes quanto ao número total de participantes, sobretudo nos fóruns em atuação nos espaços de fronteira.

A Comissão Permanente para o Desenvolvimento e Integraçáo da Faixa de Fronteira teria a atribuição de elaborar e propor diretrizes gerais para a atuação coordenada do governo federal no apoio ao desenvolvimento e integraçáo da faixa de fronteira, devendo, para tanto:

a) definir, respeitadas as especificidades de atuaçáo dos órgãos competentes, critérios de ação conjunta governamental para o desenvolvimento e a integraçáo na área abrangida pela faixa de fronteira, estimulando a integração das políticas e a parceria com os demais entes públicos, visando a complementariedade das açóes;

b) apresentar estudos que visem a melhoria da gestão multissetorial para as açôes do governo federal no apoio ao desenvolvimento e a integraçáo da área abrangida pela faixa de fronteira;

c) propor o desenvolvimento de sistema de informaçóes para o gerenciamento das açôes a que se refere o inciso II;

d) apresentar planos regionalizados de desenvolvimento e integraçáo fronteiriços; e

e) interagir com núcleos regionais estabelecidos para debater questóes de desenvolvimento e integração fronteiriços (Brasil, 2010; Decreto de 8 de setembro de 2010, revogado).

\section{OPERACIONALIZAÇÃO DA CDIF E A FAIXA DE FRONTEIRA}

Quando analisada à luz da continuidade de políticas de desenvolvimento para a regiấo fronteiriça, aportada no Programa de Desenvolvimento da Faixa de Fronteira (PDFF), a exemplo do GTI, observa-se que a CDIF, como instrumento, corresponde à agenda de fortalecimento institucional (Brasil, 2005) e ao mesmo tempo ocupa o lugar do PDFF, que tem seu encerramento gradual com a perda 
de recursos, e a partir de 2011 não tem mais lugar no conteúdo programático do Plano Plurianual (PPA) 2015-2018.

Ainda assim, tal instrumento introduziu novas e importantes iniciativas em suas estratégias para a coordenação de ações públicas no recorte fronteiriço. Uma dessas iniciativas foi a mobilizaçáo de atores locais e regionais fronteiriços para servirem à interlocução em suas regiôes (fronteira). Essas estruturas foram denominadas de núcleo estadual de fronteira, ${ }^{6}$ e em 2012 todos os estados fronteiriços haviam formado seus núcleos. Segundo a CDIF,

a formação, composição e caracterização dos referidos núcleos deverão se pautar pelas especificidades do território que representam e pela dinâmica própria das instituiçóes que ali atuam em questóes relacionadas à fronteira daquela região. A existência dos núcleos regionais é essencial para o sucesso da CDIF, na medida em que propicia a articulação das políticas setoriais com as características particulares de cada fronteira e permite o aprimoramento do diálogo federativo numa dada regiáo (Brasil, 2010).

Aos núcleos coube identificar e elencar os principais desafios e oportunidades do recorte fronteiriço, sistematizar e analisar as demandas locais e, a partir das informaçóes, elaborar seus planos regionalizados, combinando açóes do governo federal e contrapartidas de outras esferas de governo.

A CDIF, com vistas a acompanhar os trabalhos dos núcleos, construiu uma agenda de seminários e encontros regionais, com objetivo de colaborar nas discussões e na formalização dos Planos Regionalizados de Desenvolvimento e Integração Fronteiriços - PDIFs (Brasil, 2017). Também coube à CDIF definir as diretrizes para o processo de elaboração do PDIF.

1) Promover o ordenamento territorial e a gestão ambiental, de modo a possibilitar o combate à grilagem de terras públicas.

2) Resolver conflitos fundiários e destinar as terras públicas.

3) Controlar a exploração ilegal e predatória de recursos naturais.

4) Proteger os ecossistemas regionais.

5) Fomentar atividades econômicas no território, pautadas no uso sustentável dos recursos naturais com inovação tecnológica, agregação de valor e valorização da biodiversidade e dos conhecimentos das populaçôes locais, de modo a estimular a geração de emprego e renda, o fortalecimento da segurança alimentar e maior competitividade em mercados regionais, nacionais e internacionais.

6) Subsidiar o planejamento, a execução e a manutenção das obras de infraestrutura nos setores de energia, transportes, comunicaçóes e na instalaçáo de equipamentos

6. Esses núcleos, em sua maioria, organizam-se a partir de decretos estaduais que designam seus respectivos membros. São compostos por representantes do governo estadual e da sociedade civil (Brasil, 2010). 
urbanos, visando à maximização dos benefícios socioeconômicos e minimização e mitigação dos impactos negativos dessas intervençóes na região em referência.

7) Fortalecer a inclusão social e a cidadania por meio de processos participativos de gestáo das políticas públicas e de garantias do acesso da população da faixa de fronteira às políticas universais de educação, saúde, segurança pública e previdência social.

8) Embasar a construção de um novo modelo de financiamento nas áreas de fronteira da Amazônia, voltado para a redução das desigualdades sociais e regionais, geração de emprego e renda, uso sustentável dos recursos naturais.

9) Garantir e fortalecer a gestão do Plano de Desenvolvimento e Integração Fronteiriço dos estados que fazem parte da Faixa de Fronteira - PDIF (Brasil, 2017, p. 19-20).

As memórias de reunióes publicadas evidenciam que até 2013 houve certa regularidade na realização de reunióes colegiadas da CDIF, dos grupos de trabalho (GTs) e dos encontros regionais anuais dos núcleos fronteiriços.

A formação de GTs foi outra iniciativa na atuação da CDIF. Os grupos foram constituídos para tratar de temas específicos, afetos às pastas ministeriais e de instituições específicas, sob a coordenação de suas respectivas entidades (quadro 1).

QUADRO 1

Relação dos GTs temáticos

\begin{tabular}{|c|c|c|c|c|}
\hline GT & Ação & Instituições afins & Coordenação & Instâncias \\
\hline 1 & $\begin{array}{l}\text { Escolas binacionais de } \\
\text { fronteira e Instituto } \\
\text { Técnico de Fronteira }\end{array}$ & $\begin{array}{l}\text { Ministério da Educação (MEC) e } \\
\text { Ministério das Relações Exteriores } \\
\text { (MRE) }\end{array}$ & MEC & $\begin{array}{l}\text { Federal; estaduais; } \\
\text { e municipais. }\end{array}$ \\
\hline 2 & Saúde na fronteira & $\begin{array}{l}\text { Ministério da Saúde (MS), MEC, } \\
\text { Conselho Federal de Medicina } \\
\text { (CFM) e MRE }\end{array}$ & MS & $\begin{array}{l}\text { Federal; municipais; e } \\
\text { entidades representativas. }\end{array}$ \\
\hline 3 & $\begin{array}{l}\text { Aumento de investimen- } \\
\text { to em infraestrutura }\end{array}$ & $\begin{array}{l}\text { Ministério do Trabalho (MTE), } \\
\text { Ministério das Cidades (MCi- } \\
\text { dades), MDIC, Ministério do } \\
\text { Planejamento (MPOG), Ministério } \\
\text { da Justiça (MJ) e Receita Federal } \\
\text { do Brasil (RFB) }\end{array}$ & MPOG & $\begin{array}{l}\text { Federal; estaduais; e } \\
\text { municipais. }\end{array}$ \\
\hline 4 & $\begin{array}{l}\text { Funcionamento integrado } \\
\text { do controle fronteiriço }\end{array}$ & $\begin{array}{l}\text { RFB, Polícia Federal (PF), Minis- } \\
\text { tério da Agricultura, Pecuária e } \\
\text { Abastecimento (Mapa), Instituto } \\
\text { Brasileiro do Meio Ambiente e } \\
\text { dos Recursos Naturais (Ibama), } \\
\text { Agência Nacional de Vigilância } \\
\text { Sanitária (Anvisa), Agência } \\
\text { Nacional de Transportes Terrestres } \\
\text { (ANTT) e Polícia Rodoviária } \\
\text { Federal (PRF) }\end{array}$ & RFB & Federal. \\
\hline
\end{tabular}




\begin{tabular}{|c|c|c|c|c|}
\hline GT & Ação & Instituições afins & Coordenação & Instâncias \\
\hline 5 & Inclusão produtiva & $\begin{array}{l}\text { MI, MDIC, Ministério do } \\
\text { Desenvolvimento Social (MDS), } \\
\text { Ministério do Desenvolvimento } \\
\text { Agrário (MDA), Ministério da } \\
\text { Cultura, Sebrae e MRE }\end{array}$ & Ml & $\begin{array}{l}\text { Federal; estaduais; } \\
\text { municipais; e } \\
\text { entidades representativas. }\end{array}$ \\
\hline 6 & Segurança & $\begin{array}{l}\text { MJ, Ministério da Defesa (MD), } \\
\text { Ministério do Meio Ambiente } \\
\text { (MMA), Ministério da Fazenda } \\
\text { (MF), MS, Mapa, MRE e MI }\end{array}$ & MI & Federal. \\
\hline
\end{tabular}

Fonte: Apresentação dos grupos técnicos. Disponível em: <https://bit.ly/3tG8mjg>. Acesso em: 28 out. 2019. Elaboração: Equipe Fronteiras Ipea.

Além dos trabalhos dos grupos temáticos, entre os objetivos operacionais alcançados pela CDIF, há de se destacar a mobilização dos núcleos estaduais para que identificassem e sistematizassem os principais problemas e oportunidades de suas regióes de fronteira e os transformassem em dados e indicadores regionais (PDIF).

As informaçóes e os dados sistematizados e as demandas priorizadas pelos núcleos de fronteira (tabela 1) subsidiaram a relação de programas e prioridades do Plano Brasil Fronteira.?

TABELA 1

Relação das demandas identificadas e priorizadas pelos núcleos estaduais (Em \%)

\begin{tabular}{lcccccc}
\hline Arcos & Segurança & Legislação & $\begin{array}{c}\text { Ciência, tecnolo- } \\
\text { gia e inovação }\end{array}$ & $\begin{array}{c}\text { Infraestrutura } \\
\text { regional e } \\
\text { urbana }\end{array}$ & $\begin{array}{c}\text { Acesso a servi- } \\
\text { ços públicos }\end{array}$ & $\begin{array}{c}\text { Estrutura } \\
\text { produtiva }\end{array}$ \\
\hline Norte & 8 & 31 & - & 31 & 15 & 15 \\
Central & 15 & 8 & 15 & 31 & 23 & 19 \\
Sul & 12 & 6 & - & 44 & 19 & 19 \\
\hline
\end{tabular}

Fonte: Apresentação dos grupos técnicos. Disponível em: <https://bit.ly/3tG8mjg>. Acesso em: 28 out. 2019.

Elaboração: Equipe Fronteiras Ipea.

A principal evidência das informaçôes distribuídas na tabela 1 deve-se à apresentação de diferentes necessidades entre os arcos, a exemplo da segurança e legislação no arco Norte em relação aos demais arcos.

Como pode ser observado no quadro 1 e na tabela 1 , o conjunto de proposiçôes dos PDIFs estaduais, dos GTs temáticos e demais aspectos considerados na revisão da Política Nacional de Desenvolvimento Regional (PNDR), levantados pela I Conferência Nacional de Desenvolvimento Regional (CNDR), subsidiou

7. Apesar de a CDIF ter cunhado a proposta do Plano Brasil Fronteiras e de alguns dos programas e projetos relacionados no documento terem sidos parcialmente implementados, tal instrumento não chegou a ser oficializado como uma diretriz de governança de políticas públicas na FF. 
a proposta de um plano federal que alavancasse o desenvolvimento e a integração da faixa de fronteira (FF), cujo conteúdo encontra-se na publicação: Texto para Discussáo do Plano de Desenvolvimento Regional e Sustentável para a Faixa de FronteiraPlano Brasil Fronteira (Brasil, 2012), na qual a visão de futuro versa:

o Plano Brasil Fronteira pretende consolidar a faixa de fronteira como espaço de cooperação e integração cultural e comercial, de livre trânsito de pessoas, de compartilhamento de trabalho e de serviços e de construçáo de uma comunidade sul-americana coesa, de tal forma que a região ganhe escala para competir mundialmente (Brasil, 2012, p. 6).

A proposta do Plano Brasil Fronteira inclui açóes ligadas ao desenvolvimento, à integração e à segurança na FF e evidencia elementos que representam a atuação da ação pública, desde a obtenção dos recursos até a geração dos impactos provenientes dos produtos e serviços. O plano foi elaborado sob três diretrizes: i) mapeamento dos desafios e oportunidades do recorte fronteiriço; ii) delineamento de programas estruturantes e complementares; e iii) definição da carteira de projetos (diretrizes de médio e longo prazos). Destacados os desafios e as oportunidades, a proposta relaciona os programas estruturantes e complementares, como segue no quadro 2.

QUADRO 2

Relação de programas estruturantes e complementares da proposta do Plano Brasil Fronteira (2012)

\begin{tabular}{|c|c|}
\hline \multicolumn{2}{|l|}{ Programas } \\
\hline \multirow{3}{*}{ Estruturantes } & $\begin{array}{l}\text { E1 - Adensamento e diversificação da estrutura produtiva da FF e sua integração aos mercados interno } \\
\text { e externo. }\end{array}$ \\
\hline & E2 - Acesso a serviços públicos básicos para o desenvolvimento e a integração da FF. \\
\hline & $\begin{array}{l}\text { E3 - Investimentos em infraestrutura econômica e urbana para a consolidação de uma rede de cidades } \\
\text { equilibrada na FF. }\end{array}$ \\
\hline \multirow{5}{*}{ Complementares } & $\begin{array}{l}\text { C1 - Implementação de mecanismos de articulação institucional entre as diferentes organizaçães } \\
\text { governamentais e entidades da sociedade civil com atuação direta ou indireta no desenvolvimento e na } \\
\text { integração da zona de fronteira. }\end{array}$ \\
\hline & $\begin{array}{l}\text { C2 - Aperfeiçoamento das fontes de financiamento para o desenvolvimento socioeconômico da zona } \\
\text { de fronteira. }\end{array}$ \\
\hline & $\begin{array}{l}\text { C3 - Consolidação de rede de estudos aplicados ao desenvolvimento e à integração da faixa, consor- } \\
\text { ciada a incubadoras de empresas e institutos de educação profissional e tecnológica. }\end{array}$ \\
\hline & $\begin{array}{l}\text { C4 - Investimentos em segurança pública e solução de contenciosos que garantam ambiente propício } \\
\text { ao desenvolvimento e integração da FF. }\end{array}$ \\
\hline & C5 - Revisão/aprimoramento da legislação e regulamentações diversas que afetam a dinâmica da FF. \\
\hline
\end{tabular}

Fonte: Brasil (2012).

Elaboração: Equipe Fronteiras Ipea.

A relação do quadro 2 evidencia que o elenco dos objetivos estratégicos e das prioridades propostas nesse plano demonstra a tentativa de se construir um plano nacional, a partir das realidades concretas de cada região da FF. 
Apesar disso, mesmo com a construção de uma "agenda de convergência", com foco na articulação institucional efetiva com políticas públicas em andamento, como Plano Brasil Melhor, Plano Estratégico de Fronteiras, PNDR, Plano Brasil sem Miséria e o Programa de Aceleraçáo do Crescimento (PAC), a CDIF não conseguiu articular a oficialização do Plano Brasil Fronteira. A relação dos programas do plano demonstra adequação ao conjunto de prioridades levantadas pelos núcleos de fronteira (quadro 3).

QUADRO 3

Carteira de ações de curto prazo definida pelos núcleos de fronteira

\begin{tabular}{|l|l|}
\hline \multicolumn{1}{|c|}{ Programas } & \multicolumn{1}{c|}{ Carteira de curto prazo } \\
\hline E1 - Base produtiva & $\begin{array}{l}\text { Realização dos estudos para identificação, diagnóstico e elaboração de projetos de fortalecimento } \\
\text { das cadeias produtivas com potencial para alavancar o desenvolvimento da FF e identificação de } \\
\text { oportunidades de integração produtiva com outras regiões do Brasil e/ou países vizinhos. } \\
\text { Realização dos estudos para identificação, diagnóstico e elaboração de projetos de fortalecimento das } \\
\text { cadeias produtivas com potencial para promover a inclusão produtiva da população de baixa renda. } \\
\text { Elaboração dos projetos industriais, a partir dos estudos indicados anteriormente, articulados com } \\
\text { o conjunto de investimentos nacionais e sul-americanos previsto em diferentes setores econômi- } \\
\text { cos e com os projetos de integração física sul-americana. }\end{array}$ \\
\hline E2 - Acesso a serviços & $\begin{array}{l}\text { Implantação de centros de controle integrados nos onze estados fronteiriços. } \\
\text { Implantação das escolas binacionais nas cidades gêmeas. } \\
\text { Implantação do Sistema Integrado de Saúde da Faixa de Fronteira (SIS-Fronteira) nas cidades gêmeas. }\end{array}$ \\
\hline E3 - Infraestrutura & $\begin{array}{l}\text { Implantação de sistema de planejamento urbano integrado nas cidades gêmeas. } \\
\text { Implantação do PAC Cidades em todas as cidades gêmeas da FF. }\end{array}$ \\
\hline
\end{tabular}

Fonte: Brasil (2012).

Elaboração: Equipe Fronteiras Ipea.

\section{OS DESAFIOS DA CDIF NA OPERACIONALIZAÇÃO DA GOVERNANÇA PÚBLICA NA FAIXA DE FRONTEIRA}

Com a diminuição consistente de alocação de recursos, como evidenciado nos números do Sistema Integrado de Administração Financeira do Governo Federal (Siafi), que desde 2008 vem apontando essa tendência nos recursos destinados a açóes e programas para o PDFF (Nunes, 2013), a redução dos recursos foi ainda mais consistente a determinadas açóes dos programas de fronteira. Entre elas, destacam-se a estratégia de combate às desigualdades regionais de fortalecimento do potencial de desenvolvimento de cada município e a de resgate da dívida social com a população em histórica situação de vulnerabilidade. Esta última ação foi relacionada como prioridade no PDFF.

A partir de 2014, mesmo diante de uma agenda com capacidade de nortear açôes de desenvolvimento e integração da FF e do papel na formação e condução de uma rede de agentes do Estado e atores fronteiriços, com capacidade técnica e 
de se constituir em um fórum de referência, a limitação orçamentária e o desafio na concertação de todos os atores levaram a CDIF ao esvaziamento. Essa situação concorreu para que a CDIF aparecesse nas recomendaçóes da avaliação do Tribunal de Contas da Uniấo (TCU), realizada com objetivo de analisar aspectos de governança do conjunto de políticas públicas para a FF (TCU, 2015). Na avaliação do tribunal, a inexistência de um projeto que permitiria visualizar a coordenação de todos os componentes da política pública, como insumos, atividades, produtos, efeitos e impactos, inviabiliza a adoção de açôes que caracterizem uma lógica de intervenção das políticas federais para a FF (TCU, 2015).

$\mathrm{Na}$ visão geral do documento do tribunal, a avaliação considera que, na falta de uma lei específica, a CDIF em conjunto com outros instrumentos, como a PNDR ${ }^{8}$ e o Plano Estratégico de Fronteiras, ${ }^{9}$ seriam capazes de pacificar "a atuação dos entes públicos do Estado brasileiro, a açáo governamental para o desenvolvimento, a integração e a segurança na faixa de fronteira" (TCU, 2015, p. 5).

Entre os gargalos que o levantamento relacionou acerca da CDIF estão: i) baixa alocação de recursos para implementação das açóes federais na fronteira, aportada, sobretudo, em emendas parlamentares; ii) reduzido número de reunióes; iii) poder decisório das instituiçôes envolvidas; iv) falta de definição precisa das atuações dos partícipes e de seus representantes; e v) baixa prioridade governamental para a área de fronteira. Esse rol de condiçóes "limita ainda mais a capacidade de ação daquele colegiado, a ponto de nem ao menos ter conseguido aprovar seu regimento interno" (TCU, 2015, p. 9). Porém, a avaliação ressalva que a aprovação do regimento interno não teria resolvido os impasses auferidos à comissão.

Das recomendaçóes para o coordenador do MI, a avaliação levanta dois pontos gerais:

1) Promova a conscientização dos titulares das pastas integrantes da comissão quanto às necessidades e potencialidades inerentes à faixa de fronteira, para que estes se empenhem em garantir que haja recursos orçamentários suficientes para possibilitar a execução da política de desenvolvimento e integraçáo da regiáo.

2) Priorize a criação e aprovação de um regimento interno que defina critérios aos componentes da comissáo: participaçáo de membros técnicos e comprometidos; definição e partilhamento das responsabilidades e compromissos; definição de medidas e de avaliação das já realizadas e em andamento e decisão de novas agendas e periocidade nas açốes e metas; definição de pautas dos próximos encontros e publicização dos temas a serem avaliados pelos demais membros (TCU, 2015).

8. Decreto o 6.407/2007, revogado pelo Decreto № 9.810/2019. Disponível em: <https://bit.ly/3pln50D>. Acesso em: 21 out. 2019.

9. Decreto no 7.496/2011, revogado pelo Decreto no 8.903/2016. Disponível em: <https://bit.ly/3nd2f10>. Acesso em: 25 out. 2019. 
A ausência de uma política de fronteira compôs o conjunto do diagnóstico da avaliação do TCU que, segundo a visão do relator, prejudica as açóes na fronteira, devido à descontinuidade das agendas de governos. Assim, o tribunal elaborou uma longa lista de recomendaçóes aos coordenadores da CDIF (MI) e do Plano Estratégico de Fronteiras (MD, MJ e MF).

Tais recomendaçôes seguem transcritas na íntegra do documento publicado.

1) Articulem-se com os diversos órgãos e instituições integrantes dos colegiados sob suas coordenaçóes (CDIF, COC e GGI-FRON) e estabeleçam critérios e procedimentos de atuaçáo integrada, com vistas à edição de normativos interinstitucionais que reduzam a termo as funçôes e responsabilidades das partes envolvidas, guardadas suas atribuiçóes individuais dispostas em leis próprias de criação e respectivos regimentos internos.

2) Articulem-se com os demais membros integrantes da CDIF, com a finalidade de se editar um instrumento formal que consolide os elementos necessários para a caracterização de uma lógica de intervenção das políticas federais aplicadas à faixa de fronteira, sob os aspectos de desenvolvimento socioeconômico, segurança e integraçáo, de forma a alinhar insumos, atividades, produtos, efeitos e impactos em função dos problemas a serem atacados.

3) Convoquem os demais membros integrantes da CDIF a debaterem em torno de um processo de planejamento para as políticas federais voltadas para a faixa de fronteira, que compreenda as áreas de desenvolvimento, segurança e integraçáo da regiáo, de forma unificada ou setorizada, com a definição consensual dos objetivos coletivos e individuais a serem alcançados, respectivas metas e indicadores relacionados, de acordo com as prioridades estabelecidas, com a finalidade de se formalizar, de maneira legítima, instrumento de orientação estratégica a ser utilizado pelos órgãos que executam a política, facilitando, com isso, os procedimentos de monitoramento e avaliaçáa e assegurando-se, também, a transparência sobre como os produtos e serviços estarão sendo prestados à sociedade.

4) Articulem os diversos órgãos e instituiçôes sob sua coordenação com vistas a, primeiramente, promoverem a sistematização das cooperaçóes vigentes, por áreas de atuação, de acordo com critérios pré-estabelecidos, para, então, confrontarem com as demandas necessárias para a concretizaçáo de trabalhos em parceria com os países limítrofes, e, assim, definirem as prioridades a serem encaminhadas ao Ministério das Relaçôes Exteriores com a finalidade de celebrarem-se os acordos e tratados internacionais correspondentes.

5) Identifiquem em um plano consolidado, complementar ao PPA, a previsão de recursos destinados à política aplicada à fronteira, incluindo montantes orçamentários e outras formas de financiamento, pessoal qualificado, infraestrutura física, sistemas de informação, entre outros, necessários à implementação dos programas relacionados ao desenvolvimento, integração e segurança da região (TCU, 2015). 
Em 8 de novembro de 2018, por meio da Resolução nº 1, a CDIF aprova seu regimento interno. Apesar dessa aprovação vir em consonância às recomendações da avaliação, o texto particulariza a formação de grupos técnicos de trabalho, porém não especifica particularidades do contido no item 2 das recomendaçóes relacionadas no parágrafo anterior. Também não menciona a participação de outras instituiçôes e entidades na comissão.

Com seu regimento interno aprovado no fim de 2018, a CDIF é reeditada pelo Decreto n 9.961/2019 (Brasil, 2019), com algumas modificaçôes em razão da edição anterior. Criada originalmente com a participação de vinte pastas federais, na reconfiguração, a CDIF passa a ser composta por oito dessas pastas, apenas excluindo de sua composição deliberativa entidades e representações de prefeituras, governadores, micro e pequenas empresas e outras entidades.

Segundo a nova redação do termo de reedição da CDIF, representantes de outras entidades públicas e privadas, inclusive dos demais entes federativos, que antes constavam relacionadas no decreto, podem participar das reuniōes da CDIF, "na qualidade de membros convidados, sem direito a voto" (Brasil, 2019).

\section{UM CAMINHO PARA CONTINUIDADES: DIAGNÓSTICOS E SUGESTÕES}

Apesar das modificações impressas na redação do decreto de reedição da CDIF (no 9.961/2019), chama a atenção que há alguns pontos que não coadunam com as recomendaçóes do TCU, e um dos pontos que a avaliação assinalou como negativa em relação à edição anterior da CDIF diz respeito ao número reduzido de reuniōes. Na reedição da CDIF, no entanto, em seu art. 5o, "A Comissão Permanente para o Desenvolvimento e a Integração da Faixa de Fronteira se reunirá em caráter ordinário, no mínimo, três vezes ao ano e, em caráter extraordinário, por solicitação de seus membros" (Brasil, 2019).

A título de comparação entre as duas edições da comissão, as memórias de reunióes da edição anterior da CDIF permitem observar que ela realizou em média três encontros anuais (duas reunióes com os membros da comissão e um encontro regional, com a participação dos membros dos núcleos de fronteira).

A avaliação levanta alguns destaques, descritos a seguir.

1) A previsão normativa e iniciativas que despertem o interesse dos setores representativos da sociedade podem estimular a sua participaçáo na política direcionada à região.

a) Em consonância com essa orientação, seria propício propor a adoção de medidas para minimizar os efeitos dos elementos que prejudicam a participação social desejável. 
b) Nesse intento, caberia sugerir aos coordenadores da CDIF e do PEF um conjunto de iniciativas, a serem discutidas e definidas com os demais interessados, nos seguintes termos:

- $\quad$ previsão, nos normativos, quanto à previsão de participação social nos fóruns já estabelecidos, inclusive nos processos decisórios;

- adoção de açôes pertinentes que despertem o interesse da sociedade, conscientizem-na e demonstrem a utilidade e os benefícios de sua colaboração e participação para o alcance dos resultados desejados, a exemplo de seminários, oficinas de trabalho e outros meios que promovam a interação dos interessados; e

- $\quad$ elaboração de modelo de participação social que garanta o envolvimento dos interessados, de forma equitativa e balanceada, na definição das prioridades da política.

2) Almeja-se, com isso, ampliar a participação da sociedade na política de fronteira que se executa, tornando-a mais compatível com os anseios da coletividade.

3) A prática da participação social seria, inclusive, um ótimo aprendizado, tanto para gestores quanto para os atores da sociedade, pois conduziria ao reconhecimento do diálogo com diferentes necessidades existentes e ampliaria os níveis de confiança mútua (TCU, 2015).

Também há discrepância entre o número de reunióes estipulado na Resolução $\mathrm{n}^{\mathrm{o}} 1$, de 8 de novembro de $2018,{ }^{10}$ que aprovou o regimento interno da comissão. $\mathrm{O}$ seu art. 8 determina que a CDIF deve se reunir, ordinariamente, pelo menos quatro vezes ao ano e, extraordinariamente, por convocação de sua secretaria executiva. No caso, deve ser considerada a importância das reunióes para deliberar ações e papéis no rol de atribuiçóes da comissão, assim a quantidade de encontros necessários deveria ser avaliada por seus membros, considerados os mais capacitados na promoção de debates de temas tão complexos e de grande abrangência. Há, também, de se considerar que o número de encontros e reunióes da edição anterior foi criticado na auditoria do TCU.

Outro ponto destacado na auditoria do tribunal particulariza maior participação da comunidade fronteiriça nas discussões para a construção de políticas públicas voltadas à região. Nesse quesito, destacam-se as atividades da pesquisa realizada pelo Ipea/MDR, cujas informaçóes levantadas evidenciam que a população fronteiriça também deseja maior participação na formulação das açóes que conduzam melhorias em seus lugares de vivência. Entretanto, a nova reedição da CDIF (Decreto no 9.961/2019) suprime atores importantes como a RFB, órgão do Ministério da Economia que não foi incluído na relação de entidades federais 
com representação na comissão, bem como de outros entes governamentais e entidades fronteiriças importantes que ficaram sem representação na CDIF (art. $3^{\circ}$ ).

No mesmo sentido, a realização das oficinas de trabalho em pontos dos arcos da fronteira evidenciou que a ampliação de atores nas discussóes das questóes fronteiriças pode ajudar a comissão a entender as heterogeneidades regionais e as dinâmicas transfronteiriças, para melhor delinear as demandas e os problemas de seus locais de vivência.

Acerca da edição anterior da CDIF, os dados produzidos e disponíveis por meio dos núcleos de fronteira mapearam as prioridades regionais e, em conjunto aos trabalhos dos GTs, definiram três macroprogramas: i) base produtiva; ii) acesso a serviços; e iii) infraestrutura.

Os programas prioritários destacados foram utilizados para a composição das carteiras de curto e médio prazos, da proposta do Plano Brasil Fronteira, ${ }^{11}$ indicando os órgãos responsáveis e as instituições pela condução de cada ação específica. Logo, atende ao que vem ao encontro do que trata o art. 2을 "VII - apresentar planos regionalizados de desenvolvimento e integração fronteiriços", que já se encontravam elaborados nos planos regionais (Brasil, 2017).

Algumas das açóes relacionadas na carteira de curto prazo foram realizadas, entre as quais se destacam os levantamentos, estudos e diagnósticos publicados.

Enquanto sugestão para o avanço na formulação de proposiçôes e açôes para o recorte da fronteira brasileira, indica-se a utilização de estudos, diagnósticos e mapeamentos das prioridades da região fronteiriça disponíveis a seguir.

1) Planos Regionais de Fronteira (2017): elaborados pelos núcleos de fronteira (regionais).

2) Avaliação do TCU - Relatório de auditoria operacional do TCU: avaliação de governança de políticas públicas. Fortalecimento da FF. Acórdão oㅡ 2.252 (2015).

3) Avaliação do TCU sobre o Sistema Integrado de Monitoramento de Fronteiras (Sisfron), 2016.

4) Relação de publicações do projeto realizado pelo Ipea: $A$ politica Nacional de Desenvolvimento Regional (PNDR) e a Faixa de Fronteira. Livros volumes de 1 a 5: Fronteiras do Brasil: uma avaliação de política pública, v. 1 (Pêgo e Moura, 2018); Fronteiras do Brasil: diagnóstico e agenda de pesquisa para política pública, v. 2 (Pêgo et al., 2017); Fronteiras do Brasil: uma avaliação do Arco Norte, v. 3 (Pêgo et al., 2018); Fronteiras do Brasil: uma avaliação do Arco Central, v. 4 (Pêgo et al., 2019); Fronteiras do Brasil: uma avaliação do Arco Sul, v. 5 (Pêgo et al., 2020a); assim como relatórios institucionais e publicaçóes diversas do projeto -

11.0 conteúdo do Plano Brasil foi produzido em 2012, porém não chegou a ser implementado (seção 1 deste capítulo). 
por exemplo, estudo técnico sobre cidade gêmea Cáceres (Brasil) - San Matías (Bolívia) (Pêgo et al., 2020b).

5) Diagnóstico socioeconômico e demográfico da faixa de fronteira (Brasil, 2015), elaborado pelo Grupo Retis, da Universidade Federal do Rio de Janeiro - UFRJ (Pesquisa Segurança Pública nas Fronteiras - Senasp/MJ).

6) Mapeamento das políticas públicas federais na FF: interfaces com o Plano Estratégico de Fronteiras e a Estratégia Nacional de Segurança Pública nas Fronteiras (Pesquisa Segurança Pública nas Fronteiras - Senasp/MJ).

Não obstante, devido à fronteira ser dinâmica e seus arranjos sociais, econômicos e produtivos serem em parte condicionados às decisóes dos países vizinhos, há necessidade de contínuo acompanhamento e avaliação das políticas e ações públicas, assim como proposiçáo de novos alinhamentos para o recorte fronteiriço.

Com o papel de articulação e coordenação dessas ações, a CDIF, por meio da Portaria no 2.858, de 29 de novembro de 2019, ${ }^{12}$ aprova o novo regimento interno da comissão, mesmo tendo sido aprovado em 2018 - Resolução $n^{\circ}$ 1, de 8 de novembro de 2018.

A nova portaria relaciona as rotinas da comissão, e a comparação com a edição anterior identifica somente dois pontos que não se encontravam devidamente contemplados nos demais atos deliberados à comissão. Os pontos destacados encontram-se relacionados no capítulo I, da definição e atribuiçáo, art. $2^{\circ}$ :

8) interagir com núcleos regionais estabelecidos para debater questóes de desenvolvimento e integraçáo fronteiriços; e

10) propiciar a inclusão da participação social em seus processos decisórios, sempre que possível.

Devido às ínfimas alterações em relação ao ato de formalização do regimento interno de 2018, não há como mensurar que a publicação do novo regimento (n⿳⺈ 2.858/2019) possa trazer maior contribuição à governança fronteiriça, mesmo com clara aproximação do formato implementado pelo decreto que criou a comissão em 2010. Por se tratar de um modelo testado anteriormente, as chances de sucesso na governança da fronteira encontram-se em não repetir os erros, aproveitar as oportunidades que foram abertas e avançar nas proposiçóes.

\section{CONSIDERAÇÕES FINAIS}

Entende-se que instrumentos de governança devem ser continuamente testados e aprimorados, e o decreto de reedição da CDIF, publicado em agosto de 2019, não apresentou avanços em termos de governança da FF. Se comparado à edição

12. Disponivel em: <https://bit.ly/2JWg3PX>. Acesso em: 7 dez. 2019. 
anterior (2010), a principal modificação impressa na reedição da comissão foi a diminuição no número de participantes.

$\mathrm{Na}$ edição anterior da CDIF, fica subjacente que, apesar da dificuldade na coordenação, muito em virtude do elevado número de membros (entidades do governo federal e civis), entende-se que a experiência foi positiva, sobretudo no que diz respeito aos resultados apresentados como eixo norteador para a construção de uma agenda para a FF.

Apesar disso, com o esvaziamento de políticas públicas de identidade territorial fronteiriça, a setorização dos mecanismos de investimentos e as mudanças na agenda de governo levaram a CDIF, enquanto instrumento de governança territorial fronteiriça, ao esvaziamento. Porém, as dinâmicas fronteiriças permaneceram em efervescência: migrações, crimes transfronteiriços, práticas ilícitas, violência e outras ocorrências. Essas dinâmicas fronteiriças levam à necessidade de açóes públicas de desenvolvimento produtivo e econômico para o recorte fronteiriço.

Nas fronteiras, o desafio da governança é a construção dos mecanismos plurinacionais. Salientou-se que, em raros momentos, os APLs são pensados de forma integrada. Nesse caso, as dificuldades, novamente, são os marcos legais diversos entre si, para uma região que concentra os mesmos problemas.

\section{REFERÊNCIAS}

BRASIL. Ministério da Integração Nacional. Secretaria de Programas Regionais. Programa de Desenvolvimento da Faixa de Fronteira. Proposta de reestruturaçáo do programa de desenvolvimento da Faixa de Fronteira: bases para uma política integrada de desenvolvimento regional para a faixa de fronteira. Brasília: MI, 2005.

. Ministério de Desenvolvimento, Indústria e Comércio Exterior; FIESP FEDERAÇÃO DAS INDÚSTRIAS DO ESTADO DE SÃO PAULO. Manual de Atuação em Arranjos Produtivos Locais (APLs). São Paulo: MDIC; Fiesp, 2007. Disponível em: <https://bit.ly/3rxEjbR>. Acesso em: 9 fev. 2021.

. Ministério da Integração Nacional. Bases para uma proposta de desenvolvimento e integraçáo da Faixa de Fronteira. Brasília: Grupo de Trabalho Interfederativo de Integração Fronteiriça, 2010.

. Ministério da Integração Nacional. Texto para Discussão do Plano de Desenvolvimento Regional e Sustentável para a Faixa de Fronteira - Plano Brasil Fronteira. Brasília: MI, out. 2012.

. Ministério da Justiça. Secretaria Nacional de Segurança Pública. Diagnóstico socioeconômico e demográfico da faixa de fronteira: áreas críticas de segurança pública. Brasília: MJ, 2015. 
. Ministério da Integração Nacional. Consolidaçáo dos planos de desenvolvimento e integraçáo das faixas de fronteira. Brasília: MI, 2017.

Decreto no 9.961, de 8 de agosto de 2019. Institui a Comissão Permanente para o Desenvolvimento e a Integração da Faixa de Fronteira. Diário Oficial da União, Brasília, n. 153, p. 3, 9 ago. 2019. Seção 1. Disponível em: <https://bit. ly/36Al5cS>. Acesso em: 25 set. 2019.

NUNES, $M$. Contrastes e convergências socioterritoriais na faixa de fronteira internacional oeste brasileira: impactos das políticas contemporâneas. 2013. Tese (Doutorado) - Instituto de Geociências e Ciências Exatas da Universidade Estadual Paulista, Rio Claro, São Paulo, 2013.

PEGG, B. et al. (Orgs.). Fronteiras do Brasil: diagnóstico e agenda de pesquisa para política pública. Brasília: Ipea; MI, 2017. v. 2.

Fronteiras do Brasil: uma avaliação do arco Norte. Brasília: Ipea; MI, 2018. v. 3.

Fronteiras do Brasil: uma avaliação do arco Central. Rio de Janeiro: Ipea; MDR, 2019. v. 4.

. Fronteiras do Brasil: uma avaliação do arco Sul. Rio de Janeiro: Ipea; MDR, 2020a. v. 5.

PÊGO, B. et al. Estudo técnico sobre a viabilidade de criação da "cidade gêmea" Cáceres (Brasil) - San Matías (Bolívia). Brasília: Ipea; MDR, 2020 b.

PÊGO, B.; MOURA, R. (Orgs.). Fronteiras do Brasil: uma avaliação de política pública. Rio de Janeiro: Ipea; MI, 2018. v. 1.

TCU - TRIBUNAL DE CONTAS DA UNIÃO. Relatório de auditoria operacional para avaliação de governança de políticas públicas de fortalecimento da faixa de fronteiras - Acórdão no 2.252/2015. Brasília: TCU, 2015. Disponível em: <https://bit.ly/3eTlr1L>. Acesso em: 20 mar. 2020. 


\section{ELEMENTOS PARA UMA NOVA PROPOSTA DE DESENVOLVIMENTO E INTEGRAÇÃO FRONTEIRIÇA}

\section{INTRODUÇÃO}

Este capítulo organiza-se tematicamente, compondo-se das recomendaçôes/proposições gerais referentes a cada tema e das específicas de cada arco da fronteira, colhidas nas atividades realizadas pelo projeto desenvolvido na parceria Ipea e Ministério do Desenvolvimento Regional - MDR (Pêgo et al., 2017; 2018; 2019; 2020a; 2020b; Pêgo e Moura, 2018). Complementarmente, inclui proposiçóes advindas dos planos de integração e desenvolvimento, realizados pelos núcleos de fronteira, em atividade coordenada pelo então Ministério da Integração Nacional - MI (Brasil, 2017). No conjunto de observaçóes e proposiçóes sistematizado, consideram-se:

- sentido da fronteira, concepções e compreensóes relativas ao seu significado, suas oportunidades e positividades;

- avaliação das políticas públicas destinadas à faixa de fronteira terrestre (FFT), contemplando a formulação de políticas para a região e a presença do Estado na fronteira, os mecanismos de planejamento e a gestão dessas políticas públicas, bem como a avaliação da própria faixa de fronteira (FF), no tocante à sua largura como uma unidade fixa em toda sua extensão;

- análise das dinâmicas da atividade econômica e do trabalho, particularizando a informalidade;

- condiçóes da infraestrutura urbana e regional, com destaque para os transportes e as conexôes, a energia e as comunicaçóes, bem como para as condiçóes dos postos de controle fronteiriço;

- avaliação dos serviços e das políticas sociais, em particular relativos à saúde, à educação e à cultura, bem como também aos meios de cooperação para a prestação dos serviços;

- apreciação sobre os povos tradicionais, os indígenas e os movimentos migratórios;

- meio ambiente e a biodiversidade, os recursos naturais e a vulnerabilidade ambiental, assim como a ação de organizaçôes não governamentais; 
- exame das condiçóes da defesa e da segurança pública, suas diferentes concepçóes e interpretaçóes, o trânsito de ilícitos, o controle e a fiscalização na fronteira;

- leitura do espaço urbano dos arranjos transfronteiriços, das cidades da fronteira e sua inserção na rede urbana, da gestão cooperada nesses arranjos e da mobilidade transfronteiriça; e

- ponderaçôes sobre o atual quadro das políticas de integração e acordo bi e trilaterais, abordando a integração na prática e a integração e a cooperação no trato de serviços na fronteira.

\section{SÍNTESE DAS PROPOSIÇÕES}

\subsection{0 sentido da fronteira}

\subsubsection{Concepç̃̃es e compreensões sobre a fronteira}

Romper as atuais relaçóes marcadas por preconceitos, particularmente de brasileiros quanto aos bolivianos e paraguaios, muito pela sua herança indígena, foi uma das recomendaçóes decorrentes de todos os eventos (Pêgo et al., 2017; 2018; 2019; 2020a; 2020b; Pêgo e Moura, 2018). Da mesma forma, eliminar a postura de colonizador do brasileiro, que transparece em suas açóes e posiçóes em relação aos vizinhos fronteiriços. Foi recomendado olhar a fronteira sob a perspectiva de quem está do "outro lado", em uma relação de alteridade e reciprocidade (Pêgo et al., 2017; 2019).

Deve-se, também, superar um discurso construído de que os povos vizinhos dão despesas ao se beneficiarem das políticas públicas municipais (particularmente saúde e educação), sem pagar impostos, mesmo tendo dados que registram a elevada contrapartida da presença e consumo dos povos vizinhos nas cidades brasileiras dos arranjos transfronteiriços. E o mais necessário: abolir a associação "do outro" com a rota de ilícitos que se estabelece em muitos pontos da fronteira (Pêgo et al., 2019; 2020b).

Recomendou-se não aceitar a ideia que passa entre muitos gestores públicos de que "temos que construir muros, temos que separar, não podemos ficar atendendo ao povo do outro lado". Essa ideia está presa ao conceito de limite; não vislumbra a fronteira como uma potencialidade, mas como um problema (Pêgo et al., 2019; 2020b).

Da mesma forma, é urgente superar o tradicional e predominante olhar do gestor público no território fronteiriço sob o ponto de vista de segurança pública e defesa; ou seja, superar o paradigma da fronteira como área periférica responsável apenas pela entrada de "ameaças" ao restante do território nacional. Para tanto, é 
necessário romper a concepção sobre a FF resultante de uma construção militar que entende fronteira como separação, defesa, e não como aproximação ou segurança cidadã. Deve-se exercitar a compreensão desse recorte territorial, na perspectiva de um lugar onde as pessoas reproduzem suas estratégias de sobrevivência, como ocorre nos demais recortes de seus respectivos territórios nacionais, e que nem sempre estão ligadas à prática de ilícitos (Pêgo et al., 2017; 2018; 2019; 2020a; 2020b; Pêgo e Moura, 2018).

\subsubsection{Oportunidades e positividades}

De modo geral, foi proposto valorizar as oportunidades e as positividades existentes nas diversas fronteiras brasileiras, enfrentando os desafios impostos pelas especificidades desses espaços, sob a compreensão de que, mais que o acirramento de controle e de medidas de segurança, estratégias de desenvolvimento certamente são mais efetivas para superar as condiçôes de desigualdade socioeconômica, inclusive combatendo as práticas de ilícitos. Agrega-se a isso promover relaçóes de cooperação e reciprocidade entre Brasil e países vizinhos (Pêgo et al., 2017; 2018; 2019; 2020a; 2020b; Pêgo e Moura, 2018).

No arco Norte, recomendou-se pensar a Amazônia do ponto de vista pan-amazônico e tornar a Pan-Amazônia uma realidade, a partir da integração dos povos, do compartilhamento da ciência e tecnologia, do comércio, da inclusão produtiva e da melhoria na qualidade de vida dos que nela vivem (Pêgo et al., 2017; 2018).

A Amazônia depende do desenvolvimento econômico trazido pela população que vive nesse espaço, e, por isso, as ações devem estimular uma maior integração política, social e cultural entre os povos amazônicos. As políticas públicas devem objetivar a ocupação e o controle adequados do território e considerar que heterogeneidade e integraçáo são importantes para o desenvolvimento.

Participantes do arco Central propuseram valer-se das oportunidades abertas pelas instituições de ensino e colocar mais foco na reflexáo e pesquisa sobre a fronteira, criando uma universidade temática em Corumbá (onde já funciona um Programa de Pós-graduação em Estudos Fronteiriços), ${ }^{1}$ especializada em assuntos fronteiriços, articulada entre os países vizinhos, a exemplo da Universidade Federal da Integração Latino-Americana (Unila), além de ampliar os cursos e os projetos já implementados nos institutos federais para a capacitação e a formação de mão de obra voltada às vocaçóes econômicas regionais (Pêgo et al., 2019; 2020a).

Entre os municípios que fazem parte do ecossistema do Pantanal, verificou-se a consciência da vulnerabilidade deste bioma tâo importante e atrativo ante a exploraçáo turística e pecuária extensiva, propondo-se expandir um ecoturismo que

1. Universidade Federal de Mato Grosso do Sul (UFMS) - Campus do Pantanal (CPAN). 
busque novos conhecimentos e práticas que visem à integração das açóes relacionadas ao desenvolvimento cultural, econômico e social com o turismo da regiáo, de forma sustentável, sendo fundamental agregar, para tanto, entre outros, serviços de defesa sanitária animal e vegetal em consonância com as políticas e os acordos bilaterais.

Recomendou-se aproveitar as rodovias e a ferrovia concluídas ou quase concluídas, que passam pelo arco Central, particularmente na regiāo de Corumbá-Ladário, que possibilitariam conectar o país ao Peru e ao Chile. Nesse contexto, a região de Cáceres, do ponto de vista econômico, poderia constituir-se em localização estratégica da fronteira devido às perspectivas que se abririam pelo grande mercado consumidor dos países vizinhos (Pêgo et al., 2020a).

No arco Sul, discutiu-se a necessidade de agilizar a implementação dos diversos acordos bilaterais já existentes - Brasil-Argentina e Brasil-Uruguai -, assim como os do Mercosul, entre outros; a adoção de medidas de equivalência (desburocratizadas), sobretudo em relação à circulação de pessoas, aos serviços, à educação e ao trabalho; e a premência de facultar termos e acordos, revogando limitaçóes legais que impedem a mútua cooperação entre governos locais e provinciais para o desenvolvimento integrado. Para isso, mobilizar as instituiçóes de pesquisa brasileiras, uruguaias e argentinas para que visualizem as potencialidades locais - como a existência de diversos modais para circulação de matéria-prima e organização produtiva - e elaborem projetos conjuntos, utilizando as diversas fontes de financiamento para a sua execução, tais como as oriundas do Fundo para a Convergência Estrutural do Mercosul (Focem), do Fundo Financeiro para o Desenvolvimento da Bacia do Prata (Fonplata), do Banco Interamericano de Desenvolvimento (BID), do Banco Mundial e do Fundo dos BRICS (Pêgo et al., 2017; 2020b).

\subsection{Políticas públicas}

\subsubsection{Observações apresentadas}

As políticas de desenvolvimento territorial para as áreas fronteiriças deveriam consistir na combinação de políticas econômicas e de integração física com políticas de desenvolvimento social e institucional, uma vez que constituem açôes públicas inter-relacionadas pelo envolvimento direto na condição especial dessas áreas. Sugere-se que essas políticas deem ênfase à gestão das interaçôes e se encarreguem de criar espaços de diálogo e concertação entre as diferentes componentes das políticas territoriais, a fim de produzir as devidas coordenaçôes e sinergias dos esforços entre o local e o regional, como cabe às políticas de desenvolvimento territorial. Esses esforços requerem permanência e constância, consistência e congruência. Requerem que os países compreendam que o desenvolvimento territorial das áreas de fronteira necessita de políticas interestados consistentes e estáveis (Pêgo et al., 2017; Pêgo e Moura, 2018). 
Foi recomendado que os temas referentes à fronteira sejam tratados nas escalas continental, nacional e regional/local, lembrando que atualmente os planos mais articulados são os resultantes de iniciativas locais. Recomendou-se, ainda, a organização de unidades mínimas de produçâo de informação, coleta e pesquisa, nos moldes da nomenclatura das unidades territoriais estatísticas (NUTs) ou do geocódigo padrão da União Europeia, pois não é possível realizar boas políticas públicas sem se ter uma unidade territorial adequada para análise e zoneamento. Informaçóes nacionais ou estaduais isoladas são insuficientes, portanto é muito importante salientar, na agenda política, a necessária construção dessas unidades de pesquisa na escala continental junto à padronização de conceitos territoriais na produção e disseminação de estatísticas internacionais (Pêgo et al., 2017).

Para que políticas públicas possam ser efetivas, há que se ouvir os representantes dos diversos segmentos da sociedade dos municípios envolvidos. Partindo-se dessas contribuições, as estratégias a serem definidas nos níveis superiores dos governos, com participação das instâncias pertinentes, para uma política nacional de desenvolvimento da FF, articulam-se com as demais políticas públicas e açóes governamentais e sua disponibilidade orçamentária com maior propriedade (Pêgo et al., 2017; Pêgo e Moura, 2018).

Além disso, uma agenda de temas comuns das diversas políticas públicas com programas e projetos permanentes pode ser construída levando-se em conta as peculiaridades de cada regiáo fronteiriça, assimiladas pelas perspectivas regional, local e urbana. Os participantes das oficinas enfatizaram que as políticas públicas para as regiōes de fronteira deveriam estabelecer programas com metas claras e atreladas a processos contínuos de monitoramento e avaliação das açóes, com base em estruturas e recursos humanos existentes/possíveis de serem agregados à região fronteiriça, de forma a tornar factível o alcance dos objetivos estabelecidos. $\mathrm{O}$ monitoramento e a avaliação contínua dos programas permitem mudanças periódicas das açóes, de forma a incorporar a dinâmica das transformaçóes pelas quais passam as fronteiras (Pêgo et al., 2017; 2018; 2019; 2020b; Pêgo e Moura, 2018). Nesse sentido, uma proposta do núcleo de fronteira de Mato Grosso do Sul consiste em apoiar entidades representativas da sociedade civil para participação, execução e controle social das políticas públicas de acordo com a legislação vigente, por meio da oferta de capacitação de gestão (técnica, política e financeira), assim como assessoramento às entidades, visando ao atendimento de $100 \%$ dos municípios da fronteira (Brasil, 2017).

Foi ressaltada a necessidade de formular, para além das políticas de médio e longo prazos, açóes prioritárias para atendimento das demandas imediatas da comunidade local tendo em vista a realidade fronteiriça, a exemplo do ensino bilíngue nas escolas e de bibliotecas com acervo nos diferentes idiomas presentes na regiáo. 
E, ainda, a necessidade de reconhecer as características históricas e as externalidades das fronteiras, de modo a garantir a viabilidade de obras da infraestrutura de integração física para a consecução de propostas sociais, educativas e culturais entre as cidades transfronteiriças (Pêgo et al., 2017; 2018; 2019; 2020b; Pêgo e Moura, 2018). Muitas dessas obras foram propostas e também desenvolvidas pela Iniciativa para a Integração da Infraestrutura Regional Sul-Americana (IIRSA), no âmbito do Conselho Sul-Americano de Infraestrutura e Planejamento (Cosiplan).

Representantes do arco Norte recomendaram a elaboração e a execução de açóes a partir de planejamento estratégico integrado, resultando na implantação de um sistema de planejamento urbano integrado nas cidades da FF, com a participação do Estado. Recomendaram, também, a realização de Zoneamento Ecológico-Econômico (ZEE) da FF e a formação e/ou o fortalecimento de consórcios intermunicipais, particularmente no caso dos arranjos transfronteiriços (cidades gêmeas). Nesses arranjos, é imprescindível a elaboração dos Planos de Desenvolvimento Urbano Integrado (PDUIs), priorizando os espaços urbanos e a integração binacional dos serviços relativos a educação, saúde, trabalho, comunicação, mobilidade urbana, cultura, lazer, esportes e turismo (Pêgo et al., 2018).

Os participantes do arco Central deram ênfase em reconhecer que o tema do desenvolvimento da fronteira não é simplesmente um tema regional, mas também do governo central da Federação. Consideram que a formulação de uma única política pública não diferenciada para toda a FF não será efetiva diante da diversidade da regiâo, recomendando-se a identificação e o aprofundamento dos problemas específicos e de interesse comum entre municípios, de forma a definir a construção de políticas públicas setoriais integradas entre municípios fronteiriços e transfronteiriços com propostas de instrumentos diferenciados para dotar a região fronteiriça de infraestrutura e logística adequadas. Entendem, ainda, ser importante o fortalecimento da atuação da Superintendência do Desenvolvimento do Centro-Oeste (Sudeco) como representante do governo federal nos estados e municípios, na busca pelo desenvolvimento, apontando ser necessário maior envolvimento do MDR com a questão fronteiriça (Pêgo et al., 2019).

Grande destaque foi dado ao planejamento e à gestáo das políticas públicas. Sugeriu-se a proposição de planos conjuntos com os países vizinhos visando ao desenvolvimento da FF, consolidando uma agenda transnacional com programas e açóes. Para tanto, o alinhamento do planejamento ao orçamento foi recomendado, de forma a garantir o acesso aos recursos financeiros. Recomendou-se categorizar as fronteiras quanto ao uso e à ocupação do território, identificando as demandas transfronteiriças e traduzindo-as em planos e projetos para cada categoria de uso na fronteira. Salientou-se a necessidade da criação de uma carteira de projetos específicos para a regiáo de fronteira e de políticas efetivas para ampliar os inves- 
timentos conjuntos e a busca por oportunidades (Pêgo et al., 2017; 2018; 2019; 2020b; Pêgo e Moura, 2018).

Participantes do arco Sul propuseram promover o desenvolvimento regional integrado com os países vizinhos, dotando a região de serviços e infraestruturas de fronteira, firmando acordos de compensaçáo e custeio e realizando programas de formação e capacitação de quadros para a atração de recursos visando à implementação de projetos. Salientaram a necessidade da estruturação de escritórios de projetos em parceria com institutos federais de educação, ciência e tecnologia, outros parceiros regionais e dos países vizinhos (Pêgo et al., 2020b).

Sobressaíram-se, entre as sugestóes gerais, as propostas de criação e/ou fortalecimento de fóruns para planejamento, de execução integrada de estratégias para o desenvolvimento regional e do aprimoramento de trocas de informaçóes que permitam desenvolver, propor e analisar planos efetivos, representativos das demandas das populaçóes fronteiriças.

O núcleo de fronteira do Rio Grande do Sul propóe a criação de um estatuto jurídico especial de fronteira do Brasil com o Uruguai e a Argentina, visando permitir as administraçóes de cidades gêmeas, sugerindo, também, para estas a criação de conselhos binacionais de gestão, de caráter opinativo e deliberativo. Além disso, o núcleo sugere a constituição de um fundo de desenvolvimento da regiáo da FF (Brasil, 2017).

Tais propostas fortalecem o debate sobre a governança, com foco na necessidade de ampliação dessa prática, desde que apta ao envolvimento de instituiçóes e comunidades locais, e que seja voltada a pensar saídas formais para ajudar os atores locais, sem que engessem opçôes em prática (Pêgo et al., 2017a; 2018; 2019; 2020b; Pêgo e Moura, 2018). Para tanto, foi proposta a construção de um modelo de governança, com previsão de mecanismos de participação na implementação das políticas e no acompanhamento dos resultados, ou seja, a definição de arranjos de governança que possam promover maior diálogo, inclusive com os entes federativos (no caso brasileiro, estados e municípios).

Açóes cooperadas também mereceram destaque, a começar pela proposição de criar um instrumento de cooperação no nível comunitário dotado de personalidade jurídica, bem como o apoio à formação e à estruturação de consórcios intermunicipais. Retoma-se, assim, a reflexão sobre a "cooperação transfronteiriça", já em termos de se efetivar sua prática, visando à melhoria nos mecanismos de cooperação e incentivo a arranjos e estratégias locais, entre as quais salienta-se a urgência de fortalecer acordos em investimentos para o aprimoramento da infraestrutura, saneamento e logística na FF (Pêgo et al., 2017; 2018; 2019; 2020b; Pêgo e Moura, 2018). 
Tal preocupação foi ressaltada entre os participantes do arco Central, por meio do argumento da necessidade de reuniôes de integração bilateral entre os países nas áreas de fronteiras para o tratamento das precariedades e carências dos povos que ali vivem entre diferentes costumes e políticas. Dessa forma, assinalaram como negativa a descontinuidade política da Bolívia, dada a troca semestral de autoridades, na medida em que haviam acordado com esse país uma proposta de construção de um comitê fronteiriço em Corumbá e um comitê fronteiriço na Bolívia (Pêgo et al., 2019).

Foi unânime nos arcos a recomendação de se fortalecer a atuação dos núcleos estaduais de fronteira na Comissão Permanente para o Desenvolvimento e a Integração da Faixa (CDIF), a fim de estabelecer um marco legal para as fronteiras que inclua a escala do "local" nas políticas públicas da fronteira e a discussão sobre os instrumentos e as ferramentas prioritárias e específicas para uma gestão fronteiriça (Pêgo et al., 2017; 2018; 2019; 2020b; Pêgo e Moura, 2018). Nesse sentido, reforça-se a preocupação manifestada pelo núcleo de fronteira de Mato Grosso ao propor o fortalecimento do Comitê Estadual da Faixa de Fronteira (CEFF), a fim de assegurar o monitoramento e a avaliação do Plano Regionalizado de Desenvolvimento e Integração Fronteiriço (PDIF), com ênfase na realização de estudos regionais e urbanos da FF, a capacitação em gestão do desenvolvimento regional e na articulação das esferas federal, estaduais e municipais na região da fronteira (Brasil, 2017).

\subsubsection{Mecanismos de planejamento e gestão do espaço fronteiriço}

Inúmeras sugestóes foram dadas nas diversas atividades do projeto (Pêgo et al., 2017; 2018; 2019; 2020a; 2020b; Pêgo e Moura, 2018). Entre as proposiçóes apresentadas sobre este subtema, estão: i) o cruzamento das demandas identificadas com as "ofertas" existentes nos instrumentos de planejamento orçamentário (Plano Plurianual - PPA e Lei Orçamentária Anual - LOA) do governo brasileiro e a busca de integração dessas iniciativas com planos e outros instrumentos de planejamento em desenvolvimento nos países vizinhos; ii) o mapeamento das possibilidades de parcerias, fontes de financiamento, capacidade endógena para acessar recursos, capital social etc.; e iii) o estabelecimento de fundos regionais entre os estados subnacionais fronteiriços, para o avanço de açôes conjuntas na FF, a exemplo dos projetos das fronteiras da União Europeia, apoiados em fundos regionais, de um ou mais estados.

Também no âmbito geral, foram propostos incentivos para a ampliação e o fortalecimento da participação política das regióes de fronteira em frentes parlamentares, para que defendam propostas, garantam recursos e assegurem maior estabilidade institucional e continuidade na implementação das políticas públicas. 
Faz-se urgente o aperfeiçoamento das legislaçóes (bi e trilateral e/ou nacional), sendo imprescindível atualizar a legislação com vistas a promover o desenvolvimento da região, adequar as leis às necessidades dos grandes projetos, bem como também buscar formas mais ágeis de incorporar às legislaçóes locais o ordenamento jurídico dos países. Pleiteou-se a aprovação de legislação que legitime a formação de consórcios entre cidades fronteiriças, facilitando o acesso a serviços públicos e privados. É também necessária a formação de um arcabouço legal que ampare, além das questóes de defesa, a continuidade de programas essenciais ao desenvolvimento, com o estabelecimento de uma agenda que agregue metas e objetivos de médio e longo prazos.

No âmbito do governo federal brasileiro, deve-se definir o locus para conduzir a estratégia de articulação intragoverno e com países vizinhos; promover a criação e/ou o fortalecimento de parcerias entre instituições subnacionais dos países vizinhos para açóes coordenadas entre os municípios, departamentos e províncias; assim como assegurar a operacionalidade da articulação entre planos nacional, bilateral e regional, que, de antemão, sabe-se que é complexa, portanto não necessariamente imediata.

Nesse contexto, no arco Central, reforçou-se a necessidade de rever a atuação do Estado brasileiro na fronteira, pois essa não é uniforme, visto que demonstra diversas visões, particularmente dos ministérios, que têm várias formas de atuação, e não se observa grande certeza quanto ao seu resultado, se está criando facilidades ou dificuldades para as populaçóes da fronteira. No caso de estudos acadêmicos ou de políticas públicas, os ministérios têm de olhar de forma particular para as regióes de fronteira, pois atualmente a atuação desses órgãos se dá de maneira uniforme. É imperativo admitir que os problemas dos municípios situados na linha de fronteira são diferentes, e com níveis de complexidade muito maiores, daqueles situados na faixa ou mesmo fora dela. Isso significa admitir também que a FF pode ser redimensionada (Pêgo et al., 2019).

É necessário que os recursos sejam adequadamente priorizados, dadas as tantas especificidades da região, estudando novas formas de financiamento para projetos locais transfronteiriços, que reflitam em ganhos de escala e coesão socioeconômica, especialmente nas cidades gêmeas. Cabe, também, debater a transferência de recursos financeiros entre os lados da fronteira, além de minimizar a dependência de recursos de organismos internacionais.

Ademais, como recomendação dos participantes do arco Norte, devem-se aperfeiçoar os mecanismos relativos às fontes de financiamento para o desenvolvimento da FF e formular um programa de consolidação de redes de estudos aplicados ao desenvolvimento e à integração da FF, consorciado a incubadoras de empresas, institutos de educação e formação profissional e tecnológica (Pêgo et al., 2018). 
Os participantes do arco Central salientaram que não se deveria cair na ilusão de que o governo federal está investindo pesadamente na FF, pois, infelizmente, a realidade histórica é que ela foi colocada em segundo plano. Recomendaram buscar financiamentos específicos para fomentar a pesquisa na e sobre a fronteira. Também propuseram que fosse revista a impossibilidade de utilizar o Fundo Constitucional de Financiamento do Centro-Oeste (FCO) para obras como rodovias, infraestrutura urbana e grandes obras de integração. De modo ainda mais enfático, recomendaram que se movessem esforços para conquistar uma governança específica de fronteira, e que se voltasse a uma política que fosse mais sistemática (Pêgo et al., 2019).

No arco Norte, foi recomendado conhecer, difundir e reproduzir experiências e políticas públicas exitosas para a população fronteiriça, apontando como exemplo o Madre de Dios, Acre e Pando (MAP) - sigla que corresponde às iniciais dos três estados/departamentos que fazem a fronteira Peru, Brasil e Bolívia, respectivamente -, articulados com vistas a açóes cooperadas. Essa experiência foi destacada como uma grande iniciativa trilateral, que surgiu na Universidade Federal do Acre (Ufac). Outras experiências de gestão urbana destacadas foram as de Dionísio Cerqueira (Santa Catarina), Barracão (Paraná) e Bernardo de Irigoyen (Argentina), assim como o modelo de gestão integrada de Quebrada de Santo Antonio, envolvendo Letícia (Colômbia) e Tabatinga - Amazonas (Pêgo et al., 2018). Participantes do arco Sul agregaram a essa proposiçáo que se elaborasse um catálogo de boas práticas sobre soluçōes fronteiriças já implementadas, ou uma plataforma interativa para intercâmbio de informaçóes e experiências, como completaram os participantes do arco Norte (Pêgo et al., 2020b).

Também foi apontado um fundo de cooperação e vários projetos conjuntos em prática na fronteira do Peru com o Equador, que já foi zona de conflito. Nas regióes de conflito, esse tema avança com mais força, pelo reconhecimento da importância da coesão socioeconômica e da integração para a construção de um território de paz. A partir desses exemplos, foi proposto o levantamento de outras iniciativas continentais que trouxessem exemplos da dinâmica de boas práticas e acordos de cooperação (Pêgo et al., 2020b).

\subsubsection{Ponderações sobre a FF}

Participantes do arco Sul destacaram as limitaçóes impostas pela FF e sugeriram que essa deveria ser mantida apenas para efeito de segurança nacional, liberando-a de restriçóes para que possa fluir o desenvolvimento. Recomendaram reduzir a largura dessa área e mudar sua concepção, de uma área de segurança e defesa para uma área de políticas sociais específicas e facilidade de mobilidade entre os povos da fronteira (Pêgo et al., 2020b). Os participantes dos arcos Central e Norte também advogaram redimensioná-la, sendo que o primeiro apontou como necessária 
uma nova concepção de FF, com reciprocidade do país vizinho quanto à largura e a outras definiçōes, como faixa de livre comércio e circulação, acordos bilaterais para controle e fiscalização, entre outros (Pêgo et al., 2018; 2019).

Outras recomendações do arco Sul foram implementar políticas específicas para as cidades de fronteira, integradas com os países vizinhos, que facilitem os trâmites, atualmente muito burocráticos, e definir uma agenda para fortalecimento da vontade política para a região. Ou seja, essa área deveria ficar restrita às cidades gêmeas da linha de fronteira, acompanhada de uma área prioritária para investimentos públicos, uma vez que o investimento privado tem dificuldades de acontecer, devido à afastada localizaçáo - cidades distantes dos grandes centros (Pêgo et al., 2020b).

\subsection{Economia e trabalho}

\subsubsection{Atividade econômica e geração de postos de trabalho}

No âmbito geral, foi proposto combater a elevada desigualdade de renda e reduzir a pobreza, promovendo uma distribuição mais igualitária da riqueza, devendo priorizar programas que alavanquem a distribuição de renda, aumentem a empregabilidade e gerem oportunidades de trabalho para jovens e adultos desempregados e com baixa escolaridade (Pêgo et al., 2017; 2018; 2019; 2020a; 2020b; Pêgo e Moura, 2018).

Associadas às oscilaçóes de demandas sociais estão as mudanças na economia pelas quais passam os países. Sugeriu-se analisar as formas como os habitantes das fronteiras lidam com as transformaçóes em curso; pensar as frentes de expansão dos investimentos privados não a partir dos denominados pioneiros, mas dos setores marginalizados e subordinados nestas frentes de expansão, como os posseiros, os camponeses e os indígenas; e sugerir estratégias nacionais ou binacionais para fortalecer a diversificação das cadeias produtivas na FF, voltadas à inclusão dos pequenos e médios produtores (Pêgo et al., 2018).

Nessa reflexão, é preciso dar mais atenção ao mundo rural, tratando especificamente do papel dos assentamentos rurais implantados nas zonas de fronteiras, no contexto das ampliações das relações fronteiriças entre países vizinhos. E estender essa abordagem às demais formas do habitat rural e da sua menor ou maior integração às redes de localidades e cidades. Assim, integrar mais a economia da região de fronteira à própria economia nacional, em paralelo com a integração com a própria economia internacional (Pêgo et al., 2018).

No arco Norte, recomendou-se que seja superada a predominância dos níveis críticos de desenvolvimento em diversas dimensões nesse arco, ou seja, que se alavanque o desenvolvimento, reduzindo as disparidades evidentes em comparaçáo aos demais arcos. Para tal, desenvolver uma agenda específica de políticas públicas 
integradas para a região, considerando suas características próprias, com açóes orientadas aos princípios do desenvolvimento sustentável, e em diferentes frentes educação, saúde, meio ambiente etc. (Pêgo et al., 2018).

Do ponto de vista econômico, a principal recomendação é a integraçáo de cadeias produtivas, por meio de definição de arranjos produtivos locais (APLs), com destaque para as atividades agropecuárias, florestais, industriais e de turismo, também no contexto do projeto de integração com o Mercosul, incluindo o fortalecimento do serviço de assistência técnica e extensão rural e o fomento aos pequenos negócios, e que levem em conta a segurança alimentar. No caso específico de Roraima, demanda-se a implantação do polo agroindustrial e comercial de interesse comum, com foco na complementaridade das economias, efetivando Roraima como porta para o Caribe e outros mercados. Demanda-se, também, a consolidação do corredor turístico Amazônia-Caribe.

Participantes desse arco propuseram ainda: i) discutir legislaçóes especiais para a fronteira, com a criação de incentivos econômicos para a produção industrial e a exportação de bens e com um olhar mais apurado para a economia fronteiriça; ii) desenvolver acordos econômicos bilaterais focados nas potencialidades e necessidades dos mercados locais e regionais; iii) prover fontes de financiamento para empreendimentos de comércio, serviços e turismo locais; iv) aumentar a integração das atividades produtivas desenvolvidas, buscando adensamento das cadeias produtivas, como forma de desenvolvimento e agregaçấo de valor; v) implementar uma política pública de desenvolvimento local e regional na FF que atenda às idiossincrasias regionais e que considere as riquezas locais, o dinamismo e a reciprocidade; e vi) consorciar a prestação de alguns serviços pelos municípios (Pêgo et al., 2018).

Ressalta-se a proposta do núcleo de fronteira de Roraima (Brasil, 2017) com relação à efetivação de novos acordos e à ampliação do existente de cooperação na área de agricultura, indústria e agroindústria, por meio da organização de polo agroindustrial e comercial de interesse comum, com foco na complementaridade das economias. Foi citada, similarmente, na oficina do arco Norte e pela proposta do núcleo de fronteira, a relevância da efetivação de Roraima como a entrada para o Caribe e os mercados do Atlântico Norte e da organização e consolidação dos APLs, salientando-se que a viabilização desse polo passa pela garantia de investimentos em infraestrutura (rodovias e energia), logística (silos), assistência técnica, financiamento e adequada base institucional de suporte à implantação. Nesse sentido, aspiram também a efetivação de uma área de livre comércio (ALC) em Bonfim (fronteira com Lethem-Guiana). Com relação ao setor turístico, o núcleo propõe a consolidação do Corredor Turístico Amazônia-Caribe (Roraima-Bolívar-Georgetown), bem como a regulamentaçáo do turismo em terra indígena. 
Já as ações previstas pelo núcleo de fronteira do Amapá preveem a exploração de recursos pesqueiros do setor Atlântico do estado, bem como estudos das potencialidades econômicas dos recursos florestais na FF, visando à sua utilização em sistemas sustentáveis, por meio da valorização tecnológica das espécies vegetais de múltiplo uso da Floresta Tropical da Zona de Fronteira; da prospecção na flora nativa da variabilidade genética de frutas tropicais e montagem do banco ativo de germoplasma; do redesenho de agroecossistemas degradados com foco em sistemas agroflorestais; do desenvolvimento e aprimoramento de tecnologias na cadeia produtiva hortícola com agricultores familiares; e do georreferenciamento, levantamento topográfico e cadastral da gleba patrimonial urbana e da área de expansão urbana para fins de regularização fundiária no município de Oiapoque (Brasil, 2017).

Observam-se, ainda, propostas econômicas relacionadas à mineração, como a manifestada pelo núcleo de fronteira do Pará, quanto à liberação da implantação de projetos minerais como de exploração de bauxita e petróleo e gás natural. São aguardados com expectativa de melhorias econômicas e sociais para a região da Calha Norte (Brasil, 2017).

Para os participantes do arco Central, é preciso estabelecer uma política de Estado de mineraçáo que trate a regiâo como prioridade. $\mathrm{O}$ contexto para operacionalizar a verticalização da cadeia produtiva do minério de ferro e manganês impóe que o governo do estado assuma essa prioridade, pois não é competência do município. É exemplo o hidrocarboneto, que tem, a todo tempo, oferta contínua, qualidade assegurada, uma série de fatores benéficos, porém essa cadeia não se verticaliza. É necessário pensar em formas pelas quais os municípios da fronteira possam não só gerar, mas também captar valor. Valor que está transitando de um lado para o outro, não só para o gás, mas para outros fluxos econômicos (Pêgo et al., 2019).

Foi proposto otimizar a regiáo com infraestrutura e logística que garantam a geração de emprego e renda e a inserção dos produtos e serviços da FF nos mercados interno e externo; fortalecer os serviços e implementar a extensão rural e a assistência técnica aos agricultores familiares; integrar as açóes relacionadas ao desenvolvimento econômico, social e turístico da região, buscando a harmonização das políticas e dos acordos bilaterais; implementar zona de livre comércio; simplificar e agilizar a formalização dos empreendimentos comerciais na FF, incentivando a criação de novos centros comerciais; e viabilizar os free shops nas cidades gêmeas.

Foi proposto, ainda, aproveitar as oportunidades relacionadas ao desenvolvimento do turismo de fronteira (patrimônio arquitetônico, histórico e natural, turismo de compras etc.), que inclui o alinhamento de políticas públicas e o fortalecimento de negócios integrados, promovendo um intercâmbio cultural. 
Nesse âmbito, abrir um diálogo com Santa Cruz para colocar o destino Corumbá e Bonito nas agências bolivianas (Pêgo et al., 2019). Para os núcleos de fronteira, promover esforços de marketing (participação em eventos e roadshows) nos países integrantes do Mercosul para aumentar o fluxo turístico nos roteiros da faixa central (Brasil, 2017).

Necessário, também, implementar lei para a preservação do peixe dourado, que atrai muitos turistas na atividade de "pesca e solta", e permitir seu monitoramento (Pêgo et al., 2019; 2020a). Deve-se, ainda, recuperar a malha ferroviária e trazer o Trem do Pantanal (expresso Oriental) para transportar passageiros e turistas (Pêgo et al., 2019). Em Rondônia, fomentar o Festival Folclórico de Guajará-Mirim, o segundo maior evento no Brasil ligado ao folclore do Boi Bumbá (Brasil, 2017).

Outro ponto que merece tratativa é repensar as taxas e as cotas impostas pela alfândega brasileira, visto que prejudicam o turismo local; além de atrair o turista externo, há que se oferecer incentivos para que o fronteiriço conheça a fronteira, pois muitos nunca entraram no país vizinho e vice-versa (Pêgo et al., 2019; 2020a).

Entre os participantes do arco Sul, foram destacadas propostas quanto a autorizar (permitir) o desenvolvimento de atividades de agregação de valor nas regiôes de fronteira, facilitando a circulação da matéria-prima e a organização produtiva; e obter financiamentos voltados especificamente para as cidades fronteiriças (Pêgo et al., 2020b). Destaca-se, na agricultura, um programa de combate à desertificação nas fronteiras com Uruguai e Argentina contida nas propostas do núcleo de fronteira do Rio Grande do Sul (Brasil, 2017). Além dessas ações, Pêgo et al. (2020b) listam outras ligadas ao turismo, tais como:

- criar um plano de turismo integrado e articulado entre os países, que potencialize as diversas dimensōes da atividade, expressas na região;

- desenhar rotas e circuitos turísticos, articulados entre os países vizinhos;

- promover sinalização bilíngue unificada para as rotas turísticas binacionais;

- incorporar o tema acessibilidade na proposta turística a ser elaborada;

- desenvolver o turismo histórico, cultural, ambiental, comercial, aquático etc.;

- inventariar o patrimônio histórico, cultural, arquitetônico e paisagístico;

- instalar infraestrutura adequada ao tipo de turismo de região de fronteira;

- compatibilizar as legislaçóes para a atividade turística entre os países;

- incentivar atividades de observação de aves no corredor biológico trinacional (Espinilho-BR/Rincón de Franquía-UY/General Ávalos-AR);

- captar recursos para projetos e atividades turísticas; 
- capacitar recursos humanos para gestão e promoção da atividade turística (integração com universidades e institutos federais - IFs); e

- criar um calendário de eventos e atividades culturais e esportivas, que integre os três países.

O núcleo de fronteira do Paraná (Brasil, 2017) apresentou projeto de implantação de um centro de inteligência do turismo na região de fronteira, incluindo o estado no Programa Turismo de Fronteiras (Frontur), coordenado pelo Ministério do Turismo (MTur), visando ao apoio à formataçáo de roteiros turísticos integrados, como caminhos da fronteira, caminhos integrados ao lago de Itaipu, Guaíra-Mundo Novo-Salto del Guairá, Doce Iguassu, Iguassu-Misiones etc.; e reforma e readequação do Centro Náutico e Recreativo Marinas de Guaíra. Além do turismo, destacam-se propostas desse núcleo de fronteira em outras áreas econômicas: i) implantação de centro de criação e desenvolvimento de software, em Cascavel, Toledo e Francisco Beltrão; ii) estruturação de espaços de desenvolvimento de tecnologias sociais nas áreas disponíveis em Guaíra, para geração de emprego e renda do desenvolvimento de iniciativas/produtos de alto conhecimento e baixa tecnologia; iii) implantação de rede tecnológica integrada da FF; iv) implantação de programas de produtividade/ sanidade/competitividade visando à criação de centros de estudos aplicados para a indústria suinícola e avícola regional e para a bacia leiteira; e v) criação de uma Zona de Processamento de Exportação (ZPE) em um polígono que abranja da linha de fronteira até $50 \mathrm{~km}$ para o interior do continente, com início no município de Guaíra, a oeste, até Barracão, no sudoeste do Paraná.

\subsubsection{Informalidade no trabalho}

Foram propostas algumas açóes gerais de urgência aos três arcos: i) assinar acordos que consigam regularizar as relaçóes de trabalho nas regióes de fronteira e que consigam ser concretizados nas relaçóes cotidianas; ii) considerar as barreiras alfandegárias para facilitar as relaçôes de consumo; iii) viabilizar não somente a complementação econômica dos habitantes das regiôes de fronteira, mas também o livre trânsito de produtos de cesta básica e o acesso total aos serviços (com açóes em conjunto entre as cidades fronteiriças); iv) criar ZPEs para facilitar a produção e a comercialização entre os países vizinhos, somadas à consolidação de processos de transporte na região; e v) efetivar o controle na extração vegetal e mineral, a exemplo da castanha (Pêgo et al., 2017; 2018; 2019; 2020a; 2020b).

A falta de informações dos estabelecimentos agropecuários do outro lado da fronteira que auxiliem na proposição de políticas públicas para a região demonstra a necessidade de organização de uma base de informação que extrapole a escala nacional para a continental (Pêgo et al., 2017). 
No arco Central, recomendou-se começar por açóes emergenciais diretas: integração do transporte, organização da pendularidade da mão de obra, ruptura de bloqueios e atuação contra a criminalidade, pois as organizaçóes criminosas facilitam a atenção a demandas da sociedade mais que o Estado, dada a sua ausência (Pêgo et al., 2019; 2020a). Os participantes do arco Sul, de forma complementar, afirmaram que, no transporte, os ônibus que circulam nas cidades fronteiriças não podem ir para a cidade pertencente ao país limítrofe, apesar da existência de interligação física (Pêgo et al., 2020b).

\subsection{Infraestrutura econômica}

\subsubsection{Transportes e conexões}

De modo geral, os participantes dos fóruns de discussão nos três arcos recomendaram: i) implementar e concluir obras de infraestrutura na FF; ii) adequar aeroportos para operação internacional; iii) realizar as manutençôes necessárias; iv) dotar de funcionários para viabilizar interligaçóes fronteiriças; e v) ofertar os serviços que devem acompanhar essas infraestruturas. Ressaltaram que os projetos de infraestrutura econômica precisam ser pensados a partir dos interesses das populaçóes fronteiriças e de suas necessidades; e as obras de infraestrutura devem ser planejadas como fonte de integração dos povos sul-americanos (Pêgo et al., 2017; 2018; 2019; 2020a; 2020b).

Especificamente no arco Central, foi proposto incentivar a regiáo com serviços de infraestrutura e logística que garantam a geração de emprego e renda e a inserção dos produtos e serviços da FF nos mercados interno e externo, além de aumentar a oferta de programas de qualificação de recursos humanos e da mão de obra fronteiriça, em parceria com instituiçóes afins, direcionados aos setores agrossilvipastoril, turismo, indústria, comércio, serviço e outros (Pêgo et al., 2019; 2020a).

Mostraram o quanto é necessário incentivar projetos integrados na região transfronteiriça que promovam o desenvolvimento local, a exemplo dos projetos no âmbito da Itaipu Binacional, empresa que passou por assinatura de tratado, consórcio, construção, operação, gerando emprego para mais de 200 mil fronteiriços. Todavia, há casos controversos que, para muitos, não refletem em desenvolvimento para a regiáo, como o gasoduto Bolívia-Brasil, que não influencia positivamente a dinâmica econômica local, caso de Corumbá (Mato Grosso do Sul); as usinas hidroelétricas de Jirau e Santo Antônio, em Rondônia; o projeto Jari, em Almeirim, na fronteira norte, entre tantos outros exemplos não tão positivos para as regióes (Pêgo et al., 2019).

$\mathrm{Na}$ construção de infraestrutura de transporte, foi recomendado que se busque maior eficácia tanto no intercâmbio entre as cidades gêmeas (ou arranjos transfronteiriços) quanto na integração entre centros da rede de cidades, em escala nacional, 
para que os produtos cheguem até as regióes de fronteira. Em relação a projetos logísticos, recomendou-se contemplar a logística do pequeno, da população que está na área de fronteira, por meio de pequenas obras, como melhoria de estradas vicinais, construção de pequenos portos, pontes, entre outros (Pêgo et al., 2019).

No caso do transporte aéreo, há que se resolver o limitante à mobilidade que está nas proibitivas taxas de embarque e desembarque entre os países. Como alternativa, foi proposta a criação de uma taxa de embarque e desembarque diferenciada nos aeroportos localizados nas regióes de fronteira, como também a realização de voos entre si, para que a mobilidade na região seja facilitada. Assim, otimizaria-se a oferta de alguns serviços que facilitariam a integração entre os países (Pêgo et al., 2019).

No arco Norte, todo o seu território necessita de investimentos em infraestrutura econômica (rodovias, aeroportos, portos, hidrovias e energia elétrica) e armazenagem (silos). Mais que isso, é preciso garantir assistência técnica, financiamento e adequada base institucional de suporte à implantaçấo de um polo de desenvolvimento; a construçáo de uma carteira de projetos de infraestrutura regionalmente estratégicos, articulados aos projetos previstos no Programa de Aceleração do Crescimento (PAC) ou pelos estados; e a instituição de um fundo ou programa de financiamento em moeda nacional, nas operaçôes comerciais na FF com os países vizinhos, envolvendo também o Mercosul, ou o estabelecimento de quotas de importação (Pêgo et al., 2017; 2018).

É urgente o fortalecimento, a ampliação e a modernização da infraestrutura terrestre: restauração e recuperação das BR-401, BR-432 e BR-174, vias de integração física entre Brasil, Guiana e Venezuela, respectivamente; implantação do Programa de Estradas Vicinais Pavimentadas na FF; ampliação da malha rodoviária; conclusão da pavimentação da estrada Oiapoque-Macapá (Pêgo et al., 2018); revitalização e asfaltamento, no Pará, da BR-163 e das PA-473 e PA-254, assim como a federalizaçáo destas (Brasil, 2017); asfaltamento da estrada que liga Lethem-Georgetown (Guiana), Suriname e Guiana Francesa pelo Projeto arco Norte (Brasil, 2017); e o desenvolvimento do Projeto Ferrovia arco Norte (Brasil, 2017).

Foi recomendado adequar as rotas e as tarifas dos serviços aéreos ao perfil da demanda. Recomendou-se, também, a adequação das normas regulares da Agência Nacional de Aviação Civil (Anac) para que considere as peculiaridades regionais nas faixas de fronteira, possibilitando atualizar os Planos Aeroviários Estaduais (PAEs), visando à ampliação física entre Brasil, Guiana e Venezuela; criação de voos regulares entre as capitais dos estados do arco Norte e as capitais dos países andinos; o reconhecimento oficial dos aeroportos de Santa Elena de Uairén (Venezuela) e Lethem, na Guiana (Pêgo et al., 2018); e a efetivação do novo terminal aduaneiro de cargas do aeroporto internacional de Boa Vista (Brasil, 2017). 
No arco Central, foi apontada a necessidade de investimentos para a melhoria da infraestrutura dos modais ferroviário, rodoviário, portuário e hidroviário; da oferta de energia e de gás natural; além da possibilidade de um polo químico siderúrgico; bem como de outros grandes projetos para a região, como ligaçóes viárias com saídas para o Pacífico. Os participantes recomendaram, ainda, que se reativem as infraestruturas ociosas, como portos, aeroportos, além da ZPE, em Cáceres (Pêgo et al., 2019; 2020a). Uma proposta do núcleo de fronteira de Mato Grosso do Sul é a inclusão de Ladário na rota bioceânica, além da reativação de seu porto de cargas (Brasil, 2017). Sobre infraestruturas de integração com a Bolívia, é necessário um voo direto entre Cuiabá e Santa Cruz, na perspectiva de que facilite as comunicaçóes e estimule o turismo na regiáo (Pêgo et al., 2019). Além disso, o núcleo de fronteira de Rondônia propõe a inserção de Guajará-Mirim na rota comercial de voos nacionais e internacionais (Brasil, 2017). Enfatizou-se a urgência de se enfrentar os problemas das rodovias, buscando recursos em ambos os lados da fronteira, além de equacionar a dificuldade do transporte com transbordo da carga, dotando de infraestrutura adequada para cargas de exportação que não necessariamente precisam estar em depósito alfandegário. Propôs-se, ainda, estruturar e sinalizar as rotas turísticas, montando uma estrutura de marketing para atrair novos empreendimentos (Pêgo et al., 2019; 2020a). Nesse contexto, cabe salientar a proposta do núcleo de fronteira de Rondônia de restauração de 7 km de trilhos da Estrada de Ferro Madeira Mamoré, em Porto Velho (Brasil, 2017).

Os participantes das atividades no arco Sul recomendam criar uma comissão de infraestrutura mista (conjunta) para avaliar e definir os eixos comuns de interesse regional (ligações bioceânicas, integração rodoviária, ferroviária, aeroviária e aproveitamento do potencial hidroviário - transporte, pontes internacionais, navegabilidade etc.). Em termos de açôes específicas à região: i) revitalizar a ponte existente entre Uruguaiana e Paso de los Libres (Argentina); ii) construir uma ponte específica para passagem de caminhôes em Uruguaiana, por ser um corredor importante do Mercosul; iii) dar tratamento separado à liberação das cargas e coletivos (trânsito de cargas com um tratamento próprio) em relação à liberação de outros passantes em veículos leves ou mesmo a pé, em diversas localidades fronteiriças (em Uruguaiana, particularmente em períodos de férias de verão); iv) apoiar a construção da ponte entre Bella Unión (Uruguai) e Monte Caseros (Argentina), ainda apenas prevista; v) prover melhorias no sistema viário regional, com a duplicação da BR-290 - Uruguaiana-Porto Alegre; vi) reconstruir a BR-472, ligando Barra do Quaraí a Uruguaiana; vii) construir a ponte sobre o rio Ibicuí, para conexão entre Uruguaiana e Itaqui; viii) revitalizar a ponte de ferroviária Barra do Quaraí-Bella Unión; ix) recuperar o Saladero, a estação ferroviária de Barra do Quaraí; e $\mathrm{x})$ avançar na definição da modelagem e respectivas autorizaçóes para a construção das pontes sobre o rio Uruguai, conforme "decisão de Recife" - pontes Itaqui-Alvear, 
Porto Xavier-San Javier e Porto Mauá-Alba Posse (Pêgo et al., 2020b). O núcleo de fronteira do Rio Grande do Sul inclui outras propostas de ligação terrestre, como a extensão do ramal ferroviário Maçambará, Itaqui e Uruguaiana, além da revitalização e extensão de ramais em outras regióes do estado; implantação de Porto Seco em São Luiz Gonzaga; construção da rodovia Transcampesina (Arroio Grande, Pedras Altas, Herval, Pinheiro Machado, Candiota, Hulha Negra e Aceguá); e implantação do corredor bioceânico de acesso ao oceano Pacífico (Brasil, 2017).

Solicitou-se, ainda, agilizar as providências para viabilizar a ampliação da aviação regional, podendo-se destacar: a proposta do núcleo de fronteira do Paraná de construção de um aeroporto regional de cargas e passageiros no oeste do estado e integração aeroportuária da tríplice fronteira, considerando aspectos normativos e operacionais; e a proposta do núcleo de fronteira do Rio Grande do Sul de ampliação de aeroportos regionais e rotas aéreas, estabelecendo rotas internacionais para Santana do Livramento, Pelotas, Bagé, Alegrete, Santa Rosa, Santo Ângelo, São Borja e Uruguaiana (Brasil, 2017).

Relativo às infraestruturas viária e ferroviária, o núcleo de fronteira do $\mathrm{Pa}$ raná relaciona uma série de propostas: i) criação de estação aduaneira trinacional; ii) criação de uma segunda ponte bimodal (rodoviária - ferroviária), interligando Foz do Iguaçu (Brasil) e Ciudad del Este (Paraguai), com finalidade de transporte de cargas; iii) duplicação, adequação e recuperação de diversas rodovias; iv) construção de novos trechos ferroviários ligando Cascavel a Guaíra (Paraná) e Guaíra - Maracaju em Mato Grosso do Sul; e v) implantação do trecho da ferrovia norte-sul entre as cidades de Cianorte-Guaíra (opção I) e Cianorte-Campo Mourão-Cascavel (opção II) e as cidades de Cascavel-Chapecó - Santa Catarina (Brasil, 2017).

O núcleo de fronteira de Santa Catarina, por sua vez, propõe a criação de grupo de trabalho para articular açóes pró-ferrovia, com participação de governo e sociedade, além da execução de projetos de recuperação e duplicação das BR163, BR-153, BR-282 e BR-158, de revitalização das SC-480, SC-283, SC-468 e SC-469 (Brasil, 2017).

Quanto ao transporte hidroviário, no arco Norte, foi proposto viabilizar a conexão hidroviária interna ao arco e integrar ao restante do território (Pêgo et al., 2018). Propostas do núcleo de fronteira do Amazonas sugerem estruturar o porto de Tabatinga para atender à rota de saída que está sendo criada como alternativa para o Polo Industrial de Manaus - PIM (via Canal do Panamá) e resolver questôes relativas ao comprometimento das condiçóes de navegabilidade dos rios Amazonas e Solimóes na regiāo de fronteira. Além disso, o núcleo de fronteira de Roraima propõe, pelo Projeto arco Norte, a construção de porto em águas profundas em Berbice, na Guiana (Brasil, 2017). 
No arco Central, propôs-se aproveitar melhor o sistema de hidrovias e construir o porto previsto, o que facilitará o escoamento dos produtos através do canal Tamengo. Esse sistema de hidrovias sofre restriçôes de navegabilidade durante o período de seca, e não foi apresentado, até o momento, estudo para viabilidade do transporte nesse período. Os participantes lamentam que o resultado histórico da construção conjunta Brasil-Bolívia, da interligação hidroviária que conectou Brasil, Paraguai, Argentina e Uruguai encontre-se abandonada (Pêgo et al., 2019). No arco Sul, foi recomendado que se aprofundem as açôes relativas ao desenvolvimento das bacias do rio Uruguai e da lagoa Mirim, garantindo navegabilidade do rio Uruguai, com escoamento pelo rio Sáo Gonçalo, perpassando a lagoa dos Patos, com saída para o oceano (Pêgo et al., 2020b). O núcleo de fronteira do Paraná propóe obras de conformação do canal de navegação de Guaíra, com uma extensão de $3 \mathrm{~km}$, e no rio Paraná, no trecho em corrente livre, desde a Usina Hidroelétrica (UHE) de Porto Primavera até Guaíra (Paraná), com extensão de $245 \mathrm{~km}$, em configuração com profundidades de $3 \mathrm{~m}$, de maneira a compatibilizar, em uma primeira etapa, os comboios que operam tanto no rio Paraná como no rio Tietê. E o núcleo de fronteira do Rio Grande do Sul propóe a conclusão dos estudos de viabilidade econômica para a implementação da hidrovia Uruguai-Brasil da lagoa Mirim (Brasil, 2017).

\subsubsection{Energia e comunicações}

De modo geral, recomendou-se a construção de linhas de transmissão de energia elétrica para otimizar a economia da FF. Particularmente no arco Norte, a infraestrutura energética precisa ser consolidada. Para isso, propôs-se: i) construção da linha de transmissão entre Manaus (Amazonas) e Boa Vista (Roraima); ii) implantação e ampliação de sistemas de geração de energia, incluindo os modelos alternativos (eólica e solar); iii) discussão dos acordos entre Brasil, Venezuela e Guiana sobre importação e exportação de energia elétrica; iv) construção de hidroelétricas com menor impacto ambiental; v) melhoria do sistema de distribuição de energia elétrica nos municípios para atender a empreendimentos locais; e vi) recursos financeiros para investimento nos sistemas de subtransmissão (Pêgo et al., 2018). No arco Norte, os participantes salientaram a urgência de ampliar os canais de comunicação, particularmente a conexão de internet, integrar os serviços de telecomunicaçôes e criar um centro integrado de controle com os países vizinhos, dotados de servidores para atendimento. Também há que se ampliar os sistemas de comunicação, com estabelecimento de parâmetros de concorrência e prioridade para o Plano Nacional de Banda Larga - PNBL (Pêgo et al., 2018).

A questão do gás natural é crucial para garantir a receita do Imposto sobre Circulação de Mercadorias e Serviços (ICMS) no arco Central. Foi proposto que se implante uma política energética de longo prazo para diminuir a dependência 
da região das variaçóes de mercado. Em vez de um parque gerador elétrico baseado em centrais hidrelétricas (que levam anos para serem construídas), sugeriu-se uma planta termoelétrica, que seria uma alternativa praticamente imediata e que usaria o gás natural da Bolívia, o qual também poderá ser utilizado para as demais atividades industriais e comerciais da regiâo (Pêgo et al., 2019).

\subsubsection{Postos de controle fronteiriços}

No arco Norte, foi dado como prioritário: complementar com aduana a ponte Oiapoque (Amapá)-Saint Georges (Guiana Francesa); concluir a pavimentação da estrada Oiapoque-Macapá; instalar o sistema alfandegário na fronteira do Brasil com a Guiana Francesa; e definir alguns pontos no acordo bilateral entre Brasil e França, para, em seguida, dar início às operaçôes da Receita Federal do Brasil (RFB) e da Polícia Federal (PF) nessa fronteira (Pêgo et al., 2018).

No arco Central, foi solicitado resolver os problemas na estrutura da imigração e das aduanas boliviana e brasileira, que padecem com a burocracia existente. Ademais, há que se compatibilizar as legislaçôes, dado que não se verifica uma mesma norma de procedimento entre os países, e permitir condiçóes de acesso de composiçóes de trens bolivianos ao território brasileiro (Pêgo et al., 2019; 2020a).

A adequação das aduanas também é um requerimento dos participantes do arco Sul. No caso da fronteira Brasil-Argentina, essa necessidade é urgente, particularmente para a sazonalidade da demanda das férias de verâo. Além disso, é necessário construir uma segunda ponte na conexão Uruguaiana-Paso de los Libres. Em Santa Catarina, é preciso estruturar e sinalizar o passo fronteiriço Paraíso a San Pedro (Argentina), na Ponte Internacional Peperi-Guaçu. De modo geral, avançar na adoção dos serviços aduaneiros integrados; instalar estruturas de reciprocidade aduaneira e de imigração nos passos fronteiriços entre Brasil, Argentina e Uruguai, mesmo nos casos nos quais náo há ponte e ainda se faz o transporte por balsa. Complementarmente, recomendou-se manter abertos os consulados e/ou vice-consulados em cidades de fronteira, assim como postos da PF (Pêgo et al., 2020b).

\subsection{Serviços e políticas sociais}

\subsubsection{Saúde}

Nos três arcos, foi apontado como prioridade do setor saúde reforçar as campanhas de vacinação, quando realizadas, nas cidades de ambos os lados da fronteira. No arco Norte, solicitou-se realizar campanhas de saúde mais abrangentes, relativas a doenças sexualmente transmissíveis (DSTs) e Aids, além das campanhas de vacinação e amamentação (Pêgo et al., 2018). O núcleo de fronteira do Amazonas aponta como problemática a inexistência de instrumento jurídico que possibilite a prestação de serviço de saúde na trifronteira Brasil-Colômbia-Peru, destacando-se, 
nessa região, a baixa oferta de atendimento especializado em média e alta complexidades. Cabe, também, salientar o apontado por esse núcleo de fronteira sobre a falta de estrutura física e logística do Distrito Sanitário Especial Indígena (DSEI) para deslocar e manter as equipes de saúde mais tempo em área indígena, como ocorre em São Gabriel da Cachoeira. O núcleo de fronteira do Amapá (Brasil, 2017) alerta também para os fatores de risco socioambientais de ocorrência da malária em áreas indígenas localizadas na FF entre Brasil, Guiana Francesa e Suriname. O núcleo propóe, para tanto, práticas de manejo ambiental seletivo para o controle vetorial; e realização de vários estudos (Brasil, 2017) e, concomitantemente aos participantes do arco Norte, do projeto de implantação do núcleo de vigilância em saúde na regiáo de Oiapoque (fronteira Brasil-Guiana Francesa), bem como projeto de construção de uma unidade básica de saúde (UBS), com implantação do Centro de Testagem e Aconselhamento (CTA) e o Serviço de Assistência Especializada (SAE) em DSTs/Aids na fronteira do município de Oiapoque (Brasil, 2017; Pêgo et al., 2018).

Tanto os participantes do arco Norte quanto o núcleo de fronteira de Roraima apresentam como proposta a celebração de acordos nas áreas de saúde entre Brasil-Guiana e Brasil-Venezuela para tratar de questóes de imunização (fortalecimento da parceria para o atendimento das endemias na fronteira); atuação da vigilância sanitária; transferência e atendimento diferenciado no trânsito de pacientes na fronteira; atendimento complementar, de acordo com especializaçóes das cidades fronteiriças e da atuação preventiva; e açôes conjuntas no tratamento do usuário de drogas (Brasil, 2017; Pêgo et al., 2018).

Particularmente com a chegada da Covid-19 (março/2020), o sistema de saúde em Roraima (Pacaraima e Boa Vista) entrou em colapso, tendo em vista os problemas de atendimentos locais já existentes mais a elevada imigração venezuelana, dada a crise estrutural que esse país vive. Apesar de todo o trabalho que o governo federal e os parceiros têm feito, por meio da Operação Acolhida, o quadro na área de saúde, nessa região, ainda é preocupante, tendo impacto também em Manaus.

Se, na saúde, é sabido que o lado brasileiro atende aos bolivianos, participantes do arco Central propuseram criar mecanismos para que os municípios recebam para fazer esse atendimento, que essa ação seja contemplada no sistema hospitalar e no sistema de saúde (Pêgo et al., 2019; 2020a). Complementam os participantes do arco Sul: i) efetivar práticas de ressarcimento para a rede hospitalar e UBS, nos casos de prestação de atendimento ao cidadão do país vizinho; ii) prever financiamento da política de saúde do fronteiriço, com o reconhecimento, pelos governos, do atendimento a estrangeiros fronteiriços, inclusive com a transferência de recursos financeiros; iii) tornar mais acessível a documentação de residente legal; iv) pleitear que o Ministério da Saúde (MS) brasileiro reconheça o hospital de Bella Unión como referência em serviços de saúde, inclusive com repasses de recursos pelos 
serviços e atendimentos realizados; v) promover a qualificação dos trabalhadores da área de saúde, com residência médica nas cidades gêmeas; e vi) realizar a integração de recursos humanos e uso das tecnologias disponíveis nas cidades gêmeas com vistas a otimizar a infraestrutura existente e a cooperação mútua (Pêgo et al., 2020b). As propostas do núcleo de fronteira do Paraná preveem projetos para construção de hospitais; implantação de hospital de reabilitação locomotora no padrão "Sara Kubitschek"; criação de hospitais internacionais nas cidades de Foz do Iguaçu e Barracão, como referência nos atendimentos de urgência e emergência e especialidades; e instalação e estruturação do hospital regional de Toledo. Faz parte da proposta do núcleo de fronteira paranaense, também, a ideia de implantar um consórcio internacional intermunicipal para atendimento de saúde ao longo da FF (Brasil, 2017).

\subsubsection{Educação e cultura}

Em relação ao baixo nível de desenvolvimento na área da educação em toda a FF, são demandas comuns nos três arcos: promover o aumento da escolarização, com medidas para elevar as matrículas e a frequência de crianças e jovens nas escolas; ofertar programas de estudo diferenciados para mães com filhos pequenos, chefes de família, jovens e adultos com baixa escolarização; e fortalecer as escolas bilíngues (Pêgo et al., 2017; 2018; 2019; 2020a; 2020b).

Além dessas açóes, os participantes do arco Central propóem: i) regularizar a obrigatoriedade do ensino do espanhol-português como segunda língua nas regióes de fronteira; ii) promover intercâmbios nas práticas docentes e conteúdos educativos entre as escolas do Brasil e as do país vizinho, que valorizem o olhar sobre a regiáo fronteiriça; iii) garantir incentivo financeiro para o transporte, a merenda escolar e a capacitação de professores; iv) dar continuidade ao Programa Escolas Interculturais de Fronteira (Peif); e v) superar os preconceitos perceptíveis ou subjetivos com relação aos bolivianos e paraguaios, que se assemelham muito ao preconceito que existe contra os indígenas na região (Pêgo et al., 2019; 2020a). O núcleo de fronteira de Mato Grosso do Sul complementa com o olhar fronteiriço sobre a diversidade, propondo a implementação de açóes do Centro Estadual de Formação de Professores Indígenas de Mato Grosso do Sul (CEFPI), na formação inicial e continuada dos professores indígenas, nas diferentes áreas do conhecimento. Na mesma linha, o núcleo de fronteira de Rondônia estabelece estratégias de revitalizaçáo e fortalecimento da língua e cultura Wayoro, por meio do planejamento e da elaboração de material de educação bilíngue Wayoro-português, em Guajará-Mirim (Brasil, 2017).

No âmbito do ensino superior, propôs-se criar parceria com as faculdades de medicina da Bolívia e do Paraguai, pois grande parte dos acadêmicos lá são brasileiros, possibilitando que a residência possa ser realizada nos hospitais 
e centros de saúde nas cidades fronteiriças; implantar curso de medicina em Corumbá e Cáceres; criar a universidade fronteiriça; estreitar o diálogo entre a universidade e as cidades gêmeas; utilizar as diversas universidades dos países para participarem como atores ativos e contribuírem na solução dos problemas, que, por excelência, são multidisciplinares; socializar os resultados de trabalhos de pesquisa das universidades da região; investir em ciência e tecnologia; e, mais especificamente, finalizar e implementar o projeto do Parque Tecnológico Internacional de Ponta Porã (Pêgo et al., 2019).

Agregam os participantes do arco Sul propostas para incentivar o aprendizado do idioma e da história do país vizinho e facilitar o intercâmbio de suas práticas culturais; reconhecer o "portunhol"; implementar cursos que integrem os três países (Brasil-Argentina-Uruguai), com reconhecimento de títulos e livre circulação de docentes e discentes de todas as idades; promover o intercâmbio de estudantes nas cidades da região, campeonatos e olimpíadas trinacionais; e realizar festivais de arte e cultura com artistas dos três países. Os participantes recomendam ainda rediscutir o problema das incompatibilidades entre os países no âmbito do Peif; expandir o projeto para outras cidades de fronteira; oferecer cursos bi e trinacionais, pelas universidades e pelos IFs; oferecer cursos de formação superior e especialização voltados aos estudos fronteiriços; e implantar cursos técnicos e profissionalizantes bi e trinacionais, de curto e longo prazos, como também sua extensão aos cursos terciários. Sugerem, ademais, que institutos de ensino superior (IES), IFs e instituiçóes dos países vizinhos programem estudos sobre as potencialidades da região, visando gerar bases de informaçóes para novos cursos e projetos, assim como para que subsidiem a elaboração de um plano de desenvolvimento integrado da tríplice fronteira; e que seja elaborado um guia com a relação de cursos e programas e projetos educativos existentes nas universidades, institutos e organizaçóes educacionais que atuam na zona de fronteira, para conhecimento e orientação à população (Pêgo et al., 2020b).

No arco Norte, o núcleo de fronteira de Roraima apresenta proposta para o estabelecimento de acordo bilateral para criação de uma escola de fronteira que realize intercâmbio entre docentes e discentes, visando/requerendo: i) professores com domínio da língua e da cultura das cidades gêmeas fronteiriças (projeto-piloto), garantindo recursos para capacitação e adicional de permanência na fronteira; ii) otimização dos calendários escolares existentes, incluindo o período de recesso para ampliação de intercâmbio; iii) produção de material pedagógico e educativo multilíngue; iv) garantia, pelos países vizinhos, de transporte do educando, ida e volta, desde a cidade de origem até a escola de fronteira; v) extensão aos municípios fronteiriços das açóes, após os resultados obtidos nas cidades gêmeas como projeto-piloto; e vi) criação de mecanismos de colaboração entre os conselhos municipais fronteiriços, para garantir e facilitar o acompanhamento de alunos brasileiros residentes na Venezuela em risco de evasão escolar. 
Além da proposta da Escola de Fronteira, o núcleo propóe para a área da educação e cultura: i) criação de mecanismos de adequação para atender à demanda de equiparação curricular na transferência dos alunos entre os países; ii) facilitação de intercâmbios em cursos profissionalizantes; iii) criação de fundo para financiamento de projetos culturais fronteiriços; iv) definição de calendário conjunto de eventos culturais entre as cidades fronteiriças; v) implantação de intercâmbio desportivo entre as cidades fronteiriças; vi) construção e implementação de complexo poliesportivo, adequado à realidade das cidades fronteiriças; e vii) implantação de instituto federal tecnológico em Pacaraima e Bonfim, com cursos em áreas estratégicas para o desenvolvimento e a integração fronteiriça.

Cabem também as propostas apresentadas pelo núcleo de fronteira do Amapá de um projeto integrado multi/transdisciplinar denominado A Sociedade Transfronteiriça Amapá-Guiana Francesa e suas Dimensóes Geopolíticas, Ambientais, Histórico-Culturais e Linguísticas, idealizado pelos municípios da regiáo; ${ }^{2}$ projetos de interação tecnocientífico entre o Amapá e a Guiana Francesa; além de campus universitário binacional em Oiapoque. Ainda com relação ao ensino superior, o núcleo de fronteira do Pará propõe também a implantação de campus da Universidade Federal do Oeste do Pará (Ufopa) nas sedes dos municípios da região para facilitar a difusão do ensino superior na área fronteiriça (Brasil, 2017).

Com a ideia de estender a educação à comunidade, participantes do arco Central propuseram a criação e a melhoria de políticas públicas voltadas aos jovens da fronteira, que orientam com informaçóes sobre os males da droga e ajudam a reduzir o envolvimento de crianças e adolescentes com o tráfico e outros ilícitos internacionais (Pêgo et al., 2019).

Um projeto que serve como exemplo e é referência na fronteira é o Moinho Cultural Sul-Americano, em Corumbá. Durante o processo de revitalização da área portuária da cidade, foram aproveitadas as antigas instalaçóes do Moinho Mato-grossense. O prédio possui auditório com capacidade para cem pessoas, refeitório, biblioteca, videoteca, salas de dança e de música e ainda amplo espaço aberto ao ar livre.

O projeto iniciou suas atividades atendendo inicialmente 180 crianças em risco social. Em 2015, com onze anos de atividades ininterruptas, o Moinho inspirou as cidades de Ladário (Mato Grosso do Sul) e Puerto Suárez (Bolívia) a projetos semelhantes. Vários participantes das atividades foram absorvidos como instrutores nas áreas afins da própria instituição, além de outros inseridos em cursos superiores, influenciados pela formação cidadã adquirida no Moinho. A instituição atua fundamentalmente na ação pedagógica, ação social e na atividade Moinho

2. Oiapoque, Calçoene, Amapá, Pedra Branca do Amaparí, Serra do Navio, Tartarugalzinho, Pracuúba e Laranjal do Jarí. 
in Concert. $\mathrm{Na}$ ação pedagógica, as atividades estão distribuídas por turmas com diferentes níveis técnicos, e cada turma possui uma grade horária de vinte horas semanais, equivalente à grade escolar regular.

$\mathrm{Na}$ ação social, o instituto desenvolve atividades "com familiares dos participantes de caráter permanente e continuado". O espetáculo Moinho in Concert consolida uma iniciativa que, de forma progressiva, tornou-se uma das realizaçóes de maior visibilidade do Instituto Moinho Cultural Sul-Americano. Além de reunir todas as áreas de expressão trabalhadas na instituição, o projeto mobiliza técnicos locais e de outras regiōes do país, conta com a participação de artistas brasileiros e convidados e aproxima o grande público de uma arte de qualidade, em que os principais protagonistas são crianças e adolescentes, nos papéis de bailarinos, instrumentistas orquestrais, solistas e coralistas, moradores de Corumbá e Ladário (Mato Grosso do Sul) e Puerto Suárez e Puerto Quijarro - Bolívia (Pêgo et al., 2019).

No arco Sul, um exemplo em curso é a ação de incrementar a cultura por meio de projetos de pesquisa, editais de fomento a festivais de cinema, teatro, feiras de livro, gastronomia, música, carnaval, campeonatos esportivos regionais etc. Nessa linha de proposta de integração cultural, vem sendo realizado o projeto de pesquisa Diploma Universitário Trinacional, Gestão de Políticas Culturais: Três Países, Três Fronteiras, Um Só Povo, na tríplice fronteira entre o Brasil, o Uruguai e a Argentina. O projeto, cuja ideia foi aprovada pelo Comitê Trinacional de Fronteira, em 2017, teve seu primeiro encontro formal, nos dias 8 e 9 de junho de 2018, em Monte Caseros, com o tema Patrimônio Cultural. A proposta educativa que defende se volta a fortalecer a integração e a cooperação na tríplice fronteira, por meio de uma série de encontros que permitirão impulsionar políticas de gestão cultural transfronteiriça enfocadas na construção de uma visão-identidade territo$\mathrm{rial} /$ regional. O principal objetivo é promover a integração de uma área de tríplice fronteira, por meio da articulação de universidades e escolas dos três países, com a criação de um diploma universitário trinacional em gestâo de políticas culturais, assim como outro em jornalismo. A estrutura e dinâmica desta instância educativa visa transformar o território ao dar um papel ativo ao sistema educativo na transformação das áreas de fronteira. Os conteúdos e as temáticas são voltados a criar uma visão regional e trinacional do território, ao mesmo tempo transformadora da educação. Informação, teoria e construção de conhecimento são apresentadas como elementos-chave de um processo transformador (Pêgo et al., 2020b).

Outras propostas desse arco focaram-se no âmbito de preservação do patrimônio histórico e cultural das cidades da tríplice fronteira, como: revitalizar a ponte de ferro Barra do Quaraí-Bella Unión; recuperar o Saladero, a estação ferroviária de Barra do Quaraí; assim como o monumento tripartite, o Porto Ceibo (Monte Caseros) e o Cantão de São Marcos - Uruguaiana (Pêgo et al., 2020b). 


\subsubsection{Cooperação para a prestação de serviços}

Para os participantes dos três arcos, a condição fronteiriça requer o fortalecimento das políticas já existentes, particularmente nas áreas de saúde e educação. Além disso, é importante que haja cooperação entre os municípios dos diferentes países e que essa cooperação seja regulamentada pelos Estados nacionais, de maneira que ambos contribuam para a geração de serviços de qualidade nessas áreas (Pêgo et al., 2017; 2018; 2019; 2020a; 2020b).

Uma alternativa é a implantação de consórcios intermunicipais e internacionais, explorando as possibilidades de açóes comuns, prévios acordos entre os poderes Executivos e Legislativos para a consolidação de serviços qualificados de saúde, educação, turismo, tecnologia da informação, combate à criminalidade etc.

É necessária também a implementação ou a adequação dos serviços de mobilidade transfronteiriça - seja para circulação, acessibilidade ou documentação - que facilite o ir e vir de fronteiriços. Os serviços de saúde e educação são os que mais provocam a mobilidade de pessoas na fronteira, que buscam atendimento de melhor qualidade ou meramente um atendimento ausente em um dos lados da fronteira.

Participantes do arco Norte recomendaram aparelhar e fortalecer a estrutura de serviço público, para torná-lo eficiente na FF, particularmente nas áreas de saúde, educação, formação profissional, segurança, como também transportes e telecomunicaçóes, além de serviços de fiscalização. Maior atenção deve ser dedicada a temas sociais. É necessário realizar concursos regionais para cargos públicos na fronteira, adequar as normas do Sistema Único de Saúde (SUS) e do Ministério da Educaçáo (MEC) para ressarcimento ao Estado referente a atendimento ao estrangeiro, além da integração entre serviços e rotinas de controle aduaneiro, de fiscalização sanitária e fitossanitária, de seguros e demais órgãos anuentes, em centro integrado e com adequados recursos físicos e humanos. Uma alternativa sugerida é promover a atração de imigrantes para atender a áreas que necessitam de mâo de obra qualificada (Pêgo et al., 2018).

\subsection{Povos da fronteira e migrações}

\subsubsection{Comunidades tradicionais e indígenas}

A forte presença de populaçôes tradicionais e povos indígenas exige medidas para evitar sua vulnerabilidade diante da "cultura massificadora" que adentra a regiáo de fronteira. Da mesma forma, é necessária a manutenção da rica sociobiodiversidade, a partir da valorização dos conhecimentos tradicionais dessas comunidades e da proteçấo do estilo de vida, incluindo a preservação das áreas onde residem. Em relação à diversidade étnico-cultural, recomendou-se promover a integração entre os diferentes costumes e tradiçóes; realizar levantamento dos acirramentos 
de conflitos ligados às questôes étnicas e raciais; e utilizar manifestaçôes e eventos culturais de cada região como forma de fortalecer uma identidade fronteiriça local (Pêgo et al., 2017; 2018; 2019).

Como proposição geral, recomendou-se tratar da inclusáo social das comunidades indígenas e da integração física dessas áreas a outros espaços e setores da sociedade, considerando que, para esses povos, não existe fronteira. Recomendou-se, ainda, viabilizar meios para a mobilidade nas regiōes de fronteira (Pêgo et al., 2017; 2018; 2019; 2020a; 2020b). Considerado fato mais recente e genérico das regióes de fronteira, recomendou-se avaliar a presença crescente de igrejas evangélicas nas áreas indígenas (Pêgo et al., 2017a).

Para os participantes do arco Norte, reconhecer a importância dos povos indígenas, assim como das demais comunidades tradicionais e ribeirinhas, consiste em entender que a Amazônia é plural, étnica e culturalmente, e que eles, sim, entendem as melhores formas para a necessária ocupação sustentável desse bioma. Dessa forma, a ênfase recaiu na necessidade de garantir um tratamento específico para essas comunidades, particularmente, considerando seu isolamento, reconhecendo e combatendo sua condição de pobreza, garantindo sua integração com outros setores da sociedade e facilitando a sua mobilidade e o acesso a serviços básicos, como a saúde e a educação. Além disso, é necessário que se amplie o diálogo entre a Fundação Nacional do Índio (Funai) e os governos estaduais e municipais para que sejam elaboradas estratégias adequadas para essas áreas de fronteira.

Também, nesse arco, foi proposto superar os impactos da invasão nos padróes de ocupação territorial indígena e assumir esses povos como sujeitos sociais comprometidos com o presente e o futuro da Amazônia, firmando o dever de não mais permitir que se ignore a contribuição histórica dos povos indígenas para a construção socioambiental da regiáo e, principalmente, a importância fundamental desses povos para a consolidação de uma "nova" Amazônia como espaço plural de convivência, de diversidade étnica (Pêgo et al., 2018).

No arco Central, muitas propostas se orientaram para a valorizaçáo das comunidades fronteiriças, a partir das suas tradiçóes, seus costumes e sua cultura, construídas ao longo do tempo e da história dos países. É dessa forma que se propôs expandir e firmar os laços de amizade e de interculturalidade que unem os povos, ampliando o conhecimento da história do outro e de seus exemplos de resistência e desenvolvimento intercultural. Espera-se que esse tipo de ação possa auxiliar no enfrentamento dos preconceitos existentes contra os povos originários das Américas e dos indígenas, combatendo, inclusive, casos de xenofobia na fronteira.

Com o mesmo intuito, propôs-se aproximar os povos das fronteiras, ao se reafirmar o papel da educação no intercâmbio e na aproximação cultural e linguística dos países e etnias, tornando o idioma do país vizinho como segunda 
língua. Falar dessas comunidades é falar da informalidade que as cercam; sendo assim, discussóes se realizaram para que se tenha um olhar diferenciado e específico no âmbito das políticas públicas para as informalidades há muito tempo consolidadas, a exemplo das relaçóes do pequeno comércio realizado por pequenos produtores rurais ou da mão de obra boliviana informal em fazendas e espaços urbanos brasileiros (Pêgo et al., 2019; 2020a).

Participantes do arco Sul propuseram o fortalecimento de uma educação transfronteiriça, estimulando a cooperação e o entendimento dos povos da fronteira, muito além dos limites políticos, de forma a descortinar o que possuem de comum em suas culturas, histórias, costumes e vida cotidiana (Pêgo et al., 2020b).

\subsubsection{Movimentos migratórios}

A proposição de maior urgência é dar a importância necessária às diásporas e aos fluxos elevados de mobilidade que se verificam entre os países fronteiriços. $\mathrm{Ou}$ seja, priorizar os novos desafios: migraçóes e refugiados. Para tanto, propôs-se: garantir e proteger a dignidade humana dos migrantes transfronteiriços, ora em um contexto social com pouca representatividade e pouco poder; tomar medidas imediatas e eficazes em relação a esse fenômeno; e combater redes não oficiais de agenciamento de trabalho (redes que se valem da condição de indocumentados e apátridas), que levam à precarização da atividade, dada a ausência de política pública que garanta suporte adequado aos migrantes. É necessário, também, efetivar o acolhimento, a documentação e a inserção social; romper o silêncio, o medo, a vulnerabilidade e a condição de "irregularidade"; ampliar a cidadania para além do conceito da nacionalidade; criar territórios livres, lugares de convivência (não de passagem), assentamentos solidários; e, com isso, garantir direitos ao migrante destituído (Pêgo et al., 2017; 2018; 2019; 2020a; 2020b).

Nessa linha de preocupação, participantes do arco Norte recomendaram mostrar seriedade e efetividade com os impactos na regiáo decorrentes da atual diáspora da Venezuela, reconhecendo que a população brasileira anteriormente já foi acolhida por venezuelanos; desenvolver ações além da construção de abrigos e da interiorização dos imigrantes, para que se possa conter a expansão dos impactos migratórios em outras regiôes do país; fortalecer o diálogo com as organizações internacionais, que têm tido papel importante não somente na assistência humanitária, mas também na mediação internacional da crise na Venezuela, nos governos de países vizinhos; e ter ciência de que há elementos desse país que são estratégicos para garantir o futuro do estado de Roraima, como em relação à dependência da energia elétrica venezuelana. É importante destacar que a relação de Roraima com a Venezuela é muito diferente da do Brasil com esse país (Pêgo et al., 2018). 
No arco Central, recomendou-se maior atenção ao que pode ser considerada também uma diáspora boliviana para o Brasil, na busca por emprego. Para isso, propôs-se o fortalecimento das redes de trabalho e a atenção aos migrantes, sob o argumento de que, na presença de políticas públicas integradas e instituiçóes de defesa de direitos, a ilegalidade não tem espaço. Sugeriu-se implantar na região uma indústria têxtil para absorver essa mão de obra.

No âmbito dos serviços sociais, propóe-se criar mecanismos de controle da apropriação dessa mão de obra como trabalho escravo e de combate a coiotes e aliciadores que exploram a desinformação dos migrantes; implantar uma estrutura para orientação nos passos fronteiriços, viabilizando também espaços para o fortalecimento das instituições responsáveis pela orientação e a elaboração de documentos de identificação, de modo a evitar a clandestinidade, que dificulta a migração de retorno; construir um espaço unificado de assistência social para atender aos migrantes e a suas famílias; investir em unidades de acolhimento aos migrantes que tenham necessidade temporária de regularização de pendências migratórias; e ampliar o número de casas de migrantes nas cidades dos principais passos fronteiriços (Pêgo et al., 2019; 2020a).

No sentido oposto, criar também mecanismos de proteção aos brasileiros que migram para os países fronteiriços, auxiliando famílias em estado de pobreza extrema e indocumentadas. No caso dos presidiários, prestar apoio e combater a morosidade da justiça boliviana para com os presos brasileiros e atuar na situação de cárcere, entre outros.

No âmbito da diplomacia, há solicitação de atendimento consular nos municípios correspondentes às cidades gêmeas, como se verificou em San Matias (Pêgo et al., 2019).

Em relação à nova lei das migraçóes (Lei Federal no 13.445/2017), os participantes do arco Central argumentaram que não basta ter a lei aprovada, mas é necessário que as instituições que trabalham na segurança pública ou nas políticas públicas a conheçam e implementem as suas mudanças. Para tanto, propuseram: aplicar a lei e dar formação aos agentes que atuam nas políticas públicas e nos órgãos de segurança pública quanto aos seus novos dispositivos (Pêgo et al., 2019).

A mesma preocupação se verificou durante as atividades no arco Sul, onde se propôs assegurar que a regulamentação da lei das migraçóes preservasse os avanços obtidos e que ela não fosse desfigurada nesse processo; solicitar a definição do organismo de governo que será responsável pela condução das políticas migratórias; fazer que a instituição responsável pela coordenação da política assessore a Presidência da República, visando reduzir possíveis vetos presidenciais ligados aos povos indígenas e aos migrantes que se encontram em situação irregular; promover campanhas educativas e de esclarecimento sobre a necessária implementação da 
lei, de modo a reduzir possíveis resistências dos setores contrários à migração; e estar atento sobre possíveis atitudes mais agressivas, que irão requerer denúncia às autoridades policiais (Pêgo et al., 2020b).

\subsection{Meio ambiente}

\subsubsection{Recursos naturais e vulnerabilidade ambiental}

Foi enfatizada a necessidade de se considerar o fator ambiental em todas as definiçóes propostas, dado que a presença de ecossistemas fundamentais para a sustentabilidade ambiental necessita manter o equilíbrio e a preservação da biodiversidade. Também se sublinhou que políticas públicas que utilizam instrumentos diversificados de gestão ambiental (econômicos, regulatórios, de comando e controle, educacionais) possam se orientar, também, pelas diretrizes dos Objetivos de Desenvolvimento Sustentável - ODS 3 (Pêgo et al., 2017; 2018; 2019; 2020a; 2020b; Pêgo e Moura, 2018).

Proposição dos participantes do arco Norte é de que deve ser dedicada maior atençáo para temas ambientais, como desmatamento e queimadas, sem relegar a elaboração e a implantação de projetos de saneamento básico, resíduos sólidos e drenagem urbana, ao mesmo tempo que se reproduzam experiências como os arranjos transfronteiriços de conservação da natureza (Pêgo et al., 2018). Proposta do núcleo de fronteira do Amapá ressalta a importância, além da Amazônia, do monitoramento e gerenciamento costeiro integrado na FF da costa norte brasileira. Além disso, proposta do núcleo de fronteira do Pará localiza a questão da análise ambiental para a criação de assentamentos realizados pelo governo federal sem deixar de considerar o ponto de vista histórico da ocupação (Brasil, 2017).

Acrescem os participantes do arco Central que a gestão ambiental é um desafio que se impóe mais fortemente em regióes de fronteira, com a necessidade da gestão compartilhada das águas, de se trabalhar as cidades de forma que o gerenciamento de resíduos sólidos e o saneamento sejam compartilhados. É necessário promover fóruns e workshops para cultura de gestão ambiental, com objetivo de sensibilizar os ribeirinhos sobre a proteção de rio e matas pantaneiras; criar instrumentos para uma gestão ambiental unificada, como uma lei ambiental que abarque os dois lados da fronteira; criar e ampliar as perspectivas de sustentabilidade, com a ação de comitês temáticos, visando a novas condiçôes de empregabilidade geradas na região; e integrar e compatibilizar as políticas ambientais. Enfim, estabelecer as regras de convivência no ambiente fronteiriço (Pêgo et al., 2019).

3. Agenda 2030 das Nações Unidas para o Desenvolvimento Sustentável. São dezessete ODS: 1 - Erradicação da pobreza; 2 - Fome zero e agricultura sustentável; 3 - Saúde e bem-estar; 4 - Educação de qualidade; 5 - Igualdade de gênero; 6 - Água potável e saneamento; 7 - Energia limpa e acessível; 8 - Trabalho decente e crescimento econômico; 9 - Indústria, inovação e infraestrutura; 10 - Redução das desigualdades; 11 - Cidades e comunidades sustentáveis; 12 - Consumo e produção responsáveis; 13 - Ação contra a mudança global do clima; 14 - Vida na água; 15 - Vida terrestre; 16 - Paz, justiça e instituições eficazes; e 17 - Parcerias e meios de implementação. 
No âmbito da pesca, salientou-se também a necessidade de tornar compatível o período de defeso, pois as águas são compartilhadas, promover a preservação do peixe dourado, para atrair mais turistas na atividade de "pesca e solta", e garantir o monitoramento desse peixe (Pêgo et al., 2019).

No arco Sul, as propostas centraram na necessidade de investimentos e manutenção das reservas ambientais; na promoção de um calendário de visitaçôes locais às unidades de conservação; na implantação de sistemas de coleta e tratamento de esgoto; na obtenção de recursos para a construção de aterros sanitários, a serem executados por consórcios com outros municípios fronteiriços; e o mais urgente, em compatibilizar as legislaçóes entre os países da fronteira sobre pesca, período de piracema, proibição de determinados componentes agrotóxicos, entre outras (Pêgo et al., 2020b).

Ainda no arco Sul, participantes propuseram a criação do corredor biológico trinacional (Espinilho-BR/Rincón de Franquía-UY/General Ávalos-AR), de modo a incorporar nesse corredor a Reserva Biprovincial do rio Mocoretá-Chajari (Argentina), o Parque Natural Municipal da Formosa e o Cantão São Marcos (Uruguaiana). Para sua operacionalizaçáo, recomendaram capacitar guias locais e desenvolver um programa trinacional de educação ambiental (Pêgo et al., 2020b). A elaboração do ZEE da FF do Paraná integrado com o leste do Paraguai foi também uma proposta apresentada pelo núcleo de fronteira do Paraná (Brasil, 2017).

\subsubsection{Ação de organizações não governamentais}

No arco Norte, recomendou-se apoiar também os movimentos ambientais pela regularizaçáo fundiária, sobre a realidade rural da Amazônia, contra o esgotamento dos recursos naturais por usos predatórios e pela possibilidade de práticas de manejo responsáveis (Pêgo et al., 2018).

No arco Sul, foram propostos o fortalecimento do movimento em curso na tríplice fronteira Brasil, Uruguai e Argentina, a criação do comitê trinacional da bacia do rio Uruguai e a garantia de maior participação do Brasil, dado que, na atual Comissão Administradora do Rio Uruguai (Caru), o Brasil não tem assento, embora a maior parte da área da bacia esteja concentrada em território brasileiro (Pêgo et al., 2020b).

\subsection{Defesa e segurança}

\subsubsection{Concepções e interpretações}

Recomendou-se analisar os avanços e os desafios das principais experiências sobre segurança pública nos Estados Unidos, no México, na União Europeia, na China, na Rússia e na Índia, na busca de exemplos de ações que visem à aproximação 
entre agentes públicos e privados para a segurança do cidadão fronteiriço. Essas açóes, por meio da implementação de políticas públicas e operaçóes de segurança e defesa, viriam fortalecer as políticas de integração existentes (Pêgo et al., 2017).

Nas atividades entre os arcos, no arco Norte apontou-se a necessidade do fortalecimento dos procedimentos de segurança na FF (Pêgo et al., 2018). No arco Central, rever o trinômio de segurança, soberania e desenvolvimento, para que haja uma releitura dos conceitos e um reposicionamento, considerando o desenvolvimento como uma prioridade. De acordo com os participantes, apenas assim se criará um ambiente de segurança e soberania. Enfatizaram, também, que, sem desenvolvimento na fronteira, solicitar-se-á cada vez mais a ação das Forças Armadas, não sendo esta, necessariamente, a solução (Pêgo et al., 2019; 2020a).

No arco Sul, adicionaram a essas recomendações e reflexōes outras de ordem específica do espaço urbano, porém necessárias aos três arcos: estabelecer mecanismos seguros para que os bombeiros possam atuar nas cidades dos arranjos transfronteiriços, com marco legal próprio que assegure o cumprimento de suas açôes do ponto de vista institucional, material e humano; realizar açóes coordenadas de defesa civil, permitindo reciprocidade de atuação e colaboração entre cidades fronteiriças; e pôr em prática mecanismos e uniformizar procedimentos para fiscalização e controle de circulação de pessoas, principalmente crianças e adolescentes entre cidades da fronteira, a fim de evitar o tráfico, a exploração sexual, a prostituição e o trabalho infantil, inclusive com elaboração de materiais informativos para campanhas (Pêgo et al., 2020b).

\subsubsection{0 trânsito de ilícitos}

Diante do rol de problemas ligados ao trânsito de ilícitos pela fronteira, as proposiçōes trazidas pelos participantes do arco Sul atendem também às reivindicaçóes dos demais arcos: garantir maior segurança nas fronteiras, com a finalidade de inibir o tráfico de drogas, produtos e pessoas; investir em infraestrutura, que gerará desenvolvimento e progresso; implantar sistemas de videomonitoramento em pontos específicos da fronteira; articular, reaparelhar, garantir maior integração e cooperação entre os órgãos de segurança, imprescindivelmente onde há maior incidência desses crimes; viabilizar e estimular a troca de informaçóes entre os órgáos; entender a dinâmica dos ilícitos e realizar investimento maciço em tecnologias de controle; e estreitar diálogo com os outros países que eventualmente estão no processo de combate às drogas e ao tráfico de armas, com atuação não só na oferta, mas também na demanda (Pêgo et al., 2020b).

Ainda nesse arco, alertou-se que, no combate ao tráfico, é urgente resolver a pendência sobre a aplicação da lei segundo a qual veículo apreendido com drogas deve ser utilizado exclusivamente nas ações de combate às drogas. Embora a secretaria de segurança receba veículos argentinos apreendidos, o emplacamento é 
inviabilizado, pois a numeração do chassi argentino é incompatível com a exigida pelo Departamento de Trânsito (Detran) para autorizar que aquele veículo opere conforme a lei brasileira (Pêgo et al., 2020b).

Para contemplar a grande extensão do limite seco do arco Central, que traz maior vulnerabilidade à defesa e à segurança, recomendaram-se ações estratégicas de policiamento itinerante na FF e bloqueios policiais para fiscalização, com ação efetiva da inteligência local e órgãos superiores, que garantam resultados desarticuladores ao crime organizado. Pleiteou-se o desenvolvimento de um programa nacional e permanente de atuação das forças armadas e de segurança pública, de forma integrada na FF, em longo prazo, o que impactaria no imaginário popular, trazendo maior sensação de segurança, além de inibir tentativas criminosas na fronteira (Pêgo et al., 2019).

Adicionam os participantes do arco Norte que as políticas públicas devem promover açóes efetivas no combate e enfrentamento aos ilícitos na FF, tais como: realizar investimentos em infraestrutura de segurança (sistema informatizado, por exemplo), com implantação de sistema de vigilância 24 horas nas fronteiras, para veículos e passageiros; manter a presença dos órgãos estaduais e federais de vigilância sanitária; desenvolver açóes operacionais conjuntas de bloqueio e fiscalização; compartilhar informaçôes entre as forças que atuam na região de fronteira; adotar tecnologias para suporte aos profissionais da segurança pública; agilizar os processos judiciais para os crimes de maior potencial ofensivo; e criar um programa de integração entre naçóes fronteiriças (Pêgo et al., 2018).

\subsubsection{Controle e fiscalização}

As proposiçóes colhidas no arco Central se voltam aos três arcos generalizadamente: criar um policiamento especializado de fronteira em todos os estados fronteiriços; manter um programa nacional e permanente de atuaçáo das Forças Armadas e de segurança pública, de forma integrada na FF, de modo a inibir tentativas criminosas na fronteira; discutir com a presença do município a segurança pública na área de fronteira; dotar os municípios da fronteira de uma estrutura diferenciada para trabalhar a segurança pública cidadã, para torná-los mais próximos da população; compatibilizar a coincidência territorial entre o Brasil, o Paraguai e a Bolívia para acompanhamento dos fatos e da criminalidade; adequar a infraestrutura alfandegária visando à integração das atividades de controle fronteiriço a serem realizadas em conjunto com os países vizinhos; operacionalizar as açóes de segurança de forma integrada entre os países e suas unidades fronteiriças; e garantir a presença dos demais órgãos fiscalizadores na regiāo de fronteira (Pêgo et al., 2018; 2019; 2020b). Complementam os participantes do arco Sul quanto à necessidade de ampliar a fiscalização e o controle, incluindo fiscalizar portos e contêineres lacrados. É preciso aumentar a amostra de contêineres fiscalizados (Pêgo et al., 2020b). 
Também cabem aos demais arcos as proposiçóes do arco Norte quanto ao aumento do efetivo de servidores (Polícia Rodoviária Federal - PRF, PF, polícias Militar - PM e Civil - PC, RFB e Vigilância Sanitária), para abertura dos postos de controle fronteiriço por 24 horas, e quanto a criar remuneraçáo adicional de fronteira, além de oferecer capacitação bilíngue aos policiais e demais agentes da área de fronteira (Pêgo et al., 2018). Reiteram os participantes do arco Central que esse efetivo deve ser de fato compensado por estar sujeito aos problemas diários dos ilícitos, como o tráfico de drogas, posto que atualmente esse efetivo recebe salários iguais aos dos servidores do centro ou de pequenos municípios. Além dessa compensação, buscar formas de impedir muita rotatividade de servidores na fronteira. Postulam que é necessário somar o poder de força: "a falta de segurança pública é o principal sintoma de adoecimento de uma fronteira” e demanda açôes conjuntas entre Marinha, Exército e Aeronáutica, como também entre os países fronteiriços (Pêgo et al., 2019).

Propóem, ainda, que se reforce a presença de unidades especializadas na fronteira, com efetivo integrado ao cotidiano fronteiriço, com vivência em sua realidade. Reconhecem que esse é o grande segredo de sucesso do Grupo Especial de Fronteira (Gefron) de Mato Grosso, por exemplo. O policial conhece o que se produz nas regióes produtivas, participa de todo o cotidiano da fronteira e começa a se relacionar com as pessoas ali presentes. Daí, toda abordagem é uma conversa, um diálogo, uma verificação, com troca de informaçóes. E quanto mais antigo o policial, maior a capacidade de identificar os pontos mais críticos, o que o leva a maiores acertos na fiscalização e nas apreensôes. A experiência da convivência torna tudo muito simples, afirmam (Pêgo et al., 2019).

Também foi destacada a importância da convivência cotidiana entre forças de fiscalização, controle e população. No arco Sul, foi proposto que seja reinstalada uma guarnição permanente de fronteira, como havia a dos Fuzileiros Navais, pois traria mais tranquilidade ao fronteiriço, bem como evitaria o tráfico e o contrabando de armamentos (informam que há estrutura para isso) para atuar na região de Barra do Quaraí, podendo combater, também, o abigeato (Pêgo et al., 2020b).

Sobre a questão ambiental, necessidade destacada no arco Central é a criação de um posto do Instituto Brasileiro do Meio Ambiente e dos Recursos Naturais Renováveis (Ibama) no controle fronteiriço da região de Cáceres, para despachos e liberação dos produtos de sua competência, além de controle ambiental, pois todos os trâmites atuais são realizados em Cuiabá. Mais que isso, é fundamental aproximar os postos da RFB, do Instituto de Defesa Agropecuária de Mato Grosso (Indea), da PF e da Polícia de Fronteira do controle fronteiriço, assim como instalar no local agência do Banco do Brasil (BB), com oferta de serviço cambial. É necessário, ainda, suprir a ausência de consulados do Brasil na região (Pêgo et al., 2020a). 
Especificamente em relação ao Sistema Integrado de Monitoramento de Fronteiras (Sisfron), nas atividades gerais, postulou-se que é urgente superar as indefiniçôes no ritmo da implementação desse sistema. O espaço fronteiriço exige, cada vez mais, a presença de um maior contingente do Estado na região, para inibir e controlar os crimes transfronteiriços; a capacidade de enfrentamento dos crimes ambientais e controle mais sistemático do volume de produtos ilegais que atravessam o limite internacional e que, comumente, vão circular nos grandes centros urbanos brasileiros; além de investimentos em tecnologia de ponta, pois, dados os sucessivos contingenciamentos de recursos, as alternativas propostas poderão estar defasadas quando o projeto for totalmente implantado (Pêgo et al., 2017; Pêgo e Moura, 2018).

Reforçam essa recomendação os participantes do arco Central, que alegam que a disponibilidade desses equipamentos de vigilância é uma necessidade operacional, sejam câmeras de monitoramento, sejam rádios comunicadores para as equipes de serviço e drones, que são alguns exemplos de auxílio tecnológico fundamentais para o enfrentamento de ilícitos na fronteira. O projeto-piloto do Sisfron se encontra ainda em fase de testes e diagnósticos de materiais no âmbito do Comando Militar do Oeste $(\mathrm{CMO})$ e se estende às regióes de fronteira de Mato Grosso do Sul, Mato Grosso e Rondônia (Pêgo et al., 2019).

\subsection{Arranjos transfronteiriços}

\subsubsection{Cidades da fronteira e rede urbana}

O comportamento recente da rede urbana brasileira e as tendências apresentadas sinalizam a necessidade de políticas regionais específicas à condição fronteiriça. A elevada densidade de centros na FF do arco Sul, contrapondo-se à rarefação presente nos demais arcos, aponta, por um lado, presença diferenciada de meios de comunicação e, por outro, necessidade de reforço do sistema existente para que garanta acesso à oferta centralizada de bens e serviços de maior qualificação e especialidade. Mesma atenção particular deve ser dada à problemática gerada pela demarcação de terras indígenas e às exigências diferenciadas de seus povos, assim como à gestão ambiental das extensas porçôes fronteiriças (Pêgo et al., 2017; Pêgo e Moura, 2018).

Sob a ótica regional, os participantes do arco Sul propõem a construção de um plano estratégico de desenvolvimento integrado para as zonas de fronteira (bi e trinacional). Mostram que é imprescindível formar equipes interdisciplinares para a construção desse plano de desenvolvimento e sugerem que esse plano seja elaborado respeitando e abrindo espaços para participação por arco, por arranjos transfronteiriços, em consórcios etc. Recomendam que as universidades dos estados e também as dos países vizinhos se articulem para a execução desse plano de 
desenvolvimento integrado e que nele haja a superação do limite e divisa entre os países no lugar onde as pessoas vivem. Salientam a necessidade de que as universidades tragam mais contribuiçóes para as cidades da fronteira, que olhem com mais atenção a região e contribuam com seu desenvolvimento (Pêgo et al., 2020b).

No âmbito urbano, é preciso realizar mais estudos para entender a conformação dos arranjos transfronteiriços, as articulaçôes internas e entre eles, bem como deles para com a rede de cidades. Nesses estudos, os participantes, de modo geral, pediram que se dedicasse maior cuidado na identificação de novos arranjos e na aprovação da criação de potenciais cidades gêmeas (Pêgo et al., 2017; Pêgo e Moura, 2018). Recomendaram os participantes do arco Norte que as cidades fronteiriças fossem categorizadas de acordo com seus fluxos, usos de serviços etc., para a gestão e o planejamento de políticas públicas (Pêgo et al., 2018).

Reclamaram os participantes do arco Central que o estado de Mato Grosso não tinha algum município no rol das cidades gêmeas formalizadas, embora Cáceres, em sua relaçâo com San Matías (Bolívia), cumprisse os requisitos para isso. Essa observação foi considerada, e, a partir de estudo específico do Ipea e integrado a esta pesquisa, Cáceres, em sua interação com San Matías, já foi instituída como cidade gêmea. ${ }^{4}$ A criação de uma cidade gêmea ajuda a estreitar mais os laços de integração e a colocar mais foco na questão social transfronteiriça - e, como salientaram os participantes, as soluçóes estão no econômico e social, antes de chegar ao ponto da atuação policial. Além disso, a cidade gêmea favorece os acordos já existentes de saúde animal, subsidia novos acordos e rompe burocracias da fiscalização, visitas internacionais, autorizações etc. - a bovinocultura boliviana já está integrada, mas o trânsito de animais é proibido (Pêgo et al., 2020a).

Pontuou-se, nos debates gerais, a necessidade de conhecer melhor as ligaçóes desses arranjos para fora do Brasil. Uma grande alternativa seria provocar uma mudança cultural e de gestão no método da aplicação dos investimentos e na definição de pautas e agendas. As experiências dessas configuraçóes transfronteiriças devem ser utilizadas como paradigmas de um processo crescente de integração, na medida em que, na prática, já ocorre interação. Nesses debates, concluiu-se com a afirmação inconteste de que a fronteira e os arranjos transfronteiriços são o caminho para a integração sul-americana (Pêgo et al., 2017; Pêgo e Moura, 2018).

Em se tratando da rede urbana, nas atividades gerais, apontou-se que, além dos arranjos transfronteiriços, é necessário pesquisar também a importância das "cidades conectoras" nas relaçôes fronteiriças, sobre o tecido contínuo de relações que se constroem a partir da localização de empresas, atividades agropecuárias e mineração. É fundamental que se identifiquem os aspectos particulares das

4. Portaria MDR no 1.080, de 24 de abril de 2019, publicada no Diário Oficial da União (DOU) de 29 de abril de 2019. Cáceres (Mato Grosso) passou a ser a 33a cidade gêmea brasileira. 
interligações e articulações entre cidades dos países do continente, distinguindo as cidades que possuem articulação das que não a possuem. É essencial observar as diferenças internas aos arcos, sem perder de vista a importância das articulaçóes das redes urbanas por meio dessas cidades conectoras em escala continental, e considerar as especificidades das localidades e cidades situadas próximas da fronteira ou diretamente na fronteira. O grande desafio está em juntar rede urbana e fronteira, em mesclar esse olhar para dentro (pensando uma rede urbana nacional) com o olhar para fora (para a rede urbana continental), sem perder de vista a dimensão fronteiriça. Enfim, é preciso pensar a cidade, sobretudo aquelas cidades e localidades menores, integradas ao seu mundo rural, porque boa parte da fronteira brasileira está em extensas regióes rurais, de florestas (Pêgo et al., 2017; Pêgo e Moura, 2018).

Para se pensar nas cidades amazônicas, por exemplo, deve-se observar uma tríade de encontros: das cidades, da floresta e da fronteira. E, assim, debater sobre as especificidades das cidades de fronteira, assumindo um caráter mais geopolítico na definição dos recortes de análise, planejamento e gestão, o que poderia, inclusive, orientar melhor a definição dos "arcos", como sugerem os participantes do arco Norte (Pêgo et al., 2018).

Como ideia síntese, propôs-se estimular o surgimento de políticas de Estado para o território que assimilem as perspectivas regional e urbana em suas mutaçóes e que integrem o ordenamento territorial e as políticas de desenvolvimento urbano e regional. Isso demanda enfrentar teórica e empiricamente um novo cenário urbano que confronta as práticas cotidianas para a governança e a formulação de políticas, posto que transpassa as várias escalas federativas, inclusive a internacional, e não contempla uma concepção efetiva de integração territorial (Pêgo et al., 2017; Pêgo e Moura, 2018).

\subsubsection{A gestão nos arranjos transfronteiriços}

Um rol de importantes sugestóes foi sendo construído entre os participantes das atividades gerais, com o objetivo de favorecer a interação e facilitar o cotidiano das pessoas que se movem nessas áreas urbanas transfronteiriças: desburocratizar o atendimento às populações dos diferentes países; facilitar o controle de acesso de estrangeiros aos serviços de saúde, educação, segurança e transporte público (oferta/ consumo); aprovar currículos escolares ou desobrigar traduções juramentadas para fins cotidianos; reduzir a hiperdocumentaçáo; viabilizar a carteira transfronteiriça e unificar suas condiçóes de acesso e de uso (por exemplo, é gratuita para brasileiro no Uruguai, já no Brasil, o mesmo documento é cobrado do cidadão uruguaio fronteiriço); efetivar os free shops; controlar as relaçóes não oficiais; garantir recursos e infraestrutura para fiscalização alfandegária; combater a criminalidade; e promover uma mudança cultural para que efetivamente se procedam as mudanças necessárias (Pêgo et al., 2017; 2018; 2019; 2020a; 2020b; Pêgo e Moura, 2018). 
Acrescem os participantes das atividades no arco Norte a necessidade de aproximar os órgãos de planejamento e administração das cidades vizinhas da linha de fronteira para atuação compartilhada, como adoção de medidas, agendas e campanhas conjuntas de mobilização social, vacinação, educação no trânsito, violência doméstica, desastres naturais, assim como a realização de eventos cívicos. $\mathrm{E}$, acima de tudo, viabilizar uma estrutura-base para a geração de emprego e renda nas cidades de ambos os países (Pêgo et al., 2018).

No âmbito da gestâo municipal, em todos os arcos, enfatizou-se a potencialidade dos consórcios intermunicipais e internacionais, que explorem as possibilidades de açóes comuns e a realização de acordos entre os poderes Executivos e Legislativos, para: consolidar serviços qualificados em saúde, educação, mobilidade, turismo, combate à criminalidade; formular programas de investimentos comuns; criar sistemas de informaçóes e aperfeiçoar as tecnologias de informaçóes; e ampliar a oferta de serviços como saneamento básico, serviços sociais e transportes urbanos. Mas se alertou que esses consórcios devem estar articulados a programas regionais, pois só assim não fragmentam ou duplicam políticas e programas e podem criar possibilidades de melhor uso dos recursos existentes.

Além deles, sugeriu-se buscar alternativas internacionais de recursos, como, por exemplo, na agência espanhola de desenvolvimento, que tem cooperado nos países vizinhos, como também assegurar a atenção do estado, capital e redes sociais. Assim, organizar as oportunidades, as possibilidades e as potencialidades para otimizar seus resultados. Recomenda-se, também, administrar a dualidade entre políticas internacionais e políticas locais, particularmente nos arranjos transfronteiriços; compreender o local binacional, que é onde as questôes devem ser resolvidas; realizar acordos bi, tri nacionais, mas dar a eles continuidade; e simplificar os processos de cooperação entre os estados e os municípios fronteiriços e seus homólogos vizinhos (Pêgo et al., 2017; 2018; 2019; 2020a; 2020b; Pêgo e Moura, 2018).

Participantes no arco Norte reiteraram que é imperativo melhorar a oferta de equipamentos e serviços (saúde, educação, cultura e mobilidade); firmar acordos e oferecer facilidades para a mobilidade, de forma que o cidadáo fronteiriço possa utilizar os serviços oferecidos nas cidades de fronteira; e combater a desigualdade social. Deve-se considerar a assimetria entre os países, o que exige açóes que tenham como objetivo o desenvolvimento concomitante dos dois lados da fronteira, pois a fronteira se trata de um ponto de conexão, e não de separação. Sobre o caso de Pacaraima (Roraima), foi unânime a recomendação da urgência quanto a regularizar a situação fundiária do município que se encontra em uma área indígena, com status jurídico indefinido. Da mesma forma, o quanto é urgente viabilizar o documento de identidade fronteiriça, visando facilitar a circulação de pessoas, a realizaçáo de negócios e o desenvolvimento de atividades (Pêgo et al., 2018). 
Reforçaram os participantes do arco Sul a importância da gestão integrada do território, por meio de consórcios públicos internacionais, e demandaram: garantir maior atuação dos comitês de fronteira; criar comitês binacionais setoriais (com caráter consultivo, propositivo); compor um comitê trinacional para o Eixo Austral que seja paritário e de representação paradiplomática; criar uma comissão permanente das cidades da fronteira, que se reúna sistematicamente para discutir ações integradas dos governos e da sociedade civil; ampliar os meios formais de discussão e participação das comunidades; definir uma agenda de formação, capacitação de lideranças regionais da FF, com a participação dos governos e atores locais; constituir fóruns consultivos e deliberativos por meio da representatividade dos três setores da zona fronteiriça integrada; encaminhar e colocar em prática as propostas extraídas em reunióes de fronteira; e reconhecer os encaminhamentos das decisóes das reunióes locais, bi e trinacionais.

Pleitearam que a gestão cooperada entre as cidades dos arranjos transfronteiriços reconheça laços de fraternidade e valorize o patrimônio tangível e intangível como elemento integrador da identidade cultural local; estabeleça cooperação horizontal para o fortalecimento institucional e a articulação vertical com os diferentes níveis de governo dos países; incorpore a resiliência como fator estratégico de desenvolvimento e considere efetivamente a realidade fronteiriça no planejamento e gestão integrada de políticas públicas. Em adendo, muito se discutiu sobre a importância de que se criem mecanismos para intercambiar experiências, práticas e inovaçôes (Pêgo et al., 2020b).

Ao MDR os participantes do arco Norte recomendaram criar uma plataforma no site da instituição e/ou no site do Ipea com as questóes trabalhadas pelos grupos temáticos nos eventos realizados e previstos pelo projeto Fronteiras do Brasil, para que os atores que não puderam estar presentes pudessem tomar conhecimento dos resultados e se manifestar, validando ainda mais o conteúdo dos trabalhos. Essa plataforma deveria, ainda, permitir a entrada para proposiçóes, relatos de experiências, acesso a arquivos, bem como resgatar as propostas aprovadas em eventos anteriores (Pêgo et al., 2018).

\subsubsection{Mobilidade transfronteiriça}

Deve ser considerada e priorizada a demanda por meios de mobilidade transfronteiriça, assim como é desejável que sejam observados os serviços de saúde e educação, viabilizados por essa mobilidade, quando implementadas obras de infraestrutura relacionadas aos deslocamentos cotidianos da população e à sua acessibilidade (Pêgo et al., 2017; Pêgo e Moura, 2018).

Na escala dos arranjos transfronteiriços do arco Norte, são necessárias a criação de linhas regulares de transporte público (com tarifas urbanas, locais) e a integração de tarifas locais de telefonia e postagem nas cidades dos arranjos transfronteiriços. 
Como alternativa ao custo elevado de taxas aeroportuárias, propôe-se a criação de uma taxa de embarque e desembarque diferenciada nos aeroportos localizados nas regióes de fronteira, como também a realização de voos entre si, para que a mobilidade na região seja facilitada. Assim, otimizar-se-ia a oferta de alguns serviços que facilitariam a integração entre os países (Pêgo et al., 2018).

Preocupados com as diferenças de atenção encontradas nos países limítrofes, participantes do arco Sul recomendaram criar condiçôes de igualdade quanto à acessibilidade de pessoas com necessidades especiais entre cidades dos países vizinhos, assim como implementar medidas de acessibilidade nas cidades da FF brasileira, ainda relegadas (Pêgo et al., 2020b).

\subsection{Integração e desenvolvimento}

\subsubsection{A integração na prática}

Entre as proposições de cunho geral, a principal é inserir a integração na agenda prioritária dos governos, para consolidar novas formas de cooperaçáo e desenvolvimento nas regiōes de fronteira. Em decorrência dessa ação, formular políticas de coesão e convergência, e não apenas de integração, além de elaborar novas políticas de integração e dar continuidade às políticas de cooperação em desenvolvimento, introduzindo perspectivas temporais maiores e mais estáveis (Pêgo et al., 2017; Pêgo e Moura, 2018).

$\mathrm{Na}$ agenda sobre iniciativas de integração do subcontinente, deve-se considerar não só a circulação das mercadorias e os fluxos de produção, mas também as condiçóes de vida e de habitat em ambos os lados da fronteira, envolvidas no movimento geral de urbanizaçáo, articulado com feiçóes e práticas diversas por centralidades de diferentes portes. O desafio dessa agenda é buscar a integração dos países vizinhos nestas iniciativas, com planos e instrumentos de planejamento e desenvolvimento. Maior ainda o desafio de se construir, dentro do processo de integração, a noção de uma supranacionalidade (nos moldes da Uniâo Europeia), que garanta resultados concretos a estes tipos de acordo (Pêgo et al., 2017; Pêgo e Moura, 2018).

No âmbito do governo federal brasileiro, deve-se definir o locus para condução da estratégia de articulação intragoverno e com países vizinhos; promover a criação e/ou o fortalecimento de parcerias entre instituiçóes subnacionais dos países limítrofes para açóes coordenadas entre os municípios, departamentos e províncias; e assegurar a operacionalidade da articulação entre planos bilateral, nacional e regional, que de antemão sabe-se que é complexa, portanto, não necessariamente imediata (Pêgo et al., 2017; Pêgo e Moura, 2018). 
As instituições multilaterais podem ser utilizadas como meio de articulação política de integração às iniciativas dos governos subnacionais. Instituiçóes multilaterais e blocos comerciais podem contribuir na interlocução para açóes que priorizem as demandas das regiôes fronteiriças, na governança e na institucionalização de fóruns de diálogo e trocas de experiência para integração e desenvolvimento coordenado. Com essa compreensão, propóe-se que seja ativada a proposta de acordo fronteiriço que está em discussão no Mercosul e que, cada vez mais, coloque-se o tema "integração fronteiriça" na agenda prioritária de negociação desse bloco regional.

Essa proposta de acordo fronteiriço em discussão no âmbito desse bloco vem sendo colocada ao longo de várias reunióes e trata de circunstâncias subnacionais, desenvolvimento subnacional, municípios, estados etc. Em relação a ela, havia uma grande solicitação. Reforça-se, portanto, a importância de se levar este debate a uma instância integradora e coordenadora supranacional (Mercosul), em um paralelo à União Europeia, para que essa instância assuma uma proposta de regulamento sobre cooperação territorial (Pêgo et al., 2017; Pêgo e Moura, 2018).

Um grande desafio apontado pelos participantes do arco Norte foi o de estabelecer uma agenda de gestáo interfederativa para a resoluçáo das questôes das fronteiras brasileiras. Para dar concretude a essa agenda, deve-se: criar instituições conjuntas e mecanismos binacionais que abarquem o nível binacional e o de interagências, à semelhança do que tem sido feito no caso da segurança; executar a paradiplomacia subnacional e interagências; ampliar a participação dos parlamentares dos estados fronteiriços nas demandas específicas e qualificadas para a FF; e ampliar os protocolos comuns entre os órgãos de fronteira (Pêgo et al., 2018).

Sugeriram, ainda, construir um sistema de governança transfronteiriça, com participação do setor público, privado, sociedade civil e setor produtivo, como os consórcios municipais transfronteiriços, ativando e fortalecendo as instituiçóes existentes. Porém, sem desconsiderar a retomada e a atualização da estrutura já montada: Comissão Permanente para o Desenvolvimento e Integração da Faixa de Fronteira; Fórum Nacional de Secretários e Gestores Municipais de Relaçóes Internacionais; Fórum de Governadores da Amazônia Legal; Fórum de Relaçôes Internacionais; Comissóes de Vizinhança (âmbito binacional); e Fórum do Mercosul. Em todos os casos, institucionalizar essas relações, com transparência e participação efetiva, o que exige garantir reciprocidade entre os entes binacionais no caso das políticas públicas de fronteira; maior envolvimento dos estados e da sociedade nas discussóes e decisóes relativas às fronteiras; e incentivo a iniciativas locais para realização de eventos de integração social, carentes do apoio do Estado (Pêgo et al., 2018).

Sobre normas e procedimentos, recomendaram harmonizar a legislação nas áreas de transporte de mercadorias e pessoas e de fiscalização sanitária e fitossanitária da FF. Para tal, propóe-se: ampliar o sistema de pagamento em moeda local 
para os países vizinhos no âmbito do Mercosul, no mesmo modelo do convênio celebrado entre Brasil e Argentina; diminuir e unificar barreiras não tarifárias no âmbito do Mercosul; revisar o Acordo de Transporte Rodoviário Internacional de Passageiros e Cargas entre Brasil e Venezuela (Decreto nํㅜ 975, de 1을 de março de 1999); obter sansão de emenda do anexo II do Acordo de Transporte Rodoviário Internacional de Passageiros e Cargas entre Brasil e Guiana; e gestionar para que a RFB normatize o Acordo de Alcance Parcial de Complementação Econômica no 38, entre Brasil e Guiana (Pêgo et al., 2018).

No arco Central, propôs-se disseminar a cooperação interagências, nos níveis federal e estaduais, no combate aos ilícitos transfronteiriços. Os participantes asseveraram que os meios de regulação e mecanismos institucionais interfederativos e de cooperação internacional precisam levar em consideração as particularidades de cada fronteira. É, também, fundamental integrar a Bolívia ao Mercosul, atualizar e voltar a pôr em vigência o Tratado de Roboré, para dinamizar a economia regional, como também promover e realizar eventos nas cidades fronteiriças, como rodada de negócios, seminários e açóes de cidadania com objetivo de promover essas cidades. Mais que tudo, transformar as questôes de fronteira e da integração nacional em uma questão federativa, reforçando a proposta de integração, que exigirá um processo de formalização daquilo que atualmente é funcional - quase ilegal (Pêgo et al., 2019).

Para o arco Sul, deve-se acelerar a implementação do compromisso celebrado entre os presidentes do Brasil e da Argentina, expresso na Declaração Conjunta firmada em 7 de fevereiro de 2017, em Brasília, com temas como: facilitação do comércio; cooperação regulatória; negociações externas do Mercosul; investimentos e contratações públicas; fortalecimento comercial e econômico do Mercosul; promoçáo comercial conjunta; defesa comercial; transporte aéreo; integração da infraestrutura física; agricultura; combate ao narcotráfico; cooperação para a segurança das fronteiras; cooperação em matéria nuclear e espacial; cooperação em telecomunicações; cooperação jurídica; e integração e cooperação consular. Há, também, a Carta de Corrientes (II Encontro de Governadores BR-AR), que destaca temas da mais alta prioridade para os governos regionais fronteiriços e circunvizinhos (Pêgo et al., 2020b).

Diversos acordos bilaterais Brasil-Argentina e Brasil-Uruguai precisam ser implementados, com a adoção de medidas de equivalência (desburocratizadas), sobretudo em relação à circulação de pessoas, aos serviços e à integração comunitária. É preciso ainda: adequar a legislação nacional dos países fronteiriços, incluindo propostas para a FF; viabilizar o desenvolvimento fronteiriço; além de facultar a celebraçáo de termos, acordos e contratos de mútua cooperação entre governos locais e provinciais. Entre esses, agilizar a implementação do Acordo de Localidades Fronteiriças Vinculadas (Tratado de Puerto Iguazú, de 30 de novembro de 
2005), que atende a muitos dos interesses das cidades gêmeas; permitir acordos de reciprocidade e mútua convivência entre cidades e municipalidades fronteiriças em espaço contíguo; celebrar acordos internacionais que visem à dupla cidadania e ao atendimentos aos cidadãos (Brasil/países da fronteira) em todos os aspectos (saúde, educação, assistência etc.), além do livre comércio, principalmente nas cidades gêmeas. Alguns fóruns poderiam abrir maior espaço para a celebração de acordos internacionais, como ocorre com o Parlamento do Mercosul (Parlasul), que reúne parlamentares, mas carece ainda de maior objetividade em sua atuação e em informar com mais transparência como está funcionando (Pêgo et al., 2020b).

No âmbito da articulação internacional, foi proposto também que houvesse uma contrapartida aos empréstimos concedidos e aos serviços prestados por parte da municipalidade brasileira, que encontra obstáculos legais e aduaneiros para ressarcimentos. No caso do atendimento em saúde, assegurar integraçáo entre os sistemas e reciprocidade do lado argentino e do lado uruguaio (Pêgo et al., 2020b).

Alguns exemplos foram destacados pelos participantes do arco Sul, por materializarem a integração transfronteiriça, como: o Parque Turístico Ambiental da Integração, entre Barracão-Dionísio Cerqueira-Bernardo de Irigoyen (Argentina), no qual há um percurso para caminhada com trilhas que dão voltas, entrando e saindo do Brasil e da Argentina; ou o Parque Internacional, na fronteira do Brasil com o Uruguai, em Rivera-Livramento, no qual aconteceu, em agosto de 2018, o Encontro Binacional de Gastronomia, com o almoço servido em uma imensa mesa sobre a linha de fronteira e cinco pratos representativos da gastronomia da cadeia produtiva de carnes na regiáo (Pêgo et al., 2020b).

\subsubsection{Integração e cooperação no trato de serviços na fronteira}

Com apoio de todos os arcos, propôs-se que fossem atendidos os requisitos básicos para um adequado exercício de coordenação federal: i) melhorar a definição dos papéis de estados e municípios no processo de formulação, pactuação e execução de projetos; ii) apoiar estados e municípios na formulação de projetos; iii) aprimorar a legislação relacionada à cooperação internacional e à cooperação territorial, com vistas a prover segurança jurídica às unidades subnacionais em açóes relacionadas à suas competências; e iv) avançar nas negociações internacionais com o Mercosul, para alinhar as políticas de fronteira com as dos países vizinhos (Pêgo et al., 2018; 2019; 2020b).

Como sugestão para eliminar os obstáculos à cooperação territorial, apontou-se a necessidade de criar um instrumento de cooperação em âmbito comunitário, dotado de personalidade jurídica, a exemplo dos Agrupamentos Europeus de Cooperação Territorial (Aect), da União Europeia. Advertiu-se que a questão 
internacional deveria estar subordinada ao território, pois este é o foco, e não a questão internacional. Recomendou-se valer-se das oportunidades internacionais para manter o tema na centralidade das agendas, como o uso da Agenda 2030, para reunir demandas das fronteiras, no contexto de um quadro mais geral, internacional, contemplando a realização de programas de formação local e regional e de assistência técnica articulada para a sua implementaçáo, assim como para o alcance dos ODS (Pêgo et al., 2017; Pêgo e Moura, 2018).

Desafios urgentes são atualizar a Lei no 6.634/1979 - que regula algumas atividades sensíveis e estratégicas realizadas na FF - e a Lei no $10.683 / 2003$ - que dispóe sobre a organização da Presidência da República e dos ministérios e atribui ao MDR a competência para realizar obras públicas na FF, com vistas a promover o desenvolvimento da região e simplificar os processos de cooperação entre os estados e os municípios fronteiriços e seus homólogos vizinhos. É necessário o reconhecimento da cooperação transfronteiriça como distinta da cooperação internacional técnica convencional, devido ao forte caráter territorial da primeira. Essa cooperação transfronteiriça precisa ser disseminada e reconhecida no contexto de uma legislação revista, que incentive esse tipo de cooperação. Os consórcios fronteiriços são a porta de entrada para o debate sobre a "cooperação transfronteiriça" com os principais atores locais e federais, com o intuito de formalizá-la e impulsioná-la (Pêgo et al., 2017; Pêgo e Moura, 2018).

Os participantes das atividades gerais reivindicaram a construção de um banco de dados estatísticos sul-americano, para cobrir uma lacuna que cria uma situação de emergência, pela sua importância estratégica na definição de políticas territoriais. Tendo em conta que produzir a informação estatística é uma atribuição de Estado, consideraram que a constituição e a gerência desse órgão de estatística caberia à então União das Naçóes Sul-Americanas - Unasul (Pêgo et al., 2017).

Participantes do arco Norte enfatizaram a importância da implementação do programa de desenvolvimento da Secretaria de Planejamento e Desenvolvimento do Estado de Roraima (Seplan), que se volta a integrar o estado à Comunidade do Caribe, e visualiza uma região geoeconômica para atender às demandas e, também, para receber produtos e serviços do Brasil, da Guiana e da Venezuela (Pêgo et al., 2018).

Os participantes do arco Central apontaram que os governos da Bolívia e do Brasil precisam trabalhar mais intensamente e com agilidade no processo de integração. O Ministério das Relaçôes Exteriores (MRE) deve promover reuniôes bilaterais, para resolver problemas que deixam os povos em uma situação difícil, "por conta de um governo que não investe em sua fronteira". A Bolívia deve fazer parte do Mercosul, para garantir que o que se combina nos acordos tratados tenha continuidade. Essa atitude seria imprescindível para conter as 
dificuldades do povo que mora nessa fronteira, que já não apresenta índices de pobreza, mas índices de miséria. É preciso montar comitês fronteiriços no Brasil e na Bolívia para que discutam o que é melhor para as pessoas da região, e não apenas o que é melhor aos acordos que são tratados em âmbito federal (Pêgo et al., 2019).

Entre as propostas mais específicas do arco Sul, destacam-se: i) efetivar o sistema de identificação unificada e implementar a identidade unificada do Mercosul para cidadão fronteiriço; ii) simplificar trâmites de validação de certificados; iii) criar possibilidade de um registro especial para atuação de médicos do país vizinho em municípios da linha de fronteira e nas cidades gêmeas, nos moldes do programa Mais Médicos; iv) resolver o impedimento de registros de nascidos vivos em outros países, para evitar sub-registros nas estatísticas nacionais e garantir o direito à naturalidade brasileira ao nascido e os direitos trabalhistas a mães e pais; v) facilitar os trâmites para o traslado de corpos entre as cidades fronteiriças; vi) validar a carteira de motorista brasileira como documento para passar ao lado argentino da fronteira; vii) unificar a legislação em relação ao rio Uruguai; e viii) criar uma carteira na área de navegação no rio Uruguai, como a carteira que existe com da Argentina (Pêgo et al., 2020b).

Por fim, sugeriram prosseguir a discussão para melhoria do Estatuto da Fronteira como marco regulatório para o desenvolvimento regional e a integração com os países limítrofes; implementar esse estatuto, possibilitando a negociaçáo entre as díades para articulação e financiamento das necessidades locais em um processo descentralizado; e dar maior visibilidade aos processos de integração (Pêgo et al., 2020b).

\section{SUBSÍDIOS PARA UMA AGENDA DE PESQUISAS SOBRE FRONTEIRAS}

\subsection{Recomendações para uma agenda geral}

A fronteira tem um caráter diferenciado, pois seus problemas locais, mesmo de competência municipal, ganham dimensão internacional. Com isso, não se deve estudar a fronteira abordando apenas um dos lados, pois esse viés obscurece os processos que se dáo com a correspondência do outro lado, peculiares às regiôes marcadas pela condição fronteiriça. Uma contribuição que vai além do reconhecimento desse caráter diferenciado seria desenvolver o conceito de "cooperação transfronteiriça”, conceito ainda não consolidado nem reconhecido oficialmente (Pêgo et al., 2017).

A compreensão sobre a existência de "várias fronteiras" remete a novas concepções e novos conceitos sobre o tema, que começam pela adequação conceitual, de informaçóes e instrumentos de análise, formulação de políticas, programas 
e projetos, assim como mecanismos de gestão em função das práticas diversas (algumas marginais) que acontecem na fronteira. Destaca-se a importância de se intensificarem os debates para se clarificarem os conceitos de cooperação internacional, cooperação territorial e cooperação transfronteiriça (Pêgo et al., 2017; 2018; 2019; 2020b).

Ao mesmo tempo, recomenda-se cartografar as escalas que se colocam em movimento a partir dos grandes agentes nacionais e internacionais e das práticas das comunidades presentes na região fronteiriça. Em relação aos primeiros, analisar os efeitos que suas noçôes de legalidade, justiça, governo e "civilidade" trazem para a vida daqueles que habitam os territórios e os lugares das múltiplas fronteiras; e em relação às práticas comunitárias, entender as muitas outras estratégias e seu sentido nos lugares, como meios para as vidas das pessoas (Pêgo et al., 2017).

Teve ênfase a proposta de incentivo a pesquisas acadêmicas relacionadas ao desenvolvimento das regióes de fronteira, com o compartilhamento de conhecimentos e tecnologia (por exemplo, para combate a doenças tropicais). Também obteve ênfase a necessidade da produção de informaçóes sobre fluxos, regiôes, redes, conexóes e articulaçóes entre cidades, aproveitando o contexto de valorização das cidades na agenda global (Pêgo et al., 2017; Pêgo e Moura, 2018).

Para tanto, é necessário que o Brasil estimule a produção de informaçóes pelos países vizinhos, para a execução de uma política de fronteira com mais efetividade, além de compatibilizar informaçóes e metodologia para se compreenderem as conexóes internacionais entre as cidades. Deve-se considerar a própria fronteira internacional como uma fonte de dados, e o Estado deve gerar as estatísticas. É na passagem pela fronteira que muitos dados são produzidos, podendo, pelo menos, ser estimulada uma interlocução diferente daquela que se volta à cidade, à aglomeração, à área. O problema é que, muitas vezes, esses dados são considerados "sensíveis", e, a partir de preocupaçóes geopolíticas, os estudos econômicos, de comércio, os fluxos nem sempre são transparentes. Há que se superar, portanto, os limites que esses dados apresentam (Pêgo et al., 2017).

Em termos operacionais, salientou-se a necessidade de se definirem as informaçóes necessárias à análise dos deslocamentos cotidianos na FF, dos fluxos de mobilidade e suas motivaçóes; ir em busca da produção de dados sistêmicos sobre cidades do Brasil e países vizinhos; e organizar bases que informem e qualifiquem as condiçóes sociais de seus povos. As fronteiras têm características históricas que devem ser exploradas, ou seja, sua estabilidade, sua existência, seus mecanismos e suas externalidades. A própria fronteira internacional poderia transformar-se em uma fonte para um banco de dados que captasse as descontinuidades das economias nacionais, da população na fronteira, assim como a comutação das pessoas entre os lugares. Como sugestáo, fazer um estudo-piloto que levante dados sobre a 
interação entre as populações do Brasil e dos países vizinhos, tal como um estudo internacional das regióes de influência das cidades, e uma classificação dos centros urbanos do subcontinente (Pêgo et al., 2017).

Ao se tratar da relação entre rede urbana e fronteiras, pontuou-se que é preciso ter a ambição de se investigar com uma abrangência continental, algo muito raro e pouco frequente na América Latina. Ou seja, aproximar a prática de pesquisa sobre redes urbanas - seja em escala continental, seja em escala nacional - da fronteira, dos diversos recortes fronteiriços, com suas grandes diversidades internas. Cabe aos latino-americanos construir espaços de reflexão teórica, política e de imaginação do continente, sem a dependência atual da produção norte-americana - maior que em relação às próprias pesquisas produzidas no subcontinente.

Cabe produzir uma interpretação geral da rede urbana sul-americana ou da configuração do sistema urbano sul-americano, ${ }^{5}$ para avaliar se a América do Sul configuraria uma rede urbana integrada. É preciso fazer o esforço de integração e de articulação das fronteiras às redes urbanas ou aos componentes da rede urbana com o que conta o continente, além de romper a dicotomia entre áreas rurais e áreas urbanas. Recomendou-se, ainda, a realização de mais estudos para entender a conformação de arranjos transfronteiriços ou cidades gêmeas, as articulaçóes entre eles e com a rede de cidades. Nesses estudos, como pontuado, pediu-se cuidado na identificação de novos arranjos e na aprovação da criação de potenciais cidades gêmeas, assim como a revisão dessa nomenclatura, que não condiz com o conceito (Pềgo et al., 2017).

Como persiste a dicotomia entre as áreas rurais, que predominam nas áreas fronteiriças, e as áreas de adensamento do fenômeno urbano, sugeriu-se utilizar as categorias rural e urbana nos estudos sobre fronteiras, mesmo quando específicos aos arranjos transfronteiriços ou às cidades gêmeas, buscando identificar a coesão territorial do espaço do lado brasileiro e do outro país a partir de comparabilidade e classificação. Dessa forma, observar se há algum tipo de diferenciação que possa ser uma ameaça à coesão entre as regiôes (Pêgo et al., 2017).

Outro fenômeno a ser priorizado nas pesquisas é a migração transfronteiriça, que se amplifica e traz desafios urgentes à agenda social das fronteiras. Como garantir e proteger a dignidade humana dos imigrantes? $\mathrm{O}$ que o Brasil promete fazer em relação a esse fenômeno? Também se pediu ênfase em relação ao fluxo de pessoas captado nos movimentos pendulares, ou comutação transfronteiriça, responsáveis por efetivar a interação transfronteiriça entre pessoas e mercadorias. Recomendou-se que sejam estudados em detalhe, de modo a avaliar quais fluxos urbanos são mais intensos, em que direçóes se movimentam e se garantem coesão interna à região; buscar um aprimoramento das informaçóes sobre esses e outros fluxos, em

5. Os participantes recomendaram considerar a pesquisa sobre a escala continental da rede urbana elaborada pelo Ipea, que pode constituir referência fundamental para outros trabalhos já realizados (Pêgo et al., 2017). 
complemento a informaçôes de estoque, ampliando dados sobre os demais países da América do Sul; aplicar, nas pesquisas e análises, os fluxos secundários, mesmo que exijam procedimentos mais complexos, como utilizar dados do Departamento de Informática do Sistema Único de Saúde (Datasus), disponibilizados pelo MS, sobre deslocamentos para acesso à saúde pública, no estudo das ligaçôes entre municípios da FF (Pêgo et al., 2017).

Sublinhou-se a necessidade de se considerar, nos estudos sobre a fronteira, as diferenças sociais, econômicas, culturais e étnicas entre os sujeitos sociais que interagem (não apenas os que habitam) na região, principalmente em áreas com a presença de indígenas ou com convivência de indígenas e não indígenas. Também se recomendou considerar as mudanças econômicas recentes nos países do continente e nas cidades de fronteira, no perfil demográfico e na diversidade da população (Pêgo et al., 2017).

Outra recomendação foi avaliar quais questóes - referenciais teóricos, interesses políticos e preocupaçóes acadêmicas - estão orientando a investigaçáo social sobre fronteiras. Nesse sentido, foi ponto comum entre os participantes o entendimento de que, antes de iniciar novos estudos, é importante explorar recursos existentes, como o recurso do Unbral Fronteiras, ${ }^{6}$ no qual uma pluralidade de estudos e pesquisas pode oferecer resultados imediatos ou subsídios que permitam superar etapas dispendiosas de trabalho e, assim, encontrar as referências disponíveis. Foi citado o estudo desenvolvido pelo Grupo Retis, da Universidade Federal do Rio de Janeiro - UFRJ (Brasil, 2015), com destaque para o conceito e a identificação de áreas críticas nas fronteiras - conceito que reuniu dados sobre incidência criminal, tráfico de drogas, contrabando, redes de proteção e vulnerabilidade socioeconômica na fronteira (Pêgo et al., 2017).

Recomendou-se a formação de uma linha de pesquisa sobre o tema, para privilegiar a interlocução com os IFs, as novas universidades - como a Universidade Federal do Pampa (Unipampa), a Universidade Federal da Fronteira do Sul (UFFS) e outras tantas - que estấo na faixa ou na linha de fronteira, assim como a integração com as universidades dos municípios dos países vizinhos para a formação de redes acadêmicas de estudos e pesquisas. Com isso, dar voz e espaço para novos pesquisadores, devido à emergência de temáticas, abordagens e questionamentos, sem desconsiderar o acúmulo dos estudos que já foram feitos, e direcionar a produção futura, por meio de editais, oportunidades de publicação e de visibilidade. Propôs-se, ainda, que fosse articulado um "observatório em rede", envolvendo as diversas instituiçóes de pesquisa sobre fronteiras, visando garantir estudos articulados e o tratamento de dados mais confiáveis e consolidados (Pêgo et al., 2017).

6. Portal de acesso aberto das universidades brasileiras sobre limites e fronteiras. Mais detalhes, ver: <https://bit. ly/3axENcj>. Acesso em: 16 mar. 2020. 
Foi destacada a necessidade de aumentar a presença de pesquisadores dos países vizinhos nos grupos nacionais de pesquisa sobre fronteiras, e reforçada a importância da cooperação com centros de pesquisa e pesquisadores sobre fronteiras, a exemplo da Faculdade Latino-Americana de Ciências Sociais (Flacso). Sugeriu-se, como exemplo a ser seguido, espelhar-se em práticas da Uniáo Europeia, com a ressalva de que é válido conhecer essa experiência, mas também a experiência centro-americana, na qual ocorreram avanços muito importantes, por meio da integração econômica, regional e territorial, em contexto político e institucional mais parecido com o brasileiro (Pêgo et al., 2017).

E, também, promover a adequação da pesquisa acadêmica e a integralização de seus resultados nas formulações de estratégias e programas de ação (abordagem teórico-metodológica e informaçóes), superando a dificuldade de integração entre conhecimento científico, acadêmico e política pública, não só nas fronteiras, mas em todo o continente sul-americano. Isso viria garantir que, na aproximação entre a pesquisa acadêmica e a formulação de políticas públicas, pudessem ser assegurados benefícios práticos de imediato para os moradores da fronteira (Pêgo et al., 2017).

$\mathrm{Na}$ área de defesa e segurança, sugere-se que se estudem quais os efeitos que as novas práticas, noçóes de legalidade, de justiça e do dever de civilidade, trazem para a vida das pessoas, nacionais e estrangeiras, que habitam os territórios nos limites da fronteira (Pêgo et al., 2017).

Como grande preocupação que perpassa os pesquisadores do tema fronteiras, salientou-se a negatividade que pesa sobre as regiôes fronteiriças, tornando necessário discutir a mensagem que emana dos meios de comunicação (televisóes, rádios, jornais impressos, internet etc.), desde os meios distantes até aqueles que atuam no interior dos territórios fronteiriços. No contraponto, é necessário discutir e considerar as formas como as fronteiras são imaginadas e sentidas por todos aqueles que vivenciam essa realidade de limites, controles, transiçóes e travessias, seja nos simples cruzamento em estradas, seja nos mares, rios, aeroportos, portos de fronteiras e territórios internacionais. Mais que isso, analisar como estâo sendo articuladas as fronteiras, na sua dimensão metafórica, em relação a outras noções próximas, como margens, limites e periferias, e responder à questão: qual é o problema principal e o efeito de retroalimentaçấo que existe quando se divulga, propaga, proclama a ilegalidade da fronteira? Como uma grande parte da população fronteiriça se encontra situada em um campo fora da cidadania, acaba sendo injustamente criminalizada.

Portanto, é urgente entender essas muitas outras estratégias, ver qual é o sentido delas nos lugares, sem romantizar; simplesmente entender que as pessoas estáo usando seus meios para suas vidas e que, às vezes, esses meios náo são necessariamente aqueles que o Estado estabelece (Pêgo et al., 2017; 2018; 2019; 2020a; 2020b; Pêgo e Moura, 2018). 
Uma oportunidade muito celebrada nos três arcos diz respeito à fronteira litorânea, que não é objeto desta etapa da pesquisa. Trata-se da imensidão da fronteira marítima e do mar territorial brasileiro, ou seja, a chamada Amazônia Azul. A regiáo de abrangência desse projeto representa grandes oportunidades e desafios ao Estado e à sociedade brasileira. Suas riquezas naturais são vitais para o crescimento econômico e o desenvolvimento social do país.

Ademais, a presença de grandes centros urbanos e de rotas de comércio internacional nessa área ressalta ainda mais sua importância estratégica. Contudo, sua distribuição ao longo de uma área geográfica vasta e aberta torna difícil sua vigilância e defesa por parte das autoridades nacionais. Tal fronteira deveria ser detidamente considerada em novos estudos e subsídios à proposição de políticas públicas, pois proteger suas riquezas e infraestruturas é tarefa central para o Estado como um todo. No entanto, carecem de estudos sobre a condição fronteiriça exercida por muitos municípios da porção litorânea brasileira e a relação existente entre a problemática dessa região com a fronteira terrestre (Pêgo et al., 2017; 2018; 2019; 2020a; 2020b; Pêgo e Moura, 2018).

Especificamente, recomenda-se: priorizar, na agenda de pesquisas, estudos e debates para a construção de um conceito de economia do mar, adequado aos objetivos do país em relação ao seu território marítimo e costeiro; desenvolver uma metodologia específica e buscar informaçôes suficientes para se construir um produto interno bruto do mar (PIBMar); e ampliar o debate, nos meios acadêmico e governamental, sobre a importância da economia oceânica para o país. Com os resultados dessas açôes, avançar nas reflexôes e priorizar, na agenda governamental, a formulação de uma política nacional para aproveitamento dos recursos do mar, voltada a desenvolver a área e contribuir para a economia nacional; assim como elaborar planos estratégicos para a criação ou o fortalecimento de atividades marinhas sustentáveis e geradoras de empregos, incluindo, entre elas, a indústria marinha e a formação de clusters regionais de desenvolvimento, que façam convergir empresas, governo e centros tecnológicos e de pesquisa para um mesmo fim.

\subsection{Agendas para os arcos Norte, Central e Sul}

\subsubsection{Recomendações de agenda para o arco Norte}

Os participantes das atividades no arco Norte posicionaram-se sobre a urgência de se avançar na compreensão da fronteira como espaço de diversidade, uniáo e encontro entre o país e seus vizinhos. Consoante a isso, deve-se repensar o significado e o conceito de FF, como também o sentido das restriçôes que dela derivam ao desenvolvimento regional, promovendo uma mudança de paradigma (Pêgo et al., 2018). 
Para tanto, é necessário superar os afastamentos significativos quanto às açôes que variam entre ideias de integração, educação, conservação e ocupação, mediante a realização de arranjos, modelos, sistemas, projetos e políticas públicas. É preciso promover interligaçóes entre termos que indicam as açóes a serem realizadas e que, consequentemente, contribuem para o desenvolvimento da área, tais como trabalhar a política pública na FF, conservar os arranjos produtivos da Amazônia, ou fazer a Amazônia sustentável, entre outros.

Pesquisadores da regiāo destacaram que é muito comum o discurso da fronteira como problema e que são poucos os estudos sobre as relaçōes de poder e dominação nas zonas fronteiriças. E questionaram: isso acontece porque as fronteiras são realmente espaços inferiorizados? Faltam pesquisas mais direcionadas a especificidades da fronteira, que abram espaço às condiçóes socioculturais e socioeconômicas dos povos da fronteira. E o mais importante: faltam açóes que permitam aos que vivem na fronteira se perceberem como sujeitos históricos da produção desse espaço.

Recomendaram que, nos estudos sobre fronteira, deveriam ser levadas em consideração as diferenças sociais, econômicas, culturais e étnicas entre os sujeitos sociais da região, principalmente em áreas de fronteira que têm a presença de indígenas e não indígenas, e são marcadas por características rurais mesmo no contexto urbano, como é o caso da tríplice fronteira Brasil-Venezuela-Guiana.

Diante do contexto amazônico, o grande desafio é compreender a região como um espaço múltiplo em sua configuração física, diversificado em seus aspectos sociais, culturais, étnicos e políticos. Paralelamente à percepção da grandiosidade da Amazônia, demonstrar que foram criados preconceitos sobre a região e suas gentes, como o discurso que toma a Amazônia como uma terra sem gente, um "imenso vazio demográfico". Compreensóes dessa ordem devem ser desconstruídas cientificamente, e postos em evidência os reais interesses que garantem que se consolidem. O grande desafio é reconhecer que a Amazônia é uma "terra sem homens" apenas no discurso oficial, que procura atrair contingentes populacionais para a região, como forma de afirmar a presença e o domínio do Estado sobre suas terras e suas fronteiras.

Conclusivamente, palestrante e professora da Universidade Federal de Roraima (UFRR) enfatizou que "na fronteira o espaço pressupóe o território", o que pressupóe que pesquisas futuras devem "revelar os elementos constituintes de uma leitura pós-colonial, pautada na ideia de desenvolvimento e progresso"; "reconhecer os diferentes projetos de territorialização referenciados por identidades territoriais e pressupostos epistemológicos distintos"; "observar as disputas políticas e epistêmicas como constituintes da fronteira"; e "visualizar também a experiência da fronteira como base para se pensar em uma epistemologia fronteiriça” (Pêgo et al., 2018). 


\subsubsection{Recomendações de agenda para o arco Central}

Os participantes das várias atividades realizadas no arco Central recomendaram incentivar fóruns interinstitucionais de fronteira, que, a partir do conhecimento local, venham a contribuir para a formulação de políticas de desenvolvimento. Enfatizaram a necessidade da presença do debate na região, a disponibilização dos dados existentes, os resultados das pesquisas realizadas, para que enriqueçam os trabalhos locais. Pontuaram, como imperativo, que o Ipea e o MDR levassem até Brasília todas as sugestóes e demandas debatidas e aprovadas durante as atividades da pesquisa Fronteiras do Brasil, como forma de incrementar as possibilidades de produção na regiáo, e para que não se tenha mais de assistir a casos em que recursos destinados para a área de fronteira venham a ser utilizados por outras áreas do governo. Recomendaram, ainda, que não fossem trazidos aos povos da fronteira projetos de pesquisa com soluções, pois a pesquisa visa justamente elucidar questóes que ainda são desconhecidas (Pêgo et al., 2019; 2020a).

Nas pesquisas a serem realizadas, deve-se assumir a heterogeneidade da região, em termos de solo; hidrografia; fragilidades que se encontram, particularmente, em áreas como o Pantanal; e instabilidades decorrentes do uso do solo por atividades que atualmente estão sendo desenvolvidas. Sugeriu-se a realização de pesquisa que distinga cidades com especificidades fronteiriças das demais da FF, posto que não se percebem diferenças entre estas cidades com baixa complexidade de fronteirização e aquelas cidades que estão fora da FF.

Em ambos os casos, quando consultadas sobre "o grande problema da FF", apareceram as mesmas respostas e reivindicaçôes. Cidades localizadas efetivamente na linha de fronteira e com níveis de complexidade de fronteirização elevados poderão apresentar problemas e reivindicaçóes muito particulares, e, com isso, as cidades na FF não devem ser integradas homogeneamente na implementação de políticas públicas específicas. Isso significa que a FF deve ser rediscutida, e mesmo redimensionada.

E, por fim, palestrante e professor da UFMS, com assentimento dos demais participantes, recomendou que a implementaçáo de qualquer programa na fronteira requeresse detalhamentos particulares que levem em consideração o meio geográfico em cada arco, e que as metodologias não sejam reproduzidas com rigidez, pois "não dá para pegar a metodologia de identificação de níveis de complexidade de fronteirização adotada no arco Central e aplicar com as mesmas métricas para o Sul, ou para o Norte. São coisas diferentes" (Pêgo et al., 2019).

\subsubsection{Recomendações de agenda para o arco Sul}

Participantes das atividades do arco Sul solicitaram uma agenda de pesquisa acadêmica mais próxima das necessidades das comunidades fronteiriças e articulada entre pesquisadores dos países limítrofes, para garantir a compreensão de que a fronteira 
representa um conjunto. Propuseram que fosse rompida a desintegração existente entre as universidades e que se ativasse um diálogo entre si e com as comunidades. Além disso, que estudos e pesquisas realizados nas diferentes regióes trouxessem retorno aos povos locais; que acatassem e subsidiassem soluções às demandas da regiâo; que buscassem experiências que já trouxeram resultados em outras regiốes; e que contribuíssem na formulação de políticas públicas e de planos de desenvolvimento efetivamente adequados à realidade fronteiriça (Pêgo et al., 2020b).

As apresentaçóes e os debates ocorridos no arco Sul salientaram a importância de se colocar com mais ênfase na agenda de estudos e pesquisas as dinâmicas espaciais da integração regional, que têm como ponto relevante a articulação com países vizinhos, recolocando o foco na construção de infraestrutura.

Também prioritários são estudos sobre as dinâmicas espaciais da securitização na escala nacional, que se expressam nacionalmente como criminalização da fronteira. Em muitos fóruns, se observa nitidamente uma interseção entre fronteira e crime, uma criminalização, um preconceito contra a fronteira. É preciso colocar em pauta, com muita clareza, a discussão sobre essa discriminaçáo que vem sendo construída em relação à fronteira, sobre as dinâmicas espaciais da securitização na escala local, que, sob a aparência de possibilidade de modernização dos equipamentos, aparece por meio das estruturas políticas. Este é, portanto, o momento no qual a universidade, os estudos e as pesquisas têm um papel importantíssimo na produção e circulação de dados que elucidem o processo, que evidenciem as questôes e os interesses das estruturas políticas, dos dados sobre violência, tráfico etc.

Outro conjunto de estudos necessários é o que confirme o que torna impossível de ser materializada a expectativa de cauterização dos fluxos transfronteiriços ilícitos. É evidente que a porosidade da fronteira não é dada pela geografia, tampouco pelas estruturas de transporte, pela conectividade, mas sim pelas políticas do Estado em seu encontro com as redes de poder locais. Essas redes e esse encontro devem ser esmiuçados com rigor científico, como dinâmicas sociais; e desvendadas as redes de poder, as negociaçóes e as renegociaçóes, as facilidades e as dificuldades criadas para se cruzar fronteiras. E apontar alternativas para se construir uma fronteira com capacidade de controle seletivo, mas sem a necessidade de fechar, cauterizar, murar. "A gente quer poder passar. Não quer que isso seja impossível. E outras coisas, se abastecer também de serviços públicos que são muito relevantes, que estão presentes, muitas vezes logo ao lado e são a solução mais fácil, mais barata. Seria bom que isso fosse reconhecido", ponderou a palestrante e professora da Universidade Federal do Rio Grande do Sul - UFRGS (Pêgo et al., 2020b). 


\section{REFERÊNCIAS}

BRASIL. Ministério da Justiça. Secretaria Nacional de Segurança Pública. Diagnóstico Socioeconômico e Demográfico da Faixa de Fronteira: Áreas Críticas de Segurança Pública. Brasília: MJ, 2015.

. Ministério da Integração Nacional. Consolidaçáo dos planos de desenvolvimento e integraçáo das faixas de fronteira. Brasília: MI, 2017.

PÊGO, B. et al. (Orgs.). Fronteiras do Brasil: diagnóstico e agenda de pesquisa para política pública. Brasília: Ipea; MI, 2017. v. 2.

PÊGO, B. et al. (Orgs.). Fronteiras do Brasil: uma avaliação do arco Norte. Brasília: Ipea; MI, 2018. v. 3.

PÊGO, B. et al. (Orgs.). Fronteiras do Brasil: uma avaliação do arco Central. Rio de Janeiro: Ipea; MDR, 2019. v. 4.

PEGO, B. et al. Estudo técnico sobre a viabilidade de criação da "cidade gêmea" Cáceres (Brasil) - San Matías (Bolívia). Brasília: Ipea; MDR, 2020a.

PÊGO, B. et al. (Orgs.). Fronteiras do Brasil: uma avaliação do arco Sul. Rio de Janeiro: Ipea; MDR, 2020b. v. 5.

PÊGO, B.; MOURA, R. (Orgs.). Fronteiras do Brasil: uma avaliação de política pública. Rio de Janeiro: Ipea; MI, 2018. v. 1. 



\section{CONTRIBUIÇÕES INICIAIS PARA O ESTUDO DA FRONTEIRA LITORÂNEA}

\section{INTRODUÇÃO}

Durante as atividades realizadas nos três arcos da fronteira terrestre, um tema que pontuou as sugestóes de novos itens para a agenda de pesquisa acadêmica e a agenda das prioridades no âmbito governamental disse respeito à fronteira litorânea (Pêgo et al., 2017; 2018; 2019; 2020). Mesmo sem ter sido objeto dessa etapa da pesquisa em realização na parceria Ipea e Ministério do Desenvolvimento Regional (MDR), esse tema não apenas perpassou os debates temáticos, como também ganhou destaque entre os capítulos autorais do volume 1 da coleção Fronteiras do Brasil (Pêgo e Moura, 2018). ${ }^{1}$

A condição de fronteira exercida pela faixa litorânea tem importância e especificidade que ainda náo foram absorvidas nos estudos gerais sobre fronteiras. No entanto, já garantiu centralidade entre os realizados pelas Forças Armadas (FA) do Brasil. O projeto Amazônia Azul, desenvolvido pela Marinha do Brasil (MB), volta-se à imensidão da fronteira marítima e do mar territorial (MT) brasileiros; uma região que representa grandes oportunidades e desafios ao Estado e à sociedade, pois suas riquezas naturais são vitais para o desenvolvimento do país. Ademais, adensa na linha da costa a presença de grandes centros urbanos, infraestruturas e rotas de comércio internacional, que ressaltam a importância estratégica dessa área.

Como a fronteira terrestre, a extensão da fronteira litorânea ao longo de uma área geográfica vasta e aberta torna difícil sua vigilância e seu controle por parte das autoridades nacionais. A deficiência da vigilância torna inexpressivas as apreensóes de ilícitos, pois esses produtos muitas vezes entram por contêineres pelos portos e aeroportos, como destacaram participantes das atividades nos arcos fronteiriços.

Por essas consideraçóes, foi recomendado que a fronteira litorânea passasse a ser detidamente considerada em novos estudos e subsídios a políticas públicas sobre fronteiras, dado que proteger suas riquezas, otimizar sua infraestrutura e garantir segurança à sociedade brasileira é tarefa central para o Estado como um todo. Para tanto, é necessário que sejam discutidos conceitos, organizadas bases de informaçôes e mapeamentos sobre a região, bem como desencadeadas análises específicas sobre o exercício da condição fronteiriça pelos muitos municípios que a integram, 
ressaltando-se as oportunidades e as limitaçóes dessa zona de fronteira. Imprescindível ainda que se analisem as relaçóes existentes entre a fronteira litorânea e a fronteira terrestre. Na próxima seção, serão pontuados sinteticamente alguns dos principais elementos a serem considerados em detalhe em possíveis futuros trabalhos.

\section{ALGUNS CONCEITOS}

Fronteira é um termo rico em conceitos e significados, desde os pontos de vista geográfico, territorial, econômico, social, simbólico ou político, entre outros. É uma delimitaçáo física ao exercício de poder, que muitas vezes se concretiza em muros ou outras tantas formas materiais, sob controle humano ou de alta tecnologia, voltadas a separar, a escolher quem e o que pode passar por esta. Uma visita a esse amplo espectro, como a realizada por Moreira (2018), no volume autoral de publicaçóes desta pesquisa, leva a admitir que a presença de um país vizinho perpassa a maioria das concepçóes. E não há um conceito ou um entendimento formalizado para a fronteira litorânea, pois prescinde de um vizinho, da possibilidade de se materializar muros. Também não há o transfronteiriço, posto que o "lado de lá" dilui-se em águas marinhas.

Assim, ao inserir o tema na agenda, há de voltar-se às reflexōes teórica e conceitual que lhe garantam sustentação. Em se tratando de uma faixa litorânea terrestre a ser estudada, haja vista conceitos relacionados à fronteira, há um alinhamento de municípios, defrontantes ao mar ou não, que exercem um papel de natureza estritamente fronteiriça; qual seja, a de portais de entradas e saídas do país de pessoas ou mercadorias, e todas as atividades que se referem a isso. Assim, o exercício dessa condição fronteiriça difere de alguns dos muitos municípios situados no que se poderia denominar faixa de fronteira litorânea (FFL) de outros localizados na mesma faixa delineada para esta reflexáo.

Se for observada a faixa de fronteira terrestre (FFT) - amplamente estudada neste trabalho-, além dos municípios que formalmente são portais fronteiriços, outros desempenham informalmente esse papel, afora que um número grande de municípios realiza interações transfronteiriças e conexôes interfronteiriças, criando uma dimensão territorial que perpassa fronteiras. Analogamente, a FFL reproduz os municípios na condição informal de portais, assim como integra um conjunto expressivo daqueles que vivem em função da presença do mar. Nesta, as interaçóes transfronteiriças são menos evidentes e palpáveis, pois, conforme já dito, "diluem-se em águas marinhas", o que permite algumas questôes interpretativas.

Se a chamada Amazônia Azul, ${ }^{2}$ ou território marítimo brasileiro, difere da Amazônia Verde, fundamentalmente, pela sua ausência populacional, isso não impede a

2. Explicação sobre os limites da Amazônia Azul pode ser vista adiante, na seção 3 deste capítulo. 
ocorrência de catástrofes ambientais provocadas pelo homem, conforme visto pelo recente derramamento de petróleo que chegou às praias brasileiras, expondo a dificuldade de proteger a costa litorânea em face do grande número de embarcaçóes comerciais que cruzam o oceano Atlântico. $\mathrm{O}$ acontecimento expôs, em grande parte, o quanto é complexo para o governo em relação aos desafios de um planeta em transformação. Ainda, do ponto de vista dos ecossistemas marinhos e terrestres, não há como deixar de mencionar também os reflexos iminentes das mudanças climáticas globais.

Assim, talvez possa dizer-se que as interaçôes transfronteiriças sob a perspectiva da fronteira marítima estão relacionadas a uma questão global, e não apenas a questóes bi ou trilaterais tratadas entre países com divisas confrontantes como ocorre com a FFT. Em verdade, de acordo com Costa (2017), é sabido que tal relação globalizada é concernente ao domínio marítimo e à defesa da liberdade dos mares a partir dos quais nasceu o direito internacional, no início do século XVII, no qual se insere que "a ideia de que o alto-mar é livre para a navegação enseja, por outro lado, a questão da extensão da soberania territorial dos Estados" (idem, ibidem, p. 34). A questão da soberania de territórios marítimos delineara-se dessa forma em torno do controle sobre a exploração de rotas de navegação e defesa da terra firme, redundando mais tarde em limites a serem estipulados em função de exploração dos setores pesqueiro e mineral.

No Brasil, os esforços para a delimitação da Amazônia Azul encontram respaldo na existência de recursos econômicos naturais marítimos de interesse nacional de defesa e proteção. Os leilóes de outorga onerosa do pré-sal, localizado na Zona Econômica Exclusiva (ZEE) da Amazônia Azul, por exemplo, são raramente associados pela sociedade brasileira sob o enfoque marítimo e terrestre conjuntamente. Costa (2017, p. 11) afirma que "a sociedade brasileira ainda vê o mar de sua perspectiva terrestre, enfatizando a zona litorânea”. Contudo, para o autor, a ZEE oferece "oportunidades de integração nacional em áreas tão diversas quanto ciência, tecnologia e cultura” (idem, ibidem).

Verifica-se que um entendimento mais abrangente vem sendo construído ao longo de várias décadas nas instituições brasileiras, em especial pelo Ministério do Meio Ambiente (MMA), embora seja ainda perceptível baixa integração com os instrumentos de uso e ocupação do solo das cidades litorâneas. A fronteira litorânea, genericamente, é compreendida como um território marinho rico em recursos, uma linha de costa densa em centralidades urbanas, população e riquezas, um ponto de chegada e partida (pessoas, cargas, lícitos e ilícitos), bem como um território de disputas internacionais. Legislaçóes, políticas públicas, planos e programas voltam-se ao controle desse espaço, e, para tanto, criam-se conceitos específicos a elementos que guardam proximidade temática a essa fronteira.

Pode-se admitir como consolidada a compreensão de que as regiôes costeiras mundiais são dotadas de importância estratégica peculiar, pois conectam aspectos econômicos, socioculturais e ecológicos (Tischer e Polette, 2016). Tais áreas, 
também denominadas zonas costeiras (ZCs), são altamente dinâmicas devido à transferência de energia e matéria que ocorre entre os sistemas terrestres e marinhos (FAO, 1998). Esse intrincado sistema de relaçóes, somado a uma maior densidade demográfica comparativamente aos espaços interiores do território brasileiro, gera desafios complexos que carecem de açôes.

A própria expressão zona costeira não possui uma definição comum. Devido ao fato de que os limites geográficos não correspondem aos limites legais estabelecidos pelos países, para efeitos de gestão e políticas públicas desse território, é comum a adoção pelas naçóes da concepção definida pela Organização para a Cooperação e Desenvolvimento Econômico (OCDE), que sugere que os limites dessas zonas devem ser delineados consoante ao problema ou aos objetivos específicos de gestão (Crossland e Kremer, 2001).

No Brasil, tal conceituação é deveras recente, pois, apesar de historicamente a ZC brasileira ter notoriedade, haja vista que a ocupação do território se desencadeou a partir da faixa litorânea, ${ }^{3}$ somente em 1988 ganhou destaque. No art. 255, $₫ 4^{\circ}$, da Constituição Federal de 1988 - CF/1988 (Brasil, 1988b), a ZC passou a ser considerada patrimônio nacional, juntamente com a Floresta Amazônica, a Mata Atlântica, a Serra do Mar e o Pantanal Mato-Grossense.

Ainda no campo das políticas públicas, as características desse território reverberaram em diversos impactos, levando ao entendimento da necessidade de gerenciamento da costa brasileira. Esse entendimento justificou a elaboração, em 1988, do Plano Nacional de Gerenciamento Costeiro (PNGC), ${ }^{4}$ que, por meio da Lei Federal no 7.661/1988, instituiu a ZC brasileira. Essa zona se estende entre a foz do rio Oiapoque, no Amapá, e Chuí, no Rio Grande do Sul, com 8.698 km de extensão e uma área de cerca de 514 mil quilômetros quadrados, e permanece um desafio perene para a gestão, devido à multiplicidade de situaçóes existentes em tal território (Nicolodi e Petermann, 2010).

Conforme expresso no Decreto Federal no 5.300/2004, "a Zona Costeira brasileira corresponde ao espaço geográfico de interação do ar, do mar e da terra, incluindo os seus recursos renováveis ou náo, abrangendo uma faixa marítima e uma faixa terrestre" (Brasil, 2004, art. 3o, caput).

3. Área de origem fomentada pela necessidade de defesa e exploração econômica que, por meio do oceano, teve no transporte de mercadorias acesso ao comércio no mercado europeu, sendo ainda na atualidade importante instrumento para as commodities brasileiras rumo aos mercados internacionais (IBGE, 2011b).

4. O PNGC tem o objetivo de "planejar e gerenciar de forma integrada, descentralizada e participativa as atividades socioeconômicas na Zona Costeira de forma a garantir a utilização sustentável dos recursos e ecossistemas costeiros", transcendendo a simples intenção de preservação ambiental, estando contempladas ações relativas a aspectos como: "urbanização; ocupação e uso do solo, do subsolo e das águas; parcelamento do solo; sistema viário e de transporte; sistema de produção, transmissão e distribuição de energia; habitação e saneamento básico; turismo, recreação e lazer; patrimônio natural, histórico, étnico, cultural e paisagístico" (art. 50) (Belchior, 2008, p. 53). No PNGC, ficou estabelecido que o gerenciamento costeiro é uma atividade integrada, cuja responsabilidade deve ser compartilhada por todas as esferas governamentais (federal, estaduais e locais), deixando claro o papel descentralizador do plano (Brasil, 1988b). 
A ZC, de acordo com o Decreto Federal no 5.300/2004, possui os seguintes limites (mapa 1).

1) Faixa marítima, que é o espaço que se estende por 12 milhas náuticas $(22,2$ $\mathrm{km}$ ) das linhas de base (média da água mais baixa da maré), estabelecidas de acordo com a Convenção das Naçóes Unidas sobre o Direito do Mar, da Organização das Nações Unidas (CNUDM/ONU) - (Brasil, 1995a).

2) Faixa terrestre, que é o espaço compreendido pelos limites dos municípios que sofrem influência direta dos fenômenos ocorrentes na ZC, estando inclusos os municípios defrontantes com o mar; os que, mesmo não defrontantes, se localizam nas regióes metropolitanas (RMs) litorâneas; os contíguos às grandes cidades e às capitais que apresentam processo de conurbação; e os municípios próximos ao litoral, até $50 \mathrm{~km}$ da linha de costa, que aloquem, em seu território, atividades ou infraestruturas de grande impacto ambiental sobre a ZC, conforme o Instituto Brasileiro de Geografia e Estatística (IBGE, 2011b). A relação dos municípios localizados na área de influência dessa zona foi atualizada pelo IBGE, em 2018, tendo se reduzido de 367 para 274 municípios, sendo 269 destes defrontantes ao mar. Essa redução se deve aos critérios do decreto citado, sobre regras de uso e ocupação da ZC, assim como os critérios de gestão da orla marítima, as normas do IBGE e as definiçóes próprias das Unidades da Federaçáo (UFs) abrangidas. 


\section{MAPA 1}

Zona Costeira e Amazônia Azul: MT, zona contígua, plataforma continental ${ }^{1}$ e ZEE - Brasil

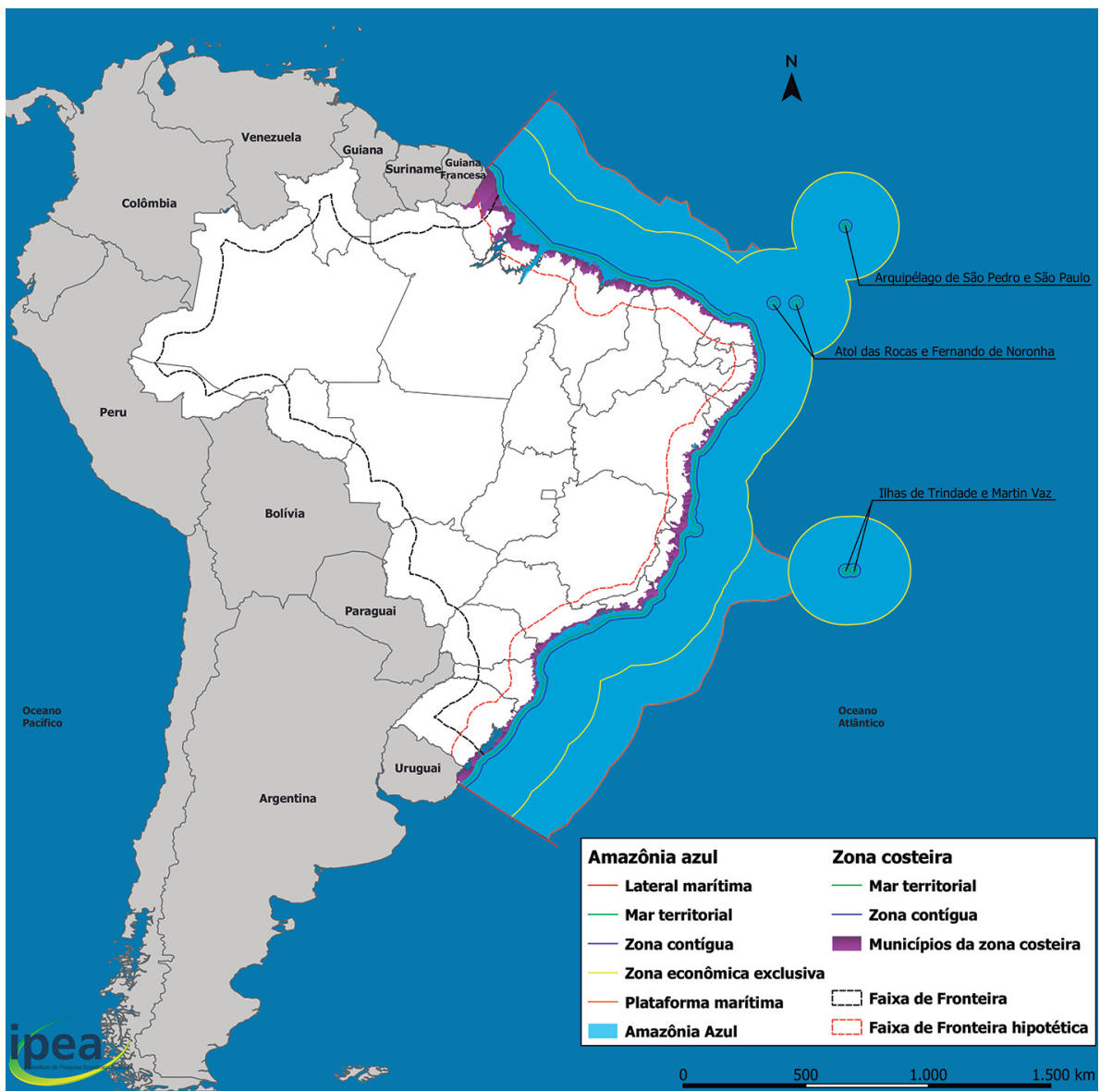

Fontes: Brasil (2004) e Base Cartográfica Contínua/IBGE (disponível em: <https://bit.ly/2J899GT>; acesso em: 20 jan. 2020). Elaboração: Equipe Fronteiras Ipea.

Nota: ${ }^{3}$ Plataforma continental (PC).

Por sua vez, o território marítimo brasileiro, ou a Amazônia Azul, de acordo com a Lei Federal no 8.617/1993, abrange as águas jurisdicionais do país nas seguintes zonas nomeadas.

1) Águas marítimas interiores compostas por rios, baías, enseadas e portos que se situam no interior da linha de base do MT.

2) Mar territorial ou faixa de 12 milhas marítimas de largura, medidas a partir da linha de baixa-mar do litoral continental e insular.

3) Zona contígua ou a faixa que se estende das 12 às 24 milhas marítimas, contadas a partir das linhas de base que servem para medir a largura do MT. 
4) Zona Econômica Exclusiva ou a faixa que se estende das 12 às 200 milhas marítimas, contadas a partir das linhas de base que servem para medir a largura do MT.

5) Plataforma continental ou o leito e o subsolo das áreas submarinas que se estendem além do seu MT, em toda a extensão do prolongamento natural de seu território terrestre, até o bordo exterior da margem continental, ou até uma distância de 200 milhas marítimas das linhas de base, a partir das quais se mede a largura do MT, nos casos em que o bordo exterior da margem continental não atinja essa distância (Brasil, 1993) (figura 1).

FIGURA 1

Amazônia Azul: perfil do território marítimo brasileiro

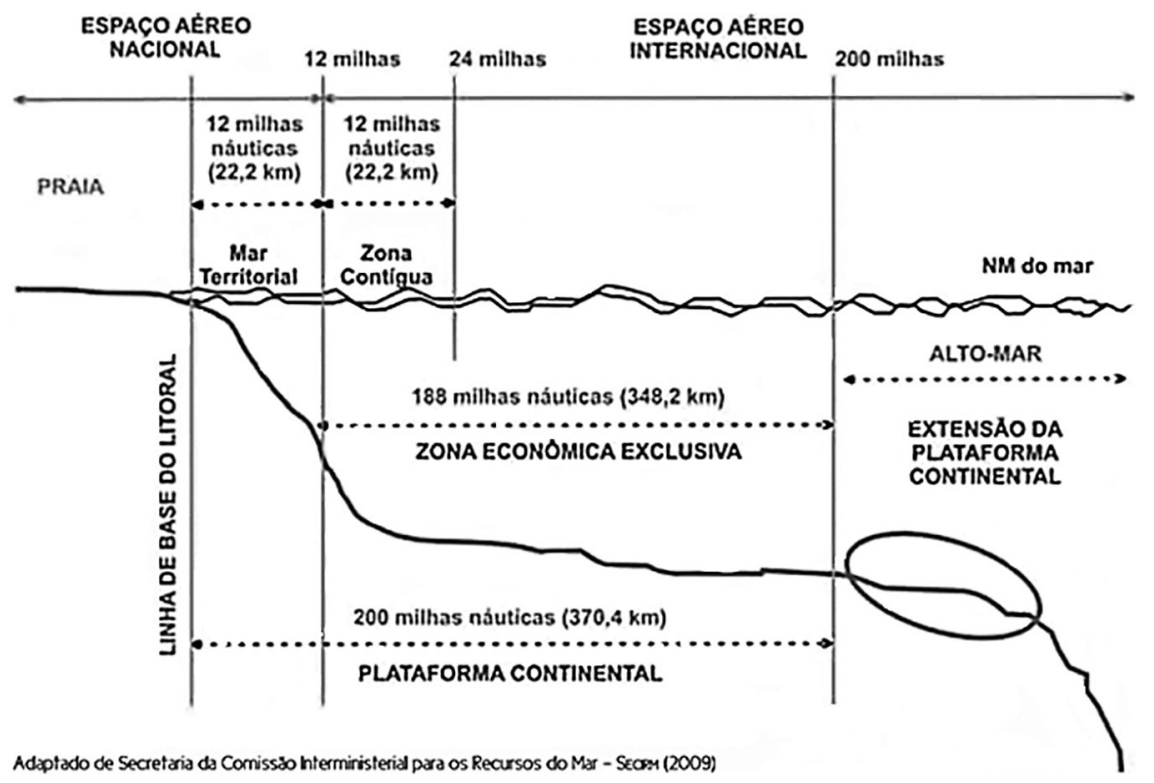

Fonte: IBGE (2011b, p. 29).

Adaptação: Equipe Fronteiras Ipea.

As águas jurisdicionais do país compõem uma área de 3,5 milhões de quilômetros quadrados, a ser ampliada se reconhecido internacionalmente o pleito brasileiro de extensão da PC para até 5,7 milhões de quilômetros quadrados - equivalente a mais da metade do território nacional. ${ }^{5}$ É uma área com importância política, econômica, estratégica, de soberania, científica e ambiental. As orientaçóes para a defesa da Amazônia Azul e o papel do poder naval do país nessa função emanam da Política Nacional de Defesa (PND). 
O Brasil foi um dos primeiros países a pleitear o reconhecimento de sua PC estendida, instituindo, pelo Decreto Federal nº 98.145/1989, o Plano de Levantamento da Plataforma Continental Brasileira (Leplac), com o objetivo de proceder o levantamento pormenorizado da PC brasileira, além das 200 milhas marítimas, de forma a determinar seus limites exteriores (Brasil, 1989). Esse plano será retomado na seção 4 deste capítulo, sobre programas em desenvolvimento.

De acordo com Paim (2014), deve-se contudo esclarecer que a soberania brasileira é exercida somente sobre o MT e as águas marítimas interiores. A autora explica que

em termos práticos, isso significa que a plataforma continental estendida além das 200 milhas náuticas não aumentou o território do Brasil, mas apenas lhe garantiu direitos de soberania sobre todos os recursos que possam ser explorados em tal área, sem que nenhum outro Estado ou particular possa exercer a exploração, a não ser que obtenha autorização prévia expressa, nos termos da CNUDM (Paim, 2014, p. 337).

Em concordância com a CNUDM, tanto as águas interiores quanto o MT fazem parte do território do Estado costeiro, sendo que, na zona contígua, embora fora desse espaço, este pode também adotar medidas de fiscalização e repressão necessárias contra violaçóes a leis e regulamentos aduaneiros, fiscais, de imigração ou sanitários. Contudo, o reconhecimento da soberania sobre os recursos da ZEE e da PC estendida gera a necessidade de defesa de um espaço geográfico maior, que depende de um eficaz sistema de controle e monitoramento (Paim, 2014).

Observa-se que não falta apenas uma reflexão conceitual sobre fronteira litorânea. Falta, também, uma discussão pormenorizada sobre os elementos constitutivos dessa fronteira, que unifique entendimentos díspares, que acelere processos demarcatórios, enfim, que dê centralidade a um tema que, como se revelará a seguir, é relevante ao desenvolvimento nacional e às relaçóes do Brasil com outros países do mundo. Dada essa lacuna, para pontuar alguns desses elementos, esta abordagem reproduzirá no litoral, como a FFL, os mesmos parâmetros de demarcação da FFT; qual seja, a extensão ao longo da costa, com $150 \mathrm{~km}$ de largura.

\subsection{A construção de uma faixa hipotética}

Como antecipado, para efeitos deste estudo introdutório sobre o tema, foram considerados integrantes da FFL os municípios inseridos ou cortados pela faixa de 150 km de largura a partir da linha da costa, como espelho da FFT, reproduzindo-se a mesma dimensão desta para efeitos da organização das informaçóes. Integram esse recorte dezessete UFs banhadas pelo Atlântico e, dada a largura da faixa, pequena parcela do estado de Minas Gerais, que náo defronta com o oceano. Ao todo, compóem um conjunto de 2.068 municípios, sendo que trinta destes estão concomitantemente inseridos na FFT e na FFL, particularmente aqueles pertencentes ao Amapá e ao Rio Grande do Sul. 
Dada que a largura da FFT foi objeto de análise com interpretações diferentes, antes de realizar a escolha desse recorte como faixa hipotética, foram avaliadas algumas possibilidades alternativas para sua delimitação. Primeiramente, buscou-se a relação dos municípios integrantes da ZC, segundo o IBGE; porém, ainda não se encontra disponível uma relação que contemple as novas mensuraçóes de áreas e limites municipais, mas apenas aquelas referentes aos municípios defrontantes com o mar (mapa 2). Há de considerar-se que esses municípios se integram a conjuntos denominados pelo instituto como regiôes geográficas (de articulação) imediatas, estruturadas a partir de centros urbanos próximos, para a satisfação das necessidades imediatas das populaçóes em termos de compras de bens de consumo, trabalho, acesso a serviços de saúde e educação, bem como prestação de serviços públicos, apresentando fortes articulações internas. Supóe-se que o exercício da condição fronteiriça dos municípios defrontantes ou é compartilhado ou se reflete no âmbito desse conjunto. Assim, o segundo ensaio foi realizado, agregando as regióes imediatas nas quais se inserem os municípios defrontantes, chegando a um total de 852 municípios, satisfazendo com bastante propriedade o que poderia ser entendido como uma FF a partir do litoral. Essa amostra apenas não foi objeto de escolha neste trabalho, em razão do objetivo de não se perder a possibilidade comparativa entre as duas faixas, a litorânea (leste) e a terrestre (oeste), reproduzindo-se, assim, as mesmas dimensóes vigentes. Mas o resultado obtido aponta uma possibilidade alternativa a ser explorada para repensar as duas faixas de fronteira (FFs). 
MAPA 2

Municípios defrontantes com o mar - Brasil (2018)

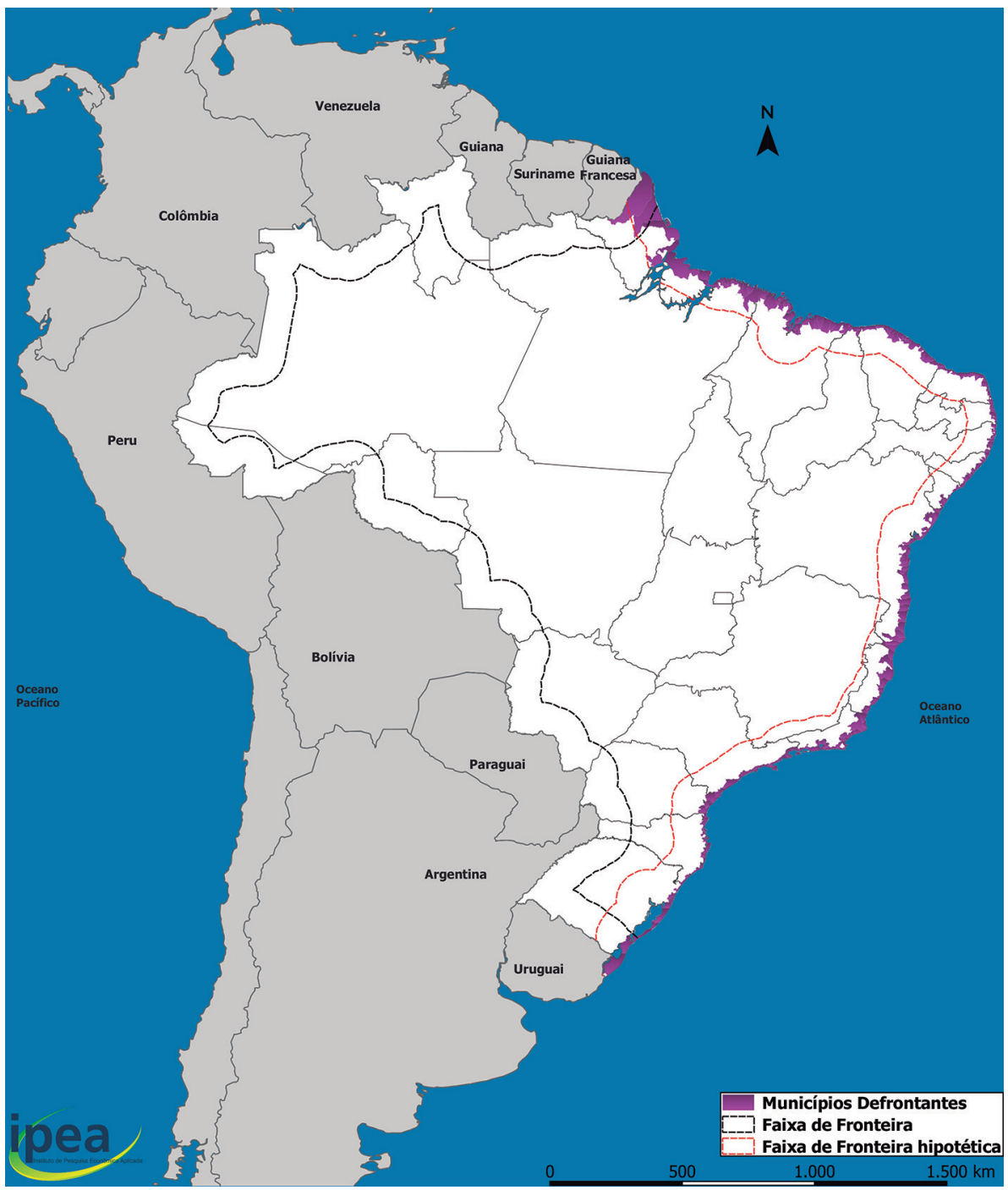

Fonte: Municípios defrontantes com o mar 2018/IBGE. Disponível em: <https://bit.ly/33a5n73>. Acesso em: 20 jan. 2020. Elaboração: Equipe Fronteiras Ipea.

Obs.: Faixa de fronteira diz respeito àquela definida em lei e faixa de fronteira hipotética é aquela considerada para fins deste estudo de caracterização da fronteira litorânea. Essa observação é válida para todos os demais mapas deste capítulo que apresentam faixa de fronteira e faixa de fronteira hipotética.

Nesta subseção, assim como a faixa hipotética considerada, as informaçóes escolhidas para caracterizar a fronteira litorânea constituem-se apenas indicativos iniciais a futuras análises. Sem dúvida, é um espaço denso, complexo e estratégico, que requer ser detalhadamente compreendido em suas funçóes fronteiriças. Portanto, objetiva-se neste momento apontar temas, fenômenos e processos que merecem 
tornar-se objetos de pesquisa, cujos resultados possam oferecer subsídios à formulação de políticas públicas específicas e adequadas a esse espaço.

\section{A IMPORTÂNCIA DA FAIXA DE FRONTEIRA LITORÂNEA}

No caso da fronteira terrestre, as relaçóes transfronteiriças produzem um espaço com natureza particular e complexidades que se tornam objeto prioritário no desenvolvimento de políticas públicas. Ademais, as relaçóes com os países vizinhos abrem possibilidades de acordos e intercâmbios fundamentais ao desenvolvimento da FF, assim como do território em sua totalidade. Isso também se dá na fronteira litorânea, na qual há um amplo espaço marítimo que concerne ao espaço da ZC e compóe com esta uma unidade, cujo equilíbrio é condição imprescindível ao desenvolvimento da FFL e do território em sua totalidade. Portanto, há irrefutável conexão e relacionamento contínuo que se estreita entre essas duas faixas de fronteiras, como já abordado na subseção 4.3 deste trabalho.

\subsection{A área terrestre}

\subsubsection{População e cidades}

A FFL teve, em 2019, uma população de 122,9 milhóes de habitantes, correspondendo a $58,5 \%$ da população do país (tabela 1 ). O conjunto de municípios que compóe essa faixa totaliza uma área de 1,2 milhão de quilômetros quadrados, ou 14,3\% da área total do território brasileiro, registrando uma densidade demográfica de 101,21 hab./ $\mathrm{km}^{2}$. Esses dados mostram condiçóes de concentração e adensamento populacional superlativas nesse recorte em relação à FFT e aos demais municípios brasileiros.

TABELA 1

Área, densidade populacional, população e taxa de crescimento segundo recortes territoriais - Brasil

\begin{tabular}{lcccc}
\hline \multirow{2}{*}{ Variável/indicador } & \multicolumn{3}{c}{ Recorte territorial } \\
\cline { 2 - 5 } & FFT & FFL & Demais municípios & Brasil \\
\hline Número de municípios - 20191 & 586 & 2.068 & 2.946 & $\mathbf{5 . 5 7 0}$ \\
Área - 2018 (km²) $^{2}$ & $2.250 .338,26$ & $1.214 .516,42$ & $5.141 .459,28$ & $\mathbf{8 . 4 9 7 . 8 0 2 , 5 0}$ \\
Área total do Brasil (\%) & 26,48 & 14,29 & 60,50 & $\mathbf{1 0 0 , 0 0}$ \\
População - 2010 & 10.715 .983 & 111.814 .859 & 69.255 .605 & $\mathbf{1 9 0 . 7 5 5 . 7 9 9}$ \\
$\begin{array}{l}\text { População estimada - 2019 } \\
\text { População estimada - 2019 (\%) }\end{array}$ & 11.733 .448 & 122.925 .326 & 76.572 .940 & $\mathbf{2 1 0 . 1 4 7 . 1 2 5}$ \\
$\begin{array}{l}\text { Taxa de crescimento da população - 2010 } \\
\text { a 2019 (\% ao ano) }\end{array}$ & 1,01 & 58,49 & 36,43 & $\mathbf{1 0 0 , 0 0}$ \\
$\begin{array}{l}\text { Densidade } \\
\text { (população de 2019/área de 2018) }\end{array}$ & 5,21 & 1,06 & 1,12 & $\mathbf{1 , 0 8}$ \\
\hline
\end{tabular}

Fontes: IBGE (2011a; 2019) e Áreas territoriais/IBGE (disponivel em: <https://bit.ly/3m2NSgw>).

Elaboração: Equipe Fronteiras Ipea.

Notas: ${ }^{1}$ Trinta municípios integram concomitantemente as FFL e FFT.

2 Inclui área da Lagoa dos Patos e Lagoa Mirim. 
Os municípios com as maiores áreas na FFL situam-se nas regióes Norte e Nordeste. Mesmo assim, entre os dezoito com mais de 5 mil quilômetros quadrados de área, encontra-se Santa Vitória do Palmar, no Rio Grande do Sul, com os demais dezessete pertencentes ao Pará, ao Amapá e ao Maranhão. O município com a maior área territorial é Oiapoque, no Amapá $\left(23.034,4 \mathrm{~km}^{2}\right)$. Os municípios com as menores áreas estão nas regióes Sul e Sudeste, sendo o limite inferior São Caetano do Sul $\left(15,3 \mathrm{~km}^{2}\right)$. Esse município e outros cinco estão entre os poucos

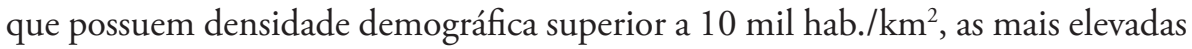
da FFL - todos integrantes da aglomeração metropolitana de São Paulo.

A FFL concentra também os municípios mais urbanizados do país. Análise da classificação dos municípios brasileiros em escalas da urbanização aponta um comportamento que distingue a FFL tanto da FFT quanto do conjunto dos demais municípios brasileiros, pela mais elevada proporção dos municípios no estágio mais avançado da urbanização, ou em metropolização (Moura, Oliveira e Pêgo, 2018). Nos dois outros recortes, sobressai-se a participação dos municípios considerados urbanizados, chegando a aproximar-se da metade dos componentes da FFT (tabela 2).

TABELA 2

Escalas da urbanização segundo recortes selecionados - Brasil (2010)

\begin{tabular}{lcccccc}
\hline \multirow{2}{*}{ Escalas } & \multicolumn{2}{c}{ Litorânea } & \multicolumn{2}{c}{ Terrestre } & \multicolumn{2}{c}{ Demais } \\
\cline { 2 - 6 } & Número & $\%$ & Número & $\%$ & Número & $\%$ \\
\hline Em metropolização & 800 & 38,66 & 113 & 19,28 & 886 & 30,10 \\
Fortemente urbanizados & 210 & 10,16 & 92 & 15,70 & 389 & 13,20 \\
Urbanizados & 767 & 37,11 & 284 & 48,46 & 1.309 & 44,42 \\
Em transição para o urbano & 288 & 13,93 & 97 & 16,55 & 360 & 12,22 \\
Não classificados' & 3 & 0,15 & 0 & 0 & 2 & 0,07 \\
Total $^{2}$ & $\mathbf{2 . 0 6 8}$ & $\mathbf{1 0 0 , 0 0}$ & $\mathbf{5 8 6}$ & $\mathbf{1 0 0 , 0 0}$ & $\mathbf{2 . 9 4 6}$ & $\mathbf{1 0 0 , 0 0}$ \\
\hline
\end{tabular}

Fontes: IBGE (2011a; 2016a); Moura, Oliveira e Pêgo (2018).

Elaboração: Equipe Fronteiras Ipea.

Notas: ${ }^{1}$ Municípios criados após 2010, não considerados na classificação.

${ }^{2}$ Há sobreposição de trinta municípios nas faixas de fronteira terrestre e litorânea.

Na faixa de FFL, particularmente na linha da costa, há um grande número de municípios com elevada população, casos de São Paulo, com 12,2 milhóes de habitantes, assim como de Rio de Janeiro, com 6,7 milhões, Salvador e Fortaleza, com mais de 2 milhões, todos defrontantes ao mar, e de Curitiba, Recife, Belém, Porto Alegre, São Luís, Maceió e Campinas, com mais de 1 milhão, a maioria também defrontante. Guarulhos e São Gonçalo, também nessa faixa de população, integram as aglomeraçóes metropolitanas de São Paulo e Rio de Janeiro, respectivamente (mapa 3). ${ }^{6}$

6. Além da população residente nessa área, dados do Censo Demográfico do IBGE (2011a) apontam que na Zona Costeira brasileira há 17,4 milhões de domicílios, dos quais 9,2\% são de uso ocasional (usado para descanso de fins de semana, férias ou outro fim), o que eleva sazonalmente esse contingente. 
MAPA 3

Distribuição da população segundo classes de tamanho - Brasil (2019)

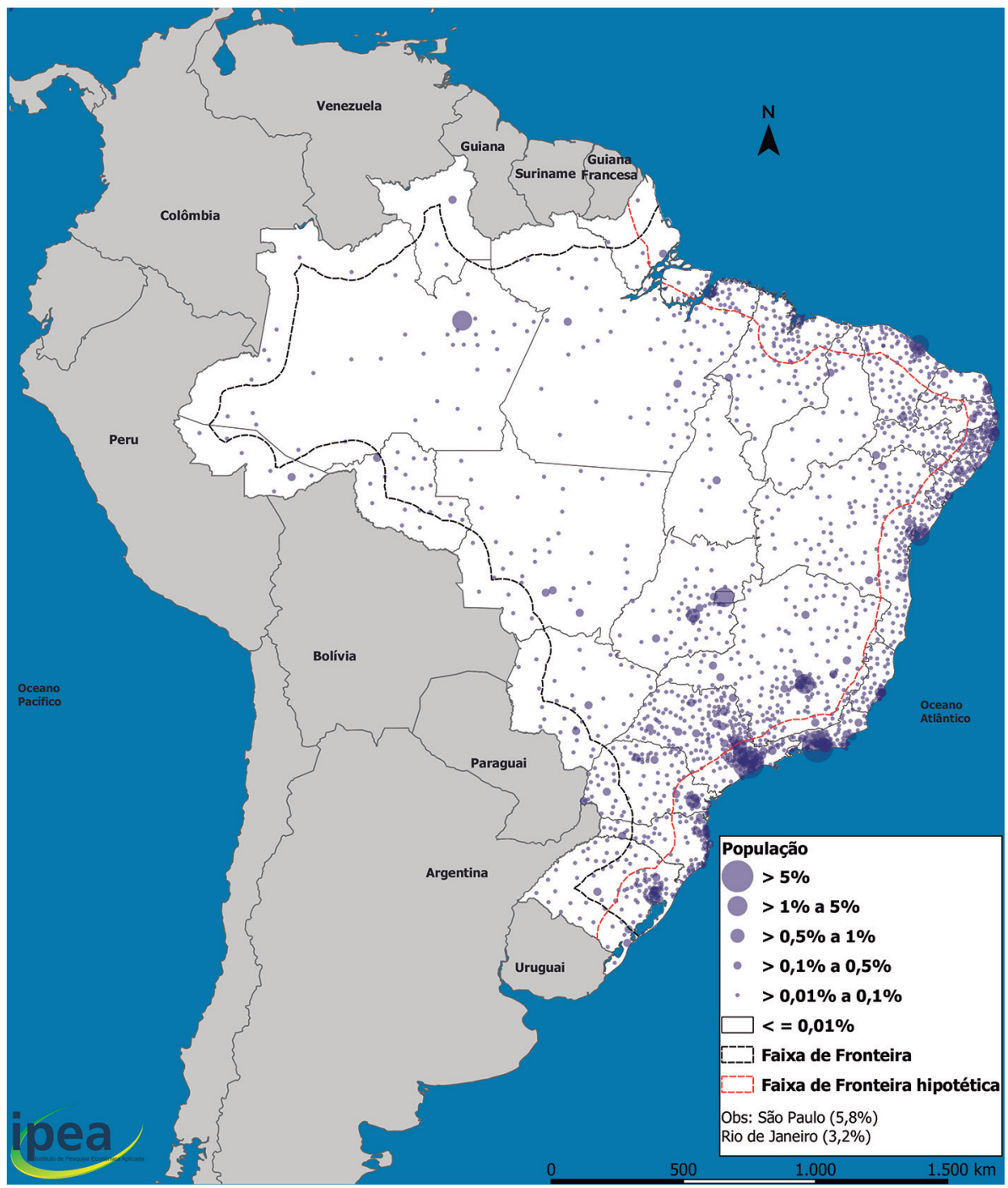

Fonte: IBGE (2019).

Elaboração: Equipe Fronteiras Ipea.

No entorno das capitais de UFs situadas nessa região, como visto no caso desses dois últimos municípios, aglutinam-se conjuntos de municípios também populosos, configurando-se aglomerados de grande concentração populacional. Segundo critérios do IBGE (2016a; 2020), registram-se na FFL vinte grandes concentraçóes de população - ou seja, arranjos espaciais com população superior a 750 mil habitantes, que reúnem 229 municípios (mapa 4). Como já visto no capítulo 
3 desta publicação, são considerados arranjos populacionais os conjuntos de dois municípios ou mais com elevado movimento pendular de pessoas para estudo e/ou trabalho, ou mancha contínua de ocupação urbana. Essas grandes concentraçóes em arranjos são polarizadas pelas cidades: na regiáo Norte, Belém; na Nordeste, São Luís, Fortaleza, Natal, João Pessoa, Recife, Maceió, Aracaju e Salvador; na Sudeste, São Paulo, Campinas, Baixada Santista, São José dos Campos, Sorocaba, Jundiaí, Rio de Janeiro e Vitória; e na Sul, Curitiba, Florianópolis e Porto Alegre. Em alguns casos, essas grandes e outras médias concentraçôes se reúnem em um continuum, formando arranjos urbano-regionais mais complexos, como no entorno da concentração polarizada por São Paulo, conformando o espaço identificado como "macrometrópole" paulista (Emplasa, 2011), e no de Porto Alegre, reconhecida como "cidade-região" (Sassi e Soares, 2019). Uma das configuraçôes mais emblemáticas desse processo na FFL é a da "megalópole" que incorpora as áreas metropolitanas de Rio de Janeiro e de São Paulo (Bartholomeu, 2019), passando por alguns arranjos populacionais do Vale do Paraíba e da Baixada Fluminense. 
MAPA 4

Áreas de concentração e arranjos populacionais - Brasil

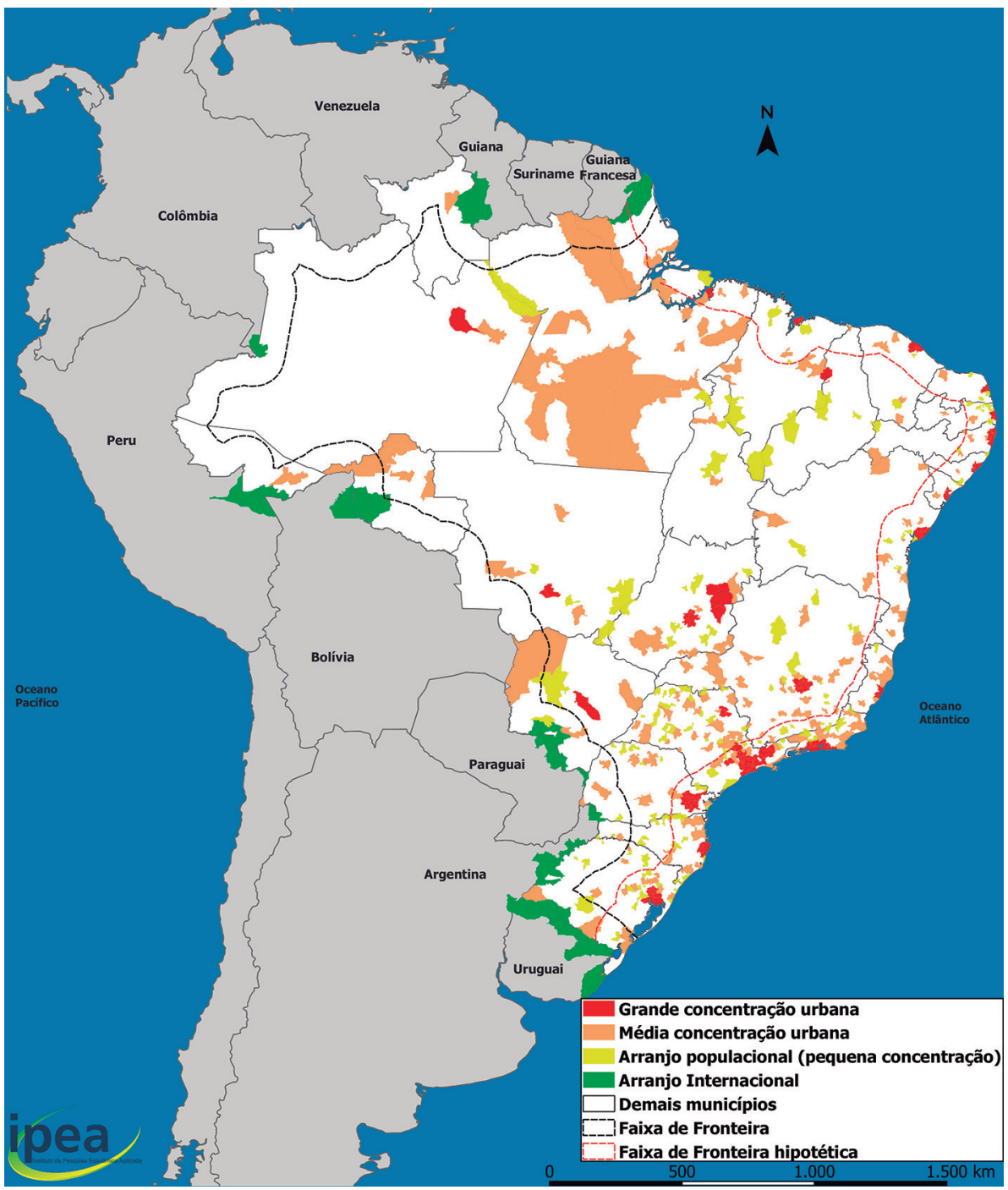

Fontes: IBGE (2016a; 2020).

Elaboração: Equipe Fronteiras Ipea.

$\mathrm{Na}$ faixa litorânea, outros 137 municípios integram médias concentraçóes populacionais, a partir da configuração de arranjos espaciais, que reúnem um contingente de população entre 100 mil e 750 mil habitantes, e 43 municípios atingem isoladamente esse patamar populacional. Pode-se afirmar que, entre os recortes territoriais em análise, na FFL se encontra o maior número de conjuntos denominados concentraçóes populacionais grandes ou médias, seja em arranjos, 
seja em centros isolados, assim como um elevado número de pequenos arranjos populacionais (com menos de 100 mil habitantes), que somam 152 municípios. Tal fenômeno de configuração de arranjos espaciais é peculiar ao estágio mais avançado da urbanização ou metropolização pela qual passa o território.

Esses arranjos espaciais são polarizados por centralidades classificadas nos patamares mais elevados da hierarquia de centros da rede urbana brasileira (IBGE, 2020). Tanto assim que, dos quinze municípios ou arranjos populacionais classificados como metrópoles pela pesquisa Regiões de Influência das Cidades (Regic) do IBGE, em 2018, onze estão localizados na FFL. Ressalta-se que, entre essas metrópoles, está a classificada como grande metrópole nacional, São Paulo, uma das duas metrópoles nacionais, Rio de Janeiro, e outras nove metrópoles. Classificadas no segundo patamar da hierarquia, encontram-se na FFL cinco capitais regionais $\mathrm{A}$, onze capitais regionais $\mathrm{B}$ e 26 capitais regionais $\mathrm{C}$, que se compóem de capitais de UFs e de outras importantes cidades articuladoras da rede urbana. Complementam essas centralidades 34 centros sub-regionais A e 99 centros sub-regionais B, assim como 48 centros de zona A e 74 centros de zona B (mapa 5). 
MAPA 5

Classificação dos centros na rede urbana - Brasil (2018)

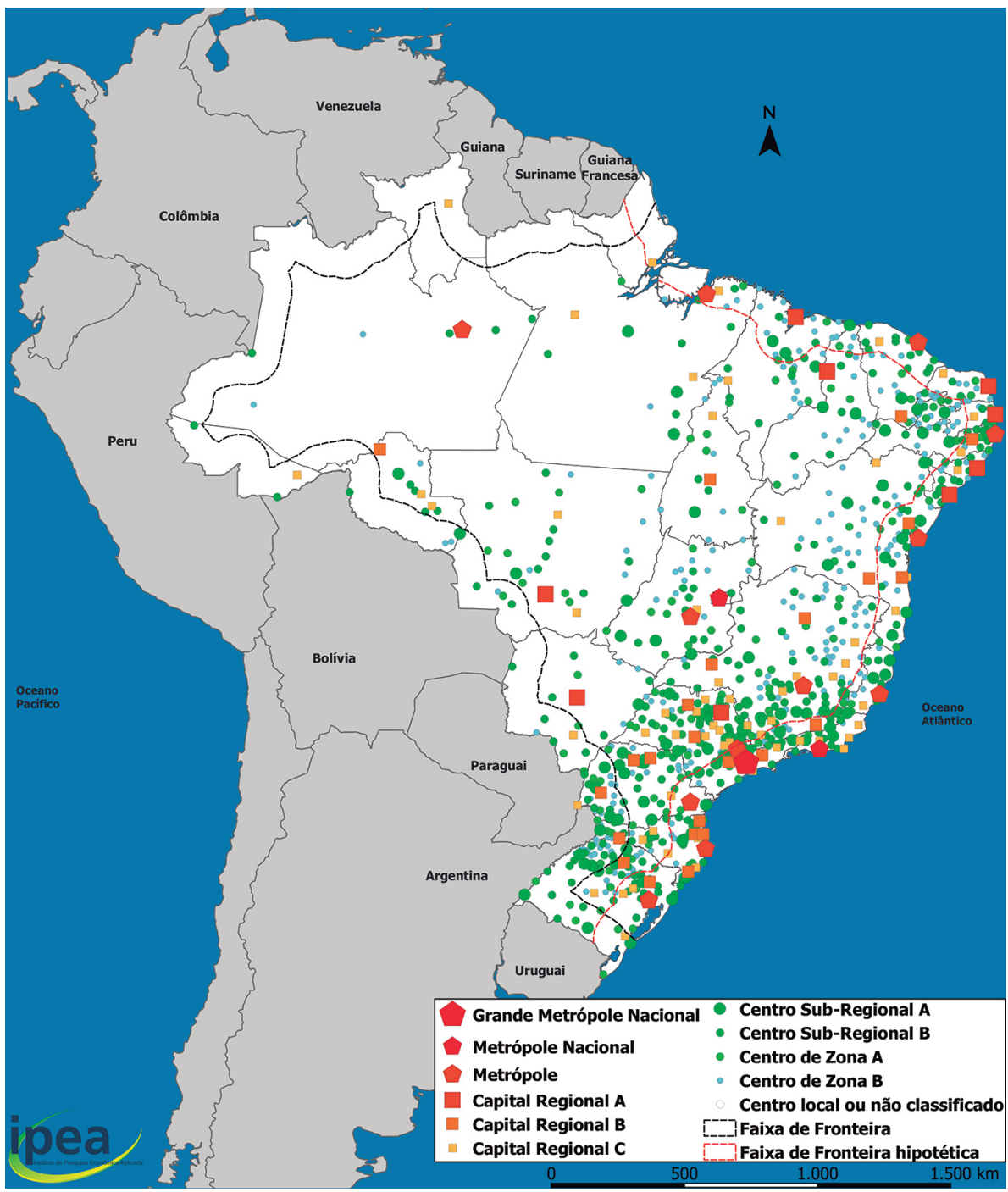

Fonte: IBGE (2020).

Elaboração: Equipe Fronteiras Ipea.

Pode-se concluir que a importância dessa regiáo enquanto área de concentração de população resulta e vai contribuir na concentração de ativos econômicos, técnico-científicos e de conhecimento e informação, bem como em infraestruturas. Segundo Santos (1996) e Santos e Silveira (2001), há nessa região as condiçóes mais avançadas de realização e transformação do espaço, dado que, a partir desses ativos, se estabelecem as condiçóes materiais e políticas à produção de uma "inteligência planetária". Esse 
conjunto caracteriza a região como um meio técnico-científico-informacional, do qual emanam não apenas a renda e a capacidade de produção e circulação dos produtos, como também o conhecimento, a informação e os meios de exercício do comando ao restante do território (Santos, 1996).

Dois exemplos materiais dessa concentração encontram-se na presença de instituiçóes de ensino superior (IES) e na malha do sistema de comunicaçóes. Em relação aos IES, que compreendem unidades de ensino e pesquisa, segundo dados do Censo da Educação Superior, para 2018, realizados pelo Instituto Nacional de Estudos e Pesquisas Educacionais Anísio Teixeira (Inep, 2019), em 2018, o Brasil possuía 2.537 IES públicas e privadas, integrando universidades $(7,8 \%$ do total das IES), centros universitários $(9,07 \%)$, faculdades $(81,51 \%)$, institutos federais de educação, ciência e tecnologia (IFs) e centros federais de educação tecnológica (Cefets); estes perfazem 1,6\% do total das IES do país (tabela 3).

TABELA 3

Número e participação de IES no total do país, segundo UFs com capitais nos recortes do território - Brasil (2018)

\begin{tabular}{|c|c|c|c|c|c|c|c|c|c|c|c|}
\hline \multirow{3}{*}{$\begin{array}{l}\text { UFs com capitais } \\
\text { incidentes nos } \\
\text { recortes }\end{array}$} & \multicolumn{10}{|c|}{ Instituições } & \multirow{3}{*}{$\begin{array}{c}\text { Total } \\
\text { geral do } \\
\text { Brasil } \\
(\%)\end{array}$} \\
\hline & \multicolumn{2}{|c|}{ Total geral } & \multicolumn{2}{|c|}{ Universidades } & \multicolumn{2}{|c|}{$\begin{array}{l}\text { Centros } \\
\text { universitários }\end{array}$} & \multicolumn{2}{|c|}{ Faculdades } & \multicolumn{2}{|c|}{ IFs e Cefets } & \\
\hline & Total & Capital & Total & Capital & Total & Capital & Total & Capital & Total & Capital & \\
\hline \multicolumn{12}{|l|}{$\mathrm{FFL}$} \\
\hline Quantidade & 1.817 & 609 & 150 & 61 & 177 & 69 & 1.468 & 463 & 22 & 16 & - \\
\hline$\%$ & 100 & 33,52 & 100 & 40,67 & 100 & 38,98 & 100 & 31,54 & 100 & 72,73 & 71,62 \\
\hline \multicolumn{12}{|l|}{ FFT } \\
\hline Quantidade & 69 & 49 & 6 & 6 & 4 & 3 & 55 & 36 & 4 & 4 & - \\
\hline$\%$ & 100 & 71,01 & 100 & 100 & 100 & 75,00 & 100 & 65,45 & 100 & 100 & 2,72 \\
\hline \multicolumn{12}{|l|}{ Demais municípios } \\
\hline Quantidade & 651 & 246 & 43 & 20 & 49 & 25 & 545 & 191 & 14 & 10 & - \\
\hline$\%$ & 100 & 37,79 & 100 & 46,51 & 100 & 51,02 & 100 & 35,04 & 100 & 71,43 & 25,66 \\
\hline \multicolumn{12}{|l|}{ Brasil } \\
\hline Quantidade & 2.537 & 904 & 199 & 87 & 230 & 97 & 2.068 & 690 & 40 & 30 & - \\
\hline$\%$ & 100 & 35,63 & 100 & 43,72 & 100 & 42,17 & 100 & 33,36 & 100 & 75 & 100 \\
\hline $\begin{array}{l}\text { Categoria sobre } 0 \\
\text { total de IES (\%) }\end{array}$ & 100 & 100 & 7,84 & 9,62 & 9,07 & 10,73 & 81,51 & 76,32 & 1,58 & 3,32 & - \\
\hline
\end{tabular}

Fonte: Inep (2019).

Elaboração: Equipe Fronteiras Ipea.

A FFL concentra $71,6 \%$ do total das IES do país, confirmando a presença de técnica, pesquisa, informação e conhecimento de maneira muito mais expressiva 
nesse recorte que nos demais. Observa-se que as capitais das UFs, sem considerar os municípios integrantes em seus aglomerados, concentram 35,6\% do total das IES. Essa concentração exacerbada se reproduz em todas as categorias de IES, nessa FF. Na FFL e entre os demais municípios, as categorias dessas instituições de ensino demonstram relativa distribuição de unidades, entre $30 \%$ e $40 \%$ do total, sendo mais elevada apenas no caso de IFs e Cefets, no qual supera $70 \% \mathrm{Na}$ FFT, que detém apenas 2,7\% das IES do país, a concentração nas capitais sobe para $71 \%$, o que contribui para deixar ainda mais desprovidos os municípios do interior, fundamentalmente nos arcos Norte e Central, dada a escassez de vias e meios de deslocamento de docentes e alunos.

A condição de deslocamento no território também privilegia a faixa de FFL. É a regiāo na qual os fluxos se desenvolvem com os menores obstáculos, unindo os fixos (cidades, equipamentos, infraestruturas, postos de serviços etc.) com os melhores meios materiais e imateriais de deslocamento. Nessa região, a mais densa do território, como já informado nesta subseção, abrem-se caminhos para fluxos internacionais terrestres, aéreos e marítimos (mapa 6). 
MAPA 6

Densidade populacional, rodovias e hidrovias (fluviais e marítimas) - Brasil

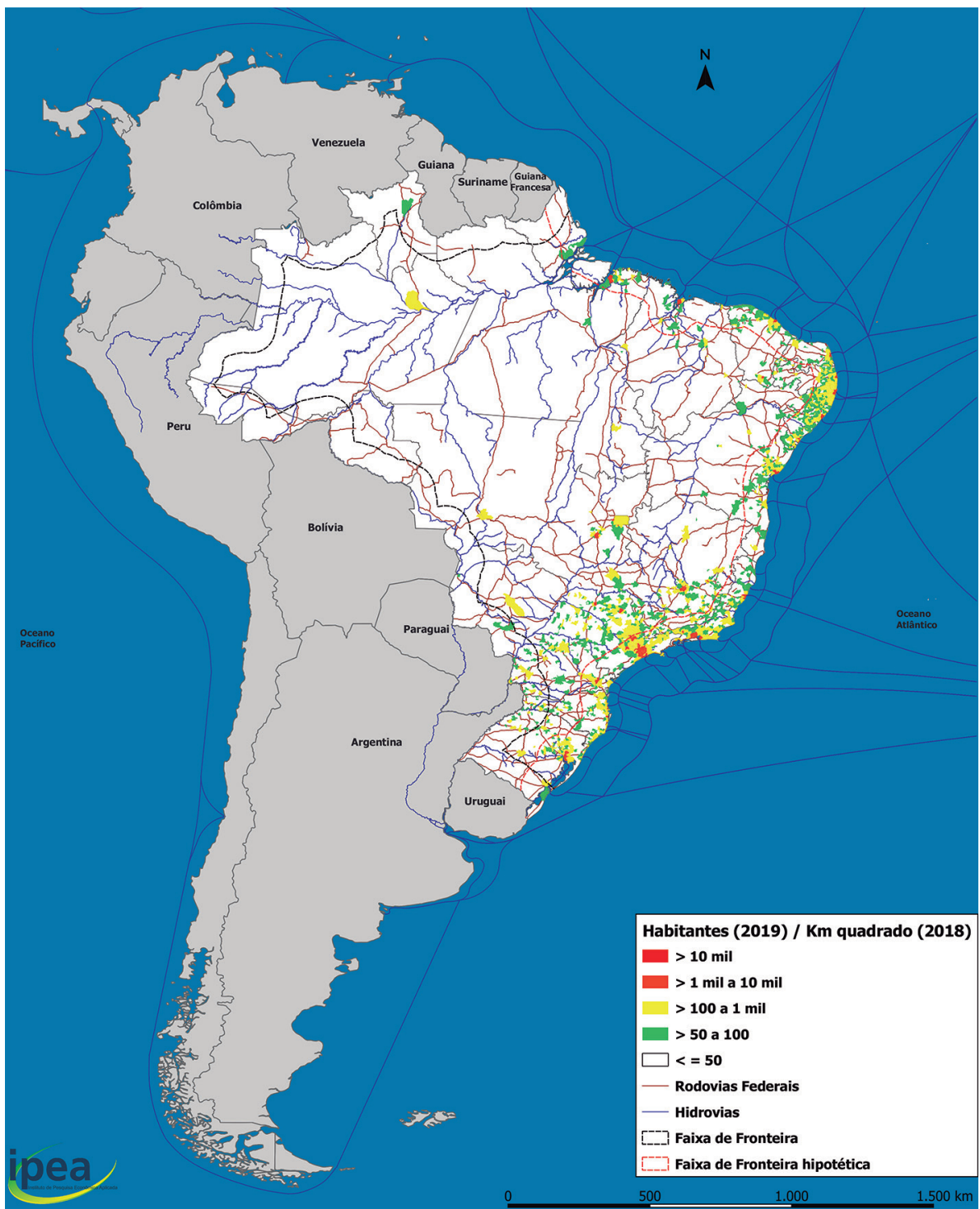

Fontes: IBGE (2019); Malha rodoviária/Departamento Nacional de Infraestrutura de Transportes (DNIT), 2018 (disponível em: <https://bit.ly/362jYUf>; acesso em: 20 jan. 2020); e Plano Nacional de Integração Hidroviária: base de dados geográficos/Agência Nacional de Transportes Aquaviários (Antaq), 2018 (disponível em: <https://is.gd/8EzTFx>; acesso em: 20 jan. 2020).

Elaboração: Equipe Fronteiras Ipea. 
O processo de urbanização concentrada no Brasil, tal qual em outros países do subcontinente América do Sul, ao mesmo tempo que favorece o avanço tecnológico, a inovação, o conhecimento, a difusão e oferta de serviços qualificados, o acesso a bens e espaços públicos e o exercício da cidadania, instaura a desigualdade entre as regiôes. $\mathrm{O}$ adensamento populacional excessivo em algumas áreas coloca em xeque as capacidades dos ecossistemas urbanos e da infraestrutura, bem como faz crescer também a desigualdade entre as pessoas, submetendo determinados segmentos sociais, também os menos providos de acesso ao conhecimento e renda, a condiçōes de maior vulnerabilidade social, além de provocar efeitos ambientais danosos, como se verá na sequência desta subseção.

\subsubsection{Economia e geração de renda}

Ao tratar-se da economia do mar - ou economia oceânica, economia dos oceanos e economia azul -, constata-se que há pouca discussão acerca do tema, seja no âmbito acadêmico, seja no governamental. Inexistem estudos suficientes, e até mesmo não há convergência sobre quais informaçóes deverão ser consideradas em sua definiçãa, embora não haja dúvida de que essa economia representaria o conjunto de atividades que direta ou indiretamente se dão ou se utilizam dos recursos do mar, ainda que ocorram em suas adjacências, no processo de expansão das fronteiras econômicas de países defrontantes aos oceanos para além de seus domínios terrestres.

Dedicar-se a construir esse conceito é imperativo e, para tal, há alguns temas imprescindíveis a serem considerados, como o crescimento e o desenvolvimento sustentáveis e inclusivos, com melhoria no bem-estar das comunidades costeiras; ampliação de suas oportunidades econômicas e proteção social; superação dos riscos derivados de exploraçóes e usos inadequados ou excessivos; e capacidade de resposta aos desastres naturais e aos impactos provocados pelas mudanças climáticas.

Também se fala sobre o produto interno bruto (PIB) do mar. Segundo Carvalho (2018), ainda não há dados estatísticos específicos para a contabilização e a contribuição econômica dos recursos ofertados pelo mar. Para a economia brasileira, isso significa dizer que: "não há nas contas nacionais brasileiras distinção entre indústrias marinhas e não marinhas, de tal forma que a economia do mar, ou PIB do mar, como é chamado em alguns países, não é estimada" (op. cit., p. 23).

Há de observar-se que, nos últimos anos, o Brasil ampliou suas fronteiras, mas não vem otimizando as oportunidades que a economia do mar pode oferecer, particularmente para seu desenvolvimento. O petróleo e o gás natural são os principais recursos a serem explorados na PC brasileira, e seus potenciais econômicos vêm sendo analisados e aproveitados. Mas outros recursos e possibilidades abrem-se na área de tecnologias, processos e produtos voltados para o mar, como a biotecnologia, a energia, a logística naval e offshore, obras costeiras e portuárias - todas com melhores resultados se associadas à pesquisa acadêmica, aos parques tecnológicos de centros universitários, entre outras parcerias que se embrionam na costa brasileira. 
Parte do contingente populacional da FFL está ocupada em atividades socioeconômicas, direta ou indiretamente, ligadas a produção de petróleo e gás natural, refinarias, portos, aeroportos, turismo, pesca e serviços que atendem à dinâmica econômica gerada por esses municípios. Abrangem, também, outros municípios que integram suas regióes de influência, além dos demais do território que afluem aos principais portais de entrada e saída de pessoas e mercadorias do país.

No que se refere à geração de riqueza, os municípios da FFL respondem por $62,4 \%$ do PIB brasileiro, em 2016. Vêm seguidos pelo conjunto dos demais municípios, que somam 33,1\% desse total. A participação dos municípios da FFT é pouco significativa, ficando em apenas $4,9 \%$ do total do produto.

A FFL tem quinze municípios com participação superior a $1 \%$ do PIB nacional, em 2016, enquanto a FFT não tem algum (tabela 4). Entre estes, destacam-se São Paulo, com participação de 10,8\%, seguido de Rio de Janeiro (5,2\%) e de Curitiba, Osasco (na área metropolitana de São Paulo) e Porto Alegre, com pouco mais de $1 \%$ do total do PIB. Em termos proporcionais a cada recorte, a FFL é a que tem menores percentuais de municípios no estrato com menos de 0,01\% de participação, correspondendo a 74,36\% dos municípios; a FF tem a maior proporção, alcançando $81,23 \%$ dos municípios. Entre os demais municípios, Brasília (3,70\%), Belo Horizonte (1,39\%), Manaus (1,10\%), Goiânia (0,73\%) e Uberlândia $(0,51 \%)$ sobressaem-se com as maiores participaçóes.

TABELA 4

Número de municípios e participação no total do PIB por estratos, segundo recorte territorial - Brasil (2016)

\begin{tabular}{lcccc}
\hline \multirow{2}{*}{ Estrato } & \multicolumn{4}{c}{ Recorte teritorial (no de municípios) } \\
\cline { 2 - 5 } & FFL & FFT & Demais municípios & Brasil \\
\hline$>5$ & 2 & 0 & 0 & 2 \\
$>1$ a 5 & 3 & 0 & 3 & 6 \\
$>0,5$ a 1 & 10 & 0 & 2 & 12 \\
$>0,1$ a 0,5 & 86 & 7 & 39 & 130 \\
$>0,01$ a 0,1 & 429 & 103 & 474 & 1.001 \\
$<=0,01$ & 1.538 & 476 & 2.428 & 4.419 \\
Número de municípios & 2.068 & 586 & 2.946 & 5.570 \\
$>5$ & 0,10 & 0,00 & 0,00 & 0,04 \\
$>1$ a 5 & 0,15 & 0,00 & 0,10 & 0,11 \\
$>0,5$ a 1 & 0,48 & 0,00 & 0,07 & 0,22 \\
$>0,1$ a 0,5 & 4,16 & 1,19 & 1,32 & $\mathbf{2 , 3 3}$ \\
$>0,01$ a 0,1 & 20,75 & 17,58 & 16,08 & 17,97 \\
$<=0,01$ & 74,36 & 81,23 & 82,42 & $\mathbf{7 9 , 3 4}$ \\
Participação no total (\%) & 100,00 & 100,00 & 100,00 & 100,00 \\
\hline
\end{tabular}

Fonte: IBGE.

Elaboração: Equipe Fronteiras Ipea. 
A distribuição dos municípios conforme participação no PIB (mapa 7) também privilegia a faixa litorânea e proximidades, particularmente nos litorais do Nordeste, Sudeste e Sul. Desde essa faixa, adentra com expressividade o sul e sudeste de Minas Gerais, o entorno do eixo Brasília-Anápolis-Goiânia, no Centro-Oeste, todo o interior do estado de Sáo Paulo, o norte e o oeste paranaenses, o oeste catarinense, o noroeste rio-grandense e as regióes central e metropolitana do Rio Grande do Sul.

\section{MAPA 7}

Participação do PIB dos municípios no total do PIB do Brasil (2016)

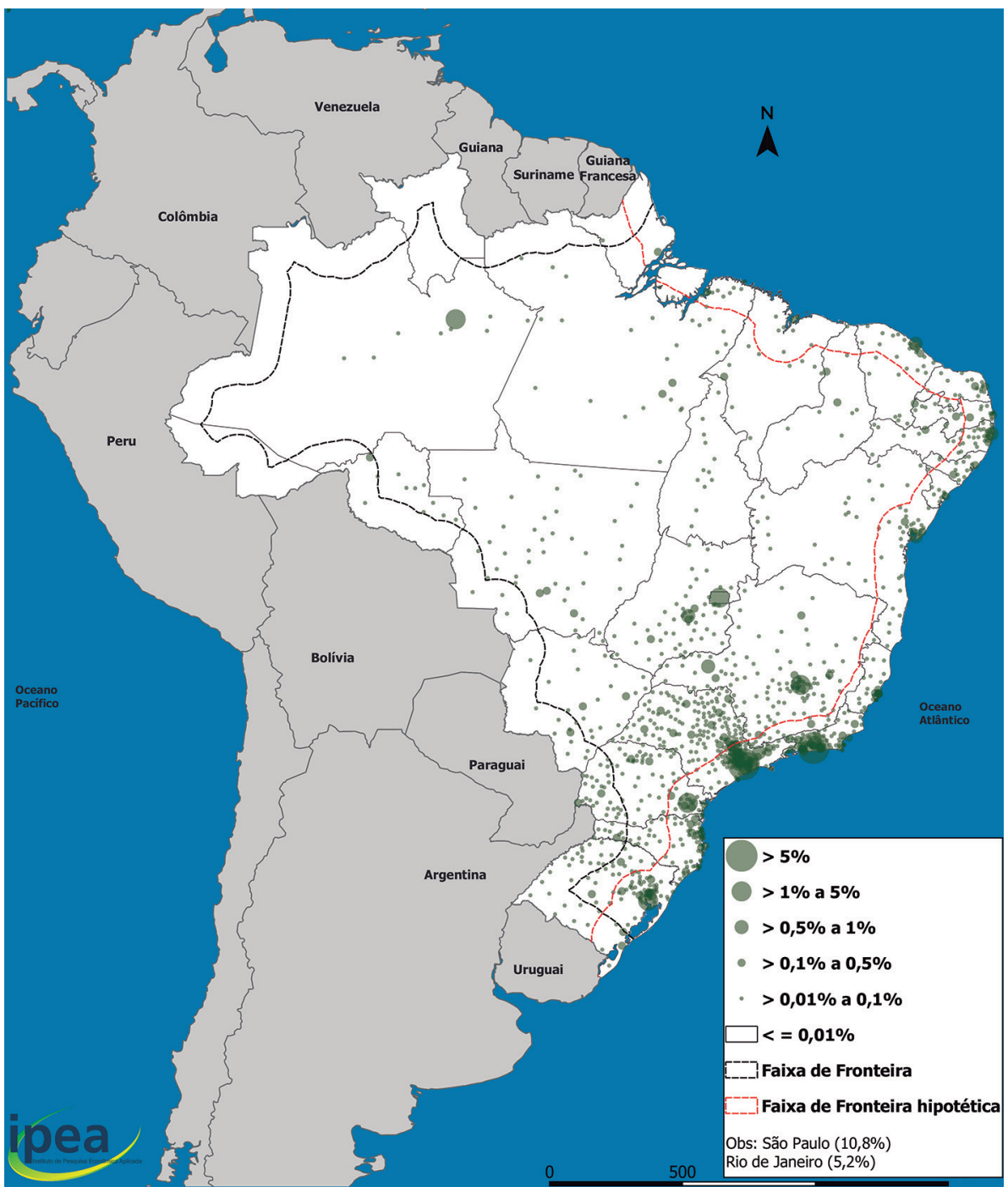

Fonte: IBGE (2016b).

Elaboração: Equipe Fronteiras Ipea. 
A composição do PIB setorial dos municípios, em 2016, conforme o IBGE (2016b), indica a agropecuária como atividade econômica predominante em 1.150 municípios brasileiros, privilegiando um elevado número de municípios dos arcos Central e Sul na FFT (mapa 8). Os serviços são predominantes em 1.897 municípios, e administração, defesa, educação e saúde públicas e seguridade social são destacadas dos serviços devido à importância dessas atividades na economia brasileira, em 2.144 municípios. Em relação à faixa de FFL, nos municípios das porçôes Norte e Nordeste predominam os serviços do grupo destacado referente à administração pública e à seguridade social, além dos demais serviços. Nas porçôes Sudeste e Sul, destacam-se os serviços e, em alguns municípios, a indústria. 
MAPA 8

PIB dos municípios: atividades econômicas predominantes - Brasil (2016)

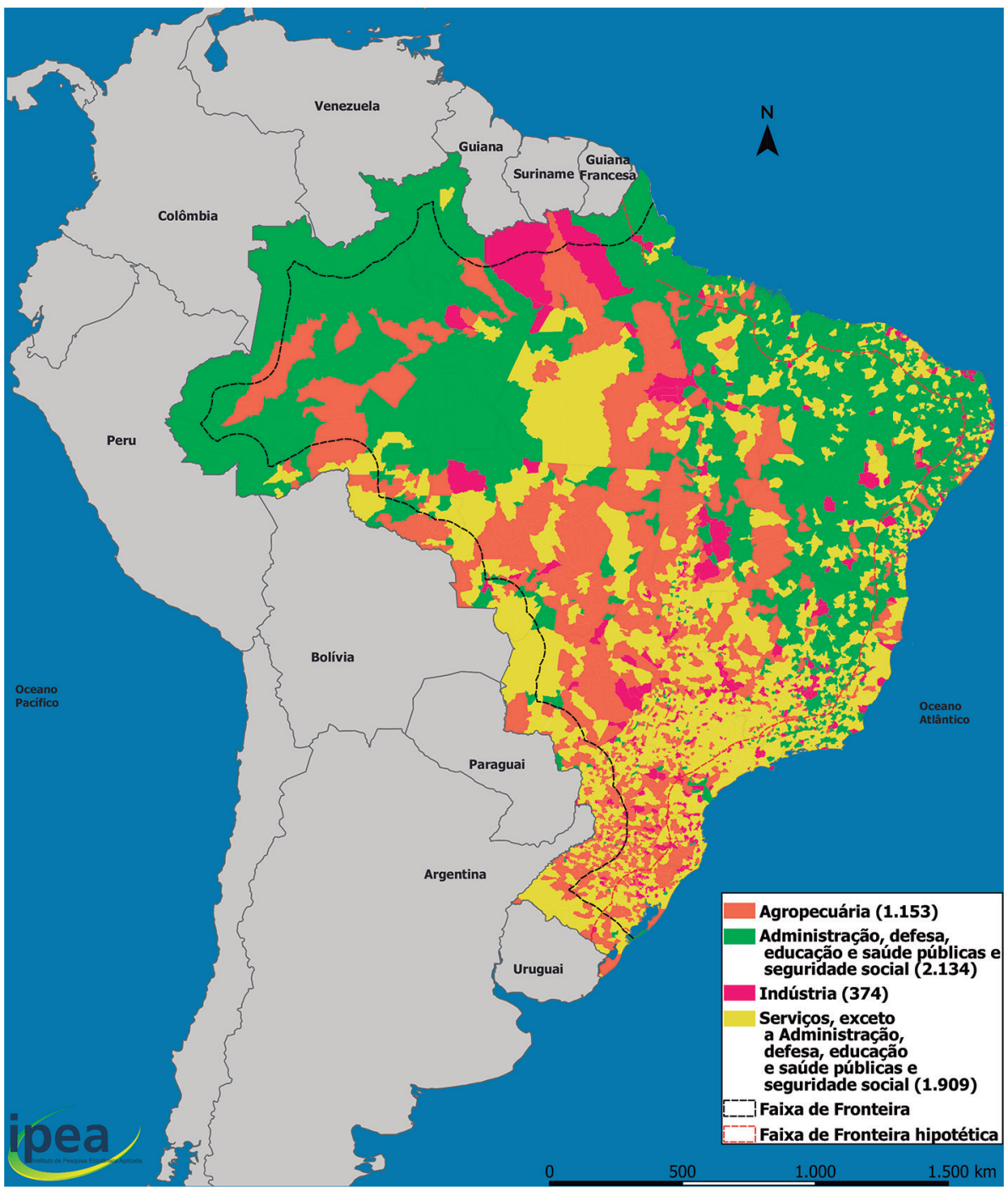

Fonte: IBGE (2016b).

Elaboração: Equipe Fronteiras Ipea.

No Brasil, a atividade industrial é predominante em apenas 379 municípios. Na FFL, há elevado número de municípios que têm a indústria como preponderante na geração do PIB, quase sempre localizados nas áreas metropolitanas das capitais estaduais. A indústria tem pouca presença entre os municípios da FFT, salvo correspondendo às atividades da indústria extrativa, no arco Norte, e de transformação - particularmente, a agroindústria -, nos arcos Central e Sul. 
No já citado estudo sobre aglomeraçóes industriais relevantes - AIRs (Neto, Silva e Severian, 2019), aquelas AIRs que comportam o maior número de empregos industriais (mais que 100 mil) são em número de doze, e, exceto a AIR correspondente a Belo Horizonte, todas as demais se localizam na FFL. Mais precisamente, situam-se em municípios das aglomeraçóes metropolitanas de São Paulo, Rio de Janeiro, Curitiba, com extensão ao leste catarinense, e Porto Alegre, estendendo-se a Caxias do Sul, bem como no Nordeste, na área metropolitana de Fortaleza (figura 2).

\section{FIGURA 2}

Grupos de AIRs, segundo número de empregos industriais gerados - Brasil (2015)

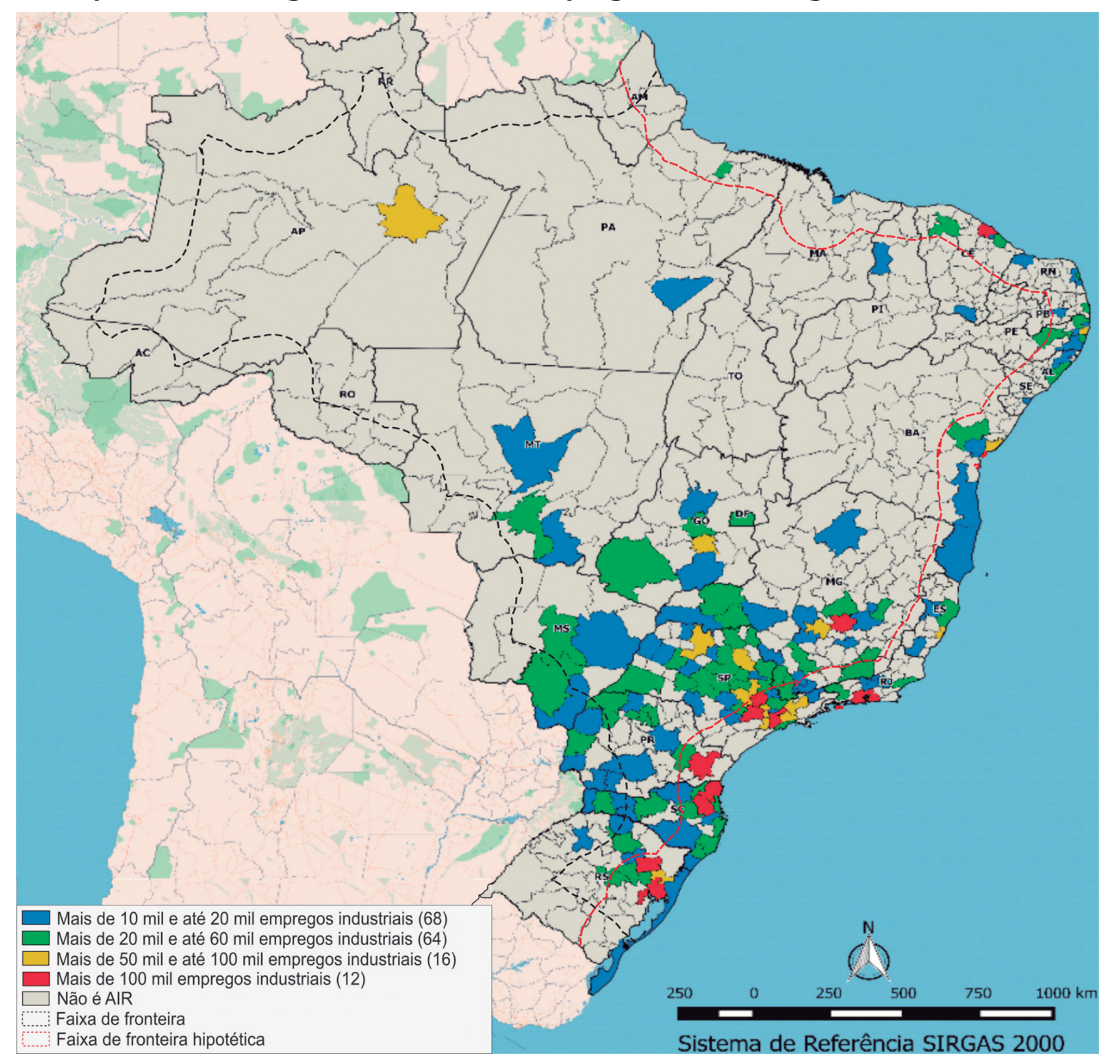

Fonte: Neto, Silva e Severian (2019, p. 27).

Adaptação: Equipe Fronteiras Ipea.

Os demais grupos, com número de emprego industrial superior a 10 mil e inferior a 100 mil, consolidam a relevância da presença da indústria na FFL, desde o Nordeste brasileiro, interiorizando-se no território a partir do Espírito Santo, em direção ao Centro-Oeste, preenchendo grande parte dos municípios do estado de São Paulo e, de modo não tão adensado, do Paraná, de Santa Catarina e do Rio Grande do Sul. 
Os serviços formam um setor representativo da atividade econômica na FFL. Esse setor, que responde por mais de metade da composição do PIB em 81,8\% dos municípios brasileiros, é pouco concentrador no Brasil; porém, segundo informações do IBGE, há atividades cuja estrutura de mercado registram grau de concentração elevado, como o transporte dutoviário (99,7\%), o transporte aéreo $(92,2 \%)$, o transporte ferroviário e metroviário $(82,0 \%)$, bem como o correio e outras atividades de entrega $(81,6 \%){ }^{7}$ Essas atividades estão territorialmente concentradas, como se abordará na sequência do trabalho, o que confirma a presença iniludível dos serviços na FF em análise (mapa 8). Ademais, a presença da atividade turística relacionada ao mar aumenta ainda mais a participação desse setor na geração de renda dos municípios defrontantes, entre outros.

3.1.3 Potencial de fixos (infraestrutura econômica) e realização de fluxos

$\mathrm{Na}$ FFL, adensam-se os elementos fixos que sustentam territorialmente as redes para fluxos nacionais e internacionais. Trata-se, entre outras, das principais infraestruturas de conectividade internas e externas ao país, fundamentalmente aeroportos e portos. Portanto, nessa FFL aterrissa a maior parte dos fluxos que atravessam a fronteira aérea brasileira.

$\mathrm{Na}$ FFL, localizam-se 55,9\% dos aeroportos de categoria internacional e 23,3\% dos de categoria nacional; dos 35 portos organizados existentes no país, 32 encontram-se nesse recorte territorial (tabela 5).

TABELA 5

Aeroportos internacionais, nacionais e portos organizados, segundo recortes territoriais - Brasil (2018)

\begin{tabular}{|c|c|c|c|c|}
\hline \multirow{2}{*}{ Terminal } & \multicolumn{4}{|c|}{ Recorte territorial } \\
\hline & $\mathrm{FFL}$ & FFT & Demais municípios & Brasil \\
\hline \multicolumn{5}{|c|}{ Aeroporto internacional } \\
\hline Quantidade & 19 & 11 & 6 & 34 \\
\hline$\%$ & 55,88 & 32,35 & 17,65 & 100,00 \\
\hline \multicolumn{5}{|c|}{ Aeroporto nacional } \\
\hline Quantidade & 142 & 92 & 380 & 609 \\
\hline$\%$ & 23,32 & 15,11 & 62,40 & 100,00 \\
\hline \multicolumn{5}{|c|}{ Porto organizado } \\
\hline Quantidade & 32 & 3 & 2 & 35 \\
\hline$\%$ & 91,43 & 8,57 & 5,71 & 100,00 \\
\hline
\end{tabular}

Fonte: Localização geográfica: aeródromos civis brasileiros (públicos e privados)/Agência Nacional de Aviação Civil (Anac), 2018. Disponível em: <https://bit.ly/3pWXdbW>. Acesso em: 20 jan. 2020.

Elaboração: Equipe Fronteiras Ipea.

Obs.: Há dois aeroportos internacionais (Pelotas/RS e Bagé/RS), cinco aeroportos nacionais (Aceguá/RS, Candiota/RS e Rio Grande/RS; e Oiapoque/AP e Macapá/AP) e dois portos organizados (Pelotas/RS e Rio Grande/RS) comuns às FFTs e FFLs.

7. Disponível em: <https://is.gd//eiN7qK>. Acesso em: 13 nov. 2019. 
O aeroporto de Guarulhos é o maior em movimentação de passageiros e cargas nacionais e internacionais. $\mathrm{O}$ do Galeão é o segundo maior em movimentação internacional de passageiros e o de Viracopos (Campinas) o segundo maior em movimentação de cargas nacionais e internacionais. Os onze aeroportos de maior movimento destacados são destinos de mais de $90 \%$ do transporte de passageiros, cargas e correio (tabela 6). Desses aeroportos, apenas Confins (Belo Horizontel MG), o de Brasília/DF e o de Manaus/AM estão localizados fora da FFL.

TABELA 6

Participação no movimento internacional com destino ao Brasil (2018)

\begin{tabular}{|c|c|c|c|c|c|c|}
\hline Aeroporto - destino & $\begin{array}{c}\text { Passageiros } \\
\text { pagos }\end{array}$ & $\begin{array}{l}\text { Passageiros } \\
\text { grátis }\end{array}$ & $\begin{array}{l}\text { Carga paga } \\
(\mathrm{kg})\end{array}$ & $\begin{array}{c}\text { Carga grátis } \\
(\mathrm{kg})\end{array}$ & $\begin{array}{c}\text { Correio } \\
(\mathrm{kg})\end{array}$ & Decolagens \\
\hline Guarulhos/SP & 61,93 & 61,97 & 51,88 & 75,36 & 99,57 & 54,45 \\
\hline Galeão/RJ & 18,84 & 21,13 & 12,38 & 10,77 & 0,66 & 18,70 \\
\hline Viracopos (Campinas/SP) & 2,69 & 6,23 & 27,21 & 0,46 & 0,00 & 7,21 \\
\hline Confins/MG & 2,52 & 2,49 & 1,04 & 0,00 & 0,10 & 2,57 \\
\hline Recife/PE & 2,29 & 1,66 & 1,64 & 0,02 & 0,00 & 2,20 \\
\hline Porto Alegre/RS & 2,17 & 1,13 & 0,39 & 9,86 & 0,01 & 3,44 \\
\hline Brasilia/DF & 2,08 & 1,20 & 0,07 & 0,00 & 0,00 & 2,21 \\
\hline Salvador/BA & 1,71 & 0,89 & 1,41 & 0,88 & 0,00 & 1,66 \\
\hline Fortaleza/CE & 1,63 & 1,24 & 1,40 & 2,12 & 0,02 & 1,53 \\
\hline Manaus/AM & 0,56 & 0,32 & 0,76 & 0,03 & 0,00 & 2,19 \\
\hline Curitiba/PR & 0,33 & 0,01 & 0,43 & 0,14 & 0,00 & 1,29 \\
\hline Demais & 3,26 & 1,75 & 1,38 & 0,37 & $-0,35$ & 2,56 \\
\hline Total & 100,00 & 100,00 & 100,00 & 100,00 & 100,00 & 100,00 \\
\hline Mais movimentados & 96,74 & 98,25 & 98,62 & 99,63 & 100,35 & 97,44 \\
\hline $\mathrm{FFL}$ & 91,59 & 94,25 & 96,75 & 99,60 & 100,25 & 90,47 \\
\hline
\end{tabular}

Fonte: Localização geográfica: aeródromos civis brasileiros (públicos e privados)/Anac, 2018. Disponível em: <https://bit. ly/3pWXdbW>. Acesso em: 20 jan. 2020.

Elaboração: Equipe Fronteiras Ipea.

Obs.: 1. Em itálico, aeroportos que não fazem parte da FFL.

2. As informações apresentadas são apuradas com base em dados periodicamente registrados pelas empresas aéreas na Anac, nos termos da regulamentação vigente. Dados disponíveis até novembro de 2018, colhidos em 17 de novembro de 2019. Disponível em: <https://bit.ly/3ffYOok>. Acesso em: 20 fev. 2020.

3. Passageiros pagos: trata-se daqueles que ocupam assentos oferecidos e que geram receita, com a compra de assentos, para a empresa de transporte aéreo; passageiros grátis: incluem as pessoas que viajam gratuitamente, as que se valem dos descontos de funcionários das empresas aéreas e seus agentes, bem como os funcionários de empresas aéreas que viajam a negócios pela própria empresa; cargas pagas: referem-se à quantidade total, expressa em quilogramas, de todos os bens que tenham sido transportados na aeronave, exceto correio e bagagem, e tenham gerado receitas diretas ou indiretas para a empresa aérea; cargas grátis: concernem à quantidade total, expressa em quilogramas, de todos os bens que tenham sido transportados na aeronave, com exceção de correio e bagagem, e não tenham gerado receitas diretas ou indiretas para a empresa aérea. Disponível em: <https://bit.ly/2HjTIAp>. Acesso em: 20 fev. 2020.

No movimento de partidas, os aeroportos de origem com os maiores volumes de fluxos de pessoas e cargas também são Guarulhos e Galeão, este após Viracopos 
quanto à origem de cargas. Como nos destinos, os onze aeroportos destacados são origem de mais de $90 \%$ xxxdo transporte de passageiros, cargas e correio (tabela 7). Há de chamar-se atenção da participação do aeroporto Salgado Filho (Porto Alegre) no movimento de origem e destino de cargas, e o de Manaus no movimento de origem.

TABELA 7

Participação no movimento internacional de origem no Brasil (2018)

\begin{tabular}{|c|c|c|c|c|c|c|}
\hline $\begin{array}{l}\text { Aeroporto - } \\
\text { origem }\end{array}$ & Passageiros pagos & Passageiros grátis & Carga paga (kg) & Carga grátis (kg) & Correio (kg) & Decolagens \\
\hline Guarulhos/SP & 61,99 & 62,81 & 45,79 & 69,81 & 77,90 & 53,72 \\
\hline Galeão/RJ & 18,74 & 20,03 & 7,65 & 6,15 & 21,99 & 18,40 \\
\hline $\begin{array}{l}\text { Viracopos (Cam- } \\
\text { pinas } / S P)\end{array}$ & 2,71 & 6,49 & 34,15 & 12,22 & 0,00 & 6,41 \\
\hline $\begin{array}{l}\text { Confins (Belo } \\
\text { Horizonte/MG }\end{array}$ & 2,49 & 2,44 & 0,94 & 0,02 & 0,07 & 2,54 \\
\hline Recife/PE & 2,36 & 1,62 & 0,80 & 0,01 & 0,00 & 2,21 \\
\hline Porto Alegre/RS & 2,22 & 1,15 & 0,50 & 10,64 & 0,02 & 3,37 \\
\hline Brasilia/DF & 2,00 & 1,17 & 0,33 & 0,01 & 0,00 & 2,15 \\
\hline Salvador/BA & 1,68 & 0,76 & 0,53 & 0,03 & 0,00 & 1,68 \\
\hline Fortaleza/CE & 1,54 & 1,38 & 0,35 & 0,52 & 0,00 & 1,51 \\
\hline Manaus/AM & 0,59 & 0,30 & 6,51 & 0,00 & 0,01 & 1,97 \\
\hline Curitiba/PR & 0,33 & 0,01 & 1,96 & 0,01 & 0,00 & 1,42 \\
\hline Demais & 3,34 & 1,85 & 0,49 & 0,60 & 0,01 & 4,64 \\
\hline Total & 100,00 & 100,00 & 100,00 & 100,00 & 100,00 & 100,00 \\
\hline $\begin{array}{l}\text { Mais movimen- } \\
\text { tados }\end{array}$ & 96,66 & 98,15 & 99,51 & 99,40 & 99,99 & 95,36 \\
\hline FFL & 91,57 & 94,24 & 91,74 & 99,37 & 99,92 & 88,70 \\
\hline
\end{tabular}

Fonte: Localização geográfica: aeródromos civis brasileiros (públicos e privados)/Anac, 2018. Disponível em: <https://bit. ly/3pWXdbW>. Acesso em: 20 jan. 2020.

Elaboração: Equipe Fronteiras Ipea.

Obs.: 1. Em itálico, aeroportos não inseridos na FFL.

2. As informações apresentadas são apuradas com base em dados periodicamente registrados pelas empresas aéreas na Anac, nos termos da regulamentação vigente. Dados disponíveis até novembro de 2018, colhidos em 17 de novembro de 2019. Disponivel em: <https://bit.ly/3ffYOok>. Acesso em: 20 fev. 2020.

3. Passageiros pagos: trata-se daqueles que ocupam assentos oferecidos e que geram receita, com a compra de assentos, para a empresa de transporte aéreo; passageiros grátis: incluem as pessoas que viajam gratuitamente, as que se valem dos descontos de funcionários das empresas aéreas e seus agentes, bem como os funcionários de empresas aéreas que viajam a negócios pela própria empresa; cargas pagas: referem-se à quantidade total, expressa em quilogramas, de todos os bens que tenham sido transportados na aeronave, exceto correio e bagagem, e tenham gerado receitas direta ou indireta para a empresa aérea; cargas grátis: concernem à quantidade total, expressa em quilogramas, de todos os bens que tenham sido transportados na aeronave, com exceção de correio e bagagem, e não tenham gerado receitas diretas ou indiretas para a empresa aérea. Disponível em: <https://bit.ly/2HjTIAp>. Acesso em: 20 fev. 2020.

Tanto os aeroportos quanto os portos são amplamente conectados por rodovias federais e, no caso dos portos, por ferrovias, particularmente nas regióes Sudeste e Sul, e, em menor quantidade, na região Nordeste. Conectam-se, também, por algumas poucas hidrovias, principalmente na regiáo Norte (mapa 9 e figura 3). Concentram-se na FFL e ao longo dos principais rios da bacia amazônica. 
MAPA 9

Aeroportos internacionais e rodovias federais - Brasil (2018)

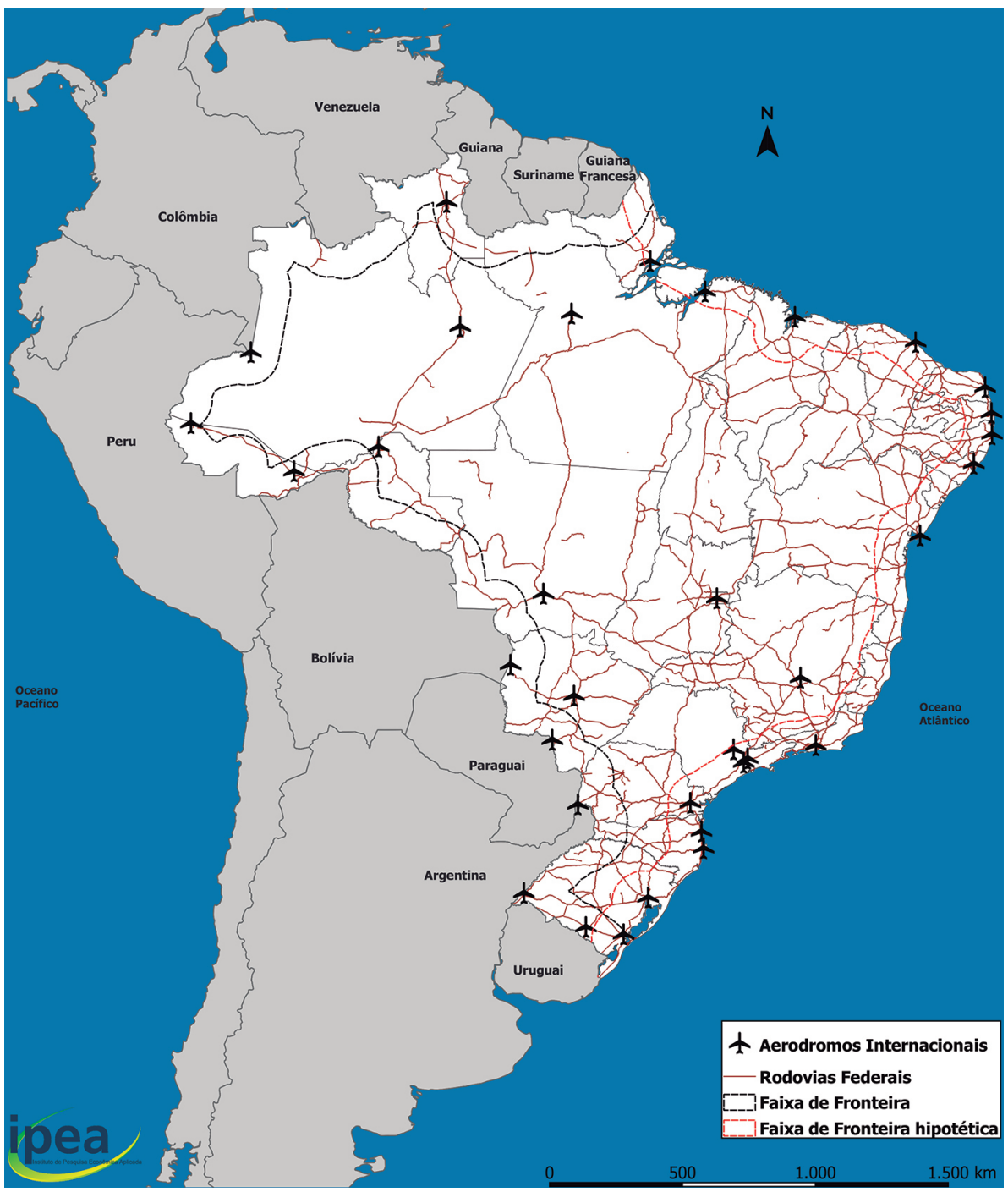

Fontes: Malha rodoviária/DNIT, 2018 (disponível em: <https://bit.ly/362jYUf>; acesso em: 20 jan. 2020); e Localização geográfica: aeródromos civis brasileiros (públicos e privados)/Anac, 2018 (disponivel em: <https://bit.ly/3pWXdbW>; acesso em: 20 jan. 2020).

Elaboração: Equipe Fronteiras Ipea. 
FIGURA 3

Conectividades rodoviária, ferroviária e hidroviária aos portos organizados nacionais Brasil (2018)

$3 \mathrm{~A}$ - Conectividade rodoviária $3 \mathrm{~B}-$ Conectividade ferroviária

3C - Conectividade hidroviária
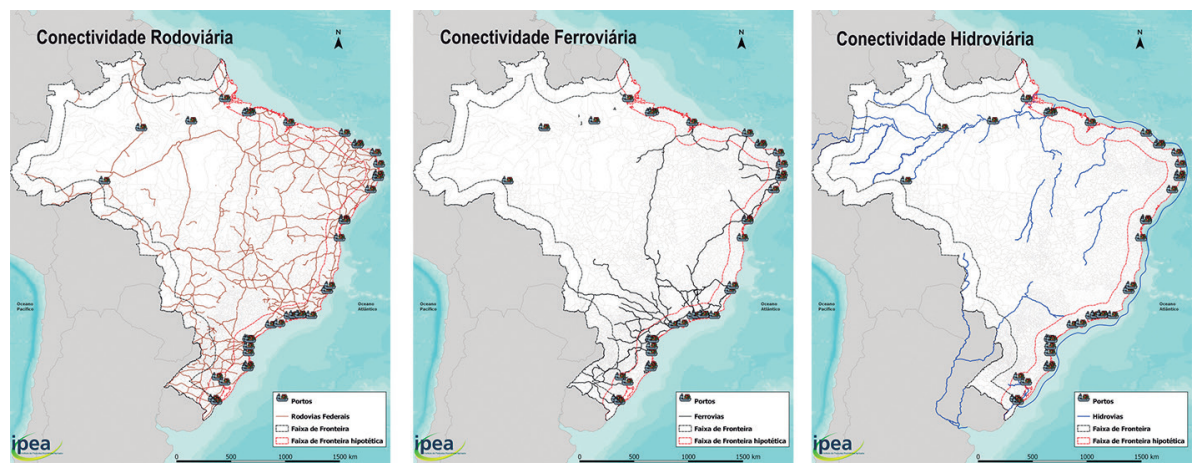

Fontes: Malha rodoviária/DNIT, 2018 (disponível em: <https://bit.ly/362jYUf>; acesso em: 20 jan. 2020); Brasil (2018c); e Plano Nacional de Integração Hidroviária: base de dados geográficos/Antaq, 2018 (disponível em: <https://is.gd/8EzTFx>; acesso em: 20 jan. 2020).

Elaboração: Equipe Fronteiras Ipea.

Em termos de infraestruturas de apoio à produção, a FFL também é localização privilegiada. Exemplifica essa importância a concentração de dutovias, em seus minerodutos, gasodutos e oleodutos, com alguns ramos que beneficiam a FFT; caso do oleoduto do rio Solimôes e dos gasodutos Brasil-Bolívia e Bolívia-Mato Grosso (mapa 10). ${ }^{8}$

8. 0 terminal aquaviário da Petrobras (Coari/Amazonas) recebe petróleo e gás natural produzido na região de Urucu, pelo oleoduto rio Solimões, armazena e entrega a navios para o abastecimento da Refinaria de Manaus, que supre os estados do Pará, de Rondônia, do Maranhão e partes do Ceará e de Pernambuco. Disponível em: <https://bit. ly/333oAaO>. Acesso em 13 dez. 2019. 0 gasoduto Brasil-Bolívia, também operado pela Petrobras, origina-se em Rio Grande e alcança Puerto Suárez, nesse país, entrando no Brasil, em seu trecho norte, por Corumbá/MS, seguindo Guararema/SP, e, em seu trecho sul, de Paulínia/SP a Canoas/RS. Disponível em: <https://is.gd/grrWeZ>. Acesso em: 13 dez. 2019. A GasOcidente de Mato Grosso Ltda. (GOM) opera o gasoduto que se origina em Chiquitos, na Bolívia, e entra nesse estado por Cáceres, indo até a usina termoelétrica de Cuiabá, no Mato Grosso. Disponível em: <https:// bit.ly/2URHfl3>. Acesso em: 13 dez. 2019. 
MAPA 10

Dutovias - Brasil (2018)

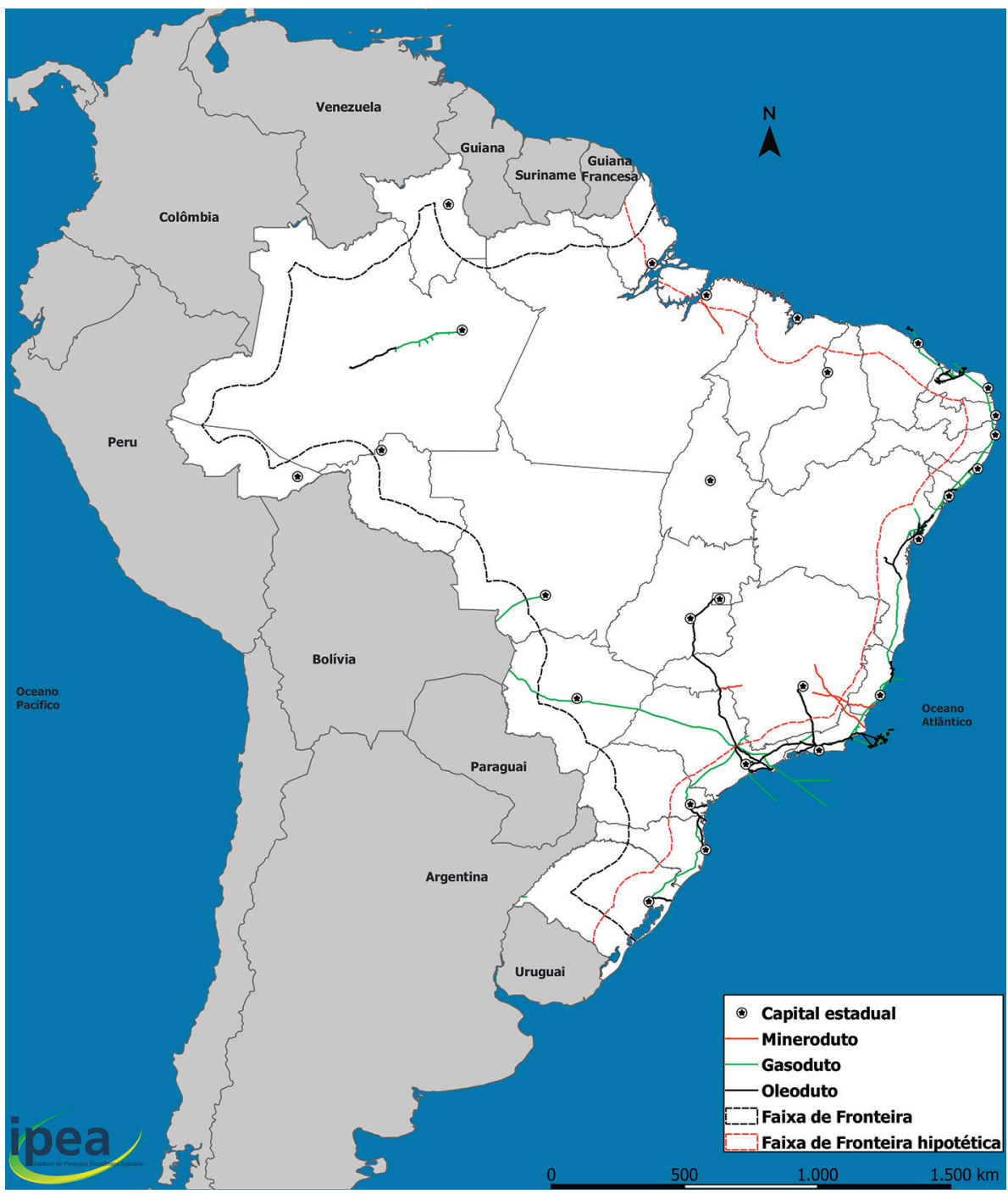

Fonte: Arquivo Shapefile Dutoviário com classificação dutoviária da Empresa de Planejamento e Logística S/A (EPL), 2018. Disponivel em: <https://bit.ly/362tQNJ>. Acesso em: 20 jan. 2020.

Elaboração: Equipe Fronteiras Ipea.

Unidades geradoras de energia também pontuam densamente a FFL. Das usinas eolioelétricas, 59,8\% localizam-se nesse recorte territorial, assim como termelétricas por combustíveis fósseis $(52,3 \%)$ e pequenas centrais hidrelétricas $(30,4 \%)$, para citar as maiores concentraçôes (tabela 8 e figura 4). No caso das usinas termonucleares, as três existentes estâo defrontantes ao Atlântico, na praia 
de Itaorna, em Angra dos Reis/Rio de Janeiro. Similarmente, Porto de Moz/Pará concentra mais de $90 \%$ das usinas fotovoltaicas do país.

TABELA 8

Unidades geradoras de energia e capacidade, segundo recortes territoriais - Brasil (2018)

\begin{tabular}{|c|c|c|c|c|c|c|}
\hline \multirow{3}{*}{ Unidade geradora } & \multicolumn{6}{|c|}{ Recorte territorial } \\
\hline & \multicolumn{2}{|c|}{$\mathrm{FFL}^{1}$} & \multicolumn{2}{|c|}{$\mathrm{FFT}^{1}$} & \multicolumn{2}{|c|}{ Demais municípios } \\
\hline & Quantidade & $\%$ & Quantidade & $\%$ & Quantidade & $\%$ \\
\hline Hidrelétrica & 53 & 26,90 & 27 & 13,71 & 120 & 60,91 \\
\hline Pequena central hidrelétrica & 133 & 30,37 & 94 & 21,46 & 212 & 48,40 \\
\hline Fotovoltaica & 29 & 2,01 & 6 & 0,42 & 1.409 & 97,64 \\
\hline Eolioelétrica & 365 & 59,84 & 61 & 10,00 & 232 & 38,03 \\
\hline Termelétrica (combustível renovável) & 120 & 22,02 & 45 & 8,26 & 382 & 70,09 \\
\hline Termelétrica (combustível fóssil) & 1.233 & 52,29 & 301 & 12,77 & 850 & 36,05 \\
\hline Termonuclear & 3 & 100,00 & 0 & 0,00 & 0 & 0,00 \\
\hline
\end{tabular}

Fonte: Dados geográficos do setor elétrico/Agência Nacional de Energia Elétrica (Aneel), 2018. Disponível em: <https://is.gd/ U2Fd2i >. Acesso em: 20 jan. 2020.

Elaboração: Equipe Fronteiras Ipea.

Notas: ${ }^{1}$ Há trinta municípios que integram tanto a FFT como a FFL.

${ }^{2}$ Aquelas que obtêm energia a partir da biomassa, que compreende qualquer matéria orgânica que possa ser transformada em energia elétrica, térmica ou mecânica.

FIGURA 4

Unidades geradoras de energia - Brasil (2018)

$4 \mathrm{~A}$ - Usinas hidrelétricas

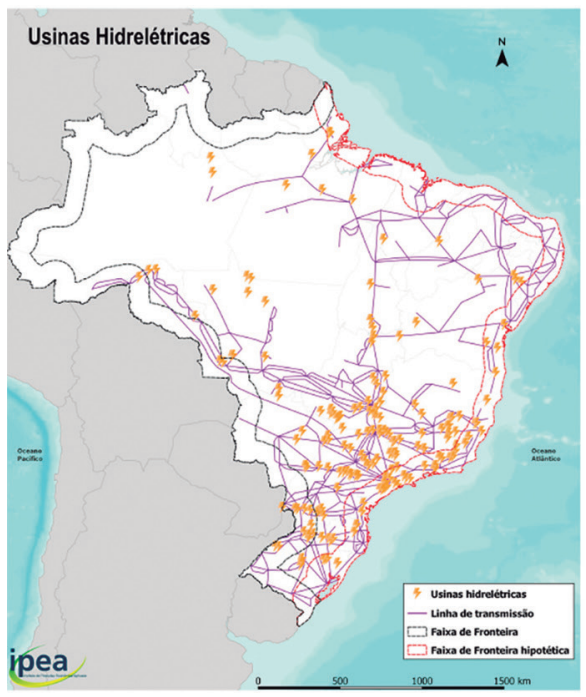

4B - Pequenas centrais hidrelétricas

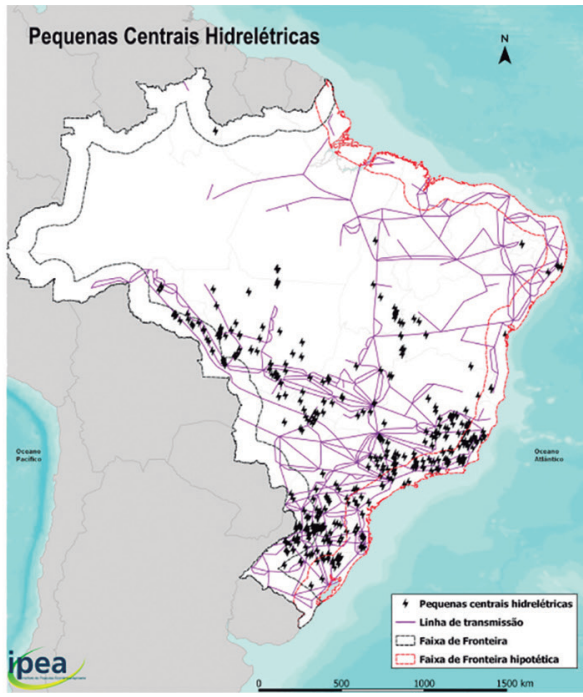


4C - Usinas fotovoltaicas

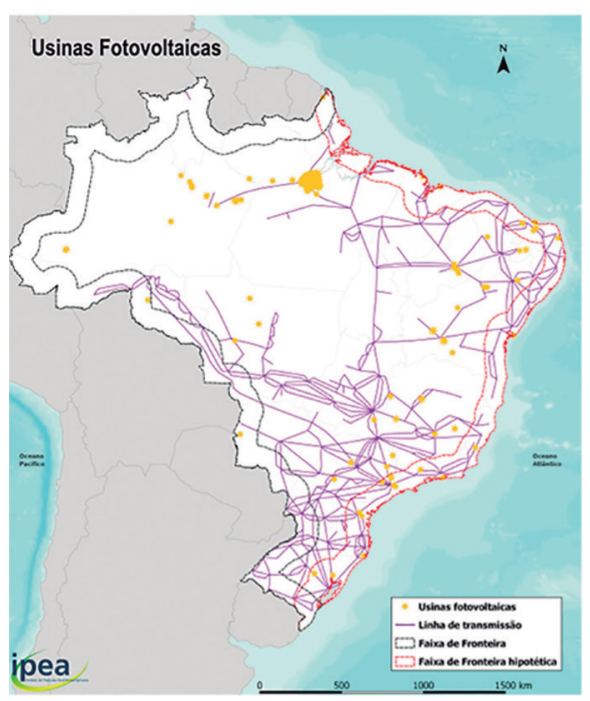

$4 \mathrm{E}-$ Usinas termelétricas

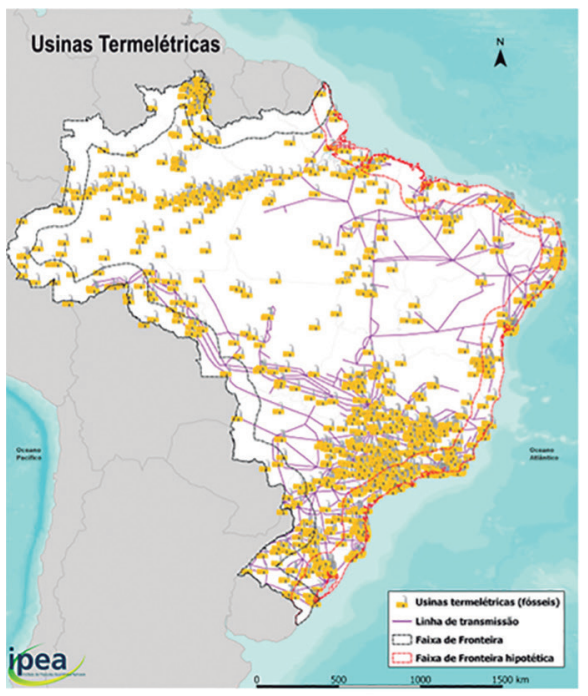

4D - Usinas eolioelétricas

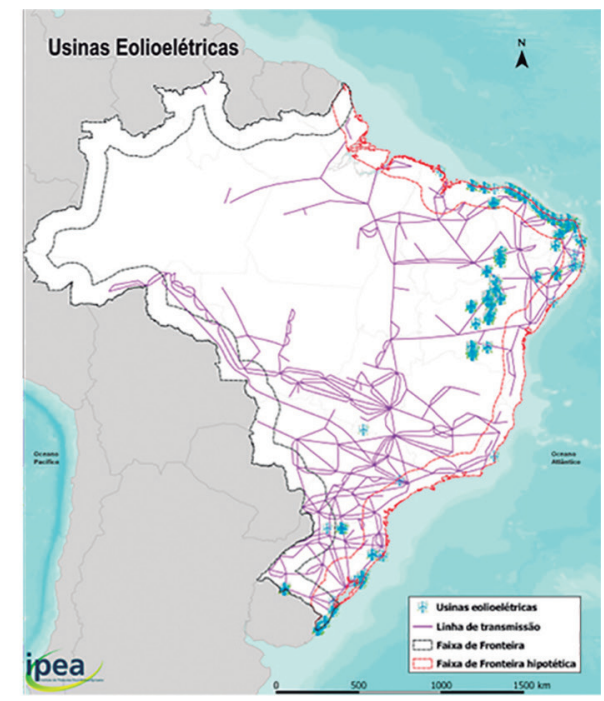

4F - Usinas termelétricas de combustível renovável

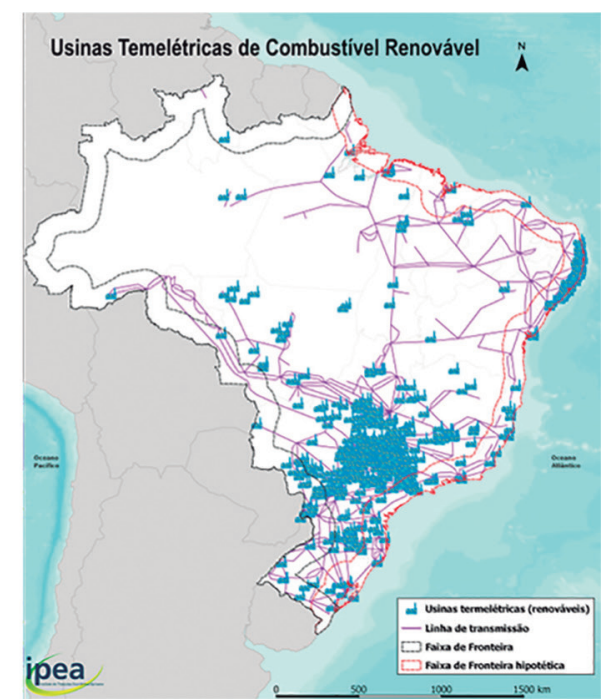

Fonte: Dados geográficos do Setor Elétrico/Aneel, 2018. Disponível em: <https://is.gd/U2Fd2i>. Acesso em: 20 jan. 2020. Elaboração: Equipe Fronteiras Ipea. 


\subsubsection{Fluxos econômicos e mobilidade de pessoas}

Essa concentração de unidades fixas de infraestrutura não faria sentido sem a viabilidade de fluxos, sejam de energia, circulação e informação, assim como de outros materiais e imateriais. Mas, além de unidades geradoras e distribuidoras, ou de portais de recepçáo e partida, uma imensa abertura oceânica permite que, oficial ou clandestinamente, um fluxo de pessoas e mercadorias seja contínuo e intenso na fronteira litorânea.

Considerando-se o movimento oficial de importaçôes e exportações, segundo o Ministério da Economia $(\mathrm{ME})^{9}$ as exportaçōes $(X)$ brasileiras somaram, em 2018, US\$239, 5 bilhões e as importações $(M)$, US\$ 181,2 bilhôes. O fluxo de comércio $(X+M)$ cresceu $13,7 \%$ no ano e chegou a US\$ 420,7 bilhóes. As exportaçôes têm como principais mercados de destino, com desempenho positivo: China (US\$ 66,6 bilhôes, com alta de 32,2\%, na comparação com 2017), com destaque para as exportaçóes de commodities agrícolas e minerais: soja, petróleo bruto, minério de ferro, celulose, carne bovina, ferroliga, carne de frango, algodão em bruto, entre outras; União Europeia (US\$ 42,1 bilhóes, alta de 20,1\%), com destaque a produtos básicos, como farelo de soja, minério de ferro, celulose, café em grão, petróleo bruto, soja, minério de cobre, entre outros; e Estados Unidos (US\$ 28,8 bilhóes, alta de 6,6\%), influenciada pelo crescimento das vendas de aço semimanufaturado, petróleo bruto, partes de motores de aviōes, máquinas e aparelhos para terraplenagem. As exportaçóes brasileiras para esse país, em 2018, foram na ordem de $60 \%$ de bens manufaturados, o que consolida o mercado norte-americano como o maior destino de produtos industrializados do Brasil. A Argentina é o principal parceiro comercial do Brasil na América Latina, mas as exportaçóes (US\$14,9 bilhôes) tiveram queda de 15,5\%, motivada particularmente pela redução nas vendas de produtos do setor automotivo.

Quanto às importaçôes, os principais parceiros comerciais brasileiros correspondem aos das exportaçóes: China (US\$ 35,5 bilhóes, com alta de 26,6\% em relação a 2017); União Europeia (US\$ 34,8 bilhôes, alta de 7,9\%); Estados Unidos (US\$ 28,9 bilhóes, alta de 16,1\%); e Argentina (US\$ 11,1 bilhóes; nesse caso, com alta de 16,7\%).

9. Disponivel em: <https://bit.ly/3fiLM9B >. Acesso em: 17 jan. 2020. 
Toda essa movimentação se vale não apenas majoritariamente de portos marítimos, mas também de aeroportos, como abordado na subseção anterior. Por sua vez, para a produção agropecuária brasileira, que ocupa uma área de grande extensão no território, os fluxos de insumos e os destinos da produção conectam o interior do país à rede de portos. Internamente, circulam fundamentalmente pelas rodovias e em menor escala pelas ferrovias e hidrovias existentes.

A cadeia de grãos representa cerca de $60 \%$ da carga agropecuária de exportação. Em volume, extensão e capilaridade, os grãos de soja e milho são as principais cargas agropecuárias demandantes de infraestrutura e logística do país, e sua utilização dos modais determina o escoamento de outros produtos agropecuários. Estudo da Empresa Brasileira de Pesquisa Agropecuária (Embrapa) delimita oito bacias logísticas da agropecuária brasileira (Castro et al., 2015). ${ }^{10}$ Essas bacias congregam conjuntos de municípios, dos quais o escoamento da safra se dá preferencialmente pelas mesmas rotas, modais e destinos. Com exceção da bacia Norte Ocidental, todas as demais rumam em direção ao litoral brasileiro, e até mesmo a citada, por vias fluviais, alcança portos marítimos para o escoamento de sua safra (mapa 11). 


\section{MAPA 11}

Bacias logísticas da agropecuária - Brasil (2015)

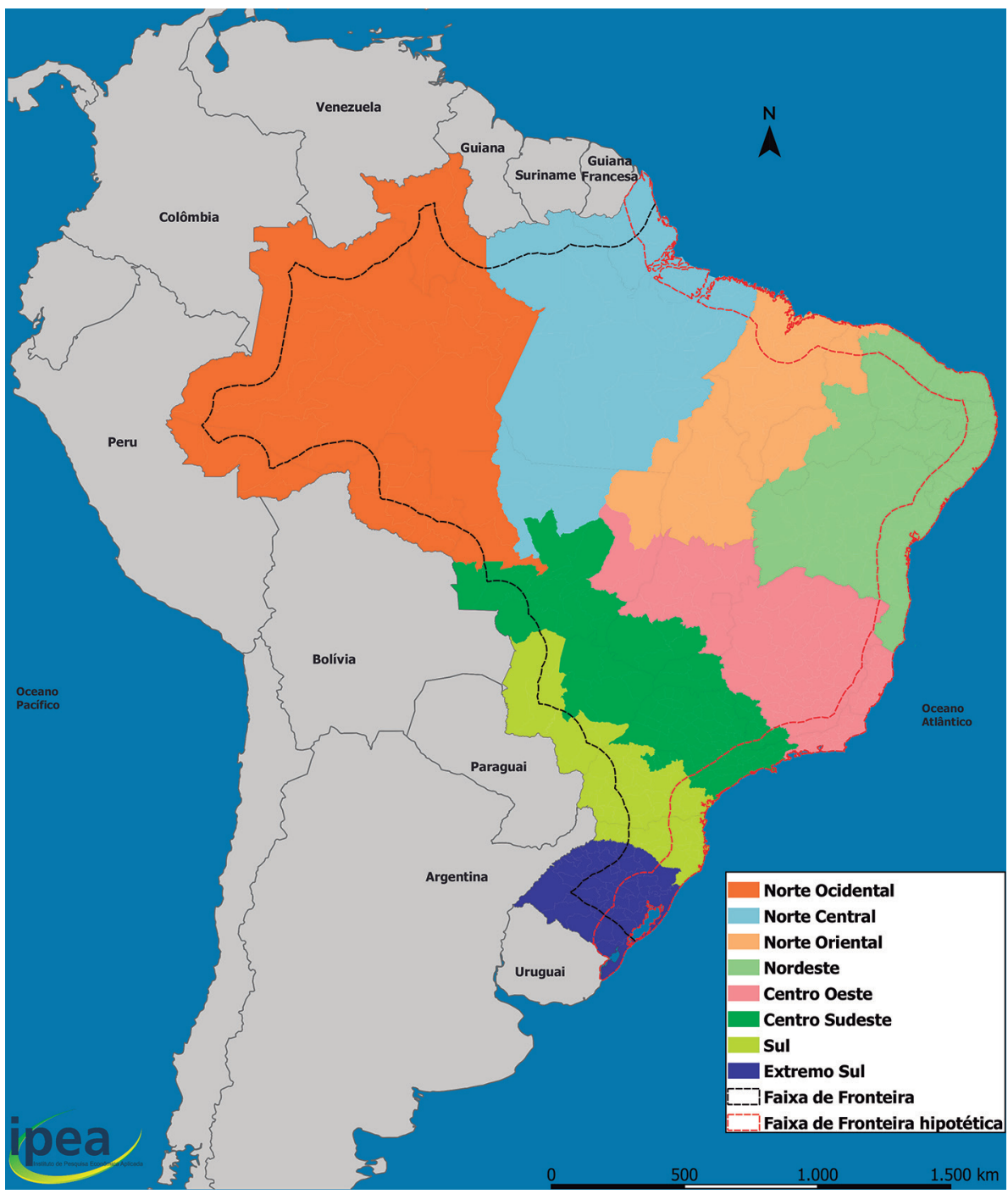

Fontes: Castro et al. (2019) e Áreas territoriais/IBGE, 2018 (disponivel em: <https://bit.ly/3m2NSgw>; acesso em: 20 jan. 2020). Elaboração: Equipe Fronteiras Ipea.

Em outro estudo, realizado pelo Ministério dos Transportes, Portos e Aviação Civil (MTPA), foram mapeados os corredores logísticos estratégicos de exportação, com os destinos da produção do país, particularmente o complexo de soja e milho (figura 5), de minérios de ferro e ferro-gusa (figura 6), bem como de veículos automotores (figura 7), convergindo para os principais portos organizados. 
FIGURA 5

Principais corredores de exportação do complexo soja e milho - Brasil (2015)

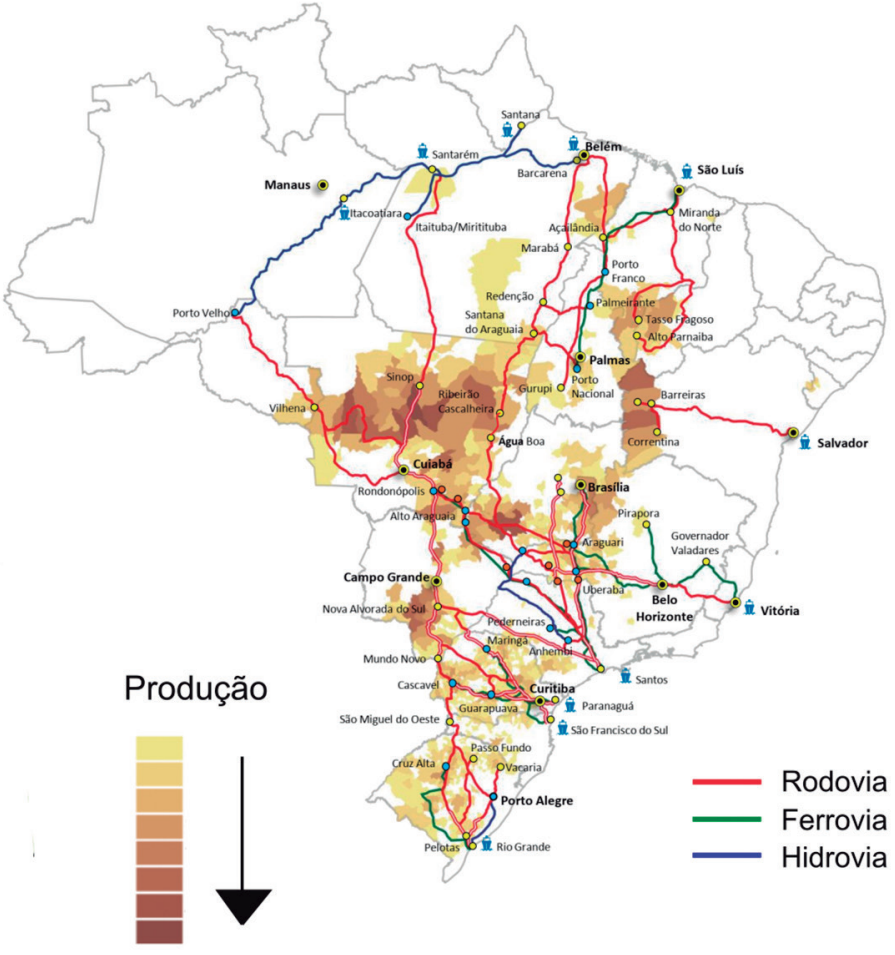

Fonte: Brasil (2017, p. 38).

Adaptação: Equipe Fronteiras Ipea. 
FIGURA 6

Principais corredores de exportação do complexo ferro e ferro-gusa - Brasil (2015)

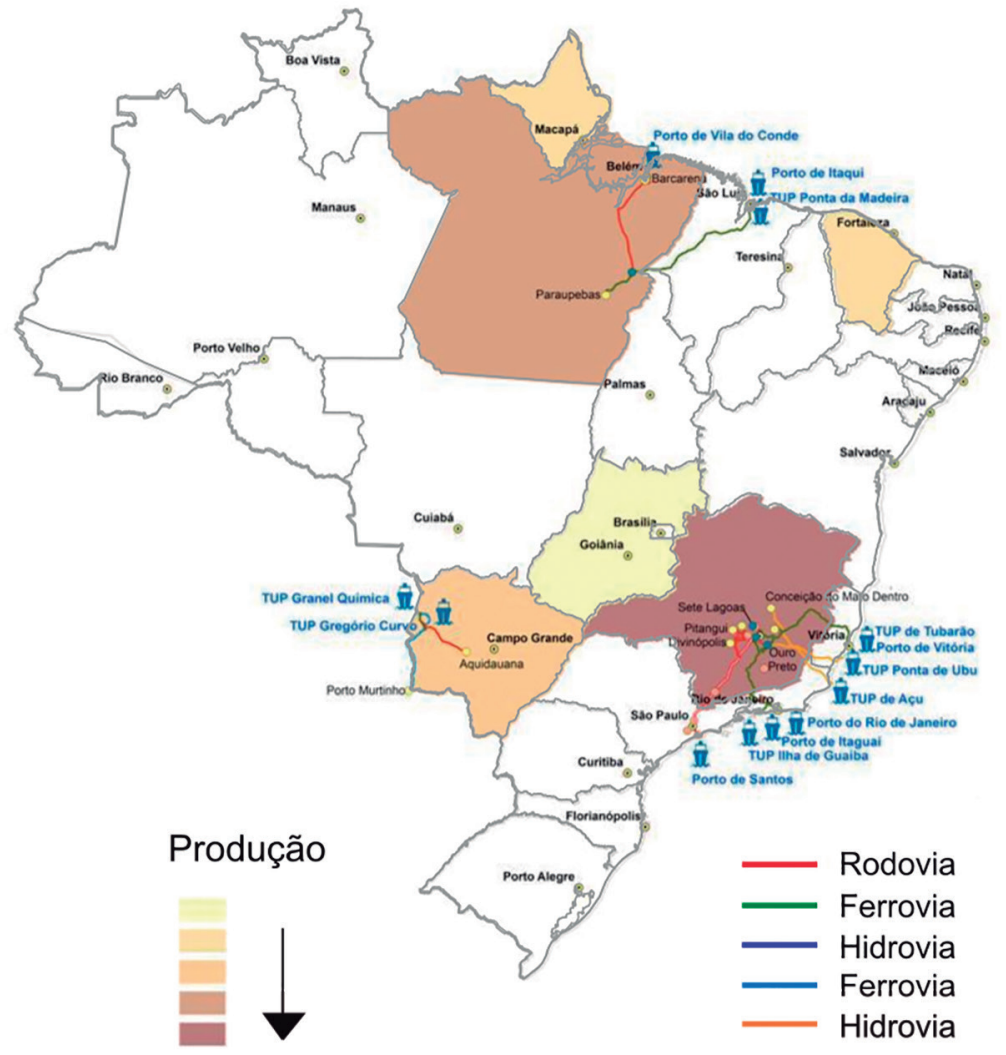

Fonte: Brasil (2018a, p. 53).

Adaptação: Equipe Fronteiras Ipea. 
FIGURA 7

Principais corredores de exportação do complexo veículos automotores - Brasil (2015)

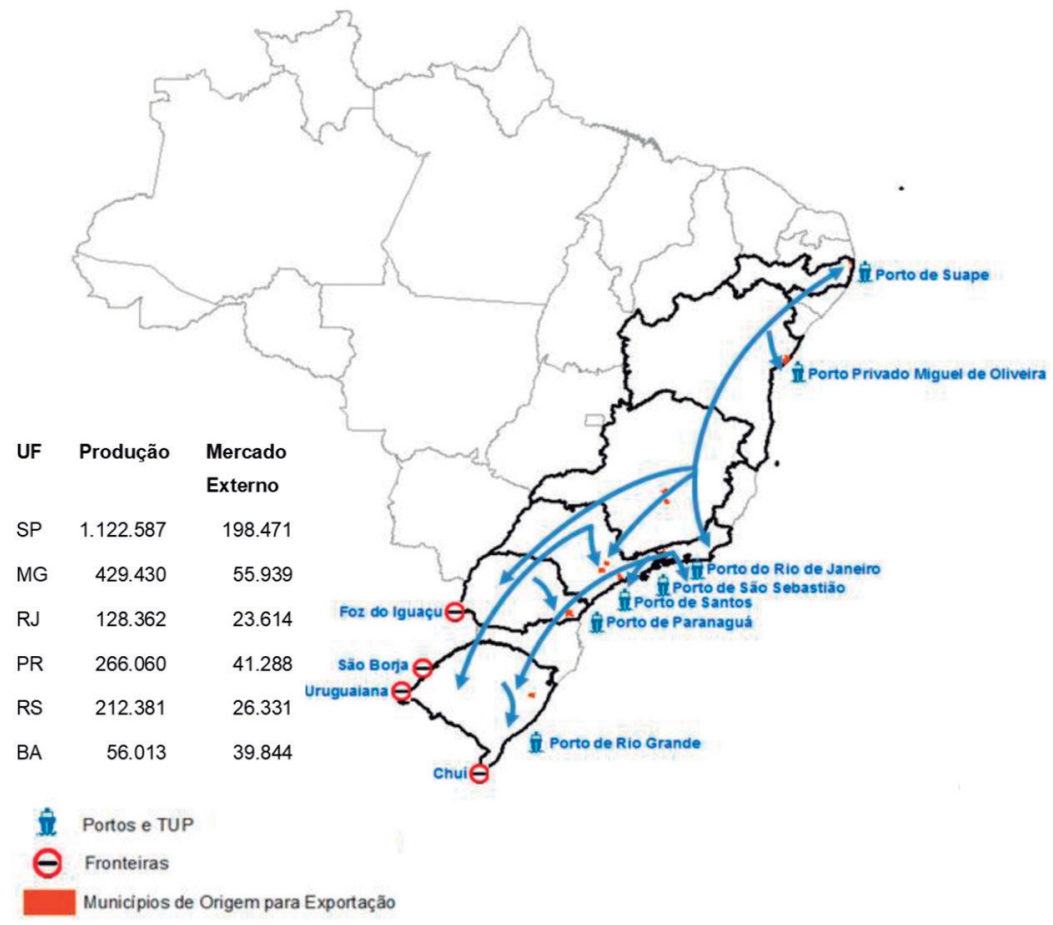

Fonte: Brasil (2018b, p. 32).

Adaptação: Equipe Fronteiras Ipea.

Os portos de destino dos corredores logísticos da produção da região Norte são: Itacoatiara, no Amazonas; Santarém, no Pará; Belém/Barcarena, no Pará; e São Luís, no Maranhão, para produtos do complexo soja e milho. Para minério de ferro e ferro-gusa, são Belém/Barcarena, no Pará; e Itaqui, no Maranhão. Da produção do Nordeste, Salvador, na Bahia, é o destino dos produtos do complexo soja e milho e Suape, em Pernambuco, é o dos veículos automotores. Da produção da região Sul, além de Paranaguá, no Paraná, e São Francisco do Sul, em Santa Catarina, Rio Grande, no Rio Grande do Sul, é também porto de destino da produção do complexo de soja e milho. Rio Grande e Paranaguá são também portos a que se destinam os veículos automotores. Da produção do Centro-Oeste, além de Itacoatiara, no Amazonas; Santarém, no Pará; Belém/Barcarena, no Pará; e São Luís, no Maranhão; também há os portos de Vitória, no Espírito Santo; Santos, em São Paulo; Paranaguá, no Paraná; e São Francisco do Sul, em Santa Catarina, para o complexo soja e milho; e de Corumbá, no Mato Grsso do Sul, para o de minério de ferro e ferro-gusa. 
Os movimentos regulares de pessoas pelas fronteiras brasileiras são majoritariamente por aeroportos e postos da fronteira terrestre. Entre 2010 e 2018, as motivaçóes principais, segundo o relatório anual do Observatório das Migraçóes Internacionais (OBMigra), foram por motivo de turismo, tanto de brasileiros a lazer ou negócios, quanto de estrangeiros em visita ao país, compondo mais de $80 \%$ de entradas e saídas (Cavalcanti, Oliveira e Macedo, 2019). Seguem as pessoas em trânsito, residentes e fronteiriços, em movimentos temporários, estes últimos com participação bem inferior às demais categorias (tabela 9). Vale destacar que o relatório considera fronteiriços os estrangeiros que residem em países limítrofes e obtêm autorização para circular nos municípios brasileiros contíguos às fronteiras com seus países de origem, por motivo de trabalho, bem como para acessar comércio ou serviços. As nacionalidades das pessoas que se movem pelos postos de fronteira são majoritariamente de brasileiros, seguidos por argentinos, estadunidenses, paraguaios, chilenos e uruguaios. ${ }^{11}$

TABELA 9

Entradas e saídas nos pontos de fronteira do território, segundo a classificação - Brasil (2010-2018)

\begin{tabular}{lcccc}
\hline \multirow{2}{*}{ Classes } & \multicolumn{2}{c}{ Entrada } & \multicolumn{2}{c}{ Saída } \\
\cline { 2 - 5 } & Número & $\%$ & Número & $\%$ \\
\hline Brasileiros & 56.780 .919 & 52,9 & 59.292 .885 & 54,7 \\
Residentes & 20.497 .242 & 19,1 & 20.030 .552 & 18,5 \\
Turista & 16.099 .338 & 15,0 & 15.807 .503 & 14,6 \\
Temporários & 6.574 .027 & 6,1 & 6.238 .378 & 5,8 \\
Em trânsito & 5.766 .811 & 5,4 & 5.518 .612 & 5,1 \\
Fronteiriços & 1.551 .526 & 1,4 & 1.597 .732 & 1,5 \\
Outros & 1.988 & 0,0 & 4.769 & 0,0 \\
Total & 107.271 .851 & 100,0 & 108.490 .431 & 100,0 \\
\hline
\end{tabular}

Fonte: Cavalcanti, Oliveira e Macedo (2019).

Elaboração: Equipe Fronteiras Ipea.

Nota: ${ }^{1}$ Reúne não nacionais deportados, expulsos, não aplicável e ignorados.

Entre os postos de fronteira, segundo o relatório citado, os aeroportos internacionais de Guarulhos, do Rio de Janeiro (Galeão), de Viracopos, de Confins e de Porto Alegre são os que operam as maiores movimentaçóes de brasileiros, respondendo por mais de $84 \%$ dos movimentos de entrada e saída (tabela 10).

11. Os cubanos, devido "ao Programa Mais Médicos, a partir de 2013, incrementaram substancialmente as entradas no Brasil. Como na categoria temporários se enquadram os indivíduos amparados pelo Acordo de Residência do Mercosul e aqueles que vêm desenvolver atividades profissionais de curta duração, muito possivelmente em função da crise econômica, que por aqui se instalou com mais força em 2015, os migrantes com origem nos demais países experimentaram redução nos deslocamentos" (Cavalcanti, Oliveira e Macedo, 2019, p. 79). 
TABELA 10

Entradas e saídas de brasileiros do território nacional, por principais aeroportos Brasil (2010-2018)

\begin{tabular}{lcccc}
\hline \multirow{2}{*}{ Aeroporto } & \multicolumn{2}{c}{ Entrada } & \multicolumn{2}{c}{ Saída } \\
\cline { 2 - 5 } & Número & $\%$ & Número & $\%$ \\
\hline Guarulhos (São Paulo) & 34.805 .989 & 60,7 & 35.568 .578 & 59,4 \\
Galeão (Rio de Janeiro) & 9.241 .509 & 16,1 & 9.655 .909 & 16,1 \\
Salgado Filho (Porto Alegre/RS) & 1.689 .380 & 2,9 & 1.774 .181 & 3,0 \\
Confins (Belo Horizonte/MG) & 1.608 .857 & 2,8 & 1.695 .108 & 2,8 \\
Viracopos (Campinas/SP) & 1.318 .008 & 2,3 & 1.346 .907 & 2,2 \\
Outros & 8.708 .633 & 15,2 & 9.874 .603 & 16,5 \\
Total & $\mathbf{5 7 . 3 7 2 . 3 7 6}$ & $\mathbf{1 0 0 , 0}$ & $\mathbf{5 9 . 9 1 5 . 2 8 6}$ & $\mathbf{1 0 0 , 0}$ \\
\hline
\end{tabular}

Fonte: Cavalcanti, Oliveira e Macedo (2019).

Elaboração: Equipe Fronteiras Ipea.

Mas há casos recentes que sinalizam novas estratégias nos movimentos migratórios com destino ao país. Em maio de 2018, uma precária embarcação estrangeira, supostamente de bandeira haitiana, com 25 imigrantes de origem africana, conduzida por dois brasileiros, após 35 dias à deriva no mar, foi resgatada em São José de Ribamar, no Maranhão (Imigrantes..., 2018). É um caso de travessia marítima para imigração ilegal em busca de refúgio no país, com o objetivo de conquistar melhores condiçôes de vida, que se valeu da enorme abertura da fronteira litorânea brasileira.

\subsection{A área marinha}

\subsubsection{Recursos minerais}

Conforme já citado, o Brasil possui soberania de exploração de uma área oceânica de aproximadamente 4,5 milhóes de quilômetros quadrados, o que equivale a cerca de 50\% da sua área continental. Da Amazônia Azul, retira-se cerca de 95\% do petróleo, $80 \%$ do gás natural e $45 \%$ do pescado produzido no país; e, ainda, pelas rotas marítimas escoam-se mais de $95 \%$ do comércio exterior brasileiro. A chamada economia do mar ou economia azul revela-se como a nova fronteira da economia mundial, baseada no uso sustentável dos oceanos e de seus recursos, voltado ao crescimento econômico, ao desenvolvimento tecnológico, à segurança alimentar, à geração de empregos e à preservação do meio ambiente marinho. ${ }^{12}$

O potencial econômico da vasta dimensão das bacias de petróleo do pré-sal foi uma das principais motivaçóes para o pedido de extensão para além das 200 milhas 
do limite da PC. As rochas do pré-sal estendem-se por cerca de $800 \mathrm{~km}$ da plataforma marítima brasileira, do norte da bacia de Campos ao sul da bacia de Santos, compreendendo uma faixa que se estende do litoral sul do estado do Espírito Santo ao estado de Santa Catarina, com largura de até $200 \mathrm{~km}$. Fruto de um longo processo de investimento na tecnologia de exploração em águas profundas, em setembro de 2006, a Petróleo Brasileiro S/A (Petrobras) realizou sua primeira descoberta no campo da bacia de Santos, o poço Tupi (Morais, 2013). Tal descoberta contribuiu para

a duplicação das reservas nacionais, cujos totais comprovados ultrapassaram 30,0 bilhôes de barris de petróleo no final de 2014. (...) a produção do pré-sal ultrapassou um milhão de barris de óleo equivalente (BOE) diários no mês de agosto de 2015 (Judice e Piñon, 2016, p. 30 e 31).

Em agosto de 2019, a produção diária chegou a aproximadamente 2,9 milhóes de barris de petróleo e a de gás natural a 133,3 milhôes de metros cúbicos/dia.

Associado ao mar, outro recurso energético que deve ser destacado pelo seu potencial na redução da dependência de combustíveis fósseis, contribuindo para a desaceleração do aquecimento global, é a geração de energia elétrica a partir de processos marinhos dinâmicos, como ondas, correntes e marés, e termodinâmicos, como gradientes verticais de temperatura e horizontais de salinidade, além dos processos eólicos que ocorrem sobre a ZEE. Tecnologias avançadas no aproveitamento dessa energia por meio de barragens e turbinas submarinas têm sido desenvolvidas em vários lugares do mundo, como a França, a Coreia do Sul, o Canadá, a China e o Reino Unido. No Brasil, uma usina de ondas brasileira foi testada no porto de Pecém, no Ceará, sendo a primeira estrutura da América do Sul a utilizar energia das ondas do mar para produção de energia elétrica. Por sua vez, a costa norte do estado de Sáo Paulo demonstra potencialidade para o aproveitamento da energia gerada pelo atrito entre o ar (vento) e a camada superficial da água (Castro et al., 2017, p. 18).

A Amazônia Azul apresenta, ainda, uma vasta gama de possibilidades de exploração de recursos minerais existentes no leito ou no subsolo marinho. Entre estes, areia e cascalho são aqueles que apresentam maior potencial em volume, depois do petróleo e do gás natural, para a indústria da construção civil; para a agroindústria ou indústria farmacêutica, formas livres de algas calcáreas, como os rodolitos, são potenciais pela alta concentração de carbonato de cálcio e de magnésio; metais nobres, como ilmenita, mozanita, zirconita e rutilo, ocorrem em praticamente toda a Amazônia Azul; e diversos minerais, como fosfatos, potássio, magnésio, enxofre, carvão ou hidratos de metano, foram observados na ZEE brasileira. Portanto, há recursos minerais abundantes de interesse para o Brasil; contudo, esbarram em duas condiçôes principais: a viabilidade econômica em relação ao existente no continente; e tecnologias adequadas para a exploração marinha, que deve considerar ainda uma exploração que não cause impactos ambientais, como 
a destruição de hábitats recifais pelo aumento na turbidez das águas marinhas ou pela remoção de suas camadas (Castro et al., 2017, p. 16-17).

\subsubsection{Recursos vivos}

Em 2010, o Brasil ocupou o 19ำ lugar entre os maiores países produtores de pescado, representando $0,76 \%$ da produção mundial, sendo que desta, $62,1 \%$ consistia em pesca extrativa. Em 2011, o boletim estatístico da pesca e aquicultura do Brasil (Brasil, 2011) registrou um total de 553.670 t de pesca extrativa marinha e de $84.214,3$ t de aquicultura marinha no Brasil. Apesar de os números parecerem expressivos, a verdade é que a pesca no país possui mais um valor social do que econômico. Castro et al. (2017) revelam que

as características físico-químicas das águas da Amazônia Azul não são totalmente favoráveis ao desenvolvimento da cadeia alimentar marinha, tornando, portanto, nossas costas oligotróficas em sua maior parte, isto é, relativamente pobres em nutrientes e com pequena produçấo primária (Castro et al., 2017, p. 13).

Em síntese, de acordo com os autores, a costa brasileira possui pouco peixe ou pequena biomassa, em razão de duas características básicas que limitam a concentração de nutrientes nos locais propícios para a reprodução marinha costeira. ${ }^{13}$ Argumentam que o pouco do pescado existente é disputado por cerca de 1 milhão de pescadores "artesanais", que praticam uma pesca de subsistência ao longo da costa. Ademais, é preocupante o impacto sobre o ecossistema causado na costa pela pesca industrial e comercial de pequena escala, a exemplo do arrasto camaroeiro a partir do qual a integridade física e biológica do fundo marinho é seriamente comprometida (Castro et al., 2017, p. 14).

Os povos do mar, assim considerados os "habitantes tradicionais das áreas costeiras, os pescadores artesanais - também chamados de praieiros, jangadeiros, caiçaras e açorianos" (Callou, 2010, p. 45), possuem características sociais, culturais e tecnológicas praticamente inalteradas ao longo do tempo, justamente por não adquirirem significado histórico na economia brasileira. Assim como os povos da Amazônia (Verde) trazem consigo conhecimentos dos fenômenos naturais (mar e terra) de uma vida anfíbia, entendendo das propriedades das plantas (remédios, construçóes de embarcaçóes e casas), dos ventos, dos movimentos das águas e da vida marinha.

Para Callou, a invisibilidade desses povos passa pelas esferas política e acadêmica, pois as políticas públicas têm sido indiferentes às reivindicaçôes dessa parcela da sociedade:

13. As águas tropicais que atravessam o Atlântico carregadas por correntes marinhas chegam empobrecidas à costa brasileira, sendo que as águas profundas carregadas por essas correntes, embora ricas em nutrientes, permanecem em profundidade onde não há penetração da radiação solar e é dificultada a fotossíntese necessária. 
Política, no sentido de que os movimentos sociais de pescadores precisam ser apoiados pela sociedade, pois, em última instância, os pescadores e pescadoras artesanais fornecem índices consideráveis de pescado para a alimentação no país, ao mesmo tempo em que preservam o meio ambiente, dadas as características do seu modo de vida. Acadêmica, na medida em que as universidades e centros de pesquisa podem produzir mais conhecimento e tecnologias comprometidos com o desenvolvimento sustentável (Callou, 2010, p. 47).

A pesca oceânica, por sua vez, de elevada biomassa, possui ainda uma série de outras vantagens em relaçáo à pesca costeira:

a) grande proximidade das principais áreas de pesca, no caso do Brasil; b) algumas espécies capturadas, como as albacoras, apresentam um alto valor comercial para exportação, constituindo-se em uma importante fonte de divisas para o país; c) outras espécies, também presentes nas capturas, como os dourados, apresentam preço relativamente mais baixo, apesar do seu alto valor nutritivo, representando uma importante fonte de proteínas para o consumo interno; d) ciclo de vida independente dos ecossistemas costeiros, já intensamente degradados; e e) ampla distribuição (Hazin, 2010, p. 36).

Contudo, de acordo com Hazin (2010), o estoque da maioria de atuns e afins, a exemplo dos estoques costeiros, já está sendo capturado em níveis próximos às capacidades máximas sustentáveis. Assim, a continuidade das atividades depende de negociações internacionais para ampliação da sua cota, além de vencer outros entraves; entre estes, a falta de máo de obra especializada, de tecnologia e de embarcaçôes adequadas e, também, de pesquisa e informações técnicas capazes de contribuir para aumentar a competitividade e a eficiência da frota nacional.

A aquicultura é considerada um caminho de grande interesse para a redução do deficit mundial entre a demanda e a oferta de pescados. $\mathrm{O}$ Brasil apresenta em sua privilegiada extensão litorânea condiçóes excepcionais para a expansão da maricultura. Entre as práticas, tem se destacado a carcinicultura com a produção $65.670 \mathrm{t}$ de camarões, em 2011 (78\%), concentrados nos estados do Rio Grande do Norte e do Ceará, e a produção de moluscos, entre os quais a produção de mexilhóes, ostras e vieiras, com 18.541,7 t (22\%), a maior parte em Santa Catarina (Brasil, 2011). Contudo, segundo Cavalli e Ferreira (2010, p. 39), para que esse potencial possa prosperar "há necessidade de se adotar, cada vez mais, práticas de cultivo ecologicamente sustentáveis, como a diminuição do uso de insumos oriundos da pesca.” De acordo com os autores, há de concentrar-se em medidas regulatórias para a proteção dos ecossistemas costeiros, de tal forma que a maricultura possa expressar-se como fonte incessante de emprego e renda e de fornecimento de alta qualidade de alimentos.

Além dos recursos da pesca costeira e oceânica e da maricultura, duas outras práticas estão associadas ao potencial dos recursos vivos existentes no mar. A primeira destas diz respeito à aquariofilia global, que movimenta até US $\$ 30$ bilhóes 
por ano em organismos ornamentais, como peixes e corais, grande parte de maneira predatória. Além disso, há a biotecnologia marinha e seu enorme potencial ao fornecimento de insumos às indústrias médica, farmacêutica, alimentar e de cosméticos (Castro et al., 2017).

Castro et al. (2017, p. 20) denominam de recursos não extrativos os serviços ecossistêmicos que "são recursos marinhos inerentes ao meio, não mensuráveis". Consideram nesse espectro a característica que faz do mar a principal via de transporte do comércio exterior, bem como o turismo ao longo do litoral, que explora a paisagem e as formas de lazer costeiras. De acordo com os autores, o turismo contribui atualmente "com cerca de $10 \%$ do PIB nacional, incluindo a hotelaria, gastronomia, pesca esportiva, esportes marinhos, turismo subaquático, entre outras" (op. cit., p. 21). E, ainda, como ponto de fundamental importância, consideram recurso náo extrativo a característica do mar de ser um grande controlador do clima global e da temperatura média do planeta, em razão da alta capacidade que possui em conservar a energia do sol e propiciar temperaturas médias terrestres em torno de $14^{\circ} \mathrm{C}$. De acordo com os autores:

alteraçôes no delicado equilíbrio termodinâmico existente entre o oceano e a atmosfera, com pequenos aquecimentos sistemáticos desta última, podem ser catastróficas para a sociedade global. A manutenção do clima na Terra, e das temperaturas que possibilitaram o desenvolvimento da vida em nosso planeta, dependem desse equilíbrio, que é regulado principalmente pela concentração de gases de efeito estufa, como o gás carbônico, na atmosfera (Castro et al., 2017, p. 21).

A necessidade de conservação, proteção e uso adequado dos recursos marinhos da Amazônia Azul insere-se como grande prioridade e desafio para a sustentabilidade do planeta. Revestem-se de importância as açóes que incrementem a chamada mentalidade marinha na sociedade brasileira, de forma a adotar uma postura que considere a Amazônia Azul, assim como a Amazônia e os demais biomas brasileiros, sistemas indivisíveis que integram continente, mar e oceano.

O segundo Macrodiagnóstico da Zona Costeira e Marinha (MZCM), elaborado em 2008 - em concordância com as recomendações do Decreto Federal no 5.758/2006, o qual instituiu o Plano Estratégico Nacional de Áreas Protegidas (PNAP) (Brasil, 2006) -, define as áreas prioritárias para a conservação, o uso sustentável e a repartição dos benefícios da biodiversidade marinha (figura 8), de forma a orientar a criação de unidades de conservação. 


\section{FIGURA 8 \\ Áreas prioritárias para a conservação, o uso sustentável e a repartição dos benefícios} da biodiversidade marinha - Brasil

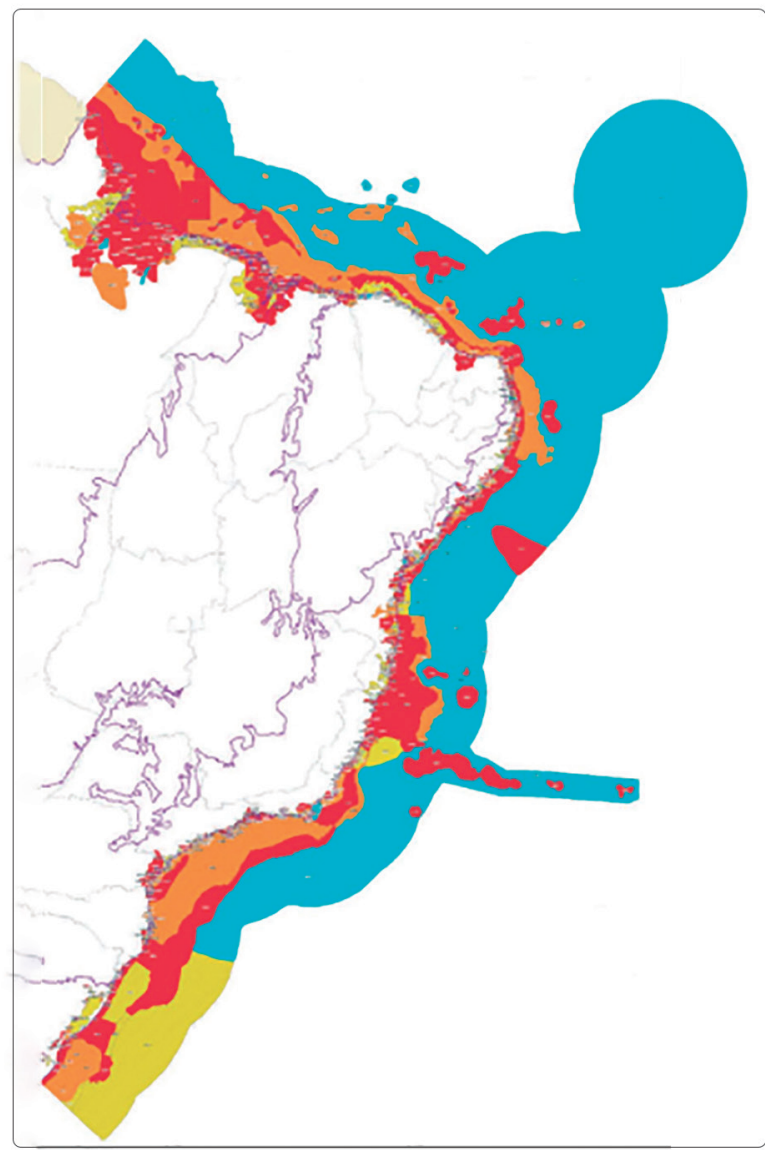

Importância Biológica

Fonte: MZCM (Brasil, 2008).

Adaptação: Equipe Fronteiras Ipea.

O MZCM destaca a diretriz do decreto que indica a criação e a gestão das áreas marinhas, com vistas à conservação da biodiversidade e à recuperação dos estoques pesqueiros. Indica 506 áreas prioritárias para a ZC - sendo cada uma destas com interface em um dos biomas continentais - e 102 na zona marinha, destacando que pela primeira vez estava sendo realizado um zoneamento sobre a ZEE. Em mais de $50 \%$ das áreas prioritárias, a importância biológica foi classificada como extremamente alta, tendo como recomendação a criação de diferentes categorias de unidades de conservação, recuperação de áreas degradadas e/ou espécies ameaçadas, criação de mosaicos de corredores ecológicos e ordenamento pesqueiro. Vale ressaltar que grande parte da ZEE foi considerada insuficientemente conhecida. 


\subsection{Desafios socioambientais}

Apesar dos cenários de potencialidades para propulsão do desenvolvimento em território nacional, há regióes na ZC brasileira densamente povoadas e socialmente desfavorecidas, com intricadas redes tecnológicas e graves implicaçóes socioeconômicas. Particularmente, mas não apenas nessas áreas, um grande desafio é a prevenção e o combate à violência urbana, fundamentalmente pelo controle de ilícitos. Como a maioria dos portos e aeroportos do país situa-se na FFL, essa faixa apresenta grande vulnerabilidade náo somente no que diz respeito à entrada e à saída de drogas, armas e produtos contrabandeados, como também ao tráfico de pessoas. Nas atividades nos arcos da fronteira terrestre, foi recorrente a informação de que é insignificante o volume de apreensóes e dos ilícitos que passam sem serem apreendidos nos postos de controle fronteiriços terrestres, em relação aos postos de controle em portos e aeroportos.

Além das vulnerabilidades sociais, a população dessa FF está sujeita a vulnerabilidades ambientais decorrentes de poluição, insuficiência e inadequação do esgotamento sanitário urbano, degradação florestal, desmatamento, entre outros fatores que requerem uma ação integrada prioritária dos formuladores de políticas (Nicolodi e Pettermann, 2011).

Sublinha-se que há grande heterogeneidade na distribuição e no crescimento da população no interior da FFL (mapa 3). Se, por um lado, a população está muito concentrada em porçóes específicas dessa faixa - no Sul e Sudeste, bem como nas áreas metropolitanas do Nordeste - por outro, há ainda regióes pouco habitadas e muito relevantes em termos da biodiversidade presente. Nessa porção do território, também coexistem áreas escassamente povoadas, onde há pequena escala comercial ou comunidades piscatórias de subsistência, descendentes de quilombolas (moradores de comunidades de descendentes escravos africanos fugitivos), tribos indígenas e outros grupos que vivem em seus estilos de vida tradicionais (IBGE, 2011b).

Dados do índice de vulnerabilidade social (IVS) registram que nessa FF há proporçâo elevada $(35,37 \%)$ de municípios com IVS entre baixo e muito baixo (tabela 11). Ao mesmo tempo, 46,32\% dos municípios têm esse índice nas condições de alta a muito alta vulnerabilidade. 


\begin{tabular}{|c|c|c|c|c|c|}
\hline \multirow{2}{*}{ Recorte } & \multicolumn{5}{|c|}{ Vulnerabilidade } \\
\hline & Muito alta & Alta & Média & Baixa & Muito baixa \\
\hline \multicolumn{6}{|l|}{ FFT } \\
\hline Quantidade & 88 & 262 & 144 & 41 & 51 \\
\hline$\%$ & 15,02 & 44,71 & 24,57 & 7,00 & 8,70 \\
\hline \multicolumn{6}{|l|}{$\mathrm{FFL}^{1}$} \\
\hline Quantidade & 432 & 524 & 378 & 516 & 214 \\
\hline$\%$ & 20,93 & 25,39 & 18,31 & 25,00 & 10,37 \\
\hline \multicolumn{6}{|c|}{ Demais municípios² } \\
\hline Quantidade & 333 & 619 & 752 & 927 & 314 \\
\hline$\%$ & 11,31 & 21,02 & 25,53 & 31,48 & 10,66 \\
\hline \multicolumn{6}{|l|}{ Brasil } \\
\hline Quantidade & 812 & 1.182 & 1.263 & 1.692 & 616 \\
\hline$\%$ & 14,59 & 21,24 & 22,7 & 30,4 & 11,07 \\
\hline
\end{tabular}

Condiçôes de vulnerabilidade elevada não apenas guardam relação com componentes sociais e de trabalho, como também são referentes às condiçóes do domicílio. A precariedade do domicílio na linha da costa aponta para mais um quadro de vulnerabilidade: aquela que se expressa pelos efeitos da mudança climática. Tais mudanças, para muitos, ainda relegadas ao porvir, já estão a exigir grande reflexão sobre a necessidade de propostas para adaptação das cidades aos fenômenos que começam a causar efeitos dramáticos à população, e virão a exigir, em curto prazo, medidas de emergência climática.

Atualmente, são sentidos esses efeitos em cidades litorâneas, com aumento de deslizamento de terras em função de chuvas, inundaçóes, mortes e desabrigos. E mesmo que haja o alerta da necessidade de adaptação das cidades como contentoras do aquecimento global ou receptoras de seus impactos, pouco vem sendo efetivamente pensado e realizado nesse sentido. Além do aumento da intensidade de chuvas, o nível do mar já vem mostrando sinais de avanço, o que coloca em risco todo o conjunto de cidades defrontantes ao Atlântico. Essa talvez seja a ameaça mais urgente, o maior desafio socioambiental nessa FF.

O MZCM oferece detalhes sobre o potencial de risco ambiental, composto por fenômenos naturais, processos sociais e tecnológicos nas zonas costeira e marinha. O potencial de risco natural concentrou-se no mapeamento de risco à inundação das áreas costeiras, concluindo que efeitos da mudança global do clima podem ser observados pelas variaçóes de ondas e correntes, bem como pelo aumento relativo 
do nível médio do mar. No macrozoneamento, observa-se que "a perda de terras no litoral, em áreas de baixa altitude, pode rapidamente destruir variados e importantes ecossistemas como lagunas, lagoas e manguezais, além de refletir em perdas de patrimônio público e privado" (Brasil, 2008, p. 102). Considera-se importante $\mathrm{o}$ instrumento para áreas ressaltadas que se constituem em setores que necessitam de intervenção imediata, a partir de planejamento e ordenamento da ocupação do espaço. Ressalta-se que, conforme será exposto posteriormente na subseção 4.2.2 deste capítulo, GI-Gerco e seus programas, a ação de revisão do MZCM encontra-se paralisada por falta de recursos.

O potencial risco social focou nos indicadores de saneamento (coleta de lixo e esgotamento sanitário) da ZC que, de acordo com o MZCM,

realçam um dos problemas mais graves encontrados na gestáo territorial, com desdobramentos negativos para o pleno aproveitamento dos recursos e a otimizaçáo da ocupação, seja nos grandes centros urbanos, nas cidades de médio ou pequeno porte (Brasil, 2008, p. 121).

As cartas de risco social adotam metodologia que identifica os distritos com potencial de risco alto e muito alto, como áreas prioritárias para a formulação de políticas públicas nas áreas do meio ambiente. Assume-se que a carência do saneamento reflete propensão à proliferação de doenças de veiculação hídrica $\mathrm{e}$ de vetores de outras doenças que vão atingir a população exposta a essas vulnerabilidades - entendida como a parte da população com renda menor do que três salários mínimos (SMs) mensais.

O potencial risco tecnológico foi definido como "o potencial de ocorrência de eventos danosos à vida, em curto, médio e longo prazos, em consequência das decisóes de investimento na estrutura produtiva (Brasil, 2008, p. 149)”. As cartas geradas apontam o potencial risco de desastres oriundos de fontes ditas tecnológicas, como unidades geradoras de energia e, também, as indústrias; nesse caso, classificando-se o potencial poluidor decorrente dos diferentes tipos de indústrias (quadro 1).

QUADRO 1

Relação do potencial poluidor com os tipos de indústrias - Brasil

\begin{tabular}{|l|l|}
\hline \multicolumn{1}{|c|}{ Potencial poluidor } & \multicolumn{1}{c|}{ Tipos de indústria } \\
\hline \multirow{4}{*}{ Muito alto } & Borracha \\
& Fumo e couros \\
& Química \\
& Extração mineral \\
& Minerais não metálicos \\
\hline \multirow{3}{*}{ Alto } & Metalúrgica \\
& Têxtil \\
& Alimentos e bebidas \\
& Papel e gráfica \\
\hline
\end{tabular}




(Continuação)
\begin{tabular}{|l|l|}
\hline \multicolumn{1}{|c|}{ Potencial poluidor } & \multicolumn{1}{c|}{ Tipos de indústria } \\
\hline \multirow{3}{*}{ Médio } & Mecânica \\
& Material de transportes \\
& Calçados \\
& Madeira e mobiliário \\
\hline \multirow{3}{*}{ Baixo } & Eletrônica e comunicações \\
& Construção civil \\
& Serviços de utilidade pública \\
\hline
\end{tabular}

Fonte: MZCM (Brasil, 2008, p. 150).

Elaboração: Equipe Fronteiras Ipea.

Destaca-se a constatação do MZCM (Brasil, 2008) de que a situação de alto risco é agravada por componentes regionais, especialmente associados à densidade da estrutura produtiva ou à concentração espacial do equipamento energético em zonas e centros industriais. Baseado em dados do plano, em 2008, e apontando para uma necessária atualização, assim foram resumidos os cenários de complexos produtivos costeiros.

1) Concentração produtiva no trecho entre Santos (São Paulo) e Macaé (Rio de Janeiro), onde estão presentes campos de extração, terminais e dutos de petróleo e gás, usinas termoelétricas e nucleares e expressiva concentração dos complexos químicos e metalmecânico.

2) Deslocamento do complexo químico para o litoral nordestino, no eixo Salvador-Aracajú-Maceió, associado à expansão da fronteira energética no litoral, que faz com que a concentração de dutos, terminais e fábricas seja expressiva.

3) Expansão da fronteira energética em direção ao litoral sul, com o aumento da prospecção na bacia de Santos, a construção de gasodutos, a ampliação da indústria química em Paranaguá (Paraná) e do Polo Petroquímico de Triunfo, nas vizinhanças de Porto Alegre (Rio Grande do Sul), e a concentração de indústrias químicas, de papel e celulose e de couro e calçados, sendo que o papel do porto de Rio Grande, onde os níveis de risco apresentados são relevantes, deve ser considerado com $\mathrm{a}$ área metropolitana de Porto Alegre.

4) Trecho da ZC entre Mucuri, litoral sul da Bahia, até o centro-norte do Espírito Santo (Linhares e Aracruz), que está se especializando na produção de celulose para o mercado externo.

5) Complexo metalmecânico e de papel e celulose nos estados do Pará e do Maranhão.

Em uma perspectiva, o MZCM aponta a importância de ressaltar o potencial risco tecnológico, na medida em que é crítica nessas áreas: 
a possibilidade de ocorrência de poluição acidental por eventos não previstos, tais como derramamentos, vazamentos, emanaçóes não controladas, contaminaçáo ambiental por lançamentos industriais de gases, material particulado, efluentes líquidos e resíduos sólidos (Brasil, 2008, p. 153).

Necessita-se, assim, de medidas de prevenção de acidentes por parte das empresas que operam na ZC, assim como o efetivo monitoramento e a fiscalização por parte do governo.

\section{PROGRAMAS EM DESENVOLVIMENTO NA FRONTEIRA LITORÂNEA}

\subsection{Ambiente marítimo e terrestre: questão articulada entre duas instituições}

Em se tratando de programas que se relacionam com a faixa litorânea e tangente à questão fronteiriça, é importante situar que envolvem duas frentes distintas de governo, que se articularam ao longo do tempo em torno da questão marítima. Umas destas é a $\mathrm{MB}$, que desenvolveu suas açóes tendo como foco inicial a proteção e a defesa dos recursos naturais existentes no interior da fronteira marítima; a outra é o MMA, pelas questóes de degradação ambiental da costa brasileira.

Por meio do Decreto Federal no 74.557/1974, foi criada a Comissão Interministerial para os Recursos do Mar (Cirm), com a finalidade de coordenar os assuntos relativos à consecução da Política Nacional para os Recursos do Mar (PNRM), cujas diretrizes gerais foram baixadas pelo presidente da República em 12 de maio de 1980 (Brasil, 1974). Nessa época, em 1981, foi instituída a Política Nacional do Meio Ambiente - PNMA (figura 9). De acordo com o relatório produzido pelo MMA, em função dos 25 anos do gerenciamento costeiro do Brasil,

as políticas Nacionais para os Recursos do Mar (PNRM) e de Meio Ambiente (PNMA) surgem paralelamente e, de início, de forma desarticulada. Por um lado, a Política dos Recursos do Mar náo enfatizava de forma adequada o enfoque ambiental, ao orientar sua visão de manejo dos recursos marinhos sob uma perspectiva setorial e economicista focada na importância e valor dos recursos marinhos. Por outro lado, a Política Nacional do Meio Ambiente (PNMA) não contemplava, com a atenção necessária, os ambientes costeiros e marinhos e suas dinâmicas (Brasil, 2015, p. 18). 
FIGURA 9

Linha do tempo e organograma da Política Nacional para os Recursos do Mar - Brasil

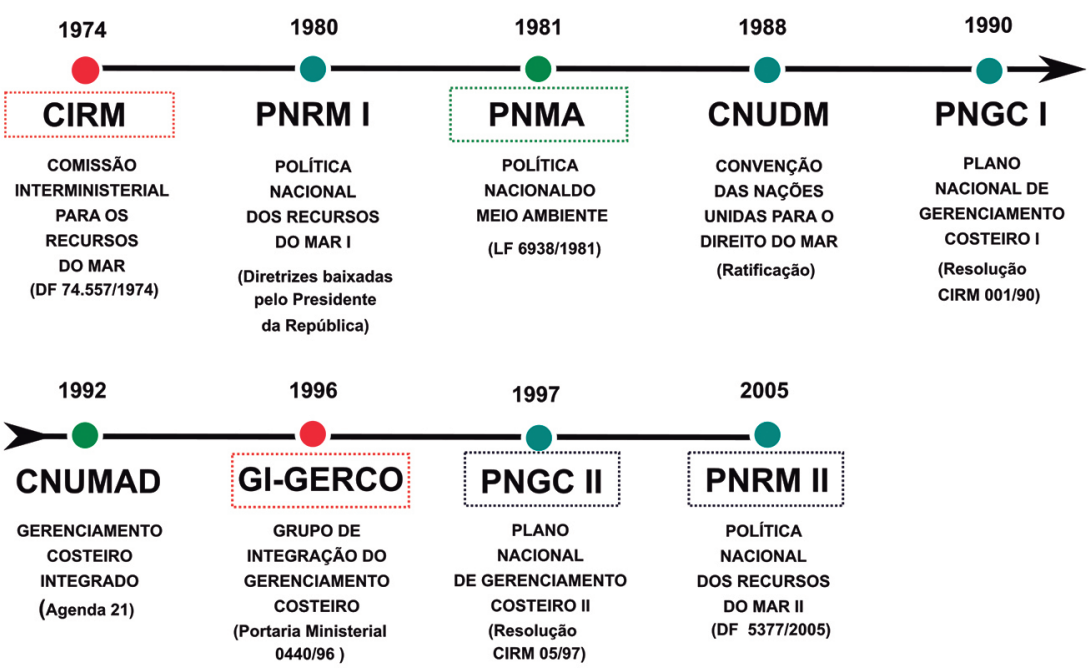

POLÍTICA, PLANOS E INSTRUMENTOS: RELAÇÕES

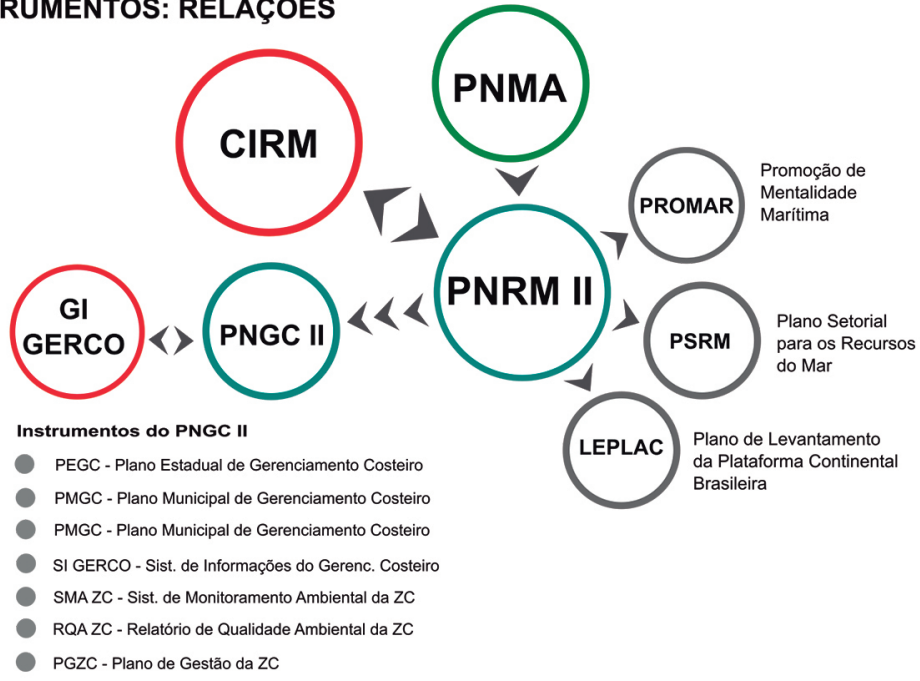

Fontes: Brasil (2015) e Marinha do Brasil (disponível em: <https://is.gd/3QPJXh>). Elaboração: Equipe Fronteiras Ipea.

Para o ambiente costeiro, a então Secretaria do Meio Ambiente organizou, em 1982, o Programa Nacional de Gerenciamento Costeiro, que, empreendendo inúmeras discussóes envolvendo gestores públicos e a academia, estruturou um 
programa de zoneamento costeiro (Brasil, 2015). Como parte integrante de ambas as políticas (PNRM e PNMA), a Lei Federal no 7.661/1988 instituiu o Plano Nacional de Gerenciamento Costeiro, com vistas a "orientar a utilização nacional dos recursos da Zona Costeira, de forma a contribuir para elevar a qualidade de vida de sua populaçáo, e a proteção do seu patrimônio natural, histórico, étnico e cultural" (Brasil, 1988a, art. 2º), a ser submetido e aprovado pela Cirm, com audiência do Conselho Nacional do Meio Ambiente (Conama). A lei definiu como $\mathrm{ZC}$ o espaço geográfico de interaçáo do ar, do mar e da terra, incluindo-se seus recursos renováveis ou não, abrangendo uma faixa marítima e outra terrestre, sendo estas a serem definidas pelo plano. Em 1990, é apresentada a primeira versão do PNGC por intermédio da Resolução Cirm no 1/1990, que delegou, por sua vez, a delimitação dos limites terrestre e marítimo da ZC aos planos estaduais de gerenciamento costeiro (Brasil, 1990). Segundo Brasil (1996, apud Brasil, 2015),

o atrelamento das atividades do PNGC à conclusão dos zoneamentos, com atribuiçáo exclusiva para a elaboração na esfera estadual, reforçou um modelo de execução quase que centrado unicamente no nível dos estados, sem uma visão de atuação própria para a Uniáo. Faltava à Uniáo uma macro visualização dos processos, que não se confundisse, mas complementasse a escala de visão do zoneamento estadual Brasil (1996, apud Brasil, 2015, p. 20).

No âmbito das atividades da Cirm sob a alçada da MB, reveste-se de importância a ratificaçáo pelo Brasil, em 1988, das resoluçóes oriundas da CNUDM, com firma em Montego Bay, na Jamaica, em 1982, conhecida como "A Constituição do Mar”. Entre outros aspectos, a convenção definiu os espaços marítimos (águas interiores, MT, zona contígua, ZEE, PC, alto-mar e fundos marinhos), verificando-se, dessa forma, clara distinção entre os espaços da PNRM e da PNMA.

Cabe mencionar que, na Conferência das Naçóes Unidas para o Meio Ambiente e Desenvolvimento (CNUMAD) da ONU, que ocorreu no Rio de Janeiro em 1992, se considerou a proteção do litoral como um dos temas relevantes a serem tratados pelos países-membros, e o conceito de gerenciamento costeiro integrado (GCI) tornou-se parte integrante do capítulo 17 da Agenda 21. De acordo com esse capítulo,

o meio ambiente marinho - inclusive os oceanos e todos os mares, bem como as zonas costeiras adjacentes - forma um todo integrado que é um componente essencial do sistema que possibilita a existência de vida sobre a Terra, além de ser uma riqueza que oferece possibilidades para um desenvolvimento sustentável (ONU, 1992, Agenda 21, capítulo 17).

As novas abordagens exigiriam programas de caráter integrado nas seguintes áreas: 
- gerenciamento integrado e desenvolvimento sustentável das ZCs, inclusive ZEEs;

- $\quad$ proteção do meio ambiente marinho;

- $\quad$ uso sustentável e conservação dos recursos marinhos vivos de alto mar;

- $\quad$ uso sustentável e conservação dos recursos marinhos vivos sob jurisdição nacional;

- análise das incertezas críticas para o manejo do meio ambiente marinho e a mudança do clima;

- fortalecimento da cooperação e da coordenação no plano internacional, inclusive regional; e

- desenvolvimento sustentável das pequenas ilhas.

Ressalta-se a visão integrada dada a partir do entendimento do que é ambiente marinho que não guarda limites entre costa, mar e oceano, em especial no que se refere a questões ambientais internacionais, como em relação à mudança climática.

Em 1997, a Resolução Cirm no 5 aprova o II Plano Nacional de Gerenciamento Costeiro, cuja coordenação para a atualização foi atribuída à Cirm a partir do Decreto Federal no 1.540/1995 (Brasil, 1995b). Na forma de lei, as diretrizes do PNGC II regulamentaram a Lei Federal no $7.661 / 1988$ por intermédio do Decreto Federal nº 5.300/2004, com regras de uso e ocupação da ZC e critérios de gestão da orla marítima. Conforme o documento do plano, este buscou adequar-se

à sua prática atual, contemplando, assim, a experiência acumulada no âmbito do Ministério do Meio Ambiente, dos Recursos Hídricos e da Amazônia Legal (MMA) e pelos diversos executores de suas atividades, incorporando, consequentemente, as novas demandas surgidas no âmbito da sociedade, cujo marco balizador está representado nos documentos gerados pela Conferência das Naçóes Unidas para o Meio Ambiente e Desenvolvimento, conhecida como Rio-92, destacando-se a chamada "Declaração do Rio sobre o Meio Ambiente e Desenvolvimento" e a "Agenda 21" (Brasil, 1997).

Entre os novos conteúdos incorporados, ressalta-se a formação do Grupo de Integração do Gerenciamento Costeiro (GI-Gerco), que, no âmbito da Cirm, foi criado para promover a articulação das ações federais incidentes na ZC, a partir da aprovação de planos de ação federal, sendo que coube ao MMA a função de coordenação nacional, bem como do Subgrupo de Integração dos Estados, vinculados ao GI-Gerco. Esse grupo foi criado pela Portaria Ministerial no 440/1996 (Brasil, 1996).

A ZC, que nesta versão do plano incorpora claros limites, formados pela faixa marítima e terrestre, junta-se aos avanços conquistados pelo PNGC II, com o propósito de incorporar a dimensão ambiental nas políticas setoriais. Dessa forma, 
visa-se a uma gestão integrada dos ambientes terrestres e marinhos, tendo-se como um dos princípios fundamentais a observância da PNMA e da PNRM de forma articulada e compatibilizada com as demais políticas incidentes na sua área de abrangência e atuação.

Assim, além dos instrumentos da PNMA, o PNGC II considera ainda para sua gestấo:

- Plano Estadual de Gerenciamento Costeiro (PEGC);

- Plano Municipal de Gerenciamento Costeiro (PMGC);

- Sistema de Informaçóes de Gerenciamento Costeiro (SI-Gerco);

- Sistema de Monitoramento Ambiental da Zona Costeira (SMA-ZC);

- Relatório de Qualidade Ambiental da Zona Costeira (RQA-ZC);

- Zoneamento Ecológico-Econômico Costeiro (ZEEC); e

- Plano de Gestão da Zona Costeira (PGZC).

Tais acontecimentos e as discussões no âmbito nacional e internacional ao longo da década de 1990 impulsionaram o desenvolvimento de mudanças conceituais e o comportamento da sociedade, com reflexos evidentes nas ferramentas de gestáo pública brasileira. No encalço dessas mudanças, também se aprovou, em 2005, a nova PNRM, pelo Decreto Federal no 5.377/2005, em substituição às diretrizes de 1980 , com a finalidade de orientar o desenvolvimento das atividades que visem à efetiva utilização, exploração e aproveitamento dos recursos vivos, minerais e energéticos do MT, da ZEE e da PC, de acordo com os interesses nacionais, de forma racional e sustentável para o desenvolvimento socioeconômico do país, gerando emprego e renda e contribuindo para a inserção social (Brasil, 2005).

A PNRM possui as açóes orientadas e coordenadas pela Cirm, cabendo reiterar a estreita inter-relação formada, ao menos legalmente, por meio da criação do GI-Gerco, este coordenado pelo MMA na função de articulador interinstitucional e interfederativo, mas no âmbito da Cirm, sob coordenação da MB. Constitui-se em ponto de avanço necessário para um futuro incerto do processo de desenvolvimento em curso, com graves rebatimentos socioambientais de escala planetária. Se, por um lado, se ganha ao explorar o rico universo de potencialidades da costa brasileira do ponto de vista tanto de seus recursos naturais, como comerciais e de infraestrutura, por outro, são evidentes os problemas oriundos do uso inadequado dos meios terrestres e aquáticos da costa brasileira e, acima disso, das repercussóes sentidas desde mares e oceanos de ameaças globais desenvolvidas pelo ser humano. 
A questão dos oceanos foi um dos principais temas debatidos na Conferência Rio $+20,{ }^{14}$ ocorrida no Rio de Janeiro, em 2012, e na assembleia realizada na sede da ONU, em Nova Iorque, também em 2012, que culminou com a aprovação dos Objetivos de Desenvolvimento Sustentável (ODS). Entre estes, destaca-se o ODS 14, Vida na água, que versa sobre a "Conservação e uso sustentável dos oceanos, dos mares e dos recursos marinhos para o desenvolvimento sustentável". O tema foi tratado detidamente, com a realização, em junho de 2017, no mesmo local, da Conferência das Naçóes Unidas sobre os Oceanos. Com participação brasileira, foi aprovado o documento Nosso oceano, Nosso futuro: chamada para ação (ONU, 2017), no qual os representantes afirmaram o compromisso de conservar e usar sustentavelmente os oceanos, os mares e os recursos marinhos para o desenvolvimento sustentável, reconhecendo que o oceano conecta populaçóes e mercados e representa parte importante da herança natural e cultural da sociedade e que também fornece metade do oxigênio que se respira e absorve mais de um quarto do dióxido de carbono produzido, exercendo papel vital no ciclo da água e no sistema climático. Reconhece a necessidade de abordar os impactos adversos que prejudicam a habilidade crucial do oceano de agir como um regulador climático, como fonte de biodiversidade marítima, como um provedor vital de alimento e nutrição, turismo e serviços de ecossistema. Além disso, o oceano tem a função de ser um motor de desenvolvimento e crescimento econômico sustentáveis ( $o p$. cit.). Uma nova Conferência das Naçóes Unidas sobre os Oceanos estava prevista para junho de 2020, na cidade de Lisboa.

Pode-se argumentar que o desenho institucional já formado se encontra em fase avançada de articulação, na medida em que integra duas frentes governamentais (MMA e MB) que atuam com a participação de vários níveis federativos, no que se refere à necessária coesão para análise das questóes terrestres e marítimas tratadas conjuntamente sob o ponto de vista ambiental, social e de proteção e defesa da fronteira. Nesse contexto, uma pesquisa sobre a condição fronteiriça de uma FFL definida para o estudo insere-se em situação de vantagem. Em primeiro lugar, pela existência e pelo funcionamento de um fórum articulado de discussóes e resoluçóes dos problemas; em segundo lugar, porque tal instância se articula por uma motivação que permeia e instiga a atual perspectiva de pesquisa para a fronteira litorânea: as relaçóes internacionais transfronteiriças, que, tendo em vista ser um movimento da sociedade, parte dos espaços que ocupa e usa predominantemente (a ZC, formada pela faixa terrestre e faixa marítima ou pelo MT, espaço de atuação do GI-Gerco e da Cirm), bem como a ZEE (entre o MT e o limite fronteiriço espaço de atuação da Cirm) até as águas internacionais e os territórios além-mar.

14. Sobre o tema, ver os links disponiveis em: <https://is.gd/mEF1jj> e <https://is.gd/Ep4CMu>. Acesso em: 12 dez. 2019. 
Assim, os projetos e programas desenvolvidos e em desenvolvimento pelas instâncias formadas sobre o tema constituem-se em objetos de interesse para uma futura pesquisa. Apresenta-se a seguir uma visão geral desses projetos, organizados em programas desenvolvidos pela Cirm e GI-Gerco, além de programas estratégicos de defesa da Marinha brasileira.

\subsection{Programas estratégicos de desenvolvimento e defesa}

\subsubsection{Cirm e seus programas na Amazônia Azul}

A PNRM (Decreto Federal no 5.377/2005) tem por finalidade orientar o desenvolvimento das atividades que visem à efetiva utilização, exploração e aproveitamento dos recursos vivos, minerais e energéticos do MT, da ZEE e da PC, de acordo com os interesses nacionais, de forma racional e sustentável para o desenvolvimento socioeconômico do país, gerando emprego e renda e contribuindo para a inserção social. A lei define, também, que as açóes a serem empreendidas para alcançar seus objetivos seriam executadas sob orientação e coordenação dos órgãos integrantes da Cirm, sendo que, para tanto, a PNRM se desdobraria em planos setoriais plurianuais. Assim, o Plano Setorial para os Recursos do Mar (PSRM) encontra-se em sua nona versão (2016-2019). Além deste, destacam-se sob a gerência da Cirm o Leplac e o PNGC; sobre o último, os programas gerados compốem a subseção 4.2.2 a seguir, intitulada GI-Gerco e seus programas.

Conforme o documento que apresenta o IX PSRM (2016-2019), este constitui um aprimoramento do anterior e mantém o modelo de gestão participativa integrada por ministérios, por órgãos de fomento, pela comunidade acadêmica e pela iniciativa privada, tanto na sua elaboração quanto na execução das açóes. O IX PSRM compreende nove açôes (quadro 2) que visam promover o uso compartilhado do ambiente marinho com a adequada utilizaçáo dos meios existentes e da capacidade instalada, além da defesa dos interesses político-estratégicos do Brasil no mar, nos âmbitos nacional e internacional, com vistas a ampliar a presença brasileira em águas nacionais e internacionais e nas ilhas oceânicas (Cirm, 2016).

QUADRO 2

Ação, organização coordenadora e objetivo do IX PSRM ${ }^{1}$

\begin{tabular}{|l|l|l|}
\hline \multicolumn{1}{|c|}{ Ação } & \multicolumn{1}{|c|}{ Organização coordenadora ${ }^{2}$} & \multicolumn{1}{c|}{ Objetivo } \\
\hline $\begin{array}{l}\text { Pesquisas científicas nas ilhas oceânicas } \\
\text { (Prototrindade e Proarquipélago) }\end{array}$ & $\begin{array}{l}\text { Marinha do Brasil, por meio } \\
\text { da Secretaria da Comissão } \\
\text { Interministerial para os Recursos } \\
\text { do Mar (Secirm) }\end{array}$ & $\begin{array}{l}\text { Desenvolver pesquisa científica nas ilhas } \\
\text { oceânicas, assegurando a conservação dos } \\
\text { seus ecossistemas terrestres e marinhos e } \\
\text { os direitos de soberania sobre a ZEE e a PC } \\
\text { no entorno do Arquipélago de São Pedro e } \\
\text { São Paulo. }\end{array}$ \\
\hline $\begin{array}{l}\text { Avaliação, Monitoramento e Conservação da } \\
\text { Biodiversidade Marinha (Revimar) }\end{array}$ & Ministério do Meio Ambiente & $\begin{array}{l}\text { Estabelecer as bases científicas e ações inte- } \\
\text { gradas capazes de subsidiar políticas, ações } \\
\text { e estratégias de gestão compartilhada, com } \\
\text { o objetivo de conservação e uso sustentável } \\
\text { dos recursos vivos. }\end{array}$ \\
\hline
\end{tabular}


(Continuação)

\begin{tabular}{|c|c|c|}
\hline Ação & Organização coordenadora ${ }^{2}$ & Objetivo \\
\hline Aquicultura e Pesca (Aquipesca) & $\begin{array}{l}\text { Ministério da Agricultura, Pecuá- } \\
\text { ria e Abastecimento (Mapa) }\end{array}$ & $\begin{array}{l}\text { Articular, em ambiente cooperativo inter- } \\
\text { ministerial, a execução de ações prioritárias } \\
\text { do Plano de Desenvolvimento Sustentável } \\
\text { da Pesca e Aquicultura, a fim de promover } \\
\text { a pesca sustentável, o monitoramento } \\
\text { da atividade pesqueira, a promoção da } \\
\text { ciência e tecnologia (C\&T), a qualificação } \\
\text { profissional de pescadores e aquicultores e o } \\
\text { desenvolvimento da maricultura. }\end{array}$ \\
\hline Biotecnologia Marinha (Biomar) & $\begin{array}{l}\text { Ministério da Ciência, Tecnologia } \\
\text { e Inovações (MCTI) }\end{array}$ & $\begin{array}{l}\text { Promover e fomentar o estudo e a explora- } \\
\text { ção sustentável do potencial biotecnológico } \\
\text { da biodiversidade marinha existente nas } \\
\text { áreas jurisdicionais brasileiras e em outras } \\
\text { áreas de interesse nacional, com vistas aos } \\
\text { desenvolvimentos científico, tecnológico e } \\
\text { econômico do país. }\end{array}$ \\
\hline $\begin{array}{l}\text { Avaliação da Potencialidade Mineral da Plata- } \\
\text { forma Jurídica Brasileira (Remplac) }\end{array}$ & $\begin{array}{l}\text { Ministério de Minas e Energia } \\
\text { (MME) }\end{array}$ & $\begin{array}{l}\text { Avaliar a potencialidade mineral da PC, a } \\
\text { fim de possibilitar a utilização sustentável } \\
\text { dos recursos não vivos. }\end{array}$ \\
\hline $\begin{array}{l}\text { Prospecção e Exploração de Recursos Minerais } \\
\text { da Área Internacional do Atlântico Sul e } \\
\text { Equatorial (Proarea) }\end{array}$ & $\begin{array}{l}\text { Ministério das Relações Exterio- } \\
\text { res (MRE) }\end{array}$ & $\begin{array}{l}\text { Dar seguimento às atividades de identifica- } \\
\text { ção e avaliação da potencialidade mineral } \\
\text { de regiões com importância econômica e } \\
\text { político-estratégica localizadas na área, } \\
\text { com vistas à elaboração de proposta, a ser } \\
\text { apresentada à Autoridade Internacional dos } \\
\text { Fundos Marinhos (Isba), para prospecção e } \\
\text { exploração desses recursos minerais, bem } \\
\text { como implementar atividades previstas em } \\
\text { Plano de Trabalho aprovado pela Isba. }\end{array}$ \\
\hline $\begin{array}{l}\text { Sistema Brasileiro de Observação dos Oceanos } \\
\text { e Estudos do Clima (Goos Brasil) }\end{array}$ & $\begin{array}{l}\text { Marinha do Brasil, por meio } \\
\text { da Diretoria de Hidrografia e } \\
\text { Navegação (DHN) }\end{array}$ & $\begin{array}{l}\text { Ampliar e consolidar um sistema de } \\
\text { observação permanente dos oceanos, da } \\
\text { ZC e da atmosfera, bem como fomentar o } \\
\text { sistema para disponibilização dos dados } \\
\text { coletados para acesso público, a fim de } \\
\text { subsidiar estudos, aprimorar o conhecimento } \\
\text { científico e apoiar a elaboração de previsões } \\
\text { meteoceanográficas e ações, contribuindo } \\
\text { para redução de riscos e vulnerabilidades } \\
\text { decorrentes de eventos meteoceanográficos } \\
\text { extremos que afetam o Brasil. }\end{array}$ \\
\hline Promoção de Mentalidade Marítima (Promar) & MB, por meio da Secirm & $\begin{array}{l}\text { Promover o desenvolvimento de uma menta- } \\
\text { lidade marítima na população brasileira. }\end{array}$ \\
\hline $\begin{array}{l}\text { Formação de Recursos Humanos em Ciências } \\
\text { do Mar (PPG-Mar) }\end{array}$ & Ministério da Educação (MEC) & $\begin{array}{l}\text { Fortalecer a formação de recursos humanos } \\
\text { qualificados, com o objetivo de promover } \\
\text { o conhecimento sobre os componentes, } \\
\text { os processos e o recursos dos ambientes } \\
\text { marinho e costeiro. }\end{array}$ \\
\hline
\end{tabular}

Fonte: Cirm (2016).

Elaboração: Equipe Fronteiras Ipea.

Notas: ${ }^{1}$ Para mais informações, conferir Cirm (2016). Disponível em: <https://bit.ly/2IXSRkd>. Acesso em: 12 dez. 2019.

2 Nesta coluna, os ministérios e os departamentos correspondem a 2015.

Verifica-se que a área de abrangência do IX PSRM vai além da definição finalística da PNRM, incluindo-se a ZC, conforme justificativa do documento, com base nos princípios básicos da política. Demonstra que inclui na área de abrangência a intenção estratégica constante na PNRM no que se refere à exploração 
e ao aproveitamento sustentável dos recursos do mar, por meio da "promoção da gestão integrada dos ambientes costeiro e oceânico, visando o uso sustentável dos recursos do mar, e a proteção dos ecossistemas, da biodiversidade e do patrimônio genético, cultural e histórico das áreas marinhas sob jurisdição nacional" (Brasil, 2005). De acordo com o IX PSRM:

Além das atividades pesqueiras, de exploração e de produção de hidrocarbonetos, outros usos dos recursos naturais marinhos são ainda potenciais em nosso país, tais como a exploração mineral em águas rasas e profundas e o desenvolvimento da pesquisa científica e inovaçáo tecnológica, utilizando o potencial biotecnológico derivado do conhecimento da biodiversidade. Mais recentemente, também, tem-se vislumbrado o potencial desses recursos para produção de energia a partir de fontes renováveis, como energia eólica, de ondas e de marés. Essas possibilidades demonstram a compatibilização da gestão de áreas protegidas nas suas diversas categorias de manejo, com a conservação da biodiversidade e o uso sustentável dos seus recursos (Cirm, 2016, p. 7).

A Cirm reconhece a necessidade de promover o desenvolvimento de um plano com vistas a garantir o desenvolvimento sustentável, compatível com a premência das açóes de conservaçáo das zonas costeira e dos oceanos, e permitindo a realização dos objetivos nacionais, tanto econômicos, como ambientais e sociais, salvaguardando interesses estratégicos e de defesa nacional (Cirm, 2016, p. 7).

O plano contempla, dessa forma, quatro temas principais: i) recursos vivos açóes 1, 3 e 4; ii) recursos não vivos - açóes 5 e 6; iii) monitoramento e observação dos oceanos e estudos do clima - açóes 2 e 7; e iv) recursos humanos em ciências do mar - ações 8 e 9 .

Além do PSRM, o Leplac destaca-se pela sua importância estratégica para o Brasil de demarcação do limite exterior da PC brasileira, abertura dada pelo art. 76 da CNUDM, que define sua extensão "até o bordo exterior da margem continental ou até a distância de duzentas milhas marítimas de base a partir das quais se mede a largura do MT, nos casos em que o bordo exterior da margem continental não atinja essa distância (ONU, 1982, art. 76)". Portanto, a partir dos critérios do art. 76 da CNUDM, o Leplac iniciou, em 1989, estudos para a incorporação de uma extensa área além das 200 milhas marítimas. A proposta, coordenada pela Cirm, foi encaminhada à Comissão de Limites da Plataforma Continental (CLPC) da ONU, em maio de 2004, sendo que, em 2007, após concluir análise da proposta, a CLPC não concordou com cerca de 190 mil quilômetros quadrados dos 960 mil quilômetros quadrados reivindicados.

Dessa forma, a segunda fase do Leplac em andamento constitui-se na revisão da proposta, sendo que, para tanto, a margem continental brasileira foi dividida em três áreas/margem: Sul, Equatorial e Oriental/Meridional. Considerando-se a 
proposta apresentada pelo Brasil das três áreas, a Amazônia Azul poderá passar a ter uma área de cerca de 5,7 milhóes de quilômetros quadrados. Informaçóes da $\mathrm{MB}$ permitem entender a situação em andamento, conforme descrito a seguir. ${ }^{15}$

1) Proposta da regiâo Sul, inserida em parte da Margem Meridional, foi encaminhada à $\mathrm{ONU}$ em abril de 2015 e apresentada à Comissão de Limites da Plataforma Continental, em 25 de agosto de 2015. Em março de 2019, a CLPC aprovou na sua totalidade o limite exterior proposto pelo Brasil, incorporando à nossa PC uma área de cerca de $170 \mathrm{mil}$ quilômetros quadrados.

2) Proposta da Margem Equatorial foi encaminhada à ONU em 8 de setembro de 2017 e apresentada na Reunião Plenária da Comissão de Limites, em 8 de março de 2018, sendo que deve ter sua análise iniciada em 2019.

3) Proposta da Margem Oriental/Meridional com a inclusão da elevação de Rio Grande (ERG) foi encaminhada à ONU, em 7 de dezembro de 2018, e possivelmente será analisada a partir de 2023.

\subsubsection{GI-Gerco e seus programas}

No âmbito da Cirm, a formação do GI-Gerco em 1996 - a partir de uma diretriz do PNGC II, Decreto Federal no 5.300/2004 -, como fórum permanente de interlocução entre as instituiçôes governamentais, contribuiu para a criação de ferramentas de gestão, destacando-se, entre estas, sua própria agenda de atuação, denominada Plano de Ação Federal (PAF), sob coordenação do MMA. Até o momento, foram elaborados quatro planos, os dois últimos compostos por planos de ação para um período determinado: PAF I (1998); PAF II (2005); PAF III (biênio 2015-2016); e PAF IV (triênio 2017-2019).

O I PAF, de 1998, foi estruturado a partir de quatro programas: i) ordenamento da ocupaçáo e uso do solo; ii) conservação e proteçáo do patrimônio natural, histórico e cultural; iii) controle ambiental; e iv) suporte ao desenvolvimento do plano (articulação, capacitação, informação/tecnologia etc.). Nesse espectro de atuação, destacam-se algumas atividades consolidadas até o II PAF, de 2005, ao longo de sete anos. Primeiro, a criação da Comissão Coordenadora dos Assuntos da Organização Marítima Internacional (CCA-IMO), instituída pela Portaria Interministerial no 367/1998. Naquele ano, também houve a elaboração da Agenda 
Ambiental Portuária; visão de gestão integrada ${ }^{16}$ de ambientes marinhos e costeiros pelo GI-Gerco que coordenou, desde 1999, o PGZC. Em 2000, criou-se a "Lei do Óleo" (Lei Federal no 9.966/2000), em resposta às emergências ambientais por derramamento de óleo ocorrido na baía de Guanabara, no Rio de Janeiro, em decorrência do vazamento da Refinaria Reduc. Entre 2000 e 2004, ocorreram o desenvolvimento de metodologia e o início de execução das cartas de sensibilidade ambiental a derramamentos de óleo (Brasil, 2015).

A segunda versão do PAF, em 2005, foi realizada após revisão do GI-Gerco acerca das atividades do plano anterior, identificando-se as prioridades de ação do novo PAF a partir do Macrodiagnóstico da Zona Costeira do Brasil, elaborado em 1996, mas que somente em 2004 foi estipulado como instrumento de gestão. Se, por um lado, o macrodiagnóstico apontava que os estuários eram áreas prioritárias de ação em funçáo dos vetores de expansáo e seus impactos, a vulnerabilidade para a gestão indicava a necessidade de instrumentalizar os três níveis de governo para as atividades de ordenamento e gestão ambiental e territorial. Dessa forma, as linhas de ação foram ordenadas em três grandes linhas de ação: i) ordenamento ambiental territorial da ZC; ii) conservaçáo e proteção do patrimônio natural e cultural; e iii) controle e monitoramento (Brasil, 2015). Ao longo dos dez anos que precederam a implementação do III PAF, em 2015, destacam-se a consecução das seguintes atividades: em 2008, a apresentação da segunda versão do MZCM; em 2010, o acordo de cooperação técnica, científica e tecnológica com o governo espanhol para um projeto de modelagem costeira (Sistema de Modelagem Costeira para o Brasil - SMC-Brasil); e apresentação, em 2012, do VIII PSRM (2012-2015), que inovou em relação às versóes anteriores por introduzir a gestão participativa.

O III PAF, apresentado em 2014, previu ações para o biênio 2015-2016. Com vista ao uso sustentável e harmônico dos recursos e do espaço territorial costeiro, foi organizado mediante três linhas direcionadoras das ações: i) melhoria da qualidade ambiental costeira e estuarina; ii) melhor articulação institucional para elaborar e efetivar açóes; e iii) hierarquização e priorização de ações na ZC.

Em 2017, novos debates foram realizados nas sessóes do GI-Gerco para a criação do IV PAF, para o triênio 2017-2019. A metodologia de trabalho envolveu discussôes deliberativas que culminaram em propostas de açóes, cujo proponente se encarregou de elaborar uma pré-proposta de plano de trabalho. Cada plano de trabalho teve na sequência seu cronograma detalhado por um coordenador da

16. De forma simplificada, o conceito de gestão integrada de ambientes costeiros e marinhos pressupõe a abordagem de dois aspectos principais. 0 primeiro abrange a mediação de conflitos de múltiplos usos e a consequente busca das parcerias necessárias à integração no processo de tomada de decisões. 0 segundo trata das interações oceano-continente e seus fluxos de matéria e energia, que tornam indissociável o tratamento integrado desses ambientes, de forma a considerar as contribuições ao ambiente marinho derivadas da terra e as influências da dinâmica oceânica sobre os ambientes terrestres (Brasil, 2015, p. 24-25). 
ação e possíveis parceiros para a execução da ação. Cada um dos dezoito planos de trabalho resultantes foi posteriormente discutido em sessóes do GI-Gerco, definindo-se que esse PAF teria duração de três anos. Destaca-se esse formato de elaboração do plano, pois define responsabilidades e compromissos desde sua criação, baseando-se na participação mais aproximada de executores que podem influenciar sobremaneira na factibilidade das açóes, partindo-se da realidade de força de trabalho de suas instituiçóes. Parece atender ao diagnóstico de centralidade do MMA, ao observar a dificuldade de execução das açóes de responsabilidade das outras instituiçóes que conformam o GI-Gerco. O quadro 3 apresenta as dezoito açóes, com suas respectivas coordenação e objetivos.

QUADRO 3

Coordenador e objetivo das ações do IV PAF-ZC (triênio 2017-2019)

\begin{tabular}{|c|c|c|}
\hline Ação & Coordenador & Objetivo \\
\hline $\begin{array}{l}\text { Plano de Ação para o Combate ao Lixo } \\
\text { no Mar }\end{array}$ & Comunidade científica & $\begin{array}{l}\text { Promover a integração multissetorial para prevenção e } \\
\text { remediação dos resíduos sólidos no ambiente marinho. }\end{array}$ \\
\hline $\begin{array}{l}\text { Macrodiagnóstico da Zona Costeira e } \\
\text { Marinha do Brasil }\end{array}$ & MMA & Produzir nova versão do MZCM. \\
\hline Projeto Alt-Bat & MMA & $\begin{array}{l}\text { Apoiar o Comitê de Integração dos Componentes Verticais } \\
\text { Terrestre e Marítima da Comissão Nacional de Cartogra- } \\
\text { fia (CICVTM/Concar) no desenvolvimento de metodologia } \\
\text { para a integração das altitudes terrestres e marítimas } \\
\text { (Projeto Alt-Bat). }\end{array}$ \\
\hline $\begin{array}{l}\text { Encontro Nacional de Gerenciamento } \\
\text { Costeiro }\end{array}$ & MMA & Organizar o Encontro Nacional de Gerenciamento Costeiro. \\
\hline $\begin{array}{l}\text { Procosta - fase 1: concepção, formaliza- } \\
\text { ção e divulgação }\end{array}$ & MMA & $\begin{array}{l}\text { Estabelecer um programa de monitoramento, gestão e } \\
\text { conservação da atual Linha de Costa e da Zona Costeira } \\
\text { (Programa Nacional para a Conservação da Linha de } \\
\text { Costa - Procosta). }\end{array}$ \\
\hline $\begin{array}{l}\text { Prevenção, controle e monitoramento } \\
\text { socioambiental nos portos do Brasil }\end{array}$ & MMA & $\begin{array}{l}\text { Monitorar e acompanhar as ações de gerenciamento de } \\
\text { resíduos sólidos, de efluentes líquidos e da fauna sinantrópica } \\
\text { nociva; realizar diagnose das espécies exóticas invasoras } \\
\text { aquáticas no território portuário; estimular a expansão de } \\
\text { cooperativas e/ou associações de catadores e catadoras } \\
\text { na coleta seletiva de materiais recicláveis, com fomento às } \\
\text { ações de economia solidária e educação socioambiental nos } \\
\text { portos; e incentivar as boas práticas da relação porto-cidade, } \\
\text { a fim de maximizar os impactos positivos e minimizar os } \\
\text { impactos negativos causados pela atividade portuária, por } \\
\text { meio de capacitação e qualificação em saúde, segurança, } \\
\text { bem como educação ambiental e social. }\end{array}$ \\
\hline $\begin{array}{l}\text { Desenvolver metodologia de avaliação } \\
\text { dos planos de gestão integrada }\end{array}$ & $\begin{array}{l}\text { Secretaria de Patrimônio } \\
\text { da União }\end{array}$ & $\begin{array}{l}\text { Criar estratégia de monitoramento e fomento para que os } \\
\text { planos municipais de gestão integrada da orla sejam elabo- } \\
\text { rados, com o objetivo de que a gestão das praias possa ser } \\
\text { transferida aos municípios, segundo a Lei no } 13.240 / 2015 \text {. }\end{array}$ \\
\hline $\begin{array}{l}\text { Promover ações de treinamento e } \\
\text { capacitação voltadas para a ZC }\end{array}$ & Comunidade científica & $\begin{array}{l}\text { Capacitar técnicos das prefeituras dos municípios costeiros } \\
\text { acerca de temas relevantes, tais como: ordenamento terri- } \\
\text { torial e plano diretor; Projeto Orla e a Lei no } 13.240 / 2015 \text {; } \\
\text { e riscos costeiros e mudanças climáticas globais, bem como } \\
\text { gestão de praias. }\end{array}$ \\
\hline
\end{tabular}


(Continuação)

\begin{tabular}{|c|c|c|}
\hline Ação & Coordenador & Objetivo \\
\hline $\begin{array}{l}\text { Integrar e articular o Projeto Orla aos } \\
\text { planos diretores municipais }\end{array}$ & Comunidade científica & $\begin{array}{l}\text { Apresentar o Projeto Orla aos municípios costeiros brasileiros } \\
\text { que ainda não o possuem; implementar e consolidar o Projeto } \\
\text { Orla nos municípios costeiros brasileiros que já possuem o } \\
\text { programa; diagnosticar o estado atual do Projeto Orla nos } \\
\text { municípios costeiros; diagnosticar o estado atual dos planos } \\
\text { diretores municipais entre } 2006 \text { a 2017; e diagnosticar as } \\
\text { ações dos comitês gestores da orla, bem como dos conselhos } \\
\text { das cidades nos municípios costeiros. }\end{array}$ \\
\hline $\begin{array}{l}\text { Ampliar o número de estados com } \\
\text { PEGCs }\end{array}$ & $\begin{array}{l}\text { G17 - Subgrupo de } \\
\text { Integração dos Estados } \\
\text { Costeiros }\end{array}$ & $\begin{array}{l}\text { Ampliar o número de estados com os PEGCs elaborados } \\
\text { e implantados. }\end{array}$ \\
\hline $\begin{array}{l}\text { Identificar e divulgar as boas práticas } \\
\text { desenvolvidas pelo G17 e por municípios } \\
\text { costeiros relacionadas à gestão das zo- } \\
\text { nas costeira, marinha e flúvio-estuarina }\end{array}$ & G17 & $\begin{array}{l}\text { Identificar, divulgar e potencializar as experiências exitosas } \\
\text { em associação a outros atores e regiões da ZC. }\end{array}$ \\
\hline $\begin{array}{l}\text { Identificar os estados que ainda não } \\
\text { implantaram o ZEEC e acompanhar } \\
\text { os que estão em fase de elaboração e } \\
\text { implantação, com vistas ao fortalecimen- } \\
\text { to desse instrumento do PNGC }\end{array}$ & G17 & $\begin{array}{l}\text { Com base no diagnóstico desenvolvido pela Diretoria de } \\
\text { Zoneamento Territorial do MMA, identificar a situação dos } \\
\text { estados quanto aos ZEECs, com vistas a estimular os que } \\
\text { ainda não implementaram esse instrumento. }\end{array}$ \\
\hline $\begin{array}{l}\text { Avaliar as ações efetivas dos comitês da } \\
\text { Orla Marítima e dos planos de gestão } \\
\text { integrada (PGIs), considerando as modi- } \\
\text { ficações recentes da Lei no } 13.240 / 2015 \\
\text { e o termo de adesão, por intermédio das } \\
\text { comissões técnicas estaduais }\end{array}$ & G17 & $\begin{array}{l}\text { Analisar a efetividade dos comitês da Orla Marítima na } \\
\text { elaboração e implantação dos PGIs, considerando as } \\
\text { modificações recentes da Lei no } 13.240 / 2015 \text { e o termo de } \\
\text { adesão, por intermédio das comissões técnicas estaduais. }\end{array}$ \\
\hline $\begin{array}{l}\text { Regular o tráfego de veículos automoto- } \\
\text { res e embarcações em área de praias }\end{array}$ & G17 & $\begin{array}{l}\text { Propor rotas alternativas que permitam assegurar a demanda } \\
\text { pelos passeios turísticos nas praias em veículos automotores, } \\
\text { com vista a manter essa atividade com sustentabilidade. }\end{array}$ \\
\hline $\begin{array}{l}\text { Contribuir para a implementação do Ob- } \\
\text { jetivos do Desenvolvimento Sustentável } \\
\text { (ODS) } 14 \text { (vida subaquática) no Brasil }\end{array}$ & Sociedade civil & $\begin{array}{l}\text { Incentivar a participação da sociedade civil, seja esta } \\
\text { constituída por redes de conhecimento, organizações } \\
\text { não governamentais (ONGs) e/ou movimentos sociais na } \\
\text { implementação e discussão das políticas públicas ligadas } \\
\text { às questões costeiras e marinhas, principalmente relacio- } \\
\text { nadas ao ODS } 14 \text {. }\end{array}$ \\
\hline $\begin{array}{l}\text { Contribuir para a aprovação e a } \\
\text { implementação das açôes presentes no } \\
\text { Projeto de Lei (PL) no } 6.969 / 2013\end{array}$ & Sociedade civil & $\begin{array}{l}\text { Instituir a Política Nacional para a Conservação e o Uso } \\
\text { Sustentável do Bioma Marinho Brasileiro (PNCMar) e buscar } \\
\text { mecanismos e sinergias para sua implementação. }\end{array}$ \\
\hline $\begin{array}{l}\text { Desenvolver estudo de caso regional de } \\
\text { governança costeira-marinha integrada } \\
\text { para o ecossistema Babitonga (Santa } \\
\text { Catarina) }\end{array}$ & $\begin{array}{l}\text { Associação Nacional } \\
\text { de Órgãos Municipais } \\
\text { de Meio Ambiente } \\
\text { (ANAMMA) }\end{array}$ & $\begin{array}{l}\text { Desenvolver um estudo de caso de integração das políticas } \\
\text { de gestão ambiental pública e desenvolvimento sustentável. }\end{array}$ \\
\hline $\begin{array}{l}\text { Promover ações para divulgação e } \\
\text { implementação da Lei no } 12.340 / 2015 \\
\text { e sua regulamentação sobre a transfe- } \\
\text { rência da gestão das praias urbanas aos } \\
\text { municípios }\end{array}$ & $\begin{array}{l}\text { Ministério Público Federal } \\
\text { (MPF) }\end{array}$ & $\begin{array}{l}\text { Capacitar as secretarias do Patrimônio da União, membros do } \\
\text { MPF, órgãos ambientais, advogados da União e prefeituras } \\
\text { a exercer suas atribuições/competências. }\end{array}$ \\
\hline
\end{tabular}

Fonte: IV PAF para a ZC (2017-2019). Disponível em: <https://bit.ly/35P0lyD>. Acesso em: 12 dez. 2019.

Elaboração: Equipe Fronteiras Ipea.

\subsubsection{Programas estratégicos de defesa da Marinha brasileira na Amazônia Azul}

As dimensóes da Amazônia Azul ou das águas jurisdicionais brasileiras, que compóem atualmente cerca de 3,5 milhóes de quilômetros quadrados, representam uma vasta área não somente de oportunidades para a pesquisa biotecnológica e 
mineral ou de preservação da biodiversidade, mas também de necessidade de defesa para a proteção de uma área aberta, caminho de rotas comerciais que partem e chegam ao longo de toda a costa marítima, onde vive a maior parte da populaçáo brasileira, o que enfatiza a soberania nacional. Com esse objetivo, a MB exerce um importante papel, para o qual necessita de equipamentos apropriados que possam dar conta de vigiar e defender a fronteira marítima, protegendo suas riquezas e assegurando a manutenção de fluxos vitais à vida econômica nacional (Andrade e Franco, 2018, p. 15).

A PND, com sua Estratégia Nacional de Defesa (END), lançada em 2008 e revista em 2012, compóe o conjunto de diretrizes para adequada preparação, capacitação e aparelhamento do conjunto das FA, de forma a garantir a segurança do país. De acordo com Andrade, Franco e Hillebrand (2019, p. 22), o Plano de Articulaçáo e Equipamento de Defesa (Paed), previsto na política e estratégia, encontra-se em fase de revisão, podendo-se ressaltar que a MB já possuía um programa próprio de reaparelhamento, o Programa de Reaparelhamento da Marinha (PRM). De fato, houve diversos programas de reaparelhamento da MB desde a proclamação da República (Sales, 2015). O atual PRM foi encaminhado formalmente ao Ministério da Defesa (MD), em 2005. Informaçóes da $\mathrm{MB}^{17}$ apresentam como principais projetos estratégicos de defesa para a Amazônia Azul: o Programa Nuclear da Marinha (PNM), a Construção do Núcleo do Poder Naval e o Sistema de Gerenciamento da Amazônia Azul (SisGAAz).

O PNM dará ao Brasil capacidade técnica para o projeto, a construção e a operação de plantas núcleo-elétricas de tecnologia nacional. A energia gerada por essas plantas poderá ser utilizada tanto para a propulsão de meios navais, como os submarinos SN-BR, de propulsão nuclear, quanto para a alimentação de redes elétricas urbanas e rurais.

A partir do Programa de Construção do Núcleo do Poder Naval, que pretende ampliar e modernizar a capacidade operacional da $\mathrm{MB}$, estão sendo desenvolvidos submarinos convencionais e de propulsão nuclear e a construção de um estaleiro e uma base naval. Como resultados iniciais, foi inaugurado, em fevereiro de 2018, o Estaleiro de Construçáo, e, em dezembro de 2018, foi lançado ao mar o submarino Riachuelo, o primeiro submarino construído no âmbito do programa. Há, ainda, a previsão, para 2020, do lançamento ao mar do segundo submarino convencional do programa, o submarino Humaitá. O programa prevê, também, a construção de navio-aeródromo, de navio anfíbio e de meios de superfície, bem como a produção de navios-patrulha de $500 \mathrm{t}$ e de corvetas de classe Barroso. 
O SisGAAz consiste em um conjunto de sistemas que tem como objetivo ampliar a capacidade de monitoramento e controle das águas jurisdicionais e das regióes de busca e salvamento sob responsabilidade do Brasil. O projeto abrange a utilização de satélites, radares e equipamentos de sensoriamento submarino, com o objetivo de monitorar o MT brasileiro. A estrutura integrará redes de informação e de apoio à decisão. Apesar da importância atribuída ao programa pela $\mathrm{MB}$, a necessidade de proteger as áreas jurisdicionais brasileiras para o qual o SisGAAz possui papel fundamental,

defronta-se com a necessidade de reestabelecer o equilíbrio das contas públicas e superar a crise fiscal que se instalou no país nos últimos anos. Tal cenário fez que os recursos disponíveis à defesa e aos programas estratégicos das Forças Armadas, de maneira geral, se tornassem ainda mais escassos, levando à necessidade de reformulaçáo de alguns programas importantes, incluindo o SisGAAz (Andrade, Rocha e Franco, 2019, p. 32).

O monitoramento, controle das movimentaçóes e dos vetores de acesso, encontra-se em situação de risco de descontinuidade devido à falta de recursos orçamentários, sendo crítico o cumprimento da missão de defesa da Amazônia Azul. Isso ganha ainda mais relevância quando se considera que a conclusão dos processos de delimitação jurídica das águas jurisdicionais do país (reconhecimento da extensão da sua PC por parte das autoridades internacionais) se encontra em estágio consideravelmente avançado.

\section{REFERÊNCIAS}

ANDRADE, I. O.; FRANCO, L. G. A. A Amazônia Azul como fronteira marítima do Brasil: estratégia e imperativos para a defesa nacional. In: PÊGO, B.; MOURA, R. (Orgs.). Fronteiras do Brasil: uma avaliação de política pública. Rio de Janeiro: Ipea; MI, 2018. v. 1.

ANDRADE, I. O.; FRANCO, L. G. A.; HILLEBRAND, G. R. L. Ciência, tecnologia e inovaçáo nos programas estratégicos da Marinha do Brasil. Brasília: Ipea, 2019. (Texto para Discussão, n. 2471).

ANDRADE, I. O.; ROCHA, A. J. R.; FRANCO, L. G. A. Sistema de Gerenciamento da Amazônia Azul: soberania, vigilância e defesa das águas jurisdicionais brasileiras. Brasília: Ipea, 2019. (Texto para Discussão, n. 2452).

BARTHOLOMEU, M. C. As delimitaçôes da unidade regional entre Rio de Janeiro (RJ) e São Paulo (SP): da megalópole à megarregião. In: CONGRESSO OBSERVATÓRIO DAS METRÓPOLES - 20 ANOS: AS METRÓPOLES E O DIREITO À CIDADE - DILEMAS, DESAFIOS E ESPERANÇAS, Rio de Janeiro. Anais... Rio de Janeiro: Ippur; Observatório das Metrópoles, 2019. 
BELCHIOR, C. Gestáo costeira integrada: estudo de caso do Projeto Ecomanage na regiāo estuarina de Santos-São Vicente, SP, Brasil. 2008. Dissertação (Mestrado) - Programa de Pós-Graduação em Ciência Ambiental, Universidade de São Paulo, São Paulo, 2008.

BRASIL. Decreto-Lei no 74.557, de 12 de setembro de 1974. Cria a Comissão Interministerial para os Recursos do Mar (Cirm) e dá outras providências. Brasília: Presidência da República, 13 set. 1974. Disponível em: <https://bit.ly/2IXLxot>. Acesso em: 22 jan. 2020.

. Lei no 7.661, de 16 de maio de 1988. Institui o Plano Nacional de Gerenciamento Costeiro e dá outras providências. Brasília: Congresso Nacional, 18 maio 1988a. Disponível em: <https://bit.ly/3pTn4S6>. Acesso em: 20 jan. 2020.

. Constituiçáo Federal de 1988. Brasília: Senado Federal, 1988b.

. Decreto-Lei no 98.145, de 15 de setembro de 1989. Aprova o Plano de Levantamento da Plataforma Continental Brasileira, e dá outras providencias. Brasília: Presidência da República, 18 set. 1989. Disponível em: <https://bit. ly/3kVazSj>. Acesso em: 20 jan. 2020.

. Ministério do Meio Ambiente. Resolução Cirm no 1, de 21 de novembro de 1990. Aprova o Plano Nacional de Gerenciamento Costeiro (PNGC). Brasília: MMA, 1990. Disponível em: <https://is.gd/l2Wt8M>. Acesso em: 20 jan. 2020.

. Lei $\mathrm{n}^{\circ}$ 8.617, de 4 de janeiro de 1993. Dispóe sobre o mar territorial, a zona contígua, a Zona Econômica Exclusiva e a plataforma continental brasileiros, e dá outras providências. Brasília: Congresso Nacional, 4 jan. 1993. Disponível em: <https://bit.ly/35UyFbE>. Acesso em: 20 jan. 2020.

Decreto-Lei no 1.530, de 22 de junho de 1995. Declara a entrada em vigor da Convenção das Naçóes Unidas sobre o Direito do Mar, concluída em Montego Bay, Jamaica, em 10 de dezembro de 1982. Brasília: Presidência da República, 23 jun. 1995a. Disponível em: <https://bit.ly/3kXIUBx>. Acesso em: 20 jan. 2020.

. Decreto-Lei no 1.540 , de 27 de junho de 1995. Dispóe sobre a composição e o funcionamento do grupo de coordenação incumbido da atualização do Plano Nacional de Gerenciamento Costeiro (PNGC). Diário Oficial da Uniáo, Brasília, 28 jun. 1995b. Disponível em: <https://bit.ly/3kR3Wk8>. Acesso em: 20 jan. 2020.

. Ministério da Defesa. Marinha do Brasil. Portaria Ministerial no 440, de 20 de dezembro de 1996. Cria o Grupo de Integraçâo do Gerenciamento Costeiro (GI-Gerco). Brasília: MB; MD, 1996. Disponível em: <https://bit.ly/372PnoM>. Acesso em: 20 jan. 2020. 
. Ministério do Meio Ambiente. Resolução Cirm no 5, de 23 de dezembro de 1997. Aprova o Plano Nacional de Gerenciamento Costeiro II (PNGC II). Brasília: MMA, 1997. Disponível em: <https://is.gd/SRAWa>. Acesso em: 20 jan. 2020.

. Decreto-Lei no 5.300, de 7 de dezembro de 2004. Regulamenta a Lei no 7.661, de 16 de maio de 1988, que institui o Plano Nacional de Gerenciamento Costeiro (PNGC), dispóe sobre regras de uso e ocupação da Zona Costeira e estabelece critérios de gestão da Orla Marítima, e dá outras providências. Diário Oficial da Uniáo, Brasília, 8 dez. 2004. Disponível em: <https://bit.ly/3pVPo6o>. Acesso em: 20 jan. 2020.

. Decreto-Lei no 5.377, de 23 de fevereiro de 2005. Aprova a Política Nacional para os Recursos do Mar (PNRM). Diário Oficial da Uniáo, Brasília, 24 fev. 2005. Disponível em: <https://bit.ly/2J6qznf>. Acesso em: 20 jan. 2020.

. Decreto-Lei no 5.758, de 13 de abril de 2006. Institui o Plano Estratégico Nacional de Áreas Protegidas (PNAP), seus princípios, diretrizes, objetivos e estratégias, e dá outras providências. Diário Oficial da Uniáo, Brasília, 17 abr. 2006. Disponível em: <https://bit.ly/33aunLM>. Acesso em: 20 jan. 2020.

. Ministério do Meio Ambiente. Macrodiagnóstico da Zona Costeira e Marinha. Brasília: MMA, 2008.

. Ministério da Pesca e Aquicultura. Boletim Estatístico da Pesca e Aquicultura 2011. Brasília: MPA, 2011.

Ministério do Meio Ambiente. Plano Nacional de Gerenciamento Costeiro: 25 anos do gerenciamento costeiro no Brasil. Brasília: MMA, 2015.

Ministério dos Transportes, Portos e Aviação Civil. Corredores logísticos estratégicos: complexo de soja e milho. Brasília: MTPA, 2017. v. 1, 167 p.

. Ministério dos Transportes, Portos e Aviação Civil. Corredores logísticos estratégicos: complexo de minério de ferro. Brasília: MTPA, 2018a. v. 2, 170 p.

. Ministério dos Transportes, Portos e Aviação Civil. Corredores logísticos estratégicos: veículos automotores. Brasília: MTPA, 2018b. v. 3, 153 p.

. Ministério dos Transportes, Portos e Aviação Civil. Mapas e bases dos modos de transporte. Brasília: MTPA, 2018c. Disponível em: <https://bit. ly/3fp32tY>. Acesso em: 20 jan. 2020.

CALLOU, A. B. F. Povos do mar: herança sociocultural e perspectivas no Brasil. Revista Ciência e Cultura, núcleo temático Ciências do Mar, v. 62, n. 3, p. 4548, 2010. 
CARVALHO, A. B. Economia do mar: conceito, valor e importância para o Brasil. 2018. Tese (Doutorado) - Programa de Pós-Graduação em Economia do Desenvolvimento, Pontifícia Universidade Católica do Rio Grande do Sul, Porto Alegre, 2018. 185 p.

CASTRO, B. M. et al. A Amazônia Azul: recursos e preservaçáo. Revista USP, dossiê da Amazônia Azul, São Paulo, n. 113, p. 7-26, 2017.

CASTRO, G. S. A. et al. Macrologística: caracterização das bacias logísticas da agropecuária brasileira. In: SIMPÓSIO BRASILEIRO DE SENSORIAMENTO REMOTO, 19., 2019, Santos, São Paulo. Anais... São José dos Campos: Inpe, 2019.

CASTRO, G. S. A. et al. Macrologística da agropecuária brasileira: delimitação das bacias logísticas. Brasília: Embrapa, 2015. Disponível em: <https://bit. ly/2J3dJXg>. Acesso em: 20 jan. 2020.

CAVALCANTI, L.; OLIVEIRA, T.; MACEDO, M. (Orgs.). Imigração e refúgio no Brasil: a inserção de imigrantes solicitantes de refúgio e refugiados no mercado de trabalho - Relatório Anual 2019. Brasília: OBMigra, 2019. (Série Migrações).

CAVALLI, R. O.; FERREIRA, J. F. O futuro da pesca e da aquicultura marinha no Brasil: a maricultura. Revista Ciência e Cultura, núcleo temático Ciências do Mar, v. 62, n. 3, p. 38-39, 2010.

CIRM - COMISSÃO INTERMINISTERIAL PARA OS RECURSOS DO MAR. IX Plano Setorial para os Recursos do Mar (2016-2019). Brasília: Cirm, 2016. Disponível em: <https://bit.ly/2IXSRkd>. Acesso em: 12 dez. 2019.

COSTA, J. A. F. A Amazônia Azul e o domínio marítimo brasileiro. Revista USP, dossiê Amazônia Azul, São Paulo, n. 113, p. 7-26, abr./maio/jun. 2017.

COSTA, M. A.; MARGUTI, B. O. (Eds.). Atlas da vulnerabilidade social nos municípios brasileiros. Brasília: Ipea, 2015. 77 p.

CROSSLAND, C.; KREMER, H. Coastal zones: ecosystems under pressure. In: Oceans and coasts at Rio + 10 Global Conference. Paris: Unesco, 2001.

EMPLASA - EMPRESA PAULISTA DE PLANEJAMENTO METROPOLITANO. Estudo da morfologia e da hierarquia funcional da rede urbana paulista e regionalizaçáo do estado de Sáo Paulo. Documento 1 (Metodologia). São Paulo: SEP; Emplasa; Seade, 2011.

FAO - FOOD AND AGRICULTURE ORGANIZATION OF THE UNITED NATIONS. Integrated coastal area management and agriculture, forestry and fisheries. Rome: FAO Guidelines, 1998. 256 p. 
HAZIN, F. H. V. O futuro da pesca e da aquicultura marinha no Brasil: a pesca oceânica. Revista Ciência e Cultura, núcleo temático Ciências do Mar, v. 62, n. 3, p. 32-35, 2010.

IBGE - INSTITUTO BRASILEIRO DE GEOGRAFIA E ESTATÍSTICA. Regióes de Influência das Cidades. Rio de Janeiro: IBGE, 2008. Disponível em: <https://bit.ly/33aJXHf>. Acesso em: 20 jan. 2020.

Censo Demográfico 2010. Rio de Janeiro: IBGE, 2011a. Disponível em: <https://bit.ly/3fqWfQn>. Acesso em: 20 jan. 2020.

. Diretoria de Geociências. Atlas geográfico das zonas costeiras e oceânicas do Brasil. Rio de Janeiro: IBGE, 2011b. 176 p.

Coordenação de Geografia. Arranjos populacionais e concentraçóes urbanas no Brasil. 2. ed. Rio de Janeiro: IBGE, 2016a.

Produto interno bruto dos municípios. Rio de Janeiro: IBGE, 2016b. Disponível em: <https://is.gd/E9BdqX>. Acesso em: 20 jan. 2020.

. Diretoria de Pesquisas. Coordenação de População e Indicadores Sociais. Estimativas da população residente no Brasil e Unidades da Federaçáo com data de referência em $1^{\circ}$ de julho de 2019. Rio de Janeiro: IBGE, ago. 2019.

. Diretoria de Geociências. Coordenação de Geografia. Regióes de influência das cidades 2018. Rio de Janeiro, IBGE, 2020. Disponível em: < https:// biblioteca.ibge.gov.br/visualizacao/livros/liv101728.pdf>. Acesso em 30 jul. 2020.

IMIGRANTES resgatados em barco precário no Maranhão estavam há 35 dias no mar. O Estado de Sáo Paulo, 20 maio 2018. Disponível em: <https://bit. ly/33atenn>. Acesso em: 20 jan. 2020.

INEP - INSTITUTO NACIONAL DE ESTUDOS E PESQUISAS EDUCACIONAIS ANÍSIO TEIXEIRA. Censo da Educação Superior 2018. Rio de Janeiro: Inep/MEC, 2019. Disponível em: <https://bit.ly/3nTnPc5>. Acesso em: 20 jan. 2020.

JUDICE, L. P. C.; PIÑON, C. P. A defesa do ouro negro da Amazônia Azul. Rio de Janeiro: Escola de Guerra Naval, 2016.

MORAIS, J. M. Petróleo em águas profundas: uma longa história tecnológica da Petrobras na exploração e produção offshore. Brasília: Ipea, 2013.

MOREIRA, P. G. Trajetórias conceituais e novas formas de interação nas fronteiras brasileiras. In: PÊGO, B.; MOURA, R. (Orgs.). Fronteiras do Brasil: uma avaliação de política pública. Rio de Janeiro: Ipea; MI, 2018. v. 1, p. 21-42. 
MOURA, R.; OLIVEIRA, S.; PÊGO, B. Escalas da urbanizaçáo brasileira. Rio de Janeiro: Ipea, 2018. (Texto para Discussão, n. 2372).

NETO, A. M.; SILVA, R. O.; SEVERIAN, D. Perfil e dinâmica das desigualdades regionais do Brasil em territórios industriais relevantes. Brasília: Ipea, 2019. (Texto para Discussão, n. 2511). Disponível em: <https://bit.ly/2IUMkXt>. Acesso em: 17 jan. 2020.

NICOLODI, J.; PETTERMANN, R. Vulnerability of the Brazilian coastal zone in its environmental, social, and technological aspects. Journal of Coastal Research, n. 64, p. 1372-1379, 2011.

ONU - ORGANIZAÇÃO DAS NAÇÓES UNIDAS. Convenção das Naçóes Unidas sobre o Direito do Mar. Montego Bay: ONU, 10 dez. 1982.

. Conferência das Naçóes Unidas para o Meio Ambiente e Desenvolvimento (CNUMAD) - Agenda 21. Rio de Janeiro: ONU, 1992.

. Nosso oceano, nosso futuro: chamada para ação - documento final da Conferência das Nações Unidas sobre os Oceanos. Nova Iorque: ONU, 2017.

PAIM, M. A. A expansão da Amazônia Azul: a plataforma continental do Brasil além das 200 milhas náuticas. In: BEIRÃO, A. P.; PEREIRA, A. C. A (Orgs.). Reflexóes sobre a convençáo do direito do mar. Brasília: Funag, 2014. p. 313-346. PÊGO, B.; MOURA, R. (Orgs.). Fronteiras do Brasil: uma avaliação de política pública. Rio de Janeiro: Ipea; MI, 2018. v. 1.

PÊGO, B. et al. (Orgs.). Fronteiras do Brasil: diagnóstico e agenda de pesquisa para política pública. Brasília: Ipea; MI, 2017. v. 2.

(Orgs.). Fronteiras do Brasil: uma avaliação do Arco Norte. Brasília: Ipea; MI, 2018. v. 3.

. (Orgs.). Fronteiras do Brasil: uma avaliação do Arco Central. Rio de Janeiro: Ipea; MDR, 2019. v. 4.

. (Orgs.). Fronteiras do Brasil: uma avaliaçáo do Arco Sul. Rio de Janeiro: Ipea; MDR, 2020. v. 5.

SALES, P. D. B. Os programas de reaparelhamento da Marinha do Brasil na República. Rio de Janeiro: Ebape/FGV, 2015.

SANTOS, M. Técnica, espaço, tempo: globalização e meio técnico-científico informacional. São Paulo: Hucitec, 1996.

SANTOS, M.; SILVEIRA, M. L. O Brasil: território e sociedade no início do século XXI. 2. ed. Rio de Janeiro: Editora Record, 2001. 
SASSI, L. O.; SOARES. P. R. R. A cidade-região de Porto Alegre: análise da desconcentração metropolitana a partir de dados socioeconômicos. In: CONGRESSO OBSERVATÓRIO DAS METRÓPOLES - 20 ANOS: AS METRÓPOLES E O DIREITO À CIDADE: DILEMAS, DESAFIOS E ESPERANÇAS, 2019, Rio de Janeiro. Anais... Rio de Janeiro: Ippur; Observatório das Metrópoles, 2019. TISCHER, V.; POLETTE, M. Proposta metodológica de estabelecimento de indicadores socioambientais para a Zona Costeira brasileira. G\&DR, v. 12, n. 2, p. 355-373, maio/ago. 2016. 


\section{CONSIDERAÇÕES FINAIS}

\section{INTRODUÇÃO}

Este estudo valeu-se de substantivos diagnósticos existentes sobre as fronteiras brasileiras e foi além: percorreu fragmentos de seu território para compreender sua realidade nesse final da década de 2010 e a percepçâo de seus moradores, que vivem o cotidiano e vislumbram tendências para a região. Informaçóes sistematizadas em outras pesquisas somadas a dados secundários e cartografia temática complementaram e deram clareza às observaçóes colhidas e às proposiçóes que fecham este trabalho.

A busca central de uma jornada desta monta, realizada pelo Ipea, foi oferecer importantes subsídios à formulação de uma política nacional de fronteiras e seus desdobramentos. No decorrer da pesquisa, confirmou-se uma inquietação inicial: a fronteira terrestre guarda relaçôes intrínsecas com as fronteiras aérea e litorânea. Portanto, a condição fronteiriça se dá no plural: são fronteiras e não fronteira. Todas realizam o exercício dessa condição fronteiriça em terra. Esse entendimento sinaliza que a pesquisa não deve se encerrar neste estudo, mas se abrir em novas frentes e em novas direçóes.

\section{UM CENÁRIO DE DIVERSIDADE, DESENVOLVIMENTO, CONFLITOS E POTENCIALIDADES}

A essência plural foi ressignificada pelos participantes das atividades nos três arcos da fronteira terrestre, para quem são "várias fronteiras". Mesmo esses arcos, que dividem a faixa de fronteira (FF) para efeitos de planejamento, formulação e implementação de políticas, não contemplam essa heterogeneidade, que emana das diversidades social, cultural, histórica, paisagística e natural. Diante disso, políticas públicas e estratégias de desenvolvimento devem ser redefinidas e adequadas às especificidades dessa realidade regional e, fundamentalmente, voltadas às necessidades e às aspiraçóes da população da extensa fronteira brasileira.

Na perspectiva da ocupação do território, a análise realizada para a fronteira terrestre reforçou a forte relaçáo da cultura dos povos originais com os elementos inerentes ao meio natural em que vivem, seja na Amazônia, no Pantanal e no Cerrado, com elevada presença indígena e de comunidades tradicionais (ribeirinhos e outros povos da floresta), seja nos Pampas, com seus colonos e imigrantes. Ressaltou 
a importância das políticas existentes de proteção e preservação desses biomas e de seus recursos naturais, na proteção contra os efeitos de degradação ambiental e dos conflitos socioambientais, decorrentes de quaisquer causas. Essas políticas são importantes para os povos tradicionais da floresta e para a sustentabilidade ambiental, na qual a conciliação ser humano/natureza precisa de conhecimentos específicos, transmitidos na vivência cotidiana desses povos com o meio ambiente. Salientou-se a necessidade de práticas comuns de preservação e conservação e do apoio a atividades sustentáveis entre países vizinhos, uma vez que para os biomas não existem fronteiras.

Os níveis de precariedade e baixo grau de desenvolvimento em grande extensão da regiáo fronteiriça se dão menos pelas suas capacidades endógenas que pela intermitência de políticas públicas, pela falta de diálogo entre as instâncias federativas e, conforme percepção de muitos fronteiriços, pela ausência do Estado na regiấo, consolidando condiçôes de vulnerabilidade, instabilidade e insegurança. Uma realidade de carências é vivida por grande parte dos habitantes dos municípios fronteiriços, para os quais faltam os serviços básicos de saúde e educação e opções de trabalho e renda que evitem o trabalho infantil ou a submissão ao aliciamento por práticas ilícitas.

Além da necessidade de adequação de políticas e redefinição de estratégias de desenvolvimento para a região, a gestão urbana passa por dinâmicas que exigem novos acordos binacionais. Nos arranjos transfronteiriços, um intenso movimento pendular entre moradores dos países sustenta um conjunto de relaçóes peculiares que mesclam saberes, combinam características de seus povos, de suas culturas, de suas histórias e famílias, e de sua paisagem urbana e natural. Criam um compartilhamento no exercício de atividades e no acesso a serviços e ao consumo, ainda sem apoio em açóes para integração.

Tais "unidades" socioespaciais institucionalmente operam como fragmentos de países, pouco sensíveis aos formuladores de políticas e acordos, sem conquistarem estatutos de gestão que reconheçam a singularidade da dimensão transfronteiriça configurada. Por um lado, a desarticulação nas funções públicas de interesse comum gera demandas reprimidas; por outro, os cidadãos transfronteiriços são privados dos direitos de um novo tipo de cidadania, emanado de uma realidade que se reproduz em médios e pequenos centros, como também em longínquos povoados da linha das fronteiras do país. O desafio principal consiste em construir conjuntamente os instrumentos necessários à integração desses espaços contínuos.

Além desse desafio, deve-se saber administrar a intensa mobilidade que caracteriza esses arranjos, transformados em portais terrestres de entrada e saída para fluxos de maior distância, de migrantes e refugiados, a quem acolhem passageiramente. Também são portais de fluxos de mercadorias, e, entre elas, ilícitos 
que tornam esses espaços estigmatizados como lugares do crime, do contrabando, do tráfico - mesmo que se aponte que grandes volumes dos ilícitos se valem das fronteiras do mar e do ar. Assim, são muitas as solicitaçóes de que se ampliem na região medidas de segurança pública e de controle fronteiriço para eliminar os conflitos, o isolamento e as condiçôes de vulnerabilidade social.

Potencialidades também são expoentes na região. As fronteiras desfrutam de inquestionáveis riquezas cultural, ambiental e econômica, que se expressam no território e na identidade dos fronteiriços, prontos para participarem de um projeto de desenvolvimento e integração. É imperativo que se aproveitem as oportunidades econômicas geradas pelas frentes de expansão de negócios e o avanço da infraestrutura econômica (energia, estradas, pontes, aeroportos, portos e conectividade), de forma a incluir os pequenos e médios empreendedores, fortalecendo e integrando cadeias produtivas, e criando outras novas, com a identificação e o desenvolvimento de arranjos produtivos locais que possam dinamizar a economia local e regional.

\section{POLíTICAS PARA O DESENVOLVIMENTO E A INTEGRAÇÃO}

Apesar do reconhecimento dos avanços que as políticas públicas em pauta proporcionaram, diversos fatores influenciaram de forma negativa seu desempenho nas fronteiras, incluindo primordialmente: a baixa descentralização e articulação interfederativa; os desafios em planejamento, orçamento e gestão; a falta de institucionalidade política; a descontinuidade das políticas públicas (em sua maioria políticas de governo e não de Estado); e a deficiência de informaçóes para monitoramento e avaliação. Ademais, verificou-se que a região apresenta demandas enérgicas e acesso a serviços públicos essenciais; havendo, ainda, a necessidade premente de respaldo legal que ampare a integração e a realização de acordos entre as localidades vizinhas na zona fronteiriça brasileira, e o reconhecimento das diversidades sociocultural e territorial da fronteira nacional para açốes de retomada de desenvolvimento.

Ao reconhecer-se que são várias as fronteiras, reconheceu-se também a ineficácia da formulação de uma única política pública não diferenciada para toda a FF, e recomendou-se que se considerem as especificidades e os interesses comuns entre municípios, estados, regiôes (arcos) e países fronteiriços e transfronteiriços, de forma a que se formulem políticas públicas setoriais integradas com propostas de instrumentos diferenciados. Salientou-se a importância da criação de uma carteira de projetos específicos para a região de fronteira, orientados por políticas efetivas para investimentos conjuntos e busca de oportunidades de curto, médio e longo prazos.

Propostas de políticas para a fronteira deverão ser definidas em diferentes escalas sejam elas em função de: seus diversos espaços de interação materializados 
nos arranjos transfronteiriços; suas peculiaridades populacionais, econômicas, sociais e ambientais; ou espaços cuja estratégia deva ser regional, considerando a sua relação com o desenvolvimento local, estadual, regional e federal, com a devida interação internacional. Sugeriu-se a elaboração de planos conjuntos com os países vizinhos visando ao desenvolvimento da FF, consolidando uma agenda transnacional com programas e ações integradas.

Especificamente nos arranjos transfronteiriços, há que se considerar estratégias para consolidação da gestão compartilhada de funções públicas de interesse comum, construídas em consonância com os planos diretores das cidades, dando prioridade para a gestáo do transporte urbano de passageiros, do uso do solo, do saneamento básico e da gestão ambiental como bases estruturantes das estratégias de gestão da educação, da assistência social, da atenção à saúde, da oferta de moradia e da regularização fundiária, trabalho, atividades esportivas e culturais e segurança.

No âmbito regional, merecem destaque os acordos que têm buscado aproximar fisicamente os países fronteiriços, sobretudo aqueles voltados à construção de novas rodovias, à interligação energética e à redução da burocracia para aumento da livre circulação de bens e pessoas. No entanto, apesar da existência de iniciativas como o Mercosul - que, por meio de seu sistema próprio, poderia regular os acordos bilaterais, contribuindo, assim, para a melhoria da qualidade de vida dos cidadãos fronteiriços -, há pouca continuidade na articulação de reuniôes e grupos de trabalho sobre o tema, no âmbito do bloco. Otimizar esse canal é algo que deveria ter maior participação por parte dos gestores de uma forma geral, uma vez que acontece em nível subnacional, não dependendo da representação direta do governo federal, mas de seu incentivo/descentralização. $\mathrm{O}$ mesmo pensamento vale para medidas que venham a ser desenvolvidas fora do bloco.

Ao se pensar na formalização de dispositivos de uma política nacional de fronteira, deve ser considerado o arcabouço normativo existente sobre a regiáo e se centrar o foco em suas lacunas e controvérsias. Uma dessas é a controvérsia existente sobre a largura e as limitaçóes impostas pela FF. Por um lado, a manutenção dos $150 \mathrm{~km}$ desde a linha de fronteira atende às atribuiçóes das Forças de Defesa e Segurança, assim como às políticas de vantagens locacionais demandadas por determinados recortes da região fronteiriça (incentivos fiscais, tributários etc.). Por outro lado, não há como relacionar o baixo desenvolvimento econômico da região aos termos da Lei de Fronteira ( $n^{\circ}$ 6.634/1979), que disciplina a realização das atividades estratégicas na FF ao assentimento prévio do Conselho de Defesa Nacional (CDN).

Muitas medidas viriam do âmbito do fortalecimento institucional, como: a compatibilização de normas e o pacto entre interesses aos países fronteiriços; a maior cooperação internacional (projetos sociais, ambientais, educacionais, cultu- 
rais e de desenvolvimento) e coordenação das políticas sociais entre o Brasil e esses países; e o fortalecimento e a maior articulação das instâncias subnacionais para promover o atendimento às necessidades locais e regionais (aprovação de projetos e programas conjuntos).

Reforça-se, portanto, a importância da presença do Estado com açóes públicas permanentes e coordenadas na região. Nessa presença, mostrou-se imprescindível o fortalecimento de uma estrutura de gestáo que sustente a atuaçáo dos núcleos estaduais de fronteira junto à Comissáo Permanente para o Desenvolvimento e a Integração da Faixa de Fronteira (CDIF), para se estabelecer um marco legal que inclua as escalas local e regional nas políticas públicas da fronteira e a discussão sobre os instrumentos e as ferramentas prioritárias e específicas para uma gestão fronteiriça e transfronteiriça.

\section{OUTRAS FRONTEIRAS A ANALISAR - LITORÂNEA E AÉREA}

Muito já se conhece sobre as particularidades e os requerimentos das várias fronteiras terrestres, fundamentalmente que nestas se configuram espaços de uniáo, cooperação e diversidade. Mas ainda há muito a se conhecer sobre as fronteiras litorânea e aérea, ambas ancoradas em terra.

A condição de fronteira exercida pela faixa litorânea tem uma importância e uma especificidade ainda pouco absorvida nos estudos gerais e em uma agenda sobre fronteiras. Muitos problemas sinalizam a emergência de propostas e ações públicas nessa região, entre eles os efeitos deletérios atribuídos ao aquecimento global que podem ser sentidos em cidades litorâneas, como o aumento de deslizamento de terras em função das chuvas, inundações, resultando em mortes e desabrigados. Junto aos eventos provocados por acidentes, como o derramamento de petróleo que atingiu boa extensão do ecossistema litorâneo brasileiro, expóe-se a necessidade de açôes integradas das instâncias de governo, visando enfrentar desafios vindouros.

Além de ser a região mais habitada do Brasil e possuir os principais ativos públicos e privados (refinarias, portos, aeroportos, universidades etc.), constitui um território atrativo pela grande potencialidade mineral (principalmente petróleo), pelos processos e produtos voltados para o mar, como a biotecnologia, a energia, a logística naval e o offshore, e pelas obras costeiras e portuárias, para os quais se apresentam como necessidade recursos para o desenvolvimento de pesquisas, novas tecnologias, monitoramento e fiscalização. O importante é que já existe um desenho institucional em fase avançada de articulação entre as esferas de governo para um gerenciamento costeiro integrado, segundo preconizam a Agenda 21 e o Objetivo de Desenvolvimento Sustentável (ODS) 14, como mostrou o estudo. 


\section{DESAFIOS ESTRUTURANTES}

Dois fatos recentes de grande monta sublinharam a relevância das fronteiras e a necessidade de uma política nacional que oriente seu funcionamento diante de inesperados eventos. A diáspora venezuelana e a pandemia da Covid-19, com elementos geradores, conteúdos e origens distintos, exigiram em relação às fronteiras medidas de alta racionalidade e a serem tomadas em curto espaço de tempo. Nos dois casos, vidas humanas poderiam ser comprometidas além das restriçóes à mobilidade e às relaçóes econômicas.

No caso do primeiro evento, as fronteiras se apresentaram como traçados institucionais cuja principal característica foi serem sobrepostos por elevada mobilidade de pessoas e mercadorias, que buscam melhores condiçóes de vida, trabalho e sobrevivência, a fuga da violência sob qualquer ordem. Tal mobilidade assumiu elevadas proporçóes, desestabilizando o espaço fronteiriço, como se deu no caso da imigração venezuelana, que teve por principal porta de entrada no país o estado de Roraima, mais diretamente o município de Pacaraima e a capital Boa Vista. Ambas as cidades viveram (e seguem vivendo) período de pressão pela falta de capacidade imediata de acolhimento, saturação dos serviços públicos ofertados e condiçóes miseráveis às quais se obrigaram adultos e crianças. Constatou-se uma inércia entre o início do processo e as primeiras medidas concretas de acolhimento e interiorização dos migrantes, e, com isso, mais de uma vez se fecharam e se abriram as fronteiras entre os dois países, criando situaçóes de instabilidade, insegurança, separaçáo de vidas humanas e restrição às atividades produtivas.

Enfatiza-se que a crise migratória é um processo complexo e de alcance transnacional que precisa ser gerenciado por meio de açóes tomadas em diferentes níveis políticos, econômicos e institucionais. Por isso, uma boa resposta à crise é priorizar a abordagem sobre controle de fronteiras sendo este ao mesmo tempo humanitário. Isso significa dizer que é fundamental garantir a manutenção e a segurança dos passos fronteiriços, porém sem deixar de atender às demandas da população migrante em situação de vulnerabilidade.

No caso da pandemia da Covid-19, outra vez a decisão sobre o fechamento das fronteiras se deu aos poucos, sem a necessária certeza de que era fundamental coibir o avanço da contaminação, com efeitos ainda incalculáveis na saúde e na vida da população. Comprovada a origem externa do vírus que chegava ao Brasil, ainda assim as fronteiras marítima e aérea se mantiveram sem a fiscalização necessária de controle das condiçóes de saúde daqueles que entravam no país, e as fronteiras terrestres se mantiveram porosas. Ao mesmo tempo, brasileiros passaram por dilemas para serem repatriados diante de medidas imediatas de fechamento das fronteiras de outros países. A entrada da Covid-19 no Brasil mostrou a necessidade de açóes rápidas nos pontos de entrada e saída do país, e os encontrou desarticulados. 
O alerta dado por essa situação, que mostra possivelmente não ser a última, evidenciou a urgência de políticas incidentes nos pontos de controle migratório e aduaneiro, articuladas entre as várias fronteiras. Tendo em vista que o controle de fronteiras desempenha papel central na mitigação de surtos, faz-se mister salientar a necessidade de se otimizar o uso da triagem de passageiros nos aeroportos e nos portos como primeira medida a ser tomada em caso de pandemias (criação de protocolos que possam ser de fácil operacionalização e eficácia). Isso se deve ao fato de que a introdução de novas doenças se faz de forma mais rápida, principalmente, por meio da chegada via transporte aéreo. Uma vez identificados os indivíduos infectados ou em risco de transmissão nos aeroportos, torna-se mais ágil e prático para os gestores e responsáveis pelo controle de pandemias fornecer tratamento e isolamento imediatos, evitando, assim, novas transmissóes. A triagem de passageiros na chegada aos portos e aos aeroportos, como também em seu acesso aos portais fronteiriços terrestres, deve ser, portanto, o principal mecanismo de controle de fronteira, quando da comunicação da existência de uma pandemia. Outra medida, de caráter mais restritivo, é a proibição de entrada de pessoas vindas das regióes contaminadas.

Os dois exemplos, ainda em curso, evidenciam a importância da vigência de uma política nacional de fronteiras que contemple as inúmeras urgências a que se submetem. Uma política que tenha como princípio o respeito à soberania dos países e aos direitos (humanos e fundamentais) dos cidadáos nacionais e dos países vizinhos, que garanta a inclusão, a sustentabilidade e a segurança, e que traga em seu escopo os alinhamentos básicos para orientar estratégias rápidas e açôes eficazes. Deve vir acompanhada do fortalecimento de instituiçôes do governo que assegurem, nas relaçóes com os países vizinhos, o diálogo, a cooperação e a integração na tomada de decisóes e na busca do desenvolvimento. Devido à amplidão, à complexidade e à diversidade do território brasileiro e ao conjunto também diverso de países vizinhos, a política deve se desdobrar em programas e projetos voltados a um espaço denso de especificidades e possibilidades, um espaço de encontro e de sinergias, mas, fundamentalmente, de grandes vulnerabilidades. Destaca-se que, além da defesa e segurança, as fronteiras precisam ser espaços de integração e desenvolvimento entre pessoas e países. 



\section{NOTAS BIOGRÁFICAS}

\section{Bolívar Pêgo}

Economista pelo Centro Universitário de Brasília (UniCeub) e pós-graduado em energia pela Universidade Estadual de Campinas (Unicamp). Coordenador-geral de pesquisa em questôes regionais, urbanas e ambientais e técnico de planejamento e pesquisa na Diretoria de Estudos e Políticas Regionais, Urbanas e Ambientais (Dirur) do Ipea, desde 1980, atuando nas áreas de energia, transportes, finanças públicas, integração sul-americana e desenvolvimento urbano. Coordenador da pesquisa Fronteiras do Brasil: uma avaliação de política pública, integrante do projeto A Política Nacional de Desenvolvimento Regional (PNDR) e a Faixa de Fronteira, parceria do Ipea com o Ministério do Desenvolvimento Regional (MDR). E-mail: <bolivar.pego@ipea.gov.br>.

\section{Rosa Moura}

Geógrafa pela Universidade de São Paulo (USP), doutora em geografia pela Universidade Federal do Paraná (UFPR) e profissional sênior do Programa de Pesquisa para o Desenvolvimento Nacional (PNPD) do Ipea - projeto A Política Nacional de Desenvolvimento Regional (PNDR) e a Faixa de Fronteira, pesquisa Fronteiras do Brasil: uma avaliação de política pública - em parceria com o MDR. Pesquisadora do Observatório das Metrópoles no projeto As Metrópoles e o Direito à cidade, do programa Institutos Nacionais de Ciência e Tecnologia do Conselho Nacional de Desenvolvimento Científico e Tecnológico (INCT/CNPq). Atuou como pesquisadora no Instituto Paranaense de Desenvolvimento Econômico e Social (Ipardes), entre 1991 e 2013. E-mail: <rmoura.pr@gmail.com>.

\section{Maria Nunes}

Graduada e licenciada em geografia e formada em administração pública pela Universidade Federal de Mato Grosso (UFMT), mestra em geografia pela Universidade Federal de Sergipe (UFS) e doutora em geografia pela Universidade Estadual Paulista (Unesp). Possui experiência na área de geografia e gestão pública, atuando na docência das seguintes áreas: análise regional, educação ambiental, legislação e proteção ambiental, e temática do ensino de geografia. Atua no projeto A Política Nacional de Desenvolvimento Regional (PNDR) e a Faixa de Fronteira, pesquisa Fronteiras do Brasil: uma avaliação de política pública, desenvolvido pela Dirur/ Ipea em parceria com o MDR. E-mail: <mariahnun@gmail.com>. 


\section{Caroline Krüger}

Graduada em administração pela Universidade Federal de Pelotas (UFPel), mestra em estudos fronteiriços pela Universidade Federal de Mato Grosso do Sul (UFMS) e doutora em administração pela Faculdade de Economia, Administração e Contabilidade de Ribeirão Preto (FEA-RP) da USP. Atuou como docente nos cursos de administração da UFMS e da Faculdade Anhanguera. Membro dos seguintes grupos de pesquisa: Golden for Sustainability, pela Universidade Bocconi, e Centro de Estudos em Gestão e Políticas Públicas Contemporâneas (GPublic), pela USP. Atua no projeto A Política Nacional de Desenvolvimento Regional (PNDR) e a Faixa de Fronteira, pesquisa Fronteiras do Brasil: uma avaliação de política pública, desenvolvido pela Dirur/Ipea em parceria com o MDR. E-mail: <carolgkruger@gmail.com>.

\section{Líria Yuri Nagamine}

Graduada em arquitetura e urbanismo pela UFPR, em 1998, completou mestrado em geografia nessa mesma universidade, em 2017, na linha de pesquisa produção do espaço e cultura. Atua, desde 2019, no projeto A Política Nacional de Desenvolvimento Regional (PNDR) e a Faixa de Fronteira, pesquisa Fronteiras do Brasil: uma avaliação de política pública, desenvolvido pela Dirur/Ipea em parceria com o MDR, e é pesquisadora do Observatório das Metrópoles, desde 2013. Possui experiência técnica na área de urbanismo, atuando como coordenadora e arquiteta do Departamento de Planejamento da Coordenação da Região Metropolitana de Curitiba (1999-2008) e como gerente técnica da empresa Vertrag Planejamento (2008-2012), desenvolvendo projetos e estudos para o planejamento urbano local, municipal e regional com ênfase nos seguintes temas: região metropolitana, uso e ocupação do solo, habitação, área de mananciais, área de proteção ambiental e rede urbana de cidades.E-mail: <liriaok@gmail.com>.

\section{Gustavo Ferreira}

Bacharel e licenciado em geografia pela $\mathrm{UnB}$, mestre e doutorando em geografia sob a linha de pesquisa de geoprocessamento e sensoriamento remoto nessa mesma universidade. Atua no projeto A Política Nacional de Desenvolvimento Regional (PNDR) e a Faixa de Fronteira, pesquisa Fronteiras do Brasil: uma avaliação de política pública, desenvolvido pela Dirur/Ipea em parceria com o MDR. Trabalhou como analista de suporte em geoprocessamento no Transporte Urbano do Distrito Federal (DFTrans). Possui experiência em Sistemas de Informaçóes Geográficas (SIGs), domínio de técnicas de classificação de imagens de satélite e séries temporais, uso de técnicas de inteligência artificial em geociências, manipulação de dados geográficos e banco de dados espaciais. E-mail: <gustavoohs@gmail.com>. 


\section{Paula Moreira}

Graduada e licenciada em ciências sociais e mestra em relaçóes internacionais pela Universidade do Estado do Rio de Janeiro (UERJ) e doutora em relaçôes internacionais, na área de política internacional e comparada, pela Universidade de Brasília (UnB). Atuou como pesquisadora no Observatório Político Sul-Americano (OPSA) e foi assistente de editoração do periódico Mural Internacional do Programa de Pós-Graduação em Relaçōes Internacionais da UERJ. Atualmente, contribui no projeto A Política Nacional de Desenvolvimento Regional (PNDR) e a Faixa de Fronteira, pesquisa Fronteiras do Brasil: uma avaliação de política pública, desenvolvido pela Dirur/Ipea em parceria com o MDR e, também, no Grupo de Estudo Interdisciplinar sobre Fronteiras da Universidade Federal de Roraima (Geifron/ UFRR). E-mail: <pg.moreira@outlook.com>. 




\section{Ipea - Instituto de Pesquisa Econômica Aplicada}

\section{EDITORIAL}

\section{Chefe do Editorial}

Reginaldo da Silva Domingos

\section{Assistentes da Chefia}

Rafael Augusto Ferreira Cardoso

Samuel Elias de Souza

\section{Supervisão}

Camilla de Miranda Mariath Gomes

Everson da Silva Moura

\section{Revisão}

Amanda Ramos Marques

Ana Clara Escórcio Xavier

Clícia Silveira Rodrigues

Idalina Barbara de Castro

Luiz Gustavo Campos de Araújo Souza

Olavo Mesquita de Carvalho

Regina Marta de Aguiar

Hellen Pereira de Oliveira Fonseca (estagiária)

Ingrid Verena Sampaio Cerqueira Sodré (estagiária)

\section{Editoração}

Aeromilson Trajano de Mesquita

Anderson Silva Reis

Cristiano Ferreira de Araújo

Danilo Leite de Macedo Tavares

Jeovah Herculano Szervinsk Junior

Leonardo Hideki Higa

\section{Capa}

Jeovah Herculano Szervinsk Junior

The manuscripts in languages other than Portuguese published herein have not been proofread.

\section{Livraria Ipea}

SBS - Quadra 1 - Bloco J - Ed. BNDES, Térreo

70076-900 - Brasília - DF

Tel.: (61) 2026-5336

Correio eletrônico: livraria@ipea.gov.br 

Composto em adobe garamond pro 11/13,2 (texto) Frutiger 67 bold condensed (títulos, gráficos e tabelas) Brasília-DF 
Este livro possui nove capítulos, quais sejam: capítulo 1, introdução, faz um breve histórico da pesquisa Fronteiras do Brasil e aborda as mudanças na composição da faixa de fronteira terrestre (FFT); capítulo 2, contemporaneidade e marco legal da faixa de fronteira (FF); capítulo 3, analisa as dinâmicas dessa FF, dando destaque para a ocupação do território e seus conflitos socioambientais, interações transfronteiriças e relações interfronteiriças; capítulo 4, avaliação das políticas públicas e ações para a integração e o desenvolvimento e programas voltados à FFT; capítulo 5, são destacados os acordos bilaterais e de cooperação fronteiriça, voltados à integração e ao desenvolvimento dessa FF; capítulo 6, é analisado o modelo de gestão vigente para essa FF, criação e operacionalização da Comissão Permanente para o Desenvolvimento e Integração da Faixa de Fronteira (CDIF) e a FF, os desafios da CDIF na operacionalização da governança pública na FF e o diagnóstico e sugestões; capítulo 7, apresenta os elementos para uma nova proposta de desenvolvimento e integração fronteiriça; capítulo 8, contribuição ao avanço nos estudos de um tema destacado em todos os arcos, agrega-se uma visão introdutória sobre a fronteira litorânea, sua importância terrestre e marinha e os desafios socioambientais; e capítulo 9, são apresentadas as considerações finais, sugestões e desafios das fronteiras terrestre e litorânea.

Diante desta perspectiva, o I pea e o MDR, enquanto parceiros, têm a certeza do cumprimento de suas missões institucionais e sentem-se honrados em poder proporcionar a governo federal, Congresso Nacional, estados e municípios fronteiriços, universidades, pesquisadores, sociedade civil organizada, entre outros, esta vasta e diversa série de publicações, visando contribuir para a elaboração, o acompanhamento e a melhoria das políticas públicas sobre fronteiras no Brasil. Espera-se que este volume 6 seja uma importante referência para as discussões técnicas e elaboração de um possível plano nacional de fronteiras.

Boa leitura!

Os autores 


\section{Missão do Ipea}

Aprimorar as políticas públicas essenciais ao desenvolvimento brasileiro por meio da produção e disseminação de conhecimentos e da assessoria ao Estado nas suas decisões estratégicas.

Instituições parceiras

\section{Alcoholes del Uruguai (Alur) \\ Assembleia Legislativa de Mato Grosso \\ Câmara de Vereadores de Barra do Quaraí \\ Câmara de Vereadores de Corumbá \\ Câmara de Vereadores de Uruguaiana}

Câmara Venezuelana-Brasileira de Indústria e Comércio Centro Estadual de Educação Profissional Professor Antônio de Pinho Lima (CEPPAPL) - Boa Vista Comissão Econômica para a América Latina e o Caribe (Cepal)

Comitê Cívico de San Matías (Bolívia)

Conselho de Desenvolvimento e Integração Sul (Codesul)

Consulado da Argentina em Uruguaiana

Consulado da Bolívia em Ctáceres

Consulado da Bolívia em Corumbá

Consulado da Guiana em Boa Vista

Consulado do Brasil em Puerto Quijarro (Bolívia) Departamento de Operações de Fronteira (DOF) Mato Grosso do Sul

Escritório Regional de Saúde de Cáceres

Estação Policial Integral de San Matías (Bolívia) Exército Brasileiro (EB)

Governo do Estado de Mato Grosso

Governo do Estado de Roraima

Governo do Estado do Mato Grosso do Sul Grupo Especial de Fronteira (Gefron) - Mato Grosso Instituto Brasileiro de Geografia e Estatística (IBGE) Instituto de Defesa Agropecuária de Mato Grosso (Indea) Instituto de Pesquisa Econômica Aplicada (Ipea) Instituto Federal de Educação, Ciência e Tecnologia Farroupilha (IF Farroupilha) Instituto Federal de Roraima (IFRR) Instituto Paranaense de Desenvolvimento Econômico e Social (Ipardes) Marinha do Brasil (MB) Ministério da Defesa (MD)

Ministério do Desenvolvimento Regional (MDR)

Moinho Cultural Sul-Americano - Corumbá Núcleo de Fronteira de Santa Catarina (NFSC) Organização Não Governamental Atelier Saladero Barra do Quaraí
Parque Estadual do Espinilho

Pastoral do Imigrante de Corumbá

Polícia Civil de Mato Grosso

Polícia Federal (PF)

Polícia Militar de Mato Grosso

Polícia Militar do Mato Grosso do Sul

Polícia Rodoviária Federal (PRF)

Prefeitura de Barra do Quaraí

Prefeitura de Cáceres

Prefeitura de Corumbá

Prefeitura de Pacaraima

Prefeitura de San Matías (Bolívia)

Prefeitura de Uruguaiana

Receita Federal do Brasil (RFB)

Secretaria de Estado de Meio Ambiente,

Desenvolvimento Econômico, Produção e Agricultura

Familiar de Mato Grosso do Sul (Semagro/MS)

Secretaria de Estado de Planejamento e

Desenvolvimento de Roraima (Seplan/RR)

Secretaria de Governo da Presidência da

República (Segov/PR)

Serviço Nacional do Comércio (Senac) - Uruguaiana

Sindicato de Produtores Rurais de Cáceres

Superintendência de Desenvolvimento da Amazônia (Sudam)

Superintendência de Desenvolvimento do Centro-Oeste (Sudeco)

União das Nações Sul-Americanas (Unasul)

Universidade de Brasília (UnB)

Universidade de São Paulo (USP)

Universidade Estadual de Mato Grosso (Unemat) - Cáceres

Universidade Federal da Grande Dourados (UFGD)

Universidade Federal de Mato Grosso

Universidade Federal de Mato Grosso do Sul (UFMS) -

Campus do Pantanal (CPAN)

Universidade Federal de Pernambuco (UFPE)

Universidade Federal de Roraima (UFRR)

Universidade Federal do Rio de Janeiro (UFRJ)

Universidade Federal do Rio Grande do Sul (UFRGS)

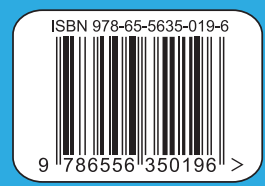

PÁTRIA AMADA

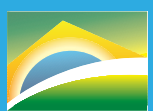
BRASIL 